Portland State University

PDXScholar

\title{
Distribution of Heavy Metals and Trace Elements in Soils of Southwest Oregon
}

Rafiqul Alam Khandoker

Portland State University

Follow this and additional works at: https://pdxscholar.library.pdx.edu/open_access_etds

Part of the Geology Commons, Sedimentology Commons, and the Soil Science Commons Let us know how access to this document benefits you.

\section{Recommended Citation}

Khandoker, Rafiqul Alam, "Distribution of Heavy Metals and Trace Elements in Soils of Southwest Oregon" (1997). Dissertations and Theses. Paper 4691.

https://doi.org/10.15760/etd.6575

This Thesis is brought to you for free and open access. It has been accepted for inclusion in Dissertations and Theses by an authorized administrator of PDXScholar. Please contact us if we can make this document more accessible: pdxscholar@pdx.edu. 


\section{THESIS APPROVAL}

The abstract and thesis of Rafiqul Alam Khandoker for the Master of Science in Geology presented April 23, 1997, and accepted by the thesis committee and the department.

COMMITTEE APPROVALS:

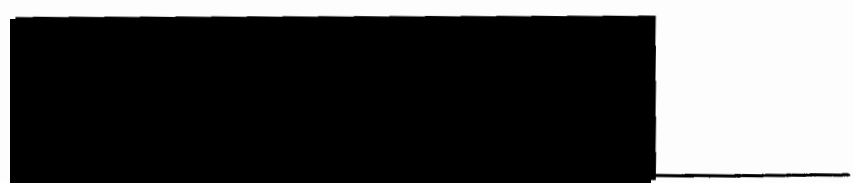

Scott F. Burns, Chair

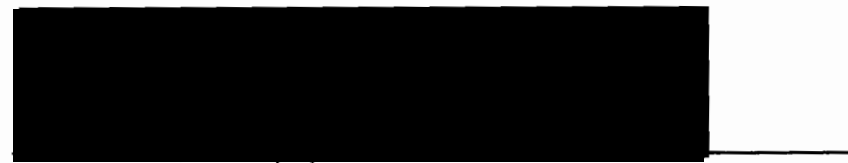

Ansel G. Johnsorn

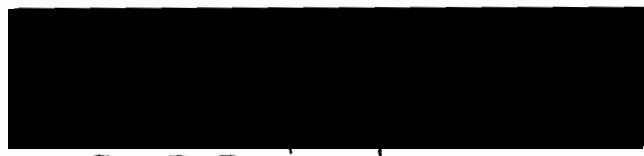

Curt D. Peterson

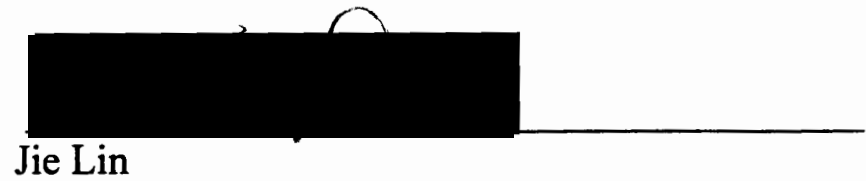

Representative of the Office of Graduate Studies

DEPARTMENTAL APPROVAL:

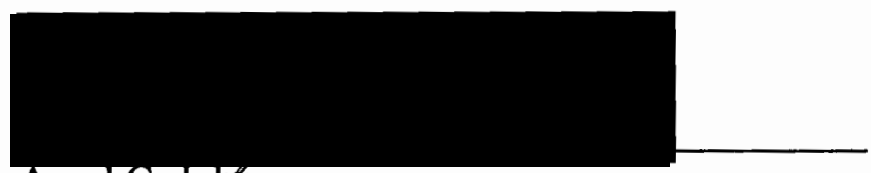

Ansel G. Jobnson

Department of Geology

\section{ACCEPTED FOR PORTLAND STATE UNIVERSITY BY THE LIBRARY}

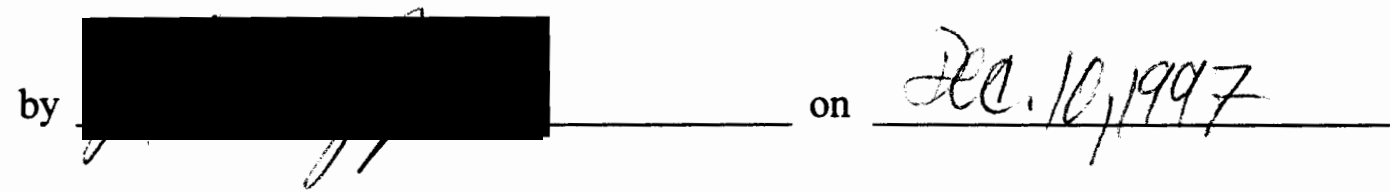




\begin{abstract}
An abstract of the thesis of Rafiqul Alam Khandoker for the Master of Science in Geology presented April 23, 1997.

Title: Distribution of Heavy Metals and Trace Elements in Soils of Southwest

\section{Oregon}

Soil samples from 118 sites on 71 geologic units in southwest Oregon were collected and analyzed to determine the background concentrations of metals in soils of the region. Sites were chosen in areas that were relatively undisturbed by human activities. The U. S. Environmental Protection Agency approved total-recoverable method was used to recover metals from samples for analysis. The twenty six metals analyzed were: $\mathrm{Ag}, \mathrm{Al}, \mathrm{As}, \mathrm{Ba}, \mathrm{Be}, \mathrm{Ca}, \mathrm{Cd}, \mathrm{Co}, \mathrm{Cr}, \mathrm{Cu}, \mathrm{Fe}, \mathrm{Hg}, \mathrm{K}, \mathrm{La}, \mathrm{Li}, \mathrm{Mg}, \mathrm{Mn}, \mathrm{Mo}$, $\mathrm{Na}, \mathrm{Ni}, \mathrm{Pb}, \mathrm{Sb}, \mathrm{Se}, \mathrm{Tl}, \mathrm{V}$ and $\mathrm{Zn}$.

The Klamath Mountains followed by the Coast Range contain the highest soil concentrations of $\mathrm{Al}, \mathrm{Ca}, \mathrm{Co}, \mathrm{Cr}, \mathrm{Cu}, \mathrm{Fe}, \mathrm{K}, \mathrm{Li}, \mathrm{Mg}, \mathrm{Mn}, \mathrm{Ni}, \mathrm{V}$ and $\mathrm{Zn}$. Soils of the Coastal Plain and High Lava Plains contain the lowest concentrations of these metals. Unusually high soil As concentrations are found at two sites in the Klamath Mountains. All $\mathrm{Be}$ and $\mathrm{Cd}$ values above laboratory's reporting limits are also from the Klamath Mountains and Coast Range. Concentrations of soil $\mathrm{Ba}$ and $\mathrm{La}$ are fairly uniform throughout the region. Soil $\mathrm{Pb}$ levels are generally low with a few exceptions in the Klamath Mountains, Coast and Cascade Ranges. The region west of the Cascade Range has higher soil $\mathrm{Hg}$ contents than in the east. 
Soil metal concentrations are generally much higher in the region west of the Cascade Range, excluding the Coastal Plain, than in the east with the exception of $\mathrm{Na}$, because of more ultramafic rocks and a wetter climate. Soil metal concentrations are directly related to soil development with the highest concentrations being found in welldeveloped Alfisols and Ultisols and the lowest concentrations in poorly developed Entisols. Most metals have similar averages and ranges of concentration compared to the rest of the United States (U.S.). Metals with high values compared to the rest of the U. S. are $\mathrm{Cr}, \mathrm{Co}, \mathrm{Cu}, \mathrm{Mn}$ and $\mathrm{Ni}$.

In general, $\mathrm{Al}, \mathrm{Co}, \mathrm{Cr}, \mathrm{Cu}, \mathrm{Fe}, \mathrm{La}, \mathrm{Li}, \mathrm{Mg}, \mathrm{Na}, \mathrm{Ni}$, and $\mathrm{V}$ are concentrated in the $\mathrm{B}$ horizon while $\mathrm{Ba}, \mathrm{Ca}, \mathrm{Hg}, \mathrm{K}, \mathrm{Mn}, \mathrm{Pb}$ and $\mathrm{Zn}$ are concentrated in the $\mathrm{A}$ horizon. 


\author{
by \\ RAFIQUL ALAM KHANDOKER
}

A thesis submitted in partial fulfillment of the

requirements for the degree of

\title{
MASTER OF SCIENCE in GEOLOGY
}

Portland State University

1997 


\section{Acknowledgments}

All praise to God who gave me patience, perseverance and strength of mind to accomplish this work.

I would like to thank many people whose contributions and support made this thesis possible. My sincere thanks go to Scott Burns, my advisor. He introduced me to the fascinating domain of soils, something I thought not important in nearly twenty years of my association with geology. He arranged this project for me, helped me to collect samples, read various drafts, and made many thoughtful suggestions. I am also grateful to him for his encouragement and for his help in other ways. I thank the members of my committee, Ansel Johnson, Curt Peterson and Jie Lin for their thoughtful comments which helped to improve the thesis.

My thanks go to Oregon Department of Environmental Quality (DEQ) for letting me work on this project and providing me with logistical support. I am indebted to many persons at the DEQ Laboratory, particularly to Ron McCartney for his great interest in this project; to George Di Domenico for helping me with sample preparation and mercury analysis; and to Donna Larson for conducting the ICP analysis and for her assistance in writing the section 'Quality of Data'. I am grateful for the Oregon Soil Scientist Society Scholarship which provided much-needed support for laboratory analysis.

I am indebted to Bill Douglas for supplying me field inventory sheets of 103 sites sampled by him and Scott Burns in an earlier radionuclide investigation of soils of 
southwest Oregon. I am thankful to Bob Pinotti and Mark Scott for their help in making maps with GIS. Julie Clark spent lots of time editing my drafts, helping me generate the final maps in ArcView and format the thesis into its final form. I am very grateful to her for all she has done for me. My appreciation goes to Christian Poppeliers for his editorial assistance on the chapter 'Results and Discussion'. I also take this opportunity to thank the geology faculty members and staff for all their help I received in various ways. I am thankful to all of my fellow graduate students who were so eager to help me whenever I would need it in the computer lab.

Finally, I would like to thank my family for their patience and support. My admiration goes particularly to my two sons, Ryin and Rakin, who have provided so much encouragement and love in spite of my inability to fulfil their minimum demands. 


\section{Table of Contents}

Acknowledgments $\quad$ iv

Table of Contents $\quad$ vi

List of Figures $\quad$ viii

List of Tables $\quad$ ix

CHAPTER I: INTRODUCTION

$\begin{array}{ll}\text { CHAPTER II: STUDY AREA } & 7\end{array}$

PHYSIOGRAPHY AND GEOLOGY

CLIMATE AND VEGETATION

$\begin{array}{ll}\text { SOILS } & 16\end{array}$

SOILS OF SOUTHWEST OREGON

CHAPTER III: PREVIOUS WORK ON THE DISTRIBUTION OF HEAVY METALS AND TRACE ELEMENTS IN SOIL $\quad 25$

CHAPTER IV: METHODOLOGY 29

FIELD METHODS

LABORATORY METHODS

QUALITY OF DATA

$\begin{array}{ll}\text { CHAPTER V: RESULTS AND DISCUSSION } & 47\end{array}$

$\begin{array}{ll}\text { SOIL_SOLUTION PH } & 47\end{array}$

DISTRIBUTION OF SOIL METAL CONCENTRATIONS

ALUMINUM (AL) 61

$\begin{array}{ll}\text { ANTIMONY (SB) } & 65\end{array}$

$\begin{array}{ll}\text { ARSENIC (AS) } & 65\end{array}$

BARIUM (BA)

BERYLLIUM (BE) $\quad 69$

$\begin{array}{ll}\text { CADMIUM (CD) } & \mathbf{7 0}\end{array}$

CALCIUM (CA)

$\begin{array}{ll}\text { CHROMIUM (CR) } & 75\end{array}$

COBALT (CO)

COPPER (CU)

IRON (FE) $\quad 86$

$\begin{array}{lr}\text { LANTHANUM (LA) } & 89\end{array}$

LEAD (PB) 
$\begin{array}{ll}\text { LITHIUM (LI) } & 94\end{array}$

MAGNESIUM (MG) $\quad 98$

$\begin{array}{lr}\text { MANGANESE (MN) } & 101\end{array}$

$\begin{array}{ll}\text { MERCURY (HG) } & 105\end{array}$

MOLYBDENUM (MO) $\quad 109$

$\begin{array}{ll}\text { NICKEL (NI) } & 109\end{array}$

POTASSIUM (K) $\quad 114$

$\begin{array}{lr}\text { SELENIUM (SE) } & 117\end{array}$

$\begin{array}{ll}\text { SILVER (AG) } & 117\end{array}$

$\begin{array}{ll}\text { SODIUM (NA) } & 118\end{array}$

THALLIUM (TL)

$\operatorname{VANADIUM~(V)~} 123$

$\begin{array}{ll}\text { ZINC (ZN) } & 125\end{array}$

LIMITATIONS OF THE STUDY 130

CHAPTER VI: CONCLUSIONS 132

$\begin{array}{ll}\text { FUTURE WORK } & 136\end{array}$

$\begin{array}{ll}\text { REFERENCES CITED } & 138\end{array}$

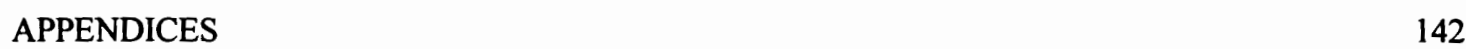

APPENDIX 1: PREVIOUS WORKS ON METAL DISTRIBUTIONS IN ROCKS AND 142 SOIL

APPENDIX 2: LIST OF GEOLOGIC UNITS WITH THEIR ASSOCIATED SOIL $\quad 166$ SAMPLING SITES

APPENDIX 3: SAMPLING SITE CHARACTERISTICS $\quad 170$

APPENDIX 4: SELECTED PHYSICAL AND MORPHOLOGICAL PROPERTIES $\quad 175$ OF THE SOILS STUDIED

APPENDIX 5: QUALITY CONTROL/QUALITY ASSURANCE DATA FOR HEAVY 181 METALS AND TRACE ELEMENTS IN SOILS OF SOUTHWEST OREGON

APPENDIX 6: DATABASE OF HEAVY METALS AND TRACE ELEMENTS IN SOUTHWEST OREGON

APPENDIX 7: DISTRIBUTION STATISTICS FOR CONCENTRATIONS OF METALS 203 IN SOILS DEVELOPED ON INDIVIDUAL GEOLOGIC UNITS IN SOUTHWEST OREGON

APPENDIX 8: HEAVY METALS AND TRACE ELEMENT CONTENTS OF SURFACE 274 SOILS OF THE UNITED STATES 


\section{List of Figures}

Number

Figure 1. Location map of the study area

Figure 2. Physiographic provinces of Oregon (after Orr and others, 1992). The study area is shown in box.

Figure 3. General soil map of Southwest Oregon (USDA, 1986)

Figure 4. A diagrammatic soil profile with US Soil Taxonomy Horizon nomenclature, modified after Alloway (1993b); description after Birkeland (1984).

Figure 5. Location of sampling sites in Southwest Oregon (for detail of sampling site locations, see Appendix 3)

Figure 6. Soil Chromium (Cr) concentrations in physiographic provinces, soil orders and major igneous rocks of Southwest Oregon

Figure 7. Soil Copper $(\mathrm{Cu})$ concentrations in physiographic provinces, soil orders and major igneous rocks of Southwest Oregon

Figure 8. Soil Lead (Pb) concentrations in physiographic provinces, soil orders and major igneous rocks of Southwest Oregon

Figure 9 Soil Mercury $(\mathrm{Hg})$ concentrations in physiographic provinces, soil orders and major igneous rocks of Southwest Oregon

Figure 10. Soil Nickel (Ni) concentrations in physiographic provinces, soil orders and major igneous rocks of Southwest Oregon

Figure 11. Soil Zinc (Zn) concentrations in physiographic provinces, soil orders and major igneous rocks of Southwest Oregon 


\section{List of Tables}

Number

Page

Table 1. Chemical symbols of elements (alphabetically) mentioned in the study (Sargent-Welch, 1979).

Table 2. Soil Orders within the U. S. Soil Taxonomy (Soil Survey Staff, 1992). Description of the soil orders is after Birkeland (1984). For soil horizon nomenclature, see Figure 4.

Table 3. Soil Map Units in Figure 3 (USDA, 1986)

Table 4. Soil Moisture and Temperature Regimes of Southwest Oregon (USDA, 1986).

Table 5. Percent differences between metal concentrations determined for sample pairs (A1 and A2)

from A horizon.

Table 6. Percent differences between metal concentrations determined for sample pairs (B1 and B2)

from B horizon.

Table 7. Minimum reporting levels for heavy metals and trace elements in soils in southwest Oregon analyzed by ICPAES ${ }^{1}$ and CVAAS $^{2}$ (from DEQ laboratory, Portland State University campus, Oregon).

Table 8. Average soil-solution pH (1:1 water) in Southwest Oregon.

Table 9. Distribution statistics for concentrations (in ppm of dry soil) of metals in surface soils (A horizon) of all sites in Southwest Oregon.

Table 10. Distribution statistics for concentrations (in ppm of dry soil) of metals in subsoils (B horizon) of all sites in Southwest Oregon.

Table 11. Distribution statistics for concentrations (in ppm of dry soil) of metals in soils on the Coastal Plain of Southwest Oregon.

Table 12. Distribution statistics for concentrations (in ppm of dry soil) of metals in soils on the Coast Range of Southwest Oregon. 
Table 13. Distribution statistics for concentrations (in ppm of dry soil) of metals in soils on the Willamette Valley of Southwest Oregon.

Table 14. Distribution statistics for concentrations (in ppm of dry soil) of metals in soils on the Cascade Range of Southwest Oregon.

Table 15. Distribution statistics for concentrations (in ppm of dry soil) of metals in soils on the Klamath Mountains of Southwest Oregon.

Table 16. Distribution statistics for concentrations (in ppm of dry soil) of metals in soils on the Basin and Range Province of Southwest Oregon.

Table 17. Distribution statistics for concentrations (in ppm of dry soil) of metals in soils on the High Lava Plains of Southwest Oregon.

Table 18. Average Distribution of Metals (in ppm dry) in Soils Developed on Major Igneous Rocks of Southwest Oregon.

Table 19. Average Distribution of Metals (in ppm dry) in Major Soil Orders of Southwest Oregon.60

Table 20. Distribution statistics for Aluminum (Al) content (ppm dry) in soils of Southwest Oregon.62

Table 21. Distribution statistics for Barium (Ba) content (ppm dry) in soils of Southwest Oregon. 67

Table 22. Beryllium (Be) values, at or above laboratory's reporting limit of $1 \mathrm{ppm}$, in Southwest

Oregon.

Table 23. Cadmium (Cd) values, at or above laboratory's reporting limit of 1 ppm, in Southwest

Oregon.

Table 24. Distribution statistics for Calcium (Ca) content (ppm dry) in soils of Southwest Oregon. 72

Table 25. Distribution statistics for Chromium (Cr) content (ppm dry) in soils of Southwest Oregon76

Table 26. Distribution statistics for Cobalt (Co) content (ppm dry) in soils of Southwest Oregon. 80

Table 27. Distribution statistics for Copper (Cu) content (ppm dry) in soils of Southwest Oregon. 83

Table 28. Distribution statistics for Iron (Fe) content (ppm dry) in soils of Southwest Oregon. $\quad 87$ 
Table 29. Distribution statistics for Lanthanum (La) content (ppm dry) in soils of Southwest Oregon.

Table 30. Distribution statistics for Lead (Pb) content (ppm dry) in soils of Southwest Oregon.

Table 31. Distribution statistics for Lithium (Li) content (ppm dry) in soils of Southwest Oregon. 96

Table 32. Distribution statistics for Magnesium (Mg) content (ppm dry) in soils of Southwest

Oregon.

Table 33. Distribution statistics for Manganese (Mn) content (ppm dry) in soils of Southwest

Oregon.

Table 34. Distribution statistics for Mercury (Hg) content (ppm dry) in soils of Southwest Oregon.106

Table 35. Distribution statistics for Nickel (Ni) content (ppm dry) in soils of Southwest Oregon. 110

Table 36. Distribution statistics for Potassium (K) content (ppm dry) in soils of Southwest Oregon.115

Table 37. Distribution statistics for Sodium (Na) content (ppm dry) in soils of Southwest Oregon. 119

Table 38. Distribution statistics for Vanadium (V) content (ppm dry) in soils of Southwest Oregon.124

Table 39. Distribution statistics for Zinc ( $\mathrm{Zn})$ content (ppm dry) in soils of Southwest Oregon. 126

Table 40. Comparison of the concentration (in ppm dry; * in percent dry) of metals in surface soils of Southwest Oregon with that of the rest of the U.S. The DEQ's cleanup level for various metals is also listed. 


\section{CHAPTER I: INTRODUCTION}

This study is an attempt to geologically and pedologically determine the background heavy metal and trace element concentrations in soils of southwest Oregon. The Oregon Department of Environmental Quality (DEQ) requires that all heavy-metal soil contaminations undergo remediation to reach background levels. Because of the lack of data, the DEQ has assigned arbitrary soil cleanup levels based on minimal research in the region (William Hartford, personal communication, 1993). There is a need for a heavy metal and trace element soil database so that cleanups are reasonable and equitable. This project was undertaken to help DEQ better define what the background heavy metal levels are in the soils of southwest Oregon.

The term 'heavy metal' is commonly adopted as a group name for the metals and metalloids which are associated with pollution and toxicity such as $\mathrm{Pb}, \mathrm{Cd}, \mathrm{Hg}, \mathrm{As}, \mathrm{Tl}$ and $U$ (see Table 1), but it also includes some elements which are essential for living organisms at low concentrations, e.g. Co, $\mathrm{Cu}, \mathrm{Mn}, \mathrm{Se}$ and $\mathrm{Zn}$ (Alloway, 1993a). The classification is based on atomic density $\left(>6 \mathrm{~g} \mathrm{~cm}^{-3}\right)$ (Phipps, 1981). Heavy metals are also classed as 'trace elements' because, of the more than ninety elements which comprise the inorganic portion of soil, all but ten (i.e. $\mathrm{O}, \mathrm{Si}, \mathrm{Al}, \mathrm{Fe}, \mathrm{Ca}, \mathrm{Na}, \mathrm{K}, \mathrm{Mg}, \mathrm{Ti}$ and P) occur at concentrations of less than $0.1 \%$ (i.e. $<1,000 \mathrm{mg} / \mathrm{kg}$ or $<1,000 \mathrm{ppm}$ ) (Jenkins and Jones, 1980). Most have average concentrations of less than $0.01 \%$ or 100 ppm (Mitchell, 1964). For convenience and consistency, all heavy metals and trace elements will hereafter be referred to as metals. 
Table 1. Chemical symbols of elements (alphabetically) mentioned in the study (Sargent-Welch, 1979).

\begin{tabular}{|c|l|c|l|}
\hline Chemical Symbols & Name & Chemical Symbols & Name \\
\hline $\mathrm{Ag}$ & Silver & $\mathrm{Mn}$ & Manganese \\
\hline $\mathrm{Al}$ & Aluminum & $\mathrm{Mo}$ & Molybdenum \\
\hline $\mathrm{As}$ & Arsenic & $\mathrm{N}$ & Nitrogen \\
\hline $\mathrm{B}$ & Boron & $\mathrm{Na}$ & Sodium \\
\hline $\mathrm{Ba}$ & Barium & $\mathrm{Ni}$ & Nickel \\
\hline $\mathrm{Be}$ & Beryllium & $\mathrm{O}$ & Oxygen \\
\hline $\mathrm{Ca}$ & Calcium & $\mathrm{P}$ & Phosphorus \\
\hline $\mathrm{Cd}$ & Cadmium & $\mathrm{Pb}$ & Lead \\
\hline $\mathrm{Co}$ & Cobalt & $\mathrm{Sb}$ & Antimony \\
\hline $\mathrm{Cr}$ & Chromium & $\mathrm{Se}$ & Selenium \\
\hline $\mathrm{Cu}$ & Copper & $\mathrm{Si}$ & Silicon \\
\hline $\mathrm{Fe}$ & Iron & $\mathrm{Sr}$ & Strontium \\
\hline $\mathrm{Hg}$ & Mercury & $\mathrm{Ti}$ & Titanium \\
\hline $\mathrm{K}$ & Potassium & $\mathrm{Tl}$ & Thallium \\
\hline $\mathrm{La}$ & Lanthanum & $\mathrm{U}$ & Uranium \\
\hline $\mathrm{Li}$ & Lithium & $\mathrm{V}$ & Vanadium \\
\hline $\mathrm{Mg}$ & Magnesium & $\mathrm{Zn}$ & Zinc \\
\hline
\end{tabular}

Traditionally, research by soil chemists has been concerned primarily with plant macronutrients (N, P and $\mathrm{K}$ ) and little work has been done on many of the metals until recently (Alloway, 1993a). This increasing attention in recent years is partly due to growing scientific and public awareness of environmental issues and partly because of recently available analytical techniques to measure heavy metal concentrations accurately. Various types of atomic spectroscopy, for example, allow large number of samples to be analyzed rapidly and accurately and thereby facilitate environmental monitoring.

Being at the interface between the atmosphere and the earth's crust as well as the 
substrate for natural and agricultural ecosystems, the soil is open to inputs of metals from many sources. Metals occur naturally in soils, usually at relatively low concentrations, as a result of the weathering and other pedogenic processes acting on the rock fragments on which the soils develop (soil parent material). Considerable variations occur between the normal concentration ranges of different metals in soils. Rocks of different types vary considerably in their mineralogical and elemental composition giving rise to marked differences in concentrations between soils even in the absence of significant inputs from external sources. The metal concentrations inherited from soil parent material are modified by pedogenic and biochemical processes, by natural inputs such as dust particles derived from soil, rocks and volcanic ash and, most importantly, by anthropogenic inputs like pollution from agricultural fertilizers and pesticides and industrial wastes (Alloway, 1993a).

Soils containing anomalously high concentrations of metals can cause acute toxicity problems; increased concentrations (particularly metals like $\mathrm{Cd}$ and $\mathrm{Pb}$ ) in the food chain may cause significant health effects in the long term (Alloway, 1993a). Metal polluted soils constitute a major environmental problem because many of the metals will persist in the soils for hundreds or even thousands of years (Kabata-Pendias and Pendias, 1984). Information on the background level concentrations of these metals in the soils is therefore essential for identification and subsequent careful management of polluted soils. 
The study area is the southwest segment of Oregon (Figure 1), encompassing nine counties: Coos, Curry, Deschutes, Douglas, Jackson, Josephine, Klamath, Lake and Lane. The boundaries are the California border on the south, the city of Eugene on the north, the city of Bend on the east and the Pacific Coast on the west. The area contains most of the major geologic-physiographic provinces of the state, namely (from the west) the Coastal Plain, Coast Range, Klamath Mountains, Willamette Valley, Cascade Range, Basin and Range, and High Lava Plains (Zoback and others, 1994). The Willamette Valley, between the Coast and Cascade Ranges, is the most urbanized part of the area, whereas the rest of the region, apart from localized and recent settlements, is sparsely populated and rural.

The aim and objective of this study is to determine the background level concentrations of metals in the soils of southwest Oregon. Attempts have also been made to relate the significance of concentrations of these metals to soil-forming factors, particularly to the predominant factors, parent material and climatic conditions. Sampling sites were selected in remote areas to avoid contamination from any anthropogenic source. Samples were collected from soils developed on each geologic unit. Due to the reconnaissance nature of this study, it is assumed that soils developed on the same geologic unit have similar elemental compositions (Meriwether and others, 1988; Meriwether and others, 1992). The twenty six metals analyzed are: $\mathrm{Ag}, \mathrm{Al}, \mathrm{As}$, $\mathrm{Ba}, \mathrm{Be}, \mathrm{Ca}, \mathrm{Cd}, \mathrm{Co}, \mathrm{Cr}, \mathrm{Cu}, \mathrm{Fe}, \mathrm{Hg}, \mathrm{K}, \mathrm{La}, \mathrm{Li}, \mathrm{Mg}, \mathrm{Mn}, \mathrm{Mo}, \mathrm{Na}, \mathrm{Ni}, \mathrm{Pb}, \mathrm{Sb}, \mathrm{Se}, \mathrm{Tl}, \mathrm{V}$ and $\mathrm{Zn}$. These metals were chosen because they are routinely analyzed at the Oregon 


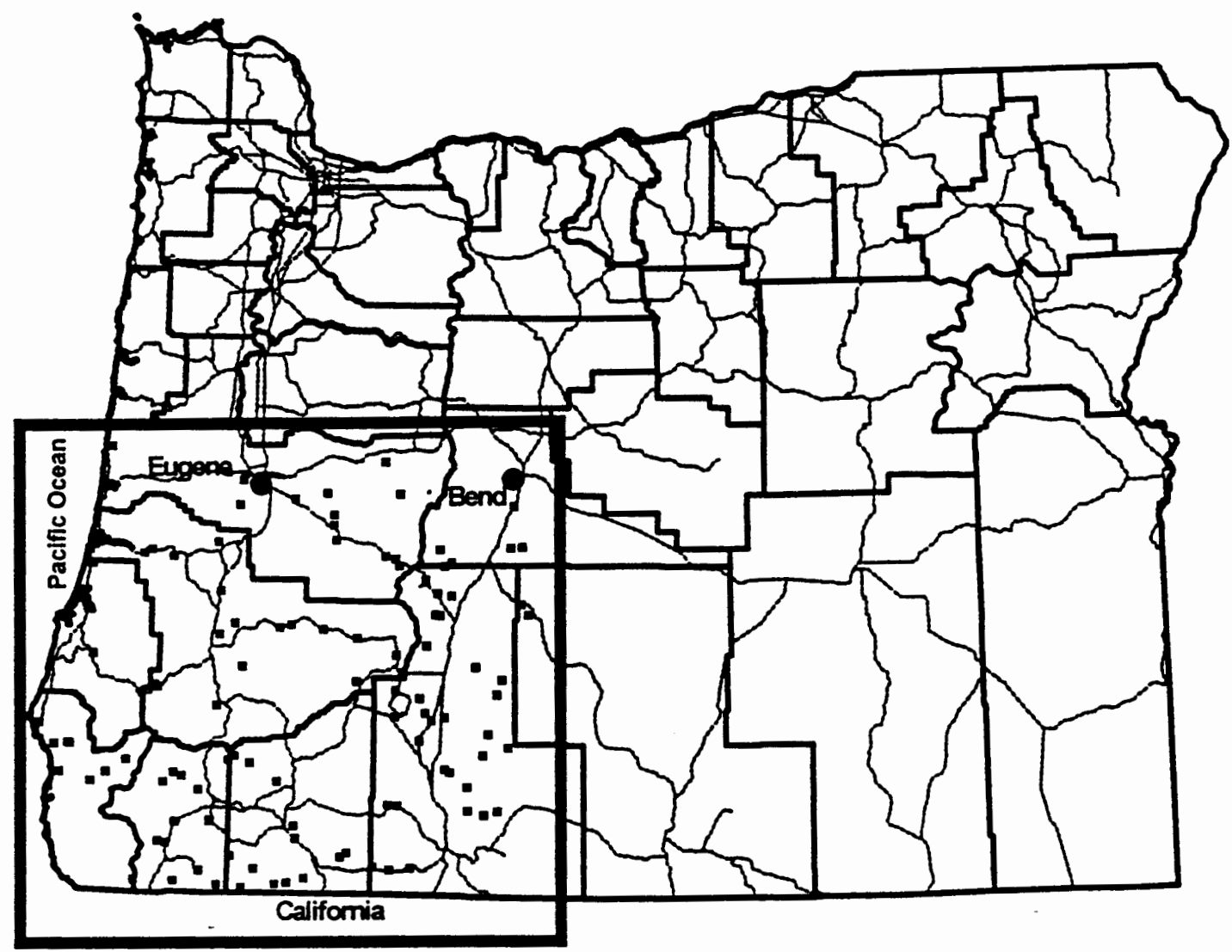

Study area $\lambda$

- Sampling sites

$\wedge_{\text {Road }}$

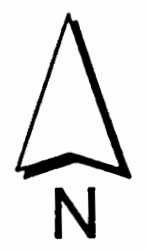

$\square$ County

$40 \quad 0 \quad 40$ Kilometers

Figure 1. Location map of the study area 
DEQ laboratory by atomic spectroscopy for environmental monitoring. The U.S. Environmental Protection Agency's priority pollutants included $\mathrm{Ag}, \mathrm{As}, \mathrm{Be}, \mathrm{Cd}, \mathrm{Cr}, \mathrm{Cu}$, $\mathrm{Hg}, \mathrm{Ni}, \mathrm{Pb}, \mathrm{Sb}, \mathrm{Se}, \mathrm{Tl}$ and $\mathrm{Zn}$ (U.S. Environmental Protection Agency, 1988). The resulting database of data collected can be used as a tool by the DEQ and the environmental industry. 


\section{CHAPTER II: STUDY AREA}

\section{PHYSIOGRAPHY AND GEOLOGY}

Southwest Oregon with its varied and spectacular physiography is picturesque.

Scenic snow-covered high mountains, serene sites like Crater Lake and Newberry Crater, and numerous cinder cones and high-elevation lakes make this region attractive to all (Orr and others, 1992). This fascinating physiography comes from a turbulent past which includes tectonic deformation, volcanism, and Quaternary glaciation. The physiographic provinces of Oregon are shown in Figure 2.

\section{Coastal Plain and Coast Range}

A long, narrow belt of moderately high mountains and coastal headlands, the Coast Range extends from Washington state and the Columbia River in the north to the Klamath Mountains in the south. The Willamette Valley lies on its east side. The crest of the range averages $456 \mathrm{~m}$ in elevation with the highest point, Marys Peak near Philomath, reaching 1,245 m (Orr and others, 1992).

The line of abrupt coastal headlands along the ocean is fairly evenly interspersed with shallow bays, estuaries, pocket beaches, and sand dunes. Along the very southwestern edge of this province, wave-cut terraces have created a narrow coastal plain with remnants of older marine terraces rising up to $486 \mathrm{~m}$ (Kelsey and Bockheim, 1994).

Early Tertiary pillow basalts and breccias (e.g., the Siletz River Volcanics in the central part of the Coast Range, and the Roseburg Volcanics in the south) form the core of the Coast Range (Duncan, 1982; Wells and others, 1984). A thick sequence of 


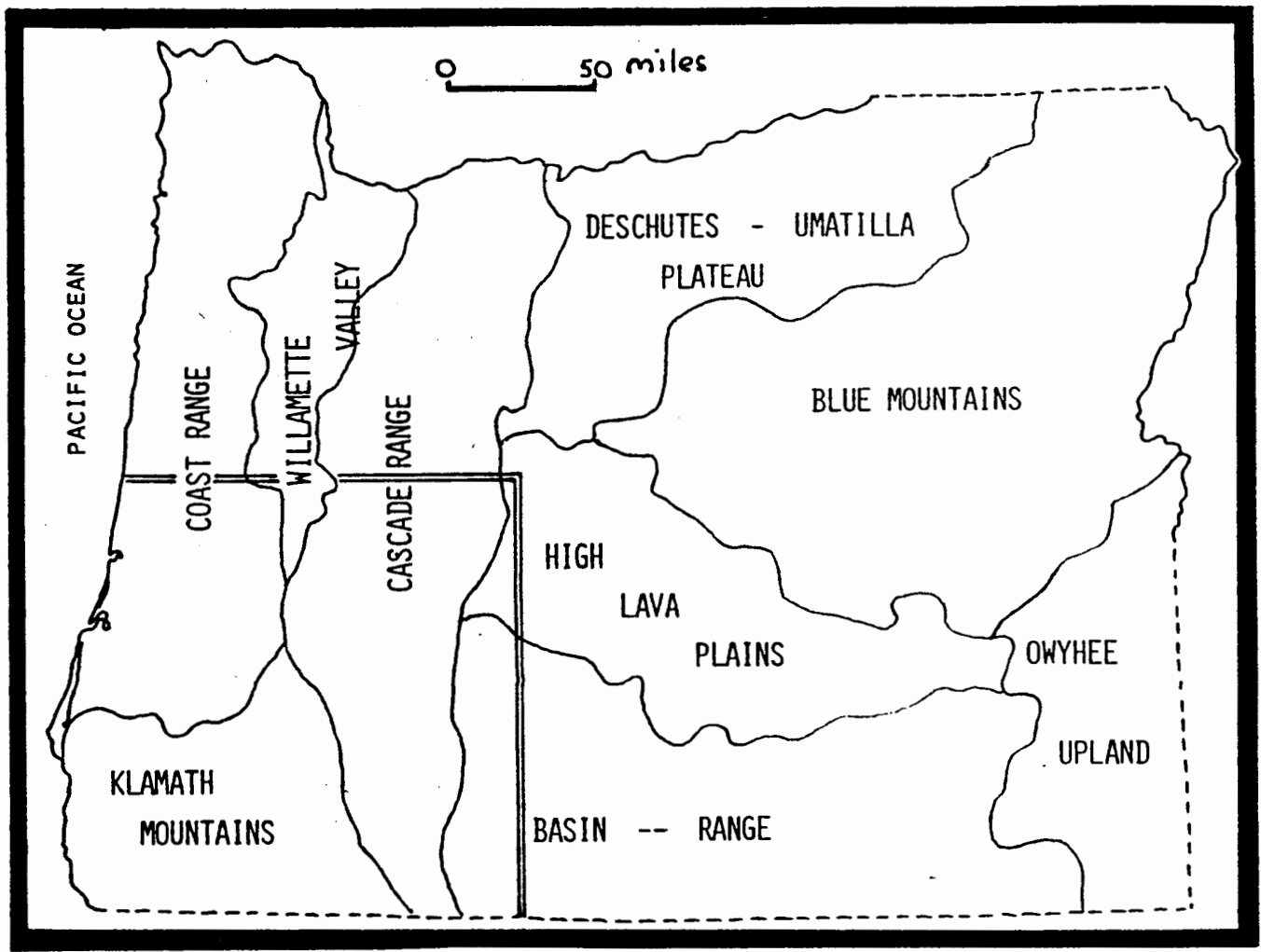

Figure 2. Physiographic provinces of Oregon (after Orr and others, 1992). The study area is shown in box. 
Eocene to early Miocene marine clastic sedimentary rocks overlies these volcanics. The early Eocene sequence includes lithic sands, silts, and muds (derived from the Klamath Mountains) of the Roseburg, Lookingglass and Flournoy Formations. The middle to late Eocene Tyee Formation consists of arkosic sands and silts derived from Idaho batholith. Provenance of the Oligocene and early Miocene pyroclastics and ash was the ancestral Cascade Mountains (Heller and others, 1987). Resistant Oligocene sills and dikes form the major peaks of the range today (Orr and others, 1992).

\section{Willamette Valley}

Enclosed between the Coast Range and Cascade Mountains, the Willamette Valley is the southern end of the Puget Sound-Willamette physiographic province which starts from Georgia Strait in Washington and pinches out near Cottage Grove, Oregon. A level and elongate alluvial plain of the Willamette River, the valley is the economic and cultural heart of Oregon. As the only natural lowland of any size in Oregon, its moderate climate supports $70 \%$ of Oregon's population as well as intense and varied agriculture (Orr and others, 1992).

The Willamette Valley, representing a north-plunging syncline, is filled with up to $600 \mathrm{~m}$ of late Pleistocene sediments. The sequence consists of about $30 \mathrm{~m}$ of Missoula Floods silts (e.g., Willamette Silts) underlain by up to $300 \mathrm{~m}$ of coarse gravels and sands of the Rowland Formation representing glacial outwash from the Cascade Mountains (Orr and others, 1992). The Rowland Formation is underlain by over $250 \mathrm{~m}$ of fluvial clays (Newton, 1969). 


\section{Cascade Mountains}

With its high glaciated volcanic peaks, the Cascade Mountain physiographic province is undoubtedly the most dramatic and scenic in Oregon. Extending south into California and north into Washington and British Columbia, the Cascade Range is actually two parallel chains. The older, deeply eroded Western Cascades sharply contrast with the more recent snow-covered High Cascades that sit on the eastern flank of the older range. The Western Cascades, with elevations of $517 \mathrm{~m}$ at the western edge to $1,763 \mathrm{~m}$ on the eastern margin, are only half the elevation of the High Cascade peaks which reach elevations of more than $3,345 \mathrm{~m}$ (Orr and others, 1992). Dominated by large stratovolcanoes (e.g., Three Sisters, Mount McLoughlin), much of the High Cascades is a structural depression (Blackwell and others, 1990). The Cascade Mountains divide Oregon into western and eastern parts with contrasting climates and touch all of the physiographic regions in the state except the Coast Range, Blue Mountains and Owyhee Uplands (Figure 2).

The Western Cascades consist primarily of Eocene to late Miocene (40 to $10 \mathrm{my}$ old) basalts with subordinate andesites and dacites (Priest, 1990). The Paleogene sedimentary sequence in the Western Cascades includes terrestrial pyroclastics of the Eocene Colestin Formation and marine sands and silts of the late Eocene-early Oligocene Eugene Formation (Orr and others, 1992).

The High Cascades consist of volcanic rocks ranging in age from $7.4 \mathrm{Ma}$ to the present (Priest, 1990). Basalts make up as much as $85 \%$ of the Quaternary High 
Cascades by volume (Orr and others, 1992). Locally basaltic andesite, dacite and rhyodacite occur. Virtually all of the High Cascade peaks (stratovolcanoes) are andesites and have an age of Pleistocene or younger (Orr and others, 1992).

\section{Klamath Mountains}

Lying south of the Coast Range, the Klamath Mountains form an elongate northsouth trending belt, three-fifths of which is in northern California and the remainder in southwestern Oregon. The Western Cascades delineate the eastern margin of the Oregon Klamaths. Although the region boasts some deep, narrow canyons and mountain peaks reaching over $2,130 \mathrm{~m}$, for the most part the province exhibits an even relief throughout (Orr and others, 1992).

The Oregon Klamath Mountain province consists of seven thrust-bounded accreted terranes of Devonian to late Jurassic age, with the oldest to the east and the youngest to the west (Wright and Wyld, 1994). Ophiolites make up much of the Klamath terranes (Moores, 1982). The Josephine ophiolite, situated in the central part of this province, is one of the largest and most complete ophiolite sequences in the world (Orr and others, 1992). Basalts, ultramafics (i.e. peridotite) and gabbros in the Klamath ophiolites have been metamorphosed to greenstone and serpentinite. Schists (e.g., Condrey Mountain Schist, Colebrook Schist, May Creek Schist, etc.), formed from shales and igneous rocks, constitute an appreciable portion of the Klamath metamorphic rocks (Orr and others, 1992). The basement terrane rocks are capped by Jurassic-Cretaceous turbidites with deep-sea cherts and volcaniclastics of the Galice, Dothan, Otter Point and other 
formations (Orr and others, 1992). The Klamath Mountain province is characterized by numerous, large granitic intrusives of late Jurassic age (e.g., plutons of Mt. Ashland, Wooley Creek, Greyback, Grants Pass, etc.) (Orr and others, 1992). Only a thin veneer of Tertiary sediments (e.g., the late Eocene, nearshore conglomerates and sands overlain by pyroclastics of the Payne Cliffs Formation) are found in discrete areas of this province along the coastal margin (McKnight, 1984).

\section{Basin and Range}

The elongate Basin and Range physiographic province occupies a vast region of the southwestern United States. The northwest extension of it into southern Oregon is bordered on the west by the Cascades and on the north by the High Lava Plains. As the name implies, the Basin and Range is a series of long and narrow, north-south trending fault-block mountain ranges alternating with broad basins. Most of the province is more than $1,220 \mathrm{~m}$ in elevation, with the highest point $2,940 \mathrm{~m}$ in Steens Mountain (which is situated east of the study area) (Orr and others, 1992).

Late Cenozoic (Miocene through Pleistocene) volcanics constitute the Basin and Range province. Basalts make up the bulk of the rocks with subordinate silica-rich andesites and dacites. In discrete areas pluvial lake sediments, which include locally derived clastics and pyroclastics of Pleistocene age, overlie the volcanics (Orr and others, 1992). 


\section{High Lava Plains}

The roughly rectangular High Lava Plains physiographic province is situated near the geographic center of Oregon. A high lava plateau averages just over $1.6 \mathrm{~km}$ above sea level. The overall topography, as the name implies, is smooth, with moderate relief. Elevation ranges from about 1,220 to $2,430 \mathrm{~m}$ (Orr and others, 1992). The low rainfall in this region has resulted in the lack of deep canyons and gullies as well as a poorly developed network of streams. The High Lava Plains in the study area consist entirely of volcanic rocks of possibly less than two million years in age. Volcanics are predominantly basaltic in composition with subordinate rhyolitic (Orr and others, 1992).

\section{CLIMATE AND VEGETATION}

\section{General Climatology}

Oregon's climate is controlled by topography and the maritime influence of the Pacific Ocean (Johnson and Dart, 1982). The Cascade Range divides Oregon into two climatic zones. The area west of those mountains has a maritime climate, whereas the east has a continental climate.

Oregon's precipitation generally originates from the Pacific Ocean. About $80 \%$ of the annual precipitation in western Oregon occurs between October and March; to a lesser degree the same is true for most of eastern Oregon (Hubbard, 1990). Most winter precipitation occurs as rain in western Oregon and snow in eastern Oregon.

The greatest annual precipitation in Oregon, as much as $365 \mathrm{~cm}$, falls on the western slopes of the Coast Range; these are the first slopes to intercept the eastwardmoving wind from the Pacific Ocean. From the crest of the Coast Range, annual 
precipitation decreases to about $90 \mathrm{~cm}$ in the Willamette Valley, then increases to about $255 \mathrm{~cm}$ near the crest of the Cascade Range (Pacific Northwest River Basins Commission, 1969).

Precipitation decreases east of the Cascade Range. Some parts of eastern Oregon receive less than $25 \mathrm{~cm}$ annually; the higher mountain areas in eastern Oregon, however, receive annual precipitation of as much as $130 \mathrm{~cm}$ (Hubbard, 1990).

In the General Soil Map - State of Oregon (USDA, 1986), climate and vegetation have been broadly described for various landscapes. The following sections are mainly from that work. Information on vegetation has been further augmented by this author's field data.

\section{Coast Range}

With the close maritime influence, the coastal region has the highest average winter temperatures, the coolest summers and the greatest rainfall in Oregon (USDA, 1986). High rainfall and mild temperatures have contributed to a heavy forest with thick vegetation. Native vegetation in the coastal belt is Sitka spruce, western hemlock and shore pine, while that in the uplands is Douglas fir and western hemlock.

Willamette Valley and Foothills of the Coast and Cascade Ranges in Western Oregon

This region has a mild, subhumid climate with cool, moist winters and warm, dry summers. The mean annual precipitation is 65 to $150 \mathrm{~cm}$ (USDA, 1986). Native vegetation is Oregon white oak, Douglas fir, shrubs and grasses. Most of the areas are 
cultivated to crops of grass seed, winter wheat, berries, orchards, grapes, Christmas trees, sweet corn and nursery crops.

\section{Cascade Mountains}

Western Cascades: Depending on the elevations, this area has a mild to cool humid climate with cool to cold wet winters and mild to cool moist summers. The annual precipitation is 150 to $280 \mathrm{~cm}$ (USDA, 1986). Native vegetation is Douglas fir, western hemlock and noble fir.

High Cascades: This region has a cold, humid climate with cold, wet winters and cool, moist summers. Areas at the highest elevations remain snow covered for most of the year. The mean annual precipitation is 75 to $305 \mathrm{~cm}$ (USDA, 1986). Native vegetation is noble fir, grand fir and lodgepole pine.

\section{Klamath Mountains}

Due to the close maritime influence, the western part of the Klamath Mountains has a similar climate and vegetation to that of the Coast Range. In the rest of this province, the area at lower elevations has a mild, subhumid climate with cool, moist winters and warm, dry summers. The mean annual precipitation is 65 to $150 \mathrm{~cm}$ (USDA, 1986). Native vegetation is Douglas fir, ponderosa pine, Pacific madrone, Oregon white oak, shrubs and grasses.

The area at comparatively higher elevations has a cool, subhumid climate with cold, moist winters and cool, dry summers. The mean annual precipitation is 100 to 180 cm (USDA, 1986). Native vegetation is white fir and Douglas fir. 


\section{Basin and Range Province}

The fault-block mountain area has a cold, subhumid climate with cold, moist winters and cool, dry summers. The mean annual precipitation is 30 to $130 \mathrm{~cm}$ (USDA, 1986). Native vegetation is ponderosa pine and white fir or Idaho fescue and quaking aspen.

The basinal area has a mild, subhumid climate with cold, moist winters and warm, dry summers. The mean annual precipitation is 30 to $50 \mathrm{~cm}$ (USDA, 1986). Native vegetation is bluebunch wheatgrass and Idaho fescue. Some areas are cultivated to crops of winter wheat, green peas, alfalfa hay and pasture grasses.

\section{High Lava Plains}

This area has almost similar climate as that of mountainous area of the Basin and Range. The mean annual precipitation is 25 to $50 \mathrm{~cm}$ (USDA, 1986). Native vegetation is ponderosa pine, lodgepole pine and antelope bitterbrush.

\section{SOILS}

\section{Introduction}

Soils form as a result of the interaction of environmental conditions and biological activity on the surface of the weathering rock or transported sediment in the landscape. Jenny (1941) expressed the factor of soil formation in an equation:

$$
\text { Soil }=f(C l, O, R, P, T)
$$

where $\mathrm{f}(\mathrm{)})$ is a function, $\mathrm{Cl}$ is climate (temperature, precipitation), $\mathrm{O}$ is organisms (vegetation and other soil biota), $\mathrm{R}$ is topography (elevation, slope angle, and slope 
orientation), $\mathrm{P}$ is parent material (the nature of minerals) and $\mathrm{T}$ is time. Of these factors, climatic conditions and parent material usually predominate.

Apart from the influence of parent material, soil formation in Oregon is controlled by topography, which in turn influences climate and vegetation. Division of Oregon into two contrasting climatic zones by the Cascade Ranges is also apparent in soil development in the region. In the wetter, maritime climate, mature soils (Alfisols and Ultisols) (see Table 2 for soil orders) have developed in parts of western Oregon, whereas the drier, continental climate of eastern Oregon has slowed soil development resulting in less developed, young soils (Entisols and Inceptisols).

Predominantly Inceptisols, with subordinate Entisols and Spodosols, have developed over the sandy materials of the coastal belt. High rainfall and mild temperatures have contributed to the formation of Alfisols and Ultisols over a large part of the heavily forested Coast Range and Klamath Mountains. Ultisols and Alfisols are also the predominant soil types carpeting the forested foothills of the Cascade Ranges in western Oregon. Parent material for these mature soils came mostly from basaltic rocks. Mollisols characterize the soils developed in the grass-shrub western Oregon interior valleys (USDA, 1986).

Cool to cold climate has influenced the development of predominantly Inceptisols in the forested high mountains which include the High Cascades and the higher elevations of the Western Cascades and Klamath Mountains. In eastern Oregon 
Table 2. Soil Orders within the U. S. Soil Taxonomy (Soil Survey Staff, 1992). Description of the soil orders is after Birkeland (1984). For soil horizon nomenclature, see Figure 4.

\begin{tabular}{|c|c|}
\hline Soil Order & Description \\
\hline Entisols & $\begin{array}{l}\text { Least developed soils, have } \mathrm{A} / \mathrm{C} \text { profile; have no distinct pedogenic horizons within one } \\
\text { meter of the surface. }\end{array}$ \\
\hline Inceptisols & $\begin{array}{l}\text { Usually young soils having one or more pedogenic horizons (commonly indistinct); have } \\
\mathrm{A} / \mathrm{Bw} / \mathrm{C} \text { profile; some are composed of very stable minerals and may be old; many are } \\
\text { formed in pyroclastic materials; found in most environments except those that are very dry. }\end{array}$ \\
\hline Aridisols & $\begin{array}{l}\text { Have an aridic moisture regime (dry }>50 \% \text { of the year) and no mollic epipedon; have a thin } \\
\text { or light-colored surface horizon (ochric epipedon). }\end{array}$ \\
\hline Mollisols & $\begin{array}{l}\text { Have a mollic epipedon (dark-colored, friable surface horizon that is generally }>18 \mathrm{~cm} \text { thick } \\
\text { and contains at least } 1 \% \text { organic matter; has a base saturation of }>50 \% \text { ); mostly developed } \\
\text { under grass vegetation. }\end{array}$ \\
\hline Alfisols & $\begin{array}{l}\text { Intermediate in many properties between Mollisols and Ultisols; have an argillic horizon (Bt) } \\
\text { and commonly do not have dark surface horizons; have a base saturation of }>35 \% \text { which is } \\
\text { less than that of Mollisols but more than that of Ultisols; developed soils. }\end{array}$ \\
\hline Spodosols & $\begin{array}{l}\text { Have a spodic horizon (a mineral soil horizon commonly below the surface); this horizon is } \\
\text { either a Bs (illuvial accumulation of mainly sesquioxides* ) or a Bh horizon (illuvial } \\
\text { concentration of mainly organic matter) or a Bhs horizon (illuvial accumulation of both } \\
\text { organic matter and sesquioxides as organic matter-sesquioxide complexes);mostly developed } \\
\text { under forest vegetation and in sandy materials; may or may not have an overlying E horizon. }\end{array}$ \\
\hline Ultisols & $\begin{array}{l}\text { Have a Bt horizon with a base saturation of }<35 \% \text {; red; old, well-developed and leached } \\
\text { soils. }\end{array}$ \\
\hline Oxisols & 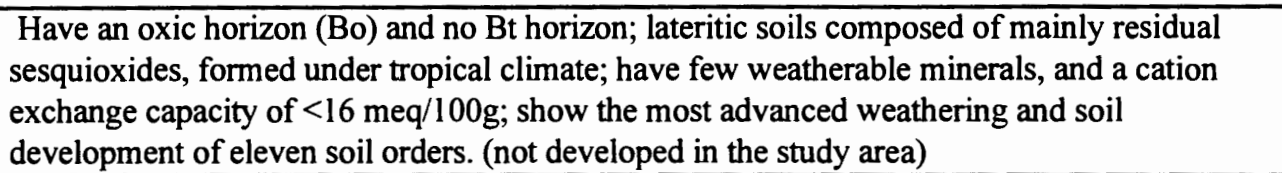 \\
\hline Vertisols & $\begin{array}{l}\text { Clayey soils ( with }>30 \% \text { clay in all horizons) and have deep, wide surface cracks when dry; } \\
\text { appreciable horizon differentiation is not possible because the soils are thoroughly mixed up. }\end{array}$ \\
\hline Andisols & $\begin{array}{l}\text { Volcanic soils that are well drained; have }>60 \% \text { pyroclastics, }<25 \% \text { organic matter, and bulk } \\
\text { density }<0.85 \text {. }\end{array}$ \\
\hline Histosols & $\begin{array}{l}\text { Have a histic epipedon (an organic surface horizon underlain by mineral soil; saturated with } \\
\text { water; generally } 20-30 \mathrm{~cm} \text { thick; contain }>30 \% \text { organic matter to a depth of } 40 \mathrm{~cm} \text { ); Bog } \\
\text { soils. }\end{array}$ \\
\hline
\end{tabular}

semiarid and cool to cold climate has slowed soil development resulting in the formation of predominantly Inceptisols and Entisols on mountainous lava and pumice plateaus, while Mollisols are developed in the grass-shrub valleys and bedrock hills and plateaus (USDA, 1986). Soil survey reports (published by USDA, Soil Conservation Service) are 
available from only three (Curry, Josephine and southern part of Klamath) of the nine counties covered in the present study (Buzzard and Bowlsby,1970; Borine, 1983;

Cahoon, 1985). The General Soil Map - State of Oregon (USDA, 1986) provides an overall view of soil development in the region. In this map (Figure 3) soil groups are identified by the letters A, B, C, D, etc. and are based on a combination of soil forming factors. The soil map units (Table 3) are identified by a two-character symbol; the first character indicates the group it occurs in and the second character is an arabic number (examples, A1, M12). Each map unit represents a natural landscape. The map unit is identified by one, two and/or three of the major soil series on that landscape. Each soil series has unique characteristics that distinguish it from all other soil series. These characteristics, such as soil moisture and temperature regimes (Table 4), are used in classifying each soil within Soil Taxonomy (Soil Survey Staff, 1975). The following section has been extracted mainly from this map (USDA, 1986) and its accompanying information.

\section{SOILS OF SOUTHWEST OREGON Coastal Belt and Coast Range}

In the coastal belt, udic isomesic soils (for soil moisture and temperature regimes see Table 4) are mainly Inceptisols. Entisols and Spodosols along with the dominant Inceptisols occur in A1 (see Table 3 for all the soil map units), while A2 consists entirely of Inceptisols. Of the udic mesic soils covering the heavily forested Coast Range, Inceptisols (C1) are again the dominant type, although Ultisols (C3) are developed over a large area. 

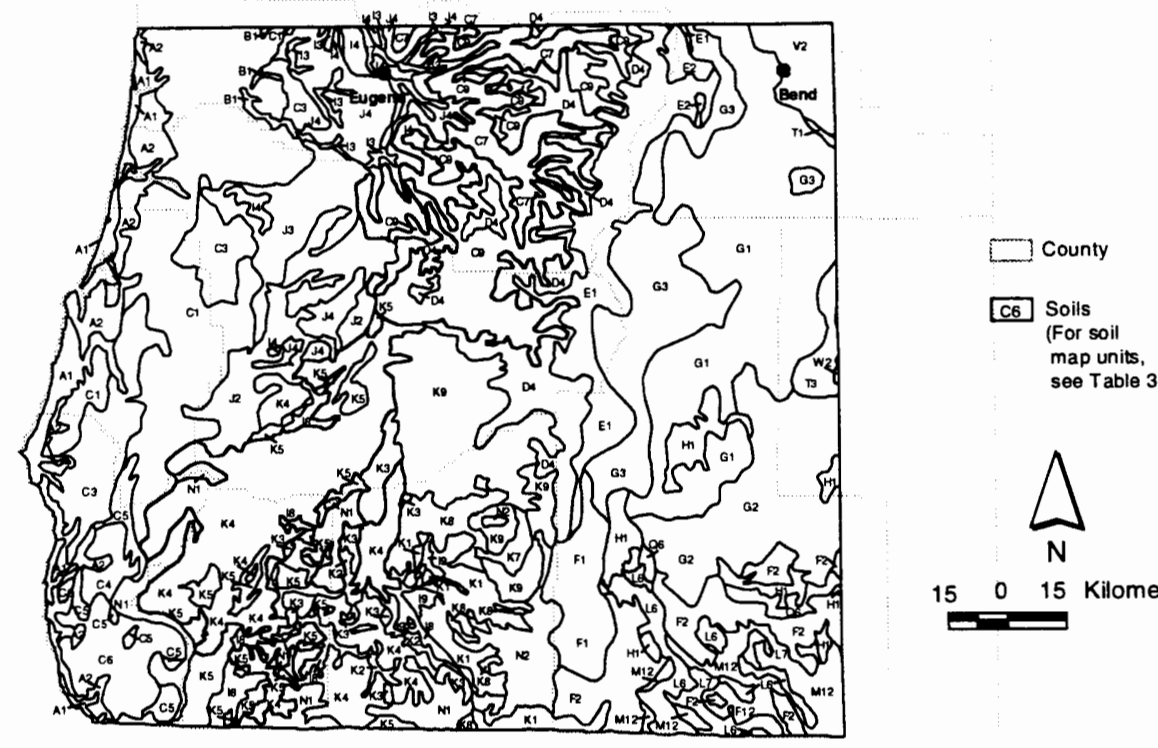

$15 \quad 0 \quad 15$ Kilometers

Figure 3. General soil map of Southwest Oregon (USDA, 1986) 
Table 3. Soil Map Units in Figure 3 (USDA, 1986)

\begin{tabular}{|c|c|c|}
\hline $\begin{array}{l}\text { Soil Map } \\
\text { Unit }\end{array}$ & Soil Order(s) & Physiographic Province(s) \\
\hline Al & Inceptisols (dominant); Entisols; Inceptisols & Coastal Plain \\
\hline$\overline{\mathrm{A} 2}$ & Inceptisols & Coastal Plain \\
\hline$\overline{\mathrm{B} 1}$ & Alfisols; Inceptisols & Willamette Valley \\
\hline$\overline{\mathrm{Cl}}$ & Inceptisols & Coast Range; Klamath Mountains \\
\hline $\mathrm{C} 3$ & Ultisols (dominant); Inceptisols & Coast Range; Klamath Mountains \\
\hline$\overline{\mathrm{C} 4}$ & Inceptisols & Coast Range; Klamath Mountains \\
\hline$\overline{\mathrm{C} 5}$ & Inceptisols; Alfisols & Coast Range; Klamath Mountains \\
\hline C6 & Ultisols & Coast Range; Klamath Mountains \\
\hline$\overline{\mathrm{C} 7}$ & Inceptisols (dominant); Ultisols & Cascade Mountains \\
\hline C9 & Inceptisols & Cascade Mountains \\
\hline$\overline{\mathrm{D} 4}$ & Inceptisols & Cascade Mountains \\
\hline E1 & Inceptisols (dominant); Spodosols & Cascade Mountains \\
\hline$\overline{\mathrm{E} 2}$ & Entisols; Rock Outcrop & Cascade Mountains \\
\hline$\overline{F l}$ & Inceptisols & Basin \& Range \\
\hline F2 & Mollisols & Basin \& Range \\
\hline G1 & Entisols & Basin \& Range; High Lava Plains \\
\hline G2 & Entisols & Basin \& Range; High Lava Plains \\
\hline G3 & Entisols (dominant); Spodosols & Basin \& Range; High Lava Plains \\
\hline H1 & Inceptisols (dominant); Histosols & Basin \& Range \\
\hline 13 & Mollisols (dominant); Vertisols & Willamette Valley \\
\hline$\overline{14}$ & Mollisols & Willamette Valley \\
\hline I8 & Mollisols & Willamette Valley \\
\hline 19 & Mollisols (dominant); Vertisols; Inceptisols & Willamette Valley \\
\hline $\mathrm{J} 2$ & Alfisols & Uplands of Western Oregon \\
\hline $\mathrm{J} 3$ & Ultisols & Uplands of Western Oregon \\
\hline $\mathrm{J} 4$ & Ultisols (dominant); Mollisols & Uplands of Western Oregon \\
\hline $\mathrm{Kl}$ & Mollisols (dominant); Vertisols & Klamath Mountains \\
\hline $\mathrm{K} 2$ & Alfisols & Klamath Mountains \\
\hline $\mathrm{K} 3$ & Inceptisols & Klamath Mountains \\
\hline $\mathrm{K} 4$ & Ultisols, Alfisols; Inceptisols & Klamath Mountains \\
\hline$\overline{\mathrm{K} 5}$ & Alfisols (dominant), Inceptisols & Klamath Mountains \\
\hline $\mathrm{K} 7$ & Alfisols & Klamath Mountains \\
\hline K8 & Mollisols & Klamath Mountains \\
\hline K9 & Inceptisols (dominant); Alfisols & Klamath Mountains \\
\hline L6 & Mollisols (dominant); Inceptisols; Aridisols & Basin \& Range \\
\hline L7 & Mollisols & Basin \& Range \\
\hline M12 & Mollisols & Basin \& Range \\
\hline Nl & Inceptisols & Klamath Mountains \\
\hline $\mathrm{N} 2$ & Mollisols (dominant); Inceptisols & Klamath Mountains \\
\hline$\overline{\text { Q6 }}$ & Mollisols (dominant); Inceptisols & Basin \& Range \\
\hline$\frac{\mathrm{T} l}{\mathrm{~T} l}$ & Mollisols & High Lava Plains \\
\hline T3 & Mollisols & High Lava Plains \\
\hline V2 & Mollisols; Aridisols; Entisols & High Lava Plains \\
\hline W2 & Aridisols (dominant); Entisols & High Lava Plains \\
\hline
\end{tabular}


Table 4. Soil Moisture and Temperature Regimes of Southwest Oregon (USDA, 1986).

\begin{tabular}{|l|l|}
\hline Soil Moisture Regimes & \\
\hline Aquic Moisture Regime & $\begin{array}{l}\text { Soils with aquic moisture regime are saturated with water during most of } \\
\text { the year; are local, related to topographic low. }\end{array}$ \\
\hline $\begin{array}{l}\text { Aridic (or Torric) Moisture } \\
\text { Regime }\end{array}$ & $\begin{array}{l}\text { Soils with aridic moisture regime are dry for }>50 \% \text { of the year or are } \\
\text { never moist for }>90 \text { days in a row; are found in the driest part of eastern } \\
\text { Oregon. }\end{array}$ \\
\hline Udic Moisture Regime & $\begin{array}{l}\text { Soils with udic moisture regime are generally moist throughout the year; } \\
\text { are found in the Coast and Cascade Ranges having the highest } \\
\text { precipitation. }\end{array}$ \\
\hline Xeric Moisture Regime & $\begin{array}{l}\text { Soils with xeric moisture regime are in western and eastern Oregon } \\
\text { having distinct dry summers and moist winters; this moisture regime has } \\
\text { a shorter dry period during the summer (about } 60 \text { days) than does the } \\
\text { aridic moisture regime. }\end{array}$ \\
\hline $\begin{array}{l}\text { Soil Temperature Regimes } \\
\text { Regime }\end{array}$ & $\begin{array}{l}\text { has a mean annual soil temperature between } 0^{\circ} \mathrm{C} \text { and } 8^{\circ} \mathrm{C} \text {; has }>5^{\circ} \mathrm{C} \\
\text { difference between mean summer and mean winter soil temperature at } \\
50 \mathrm{~cm} \text { depth; has the mean summer soil temperature }<8^{\circ} \mathrm{C} .\end{array}$ \\
\hline $\begin{array}{l}\text { Frigid Soil Temperature } \\
\text { Regime }\end{array}$ & $\begin{array}{l}\text { has a mean annual soil temperature between } 0^{\circ} \mathrm{C} \text { and } 8^{\circ} \mathrm{C} \text {; has }>5^{\circ} \mathrm{C} \\
\text { difference between mean summer and mean winter soil temperature at } \\
50 \mathrm{~cm} \text { depth; has the mean summer soil temperature }>8^{\circ} \mathrm{C} .\end{array}$ \\
\hline $\begin{array}{l}\text { Mesic Soil Temperature } \\
\text { Regime }\end{array}$ & $\begin{array}{l}\text { has a mean annual soil temperature between } 8^{\circ} \mathrm{C} \text { and } 15^{\circ} \mathrm{C} \text {; has }>5^{\circ} \mathrm{C} \\
\text { difference between mean summer and mean winter soil temperature at } \\
50 \mathrm{~cm} \text { depth. }\end{array}$ \\
\hline $\begin{array}{l}\text { Isomesic Soil Temperature } \\
\text { Regime }\end{array}$ & $\begin{array}{l}\text { is the same as mesic except that it has }<5^{\circ} \mathrm{C} \text { difference between mean } \\
\text { summer and mean winter soil temperature. }\end{array}$ \\
\hline
\end{tabular}

\section{Terraces and Floodplains of the Willamette and Other Western Oregon Interior Valleys}

The xeric mesic soils developed on the grass-shrub lands of the interior valleys of western Oregon are predominantly Mollisols. The units I4 and I8 consist entirely of Mollisols, while I3 and I9 are essentially Mollisols with subordinate Vertisols and Inceptisols. 
Foothills of the Coast and Cascade Ranges in Western Oregon

The mature xeric mesic soils carpet the forested foothills of the Coast and Cascade Ranges in western Oregon. The units J2 and J3 consist entirely of Alfisols and Ultisols, respectively, while $\mathrm{J} 4$ is mainly Ultisols with subordinate Mollisols.

\section{Cascade Mountains}

The udic mesic soils developed in steep, heavily forested terrain of the Western Cascades are almost entirely Inceptisols (C7, C9). The unit C7 shows some Ultisol development along the western margin of this physiographic province. Inceptisols (D4) entirely make up the udic, frigid and cryic soils developed on the high mountains of the Western Cascades. In the High Cascades the udic, cryic soils consist mainly of Inceptisols with subordinate Spodosols (E1). Soils of the High Cascades and the high mountains of the Western Cascades have been reclassified as mainly Andisols with subordinate Inceptisols and Spodosols (Birkeland, 1984).

\section{Klamath Mountains}

In the western Klamath Mountains, including granitic and serpentine areas, udic mesic soils consist mainly of Ultisols $(\mathrm{C} 3, \mathrm{C} 6)$ with sporadic developments of Inceptisols $(\mathrm{Cl}, \mathrm{C} 4, \mathrm{C} 5)$. The xeric frigid soils of high mountainous areas of the Klamaths are dominantly Mollisols with subordinate Inceptisols (N2) in the east, while in the south and west they are entirely Inceptisols (N1). The rest of the Klamaths is covered by xeric mesic soils. These include Alfisols and Ultisols (K2, K4, K5) with subordinate Inceptisols $(\mathrm{K} 3)$ in the forested areas, and Mollisols $(\mathrm{K} 1, \mathrm{~K} 8)$ and Inceptisols (K9) in the eastern grass-shrub land. 


\section{Basin and Range/High Lava Plains}

Wide varieties of soils are observed in the different physiographic units of the Basin and Range province. The xeric, cryic soils of mountainous lava plateaus over bedrock and volcanic ash include Inceptisols (F1) and Mollisols (F2). The xeric, cryic soils on pumice plateaus almost entirely consist of Entisols (G1, G2, G3). These soils continue in the western part of the High Lava Plains which is included in the study area. Only unit G3 shows the incipient development of Spodosols in some places. The aquic, frigid and cryic soils of valleys formed in pumice or organic deposits consist mainly of Inceptisols with subordinate Histosols (H1). Inceptisols and Entisols of the Basin and Range province have been reclassified as mainly Andisols (Birkeland, 1984). In the southern part of the province exhibiting the characteristic fault-block mountain terrain, the xeric mesic soils on floodplains and terraces of valleys are predominantly Mollisols with subordinate Inceptisols and Aridisols (L6, L7). The xeric mesic and xeric frigid soils on grass-shrub bedrock hills and plateaus are entirely Mollisols (M12) and predominantly Mollisols with some Alfisols (Q6), respectively. 


\section{CHAPTER III: PREVIOUS WORK ON THE DISTRIBUTION OF HEAVY METALS AND TRACE ELEMENTS IN SOIL}

Initially, the metal composition of a soil will be that of its geologic parent material. With time composition will diverge progressively under the influence of pedogenic processes which in turn are determined by vegetation, topography and climate.

Divergence will be manifested initially by redistribution within fabric, then between profile horizons, and finally between soils in a landscape (Jenkins and Jones, 1980). The master soil profile horizons are shown in Figure 4.

Metals occur as trace constituents of primary minerals in igneous rocks. In general, $\mathrm{Co}, \mathrm{Mn}, \mathrm{Zn}, \mathrm{Cr}, \mathrm{Ni}, \mathrm{V}$ and $\mathrm{Cu}$ are associated with relatively unstable ferromagnesian minerals concentrated in ultramafic and mafic igneous rocks. Felsic rocks, on the contrary, are poor in these metals and rich in $\mathrm{Li}, \mathrm{Be}, \mathrm{Ba}$ and $\mathrm{Sr}$ (Jenkins and Jones, 1980; Aubert and Pinta, 1980).

The metal concentrations in sedimentary rocks are dependent upon the mineralogy and adsorptive properties of the sedimentary material, the matrix and the concentrations of metals in the water in which the sediments were deposited. In general, clays and shales tend to have relatively high concentrations of many metals due to their ability to adsorb metal ions. Black (or bituminous) shales contain high concentrations of several metals and metalloids, including $\mathrm{Ag}, \mathrm{As}, \mathrm{Cd}, \mathrm{Cu}, \mathrm{Pb}, \mathrm{Mo}, \mathrm{U}, \mathrm{V}$ and $\mathrm{Zn}$ (Rose and others, 1979). Sandstones usually contain only low concentrations of most elements because 
$\begin{array}{ll}\text { US Soil Taxonomy } & \text { US Soil Taxonomy } \\ \text { (post 1982) } & \text { (pre 1982) } \\ \text { (Guthrie and Witty, 1982) } & \end{array}$

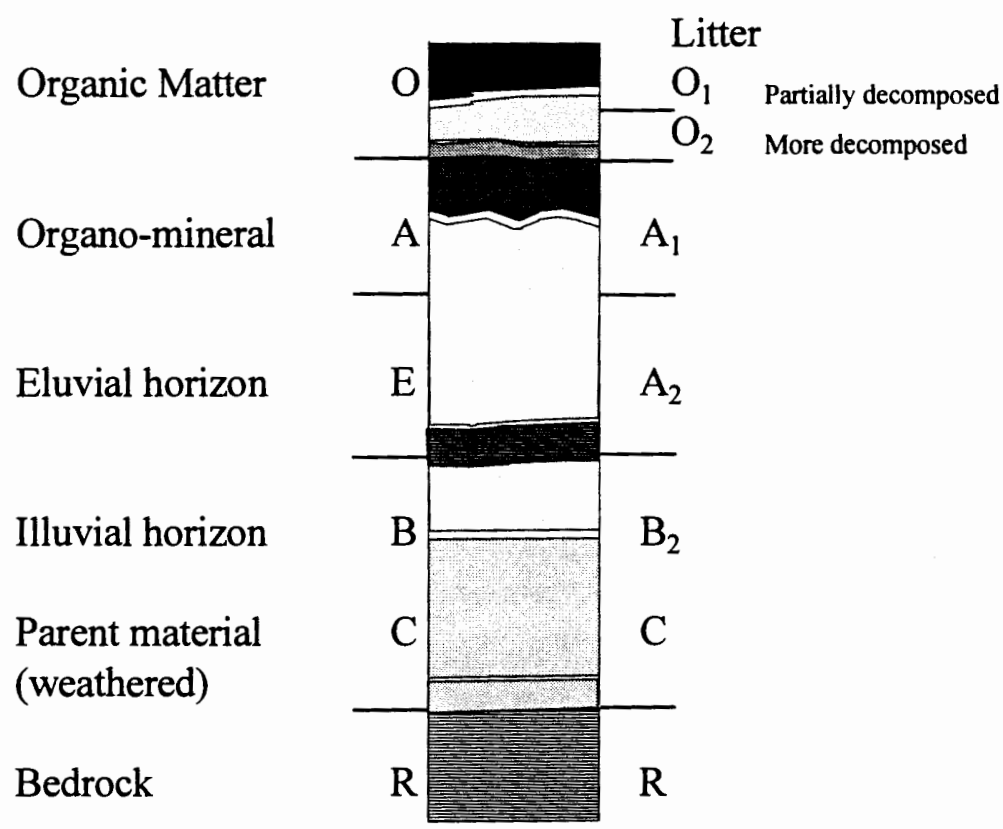

(Not all of these horizons are present in every profile)

Figure 4. A diagrammatic soil profile with US Soil Taxonomy Horizon nomenclature, modified after Alloway (1993b); description after Birkeland (1984).

The $\mathrm{O}$ and $\mathrm{A}$ horizons that are relatively high in organic matter occur at or near the surface. The only difference between the two is the amount of organic matter present. The $O$ horizon consists of mainly undecomposed organic matter. The A horizon is dominated by mineral fraction but contains decomposed organics. In some environments, eluviation of coatings of clay and free Fe oxides at the base of an $\mathrm{O}$ or $\mathrm{A}$ horizon produces the light colored $\mathrm{E}$ horizon; common near the surface of Spodosols, or in upper Alfisol and Uitisol profiles. The $\mathrm{B}$ horizon underlies an $\mathrm{O}, \mathrm{A}$, or $\mathrm{E}$ horizon and overlies the parent material. Several kinds of $B$ horizons are recognized, some based on the kinds of materials illuviated into them, others on residual concentrations of materials. For examples, Bw (development of color or structure with little or no apparent illuvial accumulation of material; common in Inceptisols); $\mathrm{Bt}$ (accumulation of silicate clay that has either formed in situ or is illuvial; hence it will have more clay than the assumed parent material and/or the overlying horizon). The $C$ horizon represents parent material from which the soil formed or is presumed to have formed. It lacks properties of A and B horizons, but includes materials in various stages of weathering. The $\mathrm{R}$ horizon is consolidated bedrock underlying soil. 
they consist mainly of quartz grains which have few trace constituents and little ability to adsorb metals.

The effects of metamorphism on metal distribution have not been studied.

Metamorphism in most instances appears to be isochemical (Jenkins and Jones, 1980) and so should involve no marked changes in total metal content from the rocks that were present before the metamorphism.

In soils, there is a positive relationship between metal content and that of argillaceous materials and humus. Even metals which are found in very low quantities, such as Mo and Se have their highest contents in very humiferous and heavy-textured soils (Aubert and Pinta, 1980). Within the soil profile, $\mathrm{Ag}, \mathrm{As}, \mathrm{Cd}, \mathrm{Cu}, \mathrm{Hg}, \mathrm{Pb}, \mathrm{Sb}$ and $\mathrm{Zn}$ are usually found concentrated in the surface horizons as a result of cycling through vegetation, atmospheric deposition and adsorption by the soil organic matter (Alloway, 1993b). The metals found concentrated in the lower horizons of the soil profile include $\mathrm{Al}, \mathrm{Fe}, \mathrm{Mg}, \mathrm{Ni}$ and $\mathrm{V}$, which tend to be associated with accumulations of translocated clays and hydrous oxides (Bowen, 1979). However, recently polluted soils often have higher contents of the pollutant metals in the topsoil because the pedogenic processes have not been operating long enough to effect a redistribution within the profile (Alloway, 1993b).

The solubility of metals in soil has great significance in their migration. Generally, in soils formed under a cool and humid climate, the leaching of metals downward through the profiles is greater than their accumulation, unless there is a high input of 
these metals into the soils. Impoverishment of soils in metals is due mainly to their mobility downward with percolating waters through the profiles of freely drained acid soils and also to metal uptake by plants. In acid soils (with $\mathrm{pH}$ below 6), several metals, such as $\mathrm{Zn}, \mathrm{Mn}, \mathrm{Ni}, \mathrm{Cu}, \mathrm{Fe}, \mathrm{Co}$ and $\mathrm{B}$, are easily leached. These metals, however, are likely to form quite stable compounds if the $\mathrm{pH}$ of the soil rises above 7 (Kabata-Pendias and Pendias, 1984). Other metals, such as Mo and Se, are mobilized in alkaline soils, while in acid soils they become almost insoluble (Jones and others, 1993).

Apart from being influenced by parent material, metal concentrations are highest in fine-textured soils rich in humus and having a neutral or alkaline $\mathrm{pH}$, for example, Mollisols and Vertisols of semiarid regions. Distribution of individual metals of interest in soils are briefly described alphabetically in Appendix 1. 


\section{CHAPTER IV: METHODOLOGY}

This chapter presents the procedures used to collect and process soil samples and the laboratory methods used to determine metal concentrations and soil-solution $\mathrm{pH}$. The analytical precision of laboratory determinations, metal variability in field duplicates (i.e. $\mathrm{A} 1 / \mathrm{A} 2$ and $\mathrm{B} 1 / \mathrm{B} 2$ sample pairs from the same pit) and statistical comparison between the $\mathrm{A}$ and $\mathrm{B}$ horizon values are also discussed.

\section{FIELD METHODS}

Soil sampling was based on geologic units. This is a reconnaissance study, so it is assumed that soils developed on the same geologic unit have similar metal chemistries. Samples were collected from two to five sites located on each major geologic unit in southwest Oregon of the geologic map of Oregon (1:500,000) (Walker and MacLeod, 1991). Rare, small units were sampled only once. If a site had abundant eolian sediment in the soil (i.e. ash) that was not related to the mapped bedrock unit, we changed the mapping unit name to reflect the eolian parent material. A total of 71 geologic units have been covered in this study (Appendix 2).

For the purpose of determining the background concentration of metals in soils, care was taken to sample soils in uncontaminated sites. Accordingly, sampling sites were selected in remote areas to avoid contamination from any possible anthropogenic source. Effort was also taken to excavate pits in undisturbed soils (as evidenced, for example, by nearby old trees) to get the natural distribution of metals in the soil profiles. 
Samples from 118 sites have been used in this study. Samples from 103 sites were collected by Bill Douglas and Scott Burns in 1994-95 for a radionuclide investigation of soils of southwest Oregon (Scott Burns, personal communication, 1995). Samples from the other 15 sites (R1-R15) were collected by Scott Burns and the author in 1995. Figure 5 shows location of the sampling sites.

The method used at all sites was to first examine the area and then choose a suitable, undisturbed location. Detailed location and elevation of the site were noted from a topographic map. The estimated slope angle, vegetation and drainage of the site were also noted. Then a soil pit was dug by a non-rusty and non-colored carbon steel spade.

Once the pit was excavated, the soils underwent preliminary investigation. This involved the visual examination of the profile, checking for horizonation, depth of development and type of parent material. A description of the profile was made following standard procedure (Soil Survey Staff, 1993), noting soil color, texture and structure. Photographs were taken of the site and profile. The moist soil color was checked using the Munsell color charts (Munsell Color Company Inc., 1992 ). The field textural analysis using fingers was done to see how developed the soil was (Birkeland, 1984), and this also helped to estimate the percent of clay present in each horizon. Next, the horizons were named and their depth was measured.

The next step was to collect samples for laboratory analysis. Four homogeneous samples were collected from the walls of the soil pit: two from the A horizon and two 


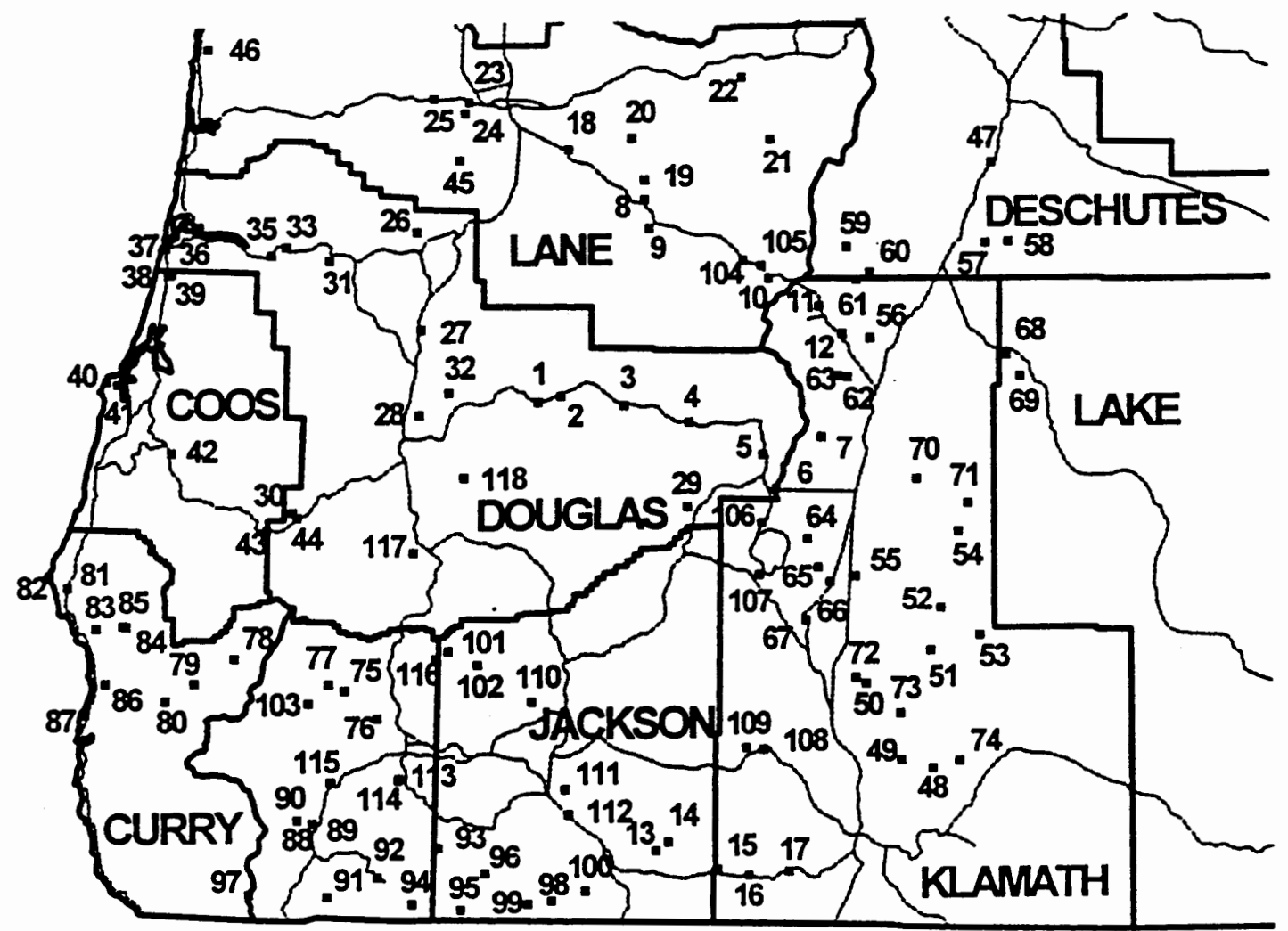

JOSEPHINEX
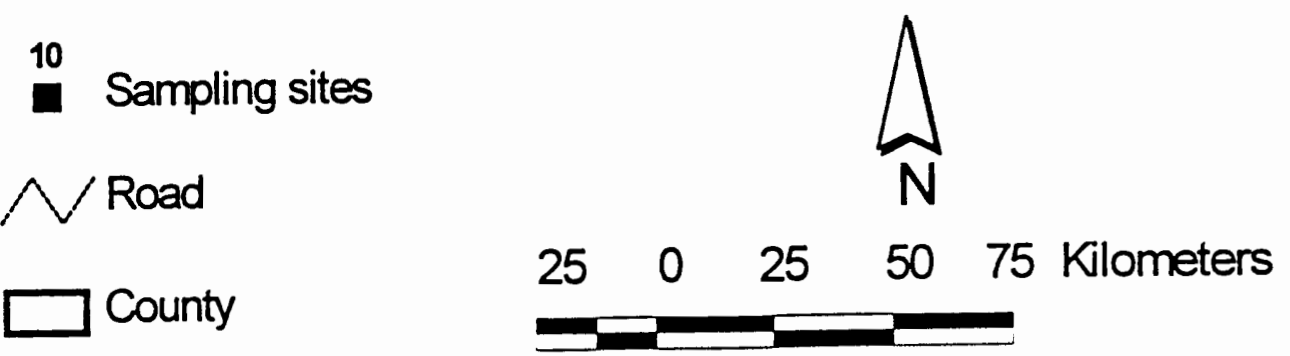

Figure 5. Location of sampling sites in Southwest Oregon (for detail of sampling site locations, see Appendix 3) 
from the B horizon. The Al sample was collected from the wall of the pit where the profile was described, while the A2 sample was taken from the opposite side. The B2 sample was taken from a lower part of the B horizon than that of B1, and both the depths were noted. The sample designation gives first site hyphenated by soil horizon and number of sample taken (for example, LM1-A1 denotes a sample collected at site LM1, from soil horizon A and \# 1 sample ). About 1000 grams of sample were collected each time in a polyethylene bag, zipped and labeled on the outside of the bag. The final step in the procedure was to note any special feature of the soils and/or of the site. Site characteristics and soil descriptions are given in Appendices 3 and 4.

\section{LABORATORY METHODS}

\section{Determination of Soil-Solution $\mathrm{pH}$}

Soil $\mathrm{pH}$ was determined using a Chemtrix $41100 \mathrm{pH}$ meter with a Whatman $\mathrm{Ag} / \mathrm{AgCl}$ electrode following the U.S. Department of Agriculture method \# 8C1a (USDA, 1972). A 1:1 solution by weight of soil to water (10 gm of dried soil to $10 \mathrm{ml}$ of distilled water) was made and was allowed to equilibrate for 30 minutes, after which the solution was mixed and the $\mathrm{pH}$ measured. For each site, $\mathrm{pH}$ values were found for two samples from $\mathrm{A}$ horizon (A1 and $\mathrm{A} 2$ ) and for two samples from $\mathrm{B}$ horizon (B1 and B2). An average of two readings gave a more representative $\mathrm{pH}$ value for the horizon. Soil $\mathrm{pH}$ controls solubility and, in turn, migration of metals in soil. 


\section{Drying and Grinding Samples}

Soil samples were spread on newspaper and dried at room temperature. The airdried soil was passed through an aluminum sieve with a $2 \mathrm{~mm}$ mesh (USA standard sieve size \#10). Particles larger than $2 \mathrm{~mm}$ were discarded at this stage. Next, about $30 \mathrm{gm}$ of homogenized and less than $2 \mathrm{~mm}$ soil was taken in an acid-washed beaker and oven-dried at $60^{\circ} \mathrm{C}$ for 24 hours, followed by cooling in a desiccator. Ten percent of samples were oven-dried in duplicate; the duplicates were selected at random. These duplicates were analyzed for quality assurance. A plastic spoon was used while handling the samples.

A ceramic sealed grinder was used for grinding samples. Between samples, the inside of the grinder was cleaned using the standard DEQ method of first grinding and discarding clean quartzitic sand, followed by grinding and discarding a little of the ovendried sample (George Di Domenico, personal communication, 1995). Blowing air and clean tissue paper were used to wipe out discarded materials. In the case of hematitic samples, the sticky iron-stains were first removed by washing with warm water and/or wiping out with isopropyl alcohol before grinding sand. All these measures minimized carryover contamination between samples. Finally, an aliquot of the sample was ground, poured on a wax weighing paper and transferred into a clean snap vial. In most cases, two minutes of grinding was sufficient to completely homogenize the sample. The nonhematitic samples were ground first, followed by hematitic ones. Samples from Douglas 
County were the last ones to be ground because of their potential to contaminate other samples with Hg (George Di Domenico, personal communication, 1995).

The total-recoverable method (SW-846, \#3050A, U.S. Environmental Protection Agency, 1994) was used to digest samples. The procedure involves a mixture of concentrated nitric and hydrochloric acids that removes most material bound by surficial coatings on soil particles but removes less than $95 \%$ of the metals from the mineral matrix. This method is commonly used by regulatory agencies (like the DEQ) to determine the amount of material that ultimately may be bioavailable. Concentrations of $\mathrm{Hg}$ in the extracts were determined by cold-vapor atomic absorption spectroscopy (CVAAS). The remaining 25 metals were determined by inductively-coupled plasma atomic emission spectroscopy (ICPAES). All metal analyses were performed in accordance with a U.S. Environmental Protection Agency (EPA)/DEQ approved method (SW-846, \#6010A, U.S. Environmenal Protection Agency, 1994).

Acid Digestion of Samples for ICPAES Analysis

All glassware used was acid-washed (in $20 \% \mathrm{HNO}_{3}$ ), triple rinsed in de-ionized (DI) water and dried. Reagents were trace metals grade and concentrated $(\sim 70 \%) \mathrm{HNO}_{3}$, $\mathrm{HCl}$, and ultrapure $30 \% \mathrm{H}_{2} \mathrm{O}_{2}$. For all purposes, no water other than DI water supplied by the DEQ lab was used. To assess the quality of data, the following standard EPA/DEQ quality assurance procedures were used (Donna Larson, personal communication, 1996). 
(1) Approximately $10 \%$ of samples were digested in duplicate. The percent differences between laboratory results for duplicate samples determine the precision of the analysis.

(2) Approximately $10 \%$ of samples were spiked with a specific amount of a solution containing known concentrations of those elements which were to be determined in the samples. Samples were spiked at random. One blank (reagents only) was also spiked per sample set. Spike solution was added before digestion. The spike recovery results indicate the accuracy of the analysis. Furthermore, the recovery results of a spiked blank show if any contaminants are present in any of the reagents or in the spike solution itself.

(3) Two reference materials (\#2711 from the U.S. National Institute of Standards and Technology, and the EPA's reference control/reference assurance study 22), having known sets of values, were digested. The recovered amounts when compared to the known amounts provide checks of the accuracy of the analysis.

Exactly one gram of re-homogenized ground sample was placed in a labeled Phillips flask and approximately $5 \mathrm{ml} \mathrm{DI}$ water was added to it. One blank (approximately $6 \mathrm{ml}$ DI water only) was digested per sample set. When spiking samples, the $5 \mathrm{ml} \mathrm{DI} \mathrm{water} \mathrm{volume} \mathrm{was} \mathrm{reduced} \mathrm{by} \mathrm{the} \mathrm{volume} \mathrm{of} \mathrm{the} \mathrm{spiking} \mathrm{solution.}$ Usually a set of 20 samples was digested at a time.

The digestion procedure involved heating (refluxing and not boiling) a sample on a $150^{\circ} \mathrm{C}$ hot plate three times (for a period of 10 minutes, 30 minutes and two hours), each 
time adding $5 \mathrm{ml} \mathrm{HNO}_{3}$ to it. Next, the sample was treated with $3 \mathrm{ml} \mathrm{H}_{2} \mathrm{O}_{2}$ (any further addition, up to a maximum of $10 \mathrm{ml}$, was always one $\mathrm{ml}$ at a time) for reacting mainly with organic content in the sample. The next step was adding $5 \mathrm{ml} \mathrm{HCl}$ to the sample and refluxing it on hot plate for 15 minutes. Each step in the digestion process was always preceded by cooling the sample to room temperature. Finally, the sample was filtered into a $100 \mathrm{ml}$ volumetric flask and the final volume brought to exactly $100 \mathrm{ml}$ with DI water.

\section{Acid Digestion of Samples For CVAAS Analysis}

Biochemical Oxygen Demand (BOD) bottles used were washed and kiln fired. All acids used $\left(\mathrm{HNO}_{3}, \mathrm{HCl}\right.$ and $\left.\mathrm{H}_{2} \mathrm{SO}_{4}\right)$ were concentrated $(\sim 70 \%)$ and of trace metals grade. For all purposes, only DI water was used. For quality assurance, $20 \%$ of samples were digested in duplicate and with spike (spiking done with a two ppb $\mathrm{Hg}$ solution). For each set of samples, one blank (one ml DI water only), one spiked blank and the EPA/DEQ approved standard reference material \# 2704 (available from the US National Institute of Standards and Technology) were digested.

Approximately two grams of ground and re-homogenized sample was weighed to two places past the decimal in a BOD bottle. Sample number, the corresponding bottle number and weight of the sample were noted. The amount of reference material taken was such that its $\mathrm{Hg}$ value was less than that of the highest calibration standard chosen (i.e. $10.0 \mathrm{ppb} \mathrm{Hg}$ ) while analyzing samples. Usually $\mathrm{Hg}$ concentration in the reference 
material was maintained between 3.5 and $4.5 \mathrm{ppb}$ to keep its absorbance well within the calibration range of the analyzer.

The salient features of the procedure are as follows. To the sample were added $3.75 \mathrm{ml} \mathrm{HCl}$ and $1.25 \mathrm{ml} \mathrm{HNO}_{3}$ and digested in water bath at $95^{\circ} \mathrm{C}$ for 30 minutes. Next, after being cooled to room temperature, $150 \mathrm{ml} \mathrm{DI}$ water, $30 \mathrm{ml} 50 \%-\mathrm{H}_{2} \mathrm{SO}_{4}$ and $10 \mathrm{ml} 4 \%-\mathrm{KMnO}_{4}$ were added to it. If permanganate color dissipated, a little of solid

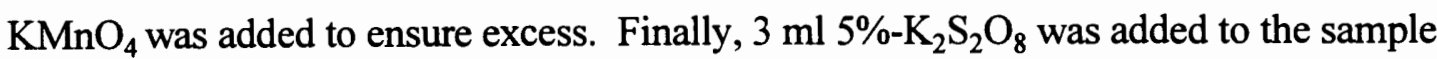
and digested for two hours in water bath at $95^{\circ} \mathrm{C}$.

Sample Analysis

ICPAES Analysis

Twenty five elements were analyzed by the DEQ at their laboratory at Portland State University (PSU) campus using inductively-coupled plasma atomic emission spectroscopy (ICPAES). Each sample was analyzed in triplicate and the average of the three values was reported. The raw data were corrected for wave length interference in the ICPAES by a spreadsheet provided by the DEQ (Donna Larson, written communication, 1996). Since 1 gm of dry sample was taken for analysis, the corrected values multiplied by 100 gave the final concentrations of the metals in $\mathrm{mg} / \mathrm{kg}$ or ppm dry. For samples run in duplicate, the final values were the average of the two.

\section{CVAAS Analysis}

$\mathrm{Hg}$ was analyzed at the DEQ laboratory using a Varian 400 atomic absorption spectroscopy and a Varian Group accessory 76 autosampler. The procedure involved reducing the $\mathrm{Hg}$ ions in the digestion solution to elemental $\mathrm{Hg}$ and vaporizing prior to 
analysis. The QC (quality control), zero (with no $\mathrm{Hg}$ ) and calibration standard solutions were prepared according to method \# 3050A in SW-846 of EPA Manual (1994). The QC was a $2.5 \mathrm{ppb} \mathrm{Hg}$ solution. The $\mathrm{Hg}$ values in the standards were of $0.5,1.0,2.0,5.0$ and $10.0 \mathrm{ppb}$. A solution of $25 \% \mathrm{SnCl}_{2}$ in $20 \% \mathrm{HCl}$ was prepared. This solution was run through the analyzer while analyzing samples to reduce $\mathrm{Hg}$ ions to elemental $\mathrm{Hg}$. Shortly before analysis, $3 \mathrm{ml}$ of $6 \%$ freshly prepared hydroxylamine hydrochloride was added to all standards, controls and samples, and shaken to dissolve $\mathrm{MnO}_{2}$. Samples were ready for analysis when solutions became clear. For each run, all the five standards were analyzed followed by zero and QC before analysis of samples. The absorbance values of standards are indicative of the calibration status of the analyzer and thereby the quality of data. The zero and standard $5.0 \mathrm{ppb} \mathrm{Hg}$ were run after every ten samples. The values of zero between -0.17 and $+0.17 \mathrm{ppb}$ (drift of one-third the reporting limit of 0.5 ppb) and those of the standard 5.0 from 4.5 to 5.5 were judged acceptable. If either of these were found to drift beyond the limits, analysis was restarted from the stage where data was anomalous.

The concentration values were given in ppb dry. Calculations were done as follows (SW- 846, \#3050A, U.S. Environmental Protection Agency, 1994):

(i) $\mathrm{ppm}$ dry $=\left(\mathrm{ppb}^{*} 0.15\right) / \mathrm{wt}$. of sample

(ii) $\%$ spike recovery $=100 *(X-Y) / S$ 
where, $\mathrm{X}=$ measured concentration of $\mathrm{Hg}$ in spiked digest in $\mathrm{ppb}, \mathrm{Y}=$ measured concentration of $\mathrm{Hg}$ in unspiked digest in ppb, and $\mathrm{S}=$ concentration of spike added (2 $\mathrm{ppb})$.

\section{QUALITY OF DATA}

\section{Analytical Precision}

To determine the quality of data obtained from both the ICPAES and CVAAS analyses, percent difference of the laboratory duplicate results, and percent recovery of the spikes and standard reference materials (SRM) were calculated. For duplicates the difference of $+/-10 \%$ is considered good while the difference of $+/-20 \%$ is acceptable. For spikes and SRM $90-110 \%$ recovery is considered good while $80-120 \%$ recovery is accepatable (Donna Larson, written communication, 1996). The quality control/quality assurance data are presented in Appendix 5.

The duplicate results are within $+/-10 \%$ difference in $84 \%$ of the values from ICPAES and in $88 \%$ of the values from CVAAS. The rest of the duplicate values are almost entirely within $+/-20 \%$ difference range. The spike recoveries are within 90 $110 \%$ range in $84 \%$ of the values from ICPAES and in $96 \%$ of the values from CVAAS. The rest of the spike recovery values are within $80-120 \%$ range. The recoveries of standard reference materials are within $90-110 \%$ in all cases.

Metal Variability for Samples $A 1$ vs $A 2$ and $B 1$ vs $B 2$

Samples from six sites (EO24, EO26, EO30, EO32, EO35, and KL7) were chosen to examine metal concentration variability between the $\mathrm{A} 1 / \mathrm{A} 2$ and $\mathrm{B} 1 / \mathrm{B} 2$ sample pairs from the same pit. This was done to see if just one A and one B sample from each pit 
Table 5. Percent differences between metal concentrations determined for sample pairs (A1 and A2) from $A$ horizon.

\begin{tabular}{|c|c|c|c|c|c|c|c|}
\hline Site & EO24 & EO26 & EO30 & EO32 & EO35 & KL7 & \\
\hline Metal & & & & & & & $\begin{array}{c}\text { Average Percent } \\
\text { Difference for Metal }\end{array}$ \\
\hline$A g$ & -- & -- & - & -- & - & - & -- \\
\hline$\overline{M o}$ & $\ldots$ & -- & -- & - & -- & - & - \\
\hline$\overline{C d}$ & - & $\overline{--}$ & -- & $\overline{--}$ & - & -- & -- \\
\hline$\overline{B a}$ & 9.9 & 0.8 & 17.4 & 20.4 & 12.2 & 19.0 & 13.3 \\
\hline$\overline{B e}$ & -- & -- & -- & -- & -- & -- & -- \\
\hline$\overline{N i}$ & 10.1 & 6.8 & 1.6 & 45.2 & 0.9 & 18.2 & 13.8 \\
\hline$\overline{\mathrm{Co}}$ & 17.4 & 21.1 & - & -- & 7.9 & - & -- \\
\hline $\mathrm{Cr}$ & 11.4 & 16.7 & 1.8 & 31.7 & 3.0 & 11.1 & 12.6 \\
\hline $\bar{V}$ & 2.2 & 3.1 & 10.9 & $\overline{16.0}$ & 7.1 & 4.5 & 7.3 \\
\hline$\overline{C u}$ & $\overline{9.5}$ & 5.0 & 9.4 & 1.9 & 2.1 & 34.9 & 10.5 \\
\hline$Z n$ & 3.5 & 11.0 & 3.1 & 10.6 & 16.4 & 6.1 & 8.0 \\
\hline$\overline{F e}$ & 10.4 & 11.8 & 1.6 & 1.8 & 3.4 & 7.2 & 6.0 \\
\hline$M n$ & 12.5 & 3.1 & 11.1 & 20.8 & 23.5 & 39.7 & 18.0 \\
\hline$K$ & 16.0 & 18.5 & 5.7 & 9.0 & 19.2 & 18.2 & 14.0 \\
\hline$\overline{A l}$ & 2.2 & 10.6 & 1.4 & 10.5 & 3.4 & 12.0 & 6.7 \\
\hline$\overline{L i}$ & -- & -- & -- & 4.4 & 8.4 & -- & -- \\
\hline$\overline{C a}$ & $\overline{9.2}$ & 6.2 & 12.5 & 11.6 & $\overline{9.3}$ & 30.9 & 13.3 \\
\hline$\overline{N a}$ & 4.7 & 11.6 & 23.8 & 8.8 & $\overline{6.6}$ & 14.5 & 11.7 \\
\hline$M g$ & 7.1 & 14.0 & 0.1 & 12.4 & 6.6 & 19.8 & 10.0 \\
\hline$L a$ & -- & -- & - & -- & 3.0 & 13.7 & $\cdots$ \\
\hline$S b$ & -- & -- & -- & -- & - & -- & -- \\
\hline$\overline{P b}$ & 15.4 & - & -- & - & - & 12.0 & - \\
\hline$T l$ & -- & -- & - & -- & - & -- & -- \\
\hline$A s$ & -- & - & $\overline{--}$ & $\overline{-}$ & $\overline{--}$ & - & - \\
\hline $\mathrm{Se}$ & -- & -- & -- & -- & -- & -- & -- \\
\hline$H g$ & 22.2 & - & -- & 46.2 & -- & - & -- \\
\hline
\end{tabular}

-- Denotes that concentrations in one or both samples are less than laboratory's minimum reporting level and differences were not computed. The average percent difference of a metal was not calculated if its concentration difference was not computed for any site. 
Table 6. Percent differences between metal concentrations determined for sample pairs (B1 and $B 2)$ from $B$ horizon.

\begin{tabular}{|c|c|c|c|c|c|c|c|}
\hline Site: & EO24 & E026 & $\overline{\text { EO30 }}$ & EO32 & E035 & KL7 & \\
\hline Metal & & & & & & & $\begin{array}{c}\text { Average Percent } \\
\text { Difference for Metal }\end{array}$ \\
\hline$A g$ & -- & -- & - & -- & - & - & -- \\
\hline Mo & -- & -- & - & - & -- & - & - \\
\hline$\overline{C d}$ & - & -- & - & - & - & -- & - \\
\hline$\overline{B a}$ & 16.1 & 23.1 & 3.5 & 21.8 & 8.4 & 1.6 & 12.4 \\
\hline$\overline{B e}$ & -- & -- & -- & - & - & -- & -- \\
\hline$\overline{N i}$ & 2.7 & 5.1 & 3.5 & 13.5 & 3.2 & 2.7 & 5.1 \\
\hline$\overline{C o}$ & 9.0 & 3.2 & 5.0 & 11.6 & 2.7 & -- & $\overline{--}$ \\
\hline$C r$ & 5.3 & $\overline{0.4}$ & 2.5 & 3.6 & 16.9 & 9.4 & 6.4 \\
\hline$V$ & 10.7 & 1.1 & 1.1 & 7.1 & 5.1 & 3.7 & 4.8 \\
\hline$C u$ & 3.6 & 8.5 & 1.4 & 4.3 & 2.6 & 1.0 & 3.6 \\
\hline$\overline{Z n}$ & 5.7 & $\overline{8.4}$ & 7.6 & 6.2 & $\overline{1.4}$ & 10.9 & 6.7 \\
\hline $\mathrm{Fe}$ & 9.7 & 10.6 & 2.9 & 11.5 & 1.3 & 5.7 & 7.0 \\
\hline$M n$ & 18.2 & 11.2 & 9.6 & 10.2 & 17.7 & 13.1 & 13.3 \\
\hline$K$ & 13.6 & 5.8 & 0.6 & 6.0 & 8.3 & 31.6 & 11.0 \\
\hline$\overline{A l}$ & 2.3 & 4.1 & 1.1 & 11.6 & 2.1 & 10.5 & 5.3 \\
\hline$L i$ & 9.8 & -- & -- & 14.0 & 1.9 & 2.1 & -- \\
\hline $\mathrm{Ca}$ & 1.5 & 0.9 & 4.4 & 13.1 & 3.1 & 4.9 & 4.6 \\
\hline $\mathrm{Na}$ & 10.8 & 5.4 & 3.9 & 17.1 & 13.0 & 12.9 & 10.5 \\
\hline$M g$ & 1.6 & 14.8 & 10.4 & 3.2 & 2.2 & 5.3 & 6.3 \\
\hline$L a$ & 1.8 & -- & -- & 17.1 & 0.4 & 14.3 & -- \\
\hline$S b$ & - & -- & - & -- & $=$ & -- & -- \\
\hline$P b$ & -- & -- & -- & -- & -- & -- & - \\
\hline$\overline{T l}$ & -- & -- & - & -- & -- & -- & - \\
\hline$A s$ & - & -- & - & $=$ & - & -- & -- \\
\hline $\mathrm{Se}$ & -- & -- & -- & -- & $\ldots$ & $\cdots$ & - \\
\hline$\overline{H g}$ & -- & - & -- & $-\cdot$ & - & -- & -- \\
\hline
\end{tabular}

-- Denotes that concentrations in one or both samples are less than laboratory's minimum reporting level and differences were not computed. The average percent difference of a metal was not calculated if its concentration difference was not computed for any site. 
could be used to save time and money. The percent difference between laboratory results for the sample pairs (Tables 5 and 6) was calculated by dividing the absolute difference between the two values (ppm) of each metal (see Appendix 6 for metal concentrations data of all sites) by the mean value for the pair and multiplying by 100 (Ames and Prych, 1995). The percent difference for a metal for a site was not calculated if the concentration in one or both samples was less than the laboratory's minimum reporting level.

For sample pairs from the A horizon the range of average differences between metal concentrations is 6 to 18 percent with the overall range of 0.1 to 46.2 percent (Table 5). For sample pairs from the $B$ horizon the range of average differences between metal concentrations is 3.6 to 13.3 percent with the overall range of 0.4 to 31.6 prcent (Table 6).

The DEQ accepts a variability of less than $20 \%$ in sampling (i.e. field duplicates) as well as in analytical results (i.e. laboratory duplicates) (SW-846, \# 6010A, U.S. Environmental Protection Agency, 1994). The range of concentration variability between the $\mathrm{A} 1 / \mathrm{A} 2$ and $\mathrm{B} 1 / \mathrm{B} 2$ couples in Tables 5 and 6 was deemed acceptable within the DEQ's 20\% variability envelope for heavy metals. Therefore, for the additional 112 sites only one sample from each of the A and B horizons was analyzed. Not enough samples were collected for each mapping unit to test variability between pits. 


\section{Comparison Between A and B Horizon Values}

The t-test was done to determine if the concentrations of a metal in the A horizon were statistically different from the B horizon at a site. Each value measured has uncertainties associated with it. Different samples taken from the same site will have different values. The values are expected to fit a normal distribution. It is possible that the $\mathrm{A}$ and $\mathrm{B}$ horizons are statistically different. Each measurement for a metal has a standard deviation associated with it. The t-test is designed to test equalities of the means in two sets of data (Davis, 1986), e.g. measured metal concentrations in the A and B horizons in our case. The variance was calculated for the metal values in A1 and A2, $\mathrm{B} 1$ and $\mathrm{B} 2$ samples from six sites (EO24, EO28, EO30, EO32, EO35 and $\mathrm{KL} 7$ ).

The variance of concentration of a metal in the $A 1$ versus $A 2$ and in the $B 1$ versus B2 samples for individual site was determined by the formula:

$$
s^{2}=\left(X_{1}-\bar{X}\right)^{2}+\left(X_{2}-\bar{X}\right)^{2}
$$

where $\mathrm{s}^{2}$ is the variance, $\mathrm{X}_{1}$ and $\mathrm{X}_{2}$ are the two values, and $\overline{\mathrm{X}}$ is the mean.

The pooled variance for the A and B horizons was computed by taking the sum of all variances and dividing it by the number of variance values minus 1 . The pooled standard deviation for the $\mathrm{A}$ and $\mathrm{B}$ horizons is the square root of the pooled variance.

The t-test was performed by the formula:

$$
t=\left(A_{i}-B_{i}\right) / S p
$$

where $A_{i}$ and $B_{i}$ are the concentration of a metal in the $A$ and $B$ horizons, respectively, and $\mathrm{Sp}$ is the pooled standard deviation. 
The null hypothesis tested by the t-statistic was

$$
H_{0}: A_{i}=B_{i}
$$

A one-tailed level of significance $(\alpha)$ of $5 \%$ and 2-degrees of freedom was used in the t-test. If the null hypothesis was rejected then it was accepted that $A_{i} \neq B_{i}$. For convenience for each metal the critical value for rejecting Ho: $A_{i}=B_{i}$ was calculated by multiplying the t-critical value at $95 \%$ confidence level with the metal's pooled standard deviation for the $\mathrm{A}$ and $\mathrm{B}$ horizons. If $\mathrm{A}_{\mathrm{i}}-\mathrm{B}_{\mathrm{i}}$ was greater than the calculated critical value for that particular metal then Ho: $A_{i}=B_{i}$ was rejected. This critical value for a metal was used to determine if its concentrations in the A and B horizons were statistically different.

The F-test was done to examine the equality of variances of concentration of metals in the A and B horizons (Davis, 1986). The pooled variance for a horizon was computed by taking the sum of all variances and dividing it by the number of variance values minus 1 . The $\mathrm{F}$ test ratio of variances between the two horizons was calculated by

$$
\mathrm{F}=\mathrm{s}_{1}{ }^{2} / \mathrm{s}_{2}{ }^{2}
$$

where $\mathrm{s}_{1}{ }^{2}$ is the larger variance and $\mathrm{s}_{2}{ }^{2}$ is the smaller. The null hypothesis tested was

$$
\text { Ho: } \mathrm{s}_{1}{ }^{2}=\mathrm{s}_{2}^{2}
$$

A one-tailed test with level of significance $(\alpha)$ of $5 \%$ and 4-degrees of freedom for both the variances was used in the testing. If the calculated value of $F$ exceeded the critical value at the $95 \%$ confidence level ( 6.39 for our specific situation) then the null 
hypothesis was rejected. If the null hypothesis is rejected, we can reject the equality of the variances between $\mathrm{A}$ and $\mathrm{B}$.

The results of the F-tests are that $\mathrm{Ca}, \mathrm{Mn}$ and $\mathrm{Zn}$ concentrations display a greater variance in the samples collected from the A horizon than from the B horizon. For the remaining metals we cannot reject the equality of variances of the values in the two horizons.

Minimum Reporting Levels

Table 7 lists the laboratory's minimum reporting levels (in ppm dry) for the metals studied. The values below the minimum reporting levels are listed as "less than the minimum reporting levels" in accordance with the practice of analytical laboratories. For example, all $\mathrm{Ag}$ values less than $1 \mathrm{ppm}$ are listed as $<1$. Appendix 6 lists the acidextractable metal concentrations data (in ppm of dry soil) of all sites. Concentration values of $\mathrm{Hg}$ have two decimal places because the minimum reporting level of the metal is $0.04 \mathrm{ppm}$. The rest of the metal values have been rounded to whole numbers in ppm. Appendix 7 lists the distribution statistics for concentrations (in ppm of dry soil) of metals in soils developed on each geologic unit. 
Table 7. Minimum reporting levels for heavy metals and trace elements in soils in southwest Oregon analyzed by ICPAES ${ }^{1}$ and CVAAS $^{2}$ (from DEQ laboratory, Portland State University campus, Oregon).

\begin{tabular}{|c|c|c|c|}
\hline Metal & $\begin{array}{c}\text { Laboratory Reporting } \\
\text { Limit (in ppm dry soil) }\end{array}$ & Metal & $\begin{array}{c}\text { Laboratory Reporting } \\
\text { Limit (in ppm dry soil) }\end{array}$ \\
\hline $\mathrm{Ag}$ & 1 & $\mathrm{La}$ & 5 \\
\hline $\mathrm{Al}$ & 10 & $\mathrm{Li}$ & 5 \\
\hline $\mathrm{As}$ & 20 & $\mathrm{Mg}$ & 50 \\
\hline $\mathrm{Ba}$ & 3 & $\mathrm{Mn}$ & 1 \\
\hline $\mathrm{Be}$ & 1 & $\mathrm{Mo}$ & 5 \\
\hline $\mathrm{Ca}$ & 10 & $\mathrm{Na}$ & 50 \\
\hline $\mathrm{Cd}$ & 1 & $\mathrm{Ni}$ & 4 \\
\hline $\mathrm{Co}$ & 6 & $\mathrm{~Pb}$ & 10 \\
\hline $\mathrm{Cr}$ & 3 & $\mathrm{Sb}$ & 20 \\
\hline $\mathrm{Cu}$ & 2 & $\mathrm{Se}$ & 30 \\
\hline $\mathrm{Fe}$ & 4 & $\mathrm{Tl}$ & 50 \\
\hline $\mathrm{Hg}$ & 0.04 & $\mathrm{~V}$ & 3 \\
\hline $\mathrm{K}$ & 50 & $\mathrm{Zn}$ & 2 \\
\hline
\end{tabular}

'inductively-coupled plasma atomic emission spectroscopy

${ }^{2}$ cold-vapor atomic absorption spectroscopy 


\section{CHAPTER V: RESULTS AND DISCUSSION}

\section{SOIL-SOLUTION PH}

The $\mathrm{t}$-test was done to determine if the mean soil-solution $\mathrm{pH}$ (1:1 water) values in the $\mathrm{A}(5.47 \pm 0.68)$ and $\mathrm{B}(5.76 \pm 0.54)$ horizons at 118 sites ( $\mathrm{pH}$ values at individual sites are listed in Appendix 4) investigated were significantly different. The calculated tvalue (3.60) exceeds the critical value (1.96) at $95 \%$ confidence level. Therefore, the A horizon soils are more acidic than the B horizon soils in the samples tested. The average soil-solution $\mathrm{pH}$ values for both the $\mathrm{A}$ and $\mathrm{B}$ soil horizons of the individual physiographic provinces are listed in Table 8. Again, the A horizon samples are generally more acidic than the B horizon samples. The two samples from the Willamette Valley are the exception. The Coast Range and Klamath Mountains samples have the same average soil $\mathrm{pH}$ values of 5.5 between them as well as between their soil horizons. Soils sampled from the semiarid eastern Klamath Mountains are less acidic than those of the humid western Klamath Mountains. The soil-solution $\mathrm{pH}$, particularly in the $\mathrm{B}$ horizon, is more acidic in soils sampled west of the Cascade Range and more alkaline east of the Cascade Range. The same observation was made by Ames and Prych (1995) in their work in the state of Washington bordering Oregon on the north. The contrasting climates and their associated vegetation west and east of those mountains have probably caused the above soil $\mathrm{pH}$ difference. 
Table 8. Average soil-solution pH (1:1 water) in Southwest Oregon.

\begin{tabular}{|c|c|c|c|c|c|}
\hline Physiographic Province & Soil Horizon & \multicolumn{4}{|c|}{ Average $\mathrm{pH}(1: 1$ water $)$} \\
\hline Coastal Plain $^{\mathrm{a}}$ & $\mathrm{A}$ & 4.4 & $+/-$ & 0.4 & $(7)^{*}$ \\
\hline Coastal Plain $^{2}$ & $\bar{B}$ & 5.2 & $+/-$ & 0.2 & (7) \\
\hline Coast Range $^{\mathrm{a}}$ & $\bar{A}$ & 5.5 & $+/-$ & 0.6 & $(16)$ \\
\hline Coast Range $^{\mathrm{a}}$ & B & 5.5 & $+/-$ & 0.4 & $(16)$ \\
\hline Willamette Valley $^{2}$ & $\mathrm{~A}$ & 6.2 & $+/-$ & 0.9 & $(2)$ \\
\hline Willamette Valley $^{2}$ & B & $\overline{5.6}$ & $+/-$ & 1.0 & (2) \\
\hline Klamath Mountains $^{2}$ & $\bar{A}$ & 5.5 & $+1-$ & $\overline{0.6}$ & (32) \\
\hline Klamath Mountains $^{2}$ & $\bar{B}$ & 5.6 & $+/-$ & 0.5 & $(32)$ \\
\hline Cascade Range & $\bar{A}$ & 5.4 & $+/-$ & 0.7 & (39) \\
\hline Cascade Range & B & 5.7 & $+/-$ & 0.5 & (39) \\
\hline Basin and Range ${ }^{\sigma}$ & $\bar{A}$ & 5.6 & $+/-$ & 0.6 & (18) \\
\hline Basin and Range $^{6}$ & $\bar{B}$ & 6.3 & $+/-$ & 0.3 & (18) \\
\hline High Lava Plains ${ }^{\sigma}$ & $\bar{A}$ & 5.3 & $+/-$ & 0.4 & (4) \\
\hline High Lava Plains $^{0}$ & $\bar{B}$ & 6.2 & $+/-$ & 0.1 & (4) \\
\hline
\end{tabular}

* number in parentheses is the number of values averaged.

a located west of the Cascade Range.

${ }^{b}$ located east of the Cascade Range.

\section{DISTRIBUTION OF SOIL METAL CONCENTRATIONS}

A total of 248 samples from 118 sites were analyzed for 26 metals by both inductively-coupled plasma atomic emission spectroscopy (ICPAES), and cold-vapor atomic absorption spectroscopy (CVAAS). This number does not include duplicate and spiked samples analyzed.

Summary statistics of metal concentrations in soils measured in this study are listed in Tables 9 through 17. Summary statistics of the data illustrate the magnitude and variability of the concentrations of specific metals in the study area. Statistics have been computed for both the A and B soil horizons for the entire area (Tables 9 and 10 ) and for the individual physiographic provinces (Tables 11 to17). Where the concentration of a metal in a sample is smaller than the laboratory's minimum reporting level, the 
minimum reporting level is used for calculating statistics. Therefore, the statistics are qualified as less than or greater than the value given for sample sets that include values less than the reporting limit (Ames and Prych, 1995). Table 18 lists the average distribution of metals in soils developed on major igneous rocks of the study area. Table 19 lists the average concentration of metals in different soil orders of the region.

$\mathrm{Ag}, \mathrm{Mo}, \mathrm{Sb}, \mathrm{Se}$ and $\mathrm{Tl}$ have no detect (i.e. sample with concentrations equal to or greater than the laboratory's minimum reporting level) in the study area, while $\mathrm{Cd}, \mathrm{Be}$ and As have only a few detects. Study of the above eight metals has been severely limited due to their soil concentrations below the detection limits of the analyzer. The remainder 18 metals have detects from most or all sites. Distribution statistics for these 18 metals are listed in Tables 20-21 and 24-39. The magnitude and variability of the soil background concentrations of specific metals in the different physiographic provinces of the study area are discussed in relation to parent rocks and soil development. When comparing the metal values for physiographic provinces and soil orders, the arithmetic means (AM) for either the $\mathrm{A}$ or $\mathrm{B}$ horizons are compared. If a metal is normally concentrated in the A horizon, the A horizon $\mathrm{AM}$ values in the provinces or soil orders are compared; if a metal is normally concentrated in the B horizon, the B horizon AM values are compared. For a metal the horizon for the $\mathrm{AM}$ value is mentioned the first time and all the subsequent $\mathrm{AM}$ values are for the same horizon. 
Table 9. Distribution statistics for concentrations (in ppm of dry soil) of metals in surface soils (A horizon) of all sites in Southwest Oregon.

\begin{tabular}{|c|c|c|c|c|c|c|}
\hline Metal & $\begin{array}{c}\text { Total Sample } \\
\text { Number/ } \\
\text { Detects }\end{array}$ & $\begin{array}{c}\text { Arithmetic } \\
\text { Mean }\end{array}$ & $\begin{array}{c}\text { Arithmetic } \\
\text { Standard } \\
\text { Deviation }\end{array}$ & Median & Minimum & Maximum \\
\hline $\mathrm{Ag}$ & $118 / 0$ & $<1$ & - & $<1$ & $<1$ & $<1$ \\
\hline $\mathrm{Mo}$ & $118 / 0$ & $<5$ & -- & $<5$ & $<5$ & $<5$ \\
\hline $\mathrm{Cd}$ & $118 / 8$ & $<1$ & - & $<1$ & $<1$ & 1.2 \\
\hline $\mathrm{Ba}$ & $118 / 118$ & 181 & 138 & 149 & 8 & 792 \\
\hline $\mathrm{Be}$ & $118 / 3$ & $<1$ & -- & $<1$ & $<1$ & 1 \\
\hline $\mathrm{Ni}$ & $118 / 115$ & $<52$ & $>126$ & 22 & $<4$ & 1,132 \\
\hline $\mathrm{Co}$ & $118 / 93$ & $<18$ & $>15$ & 13 & $<6$ & 95 \\
\hline $\mathrm{Cr}$ & $118 / 118$ & 56 & 135 & 23 & 3 & 1,302 \\
\hline $\mathrm{V}$ & $118 / 118$ & 69 & 56 & 55 & 6 & 374 \\
\hline $\mathrm{Cu}$ & $118 / 117$ & $<31$ & $>29$ & 22 & $<2$ & 148 \\
\hline $\mathrm{Zn}$ & $118 / 118$ & 74 & 38 & 70 & 11 & 196 \\
\hline $\mathrm{Fe}$ & $118 / 118$ & 29,148 & 20,778 & 25,371 & 2,648 & 107,312 \\
\hline $\mathrm{Mn}$ & $118 / 118$ & 1,527 & 1,331 & 1,208 & 24 & 7,221 \\
\hline $\mathrm{K}$ & $118 / 118$ & 1,266 & 964 & 941 & 223 & 4,973 \\
\hline $\mathrm{Al}$ & $118 / 118$ & 30,125 & 18,253 & 24,721 & 2,541 & 93,717 \\
\hline $\mathrm{Li}$ & $118 / 88$ & $<11$ & $>8.6$ & 7.6 & $<5$ & 48 \\
\hline $\mathrm{Ca}$ & $118 / 118$ & 5,741 & 3,970 & 4,793 & 638 & 18,682 \\
\hline $\mathrm{Na}$ & $118 / 118$ & 346 & 318 & 216 & 53 & 1,511 \\
\hline $\mathrm{Mg}$ & $118 / 118$ & 4,431 & 3,844 & 3,124 & 545 & 16,424 \\
\hline $\mathrm{La}$ & $118 / 77$ & $<8$ & $>4.4$ & 5.5 & $<5$ & 26 \\
\hline $\mathrm{Sb}$ & $118 / 0$ & $<20$ & -- & $<20$ & $<20$ & $<20$ \\
\hline $\mathrm{Pb}$ & $118 / 45$ & $<18$ & -- & $<10$ & $<10$ & 378 \\
\hline $\mathrm{Tl}$ & $118 / 0$ & $<50$ & -- & $<50$ & $<50$ & $<50$ \\
\hline $\mathrm{As}$ & $118 / 1$ & $<20$ & -- & $<20$ & $<20$ & 36.4 \\
\hline $\mathrm{Se}$ & $118 / 0$ & $<30$ & -- & $<30$ & $<30$ & $<30$ \\
\hline $\mathrm{Hg}$ & $118 / 109$ & $<0.1$ & $>0.06$ & 0.08 & $<0.04$ & 0.37 \\
\hline
\end{tabular}

${ }^{1}$ Detects are the number of samples with concentrations equal to or greater than the laboratory's minimum reporting level.

-- indicates statistics not computed because concentrations in most samples were less than the laboratory's minimum reporting level.

Note: Where the concentration of a metal in a sample is below the laboratory's minimum reporting level, the minimum reporting level is used for calculating statistics. Therefore, the statistics are qualified as less than or greater than the value given for sample sets that include values less than the laboratory's reporting limit. 
Table 10. Distribution statistics for concentrations (in ppm of dry soil) of metals in subsoils (B horizon) of all sites in Southwest Oregon.

\begin{tabular}{|c|c|c|c|c|c|c|}
\hline Metal & $\begin{array}{c}\text { Total Sample } \\
\text { Number/ } \\
\text { Detects }\end{array}$ & $\begin{array}{c}\text { Arithmetic } \\
\text { Mean }\end{array}$ & $\begin{array}{c}\text { Arithmetic } \\
\text { Standard } \\
\text { Deviation }\end{array}$ & Median & Minimum & Maximum \\
\hline $\mathrm{Ag}$ & $118 / 0$ & $<1$ & -- & $<1$ & $<1$ & $<1$ \\
\hline $\mathrm{Mo}$ & $118 / 0$ & $<5$ & -- & $<5$ & $<5$ & $<5$ \\
\hline $\mathrm{Cd}$ & $118 / 13$ & $<1$ & -- & $<1$ & $<1$ & 1.5 \\
\hline $\mathrm{Ba}$ & $118 / 118$ & 141 & 107 & 123 & 7 & 525 \\
\hline $\mathrm{Be}$ & $118 / 5$ & $<1$ & -- & $<1$ & $<1$ & 1.3 \\
\hline $\mathrm{Ni}$ & $118 / 115$ & $<71$ & $>201$ & 25 & $<4$ & 1,530 \\
\hline $\mathrm{Co}$ & $118 / 102$ & $<21$ & $>23$ & 16 & $<6$ & 175 \\
\hline $\mathrm{Cr}$ & $118 / 118$ & 78 & 204 & 32 & 4 & 1,815 \\
\hline $\mathrm{V}$ & $118 / 118$ & 89 & 68 & 69 & 4 & 409 \\
\hline $\mathrm{Cu}$ & $118 / 116$ & $<42$ & $>40$ & 29 & $<2$ & 193 \\
\hline $\mathrm{Zn}$ & $118 / 118$ & 69 & 37 & 67 & 9 & 183 \\
\hline $\mathrm{Fe}$ & $118 / 118$ & 37,300 & 26,338 & 30,240 & 3,066 & 137,939 \\
\hline $\mathrm{Mn}$ & $118 / 118$ & 848 & 811 & 597 & 21 & 4,951 \\
\hline $\mathrm{K}$ & $118 / 118$ & 1,083 & 941 & 780 & 73 & 5,535 \\
\hline $\mathrm{Al}$ & $118 / 118$ & 40,935 & 23,121 & 35,473 & 2,586 & 103,515 \\
\hline $\mathrm{Li}$ & $118 / 107$ & $<15$ & $>11$ & 11 & $<5$ & 54 \\
\hline $\mathrm{Ca}$ & $118 / 118$ & 3,542 & 3,023 & 2,823 & 134 & 15,173 \\
\hline $\mathrm{Na}$ & $118 / 118$ & 419 & 426 & 200 & 47 & 2,341 \\
\hline $\mathrm{Mg}$ & $118 / 118$ & 5,325 & 4,752 & 3,914 & 591 & 23,606 \\
\hline $\mathrm{La}$ & $118 / 95$ & $<9.6$ & $>5$ & 8.4 & $<5$ & 32.5 \\
\hline $\mathrm{Sb}$ & $118 / 0$ & $<20$ & -- & $<20$ & $<20$ & $<20$ \\
\hline $\mathrm{Pb}$ & $118 / 16$ & $<10$ & -- & $<10$ & $<10$ & 40 \\
\hline $\mathrm{Tl}$ & $118 / 0$ & $<50$ & -- & $<50$ & $<50$ & $<50$ \\
\hline $\mathrm{As}$ & $118 / 2$ & $<20$ & -- & $<20$ & $<20$ & 46.5 \\
\hline $\mathrm{Se}$ & $118 / 0$ & $<30$ & -- & $<30$ & $<30$ & $<30$ \\
\hline $\mathrm{Hg}$ & $118 / 72$ & $<0.06$ & $>0.04$ & 0.04 & $<0.04$ & 0.25 \\
\hline
\end{tabular}

${ }^{1}$ Detects are the number of samples with concentrations equal to or greater than the laboratory's minimum reporting level.

-- indicates statistics not computed because concentrations in most samples were less than the laboratory's minimum reporting level.

Note: Where the concentration of a metal in a sample is below the laboratory's minimum reporting level, the minimum reporting level is used for calculating statistics. Therefore, the statistics are qualified as less than or greater than the value given for sample sets that include values less than the laboratory's reporting limit. 
Table 11. Distribution statistics for concentrations (in ppm of dry soil) of metals in soils on the Coastal Plain of Southwest Oregon.

\begin{tabular}{|c|c|c|c|c|c|c|c|c|c|}
\hline \multicolumn{3}{|c|}{ In A Horizon } & \multicolumn{5}{c|}{ In B Horizon } \\
\hline & $\begin{array}{c}\text { Total } \\
\text { sample } \\
\text { number/ } \\
\text { detects }\end{array}$ & $\begin{array}{c}\text { Arith- } \\
\text { metic } \\
\text { mean }\end{array}$ & $\begin{array}{c}\text { Mini- } \\
\text { mum }\end{array}$ & $\begin{array}{c}\text { Maxi- } \\
\text { mum }\end{array}$ & Metal & $\begin{array}{c}\text { Total } \\
\text { sample } \\
\text { number/ } \\
\text { detects }\end{array}$ & $\begin{array}{c}\text { Arith- } \\
\text { metic } \\
\text { mean }\end{array}$ & $\begin{array}{c}\text { Mini- } \\
\text { mum }\end{array}$ & $\begin{array}{c}\text { Maxi- } \\
\text { mum }\end{array}$ \\
\hline $\mathrm{Ag}$ & $7 / 0$ & $<1$ & $<1$ & $<1$ & $\mathrm{Ag}$ & $7 / 0$ & $<1$ & $<1$ & $<1$ \\
\hline $\mathrm{Mo}$ & $7 / 0$ & $<5$ & $<5$ & $<5$ & $\mathrm{Mo}$ & $7 / 0$ & $<5$ & $<5$ & $<5$ \\
\hline $\mathrm{Cd}$ & $7 / 0$ & $<1$ & $<1$ & $<1$ & $\mathrm{Cd}$ & $7 / 0$ & $<1$ & $<1$ & $<1$ \\
\hline $\mathrm{Ba}$ & $7 / 7$ & 31 & 8 & 65 & $\mathrm{Ba}$ & $7 / 7$ & 37 & 7 & 77 \\
\hline $\mathrm{Be}$ & $7 / 0$ & $<1$ & $<1$ & $<1$ & $\mathrm{Be}$ & $7 / 0$ & $<1$ & $<1$ & $<1$ \\
\hline $\mathrm{Ni}$ & $7 / 5$ & $<9$ & $<4$ & 25 & $\mathrm{Ni}$ & $7 / 5$ & $<13$ & $<4$ & 27 \\
\hline $\mathrm{Co}$ & $7 / 1$ & $<6$ & $<6$ & 6.2 & $\mathrm{Co}$ & $7 / 2$ & $<6$ & $<6$ & 10.7 \\
\hline $\mathrm{Cr}$ & $7 / 7$ & 23 & 7 & 77 & $\mathrm{Cr}$ & $7 / 7$ & 33 & 6 & 81 \\
\hline $\mathrm{V}$ & $7 / 7$ & 23 & 6 & 65 & $\mathrm{~V}$ & $7 / 7$ & 38 & 4 & 75 \\
\hline $\mathrm{Cu}$ & $7 / 6$ & $<8$ & $<2$ & 19 & $\mathrm{Cu}$ & $7 / 5$ & $<11$ & $<2$ & 33 \\
\hline $\mathrm{Zn}$ & $7 / 7$ & 19 & 11 & 31 & $\mathrm{Zn}$ & $7 / 7$ & 29 & 9 & 82 \\
\hline $\mathrm{Fe}$ & $7 / 7$ & 9,455 & 2,648 & 25,055 & $\mathrm{Fe}$ & $7 / 7$ & 17,205 & 3,066 & 40,980 \\
\hline $\mathrm{Mn}$ & $7 / 7$ & 92 & 24 & 235 & $\mathrm{Mn}$ & $7 / 7$ & 257 & 21 & 1,363 \\
\hline $\mathrm{K}$ & $7 / 7$ & 545 & 298 & 896 & $\mathrm{~K}$ & $7 / 7$ & 541 & 262 & 1,176 \\
\hline $\mathrm{Al}$ & $7 / 7$ & 9,806 & 2,541 & 29,237 & $\mathrm{Al}$ & $7 / 7$ & 21,192 & 2,586 & 55,751 \\
\hline $\mathrm{Li}$ & $7 / 3$ & $<5$ & $<5$ & 23 & $\mathrm{Li}$ & $7 / 7$ & 17 & 6 & 33 \\
\hline $\mathrm{Ca}$ & $7 / 7$ & 1,446 & 640 & 1,914 & $\mathrm{Ca}$ & $7 / 7$ & 567 & 292 & 1,117 \\
\hline $\mathrm{Na}$ & $7 / 7$ & 215 & 129 & 362 & $\mathrm{Na}$ & $7 / 7$ & 150 & 98 & 194 \\
\hline $\mathrm{Mg}$ & $7 / 7$ & 1,323 & 620 & 3,314 & $\mathrm{Mg}$ & $7 / 7$ & 1,493 & 591 & 2,935 \\
\hline $\mathrm{La}$ & $7 / 4$ & $<5$ & $<5$ & 6.8 & $\mathrm{La}$ & $7 / 4$ & $<8$ & $<5$ & 13.5 \\
\hline $\mathrm{Sb}$ & $7 / 0$ & $<20$ & $<20$ & $<20$ & $\mathrm{Sb}$ & $7 / 0$ & $<20$ & $<20$ & $<20$ \\
\hline $\mathrm{Pb}$ & $7 / 3$ & $<10$ & $<10$ & 25 & $\mathrm{~Pb}$ & $7 / 0$ & $<10$ & $<10$ & $<10$ \\
\hline $\mathrm{Tl}$ & $7 / 0$ & $<50$ & $<50$ & $<50$ & $\mathrm{Tl}$ & $7 / 0$ & $<50$ & $<50$ & $<50$ \\
\hline $\mathrm{As}$ & $7 / 0$ & $<20$ & $<20$ & $<20$ & $\mathrm{As}$ & $7 / 0$ & $<20$ & $<20$ & $<20$ \\
\hline $\mathrm{Se}$ & $7 / 0$ & $<30$ & $<30$ & $<30$ & $\mathrm{Se}$ & $7 / 0$ & $<30$ & $<30$ & $<30$ \\
\hline $\mathrm{Hg}$ & $7 / 6$ & $<0.13$ & $<0.04$ & 0.19 & $\mathrm{Hg}$ & $7 / 4$ & $<0.08$ & $<0.04$ & 0.14 \\
\hline & & & & & & & & & \\
\hline
\end{tabular}

${ }^{1}$ Detects are the number of samples with concentrations equal to or greater than the laboratory's reporting limit. 
Table 12. Distribution statistics for concentrations (in ppm of dry soil) of metals in soils on the Coast Range of Southwest Oregon.

\begin{tabular}{|c|c|c|c|c|c|c|c|c|c|}
\hline \multicolumn{5}{|c|}{ In A Horizon } & \multicolumn{5}{|c|}{ In B Horizon } \\
\hline Metal & $\begin{array}{c}\text { Total } \\
\text { sample } \\
\text { number/ } \\
\text { detects }^{1}\end{array}$ & $\begin{array}{l}\text { Arith- } \\
\text { metic } \\
\text { mean }\end{array}$ & $\begin{array}{l}\text { Mini- } \\
\text { mum }\end{array}$ & $\begin{array}{l}\text { Maxi- } \\
\text { mum }\end{array}$ & Metal & $\begin{array}{c}\text { Total } \\
\text { sample } \\
\text { number/ } \\
\text { detects }^{1}\end{array}$ & $\begin{array}{l}\text { Arith- } \\
\text { metic } \\
\text { mean }\end{array}$ & $\begin{array}{l}\text { Mini- } \\
\text { mum }\end{array}$ & $\begin{array}{c}\text { Maxi- } \\
\text { mum }\end{array}$ \\
\hline $\mathrm{Ag}$ & $16 / 0$ & $<1$ & $<1$ & $<1$ & $\mathrm{Ag}$ & $16 / 0$ & $<1$ & $<1$ & $<1$ \\
\hline Mo & $16 / 0$ & $<5$ & $<5$ & $<5$ & Mo & $16 / 0$ & $<5$ & $<5$ & $<5$ \\
\hline$\overline{C d}$ & $16 / 4$ & $<1$ & $<1$ & $<1$ & $\mathrm{Cd}$ & $16 / 4$ & $<1$ & $<1$ & 1.1 \\
\hline$\overline{\mathrm{Ba}}$ & $16 / 16$ & 175 & 22 & 287 & $\overline{\mathrm{Ba}}$ & $16 / 16$ & 131 & 23 & 196 \\
\hline$\overline{\mathrm{Be}}$ & $16 / 2$ & $<1$ & $<1$ & 1 & $\overline{\mathrm{Be}}$ & $16 / 2$ & $<1$ & $<1$ & 1.3 \\
\hline$\overline{\mathrm{Ni}}$ & $16 / 16$ & 59 & 5 & 170 & $\overline{\mathrm{Ni}}$ & $16 / 16$ & 73 & 5 & 163 \\
\hline$\overline{\mathrm{Co}}$ & $16 / 15$ & $<23$ & $\overline{<6}$ & 60 & $\overline{\mathrm{Co}}$ & $16 / 15$ & $<26$ & $<6$ & 56 \\
\hline $\mathrm{Cr}$ & $16 / 16$ & 59 & 15 & 120 & $\mathrm{Cr}$ & $16 / 16$ & 77 & 30 & 161 \\
\hline $\bar{V}$ & $16 / 16$ & 82 & 27 & 219 & $\mathrm{~V}$ & $16 / 16$ & 100 & 43 & 248 \\
\hline$\overline{\mathrm{Cu}}$ & $16 / 16$ & 42 & 5 & 148 & $\overline{\mathrm{Cu}}$ & $16 / 16$ & 52 & 7 & 193 \\
\hline $\mathrm{Zn}$ & $16 / 16$ & $\overline{83}$ & 18 & 131 & $\overline{\mathrm{Zn}}$ & $16 / 16$ & 81 & 23 & 136 \\
\hline$\overline{\mathrm{Fe}}$ & $16 / 16$ & 39,369 & 15,727 & 78,302 & $\overline{\mathrm{Fe}}$ & $16 / 16$ & 48,819 & 23,048 & 98,169 \\
\hline$\overline{\mathrm{Mn}}$ & $16 / 16$ & 1,501 & 31 & 5,279 & $\overline{\mathrm{Mn}}$ & $16 / 16$ & 1,100 & 49 & 4,951 \\
\hline $\mathrm{K}$ & $16 / 16$ & 1,938 & 861 & 4,666 & $\mathrm{~K}$ & $16 / 16$ & 1,838 & 518 & 5,022 \\
\hline $\mathrm{Al}$ & $16 / 16$ & 33,582 & 17,362 & 73,145 & $\overline{\mathrm{Al}}$ & $16 / 16$ & 45,461 & 19,743 & 100,324 \\
\hline$\overline{\mathrm{Li}}$ & $16 / 16$ & 19 & 5 & 48 & $\overline{\mathrm{Li}}$ & $16 / 16$ & 24 & 5 & 54 \\
\hline $\mathrm{Ca}$ & $16 / 16$ & 5,536 & 638 & 15,137 & $\mathrm{Ca}$ & $16 / 16$ & 3,014 & 376 & 14,619 \\
\hline $\mathrm{Na}$ & $\overline{16 / 16}$ & 244 & 73 & 1,511 & $\overline{\mathrm{Na}}$ & $16 / 16$ & 287 & 59 & 2,341 \\
\hline$\overline{\mathrm{Mg}}$ & $16 / 16$ & 6,548 & 1,328 & 11,425 & $\overline{\mathrm{Mg}}$ & $16 / 16$ & 7,394 & 1,655 & 13,848 \\
\hline $\mathrm{La}$ & $16 / 16$ & 11 & 5 & 26 & $\mathrm{La}$ & $16 / 16$ & 13 & 5 & 33 \\
\hline $\mathrm{Sb}$ & $16 / 0$ & $<20$ & $<20$ & $<20$ & $\mathrm{Sb}$ & $16 / 0$ & $<20$ & $<20$ & $<20$ \\
\hline $\mathrm{Pb}$ & $16 / 8$ & $<10$ & $<10$ & 51 & $\overline{\mathrm{Pb}}$ & $16 / 6$ & $<10$ & $<10$ & 39.6 \\
\hline $\mathrm{Tl}$ & $16 / 0$ & $<50$ & $<50$ & $<50$ & $\mathrm{Tl}$ & $16 / 0$ & $<50$ & $<50$ & $<50$ \\
\hline As & $16 / 0$ & $<20$ & $<20$ & $<20$ & $\overline{\text { As }}$ & $16 / 0$ & $<20$ & $<20$ & $<20$ \\
\hline $\mathrm{Se}$ & $16 / 0$ & $<30$ & $<30$ & $<30$ & $\mathrm{Se}$ & $16 / 0$ & $<30$ & $<30$ & $<30$ \\
\hline $\mathrm{Hg}$ & $16 / 16$ & 0.12 & 0.06 & 0.37 & $\mathrm{Hg}$ & $16 / 14$ & $<0.08$ & $<0.04$ & 0.25 \\
\hline
\end{tabular}

${ }^{1}$ Detects are the number of samples with concentrations equal to or greater than the laboratory's reporting limit. 
Table 13. Distribution statistics for concentrations (in ppm of dry soil) of metals in soils on the Willamette Valley of Southwest Oregon.

\begin{tabular}{|c|c|c|c|c|c|c|c|c|c|}
\hline \multicolumn{9}{|c|}{ In A Horizon } & \multicolumn{5}{c|}{ In B Horizon } & Total \\
\hline & $\begin{array}{c}\text { Total } \\
\text { sample } \\
\text { number/ } \\
\text { Metects }\end{array}$ & $\begin{array}{c}\text { Arith- } \\
\text { metic } \\
\text { mean }\end{array}$ & $\begin{array}{c}\text { Mini- } \\
\text { mum }\end{array}$ & $\begin{array}{c}\text { Maxi- } \\
\text { mum }\end{array}$ & Metal & $\begin{array}{c}\text { cample } \\
\text { number/ } \\
\text { detects }\end{array}$ & $\begin{array}{c}\text { Arith- } \\
\text { metic } \\
\text { mean }\end{array}$ & $\begin{array}{c}\text { Mini- } \\
\text { mum }\end{array}$ & $\begin{array}{c}\text { Maxi- } \\
\text { mum }\end{array}$ \\
\hline $\mathrm{Ag}$ & $2 / 0$ & $<1$ & $<1$ & $<1$ & $\mathrm{Ag}$ & $2 / 0$ & $<1$ & $<1$ & $<1$ \\
\hline $\mathrm{Mo}$ & $2 / 0$ & $<5$ & $<5$ & $<5$ & $\mathrm{Mo}$ & $2 / 0$ & $<5$ & $<5$ & $<5$ \\
\hline $\mathrm{Cd}$ & $2 / 0$ & $<1$ & $<1$ & $<1$ & $\mathrm{Cd}$ & $2 / 0$ & $<1$ & $<1$ & $<1$ \\
\hline $\mathrm{Ba}$ & $2 / 2$ & 139 & 136 & 143 & $\mathrm{Ba}$ & $2 / 2$ & 110 & 64 & 157 \\
\hline $\mathrm{Be}$ & $2 / 0$ & $<1$ & $<1$ & $<1$ & $\mathrm{Be}$ & $2 / 0$ & $<1$ & $<1$ & $<1$ \\
\hline $\mathrm{Ni}$ & $2 / 2$ & 18 & 7 & 29 & $\mathrm{Ni}$ & $2 / 2$ & 22 & 9 & 35 \\
\hline $\mathrm{Co}$ & $2 / 2$ & 13 & 7.7 & 18 & $\mathrm{Co}$ & $2 / 2$ & 14 & 8 & 20 \\
\hline $\mathrm{Cr}$ & $2 / 2$ & 21 & 16 & 26 & $\mathrm{Cr}$ & $2 / 2$ & 25 & 21 & 29 \\
\hline $\mathrm{V}$ & $2 / 2$ & 56 & 34 & 78 & $\mathrm{~V}$ & $2 / 2$ & 66 & 44 & 89 \\
\hline $\mathrm{Cu}$ & $2 / 2$ & 20 & 11 & 29 & $\mathrm{Cu}$ & $2 / 2$ & 23 & 13 & 33 \\
\hline $\mathrm{Zn}$ & $2 / 2$ & 50 & 27 & 74 & $\mathrm{Zn}$ & $2 / 2$ & 49 & 25 & 72 \\
\hline $\mathrm{Fe}$ & $2 / 2$ & 24,263 & 16,789 & 31,736 & $\mathrm{Fe}$ & $2 / 2$ & 28,101 & 19,378 & 36,824 \\
\hline $\mathrm{Mn}$ & $2 / 2$ & 973 & 730 & 1,216 & $\mathrm{Mn}$ & $2 / 2$ & 485 & 187 & 783 \\
\hline $\mathrm{K}$ & $2 / 2$ & 1,343 & 826 & 1,860 & $\mathrm{~K}$ & $2 / 2$ & 951 & 780 & 1,121 \\
\hline $\mathrm{Al}$ & $2 / 2$ & 22,631 & 14,574 & 30,688 & $\mathrm{Al}$ & $2 / 2$ & 27,969 & 21,008 & 34,930 \\
\hline $\mathrm{Li}$ & $2 / 2$ & 6.1 & 5.4 & 6.7 & $\mathrm{Li}$ & $2 / 2$ & 8.2 & 7.9 & 8.4 \\
\hline $\mathrm{Ca}$ & $2 / 2$ & 9,502 & 3,081 & 15,923 & $\mathrm{Ca}$ & $2 / 2$ & 8,538 & 134 & 12,209 \\
\hline $\mathrm{Na}$ & $2 / 2$ & 738 & 60 & 1,416 & $\mathrm{Na}$ & $2 / 2$ & 871 & 53 & 1,689 \\
\hline $\mathrm{Mg}$ & $2 / 2$ & 4,567 & 1,317 & 7,817 & $\mathrm{Mg}$ & $2 / 2$ & 5,171 & 1,520 & 8,823 \\
\hline $\mathrm{La}$ & $2 / 2$ & 12 & 10.4 & 13 & $\mathrm{La}$ & $2 / 2$ & 14 & 12 & 15 \\
\hline $\mathrm{Sb}$ & $2 / 0$ & $<20$ & $<20$ & $<20$ & $\mathrm{Sb}$ & $2 / 0$ & $<20$ & $<20$ & $<20$ \\
\hline $\mathrm{Pb}$ & $2 / 1$ & $<10$ & $<10$ & 40 & $\mathrm{~Pb}$ & $2 / 0$ & $<10$ & $<10$ & $<10$ \\
\hline $\mathrm{Tl}$ & $2 / 0$ & $<50$ & $<50$ & $<50$ & $\mathrm{Tl}$ & $2 / 0$ & $<50$ & $<50$ & $<50$ \\
\hline $\mathrm{As}$ & $2 / 0$ & $<20$ & $<20$ & $<20$ & $\mathrm{As}$ & $2 / 0$ & $<20$ & $<20$ & $<20$ \\
\hline $\mathrm{Se}$ & $2 / 0$ & $<30$ & $<30$ & $<30$ & $\mathrm{Se}$ & $2 / 0$ & $<30$ & $<30$ & $<30$ \\
\hline $\mathrm{Hg}$ & $2 / 2$ & 0.085 & 0.08 & 0.09 & $\mathrm{Hg}$ & $2 / 1$ & $<0.05$ & $<0.04$ & 0.06 \\
\hline
\end{tabular}

${ }^{1}$ Detects are the number of samples with concentrations equal to or greater than the laboratory's reporting limit. 
Table 14. Distribution statistics for concentrations (in ppm of dry soil) of metals in soils on the Cascade Range of Southwest Oregon.

\begin{tabular}{|c|c|c|c|c|c|c|c|c|c|}
\hline \multicolumn{5}{|c|}{ In A Horizon } & \multicolumn{5}{|c|}{ In B Horizon } \\
\hline Metal & $\begin{array}{c}\text { Total } \\
\text { sample } \\
\text { numbe } \\
\mathbf{r} / \\
\text { detects }^{1}\end{array}$ & $\begin{array}{l}\text { Arith- } \\
\text { metic } \\
\text { mean }\end{array}$ & $\begin{array}{l}\text { Mini- } \\
\text { mum }\end{array}$ & $\begin{array}{l}\text { Maxi- } \\
\text { mum }\end{array}$ & $\begin{array}{c}\text { Met } \\
\text { al }\end{array}$ & $\begin{array}{c}\text { Total } \\
\text { sample } \\
\text { number/ } \\
\text { detects }^{1}\end{array}$ & $\begin{array}{l}\text { Arith- } \\
\text { metic } \\
\text { mean }\end{array}$ & $\begin{array}{l}\text { Mini- } \\
\text { mum }\end{array}$ & $\begin{array}{l}\text { Maxi- } \\
\text { mum }\end{array}$ \\
\hline $\mathrm{Ag}$ & $39 / 0$ & $<1$ & $<1$ & $<1$ & $\mathrm{Ag}$ & $39 / 0$ & $<1$ & $<1$ & $<1$ \\
\hline Mo & $39 / 0$ & $<5$ & $\overline{<5}$ & $<5$ & Mo & $39 / 0$ & $<5$ & $<5$ & $<5$ \\
\hline$\overline{C d}$ & $39 / 0$ & $<1$ & $<1$ & $<1$ & $\overline{C d}$ & $39 / 1$ & $<1$ & $<1$ & 1 \\
\hline $\mathrm{Ba}$ & $39 / 39$ & 202 & 32 & 792 & $\mathrm{Ba}$ & $39 / 39$ & 154 & 21 & 525 \\
\hline$\overline{\mathrm{Be}}$ & $39 / 0$ & $<1$ & $<1$ & $<1$ & $\overline{\mathrm{Be}}$ & $39 / 0$ & $<1$ & $\overline{<1}$ & $<1$ \\
\hline $\mathrm{Ni}$ & $39 / 38$ & $<18$ & $<4$ & 76 & $\overline{\mathrm{Ni}}$ & $39 / 38$ & $<21$ & $<4$ & $\overline{86}$ \\
\hline$\overline{\mathrm{Co}}$ & $39 / 31$ & $<15$ & $<6$ & 52 & $\overline{\mathrm{Co}}$ & $39 / 36$ & $<16$ & $\overline{<6}$ & 46 \\
\hline$\overline{\mathrm{Cr}}$ & $39 / 39$ & 21 & 3 & 99 & $\overline{\mathrm{Cr}}$ & $39 / 39$ & 25 & 4 & 122 \\
\hline $\bar{V}$ & $39 / 39$ & $\overline{64}$ & $\overline{14}$ & 212 & $\mathrm{~V}$ & $39 / 39$ & 76 & 16 & 223 \\
\hline$\overline{\mathrm{Cu}}$ & $39 / 39$ & 25 & 6 & 125 & $\overline{\mathrm{Cu}}$ & $39 / 39$ & 32 & 8 & 150 \\
\hline $\mathrm{Zn}$ & $39 / 39$ & 75 & 17 & 153 & $\overline{\mathrm{Zn}}$ & $39 / 39$ & 63 & 17 & 140 \\
\hline $\mathrm{Fe}$ & $39 / 39$ & 26,884 & 6,965 & 80,890 & $\mathrm{Fe}$ & $39 / 39$ & 31,655 & 9,857 & 82,430 \\
\hline $\mathrm{Mn}$ & $39 / 39$ & 1,610 & 129 & 5,685 & $\overline{M n}$ & $39 / 39$ & 777 & 100 & 2,555 \\
\hline $\mathrm{K}$ & $39 / 39$ & 1,043 & 223 & 4,541 & $\mathrm{~K}$ & $39 / 39$ & 796 & 168 & 3,571 \\
\hline $\mathrm{Al}$ & $39 / 39$ & 31,382 & 4,634 & 85,913 & $\overline{\mathrm{Al}}$ & $39 / 39$ & 39,601 & 12,641 & 103,515 \\
\hline$\overline{\mathrm{Li}}$ & $39 / 28$ & $<7$ & $<5$ & 15 & $\overline{\mathrm{Li}}$ & $39 / 33$ & $<9$ & $<5$ & 23 \\
\hline$\overline{\mathrm{Ca}}$ & $39 / 39$ & 5,945 & 1,886 & 17,580 & $\overline{\mathrm{Ca}}$ & $39 / 39$ & 3,726 & 998 & 12,246 \\
\hline $\mathrm{Na}$ & $39 / 39$ & 425 & 61 & 1,353 & $\mathrm{Na}$ & $39 / 39$ & 530 & 57 & 1,708 \\
\hline $\mathrm{Mg}$ & $39 / 39$ & 2,916 & 545 & 13,829 & $\overline{\mathrm{Mg}}$ & $39 / 39$ & 3,606 & 688 & 15,300 \\
\hline $\mathrm{La}$ & $39 / 25$ & $<9$ & $<5$ & 23 & $\mathrm{La}$ & $39 / 31$ & $<10$ & $<5$ & 23 \\
\hline $\mathrm{Sb}$ & $39 / 0$ & $<20$ & $<20$ & $<20$ & $\overline{\mathrm{Sb}}$ & $39 / 0$ & $<20$ & $\overline{20}$ & $<20$ \\
\hline$\overline{\mathrm{Pb}}$ & $39 / 16$ & $<10$ & $<10$ & 133 & $\overline{\mathrm{Pb}}$ & $39 / 6$ & $<10$ & $<10$ & 25 \\
\hline$\overline{\mathrm{Tl}}$ & $39 / 0$ & $<50$ & $<50$ & $<50$ & $\mathrm{Tl}$ & $39 / 0$ & $<50$ & $<50$ & $<50$ \\
\hline As & $39 / 0$ & $<20$ & $<20$ & $<20$ & As & $39 / 0$ & $<20$ & $<20$ & $<20$ \\
\hline$\overline{\mathrm{Se}}$ & $39 / 0$ & $<30$ & $<30$ & $<30$ & $\overline{\mathrm{Se}}$ & $39 / 0$ & $<30$ & $<30$ & $<30$ \\
\hline$\overline{\mathrm{Hg}}$ & $39 / 34$ & $<0.09$ & $<0.04$ & 0.26 & $\mathrm{Hg}$ & $39 / 24$ & $<0.05$ & $<0.04$ & 0.12 \\
\hline
\end{tabular}

'Detects are the number of samples with concentrations equal to or greater than the laboratory's reporting limit. 
Table 15. Distribution statistics for concentrations (in ppm of dry soil) of metals in soils on the Klamath Mountains of Southwest Oregon.

\begin{tabular}{|c|c|c|c|c|c|c|c|c|c|}
\hline \multicolumn{9}{|c|}{ In A Horizon } & \multicolumn{5}{|c|}{ In B Horizon } & Total \\
\hline & $\begin{array}{c}\text { Total } \\
\text { sample } \\
\text { number/ } \\
\text { detects }\end{array}$ & $\begin{array}{c}\text { Arith- } \\
\text { metic } \\
\text { mean }\end{array}$ & $\begin{array}{c}\text { Mini- } \\
\text { mum }\end{array}$ & $\begin{array}{c}\text { Maxi- } \\
\text { mum }\end{array}$ & Metal & $\begin{array}{c}\text { sample } \\
\text { number/ } \\
\text { detects }\end{array}$ & $\begin{array}{c}\text { Arith- } \\
\text { metic } \\
\text { mean }\end{array}$ & $\begin{array}{c}\text { Mini- } \\
\text { mum }\end{array}$ & $\begin{array}{c}\text { Maxi- } \\
\text { mum }\end{array}$ \\
\hline $\mathrm{Ag}$ & $32 / 0$ & $<1$ & $<1$ & $<1$ & $\mathrm{Ag}$ & $32 / 0$ & $<1$ & $<1$ & $<1$ \\
\hline $\mathrm{Mo}$ & $32 / 0$ & $<5$ & $<5$ & $<5$ & $\mathrm{Mo}$ & $32 / 0$ & $<5$ & $<5$ & $<5$ \\
\hline $\mathrm{Cd}$ & $32 / 4$ & $<1$ & $<1$ & 1 & $\mathrm{Cd}$ & $32 / 7$ & $<1$ & $<1$ & 1.5 \\
\hline $\mathrm{Ba}$ & $32 / 32$ & 205 & 45 & 736 & $\mathrm{Ba}$ & $32 / 32$ & 143 & 25 & 491 \\
\hline $\mathrm{Be}$ & $32 / 1$ & $<1$ & $<1$ & 1 & $\mathrm{Be}$ & $32 / 3$ & $<1$ & $<1$ & 1.3 \\
\hline $\mathrm{Ni}$ & $32 / 32$ & 120 & 6 & 1,132 & $\mathrm{Ni}$ & $32 / 32$ & 175 & 4 & 1,530 \\
\hline $\mathrm{Co}$ & $32 / 31$ & $<26$ & $<6$ & 95 & $\mathrm{Co}$ & $32 / 31$ & $<35$ & $<6$ & 175 \\
\hline $\mathrm{Cr}$ & $32 / 32$ & 135 & 5 & 1,302 & $\mathrm{Cr}$ & $32 / 32$ & 198 & 4 & 1,815 \\
\hline $\mathrm{V}$ & $32 / 32$ & 98 & 12 & 374 & $\mathrm{~V}$ & $32 / 32$ & 133 & 12 & 409 \\
\hline $\mathrm{Cu}$ & $32 / 32$ & 46 & 5 & 136 & $\mathrm{Cu}$ & $32 / 32$ & 68 & 3 & 185 \\
\hline $\mathrm{Zn}$ & $32 / 32$ & 89 & 25 & 196 & $\mathrm{Zn}$ & $32 / 32$ & 90 & 12 & 183 \\
\hline $\mathrm{Fe}$ & $32 / 32$ & 38,950 & 13,667 & 107,317 & $\mathrm{Fe}$ & $32 / 32$ & 53,062 & 14,946 & 137,939 \\
\hline $\mathrm{Mn}$ & $32 / 32$ & 2,138 & 327 & 7,221 & $\mathrm{Mn}$ & $32 / 32$ & 1,282 & 270 & 3,345 \\
\hline $\mathrm{K}$ & $32 / 32$ & 1,636 & 274 & 4,973 & $\mathrm{~K}$ & $32 / 32$ & 1,406 & 73 & 5,535 \\
\hline $\mathrm{Al}$ & $32 / 32$ & 34,706 & 17,715 & 57,938 & $\mathrm{Al}$ & $32 / 32$ & 50,912 & 22,420 & 97,974 \\
\hline $\mathrm{Li}$ & $32 / 27$ & $<15$ & $<5$ & 48 & $\mathrm{Li}$ & $32 / 30$ & $<22$ & $<5$ & 52 \\
\hline $\mathrm{Ca}$ & $32 / 32$ & 6,781 & 1,027 & 18,682 & $\mathrm{Ca}$ & $32 / 32$ & 4,091 & 691 & 15,173 \\
\hline $\mathrm{Na}$ & $32 / 32$ & 148 & 53 & 494 & $\mathrm{Na}$ & $32 / 32$ & 163 & 47 & 556 \\
\hline $\mathrm{Mg}$ & $32 / 32$ & 7,397 & 2,119 & 16,424 & $\mathrm{Mg}$ & $32 / 32$ & 8,990 & 2,414 & 23,606 \\
\hline $\mathrm{La}$ & $32 / 21$ & $<7$ & $<5$ & 16 & $\mathrm{La}$ & $32 / 23$ & $<9$ & $<5$ & 14 \\
\hline $\mathrm{Sb}$ & $32 / 0$ & $<20$ & $<20$ & $<20$ & $\mathrm{Sb}$ & $32 / 0$ & $<20$ & $<20$ & $<20$ \\
\hline $\mathrm{Pb}$ & $32 / 11$ & $<27$ & $<10$ & 378 & $\mathrm{~Pb}$ & $32 / 3$ & $<10$ & $<10$ & 12.8 \\
\hline $\mathrm{Tl}$ & $32 / 0$ & $<50$ & $<50$ & $<50$ & $\mathrm{Tl}$ & $32 / 0$ & $<50$ & $<50$ & $<50$ \\
\hline $\mathrm{As}$ & $32 / 1$ & $<20$ & $<20$ & 36.4 & $\mathrm{As}$ & $32 / 2$ & $<20$ & $<20$ & 46.5 \\
\hline $\mathrm{Se}$ & $32 / 0$ & $<30$ & $<30$ & $<30$ & $\mathrm{Se}$ & $32 / 0$ & $<30$ & $<30$ & $<30$ \\
\hline $\mathrm{Hg}$ & $32 / 31$ & $<0.12$ & $<0.04$ & 0.29 & $\mathrm{Hg}$ & $32 / 27$ & $<0.07$ & $<0.04$ & 0.24 \\
\hline
\end{tabular}

'Detects are the number of samples with concentrations equal to or greater than the laboratory's reporting limit. 
Table 16. Distribution statistics for concentrations (in ppm of dry soil) of metals in soils on the Basin and Range Province of Southwest Oregon.

\begin{tabular}{|c|c|c|c|c|c|c|c|c|c|}
\hline \multicolumn{9}{|c|}{ In A Horizon } & \multicolumn{5}{|c|}{ In B Horizon } & Total \\
Metal & $\begin{array}{c}\text { Total } \\
\text { sample } \\
\text { number } \\
\text { detects }\end{array}$ & $\begin{array}{c}\text { Arith- } \\
\text { metic } \\
\text { mean }\end{array}$ & $\begin{array}{c}\text { Mini- } \\
\text { mum }\end{array}$ & $\begin{array}{c}\text { Maxi- } \\
\text { mum }\end{array}$ & Metal & $\begin{array}{c}\text { cample } \\
\text { detects }\end{array}$ & $\begin{array}{c}\text { Arith- } \\
\text { metic } \\
\text { mean }\end{array}$ & $\begin{array}{c}\text { Mini- } \\
\text { mum }\end{array}$ & $\begin{array}{c}\text { Maxi- } \\
\text { mum }\end{array}$ \\
\hline $\mathrm{Ag}$ & $18 / 0$ & $<1$ & $<1$ & $<1$ & $\mathrm{Ag}$ & $18 / 0$ & $<1$ & $<1$ & $<1$ \\
\hline $\mathrm{Mo}$ & $18 / 0$ & $<5$ & $<5$ & $<5$ & $\mathrm{Mo}$ & $18 / 0$ & $<5$ & $<5$ & $<5$ \\
\hline $\mathrm{Cd}$ & $18 / 0$ & $<1$ & $<1$ & $<1$ & $\mathrm{Cd}$ & $18 / 1$ & $<1$ & $<1$ & 1 \\
\hline $\mathrm{Ba}$ & $18 / 18$ & 180 & 52 & 432 & $\mathrm{Ba}$ & $18 / 18$ & 171 & 49 & 456 \\
\hline $\mathrm{Be}$ & $18 / 0$ & $<1$ & $<1$ & $<1$ & $\mathrm{Be}$ & $18 / 0$ & $<1$ & $<1$ & $<1$ \\
\hline $\mathrm{Ni}$ & $18 / 18$ & 26 & 5 & 136 & $\mathrm{Ni}$ & $18 / 18$ & 32 & 5 & 154 \\
\hline $\mathrm{Co}$ & $18 / 11$ & $<12$ & $<6$ & 41 & $\mathrm{Co}$ & $18 / 13$ & $<15$ & $<6$ & 47 \\
\hline $\mathrm{Cr}$ & $18 / 18$ & 15 & 3 & 79 & $\mathrm{Cr}$ & $18 / 18$ & 21 & 4 & 91 \\
\hline $\mathrm{V}$ & $18 / 18$ & 46 & 18 & 107 & $\mathrm{~V}$ & $18 / 18$ & 62 & 21 & 142 \\
\hline $\mathrm{Cu}$ & $18 / 18$ & 23 & 8 & 56 & $\mathrm{Cu}$ & $18 / 18$ & 30 & 10 & 73 \\
\hline $\mathrm{Zn}$ & $18 / 18$ & 68 & 26 & 161 & $\mathrm{Zn}$ & $18 / 18$ & 56 & 21 & 113 \\
\hline $\mathrm{Fe}$ & $18 / 18$ & 19,526 & 7,034 & 63,476 & $\mathrm{Fe}$ & $18 / 18$ & 25,062 & 8,615 & 71,441 \\
\hline $\mathrm{Mn}$ & $18 / 18$ & 1,131 & 232 & 4,600 & $\mathrm{Mn}$ & $18 / 18$ & 409 & 124 & 943 \\
\hline $\mathrm{K}$ & $18 / 18$ & 931 & 476 & 1,771 & $\mathrm{~K}$ & $18 / 18$ & 830 & 253 & 1,875 \\
\hline $\mathrm{Al}$ & $18 / 18$ & 27,964 & 12,544 & 93,717 & $\mathrm{Al}$ & $18 / 18$ & 35,949 & 13,989 & 102,212 \\
\hline $\mathrm{Li}$ & $18 / 11$ & $<7$ & $<5$ & 12.4 & $\mathrm{Li}$ & $18 / 16$ & $<8$ & $<5$ & 14 \\
\hline $\mathrm{Ca}$ & $18 / 18$ & 5,432 & 2,642 & 12,354 & $\mathrm{Ca}$ & $18 / 18$ & 3,612 & 1,937 & 9,234 \\
\hline $\mathrm{Na}$ & $18 / 18$ & 565 & 200 & 1,491 & $\mathrm{Na}$ & $18 / 18$ & 721 & 171 & 1,739 \\
\hline $\mathrm{Mg}$ & $18 / 18$ & 2,338 & 879 & 6,756 & $\mathrm{Mg}$ & $18 / 18$ & 2,911 & 939 & 7,988 \\
\hline $\mathrm{La}$ & $18 / 8$ & $<5$ & $<5$ & 16 & $\mathrm{La}$ & $18 / 16$ & $<9$ & $<5$ & 26 \\
\hline $\mathrm{Sb}$ & $18 / 0$ & $<20$ & $<20$ & $<20$ & $\mathrm{Sb}$ & $18 / 0$ & $<20$ & $<20$ & $<20$ \\
\hline $\mathrm{Pb}$ & $18 / 5$ & $<10$ & $<10$ & 10.4 & $\mathrm{~Pb}$ & $18 / 1$ & $<10$ & $<10$ & 10 \\
\hline $\mathrm{Tl}$ & $18 / 0$ & $<50$ & $<50$ & $<50$ & $\mathrm{Tl}$ & $18 / 0$ & $<50$ & $<50$ & $<50$ \\
\hline $\mathrm{As}$ & $18 / 0$ & $<20$ & $<20$ & $<20$ & $\mathrm{As}$ & $18 / 0$ & $<20$ & $<20$ & $<20$ \\
\hline $\mathrm{Se}$ & $18 / 0$ & $<30$ & $<30$ & $<30$ & $\mathrm{Se}$ & $18 / 0$ & $<30$ & $<30$ & $<30$ \\
\hline $\mathrm{Hg}$ & $18 / 17$ & $<0.06$ & $<0.04$ & 0.17 & $\mathrm{Hg}$ & $18 / 2$ & $<0.04$ & $<0.04$ & 0.06 \\
\hline & & & & & & & & & \\
\hline
\end{tabular}

${ }^{1}$ Detects are the number of samples with concentrations equal to or greater than the laboratory's reporting limit. 
Table 17. Distribution statistics for concentrations (in ppm of dry soil) of metals in soils on the High Lava Plains of Southwest Oregon.

\begin{tabular}{|c|c|c|c|c|c|c|c|c|c|}
\hline \multicolumn{3}{|c|}{ In A Horizon } & \multicolumn{5}{|c|}{ In B Horizon } & \\
\hline & $\begin{array}{c}\text { Total } \\
\text { sample } \\
\text { number/ } \\
\text { detects }\end{array}$ & $\begin{array}{c}\text { Arith- } \\
\text { metic } \\
\text { mean }\end{array}$ & $\begin{array}{c}\text { Mini- } \\
\text { mum }\end{array}$ & $\begin{array}{c}\text { Maxi- } \\
\text { mum }\end{array}$ & Metal & $\begin{array}{c}\text { Total } \\
\text { sample } \\
\text { number/ } \\
\text { detects }\end{array}$ & $\begin{array}{c}\text { Arith- } \\
\text { metic } \\
\text { mean }\end{array}$ & $\begin{array}{c}\text { Mini- } \\
\text { mum }\end{array}$ & $\begin{array}{c}\text { Maxi- } \\
\text { mum }\end{array}$ \\
\hline $\mathrm{Ag}$ & $4 / 0$ & $<1$ & $<1$ & $<1$ & $\mathrm{Ag}$ & $4 / 0$ & $<1$ & $<1$ & $<1$ \\
\hline $\mathrm{Mo}$ & $4 / 0$ & $<5$ & $<5$ & $<5$ & $\mathrm{Mo}$ & $4 / 0$ & $<5$ & $<5$ & $<5$ \\
\hline $\mathrm{Cd}$ & $4 / 0$ & $<1$ & $<1$ & $<1$ & $\mathrm{Cd}$ & $4 / 0$ & $<1$ & $<1$ & $<1$ \\
\hline $\mathrm{Ba}$ & $4 / 4$ & 80 & 54 & 105 & $\mathrm{Ba}$ & $4 / 4$ & 88 & 36 & 133 \\
\hline $\mathrm{Be}$ & $4 / 0$ & $<1$ & $<1$ & $<1$ & $\mathrm{Be}$ & $4 / 0$ & $<1$ & $<1$ & $<1$ \\
\hline $\mathrm{Ni}$ & $4 / 4$ & 13 & 5 & 29 & $\mathrm{Ni}$ & $4 / 4$ & 15 & 7 & 33 \\
\hline $\mathrm{Co}$ & $4 / 2$ & $<7$ & $<6$ & 11 & $\mathrm{Co}$ & $4 / 3$ & $<8$ & $<6$ & 14 \\
\hline $\mathrm{Cr}$ & $4 / 4$ & 7 & 5 & 12 & $\mathrm{Cr}$ & $4 / 4$ & 8 & 5 & 14 \\
\hline $\mathrm{V}$ & $4 / 4$ & 29 & 21 & 39 & $\mathrm{~V}$ & $4 / 4$ & 39 & 30 & 47 \\
\hline $\mathrm{Cu}$ & $4 / 4$ & 12 & 10 & 15 & $\mathrm{Cu}$ & $4 / 4$ & 15 & 13 & 18 \\
\hline $\mathrm{Zn}$ & $4 / 4$ & 45 & 32 & 61 & $\mathrm{Zn}$ & $4 / 4$ & 34 & 24 & 46 \\
\hline $\mathrm{Fe}$ & $4 / 4$ & 12,129 & 8,317 & 19,180 & $\mathrm{Fe}$ & $4 / 4$ & 15,017 & 10,359 & 23,288 \\
\hline $\mathrm{Mn}$ & $4 / 4$ & 499 & 248 & 673 & $\mathrm{Mn}$ & $4 / 4$ & 263 & 137 & 430 \\
\hline $\mathrm{K}$ & $4 / 4$ & 526 & 391 & 615 & $\mathrm{~K}$ & $4 / 4$ & 436 & 244 & 567 \\
\hline $\mathrm{Al}$ & $4 / 4$ & 16,426 & 13,597 & 21,690 & $\mathrm{Al}$ & $4 / 4$ & 19,505 & 14,848 & 25,605 \\
\hline $\mathrm{Li}$ & $4 / 1$ & $<5$ & $<5$ & 6 & $\mathrm{Li}$ & $4 / 3$ & $<6$ & $<5$ & 8 \\
\hline $\mathrm{Ca}$ & $4 / 4$ & 3,276 & 2,314 & 3,968 & $\mathrm{Ca}$ & $4 / 4$ & 3,081 & 2,372 & 3,947 \\
\hline $\mathrm{Na}$ & $4 / 4$ & 614 & 470 & 767 & $\mathrm{Na}$ & $4 / 4$ & 793 & 701 & 981 \\
\hline $\mathrm{Mg}$ & $4 / 4$ & 1,798 & 805 & 3,924 & $\mathrm{Mg}$ & $4 / 4$ & 2,155 & 1,017 & 4,798 \\
\hline $\mathrm{La}$ & $4 / 1$ & $<5$ & $<5$ & 5.7 & $\mathrm{La}$ & $4 / 3$ & $<6$ & $<5$ & 8 \\
\hline $\mathrm{Sb}$ & $4 / 0$ & $<20$ & $<20$ & $<20$ & $\mathrm{Sb}$ & $4 / 0$ & $<20$ & $<20$ & $<20$ \\
\hline $\mathrm{Pb}$ & $4 / 1$ & $<10$ & $<10$ & 10 & $\mathrm{~Pb}$ & $4 / 0$ & $<10$ & $<10$ & $<10$ \\
\hline $\mathrm{Tl}$ & $4 / 0$ & $<50$ & $<50$ & $<50$ & $\mathrm{Tl}$ & $4 / 0$ & $<50$ & $<50$ & $<50$ \\
\hline $\mathrm{As}$ & $4 / 0$ & $<20$ & $<20$ & $<20$ & $\mathrm{As}$ & $4 / 0$ & $<20$ & $<20$ & $<20$ \\
\hline $\mathrm{Se}$ & $4 / 0$ & $<30$ & $<30$ & $<30$ & $\mathrm{Se}$ & $4 / 0$ & $<30$ & $<30$ & $<30$ \\
\hline $\mathrm{Hg}$ & $4 / 3$ & $<0.06$ & $<0.04$ & 0.09 & $\mathrm{Hg}$ & $4 / 0$ & $<0.04$ & $<0.04$ & $<0.04$ \\
\hline
\end{tabular}

${ }^{1}$ Detects are the number of samples with concentrations equal to or greater than the laboratory's reporting limit. 
Table 18. Average Distribution of Metals (in ppm dry) in Soils Developed on Major Igneous Rocks of Southwest Oregon.

\begin{tabular}{|c|c|c|c|c|c|c|}
\hline \multirow[t]{2}{*}{ Metal } & \multicolumn{2}{|c|}{$\begin{array}{l}\text { Ultramafic and Mafic Rocks } \\
\text { (19)* }\end{array}$} & \multicolumn{2}{|c|}{$\begin{array}{c}\text { Intermediate and Felsic } \\
\text { Rocks }^{b}(7)^{*}\end{array}$} & \multicolumn{2}{|c|}{ Felsic Rocks ${ }^{c}(8)^{*}$} \\
\hline & A Horizon & B Horizon & A Horizon & B Horizon & A Horizon & B Horizon \\
\hline$A \mathbf{l}^{\star \star}$ & $3.7(2.3)^{* * *}$ & $4.8(3.0)$ & $2.9(1.5)$ & $4.1(2.4)$ & $1.7(0.6)$ & $2.5(0.6)$ \\
\hline $\mathbf{B a}$ & $189(113)$ & $160(114)$ & $138(137)$ & $126(149)$ & $156(107)$ & $96(75)$ \\
\hline$\overline{\mathbf{C a}}$ & $6,755(4,367)$ & $3,810(3,503)$ & $4,094(2,766)$ & $3,226(2,300)$ & $3,417(1,378)$ & $2,297(1,049)$ \\
\hline Co & $<27(>26)$ & $<33(>33)$ & $<12(>9)$ & $<15(>10)$ & $<7(>1)$ & $<8(>2)$ \\
\hline$\overline{C r}$ & $110(298)$ & $149(412)$ & $43(82)$ & $50(90)$ & $8(7)$ & $11(9)$ \\
\hline$\overline{\mathrm{Cu}}$ & $47(46)$ & $63(62)$ & $22(9)$ & $30(15)$ & $9(4)$ & $14(8)$ \\
\hline $\mathrm{Fe}^{\star \star \star}$ & $4.0(3.2)$ & $5.0(4.1)$ & $2.3(1.9)$ & $2.9(2.3)$ & $1.2(0.4)$ & $\overline{1.6(0.4)}$ \\
\hline$\overline{H g}$ & $<0.09(>0.05)$ & $<0.07(>0.02)$ & $0.09(0.05)$ & $<0.08(>0.04)$ & $0.06(0.02)$ & $<0.04(>0.01)$ \\
\hline$\overline{\mathbf{K}}$ & $1,052(585)$ & $806(526)$ & $767(585)$ & $686(506)$ & $836(624)$ & $767(690)$ \\
\hline La & $<7(>4)$ & $<10(>6)$ & $<6(>2)$ & $<6(>3)$ & $<7(>4)$ & $<8(>4)$ \\
\hline$\overline{\mathbf{L i}}$ & $<8(>4)$ & $<10(>5)$ & $<14(>16)$ & $<16(>17)$ & $<8(>6)$ & $10(8)$ \\
\hline$\overline{\mathbf{M g}}$ & $4,433(4,046)$ & $5,152(4,692)$ & $3,799(4,788)$ & $4,446(5,327)$ & $1,446(588)$ & $1,728(538)$ \\
\hline$\overline{\mathbf{M n}}$ & $1,929(1,472)$ & $1,029(955)$ & $1,215(1207)$ & $386(378)$ & $984(770)$ & $487(612)$ \\
\hline $\mathrm{Na}$ & $436(341)$ & $552(511)$ & $563(514)$ & $761(668)$ & $424(243)$ & $661(440)$ \\
\hline$\overline{\mathrm{Ni}}$ & $97(254)$ & $128(344)$ & $60(116)$ & $69(125)$ & $9(5)$ & $10(4)$ \\
\hline$\overline{\mathbf{P b}}$ & $<10(>0.13)$ & $<10(0)$ & $<11(>2)$ & $<10(0)$ & $<11(>3)$ & $<10(>0.6)$ \\
\hline $\bar{V}$ & $97(91)$ & $121(103)$ & $54(27)$ & $75(47)$ & $26(7)$ & $36(14)$ \\
\hline$\overline{\mathbf{Z n}}$ & $87(42)$ & $82(40)$ & $63(32)$ & $52(27)$ & $53(26)$ & $48(33)$ \\
\hline
\end{tabular}

a include geologic units bc, Ju, Qb, QTb, QTmv, QTvm, Tb, Tmv, Tob, Tpb, Tps, Trb, Tsr and Tub. Only $\mathrm{Ju}$ is ultramafic. The remainder are mafic.

${ }^{b}$ include geologic units JTrgd, Qa, Qrd and Trh.

c include geologic units KJg, Qma, Qmp, Tat and Tsv.

* number in parentheses is the number of values averaged.

** has concentration in percent.

*** value in parentheses is the arithmetic standard deviation.

Note: (1) Concentrations of $\mathrm{Ag}, \mathrm{As}, \mathrm{Be}, \mathrm{Cd}, \mathrm{Mo}, \mathrm{Sb}$, Se and $\mathrm{Tl}$ in most or all of the samples are below their laboratory's reporting limits. Therefore these metals are not included in the above comparative study.

(2) Where the concentration of a metal in a sample is less than the laboratory's minimum reporting level, the minimum reporting level is used for calculating statistics. Accordingly the statistics of those metals are qualified as less than or greater than the value given. 
Table 19. Average Distribution of Metals (in ppm dry) in Major Soil Orders of Southwest Oregon.

\begin{tabular}{|c|c|c|c|c|c|c|c|c|}
\hline Metal & \multicolumn{2}{|c|}{$\begin{array}{l}\text { Entisols } \\
(27)^{\star}\end{array}$} & \multicolumn{2}{|c|}{$\begin{array}{l}\text { Inceptisols } \\
(44)^{*}\end{array}$} & \multicolumn{2}{|c|}{$\begin{array}{c}\text { Alfisols Vltisols } \\
(31)^{*}\end{array}$} & \multicolumn{2}{|c|}{$\begin{array}{l}\text { Mollisols } \\
(14)^{*}\end{array}$} \\
\hline & $\begin{array}{c}A \\
\text { Horizon }\end{array}$ & $\begin{array}{c}\bar{B} \\
\text { Horizon }\end{array}$ & $\begin{array}{c}\text { A } \\
\text { Horizon }\end{array}$ & $\begin{array}{c}\mathrm{B} \\
\text { Horizon }\end{array}$ & $\begin{array}{c}A \\
\text { Horizon }\end{array}$ & $\begin{array}{c}\bar{B} \\
\text { Horizon }\end{array}$ & $\begin{array}{c}\mathbf{A} \\
\text { Horizo } \\
\mathrm{n}\end{array}$ & $\begin{array}{c}\mathrm{B} \\
\text { Horizo } \\
\mathrm{n}\end{array}$ \\
\hline$\overline{\mathbf{I}^{* *}}$ & 1.5 & 2.0 & 3.0 & 3.8 & 3.8 & 5.7 & 4.3 & 5.6 \\
\hline $\mathbf{B a}$ & 98 & 84 & 203 & 161 & 189 & 126 & 252 & 228 \\
\hline$\overline{\mathrm{Ca}}$ & 3,530 & 2,977 & 5,740 & 3,375 & 5,900 & 3,359 & 9,413 & 5,188 \\
\hline$\overline{C_{0}}$ & $<7$ & $<8$ & $<15$ & $<18$ & $<29$ & $<36$ & 22 & 28 \\
\hline$\overline{\mathbf{C r}}$ & 6 & 9 & 46 & 58 & 125 & 188 & 32 & 41 \\
\hline$\overline{\mathbf{C u}}$ & $<12$ & 17 & 27 & $<34$ & 49 & 72 & 44 & 57 \\
\hline$\overline{F^{k *}}$ & 1.1 & 1.4 & 2.7 & 3.3 & 4.5 & 6.1 & 3.6 & 4.6 \\
\hline $\mathrm{Hg}$ & $<0.06$ & $<0.05$ & $<0.11$ & $<0.06$ & $<0.12$ & $<0.08$ & $<0.10$ & $<0.05$ \\
\hline $\mathrm{K}$ & 580 & 493 & $1, \overline{474}$ & 1,338 & 1,353 & 1,105 & 1,444 & 1,202 \\
\hline La & $<5$ & $<6$ & $<9$ & $<11$ & $<8$ & $<9$ & $<11$ & $<14$ \\
\hline$\overline{\mathbf{L i}}$ & $\overline{<5}$ & $\overline{<6}$ & $<13$ & $<17$ & $<14$ & $<20$ & $<9$ & $<11$ \\
\hline$\overline{\mathrm{Mg}}$ & 1,311 & 1,701 & $5, \overline{081}$ & 5,990 & 6,267 & 7,737 & 4,294 & $4, \overline{994}$ \\
\hline $\mathbf{M n}$ & 833 & 216 & 1,541 & 961 & 2,125 & 1,229 & 1,757 & 998 \\
\hline $\mathrm{Na}$ & 590 & 785 & 321 & 356 & 140 & 135 & 435 & 593 \\
\hline $\mathrm{Ni}$ & 10 & $<13$ & $<47$ & $<60$ & 107 & 160 & 32 & 39 \\
\hline$\overline{\mathbf{P b}}$ & $<10$ & $<10$ & $<21$ & $<11$ & $<23$ & $<10$ & $<10$ & $<10$ \\
\hline $\mathbf{v}$ & 29 & 38 & 57 & 71 & 114 & 152 & 88 & 113 \\
\hline$\overline{\mathbf{Z n}}$ & $\overline{49}$ & 38 & 78 & 76 & 85 & 82 & 86 & 78 \\
\hline
\end{tabular}

* number in parentheses is the number of values averaged.

** has concentration in percent.

Note: (1) Concentrations of $\mathrm{Ag}, \mathrm{As}, \mathrm{Be}, \mathrm{Cd}, \mathrm{Mo}, \mathrm{Sb}, \mathrm{Se}$ and $\mathrm{Tl}$ in most or all of the samples are beiow their respective laboratory's minimum reporting levels. Therefore these metals are not included in the above comparative study.

(2) Where the concentration of a metal in a sample is less than the laboratory's minimum reporting level, the minimm reporting level is used for calculating average. Accordingly the average values of those metals are qualified as less than the value given. 
In all cases the $t$-test at $95 \%$ confidence level was done to determine if a metal AM value for a horizon in the physiographic provinces or soil orders was statistically different between one another. The t-test at $95 \%$ confidence level was also done to determine if a metal AM value for a horizon was statistically different in soils derived from the major igneous rock units in the study area.

\section{ALUMINUM (AL)}

Distribution statistics for $\mathrm{Al}$ content in soils of the study area are listed in Table 20. At all 118 sites investigated, the $\mathrm{Al}$ concentrations in both the $\mathrm{A}$ and $\mathrm{B}$ horizons are greater than the laboratory's minimum reporting level of $10 \mathrm{ppm}$. The $\mathrm{Al}$ concentrations vary from 2,541 to $93,717 \mathrm{ppm}$ with an average of $30,125 \mathrm{ppm}$ in the A horizon and from 2,586 to $103,515 \mathrm{ppm}$ with an average of $40,935 \mathrm{ppm}$ in the B horizon.

The highest $\mathrm{Al}$ concentrations are in the analyzed samples from the Klamath Mountains ( $\mathrm{AM}$ for the $\mathrm{B}$ horizon $=50,912 \mathrm{ppm})$ and Coast Range $(\mathrm{AM}=45,461 \mathrm{ppm})$. The lowest analyzed soil Al levels are in the High Lava Plains (AM = 19,505 ppm) and Coastal Plain ( $\mathrm{AM}=21,192 \mathrm{ppm})$. The t-tests indicate that the first two values are different from the last two while the equality of values within the category cannot be rejected. Among soil orders, Alfisols/Ultisols $(\mathrm{AM}=56,844 \mathrm{ppm})$ and Mollisols ( $\mathrm{AM}=$ $56,089 \mathrm{ppm}$ ) are richest in analyzed Al. Entisols have the lowest analyzed Al concentrations $(\mathrm{AM}=20,079 \mathrm{ppm}) . \mathrm{Al}$ values in the analyzed samples from the 
Table 20. Distribution statistics for Aluminum (Al) content (ppm dry) in soils of Southwest Oregon.

\begin{tabular}{|c|c|c|c|c|c|c|c|}
\hline & $\begin{array}{l}\text { Hori- } \\
\text { zon }\end{array}$ & $\begin{array}{c}\text { Total } \\
\text { Sample } \\
\text { Number/ } \\
\text { Detects' }\end{array}$ & $\begin{array}{l}\text { Arith- } \\
\text { metic } \\
\text { Mean }\end{array}$ & $\begin{array}{l}\text { Mini- } \\
\text { mum }\end{array}$ & $\begin{array}{l}\text { Maxi- } \\
\text { mum }\end{array}$ & $\begin{array}{c}\text { Arith- } \\
\text { metic } \\
\text { Standard } \\
\text { Deviation }\end{array}$ & Median \\
\hline \multicolumn{8}{|l|}{ For all sites } \\
\hline & $\bar{A}$ & $118 / 118$ & 30,125 & 2,541 & 93,717 & 18,253 & 24,721 \\
\hline & $\mathrm{B}$ & $118 / 118$ & 40,935 & 2,586 & 103,515 & 23,121 & 35,473 \\
\hline \multicolumn{8}{|c|}{ Physiographic Provinces } \\
\hline \multirow[t]{2}{*}{ Coastal Plain } & $\mathrm{A}$ & $7 / 7$ & 9,806 & 2,541 & 29,237 & 9,804 & 6,246 \\
\hline & $\bar{B}$ & $7 / 7$ & 21,192 & 2,586 & 55,751 & 19,640 & 21,398 \\
\hline \multirow[t]{2}{*}{ Coast Range } & $\overline{\mathrm{A}}$ & $16 / 16$ & 33,582 & 17,362 & 73,145 & 16,338 & 17,362 \\
\hline & $\mathrm{B}$ & $16 / 16$ & 45,461 & 19,743 & 100,324 & 21,709 & 38,323 \\
\hline \multirow{2}{*}{$\begin{array}{c}\text { Willamette } \\
\text { Valley }\end{array}$} & $\overline{\mathrm{A}}$ & $2 / 2$ & 22,631 & 14,574 & 30,688 & 11,395 & 22,631 \\
\hline & $\overline{\mathrm{B}}$ & $2 / 2$ & 27,969 & 21,008 & 34,930 & 9,844 & 27,969 \\
\hline \multirow[t]{2}{*}{ Cascade Range } & $\overline{\mathrm{A}}$ & $39 / 39$ & 31,382 & 4,634 & 85,913 & 21,265 & 20,868 \\
\hline & $\overline{\mathrm{B}}$ & $39 / 39$ & 39,601 & 12,641 & 103,515 & 24,938 & 29,862 \\
\hline \multirow{2}{*}{$\begin{array}{c}\text { Klamath } \\
\text { Mountains }\end{array}$} & $\bar{A}$ & $32 / 32$ & 34,706 & 17,715 & 57,938 & 11,854 & 32,306 \\
\hline & $\overline{\mathrm{B}}$ & $32 / 32$ & 50,912 & 22,420 & 97,974 & 18,540 & 46,786 \\
\hline \multirow{2}{*}{$\begin{array}{l}\text { Basin and } \\
\text { Range }\end{array}$} & $\bar{A}$ & $18 / 18$ & 27,964 & 12,544 & 93,717 & 21,596 & 16,987 \\
\hline & $\mathrm{B}$ & $18 / 18$ & 35,949 & 13,989 & 102,212 & 23,987 & 25,448 \\
\hline \multirow[t]{2}{*}{ High Lava Plain } & $\mathrm{A}$ & $4 / 4$ & 16,426 & 13,597 & 21,690 & 3,734 & 15,209 \\
\hline & $\mathrm{B}$ & $4 / 4$ & 19,505 & 14,848 & 25,605 & 4,581 & 18,783 \\
\hline \multicolumn{8}{|l|}{ Soil Orders } \\
\hline \multirow[t]{2}{*}{ Entisols } & $\bar{A}$ & $27 / 27$ & 15,033 & 2,687 & 34,073 & 5,225 & 14,629 \\
\hline & $\mathrm{B}$ & $27 / 27$ & 20,079 & 2,752 & 38,105 & 6,856 & 18,549 \\
\hline \multirow[t]{2}{*}{ Inceptisols } & $\bar{A}$ & $44 / 44$ & 29,707 & 4,016 & 93,717 & 4,856 & 26,229 \\
\hline & $\overline{\mathrm{B}}$ & $44 / 44$ & 38,452 & 2,586 & 102,212 & 19,168 & 35,235 \\
\hline \multirow{2}{*}{$\begin{array}{l}\text { Alfisols/ } \\
\text { Ultisols }\end{array}$} & $\bar{A}$ & $31 / 31$ & 37,631 & 6,246 & 73,145 & 15,924 & 37,259 \\
\hline & $\mathrm{B}$ & $31 / 31$ & 56,844 & 29,679 & 100,324 & 20,008 & 57,490 \\
\hline \multirow[t]{2}{*}{ Mollisols } & $\bar{A}$ & $14 / 14$ & 42,945 & 14,574 & 85,913 & 22,412 & 35,145 \\
\hline & $\bar{B}$ & $14 / 14$ & 56,089 & 21,008 & 103,515 & 26,429 & 53,871 \\
\hline \multirow[t]{2}{*}{ Spodosol } & $\bar{A}$ & $1 / 1$ & $2,541^{2}$ & -- & - & - & -- \\
\hline & $\bar{B}$ & $1 / 1$ & $5,001^{8}$ & - & - & - & - \\
\hline \multirow[t]{2}{*}{ Vertisol } & $\mathrm{A}$ & $\overline{1 / 1}$ & $51,739^{a}$ & - & $\overline{-}$ & -- & - \\
\hline & B & $\overline{1 / 1}$ & $56,018^{2}$ & - & - & -- & - \\
\hline
\end{tabular}

${ }^{1}$ Detects are the number of samples with concentrations equal to or greater than the laboratory's reporting limit.

anly one concentration value is listed under arithmetic mean. 
different physiographic provinces as well as from the different soil orders in the study area have large standard deviations because these soils have been derived from rocks in which the $\mathrm{Al}$ concentrations vary widely.

The highest analyzed $\mathrm{Al}$ concentrations are in Mollisols and Alfisols/Ultisols formed on mafic and intermediate magmatic (geologic units cs, JTrgd, QTba, QTp, Trb, Tsr and Tub) and argillaceous sedimentary rocks (Kc, Tn and Ty). All the mentioned geologic units, except QTp, are in the Coast Range, Klamath Mountains and Cascade Range. These three physiographic provinces have comparable soil $\mathrm{Al}$ values. The lowest analyzed $\mathrm{Al}$ levels are in Entisols and Inceptisols derived from sandy and silty parent materials (Qd, Qt and $\mathrm{Tt})$. Al is rather uniformly distributed in mafic, intermediate and felsic rocks (Kabata-Pendias and Pendias, 1984). $\mathrm{Al}$ is also concentrated in argillaceous sediments, while sandstones contain the lowest values of this metal (Aubert and Pinta, 1980). The Al content of soils is inherited from parent rocks (Peterson and Girling,1981). In the study area, the average Al concentrations in soils on major types of igneous rocks are close, especially in mafic and intermediate rocks (Table 18).

In the cold and subhumid environments of the Basin and Range and High Lava Plains, Entisols formed on basaltic and andesitic rocks (QTps, QTvm, Tob and Tp) have low $\mathrm{Al}$ concentrations. This indicates that the soil $\mathrm{Al}$ content is also influenced by soil development, which in turn is greatly controlled by climatic conditions, in addition to parent rocks. In the samples from the study area, the average soil $\mathrm{Al}$ levels increase with soil development (Table 19), i.e. Entisols $<$ Inceptisols $<$ Alfisols/Ultisols. The t-test 
indicates that the mean $\mathrm{Al}$ values in these soil orders are statistically different from one another.

$\mathrm{Al}$ is highly mobile in acid soil solutions (Peterson and Girling, 1981). Samples from acid leached sandy soils of the Coastal Plain (see Table 7 for average soil-solution $\mathrm{pH}$ in the different physiographic provinces covered in this study) are extremely poor in Al. Mollisols are developed in the Willamette Valley, eastern Klamath Mountains and Basin and Range province; all are characterized by a subhumid climate and slightly alkaline soil-solution. Mollisols are richest in analyzed $\mathrm{Al}$, possibly because these soils have been able to hold the metal.

In the study area the analyzed $\mathrm{Al}$ concentrations in the $\mathrm{A}$ and $\mathrm{B}$ horizons have the pooled variance of $1,317,000$ and the pooled standard deviation of 1147 . The null hypothesis Ho: $\mathrm{A}=\mathrm{B}$ can be rejected if $\mathrm{A}-\mathrm{B}$ is greater than $3350(2.92 * 1147$, i.e. the $\mathrm{t}-$ critical value at $95 \%$ confidence level multiplied by the pooled standard deviation). The results of the analysis for the $\mathrm{Al}$ concentrations in the A horizon versus the $\mathrm{B}$ horizon at 118 sites investigated are as follows: $\mathrm{B}>\mathrm{A}$ in $83.1 \%$ of the profiles and $\mathrm{A}>\mathrm{B}$ in $0.8 \%$ of the profiles. In the rest of the profiles (16.1\%) we cannot reject the equality of the values in the two horizons. Bowen (1979) observed that $\mathrm{Al}$ is normally concentrated in the $\mathrm{B}$ horizon. The Al concentration difference between horizons is most pronounced in welldrained, humid Alfisols/Ultisols of the Coast Range and Klamath Mountains. 


\section{ANTIMONY (SB)}

In the study area all the analyzed $\mathrm{Sb}$ values in both the $\mathrm{A}$ and $\mathrm{B}$ horizons are less than the laboratory's minimum reporting level of $20 \mathrm{ppm}$. This is expected as the total Sb content of soils is usually very low with an average of about $1 \mathrm{ppm}$ (Bowen, 1979). Jones and others (1993) reported the total Sb concentrations of the U.S. soils vary from 2.3 to $9.5 \mathrm{ppm}$.

\section{ARSENIC (AS)}

In the analyzed samples from only two sites in the Klamath Mountains As has values at or above the laboratory's minimum reporting level of $20 \mathrm{ppm}$. Site KL21 contains $36.4 \mathrm{ppm}$ in the A horizon and $46.5 \mathrm{ppm}$ in the B horizon. Site R13 has 29.4 ppm in the B horizon. Both the sites occur in well-drained Alfisol (clay loam). The associated parent rocks are Condrey Mountain Schist (geologic unit $\mathrm{cm}$ ) at site KL21 and basalt (Jub) at site R13.

The normal soil As range is $1-40$ ppm (includes both the A and B horizons) with most soils being in the lower half of this range (O’Neill, 1993). In the U.S., the As values in the surface horizons of clay/clay loamy soils range from 1.7 to $27 \mathrm{ppm}$ (Kabata-Pendias and Pendias, 1984) (Appendix 8.1). Due to common As pollution, the levels of this metal are likely to be increased in topsoils (Kabata-Pendias and Pendias, 1984). The higher As values in the $B$ horizon versus the $A$ horizon at both the sites reduce the possibility of anthropogenic contamination. Boyle and Jonasson (1973) noted 
elevated As levels with sulfide-mineralization which is common in the Klamath Mountains (Orr and others, 1992).

\section{$\operatorname{BARIUM}(B A)$}

Distribution statistics for Ba content in soils of the study area are listed in Table 21. At all 118 sites investigated, the $B a$ concentrations in both the $A$ and $B$ horizons are greater than the laboratory's minimum reporting level of three ppm. The Ba levels range from 8 to $792 \mathrm{ppm}$ with an average of $181 \mathrm{ppm}$ in the A horizon and from 7 to $525 \mathrm{ppm}$ with an average of $141 \mathrm{ppm}$ in the B horizon. Kabata-Pendias and Pendias (1984) reported the U.S. surface soil Ba to range from 10 to $3,000 \mathrm{ppm}$, with an average of 265 835 ppm (Appendix 8.1). Soils of the study area have lower concentrations of Ba than soils of the rest of the U.S.

The highest $\mathrm{Ba}$ concentrations are in the analyzed samples from the Klamath Mountains ( $\mathrm{AM}$ for the $\mathrm{A}$ horizon $=205 \mathrm{ppm})$ and Cascade Range $(\mathrm{AM}=202 \mathrm{ppm})$. The Coastal Plain samples have the lowest $B a$ concentrations $(\mathrm{AM}=31 \mathrm{ppm})$. The highest analyzed $\mathrm{Ba}$ concentrations are in Mollisols $(\mathrm{AM}=252 \mathrm{ppm})$, Inceptisols $(\mathrm{A}=$ $203 \mathrm{ppm}$ ) and Alfisols/Ultisols ( $\mathrm{AM}=189 \mathrm{ppm})$. The mean Ba values in these three soil orders (Table 21) are statistically equal. Entisols have the lowest analyzed Ba concentrations $(\mathrm{AM}=98 \mathrm{ppm})$. Ba values in the analyzed samples from the different physiographic provinces as well as from the different soil orders in the study area have large standard deviations because these soils have been derived from rocks in which the Ba concentrations vary widely. 
Table 21. Distribution statistics for Barium (Ba) content (ppm dry) in soils of Southwest Oregon.

\begin{tabular}{|c|c|c|c|c|c|c|c|}
\hline & $\begin{array}{c}\text { Hori- } \\
\text { zon }\end{array}$ & $\begin{array}{c}\text { Total } \\
\text { Sample } \\
\text { Number/ } \\
\text { Detects }{ }^{1}\end{array}$ & $\begin{array}{l}\text { Arith- } \\
\text { metic } \\
\text { Mean }\end{array}$ & $\begin{array}{l}\text { Mini- } \\
\text { mum }\end{array}$ & $\begin{array}{l}\text { Maxi- } \\
\text { mum }\end{array}$ & $\begin{array}{c}\text { Arithmetic } \\
\text { Standard } \\
\text { Deviation }\end{array}$ & Median \\
\hline \multicolumn{8}{|l|}{ For all sites } \\
\hline & $\overline{\mathrm{A}}$ & $118 / 118$ & 181 & 8 & 792 & 138 & 149 \\
\hline & $\mathrm{B}$ & $118 / 118$ & 141 & 7 & 525 & 107 & 123 \\
\hline \multicolumn{8}{|c|}{ Physiographic Provinces } \\
\hline \multirow[t]{2}{*}{ Coastal Plain } & $\mathrm{A}$ & $7 / 7$ & 31 & 8 & 65 & 18 & 34 \\
\hline & $\bar{B}$ & $7 / 7$ & 37 & 7 & 77 & 24 & 36 \\
\hline \multirow[t]{2}{*}{ Coast Range } & $\mathrm{A}$ & $16 / 16$ & 175 & 22 & 287 & 77 & 173 \\
\hline & B & $16 / 16$ & 131 & 23 & 196 & 48 & 133 \\
\hline \multirow{2}{*}{$\begin{array}{c}\text { Willamette } \\
\text { Valley }\end{array}$} & $\mathrm{A}$ & $2 / 2$ & 139 & 136 & 143 & 5 & 139 \\
\hline & B & $2 / 2$ & 110 & 64 & 157 & 66 & 110 \\
\hline \multirow{2}{*}{$\begin{array}{c}\text { Cascade } \\
\text { Range }\end{array}$} & $\mathrm{A}$ & $39 / 39$ & 202 & 32 & 792 & 158 & 175 \\
\hline & $\mathrm{B}$ & $39 / 39$ & 154 & 21 & 525 & 128 & 124 \\
\hline \multirow{2}{*}{$\begin{array}{c}\text { Klamath } \\
\text { Mountains }\end{array}$} & $\mathrm{A}$ & $32 / 32$ & 205 & 45 & 736 & 149 & 173 \\
\hline & B & $32 / 32$ & 143 & 25 & 491 & 99 & 131 \\
\hline \multirow{2}{*}{$\begin{array}{c}\text { Basin and } \\
\text { Range }\end{array}$} & $\bar{A}$ & $18 / 18$ & 180 & 52 & 432 & 121 & 118 \\
\hline & $\mathrm{B}$ & $18 / 18$ & 171 & 49 & 456 & 119 & 117 \\
\hline \multirow{2}{*}{$\begin{array}{c}\text { High Lava } \\
\text { Plain }\end{array}$} & $\mathrm{A}$ & $4 / 4$ & 80 & 54 & 105 & 21 & 80 \\
\hline & $\mathrm{B}$ & $4 / 4$ & 88 & 36 & 133 & 40 & 91 \\
\hline \multicolumn{8}{|l|}{ Soil Orders } \\
\hline \multirow[t]{2}{*}{ Entisols } & $\bar{A}$ & $27 / 27$ & 98 & 8 & 204 & 49 & 86 \\
\hline & B & $27 / 27$ & 84 & 25 & 205 & 48 & 76 \\
\hline \multirow[t]{2}{*}{ Inceptisols } & $\mathrm{A}$ & $44 / 44$ & 203 & 14 & 792 & 158 & 161 \\
\hline & B & $44 / 44$ & 161 & 7 & 491 & 111 & 136 \\
\hline \multirow{2}{*}{$\begin{array}{l}\text { Alfisols/ } \\
\text { Ultisols }\end{array}$} & A & $31 / 31$ & 189 & 22 & 523 & 124 & 178 \\
\hline & $\mathrm{B}$ & $31 / 31$ & 126 & 23 & 356 & 72 & 128 \\
\hline \multirow[t]{2}{*}{ Mollisols } & $\mathrm{A}$ & $14 / 14$ & 252 & 32 & 475 & 146 & 253 \\
\hline & B & $14 / 14$ & 228 & 31 & 525 & 167 & 185 \\
\hline \multirow[t]{2}{*}{ Spodosol } & $\bar{A}$ & $1 / 1$ & $34^{2}$ & -- & - & -- & -- \\
\hline & $\mathrm{B}$ & $1 / 1$ & $10^{2}$ & -- & -- & - & -- \\
\hline \multirow[t]{2}{*}{ Vertisol } & $\mathrm{A}$ & $1 / 1$ & $175^{a}$ & -- & -- & -- & $-\cdot$ \\
\hline & B & $1 / 1$ & $170^{2}$ & -- & -- & -- & -- \\
\hline
\end{tabular}

'Detects are the number of samples with concentrations equal to or greater than the laboratory's reporting limit.

a Only one concentration value is listed under arithmetic mean. 
Inceptisols, Alfisols/Ultisols and Mollisols developed on argillaceous sedimentary rocks and volcaniclastics (geologic units Kc, TrPzs and Tus), basaltic andesite (Qtba and $\mathrm{Trb})$, granite $(\mathrm{KJg})$ and rhyolite and dacite $(\mathrm{Trh})$ have the highest analyzed concentrations of $\mathrm{Ba}$. The lowest analyzed $\mathrm{Ba}$ values are found in soils derived from clastic sedimentary rocks (silts, sands and gravels) (Qd, Qf, Qg, Qgf Qt and Tss) and ultramafics (Ju and Kjgu). The concentration of $\mathrm{Ba}$ in soils is reported to generally depend on parent rocks (Kabata-Pendias and Pendias, 1984). The above soil Ba concentrations are reasonable as $\mathrm{Ba}$ concentrates in intermediate and felsic magmatic rocks and argillaceous sediments(Kabata-Pendias and Pendias, 1984; Aubert and Pinta, 1980).

In the study area the analyzed $\mathrm{Ba}$ concentrations in the $\mathrm{A}$ and $\mathrm{B}$ horizons have the pooled variance of 281.8 and the pooled standard deviation of 16.8 . The null hypothesis Ho: $\mathrm{A}=\mathrm{B}$ can be rejected if $\mathrm{A}-\mathrm{B}$ is greater than $49.0(2.92 * 16.8)$. The results of the analysis for the $\mathrm{Ba}$ concentrations in the $\mathrm{A}$ horizon versus the $\mathrm{B}$ horizon at 118 sites investigated are as follows: $\mathrm{A}>\mathrm{B}$ in $32.2 \%$ of the profiles and $\mathrm{B}>\mathrm{A}$ in $5.9 \%$ of the profiles. In the rest of the profiles (61.9\%) we cannot reject the equality of the values in the two horizons. The Ba concentrations in the B horizon are observed in podzols of the Coastal and High Lava Plains and in some well-drained, humid soils of the Coast and Cascade Ranges. 


\section{BERYLLIUM (BE)}

Be has detects in the analyzed samples from only five sites situated in the Coast Range and Klamath Mountains. The analyzed Be values at or above the laboratory's reporting limit are listed in Table 22. The analyzed samples from both the sites LC9 and KL15 have Be levels of $1.0 \mathrm{ppm}$ in the A horizon and $1.3 \mathrm{ppm}$ in the B horizon. These are the highest Be values found in this study. The site LC9 occurs in well-drained Mollisol developed on mudstone of the Yamhill Formation (Ty) in the Coast Range. The site KL15 is in well-drained Inceptisol formed on shale and mudstone (Jss) in the Klamath Mountains. Be levels in surface soils of the U.S. range from $<1$ to $15 \mathrm{ppm}$ with an average of $1.6 \mathrm{ppm}$ (Kabata-Pendias and Pendias, 1984) (Appendix 8.1). The surface-soil Be values ( $<1$ to $1 \mathrm{ppm}$ ) found in this study are slightly lower than that of the U.S. in general. At all the five sites listed in Table 22, Be is rather uniformly distributed in the soil profiles.

Table 22. Beryllium (Be) values, at or above laboratory's reporting limit of 1 ppm, in Southwest Oregon.

\begin{tabular}{|c|c|c|c|c|c|}
\hline Site & $\begin{array}{c}\text { Physiographic } \\
\text { Province }\end{array}$ & $\begin{array}{c}\text { Geologic } \\
\text { Unit }\end{array}$ & $\begin{array}{c}\text { Conc (ppm) } \\
\text { in A Horizon }\end{array}$ & $\begin{array}{c}\text { Conc (ppm) } \\
\text { in B Horizon }\end{array}$ & Soil Order \\
\hline & Coast Range & & & & \\
\hline LC5 & Coast Range & Tmsm & 1.0 & 1.0 & Inceptisol \\
\hline LC9 & Klamath Mtn & Ty & 1.0 & 1.3 & Mollisol \\
\hline KL14 & Klamath Mtn & Jss & $<1.0$ & 1.0 & Alfi/Ultisol \\
\hline KL15 & Klamath Mtn & Jss & 1.0 & 1.3 & Inceptisol \\
\hline R12 & Klamath Mtn & Jub & $<1.0$ & 1.0 & Inceptisol \\
\hline
\end{tabular}


CADMIUM (CD)

$\mathrm{Cd}$ has detects in the analyzed samples from 16 sites located mostly in the Coast Range and Klamath Mountains. The analyzed Cd values at or above the laboratory's reporting limit are listed in Table 23.

Almost all the $\mathrm{Cd}$ detects are in the samples from most developed soils, the Alfisols/Ultisols and Mollisols. The highest analyzed soil $\mathrm{Cd}$ concentration is at site $\mathrm{KL} 16$ (1.0 ppm in the A horizon and $1.5 \mathrm{ppm}$ in the B horizon). The other notable $\mathrm{Cd}$ values are in the analyzed samples from site LC6 (1.2 ppm in the A horizon and 1.1 ppm in the B horizon) and site $\mathrm{KL} 30$ (1.0 ppm in the A horizon and $1.2 \mathrm{ppm}$ in the $\mathrm{B}$ horizon). Clay-rich soils at all these sites are developed on ultramafic/mafic rocks (geologic units bc, Ju and Tsr). The soil Cd contents ( $<1-1.2 \mathrm{ppm}$ in the A horizon and $<1.0-1.5 \mathrm{ppm}$ in the B horizon) found in this study are similar to $\mathrm{Cd}$ values (0.005 to 2.4 ppm) (includes both the A and B horizons) reported by Holmgren and others (1993) for uncontaminated soils from 36 states of the U.S.

In the study area the $\mathrm{Cd}$ concentrations in the $\mathrm{A}$ and $\mathrm{B}$ horizons have the pooled variance of 0.00 . The $\mathrm{Cd}$ values in the $\mathrm{A}$ horizon versus the $\mathrm{B}$ horizon of the soil profiles at the 16 sites listed in Table 23 are as follows: $\mathrm{B}>\mathrm{A}$ at ten sites $(62.5 \%), \mathrm{A}>\mathrm{B}$ at four sites $(25.0 \%)$ and at two sites $(12.5 \%)$ we cannot reject the equality of the values in the two horizons. Usually $\mathrm{Cd}$ tends to accumulate in the surface horizons characterized by a relatively high humus content (Alloway, 1993b). The observed slightly higher Cd levels 
in the $\mathrm{B}$ horizon than in the A horizon are possibly compatible with the slightly acidic soils of the Coast Range and Klamath Mountains (Alloway, 1993c).

Table 23. Cadmium (Cd) values, at or above laboratory's reporting limit of 1 ppm, in Southwest Oregon.

\begin{tabular}{|c|c|c|c|c|c|}
\hline Site & $\begin{array}{c}\text { Physiographic } \\
\text { Province }\end{array}$ & $\begin{array}{c}\text { Geologic } \\
\text { Unit }\end{array}$ & $\begin{array}{c}\text { Conc (ppm) } \\
\text { in A Horizon }\end{array}$ & $\begin{array}{c}\text { Conc (ppm) } \\
\text { in B Horizon }\end{array}$ & Soil Order \\
\hline & & & & & \\
\hline LM1 & Coast Range & Qls & 1.0 & $<1.0$ & Inceptisol \\
\hline LM14 & Cascade Range & Trb & $<1.0$ & 1.0 & Mollisol \\
\hline LC6 & Coast Range & Tsr & 1.2 & 1.1 & Mollisol \\
\hline LC8 & Coast Range & Tmss & 1.0 & $<1.0$ & Inceptisol \\
\hline LC10A & Coast Range & Tsr & 1.0 & 1.1 & Ultisol \\
\hline LC19 & Coast Range & Tsr & $<1.0$ & 1.1 & Ultisol \\
\hline LC23 & Coast Range & Tpb & 1.0 & 1.0 & Inceptisol \\
\hline EO7 & Basin \& Range & Tb & $<1.0$ & 1.0 & Mollisol \\
\hline KL1 & Klamath Mtn & Js & $<1.0$ & 1.0 & Ultisol \\
\hline KL6 & Klamath Mtn & cs & 1.0 & 1.0 & Alfisol \\
\hline KL9 & Klamath Mtn & JTrgd & $<1.0$ & 1.0 & Ultisol \\
\hline KL12 & Klamath Mtn & cs & 1.0 & $<1.0$ & Ultisol \\
\hline KL16 & Klamath Mtn & Ju & 1.0 & 1.5 & Alfi/Ultisol \\
\hline KL17 & Klamath Mtn & Jm & $<1.0$ & 1.1 & Alfi/Ultisol \\
\hline KL30 & Klamath Mtn & bc & 1.0 & 1.2 & Alfisol \\
\hline R13 & Klamath Mtn & Jub & $<1.0$ & 1.0 & Alfi/Ultisol \\
\hline
\end{tabular}

\section{CALCIUM (CA)}

Distribution statistics for Ca content in soils of the study area are listed in Table 24. At all 118 sites investigated, the Ca concentrations in both the A and B horizons are greater than the laboratory's minimum reporting level of $10 \mathrm{ppm}$. The Ca concentrations vary from 638 to $18,682 \mathrm{ppm}$ with an average of 5,741 ppm in the A horizon and from 134 to $15,173 \mathrm{ppm}$ with an average of 3,542 ppm in the B horizon. 
Table 24. Distribution statistics for Calcium (Ca) content (ppm dry) in soils of Southwest Oregon.

\begin{tabular}{|c|c|c|c|c|c|c|c|}
\hline & $\begin{array}{c}\text { Hori- } \\
\text { zon }\end{array}$ & $\begin{array}{c}\text { Total } \\
\text { Sample } \\
\text { Number/ } \\
\text { Detects }\end{array}$ & $\begin{array}{l}\text { Arith- } \\
\text { metic } \\
\text { Mean }\end{array}$ & $\begin{array}{l}\text { Mini- } \\
\text { mum }\end{array}$ & $\begin{array}{l}\text { Maxi- } \\
\text { mum }\end{array}$ & $\begin{array}{c}\text { Arith- } \\
\text { metic } \\
\text { Standard } \\
\text { Deviation }\end{array}$ & Median \\
\hline \multicolumn{8}{|l|}{ For all sites } \\
\hline & $\bar{A}$ & $118 / 118$ & 5,741 & 638 & 18,682 & 3,970 & 4,793 \\
\hline & $\bar{B}$ & $118 / 118$ & 3,542 & 134 & 15,173 & 3,023 & 2,823 \\
\hline \multicolumn{8}{|c|}{ Physiographic Provinces } \\
\hline \multirow[t]{2}{*}{ Coastal Plain } & $\mathrm{A}$ & $7 / 7$ & 1,446 & 640 & 1,914 & 503 & 1,553 \\
\hline & $\bar{B}$ & $7 / 7$ & 567 & 292 & 1,117 & 263 & 524 \\
\hline \multirow[t]{2}{*}{ Coast Range } & $\overline{\mathrm{A}}$ & $16 / 16$ & 5,536 & 638 & 15,137 & 3,319 & 5,245 \\
\hline & $\mathrm{B}$ & $16 / 16$ & 3,014 & 376 & 14,619 & 3,626 & 1,465 \\
\hline \multirow{2}{*}{$\begin{array}{c}\text { Willamette } \\
\text { Valley }\end{array}$} & $\bar{A}$ & $2 / 2$ & $9, \overline{502}$ & $3, \overline{081}$ & 15,923 & 9,081 & 9,502 \\
\hline & $\overline{\mathrm{B}}$ & $2 / 2$ & 8,538 & 134 & 12,209 & 8,538 & 6,172 \\
\hline \multirow{2}{*}{$\begin{array}{c}\text { Cascade } \\
\text { Range }\end{array}$} & $\bar{A}$ & $39 / 39$ & 5,945 & 1,886 & 17,580 & 4,411 & 4,370 \\
\hline & $\bar{B}$ & $39 / 39$ & $\overline{3,726}$ & 998 & 12,246 & 2,612 & 2,869 \\
\hline \multirow{2}{*}{$\begin{array}{c}\text { Klamath } \\
\text { Mountains }\end{array}$} & $\overline{\mathrm{A}}$ & $32 / 32$ & 6,781 & 1,027 & 18,682 & 4,109 & 6,159 \\
\hline & $\overline{\mathrm{B}}$ & $32 / 32$ & 4,091 & 691 & 15,173 & 3,584 & 2,899 \\
\hline \multirow{2}{*}{$\begin{array}{c}\text { Basin and } \\
\text { Range }\end{array}$} & $\bar{A}$ & $18 / 18$ & 5,432 & 2,642 & 12,354 & 2,543 & 4,550 \\
\hline & $\bar{B}$ & $18 / 18$ & 3,612 & 1,937 & 9,234 & 1,633 & 3,509 \\
\hline \multirow{2}{*}{$\begin{array}{l}\text { High Lava } \\
\text { Plain }\end{array}$} & $\mathrm{A}$ & $4 / 4$ & 3,276 & 2,314 & 3,968 & 718 & 3,411 \\
\hline & $\overline{\mathrm{B}}$ & $4 / 4$ & 3,081 & 2,372 & 3,947 & 659 & 3,002 \\
\hline \multicolumn{8}{|l|}{ Soil Orders } \\
\hline \multirow[t]{2}{*}{ Entisols } & $\mathrm{A}$ & $27 / 27$ & 3,530 & 640 & 9,111 & 1,600 & 3,341 \\
\hline & $\overline{\mathrm{B}}$ & $27 / 27$ & 2,977 & 576 & 9,234 & 1,624 & 2,735 \\
\hline \multirow[t]{2}{*}{ Inceptisols } & $\bar{A}$ & $44 / 44$ & 5,740 & 1,068 & 18,682 & 1,695 & 5,209 \\
\hline & $\overline{\mathrm{B}}$ & $44 / 44$ & 3,375 & 411 & 9,980 & 2,476 & 2,825 \\
\hline \multirow{2}{*}{$\begin{array}{l}\text { Alfisols/ } \\
\text { Ultisols }\end{array}$} & $\bar{A}$ & $31 / 31$ & 5,900 & 638 & 17,184 & 3,601 & 5,923 \\
\hline & $\overline{\mathrm{B}}$ & $31 / 31$ & 3,359 & 292 & 15,173 & 3,467 & 1,777 \\
\hline \multirow[t]{2}{*}{ Mollisols } & $\overline{\mathrm{A}}$ & $14 / 14$ & 9,413 & 3,042 & 17,580 & 5,469 & 7,957 \\
\hline & $\bar{B}$ & $14 / 14$ & 5,188 & 134 & 14,619 & 4,306 & 3,327 \\
\hline \multirow[t]{2}{*}{ Spodosol } & $\bar{A}$ & $1 / 1$ & $1,888^{2}$ & -- & - & - & -- \\
\hline & $\overline{\mathrm{B}}$ & $1 / 1$ & $465^{a}$ & -- & - & -- & -- \\
\hline \multirow[t]{2}{*}{ Vertisol } & $\bar{A}$ & $1 / 1$ & $13,409^{\mathrm{d}}$ & -- & - & - & -- \\
\hline & B & $1 / 1$ & $12,246^{2}$ & - & - & $\overline{-}$ & -- \\
\hline
\end{tabular}

${ }^{1}$ Detects are the number of samples with concentrations equal to or greater than the laboratory's reporting limit.

a Only one concentration value is listed under arithmetic mean. 
The highest analyzed soil Ca concentration is at site LM17 (15,923 ppm in the A horizon) in the Willamette Valley. Only two sites were sampled in this province (AM for the A horizon $=9,502 \mathrm{ppm}$ ). The sample from the other site (LC3) is not so rich in $\mathrm{Ca}$ (has only 3,081 ppm in the A horizon). Excluding the Willamette Valley, the highest analyzed $\mathrm{Ca}$ concentrations are in the Klamath Mountains (AM for the $\mathrm{A}$ horizon = $6,781 \mathrm{ppm})$, Cascade Range $(\mathrm{AM}=5,945 \mathrm{ppm})$, Coast Range $(\mathrm{AM}=5,536 \mathrm{ppm})$ and Basin and Range $(\mathrm{AM}=5,432 \mathrm{ppm})$. The mean Ca values in these four provinces are statistically equal. The analyzed samples from the Coastal Plain have the lowest $\mathrm{Ca}$ values $(\mathrm{AM}=1,446 \mathrm{ppm})$. Among soil orders, Mollisols have the highest analyzed $\mathrm{Ca}$ values $(\mathrm{AM}=9,413 \mathrm{ppm})$. The analyzed $\mathrm{Ca}$ values in Alfisols/Ultisols $(\mathrm{AM}=5,900 \mathrm{ppm})$ and Inceptisols $(\mathrm{AM}=5,740 \mathrm{ppm})$ are similar. Entisols have the lowest analyzed $\mathrm{Ca}$ concentrations $(\mathrm{AM}=3,530 \mathrm{ppm})$. Ca values in the analyzed samples from the different physiographic provinces as well as from the different soil orders in the study area have large standard deviations because these soils have been derived from rocks in which the Ca concentrations vary widely.

The highest analyzed $\mathrm{Ca}$ values are found in Inceptisols, Alfisols/Ultisols and Mollisols formed on mafic igneous rocks (geologic units Jv, Tbaa, Tsr, $\mathrm{TrPv}$ and Tub), alluvial deposits (Qal), volcaniclastics (Tus) and shale ( $\mathrm{Tn}$ and TrPzs). The lowest analyzed Ca levels are found in soils derived from felsic/intermediate rocks (JTrgd, $\mathrm{KJg}$,) and silty, sandy and gravelly materials (Qd, Qg, Qt, Tmss, Tss, Tt and Ty). In the study area, the average $\mathrm{Ca}$ values increase in soils derived from felsic to mafic rocks 
(Table 18). Soil Ca levels are controlled by parent rocks, and the Ca contents in igneous rocks decrease with increasing silica content (Fairbridge, 1972). Mollisols are richest in Ca because these subhumid and slightly alkaline soils have been able to hold $\mathrm{Ca}$. The analyzed samples from the Klamath Mountains have the highest average soil Ca level due to Mollisols and Alfisols/Ultisols covering a large part of this physiographic province. The analyzed samples from acid-leached sandy soils of the Coastal Plain are Ca deficient. The highest analyzed Ca concentration at site LM17 in the Willamette Valley, mentioned earlier, is in Mollisol developed on alluvial deposits (geologic unit Qal). The analyzed samples from two other sites (LC11 and LM7, both in the Coast Range) on the same parent rock also have high Ca concentrations. The alluvial deposits (Qal) have possibly been derived from Ca-rich basaltic rocks.

In the study area the analyzed $\mathrm{Ca}$ concentrations in the $\mathrm{A}$ and $\mathrm{B}$ horizons have the pooled variance of 91,113 and the pooled standard deviation of 301.9. The null hypothesis Ho: $\mathrm{A}=\mathrm{B}$ can be rejected if $\mathrm{A}-\mathrm{B}$ is greater than $881.4(2.92 * 301.9)$. The results of the analysis for the $\mathrm{Ca}$ concentrations in the $\mathrm{A}$ horizon versus the $\mathrm{B}$ horizon at 118 sites investigated are as follows: $A>B$ in $61.9 \%$ of the profiles and $A<B$ in $3.4 \%$.of the profiles. In the rest of the profiles (34.7\%) we cannot reject the equility of the values in the two horizons. The $\mathrm{Ca}$ concentration in the $\mathrm{A}$ horizon is particularly evident in Mollisols developed in subhumid climate. 


\section{CHROMIUM (CR)}

Distribution statistics for $\mathrm{Cr}$ content in soils of the study area are listed in Table 25 . At all 118 sites investigated, the $\mathrm{Cr}$ levels in both the $\mathrm{A}$ and $\mathrm{B}$ horizons exceed the laboratory's minimum reporting level of $3 \mathrm{ppm}$. The $\mathrm{Cr}$ concentrations range from 3 to $1,302 \mathrm{ppm}$ with an average of $56 \mathrm{ppm}$ in the A horizon and from 4 to $1,815 \mathrm{ppm}$ with an average of $78 \mathrm{ppm}$ in the $\mathrm{B}$ horizon. Kabata-Pendias and Pendias (1984) reported the $\mathrm{Cr}$ contents of surface soils of the U.S. to range from 3 to $1,500 \mathrm{ppm}$ with an average of 54 ppm (Appendix 8.2). The $\mathrm{Cr}$ concentrations in surface soils of the study area are comparable to those of the rest of the U.S. However, the analyzed samples from the Klamath Mountains have $\mathrm{Cr}$ levels (average $135 \mathrm{ppm}$ in the A horizon) much higher than that of the U.S. in general. The concentration of 3,117 ppm Cr (includes both the $\mathrm{A}$ and B horizons) at site KL16 in the Klamath Mountains could be one of the highest in the country.

The analyzed samples from the Klamath Mountains have the highest $\mathrm{Cr}$ levels (AM for the B horizon $=198 \mathrm{ppm}$ ). The High Lava Plains samples have the lowest analyzed soil $\mathrm{Cr}$ concentrations ( $\mathrm{AM}=7 \mathrm{ppm}$ only). Among soil orders, Alfisols/Ultisols samples are richest in $\mathrm{Cr}(\mathrm{AM}=188 \mathrm{ppm})$. Entisols samples are poorest in $\mathrm{Cr}(\mathrm{AM}=9 \mathrm{ppm}$ only). Figure 6 shows the graphic representations of soil $\mathrm{Cr}$ concentrations in physiographic provinces, soil orders and major igneous rocks of the study area.

The highest analyzed $\mathrm{Cr}$ values are in Alfisols/Ultisols derived from ultramafic 
Table 25. Distribution statistics for Chromium (Cr) content (ppm dry) in soils of Southwest Oregon

\begin{tabular}{|c|c|c|c|c|c|c|c|}
\hline & $\begin{array}{c}\text { Hori- } \\
\text { zon }\end{array}$ & $\begin{array}{c}\text { Total } \\
\text { Sample } \\
\text { Number/ } \\
\text { Detects }^{1} \\
\end{array}$ & $\begin{array}{l}\text { Arith- } \\
\text { metic } \\
\text { Mean }\end{array}$ & $\begin{array}{l}\text { Mini- } \\
\text { mum }\end{array}$ & $\begin{array}{l}\text { Maxi- } \\
\text { mum }\end{array}$ & $\begin{array}{c}\text { Arith- } \\
\text { metic } \\
\text { Standard } \\
\text { Deviation }\end{array}$ & Median \\
\hline \multicolumn{8}{|l|}{ For all sites } \\
\hline & $\bar{A}$ & $118 / 118$ & 56 & 3 & 1,302 & 135 & 23 \\
\hline & $\bar{B}$ & $118 / 118$ & 78 & 4 & 1,815 & 204 & 32 \\
\hline \multicolumn{8}{|c|}{ PhysiographicProvinces } \\
\hline \multirow[t]{2}{*}{ Coastal Plain } & $\mathrm{A}$ & $7 / 7$ & 23 & 7 & 77 & 25 & 12 \\
\hline & $\mathrm{B}$ & $7 / 7$ & 33 & 6 & 81 & 28 & 33 \\
\hline \multirow[t]{2}{*}{ Coast Range } & $\bar{A}$ & $16 / 16$ & 59 & 15 & 120 & 32 & 49 \\
\hline & $\overline{\mathrm{B}}$ & $\overline{16 / 16}$ & 77 & 30 & 161 & 44 & 60 \\
\hline \multirow{2}{*}{$\begin{array}{c}\text { Willamette } \\
\text { Valley }\end{array}$} & $\mathrm{A}$ & $2 / 2$ & 21 & 16 & 26 & 7 & 21 \\
\hline & $\overline{\mathrm{B}}$ & $2 / 2$ & 25 & 21 & 29 & 6 & 25 \\
\hline \multirow{2}{*}{$\begin{array}{l}\text { Cascade } \\
\text { Range }\end{array}$} & $\mathrm{A}$ & $39 / 39$ & 21 & 3 & 99 & 24 & 11 \\
\hline & $\mathrm{B}$ & $39 / 39$ & 25 & 4 & 122 & 29 & 13 \\
\hline \multirow{2}{*}{$\begin{array}{l}\text { Klamath } \\
\text { Mountains }\end{array}$} & $\bar{A}$ & $32 / 32$ & 135 & 5 & 1,302 & 240 & 68 \\
\hline & $\overline{\mathrm{B}}$ & $32 / 32$ & 198 & 4 & 1,815 & 365 & 95 \\
\hline \multirow{2}{*}{$\begin{array}{c}\text { Basin and } \\
\text { Range }\end{array}$} & $\mathrm{A}$ & $18 / 18$ & 15 & 3 & 79 & 19 & 7 \\
\hline & $\bar{B}$ & $18 / 18$ & 21 & 4 & 91 & 23 & 10 \\
\hline \multirow{2}{*}{$\begin{array}{l}\text { High Lava } \\
\text { Plains }\end{array}$} & $\bar{A}$ & $4 / 4$ & 7 & 5 & 12 & 4 & 5 \\
\hline & B & $4 / 4$ & 8 & 5 & 14 & 4 & 6 \\
\hline \multicolumn{8}{|l|}{ Soil Orders } \\
\hline \multirow[t]{2}{*}{ Entisols } & $\overline{\mathrm{A}}$ & $27 / 27$ & 6 & 3 & 28 & 5 & 5 \\
\hline & B & $27 / 27$ & 9 & 4 & 34 & 7 & 7 \\
\hline \multirow[t]{2}{*}{ Inceptisols } & $\bar{A}$ & $44 / 44$ & 46 & 4 & 273 & 14 & 28 \\
\hline & B & $44 / 44$ & 58 & 4 & 390 & 67 & 33 \\
\hline \multirow{2}{*}{$\begin{array}{l}\text { Alfisols/ } \\
\text { Ultisols }\end{array}$} & A & $31 / 31$ & 125 & 8 & 1,302 & 245 & 46 \\
\hline & $\overline{\mathrm{B}}$ & $31 / 31$ & 188 & 13 & 1,815 & 372 & 72 \\
\hline \multirow[t]{2}{*}{ Mollisols } & $\overline{\mathrm{A}}$ & $14 / 14$ & 32 & 7 & 89 & 22 & 24 \\
\hline & $\mathrm{B}$ & $14 / 14$ & 41 & 40 & 101 & 27 & 35 \\
\hline \multirow[t]{2}{*}{ Spodosol } & $\overline{\mathrm{A}}$ & $1 / 1$ & $9^{2}$ & - & -- & - & - \\
\hline & $\mathrm{B}$ & $1 / 1$ & $9^{a}$ & - & -- & - & - \\
\hline \multirow[t]{2}{*}{ Vertisol } & $\mathrm{A}$ & $1 / 1$ & $72^{2}$ & - & - & - & - \\
\hline & B & $1 / 1$ & $81^{2}$ & - & - & -- & - \\
\hline
\end{tabular}

${ }^{1}$ Detects are the number of samples with concentrations equal to or greater than the laboratory's reporting limit.

${ }^{a}$ Only one concentration value is listed under arithmetic mean. 

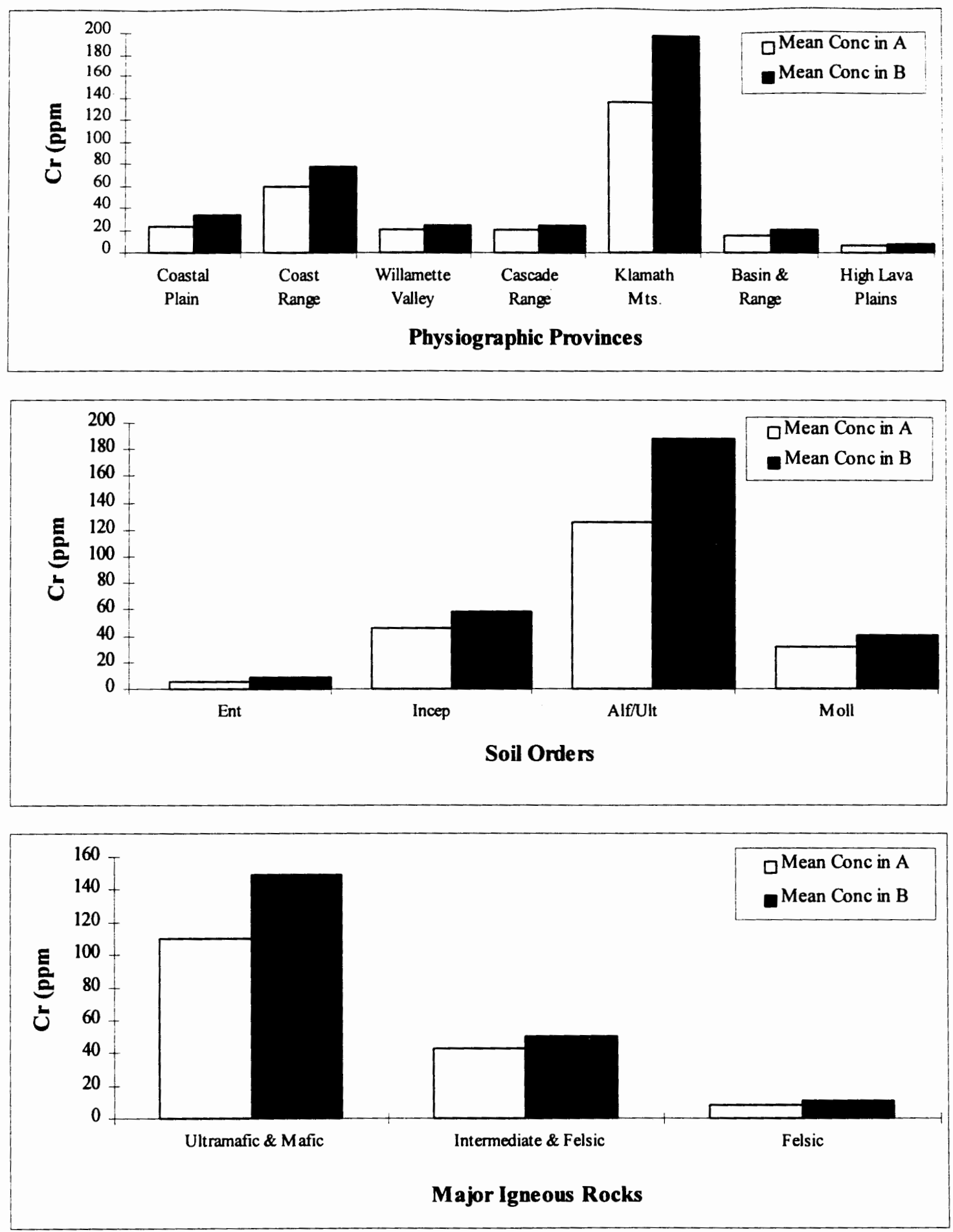

Figure 6. Soil Chromium (Cr) concentrations in physiographic provinces, soil orders and major igneous rocks of Southwest Oregon 
and mafic rocks (geologic units bc, cs, Jm, Ju, $\mathrm{KJgu}, \mathrm{Tpb}$ and $\mathrm{Tsr}$ ) in the Klamath Mountains and Coast Range. The lowest analyzed $\mathrm{Cr}$ levels are in Entisols and Inceptisols developed on felsic and intermediate igneous rocks (KJg, Qma, Qmp, Qrd, QTp and Tat) and silty, sandy and gravelly deposits (Qd, Qf, Qg, Qs, Qt, Ts and Tus). In the study area, although an apparent increase in average $\mathrm{Cr}$ contents is observed in soils derived from felsic, through intermediate, to mafic/ultramafic magmatic rocks (Figure 6), the equality of those values cannot be rejected at $95 \%$ confidence level. This is because the $\mathrm{Cr}$ concentrations in soils developed on ultramafic/mafic rocks in particular have an extremely large standard deviation (nearly three times the mean; Table 18). The soil $\mathrm{Cr}$ is inherited from parent rocks. Ultramafic and mafic rocks are richest in Cr, containing up to 3,400 ppm of this metal (McGrath and Smith, 1993; KabataPendias and Pendias, 1984). The $\mathrm{Cr}$ content of felsic igneous and sedimentary rocks ranges from 2 to $590 \mathrm{ppm}$ (Cannon, 1978). The analyzed $\mathrm{Cr}$ concentrations in soils of the study area display a great variability (have standard deviation more than twice the arithmetic mean) (Table 25). This is because soil sampled at site KL16 on geologic unit $\mathrm{Ju}$ (serpentinized ultramafic and related rocks of ophiolite sequences) contains an extremely high level of $\mathrm{Cr}$ (1,302 ppm in the A horizon and 1,815 ppm in the $\mathrm{B}$ horizon) compared to soils on other rocks. Soils on serpentines are known to contain as much as 2,000 to 4,000 ppm $\mathrm{Cr}$ (includes both the A and B horizons) (Kabata-Pendias and Pendias, 1984). Soils on serpentinized ultramafics in particular have contributed to the very high soil $\mathrm{Cr}$ level in the Klamath Mountains. 
It is clear that soil $\mathrm{Cr}$ levels increase with soil development in the study area (Table 19). In favorable environments, Alfisols/Ultisols form on ultramafic/mafic rocks because they contain relatively unstable ferromagnesian minerals which weather fast, accelerating soil development. On the other hand, Entisols/Inceptisols form on the slowly weathered silica-rich felsic/intermediate rocks.

In the study area the analyzed $\mathrm{Cr}$ concentrations in the $\mathrm{A}$ and $\mathrm{B}$ horizons have the pooled variance of 1.50 and the pooled standard deviation of 1.22 . The null hypothesis Ho: $\mathrm{A}=\mathrm{B}$ can be rejected if $\mathrm{A}-\mathrm{B}$ is greater than $3.6\left(2.92^{*} 1.22\right)$. The results of the analysis for the $\mathrm{Cr}$ concentrations in the $\mathrm{A}$ horizon versus the $\mathrm{B}$ horizon at 118 sites investigated are as follows: $\mathrm{B}>\mathrm{A}$ in $60.2 \%$ of the profiles and $\mathrm{A}>\mathrm{B}$ in $3.4 \%$ of the profiles. In the rest of the profiles (36.4\%) we cannot reject the equality of the values in the two horizons. The concentration of $\mathrm{Cr}$ in the $\mathrm{B}$ horizon is particularly evident in well-drained, humid Alfisols/Ultisols.

\section{COBALT (CO)}

Distribution statistics for Co content in soils of the study area are listed in Table 26. Out of a total of 118 , Co has 93 values in the A horizon and 102 values in the $B$ horizon above the laboratory's minimum reporting level of six ppm. The Co concentrations vary from $<6$ to $95 \mathrm{ppm}$ with an average of $<18 \mathrm{ppm}$ in the A horizon and from $<6$ to $175 \mathrm{ppm}$ with an average of $<21 \mathrm{ppm}$ in the B horizon. The Co content of surface soils of the U.S. ranges from $<1$ to $50 \mathrm{ppm}$, with the highest frequency in the range of 3 to $15 \mathrm{ppm}$ and with an average of $8.2 \mathrm{ppm}$ (Kabata-Pendias and Pendias, 
Table 26. Distribution statistics for Cobalt (Co) content (ppm dry) in soils of Southwest Oregon.

\begin{tabular}{|c|c|c|c|c|c|c|c|}
\hline & $\begin{array}{l}\text { Hori- } \\
\text { zon }\end{array}$ & $\begin{array}{c}\text { Total } \\
\text { Sample } \\
\text { Number/ } \\
\text { Detects' }\end{array}$ & $\begin{array}{l}\text { Arith- } \\
\text { metic } \\
\text { Mean }\end{array}$ & $\begin{array}{l}\text { Mini- } \\
\text { mum }\end{array}$ & $\begin{array}{l}\text { Maxi- } \\
\text { mum }\end{array}$ & $\begin{array}{c}\text { Arith- } \\
\text { metic } \\
\text { Standard } \\
\text { Deviation }\end{array}$ & Median \\
\hline \multicolumn{8}{|l|}{ For all sites } \\
\hline & $\bar{A}$ & $118 / 93$ & $<18$ & $<6$ & 95 & $>15$ & 13 \\
\hline & $\mathrm{B}$ & $118 / 102$ & $<21$ & $<6$ & 175 & $>23$ & 16 \\
\hline \multicolumn{8}{|c|}{ PhysiographicProvinces } \\
\hline \multirow{2}{*}{$\begin{array}{l}\text { Coastal } \\
\text { Plain }\end{array}$} & A & $7 / 1$ & $<6$ & $<6$ & 6.2 & $>0.07$ & $<6$ \\
\hline & B & $7 / 2$ & $<6$ & $<6$ & 10.7 & $>1.8$ & $<6$ \\
\hline \multirow[t]{2}{*}{ Coast Range } & $\overline{\mathrm{A}}$ & $16 / 15$ & $<23$ & $<6$ & 60 & $>15$ & 18 \\
\hline & $\overline{\mathrm{B}}$ & $16 / 15$ & $<26$ & $<6$ & 56 & $>16$ & 23 \\
\hline \multirow{2}{*}{$\begin{array}{l}\text { Willamette } \\
\text { Valley }\end{array}$} & $\mathrm{A}$ & $2 / 2$ & 13 & 8 & 18 & 7 & 13 \\
\hline & B & $2 / 2$ & 14 & 8 & 20 & 9 & 14 \\
\hline \multirow{2}{*}{$\begin{array}{l}\text { Cascade } \\
\text { Range }\end{array}$} & $\bar{A}$ & $39 / 31$ & $<15$ & $<6$ & 52 & $>12$ & 9 \\
\hline & $\bar{B}$ & $39 / 36$ & $<16$ & $<6$ & 46 & $>12$ & 10 \\
\hline \multirow{2}{*}{$\begin{array}{c}\text { Klamath } \\
\text { Mountains }\end{array}$} & $\bar{A}$ & $32 / 31$ & $<26$ & $\overline{<6}$ & 95 & $>19$ & 23 \\
\hline & $\bar{B}$ & $32 / 31$ & $<35$ & $<6$ & 175 & $>35$ & 25 \\
\hline \multirow{2}{*}{$\begin{array}{c}\text { Basin and } \\
\text { Range }\end{array}$} & $\overline{\mathrm{A}}$ & $18 / 11$ & $<12$ & $<6$ & 41 & $>10$ & 7 \\
\hline & $\mathrm{B}$ & $18 / 13$ & $<15$ & $<6$ & 47 & $>12$ & 9 \\
\hline \multirow{2}{*}{$\begin{array}{c}\text { High Lava } \\
\text { Plain }\end{array}$} & $\bar{A}$ & $4 / 2$ & $<7$ & $<6$ & 11 & $>2$ & $\overline{6}$ \\
\hline & $\mathrm{B}$ & $4 / 3$ & $<8$ & $<6$ & 14 & $>4$ & 7 \\
\hline \multicolumn{8}{|l|}{ Soil Orders } \\
\hline \multirow[t]{2}{*}{ Entisols } & $\mathrm{A}$ & $27 / 13$ & $<7$ & $<6$ & 15 & $>2$ & 6 \\
\hline & $\mathrm{B}$ & $27 / 18$ & $<8$ & $<6$ & 18 & $>3$ & 7 \\
\hline \multirow[t]{2}{*}{ Inceptisols } & $\mathrm{A}$ & $44 / 36$ & $<15$ & $<6$ & 45 & $>1$ & 13 \\
\hline & $\bar{B}$ & $44 / 39$ & $<18$ & $<6$ & 56 & $>13$ & 14 \\
\hline \multirow{2}{*}{$\begin{array}{l}\text { Alfisols/ } \\
\text { Ultisols }\end{array}$} & $\bar{A}$ & $31 / 29$ & $<29$ & $<6$ & $\overline{95}$ & $>21$ & 25 \\
\hline & $\mathrm{B}$ & $31 / 30$ & $<36$ & $<6$ & 175 & $>36$ & 24 \\
\hline \multirow[t]{2}{*}{ Mollisols } & $\bar{A}$ & $14 / 14$ & 22 & 6 & 47 & 12 & 19 \\
\hline & $\overline{\mathrm{B}}$ & $14 / 14$ & 28 & 7 & 50 & 13 & 28 \\
\hline \multirow[t]{2}{*}{ Spodosol } & $\mathrm{A}$ & $1 / 0$ & $<6^{\mathrm{a}}$ & - & - & - & $\cdots$ \\
\hline & $\mathrm{B}$ & $1 / 0$ & $<6^{\mathrm{a}}$ & - & - & - & - \\
\hline \multirow[t]{2}{*}{ Vertisol } & $\bar{A}$ & $1 / 1$ & $17^{2}$ & - & - & - & - \\
\hline & $\overline{\mathrm{B}}$ & $1 / 1$ & $19^{2}$ & - & - & - & -- \\
\hline
\end{tabular}

'Detects are the number of samples with concentrations equal to or greater than the laboratory's reporting limit.

${ }^{a}$ Only one concentration value is listed under arithmetic mean.

Note: Where the concentration of a metal in a sample is less than the laboratory's minimum reporting level, the minimum reporting level is used for calculating statistics, and the statistics are qualified as less than or greater than the value given. 
1984) (Appendix 8.3). Soils in the study area are comparatively richer in Co than those in the rest of the U.S.

The analyzed samples from the Klamath Mountains and Coast Range have the highest Co concentrations (AM for the $\mathrm{B}$ horizon $<35 \mathrm{ppm}$ and $<26 \mathrm{ppm}$, respectively). The Coastal Plain and High Lava Plains samples have the lowest Co values (AM $<8$ ppm and $<6 \mathrm{ppm}$, respectively). Among soil orders, Alfisols/Ultisols and Mollisols have the highest analyzed Co contents (AM $<36 \mathrm{ppm}$ and $28 \mathrm{ppm}$, respectively). Entisols have the lowest analyzed Co values $(\mathrm{AM}<8 \mathrm{ppm})$. Co values in the analyzed samples from the different physiographic provinces as well as from the different soil orders in the study area have large standard deviations because these soils have been derived from rocks in which the Co concentrations vary widely.

The highest analyzed Co values are in Alfisols/Ultisols and Mollisols derived from ultramafic and mafic rocks (geologic units bc, Jm, Ju, Qba, QTp, Tpb and Tsr) and argillaceous sediments (Tfee and TrPzs). The lowest analyzed Co levels are in Entisols and Inceptisols formed on felsic and intermediate magmatic rocks (KJg, Qma, Qmp, Qrd, QTp and Tat) and silty and sandy deposits (Qd, Qg, Qs, Qt, Ts, Tss and Tus).

The above soil Co concentrations are reasonable as the Co concentration in soils is inherited from parent materials, and mafic/ultramafic rocks and argillaceous sediments are very rich in Co compared to other rocks (Smith, 1993; Kabata-Pendias and Pendias, 1984). In the study area, the average Co levels increase in soils derived from felsic to mafic/ultramafic rocks (Table 18). The soil Co levels also increase with soil 
development, i.e. Alfisols/Ultisols $>$ Inceptisols $>$ Entisols (Table 19). The average Co values in the soil orders are statistically different at $95 \%$ confidence level. Soils of the Klamath Mountains and Coast Range have high Co levels as Alfisols/Ultisols in particular are developed over large areas of these physiographic provinces.

In the study area the analyzed Co concentrations in the A and B horizons have the pooled variance of 0.36 and the pooled standard deviation of 0.60 . The null hypothesis Ho: $\mathrm{A}=\mathrm{B}$ can be rejected if $\mathrm{A}-\mathrm{B}$ is greater than $1.8\left(2.92^{*} 0.60\right)$. The results of the analysis for the Co concentrations in the $\mathrm{A}$ horizon versus the $\mathrm{B}$ horizon at 118 sites investigated are as follows: $\mathrm{B}>\mathrm{A}$ in $50.0 \%$ of the profiles and $\mathrm{A}>\mathrm{B}$ in $7.6 \%$ of the profiles. In the rest of the profiles $(42.4 \%)$ we cannot reject the equality of the values in the two horizons. The concentration of $\mathrm{Co}$ in the $\mathrm{B}$ horizon is especially evident in clayrich Alfisols/Ultisols. The Co distribution is uniform throughout the profile in young and less developed soils, i.e. Entisols and Inceptisols.

\section{COPPER (CU)}

Distribution statistics for $\mathrm{Cu}$ content in soils of the study area are listed in Table 27. Out of a total of $118, \mathrm{Cu}$ has 117 values in the $\mathrm{A}$ horizon and 116 values in the $\mathrm{B}$ horizon at or above the laboratory's minimum reporting level of two ppm. The $\mathrm{Cu}$ concentrations vary from $<2$ to $148 \mathrm{ppm}$ with an average of $<31 \mathrm{ppm}$ in the A horizon and from $<2$ to $193 \mathrm{ppm}$ with an average of $<42 \mathrm{ppm}$ in the B horizon. For surface soils of the U.S., Kabata-Pendias and Pendias (1984) reported the mean 'background' $\mathrm{Cu}$ 
Table 27. Distribution statistics for Copper (Cu) content (ppm dry) in soils of Southwest Oregon.

\begin{tabular}{|c|c|c|c|c|c|c|c|}
\hline & $\begin{array}{l}\text { Hori- } \\
\text { zon }\end{array}$ & $\begin{array}{c}\text { Total } \\
\text { Sample } \\
\text { Number/ } \\
\text { Detects }^{1}\end{array}$ & $\begin{array}{l}\text { Arith- } \\
\text { metic } \\
\text { Mean }\end{array}$ & $\begin{array}{l}\text { Mini- } \\
\text { mum }\end{array}$ & $\begin{array}{l}\text { Maxi- } \\
\text { mum }\end{array}$ & $\begin{array}{c}\text { Arith- } \\
\text { metic } \\
\text { Standard } \\
\text { Deviation }\end{array}$ & Median \\
\hline \multicolumn{8}{|l|}{ For all sites } \\
\hline & $\bar{A}$ & $118 / 117$ & $<31$ & $<2$ & 148 & $>29$ & 22 \\
\hline & B & $118 / 116$ & $<42$ & $<2$ & 193 & $>40$ & 29 \\
\hline \multicolumn{8}{|c|}{ PhysiographicProvinces } \\
\hline \multirow[t]{2}{*}{ Coastal Plain } & $\mathrm{A}$ & $7 / 6$ & $<8$ & $<2$ & 19 & $>6$ & 8 \\
\hline & $\bar{B}$ & $7 / 5$ & $<11$ & $<2$ & 33 & $>12$ & 7 \\
\hline \multirow[t]{2}{*}{ Coast Range } & $\mathrm{A}$ & $16 / 16$ & 42 & 5 & 148 & 43 & 26 \\
\hline & $\mathrm{B}$ & $16 / 16$ & 52 & 7 & 193 & 59 & 31 \\
\hline \multirow{2}{*}{$\begin{array}{c}\text { Willamette } \\
\text { Valley }\end{array}$} & $\mathrm{A}$ & $2 / 2$ & 20 & 11 & 29 & 12 & 20 \\
\hline & B & $2 / 2$ & 23 & 13 & 33 & 14 & 23 \\
\hline \multirow{2}{*}{$\begin{array}{l}\text { Cascade } \\
\text { Range }\end{array}$} & $\mathrm{A}$ & $39 / 39$ & 25 & 6 & 25 & 24 & 16 \\
\hline & $\bar{B}$ & $39 / 39$ & 32 & 8 & 150 & 27 & 25 \\
\hline \multirow{2}{*}{$\begin{array}{c}\text { Klamath } \\
\text { Mountains }\end{array}$} & $\bar{A}$ & $32 / 32$ & 46 & 5 & 136 & 30 & 37 \\
\hline & $\bar{B}$ & $32 / 32$ & 68 & 3 & 185 & 43 & 59 \\
\hline \multirow{2}{*}{$\begin{array}{c}\text { Basin and } \\
\text { Range }\end{array}$} & $\mathrm{A}$ & $18 / 18$ & 23 & 8 & 56 & 15 & 17 \\
\hline & $\mathrm{B}$ & $18 / 18$ & 30 & 10 & 73 & 19 & 25 \\
\hline \multirow{2}{*}{$\begin{array}{c}\text { High Lava } \\
\text { Plain }\end{array}$} & $\mathrm{A}$ & $4 / 4$ & 12 & 10 & 15 & 2 & 11 \\
\hline & $\bar{B}$ & $4 / 4$ & 15 & 13 & 18 & 2 & 14 \\
\hline \multicolumn{8}{|l|}{ Soil Orders } \\
\hline \multirow[t]{2}{*}{ Entisols } & $\mathrm{A}$ & $27 / 26$ & $<12$ & $<2$ & 28 & $>6$ & 10 \\
\hline & $\bar{B}$ & $27 / 27$ & 17 & 5 & 36 & 8 & 14 \\
\hline \multirow[t]{2}{*}{ Inceptisols } & $\mathrm{A}$ & $44 / 44$ & 27 & 2 & 71 & 4 & 21 \\
\hline & $\mathrm{B}$ & $44 / 43$ & $<34$ & $<2$ & 105 & $>25$ & 28 \\
\hline \multirow{2}{*}{$\begin{array}{l}\text { Alfisols/ } \\
\text { Uitisols }\end{array}$} & $\mathrm{A}$ & $31 / 31$ & 49 & 5 & 136 & 38 & 35 \\
\hline & $\bar{B}$ & $31 / 31$ & 72 & 7 & 188 & 52 & 61 \\
\hline \multirow[t]{2}{*}{ Mollisols } & $\mathrm{A}$ & $14 / 14$ & 44 & 11 & 148 & 34 & 30 \\
\hline & $\mathrm{B}$ & $14 / 14$ & 57 & 13 & 193 & 44 & 49 \\
\hline \multirow[t]{2}{*}{ Spodosol } & $\mathrm{A}$ & $1 / 1$ & $5^{a}$ & - & - & $=$ & $=$ \\
\hline & $\bar{B}$ & $1 / 0$ & $<^{2}$ & - & - & - & - \\
\hline \multirow[t]{2}{*}{ Vertisol } & $\mathrm{A}$ & $1 / 1$ & $41^{2}$ & - & - & - & - \\
\hline & B & $1 / 1$ & $42^{2}$ & -- & - & $\cdots$ & $=$ \\
\hline
\end{tabular}

${ }^{1}$ Detects are the number of samples with concentrations equal to or greater than the laboratory's reporting limit.

Only one concentration value is listed under arithmetic mean.

Note: Where the concentration of a metal in a sample is less than the laboratory's minimum reporting level, the minimum reporting level is used for calculating statistics, and the statistics are qualified as less than or greater than the value given. 
concentrations to vary from 14 to $41 \mathrm{ppm}$ (Appendix 8.2). The average $\mathrm{Cu}$ value of $<31$ ppm in surface soils of the study area falls within the U.S. values. The national soil $\mathrm{Cu}$ average for the A horizon is exceeded in the Klamath Mountains and Coast Range (see Table 27).

The analyzed samples from the Klamath Mountains and Coast Range have the highest soil $\mathrm{Cu}$ concentrations $(\mathrm{AM}$ for the $\mathrm{B}$ horizon $=68 \mathrm{ppm}$ and $52 \mathrm{ppm}$, respectively). The lowest analyzed $\mathrm{Cu}$ values are in the High Lava Plains ( $\mathrm{AM}=15$ $\mathrm{ppm}$ ) and Coastal Plain (AM $<11 \mathrm{ppm})$. Among soil orders, Alfisols/Ultisols and Mollisols have the highest analyzed $\mathrm{Cu}$ concentrations $(\mathrm{AM}=72 \mathrm{ppm}$ and $57 \mathrm{ppm}$, respectively). Entisols have the lowest analyzed $\mathrm{Cu}$ values $(\mathrm{AM}=17 \mathrm{ppm})$. Figure 7 shows the graphic representations of soil $\mathrm{Cu}$ concentrations in physiographic provinces, soil orders and major igneous rocks of the study area. $\mathrm{Cu}$ values in the analyzed samples from the different physiographic provinces as well as from the different soil orders in the study area have large standard deviations because these soils have been derived from rocks in which the $\mathrm{Cu}$ concentrations vary widely.

The highest analyzed $\mathrm{Cu}$ concentrations are in Alfisols/Ultisols and Mollisols formed on mafic igneous (geologic units bc, cs, $\mathrm{Jv}, \mathrm{TrPv}, \mathrm{Tsr}$ and $\mathrm{Tub}$ ) and argillaceous rocks (cm and Tfee). The lowest analyzed $\mathrm{Cu}$ values are in Entisols and Inceptisols developed on silty, sandy and gravelly materials (Qd, Qt, Tss and Tt) and granitic rocks (KJg). The $\mathrm{Cu}$ content of soils is influenced by parent rocks. The above soil $\mathrm{Cu}$ levels associated with parent rocks seem compatible with $\mathrm{Cu}$ being most abundant in mafic 

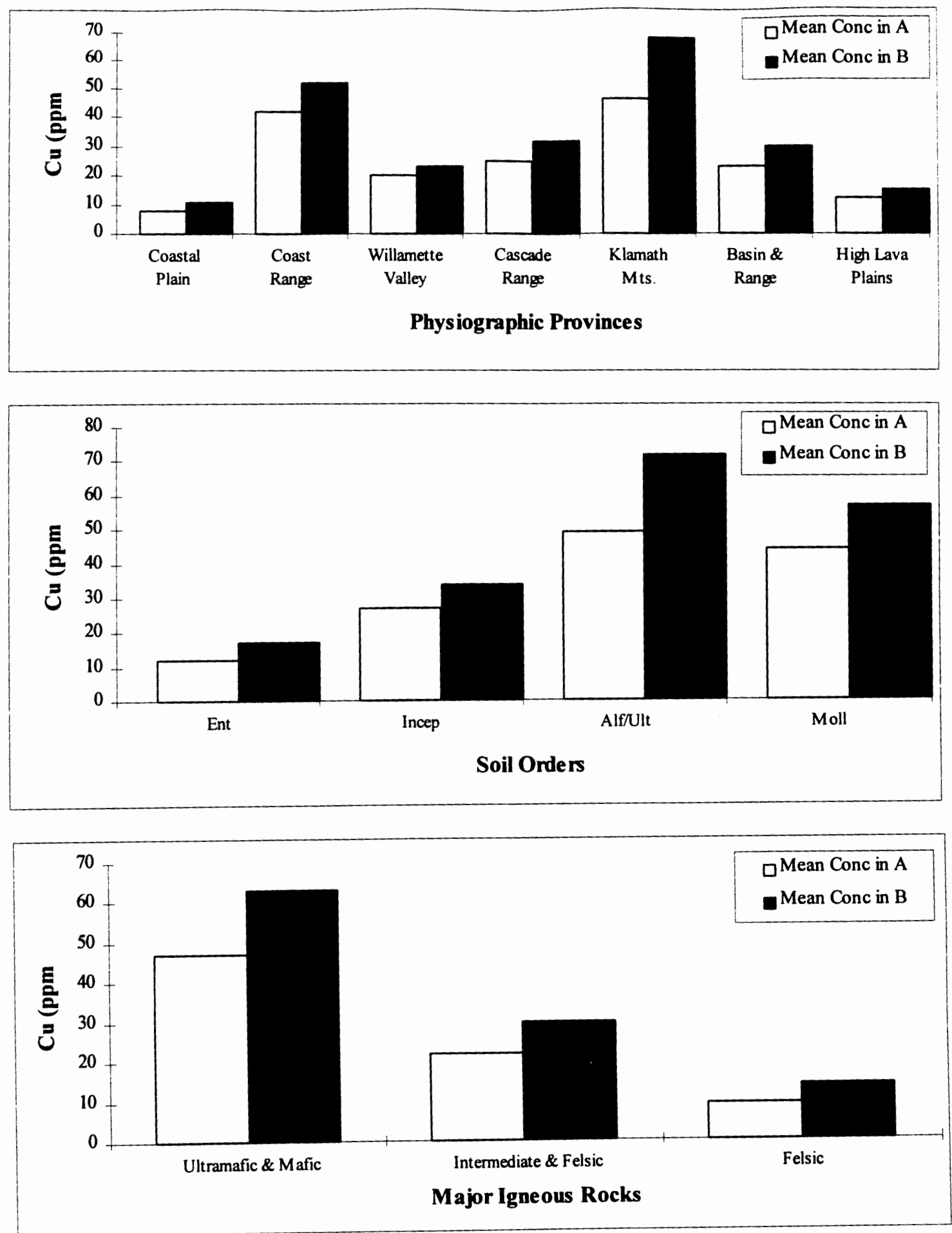

Figure 7. Soil Copper $(\mathrm{Cu})$ concentrations in physiographic provinces, soil orders and major igneous rocks of Southwest Oregon 
rocks and argillaceous sediments (Baker, 1993; Kabata-Pendias and Pendias, 1984; Aubert and Pinta, 1980). In the study area there is a distinct increase in Cu content in soils derived from felsic to mafic rocks (Table 18). The soil $\mathrm{Cu}$ levels also increase distinctly with soil development (Table 19), i.e. Alfisols/Ultisols > Inceptisols > Entisols. The average $\mathrm{Cu}$ values in the soil orders are statistically different at $95 \%$ confidence level. High $\mathrm{Cu}$ levels in the Klamath Mountains and Coast Range are mainly due to Alfisols/Ultisols covering large areas of these provinces.

In the study area the analyzed $\mathrm{Cu}$ concentrations in the $\mathrm{A}$ and $\mathrm{B}$ horizons have the pooled variance of 1.00 and the pooled standard deviation of 1.00 . The null hypothesis Ho: $A=B$ can be rejected if $A-B$ is greater than $2.9(2.92 * 1.00)$. The results of the analysis of the $\mathrm{Cu}$ concentrations in the A horizon versus the $\mathrm{B}$ horizon at 118 sites investigated are as follows: $\mathrm{B}>\mathrm{A}$ in $72.9 \%$ of the profiles and $\mathrm{A}>\mathrm{B}$ in $4.2 \%$ of the profiles. In the rest of the profiles $(22.9 \%)$ we cannot reject the equality of the values in the two horizons. The concentration of $\mathrm{Cu}$ in the $\mathrm{B}$ horizon is most apparent in welldrained, humid Alfisols/Ultisols.

IRON (FE)

Distribution statistics for Fe content in soils of the study area are listed in Table 28. At all 118 sites investigated, the $\mathrm{Fe}$ concentrations in both the $\mathrm{A}$ and $\mathrm{B}$ horizons are greater than the laboratory's minimum reporting level of four ppm. The Fe values vary from 2,648 to $107,317 \mathrm{ppm}$ with an average $29,148 \mathrm{ppm}$ in the A horizon and from 3,066 to $137,939 \mathrm{ppm}$ with an average of $37,300 \mathrm{ppm}$ in the B horizon. 
Table 28. Distribution statistics for Iron (Fe) content (ppm dry) in soils of Southwest Oregon.

\begin{tabular}{|c|c|c|c|c|c|c|c|}
\hline & $\begin{array}{l}\text { Hori } \\
\text {-zon }\end{array}$ & $\begin{array}{c}\text { Total } \\
\text { Sample } \\
\text { Number/ } \\
\text { Detects }\end{array}$ & $\begin{array}{l}\text { Arith- } \\
\text { metic } \\
\text { Mean }\end{array}$ & $\begin{array}{l}\text { Mini- } \\
\text { mum }\end{array}$ & $\begin{array}{l}\text { Maxi- } \\
\text { mum }\end{array}$ & $\begin{array}{c}\text { Arith- } \\
\text { metic } \\
\text { Standard } \\
\text { Deviation }\end{array}$ & Median \\
\hline \multicolumn{8}{|l|}{ For all sites } \\
\hline & $\mathrm{A}$ & $118 / 118$ & 29,148 & 2,648 & 107,312 & 20,778 & 25,371 \\
\hline & $\mathrm{B}$ & $118 / 118$ & 37,300 & 3,066 & 137,939 & 26,338 & 30,240 \\
\hline \multicolumn{8}{|c|}{ Physiographic Provinces } \\
\hline \multirow[t]{2}{*}{ Coastal Plain } & $\mathrm{A}$ & $7 / 7$ & 9,455 & 2,648 & 25,055 & 8,482 & 5,600 \\
\hline & B & $7 / 7$ & 17,205 & 3,066 & 40,980 & 15,478 & 9,925 \\
\hline \multirow[t]{2}{*}{ Coast Range } & $\mathrm{A}$ & $16 / 16$ & 39,369 & 15,727 & 78,302 & 19,620 & 33,218 \\
\hline & $\bar{B}$ & $16 / 16$ & 48,819 & 23,048 & 98,169 & 24,160 & 41,781 \\
\hline \multirow{2}{*}{$\begin{array}{c}\text { Willamette } \\
\text { Valley }\end{array}$} & $\bar{A}$ & $2 / 2$ & 24,263 & 16,789 & 31,736 & 10,570 & 24,263 \\
\hline & $\mathrm{B}$ & $2 / 2$ & 28,101 & 19,378 & 36,824 & 12,337 & 28,101 \\
\hline \multirow{2}{*}{$\begin{array}{l}\text { Cascade } \\
\text { Range }\end{array}$} & $\mathrm{A}$ & $39 / 39$ & 26,884 & 6,965 & 80,890 & 19,954 & 20,052 \\
\hline & $\overline{\mathrm{B}}$ & $39 / 39$ & 31,655 & 9,857 & 82,430 & 22,123 & 23,409 \\
\hline \multirow{2}{*}{$\begin{array}{c}\text { Klamath } \\
\text { Mountains }\end{array}$} & $\mathrm{A}$ & $32 / 32$ & 38,950 & 13,667 & 107,317 & 21,503 & 32,426 \\
\hline & $\bar{B}$ & $32 / 32$ & 53,062 & 14,946 & 137,939 & 29,881 & 42,930 \\
\hline \multirow{2}{*}{$\begin{array}{c}\text { Basin and } \\
\text { Range }\end{array}$} & $\bar{A}$ & $18 / 18$ & 19,526 & 7,034 & 63,476 & 15,566 & 12,224 \\
\hline & $\bar{B}$ & $18 / 18$ & 25,062 & 8,615 & 71,441 & 17,881 & 17,841 \\
\hline \multirow{2}{*}{$\begin{array}{c}\text { High Lava } \\
\text { Plain }\end{array}$} & $\mathrm{A}$ & $4 / 4$ & 12,129 & 8,317 & 19,180 & 5,013 & 10,510 \\
\hline & $\mathrm{B}$ & $4 / 4$ & 15,017 & 10,359 & 23,288 & 5,978 & 13,210 \\
\hline \multicolumn{8}{|l|}{ Soil Orders } \\
\hline \multirow[t]{2}{*}{ Entisols } & $\bar{A}$ & $27 / 27$ & 10,758 & 3,844 & 25,527 & 3,780 & 10,212 \\
\hline & $\bar{B}$ & $27 / 27$ & 13,878 & 3,846 & 29,284 & 5,232 & 13,010 \\
\hline \multirow[t]{2}{*}{ Inceptisols } & $\bar{A}$ & $44 / 44$ & 27,316 & 3,985 & 78,302 & 81 & 25,215 \\
\hline & $\mathrm{B}$ & $44 / 44$ & 32,953 & 3,066 & 98,169 & 18,041 & 29,347 \\
\hline \multirow{2}{*}{$\begin{array}{l}\text { Alfisols/ } \\
\text { Ultisols }\end{array}$} & $\mathrm{A}$ & $31 / 31$ & 44,776 & 7,685 & 107,317 & 23,937 & 39,049 \\
\hline & $\mathrm{B}$ & $31 / 31$ & 61,308 & 25,361 & 137,939 & 28,922 & 55,190 \\
\hline \multirow[t]{2}{*}{ Mollisols } & $\mathrm{A}$ & $14 / 14$ & 35,972 & 10,930 & 74,040 & 18,312 & 30,664 \\
\hline & $\mathrm{B}$ & $14 / 14$ & 45,753 & 15,457 & 82,430 & 21,306 & 43,977 \\
\hline \multirow[t]{2}{*}{ Spodosols } & $\mathrm{A}$ & $1 / 1$ & $2,648^{2}$ & - & - & -- & -- \\
\hline & B & $1 / 1$ & $4,538^{2}$ & - & - & - & - \\
\hline \multirow[t]{2}{*}{ Vertisols } & $\mathrm{A}$ & $1 / 1$ & $37,541^{2}$ & - & - & - & - \\
\hline & B & $1 / 1$ & $41,104^{2}$ & $=$ & - & $=$ & - \\
\hline
\end{tabular}

${ }^{1}$ Detects are the number of samples with concentrations equal to or greater than the laboratory's reporting limit.

anly one concentration value is listed under arithmetic mean. 
The analyzed samples from the Klamath Mountains and Coast Range have the highest soil Fe values (AM for the $\mathrm{B}$ horizon $=53,062 \mathrm{ppm}$ and 48,819 ppm, respectively). The lowest analyzed soil Fe contents are in the Coastal Plain (AM= $17,205 \mathrm{ppm})$ and High Lava Plains ( $\mathrm{AM}=15,017 \mathrm{ppm})$. Among soil orders, Alfisols/Ultisols and Mollisols have the highest analyzed Fe values $(\mathrm{AM}=61,308 \mathrm{ppm}$ and 45,753 ppm, respectively). Entisols have the lowest analyzed Fe concentrations $(\mathrm{AM}=13,878 \mathrm{ppm}) . \mathrm{Fe}$ values in the analyzed samples from the different physiographic provinces as well as from the different soil orders in the study area have large standard deviations because these soils have been derived from rocks in which the Fe concentrations vary widely.

The maximum Fe concentrations found in the B horizon samples from the Klamath Mountains, Coast Range, Cascade Range and Basin and Range provinces are $13.8 \%, 9.8 \%, 8.2 \%$ and $7.1 \%$, respectively. All these values are higher than the upper range (5\%) of Fe levels normally observed in soils (Kabata-Pendias and Pendias, 1984). The highest analyzed Fe values are in Alfisols/Ultisols developed on ultramafic and mafic rocks (geologic units bc, cs, Ju, Jub, QTp, Tpb, Trb and Tsr). The lowest analyzed Fe levels are in Entisols and Inceptisols formed on intermediate and felsic rocks (KJg, Qma, Qmp, Qrd, and Tat) and sedimentary clastics (Qd, Qf, Qg, Qs, Qt, Ts and Tus). The above soil Fe values are reasonable as the Fe content of soils is inherited from parent rocks, and $\mathrm{Fe}$ is concentrated mainly in the mafic rocks (Kabata-Pendias and Pendias, 1984). There is an increase in Fe content in soils derived from felsic to mafic rocks in 
the study area (Table 18). The soil Fe levels also increase with soil development (Table 19), i.e. Alfisols/Ultisols $>$ Inceptisols $>$ Entisols. The average Fe values in the soil orders are statistically different at $95 \%$ confidence level. High Fe concentrations in the Klamath Mountains and Coast Range have been contributed especially by Alfisols/Ultisols covering large areas of these provinces.

In the study area the analyzed Fe concentrations in the $\mathrm{A}$ and $\mathrm{B}$ horizons have the pooled variance of 629,261 and the pooled standard deviation of 793.3 . The null hypothesis $H o: A=B$ can be rejected if $A-B$ is greater than $2316.3(2.92 * 793.3)$. The results of the analysis for the Fe concentrations in the A horizon versus the B horizon at 118 sites investigated are as follows: $\mathrm{B}>\mathrm{A}$ in $77.1 \%$ of the profiles and $\mathrm{A}>\mathrm{B}$ in $0.8 \%$ of the profiles. In the rest of the profiles $(22.1 \%)$ we cannot reject the equality of the values in the two horizons. The concentration of $\mathrm{Fe}$ in the $\mathrm{B}$ horizon is particularly evident in well-drained, humid and clayey Alfisols/Ultisols. This is compatible with the findings of Knezek and Ellis (1980).

\section{LANTHANUM (LA)}

Distribution statistics for La content in soils of the study area are listed in Table 29. Out of a total of 118, La has 77 values in the $A$ horizon and 95 values in the $B$ horizon above the laboratory's minimum reporting level of five ppm. The La concentrations vary from $<5$ to $26 \mathrm{ppm}$ with an average of $<8 \mathrm{ppm}$ in the A horizon and from $<5$ to 32.5 with an average of $<9.6$ in the $B$ horizon.

The La concentrations in the analyzed samples from the different physiographic 
Table 29. Distribution statistics for Lanthanum (La) content (ppm dry) in soils of Southwest Oregon.

\begin{tabular}{|c|c|c|c|c|c|c|c|}
\hline & $\begin{array}{c}\text { Hori- } \\
\text { zon }\end{array}$ & $\begin{array}{c}\text { Total } \\
\text { Sample } \\
\text { Number/ } \\
\text { Detects' } \\
\end{array}$ & $\begin{array}{l}\text { Arith- } \\
\text { metic } \\
\text { Mean } \\
\end{array}$ & $\begin{array}{l}\text { Mini- } \\
\text { mum }\end{array}$ & $\begin{array}{l}\text { Maxi- } \\
\text { mum }\end{array}$ & $\begin{array}{c}\text { Arith- } \\
\text { metic } \\
\text { Standard } \\
\text { Deviation }\end{array}$ & Median \\
\hline \multicolumn{8}{|l|}{ For all sites } \\
\hline & $\mathrm{A}$ & $118 / 77$ & $<8$ & $<5$ & 26 & $>4.4$ & 5.5 \\
\hline & $\bar{B}$ & $118 / 95$ & $<9.6$ & $<5$ & 32.5 & $>5$ & 8.4 \\
\hline \multicolumn{8}{|c|}{ PhysiographicProvinces } \\
\hline \multirow[t]{2}{*}{ Coastal Plain } & A & $7 / 4$ & $<6$ & $<5$ & 6.8 & $>0.7$ & 5 \\
\hline & $\mathrm{B}$ & $7 / 4$ & $<8$ & $<5$ & 13.5 & $>3.6$ & 8.5 \\
\hline \multirow[t]{2}{*}{ Coast Range } & $\mathrm{A}$ & $16 / 16$ & 11 & 5 & 26 & 6 & 9 \\
\hline & $\mathrm{B}$ & $16 / 16$ & 13 & 5 & 33 & 7 & 11 \\
\hline \multirow{2}{*}{$\begin{array}{c}\text { Willamette } \\
\text { Valley }\end{array}$} & $\mathrm{A}$ & $2 / 2$ & 12 & 10.4 & 13 & 2 & 12 \\
\hline & B & $2 / 2$ & 14 & 12 & 15 & 2 & 14 \\
\hline \multirow{2}{*}{$\begin{array}{l}\text { Cascade } \\
\text { Range }\end{array}$} & $\mathrm{A}$ & $39 / 25$ & $<9$ & $<5$ & 23 & $>5$ & 5 \\
\hline & $\bar{B}$ & $39 / 31$ & $<10$ & $<5$ & 23 & $>5$ & 8 \\
\hline \multirow{2}{*}{$\begin{array}{c}\text { Klamath } \\
\text { Mountains }\end{array}$} & A & $32 / 21$ & $<7$ & $<5$ & 16 & $>3$ & 5 \\
\hline & $\mathrm{B}$ & $32 / 23$ & $<9$ & $<5$ & 14 & $>3$ & 8 \\
\hline \multirow{2}{*}{$\begin{array}{l}\text { Basin and } \\
\text { Range }\end{array}$} & $\bar{A}$ & $18 / 8$ & $<5$ & $<5$ & 16 & $>3$ & $<5$ \\
\hline & B & $18 / 16$ & $<9$ & $<5$ & 26 & $>5$ & 7 \\
\hline \multirow{2}{*}{$\begin{array}{c}\text { High Lava } \\
\text { Plain }\end{array}$} & $\mathrm{A}$ & $4 / 1$ & $<5$ & $<5$ & 5.7 & $>0.4$ & $<5$ \\
\hline & $\mathrm{B}$ & $4 / 3$ & $<6$ & $<5$ & 8 & $>1$ & 5 \\
\hline \multicolumn{8}{|l|}{ Soil Orders } \\
\hline \multirow[t]{2}{*}{ Entisols } & $\bar{A}$ & $27 / 4$ & $<5$ & $<5$ & 5.9 & $>0.2$ & $<5$ \\
\hline & B & $27 / 17$ & $<6$ & $<5$ & 10 & $>1$ & 5 \\
\hline \multirow[t]{2}{*}{ Inceptisol } & $\mathrm{A}$ & $44 / 37$ & $<9$ & $<5$ & 23 & $>6$ & 8 \\
\hline & $\mathrm{B}$ & $44 / 38$ & $<11$ & $<5$ & 27 & $>5$ & 11 \\
\hline \multirow{2}{*}{$\begin{array}{l}\text { Alfisols/ } \\
\text { Ultisols }\end{array}$} & $\bar{A}$ & $31 / 23$ & $<8$ & $<5$ & 20 & $>4$ & 7 \\
\hline & $\bar{B}$ & $31 / 26$ & $<9$ & $<5$ & 14 & $>3$ & 8 \\
\hline \multirow[t]{2}{*}{ Mollisols } & $\bar{A}$ & $14 / 12$ & $<11$ & $<5$ & 26 & $>6$ & 10 \\
\hline & B & $14 / 13$ & $<14$ & $<5$ & 33 & $>7$ & 14 \\
\hline \multirow[t]{2}{*}{ Spodosol } & $\bar{A}$ & $1 / 0$ & $<5^{a}$ & $=$ & - & $=$ & $=$ \\
\hline & B & $1 / 0$ & $<5^{a}$ & - & $\because$ & - & $=$ \\
\hline \multirow[t]{2}{*}{ Vertisol } & $\bar{A}$ & $1 / 1$ & $14.7^{\mathrm{a}}$ & - & - & - & - \\
\hline & B & $1 / 1$ & $15.6^{\mathrm{a}}$ & $=$ & $=$ & - & - \\
\hline
\end{tabular}

${ }^{1}$ Detects are the number of samples with concentrations equal to or greater than the laboratory's reporting limit.

Only one concentration value is listed under arithmetic mean.

Note: Where the concentration of a metal in a sample is less than the laboratory's minimum reporting level, the minimum reporting level is used for calculating statistics, and the statistics are qualified as less than or greater than the value given. 
provinces of the study area are fairly uniform. The slightly higher values are in the samples from the Willamette Valley (AM for the B horizon $=14 \mathrm{ppm}$ ) and Coast Range $(\mathrm{AM}=13 \mathrm{ppm})$. The lowest analyzed soil La levels are in the Coastal Plain (AM $<8$ ppm) and High Lava Plains (AM $<6 \mathrm{ppm}$ ). The analyzed concentrations of $\mathrm{La}$ in major soil orders are also fairly uniform, with slightly higher values for Mollisols (AM $<14$ ppm) and slightly lower values for Entisols (AM $<6 \mathrm{ppm}$ ). Mollisols are developed under grass vegetation mainly in the Willamette Valley, and in the valleys and bedrock hills and plateaus of south-central Oregon. Soil-solutions in these regions are slightly alkaline. Higher La concentrations in Mollisols may be related to soil alkalinity as indicated by Balashov and others (1964) in their study of rare earths in Russian platform soils. The highest analyzed $\mathrm{La}$ value ( $26 \mathrm{ppm}$ in the A horizon and $32.5 \mathrm{ppm}$ in the $\mathrm{B}$ horizon) at site LC9 is in Mollisol developed on sandstone of the Yamhill Formation (geologic unit Ty). The other analyzed high La values are found in soils formed on silts, sands and gravels (geologic units Tfee, Tmss and Tn) and felsic rocks (Tut and $\mathrm{KJg}$ ). Fairbridge (1972) also indicated high La levels in soils developed on sandy deposits, particularly beach sands, and felsic rocks.

In the study area the analyzed La concentrations in the A and B horizons have the pooled variance of 1.26 and the pooled standard deviation of 1.12 . The null hypothesis Ho: $\mathrm{A}=\mathrm{B}$ can be rejected if $\mathrm{A}-\mathrm{B}$ is greater than $3.3(2.92 * 1.12)$. The results of the analysis for the La concentrations in the A horizon versus the B horizon at 118 sites investigated are as follows: $\mathrm{B}>\mathrm{A}$ in $24.6 \%$ of the profiles and $\mathrm{A}>\mathrm{B}$ in $1.7 \%$ of the 
profiles. In the rest of the profiles $(73.7 \%)$ we cannot reject the equality of the values in the two horizons.

LEAD (PB)

Distribution statistics for $\mathrm{Pb}$ content in soils of the study area are listed in Table 30. Out of a total of $118, \mathrm{~Pb}$ has 45 values in the $\mathrm{A}$ horizon and 16 values in the $\mathrm{B}$ horizon above the laboratory's minimum reporting level of $10 \mathrm{ppm}$. The $\mathrm{Pb}$ contents vary from $<10$ to $378 \mathrm{ppm}$ with an average of $<18 \mathrm{ppm}$ in the A horizon and from $<10$ to $40 \mathrm{ppm}$ with an average of $<10 \mathrm{ppm}$ in the $\mathrm{B}$ horizon. The $\mathrm{Pb}$ contents of surface soils of the U.S. range from $<10$ to $70 \mathrm{ppm}$, with an average of $20 \mathrm{ppm}$ (Kabata-Pendias and Pendias, 1984) (Appendix 8.2). Except for a few sporadic high values, $\mathrm{Pb}$ levels in the A horizon samples of the study area are similar to that of the U.S. in general.

The analyzed samples from the Klamath Mountains have the highest soil Pb concentrations ( $\mathrm{AM}$ for the $\mathrm{A}$ horizon $<27 \mathrm{ppm}$ ). At site $\mathrm{KL} 14$ the highest $\mathrm{Pb}$ concentration of $378 \mathrm{ppm}$ (in the A horizon) is in Alfisol/Ultisol derived from a shale (geologic unit Jss). The site KL14 is located on a hill, 1.1 miles off Highway 199, about 3 miles southwest of Wonder, Oregon. At another site (R12) about 200 feet above Highway 199, west of Wonder, Oregon, 146 ppm Pb occurs in the A horizon of an Inceptisol developed on a sandstone (Jub). There are also a few sites with high analyzed soil $\mathrm{Pb}$ values in the Coast and Cascade Ranges. For example, at site $\mathrm{R} 2$ (for location see Appendix 3) in the Cascade Range, Inceptisol developed on basaltic and 
Table 30. Distribution statistics for Lead $(\mathrm{Pb})$ content (ppm dry) in soils of Southwest Oregon.

\begin{tabular}{|c|c|c|c|c|c|c|c|}
\hline & $\begin{array}{l}\text { Hori- } \\
\text { zon }\end{array}$ & $\begin{array}{c}\text { Total } \\
\text { Sample } \\
\text { Number/ } \\
\text { Detects }^{1}\end{array}$ & $\begin{array}{l}\text { Arith- } \\
\text { metic } \\
\text { Mean }\end{array}$ & $\begin{array}{l}\text { Mini- } \\
\text { mum }\end{array}$ & $\begin{array}{l}\text { Maxi- } \\
\text { mum }\end{array}$ & $\begin{array}{c}\text { Arith- } \\
\text { metic } \\
\text { Standard } \\
\text { Deviation }\end{array}$ & Median \\
\hline \multicolumn{8}{|l|}{ For all sites } \\
\hline & A & $118 / 45$ & $<18$ & $<10$ & 378 & $>39$ & $<10$ \\
\hline & $\bar{B}$ & $118 / 16$ & $<11$ & $<10$ & 40 & $>3$ & $<10$ \\
\hline \multicolumn{8}{|c|}{ PhysiographicProvinces } \\
\hline \multirow[t]{2}{*}{ Coastal Plain } & $\mathrm{A}$ & $7 / 3$ & $<10$ & $<10$ & 25 & $>6$ & $<10$ \\
\hline & B & $7 / 0$ & $<10$ & $<10$ & $<10$ & 0 & $<10$ \\
\hline \multirow[t]{2}{*}{ Coast Range } & $\mathrm{A}$ & $16 / 8$ & $<15$ & $<10$ & 51 & $>10$ & 10 \\
\hline & B & $16 / 6$ & $<10$ & $<10$ & 39.6 & $>7.4$ & 10 \\
\hline \multirow{2}{*}{$\begin{array}{c}\text { Willamette } \\
\text { Valley }\end{array}$} & $\mathrm{A}$ & $2 / 1$ & $<25$ & $<10$ & 40 & $>21$ & 10 \\
\hline & $\bar{B}$ & $2 / 0$ & $<10$ & $<10$ & $<10$ & 0 & $<10$ \\
\hline \multirow{2}{*}{$\begin{array}{l}\text { Cascade } \\
\text { Range }\end{array}$} & $\mathrm{A}$ & $39 / 16$ & $<17$ & $<10$ & 133 & $>24$ & $<10$ \\
\hline & B & $39 / 6$ & $<10$ & $<10$ & 25 & $>2.4$ & $<10$ \\
\hline \multirow{2}{*}{$\begin{array}{c}\text { Klamath } \\
\text { Mountains }\end{array}$} & $\mathrm{A}$ & $32 / 11$ & $<27$ & $<10$ & 378 & $>68$ & $<10$ \\
\hline & $\mathrm{B}$ & $32 / 3$ & $<10$ & $<10$ & 12.8 & $>0.6$ & $<10$ \\
\hline \multirow{2}{*}{$\begin{array}{c}\text { Basin and } \\
\text { Range }\end{array}$} & $\mathrm{A}$ & $18 / 5$ & $<10$ & $<10$ & 10.4 & $>0.1$ & $<10$ \\
\hline & B & $18 / 1$ & $<10$ & $<10$ & 10 & 0 & $<10$ \\
\hline \multirow{2}{*}{$\begin{array}{l}\text { High Lava } \\
\text { Plain }\end{array}$} & $\mathrm{A}$ & $4 / 1$ & $<10$ & $<10$ & 10 & 0 & $<10$ \\
\hline & B & $4 / 0$ & $<10$ & $<10$ & $<10$ & 0 & $<10$ \\
\hline \multicolumn{8}{|l|}{ Soil Orders } \\
\hline \multirow[t]{2}{*}{ Entisols } & $\mathrm{A}$ & $27 / 8$ & $<10$ & $<10$ & 14 & $>0.8$ & $<10$ \\
\hline & $\bar{B}$ & $27 / 3$ & $<10$ & $<10$ & 10 & 0 & $<10$ \\
\hline \multirow[t]{2}{*}{ Inceptisols } & $\bar{A}$ & $44 / 21$ & $<21$ & $<10$ & 146 & $>89$ & 10 \\
\hline & $\overline{\mathrm{B}}$ & $44 / 11$ & $<11$ & $<10$ & 40 & $>5$ & $<10$ \\
\hline \multirow{2}{*}{$\begin{array}{l}\text { Alfisols/ } \\
\text { Ultisols }\end{array}$} & $\bar{A}$ & $31 / 10$ & $<23$ & $<10$ & 378 & $>66$ & $<10$ \\
\hline & B & $31 / 1$ & $<10$ & $<10$ & 10 & 0 & $<10$ \\
\hline \multirow[t]{2}{*}{ Mollisols } & $\mathrm{A}$ & $14 / 5$ & $<10$ & $<10$ & 40 & $>8$ & $<10$ \\
\hline & B & $14 / 1$ & $<10$ & $<10$ & 15.8 & $>1.5$ & $<10$ \\
\hline \multirow[t]{2}{*}{ Spodosol } & $\mathrm{A}$ & $1 / 1$ & $10^{2}$ & -- & -- & - & -- \\
\hline & $\mathrm{B}$ & $1 / 0$ & $<10^{\mathrm{a}}$ & - & -- & - & - \\
\hline \multirow[t]{2}{*}{ Vertisol } & $\mathrm{A}$ & $1 / 0$ & $<10^{9}$ & - & - & - & - \\
\hline & $\bar{B}$ & $1 / 0$ & $<10^{2}$ & - & -- & -- & - \\
\hline
\end{tabular}

${ }^{1}$ Detects are the number of samples with concentrations equal to or greater than the laboratory's reporting limit.

"Only one concentration value is listed under arithmetic mean.

Note: Where the concentration of a metal in a sample is less than the laboratory's minimum reporting level, the minimum reporting level is used for calculating statistics, and the statistics are qualified as less than or greater than the value given. 
andesitic rocks (Tbaa) has $133 \mathrm{ppm} \mathrm{Pb}$ in the A horizon. Also at site LM1 in the Coast Range, Inceptisol formed on landslide and debris flow deposits (Qls) contains 104 ppm $\mathrm{Pb}$ in the $\mathrm{A}$ horizon.

In the study area the analyzed $\mathrm{Pb}$ concentrations in the $\mathrm{A}$ and $\mathrm{B}$ horizons have the pooled variance of 1.73 and the pooled standard deviation of 1.31 . The null hypothesis Ho: $\mathrm{A}=\mathrm{B}$ can be rejected if $\mathrm{A}-\mathrm{B}$ is greater than $3.8(2.92 * 1.31)$. The results of the analysis for the $\mathrm{Pb}$ concentrations in the $\mathrm{A}$ horizon versus the $\mathrm{B}$ horizon at 118 sites investigated are as follows: $\mathrm{A}>\mathrm{B}$ in $17.8 \%$ of the profiles and $\mathrm{A}<\mathrm{B}$ in $0.8 \%$ of the profiles. In the rest of the profiles $(81.4 \%)$ we cannot reject the equality of the values in the two horizons. All high $\mathrm{Pb}$ values are in the $\mathrm{A}$ horizon. This is consistent with the observations made by Wright and others (1955) in soils of eastern Canada. Figure 8 shows the graphic representations of soil $\mathrm{Pb}$ concentrations in physiographic provinces, soil orders and major igneous rocks of the study area. There is no relationship between $\mathrm{Pb}$ concentrations and soil orders/soil development since all the high values are in the $\mathrm{A}$ horizon.

\section{LITHIUM (LI)}

Distribution statistics for Li content in soils of the study area are listed in Table 31. Out of a total of 118 , Li has 88 values in the A horizon and 107 values in the B horizon above the laboratory's minimum reporting level of five ppm. The Li contents vary from $<5$ to $48 \mathrm{ppm}$ with an average of $<11 \mathrm{ppm}$ in the A horizon and from $<5$ to $54 \mathrm{ppm}$ with an average of $<15 \mathrm{ppm}$ in the horizon. The average Li concentrations in 

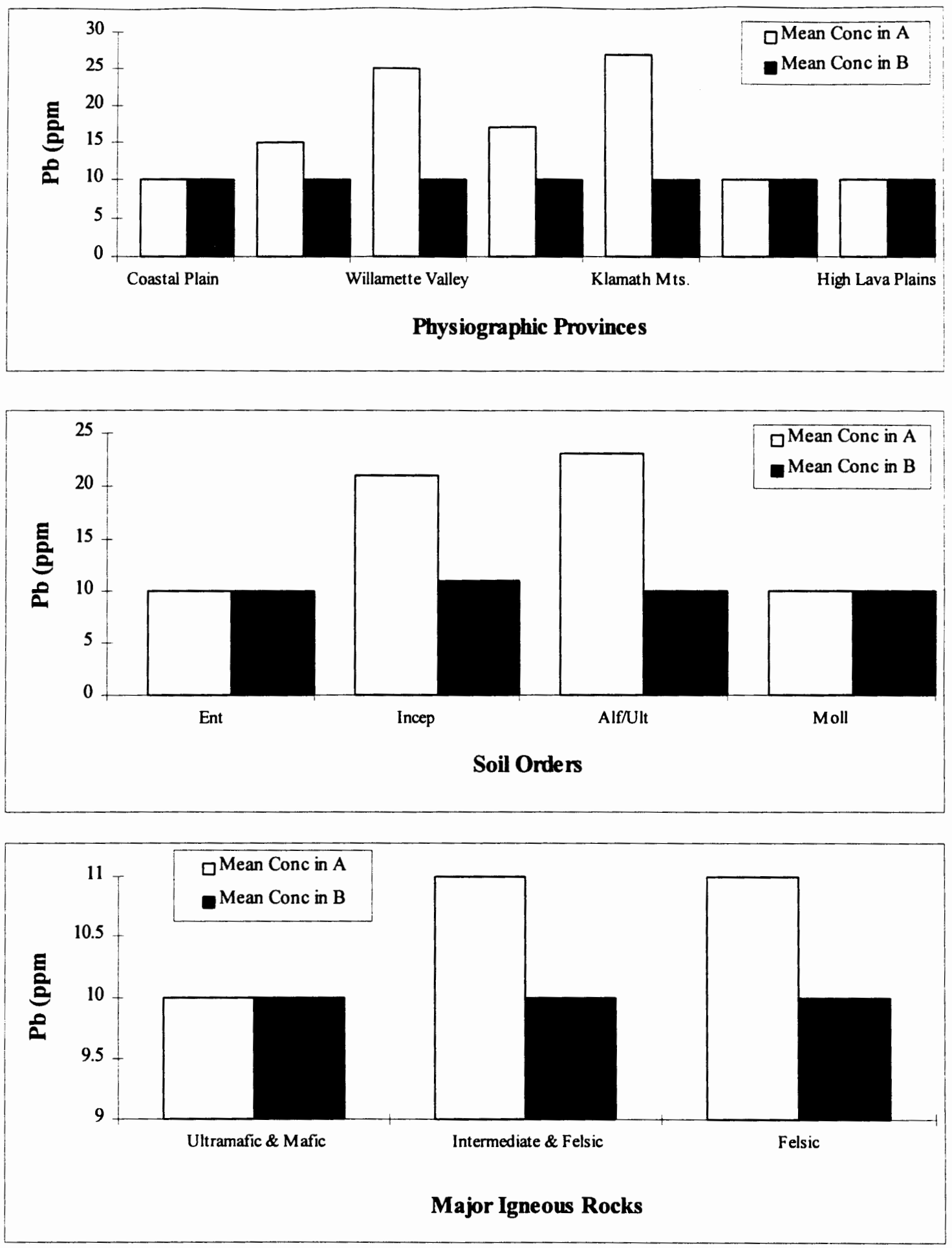

Figure 8. Soil Lead $(\mathrm{Pb})$ concentrations in physiographic provinces, soil orders and major igneous rocks of Southwest Oregon 
Table 31. Distribution statistics for Lithium (Li) content (ppm dry) in soils of Southwest Oregon.

\begin{tabular}{|c|c|c|c|c|c|c|c|}
\hline & $\begin{array}{l}\text { Hori- } \\
\text { zon }\end{array}$ & $\begin{array}{c}\text { Total } \\
\text { Sample } \\
\text { Number/ } \\
\text { Detects }{ }^{1}\end{array}$ & $\begin{array}{l}\text { Arith- } \\
\text { metic } \\
\text { Mean }\end{array}$ & $\begin{array}{l}\text { Mini- } \\
\text { mum }\end{array}$ & $\begin{array}{l}\text { Maxi- } \\
\text { mum }\end{array}$ & $\begin{array}{c}\text { Arith- } \\
\text { metic } \\
\text { Standard } \\
\text { Deviation }\end{array}$ & Median \\
\hline \multicolumn{8}{|l|}{ For all sites } \\
\hline & $\bar{A}$ & $118 / 88$ & $<11$ & $<5$ & 48 & $>8.6$ & 7.6 \\
\hline & $\bar{B}$ & $118 / 107$ & $<15$ & $<5$ & 54 & $>11$ & 11 \\
\hline \multicolumn{8}{|c|}{ PhysiographicProvinces } \\
\hline \multirow[t]{2}{*}{ Coastal Plain } & $\mathrm{A}$ & $7 / 3$ & $<8$ & $<5$ & 23 & $>7$ & 5 \\
\hline & $\mathrm{B}$ & $7 / 7$ & 17 & 6 & 33 & 11 & 15 \\
\hline \multirow[t]{2}{*}{ Coast Range } & $\bar{A}$ & $16 / 16$ & 19 & 5 & $\overline{48}$ & 11 & 20 \\
\hline & $\overline{\mathrm{B}}$ & $16 / 16$ & $\overline{24}$ & 5 & 54 & 12 & 24 \\
\hline \multirow{2}{*}{$\begin{array}{c}\text { Willamette } \\
\text { Valley }\end{array}$} & $\bar{A}$ & $2 / 2$ & 6.1 & 5.4 & 6.7 & 0.9 & 6.1 \\
\hline & $\mathrm{B}$ & $2 / 2$ & 8.2 & 7.9 & 8.4 & 0.4 & 8.2 \\
\hline \multirow{2}{*}{$\begin{array}{l}\text { Cascade } \\
\text { Range }\end{array}$} & $\overline{\mathrm{A}}$ & $39 / 28$ & $<7$ & $<5$ & 15 & $>3$ & 6 \\
\hline & $\bar{B}$ & $39 / 33$ & $<9$ & $<5$ & 23 & $>4$ & 7 \\
\hline \multirow{2}{*}{$\begin{array}{c}\text { Klamath } \\
\text { Mountains }\end{array}$} & $\bar{A}$ & $32 / 27$ & $<15$ & $<5$ & 48 & $>11$ & 13 \\
\hline & $\mathrm{B}$ & $32 / 30$ & $<22$ & $<5$ & 52 & $>14$ & 20 \\
\hline \multirow{2}{*}{$\begin{array}{c}\text { Basin and } \\
\text { Range }\end{array}$} & $\bar{A}$ & $18 / 11$ & $<7$ & $<5$ & 12.4 & $>2.7$ & 5 \\
\hline & B & $18 / 16$ & $<8$ & $<5$ & 14 & $>3.4$ & 8 \\
\hline \multirow{2}{*}{$\begin{array}{c}\text { High Lava } \\
\text { Plain }\end{array}$} & $\bar{A}$ & $4 / 1$ & $<5$ & $<5$ & 6 & $>0.5$ & $<5$ \\
\hline & B & $4 / 3$ & $<6$ & $<5$ & 8 & $>1.3$ & 5 \\
\hline \multicolumn{8}{|l|}{ Soil Orders } \\
\hline \multirow[t]{2}{*}{ Entisols } & $\overline{\mathrm{A}}$ & $27 / 11$ & $<5$ & $\overline{<5}$ & 8.5 & $>1$ & $\overline{<5}$ \\
\hline & $\mathrm{B}$ & $27 / 22$ & $<6$ & $<5$ & 10 & $>1.7$ & 5.8 \\
\hline \multirow[t]{2}{*}{ Inceptisol } & $\mathrm{A}$ & $44 / 37$ & $<13$ & $<5$ & 48 & $>3$ & 10 \\
\hline & B & $44 / 40$ & $<17$ & $<5$ & 54 & $>12$ & 13 \\
\hline \multirow{2}{*}{$\begin{array}{l}\text { Alfisols/ } \\
\text { Ultisols }\end{array}$} & $\bar{A}$ & $31 / 26$ & $<14$ & $<5$ & $\overline{48}$ & $>11$ & 9 \\
\hline & B & $31 / 30$ & $<20$ & $\overline{<5}$ & 52 & $>14$ & 16 \\
\hline \multirow[t]{2}{*}{ Mollisols } & $\mathrm{A}$ & $14 / 13$ & $<9$ & $<5$ & 22 & $>5$ & 7 \\
\hline & $\mathrm{B}$ & $14 / 13$ & $<11$ & $<5$ & 25 & $>6$ & 10 \\
\hline \multirow[t]{2}{*}{ Spodosol } & $\mathrm{A}$ & $1 / 0$ & $<5^{a}$ & -- & -- & -- & - \\
\hline & $\bar{B}$ & $1 / 1$ & $9^{2}$ & - & - & -- & - \\
\hline \multirow[t]{2}{*}{ Vertisol } & $\bar{A}$ & $1 / 1$ & $15^{\mathrm{a}}$ & - & -- & - & - \\
\hline & B & $1 / 1$ & $16^{2}$ & 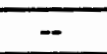 & $\cdots$ & -- & - \\
\hline
\end{tabular}

${ }^{1}$ Detects are the number of samples with concentrations equal to or greater than the laboratory's reporting limit.

anly one concentration value is listed under arithmetic mean.

Note: Where the concentration of a metal in a sample is less than the laboratory's minimum reporting level, the minimum reporting level is used for calculating statistics, and the statistics are qualified as less than or greater than the value given. 
surface soils of the U.S. range from 13 to 34 ppm (Kabata-Pendias and Pendias, 1984) (Appendix 8.5). Soils of the study area are less abundant in Li than that of the U.S. in general.

The analyzed samples from the Coast Range and Klamath Mountains contain the highest soil $\mathrm{Li}$ values (AM for the B horizon $=24 \mathrm{ppm}$ and $<22 \mathrm{ppm}$, respectively). The lowest analyzed $\mathrm{Li}$ concentrations are in the Cascade Range (AM $<9 \mathrm{ppm})$, Basin and Range (AM $<8 \mathrm{ppm})$ and High Lava Plains $(\mathrm{AM}<6 \mathrm{ppm})$. The analyzed $\mathrm{Li}$ value in Alfisols/Ultisols (AM $<20 \mathrm{ppm})$ and Inceptisols $(\mathrm{AM}<17 \mathrm{ppm})$ are comparable. Entisols are poorest in $\operatorname{Li}(\mathrm{AM}<6 \mathrm{ppm})$.

The highest analyzed Li contents are found in soils derived from granite and diorite (JTrgd) and siltstone and sandstone (Kc, Ks, KJds, Tmsm, Tmss, Tt and Ty). The lowest analyzed $\mathrm{Li}$ values are found in soils developed on sandy materials (Qd, $\mathrm{Tn}$ ), glacial deposits (Qg) and mafic and ultramafic rocks (Jub, KJgu, QTb, QTmv, QTps, Tob, and Tsr). Kabata-Pendias and Pendias (1984) indicated Li contents in magmatic rocks increase with an increase in silica, being highest in felsic rocks. The lower Tertiary marine, arkosic sands and silts in the Coast Range (i.e.geologic units Tmsm, Tmss, Tt and Ty) were derived from the Idaho batholith (Heller and others, 1987). The high soil Li levels in the Coast Range seem to have been contributed by these feldspar-rich deposits.

In the study area the analyzed $\mathrm{Li}$ concentrations in the $\mathrm{A}$ and $\mathrm{B}$ horizons have the pooled variance of 0.56 and the pooled standard deviation of 0.75 . The null hypothesis 
Ho: $\mathrm{A}=\mathrm{B}$ can be rejected if $\mathrm{A}-\mathrm{B}$ is greater than $2.2\left(2.92^{*} 0.75\right)$. The results of the analysis for the Li concentrations in the A horizon versus the B horizon at 118 sites investigated are as follows: $\mathrm{B}>\mathrm{A}$ in $50.8 \%$ of the profiles and $\mathrm{A}>\mathrm{B}$ in $0.8 \%$ of the profiles. In the rest of the profiles $(48.4 \%)$ we cannot reject the equality of the values in the two horizons. The concentration of $\mathrm{Li}$ in the $\mathrm{B}$ horizon is most apparent in welldrained, humid Alfisols/Ultisols.

\section{MAGNESIUM (MG)}

Distribution statistics for $\mathrm{Mg}$ content in soils of the study area are listed in Table 32. At all the 118 sites the $\mathrm{Mg}$ concentrations in both the $\mathrm{A}$ and $\mathrm{B}$ horizons are greater than the laboratory's minimum reporting level of $50 \mathrm{ppm}$. The Mg levels vary from 545 to $16,424 \mathrm{ppm}$ with an average of 4,431 ppm in the A horizon and from 591 to 23,606 $\mathrm{ppm}$ with an average of 5,325 ppm in the B horizon.

The analyzed samples from the Klamath Mountains and Coast Range have the highest soil $\mathrm{Mg}$ levels (AM for the $\mathrm{B}$ horizon $=8,990 \mathrm{ppm}$ and 7,394 ppm, respectively). The analyzed $\mathrm{Mg}$ concentrations in these two physiographic provinces are far higher than the 3,000 ppm average $\mathrm{Mg}$ values reported by Bowen (1966) for soils in general. The lowest analyzed soil Mg values are in the High Lava Plains (AM =2,155 ppm) and Coastal Plain ( $\mathrm{AM}=1,493 \mathrm{ppm})$. Among soil orders, Alfisols/Ultisols have the highest analyzed $\mathrm{Mg}$ concentrations $(\mathrm{AM}=7,737 \mathrm{ppm})$. The analyzed $\mathrm{Mg}$ levels in Inceptisols $(\mathrm{AM}=5,990 \mathrm{ppm})$ and Mollisols $(\mathrm{AM}=4,994 \mathrm{ppm})$ are comparable. Entisols have the lowest analyzed $\mathrm{Mg}$ values $(\mathrm{AM}=1,701 \mathrm{ppm}) . \mathrm{Mg}$ values in the 
Table 32.Distribution statistics for Magnesium (Mg) content (ppm dry) in soils of Southwest Oregon.

\begin{tabular}{|c|c|c|c|c|c|c|c|}
\hline & $\begin{array}{l}\text { Hori- } \\
\text { zon }\end{array}$ & $\begin{array}{c}\text { Total } \\
\text { Sample } \\
\text { Number/ } \\
\text { Detects }\end{array}$ & $\begin{array}{l}\text { Arith- } \\
\text { metic } \\
\text { Mean }\end{array}$ & $\begin{array}{l}\text { Minj- } \\
\text { mum }\end{array}$ & $\begin{array}{l}\text { Maxi- } \\
\text { mum }\end{array}$ & $\begin{array}{c}\text { Arith- } \\
\text { metic } \\
\text { Standard } \\
\text { Deviation }\end{array}$ & Median \\
\hline \multicolumn{8}{|l|}{ For all sites } \\
\hline & A & $118 / 118$ & 4,431 & 545 & 16,424 & 3,844 & 3,124 \\
\hline & B & $118 / 118$ & 5,325 & 591 & 23,606 & 4,752 & 3,914 \\
\hline \multicolumn{8}{|c|}{ PhysiographicProvinces } \\
\hline \multirow[t]{2}{*}{ Coastal Plain } & $\mathrm{A}$ & $7 / 7$ & 1,323 & 620 & 3,314 & 921 & 1,123 \\
\hline & $\overline{\mathrm{B}}$ & $7 / 7$ & $1,49 \overline{3}$ & 591 & 2,935 & 932 & 951 \\
\hline \multirow[t]{2}{*}{ Coast Range } & $\mathrm{A}$ & $16 / 16$ & 6,548 & 1,328 & 11,425 & 3,396 & 6,739 \\
\hline & $\mathbf{B}$ & $16 / 16$ & 7,394 & 1,655 & 13,848 & 3,769 & 6,967 \\
\hline \multirow{2}{*}{$\begin{array}{c}\text { Willamette } \\
\text { Valley }\end{array}$} & $\mathrm{A}$ & $2 / 2$ & 4,567 & 1,317 & 7,817 & 4,596 & 4,567 \\
\hline & $\bar{B}$ & $2 / 2$ & 5,171 & 1,520 & 8,823 & 5,164 & 5,171 \\
\hline \multirow{2}{*}{$\begin{array}{c}\text { Cascade } \\
\text { Range }\end{array}$} & $\bar{A}$ & $39 / 39$ & 2,916 & 545 & 13,829 & 2,751 & 1,718 \\
\hline & $\bar{B}$ & $39 / 39$ & 3,606 & 688 & 15,300 & 3,345 & 2,216 \\
\hline \multirow{2}{*}{$\begin{array}{l}\text { Klamath } \\
\text { Mountain }\end{array}$} & $\bar{A}$ & $32 / 32$ & 7,397 & 2,119 & 16,424 & 4,272 & 5,657 \\
\hline & $\mathrm{B}$ & $32 / 32$ & 8,990 & 2,414 & 23,606 & 5,743 & 6,522 \\
\hline \multirow{2}{*}{$\begin{array}{c}\text { Basin and } \\
\text { Range }\end{array}$} & $\bar{A}$ & $18 / 18$ & 2,338 & 879 & 6,756 & 1,764 & 1,762 \\
\hline & $\mathrm{B}$ & $18 / 18$ & 2,911 & 939 & 7,988 & 2,149 & 2,066 \\
\hline \multirow{2}{*}{$\begin{array}{l}\text { High Lava } \\
\text { Plain }\end{array}$} & $\mathrm{A}$ & $4 / 4$ & 1,798 & 805 & 3,924 & 1,433 & 1,231 \\
\hline & $\bar{B}$ & $4 / 4$ & 2,155 & 1,017 & 4,798 & 1,771 & 1,404 \\
\hline \multicolumn{8}{|l|}{ Soil Orders } \\
\hline \multirow[t]{2}{*}{ Entisols } & $\bar{A}$ & $27 / 27$ & 1,311 & 689 & 4,927 & 827 & 1,120 \\
\hline & B & $27 / 27$ & 1701 & 688 & 5,989 & 1,240 & 1,360 \\
\hline \multirow[t]{2}{*}{ Inceptisols } & $\bar{A}$ & $44 / 44$ & 5,081 & 545 & 16,424 & 703 & 3,944 \\
\hline & $\bar{B}$ & $44 / 44$ & 5,990 & 591 & 23,606 & 4,971 & 5,187 \\
\hline \multirow{2}{*}{$\begin{array}{l}\text { Alfisols/ } \\
\text { Ultisols }\end{array}$} & $\bar{A}$ & $31 / 31$ & 6,267 & 1,328 & 14,470 & 4,024 & 4,750 \\
\hline & $\mathrm{B}$ & $31 / 31$ & 7,737 & 1,468 & 21,446 & 4,926 & 6,327 \\
\hline \multirow[t]{2}{*}{ Mollisols } & $\bar{A}$ & $14 / 14$ & 4,294 & 1,317 & 13,829 & 3,924 & 2,565 \\
\hline & B & $14 / 14$ & 4,994 & 1,520 & 15,300 & 4,411 & 3,011 \\
\hline \multirow[t]{2}{*}{ Spodosol } & A & $1 / 1$ & $704^{2}$ & -- & -- & - & - \\
\hline & $\mathrm{B}$ & $1 / 1$ & $756^{2}$ & - & - & - & - \\
\hline \multirow[t]{2}{*}{ Vertisol } & $\bar{A}$ & $1 / 1$ & $6,914^{2}$ & - & - & - & -- \\
\hline & $\mathrm{B}$ & $1 / 1$ & $7,317^{\mathrm{a}}$ & - & - & - & - \\
\hline
\end{tabular}

'Detects are the number of samples with concentrations equal to or greater than the laboratory's reporting limit.

Only one concentration value is listed under arithmetic mean. 
analyzed samples from the different physiographic provinces as well as from the different soil orders in the study area have large standard deviations because these soils have been derived from rocks in which the $\mathrm{Mg}$ concentrations vary widely.

The highest analyzed $\mathrm{Mg}$ values are in soils developed on mafic igneous (cs, $\operatorname{Tr} \mathrm{Pv}$, Tsr and Tub) and clastic sedimentary rocks (Jm, Js, Ks and TrPzs). Mg is concentrated mainly in mafic rocks, and $\mathrm{Mg}$ content of soils is influenced by parent materials (Fairbridge, 1972). In the study area, $\mathrm{Mg}$ levels increase in soils derived from felsic to mafic rocks (Table 18). Mg levels also increase with soil development (Table 19). Alfisols/Ultisols, derived from basaltic rocks, have contributed to the high $\mathrm{Mg}$ levels in the Klamath Mountains and Coast Range.

In the study area the analyzed $\mathrm{Mg}$ concentrations in the $\mathrm{A}$ and $\mathrm{B}$ horizons have the pooled variance of 25,271 and the pooled standard deviation of 159 . The null hypothesis Ho: $\mathrm{A}=\mathrm{B}$ can be rejected if $\mathrm{A}-\mathrm{B}$ is greater than $464(2.92 * 159)$. The results of the analysis for the $\mathrm{Mg}$ concentrations in the $\mathrm{A}$ horizon versus the $\mathrm{B}$ horizon at 118 sites investigated are as follows: $\mathrm{B}>\mathrm{A}$ in $53.4 \%$ of the profiles and $\mathrm{A}>\mathrm{B}$ in $3.4 \%$ of the profiles. In the rest of the profiles (43.2\%) we cannot reject the equality of the values in the two horizons. The concentration of $\mathrm{Mg}$ predominantly in the $\mathrm{B}$ horizon is in accord with the observations made by Bowen (1979). The greatest leaching (i.e. where $B>A$ ) is most obvious in Alfisols/Ultisols. 


\section{MANGANESE (MN)}

Distribution statistics for Mn content in soils of the study area are listed in Table 33. At all the 118 sites the $\mathrm{Mn}$ concentrations in both the $\mathrm{A}$ and $\mathrm{B}$ horizons are greater than the laboratory's minimum reporting level of one ppm. The Mn levels vary from 24 to $7,221 \mathrm{ppm}$ with an average of $1,527 \mathrm{ppm}$ in the A horizon and from 21 to $4,951 \mathrm{ppm}$ with an average of $848 \mathrm{ppm}$ in the B horizon. The Mn contents in surface soils of the U.S. range from 7 to $3,000 \mathrm{ppm}$ with an average of $495 \mathrm{ppm}$ (Kabata-Pendias and Pendias, 1984) (Appendix 8.4). Soils of the study area are more abundant in Mn than that of the U.S. The highest analyzed soil Mn concentrations in the A horizon of the Klamath Mountains, Cascade Range, Coast Range and Basin and Range provinces are 7,221 ppm, 5,685 ppm, 5,279 ppm and 4,600 ppm, respectively (Table 33). All these values are higher than the highest $\mathrm{Mn}$ value (i.e. 3,000 ppm) reported for surface soils of the U.S.

The analyzed Mn concentrations in the Klamath Mountains (AM for the A horizon $=2,138 \mathrm{ppm})$, Cascade Range $(\mathrm{AM}=1,610 \mathrm{ppm})$, Coast Range $(\mathrm{AM}=1,501 \mathrm{ppm})$, Basin and Range $(\mathrm{AM}=1,131 \mathrm{ppm})$ and Willamette Valley $(\mathrm{AM}=973 \mathrm{ppm})$ are comparable. The equality of the soil $\mathrm{Mn}$ values in these physiographic provinces cannot be rejected. The lowest analyzed soil $\mathrm{Mn}$ values are in the Coastal Plain (AM $=92$ ppm). Comparable Mn values are in the analyzed samples from Alfisols/Ultisols ( $\mathrm{AM}=$ 2,125 ppm), Mollisols ( $\mathrm{AM}=1,757 \mathrm{ppm})$ and Inceptisols $(\mathrm{AM}=1,541 \mathrm{ppm})$. Entisols have the lowest analyzed $\mathrm{Mn}$ values $(\mathrm{AM}=833 \mathrm{ppm}) . \mathrm{Mn}$ values in the analyzed 
Table 33. Distribution statistics for Manganese (Mn) content (ppm dry) in soils of Southwest Oregon.

\begin{tabular}{|c|c|c|c|c|c|c|c|}
\hline & $\begin{array}{c}\text { Hori- } \\
\text { zon }\end{array}$ & $\begin{array}{c}\text { Total } \\
\text { Sample } \\
\text { Number/ } \\
\text { Detects }\end{array}$ & $\begin{array}{l}\text { Arith- } \\
\text { metic } \\
\text { Mean }\end{array}$ & $\begin{array}{l}\text { Mini- } \\
\text { mum }\end{array}$ & $\begin{array}{l}\text { Maxi- } \\
\text { mum }\end{array}$ & $\begin{array}{c}\text { Arith- } \\
\text { metic } \\
\text { Standard } \\
\text { Deviation }\end{array}$ & Median \\
\hline \multicolumn{8}{|l|}{ For all sites } \\
\hline & $\bar{A}$ & $118 / 118$ & 1,527 & 24 & 7,221 & 1,331 & 1,208 \\
\hline & $\overline{\mathrm{B}}$ & $118 / 118$ & 848 & 21 & 4,951 & 811 & 597 \\
\hline \multicolumn{8}{|c|}{ PhysiographicProvinces } \\
\hline \multirow[t]{2}{*}{ Coastal Plain } & $\mathrm{A}$ & $7 / 7$ & 92 & 24 & 235 & 86 & 52 \\
\hline & $\overline{\mathrm{B}}$ & $7 / 7$ & 257 & 21 & 1,363 & 491 & $\overline{42}$ \\
\hline \multirow[t]{2}{*}{ Coast Range } & $\overline{\mathrm{A}}$ & $16 / 16$ & 1,501 & 31 & 5,279 & 1,253 & 1,345 \\
\hline & $\overline{\mathrm{B}}$ & $16 / 16$ & 1,100 & 49 & 4,951 & 1,159 & 827 \\
\hline Willamette & $\bar{A}$ & $2 / 2$ & 973 & 730 & 1,216 & 344 & $\overline{973}$ \\
\hline Valley & B & $2 / 2$ & 485 & 187 & 783 & 421 & 485 \\
\hline Cascade & $\bar{A}$ & $39 / 39$ & 1,610 & 129 & 5,685 & 1,285 & 1,209 \\
\hline Range & $\overline{\mathrm{B}}$ & $39 / 39$ & 777 & 100 & 2,555 & 678 & 571 \\
\hline Klamath & $\bar{A}$ & $32 / 32$ & 2,138 & 327 & 7,221 & $1, \overline{440}$ & 1,717 \\
\hline Mountains & $\mathrm{B}$ & $32 / 32$ & 1,282 & 270 & 3,345 & 835 & 1,099 \\
\hline Basin and & $\bar{A}$ & $18 / 18$ & 1,131 & 232 & 4,600 & 1,146 & 704 \\
\hline Range & $\bar{B}$ & $18 / 18$ & 409 & 124 & 943 & 280 & 317 \\
\hline High Lava & $\bar{A}$ & $4 / 4$ & 499 & 248 & 673 & 180 & 537 \\
\hline Plain & $\bar{B}$ & $4 / 4$ & 263 & 137 & 430 & 122 & 243 \\
\hline \multicolumn{8}{|l|}{ Soil Orders } \\
\hline \multirow[t]{2}{*}{ Entisols } & A & $27 / 27$ & 833 & 41 & 3,235 & 809 & 644 \\
\hline & $\overline{\mathrm{B}}$ & $27 / 27$ & 216 & 30 & 473 & 114 & 178 \\
\hline \multirow[t]{2}{*}{ Inceptisols } & $\bar{A}$ & $44 / 44$ & 1,541 & 24 & 7,221 & 1,479 & 1,268 \\
\hline & $\bar{B}$ & $44 / 44$ & 961 & 21 & 4,951 & 890 & 729 \\
\hline Alfisols/ & $\overline{\mathrm{A}}$ & $31 / 31$ & 2,125 & 31 & 5,685 & 1,407 & 1,825 \\
\hline Ultisols & $\bar{B}$ & $31 / 31$ & 1,229 & 49 & 3,345 & 866 & 1,076 \\
\hline \multirow[t]{2}{*}{ Mollisols } & $\bar{A}$ & $14 / 14$ & 1,757 & 169 & 4,600 & 1,364 & 1,262 \\
\hline & $\bar{B}$ & $14 / 14$ & 998 & 164 & 2,077 & 530 & 1,041 \\
\hline \multirow[t]{2}{*}{ Spodosol } & $\mathrm{A}$ & $1 / 1$ & $52^{2}$ & - & -- & - & - \\
\hline & B & $1 / 1$ & $32^{2}$ & - & -- & - & - \\
\hline \multirow[t]{2}{*}{ Vertisol } & $\bar{A}$ & $1 / 1$ & $566^{2}$ & - & - & - & - \\
\hline & B & $1 / 1$ & $571^{\mathrm{a}}$ & - & - & $\cdots$ & $=$ \\
\hline
\end{tabular}

${ }^{1}$ Detects are the number of samples with concentrations equal to or greater than the laboratory's reporting limit.

a Only one concentration value is listed under arithmetic mean. 
samples from the different physiographic provinces as well as from the different soil orders in the study area have very high standard deviations because these soils have been derived from rocks in which the Mn concentrations vary widely.

The highest analyzed Mn values are in soils developed on ultramafic and mafic rocks (geologic units bc, cs, Ju, Jub, QTb, Trb and Tu) and clastic sedimentary and volcaniclastic rocks ( $\mathrm{Kc}, \mathrm{Tfe}, \mathrm{Tmsm}, \mathrm{TrPzs}$, Tus). The lowest analyzed Mn values are from soils on felsic and intermediate rocks (JTrgd, $\mathrm{KJg}, \mathrm{Qa}, \mathrm{Qma}, \mathrm{Qmp}, \mathrm{Qrd}$ ) and silty and sandy materials (Qd, Qf, Qt and Tss). Mn is most abundant in mafic igneous rocks, and soils derive virtually all their Mn content from parent materials (Smith, 1993; Kabata-Pendias and Pendias, 1984). In the study area, although an apparent increase in average $\mathrm{Mn}$ levels is observed in soils derived from felsic to mafic/ultramafic rocks (Table18), the equality of these values cannot be rejected at $95 \%$ confidence level. This is because the Mn concentrations in soils derived from various rocks have very large standard deviations. Mn levels increase with soil development (Table 19). High soil Mn levels in the Klamath Mountains and Coast Range owe to Alfisols/Ultisols developed on ultramafic/mafic rocks.

In the study area the analyzed $\mathrm{Mn}$ concentrations in the $\mathrm{A}$ and $\mathrm{B}$ horizons have the pooled variance of 14,626 and the pooled standard deviation of 120.9 . The null hypothesis Ho: $\mathrm{A}=\mathrm{B}$ can be rejected if A-B is greater than $353\left(2.92^{*} 120.9\right)$. The results of the analysis for the $\mathrm{Mn}$ concentrations in the A horizon versus the B horizon at 118 sites investigated are as follows: $A>B$ in $46.6 \%$ of the profiles and $B>A$ in $1.7 \%$ of the 
profiles. In the rest of the profiles $(51.7 \%)$ we cannot reject the equality of the values in the two horizons. Adriano (1986) and Aubert and Pinta (1980) suggest that Mn usually concentrates in the humiferous surface horizons. In the Coastal Plain, Mn has accumulated in the B horizon of well-drained sandy soils at a few sites (LC17, $\mathrm{KL} 7$ and KL8).

\section{$\operatorname{MERCURY(HG)}$}

Distribution statistics for $\mathrm{Hg}$ content in soils of the study area are listed in Table 34. Out of a total of $118, \mathrm{Hg}$ has 109 detects in the $\mathrm{A}$ horizon and 72 detects in the $\mathrm{B}$ horizon. For all sites $\mathrm{Hg}$ concentrations vary from $<0.04$ to $0.37 \mathrm{ppm}$ with an average of $<0.1 \mathrm{ppm}$ in the A horizon and from $<0.04$ to $0.25 \mathrm{ppm}$ with an average of $<0.06 \mathrm{ppm}$ in the B horizon. The soil $\mathrm{Hg}$ contents in the western U.S. vary from $<0.01$ to $4.6 \mathrm{ppm}$ in both the $\mathrm{A}$ and $\mathrm{B}$ horizons, with an average of $0.08 \mathrm{ppm}$ in the $\mathrm{A}$ horizon and $0.06 \mathrm{ppm}$ in the B horizon (Steinnes, 1993). Hg levels in soils of the study area are within the range of that of the western U.S. The analyzed samples from all the physiographic provinces in western Oregon (i.e. west of the Cascade Range) have higher average $\mathrm{Hg}$ values (see Table 34) than those of the western U.S. Locally, Coos County (see Figure 5 for location) samples contain the highest concentrations of $\mathrm{Hg}$ from six sites (an average of $0.17 \mathrm{ppm}$ in the A horizon and an average of $<0.13 \mathrm{ppm}$ in the B horizon). Site LC18, located in this county, has the maximum analyzed soil $\mathrm{Hg}$ value $(0.37 \mathrm{ppm}$ in the $\mathrm{A}$ horizon and $0.25 \mathrm{ppm}$ in the B horizon) in the study area. Douglas County, anticipated to contain very high soil $\mathrm{Hg}$ levels (George Di Domenico, personal communication, 
Table 34. Distribution statistics for Mercury (Hg) content (ppm dry) in soils of Southwest Oregon.

\begin{tabular}{|c|c|c|c|c|c|c|c|}
\hline & $\begin{array}{l}\text { Hori- } \\
\text { zon }\end{array}$ & $\begin{array}{c}\text { Total } \\
\text { Sample } \\
\text { Number/ } \\
\text { Detects } \\
\end{array}$ & $\begin{array}{l}\text { Arith- } \\
\text { metic } \\
\text { Mean }\end{array}$ & $\begin{array}{l}\text { Mini- } \\
\text { mum }\end{array}$ & $\begin{array}{l}\text { Maxi- } \\
\text { mum }\end{array}$ & $\begin{array}{c}\text { Arith- } \\
\text { metic } \\
\text { Standard } \\
\text { Deviation } \\
\end{array}$ & Median \\
\hline \multicolumn{8}{|l|}{ For all sites } \\
\hline & $\mathrm{A}$ & $118 / 109$ & $<0.1$ & $<0.04$ & 0.37 & $>0.06$ & 0.08 \\
\hline & B & $118 / 72$ & $<0.06$ & $<0.04$ & 0.25 & $>0.04$ & 0.04 \\
\hline \multicolumn{8}{|c|}{ PhysiographicProvinces } \\
\hline \multirow[t]{2}{*}{ Coastal Plain } & $\mathrm{A}$ & $7 / 6$ & $<0.13$ & $<0.04$ & 0.19 & $>0.06$ & 0.14 \\
\hline & $\bar{B}$ & $7 / 4$ & $<0.08$ & $<0.04$ & 0.14 & $>0.05$ & 0.06 \\
\hline \multirow[t]{2}{*}{ Coast Range } & $\bar{A}$ & $16 / 16$ & 0.12 & 0.06 & 0.37 & $>0.08$ & 0.09 \\
\hline & $\mathrm{B}$ & $16 / 14$ & $<0.08$ & $<0.04$ & 0.25 & $>0.05$ & 0.06 \\
\hline \multirow{2}{*}{$\begin{array}{l}\text { Willamette } \\
\text { Valley }\end{array}$} & $\overline{\mathrm{A}}$ & $2 / 2$ & 0.09 & 0.08 & 0.09 & 0.01 & 0.09 \\
\hline & $\bar{B}$ & $2 / 1$ & $<0.05$ & $<0.04$ & 0.06 & $>0.01$ & 0.05 \\
\hline \multirow{2}{*}{$\begin{array}{c}\text { Cascade } \\
\text { Range }\end{array}$} & A & $39 / 34$ & $<0.09$ & $<0.04$ & 0.26 & $>0.05$ & 0.08 \\
\hline & $\bar{B}$ & $39 / 24$ & $<0.05$ & $<0.04$ & 0.12 & $>0.02$ & 0.04 \\
\hline \multirow{2}{*}{$\begin{array}{c}\text { Klamath } \\
\text { Mountains }\end{array}$} & $\bar{A}$ & $32 / 31$ & $<0.12$ & $<0.04$ & 0.29 & $>0.06$ & 0.11 \\
\hline & $\mathrm{B}$ & $32 / 27$ & $<0.07$ & $<0.04$ & 0.24 & $>0.04$ & 0.06 \\
\hline \multirow{2}{*}{$\begin{array}{l}\text { Basin and } \\
\text { Range }\end{array}$} & $\bar{A}$ & $18 / 17$ & $<0.06$ & $<0.04$ & 0.17 & $>0.03$ & 0.06 \\
\hline & $\bar{B}$ & $18 / 2$ & $<0.04$ & $<0.04$ & 0.06 & 0 & $<0.04$ \\
\hline \multirow{2}{*}{$\begin{array}{l}\text { High Lava } \\
\text { Plain }\end{array}$} & $\bar{A}$ & $4 / 3$ & $<0.06$ & $<0.04$ & 0.09 & $>0.02$ & 0.06 \\
\hline & $\bar{B}$ & $4 / 0$ & $<0.04$ & $<0.04$ & $<0.04$ & 0 & $<0.04$ \\
\hline \multicolumn{8}{|l|}{ Soil Orders } \\
\hline \multirow[t]{2}{*}{ Entisols } & $\bar{A}$ & $27 / 24$ & $<0.06$ & $<0.04$ & 0.09 & $>0.02$ & 0.06 \\
\hline & $\bar{B}$ & $27 / 8$ & $<0.05$ & $<0.04$ & 0.12 & $>0.02$ & $<0.04$ \\
\hline \multirow[t]{2}{*}{ Inceptisols } & $\bar{A}$ & $44 / 41$ & $<0.11$ & $<0.04$ & 0.29 & $>0.02$ & 0.08 \\
\hline & $\mathrm{B}$ & $44 / 30$ & $<0.06$ & $<0.04$ & 0.18 & $>0.03$ & 0.05 \\
\hline \multirow{2}{*}{$\begin{array}{l}\text { Alfisols/ } \\
\text { Ultisols }\end{array}$} & $\bar{A}$ & $31 / 30$ & $<0.12$ & $<0.04$ & 0.37 & $>0.07$ & 0.11 \\
\hline & B & $31 / 28$ & $<0.08$ & $<0.04$ & 0.25 & $>0.05$ & 0.06 \\
\hline \multirow[t]{2}{*}{ Mollisols } & $\bar{A}$ & $14 / 13$ & $<0.1$ & $<0.04$ & 0.26 & $>0.06$ & 0.08 \\
\hline & $\bar{B}$ & $14 / 6$ & $<0.05$ & $<0.04$ & 0.08 & $>0.01$ & $<0.04$ \\
\hline \multirow[t]{2}{*}{ Spodosol } & $\bar{A}$ & $1 / 1$ & $0.14^{2}$ & -- & - & - & -- \\
\hline & $\mathrm{B}$ & $1 / 0$ & $<0.04^{\mathrm{a}}$ & - & - & $=$ & $=$ \\
\hline \multirow[t]{2}{*}{ Vertisol } & A & $1 / 0$ & $<0.04^{8}$ & - & - & $=$ & - \\
\hline & $\bar{B}$ & $1 / 0$ & $<0.04^{2}$ & $\because$ & -- & $\cdots$ & - \\
\hline
\end{tabular}

${ }^{1}$ Detects are the number of samples with concentrations equal to or greater than the laboratory reporting limit.

a Only one concentration value is listed under arithmetic mean.

Note: Where the concentration of a metal in a sample is less than the laboratory's minimum reporting level, the minimum reporting level is used for calculating statistics, and the statistics are qualified as less than or greater than the value given. 
1995), has an average of $<0.09 \mathrm{ppm}$ in the A horizon.and an average of $<0.06 \mathrm{ppm}$ in the B horizon, from 21 sites.

$\mathrm{Hg}$ concentrations are highest in the analyzed samples from the Coastal Plain(AM for the A horizon $<0.13 \mathrm{ppm})$, Coast Range $(\mathrm{AM}=0.12 \mathrm{ppm})$ and Klamath Mountains $(\mathrm{AM}<0.12 \mathrm{ppm})$. Each of these provinces has a few sites with very high soil $\mathrm{Hg}$ levels. $\mathrm{Hg}$ values in the analyzed samples from the Basin and Range $(\mathrm{AM}<0.06 \mathrm{ppm})$ and High Lava Plains $(\mathrm{AM}<0.06 \mathrm{ppm})$ are lowest. This shows that the soil $\mathrm{Hg}$ concentrations are higher in western Oregon than in eastern Oregon.

In their work in the state of Washington, Ames and Prych (1995) showed that organic matter concentrations in soils are generally greater in the regions west of the Cascade Range than in the east. The same is likely true for Oregon, as the physiographic setting, the climate, and the vegetation are similar in these two states. Thus, the higher soil $\mathrm{Hg}$ contents observed in western Oregon than in eastern Oregon might be related to differences in soil organic matter. Andersson (1979), in a study of $\mathrm{Hg}$ in profiles of virgin soils, demonstrated a very close correlation between $\mathrm{Hg}$ and organic matter content in acidic soils. Soils of western Oregon are also generally acidic (see Table 7 for average soil-solution $\mathrm{pH}$ in the study area). In the Coast Range at site LC18, Ultisol developed on tuffaceous siltstone and sandstone (Tss) has the highest analyzed $\mathrm{Hg}$ value of $0.62 \mathrm{ppm}$ in the study area. The other high analyzed $\mathrm{Hg}$ values are in soils derived from sedimentary and volcaniclastic (Qt, TrPzs and Tus) and volcanic rocks (cs, Tbaa, $\mathrm{Tpb}$ and Jub). Steinnes (1993) reported that high concentrations of $\mathrm{Hg}$ occur in rocks 
derived from volcanic debris or deposited in volcanic areas. Figure 9 shows the graphic representations of soil $\mathrm{Hg}$ concentrations in physiographic provinces, soil orders and major igneous rocks of the study area.

In the study area the analyzed $\mathrm{Hg}$ concentrations in the $\mathrm{A}$ and $\mathrm{B}$ horizons have the pooled variance of 0.00 . The $\mathrm{Hg}$ values in the A horizon versus the $\mathrm{B}$ horizon at 118 sites investigated are as follows: $A>B$ in $81.3 \%$ of the profiles and $A<B$ in $6.8 \%$ of the profiles. In the rest of the profiles (11.9\%) we cannot reject the equality of the values in the two horizons. The concentration of $\mathrm{Hg}$ in the A horizon of most profiles is consistent with an extensive survey of virgin soils from all the provinces of Canada by McKeague and Kloosterman (1974). Much higher concentration of $\mathrm{Hg}$ in the surface soil than in the subsoil has also been noted by Kabata-Pendias and Pendias (1984).

\section{MOLYBDENUM (MO)}

In the study area, the Mo concentrations in all the analyzed samples from both the $\mathrm{A}$ and $\mathrm{B}$ horizons are below the laboratory's minimum reporting level of five ppm. The total soil Mo contents are usually low, averaging 1-2 ppm (Massey and Lowe, 1961; Kabata-Pendias and Pendias, 1984).

NICKEL (NI)

Distribution statistics for Ni content in soils of the study area are listed in Table 35. Out of a total of 118 , Ni has 115 detects from both the A and B horizons. The Ni concentrations vary from $<4$ to $1,132 \mathrm{ppm}$ with an average of $<52 \mathrm{ppm}$ in the A horizon and from $<4$ to $1,530 \mathrm{ppm}$ with an average of $<71 \mathrm{ppm}$ in the B horizon. In surface soils 

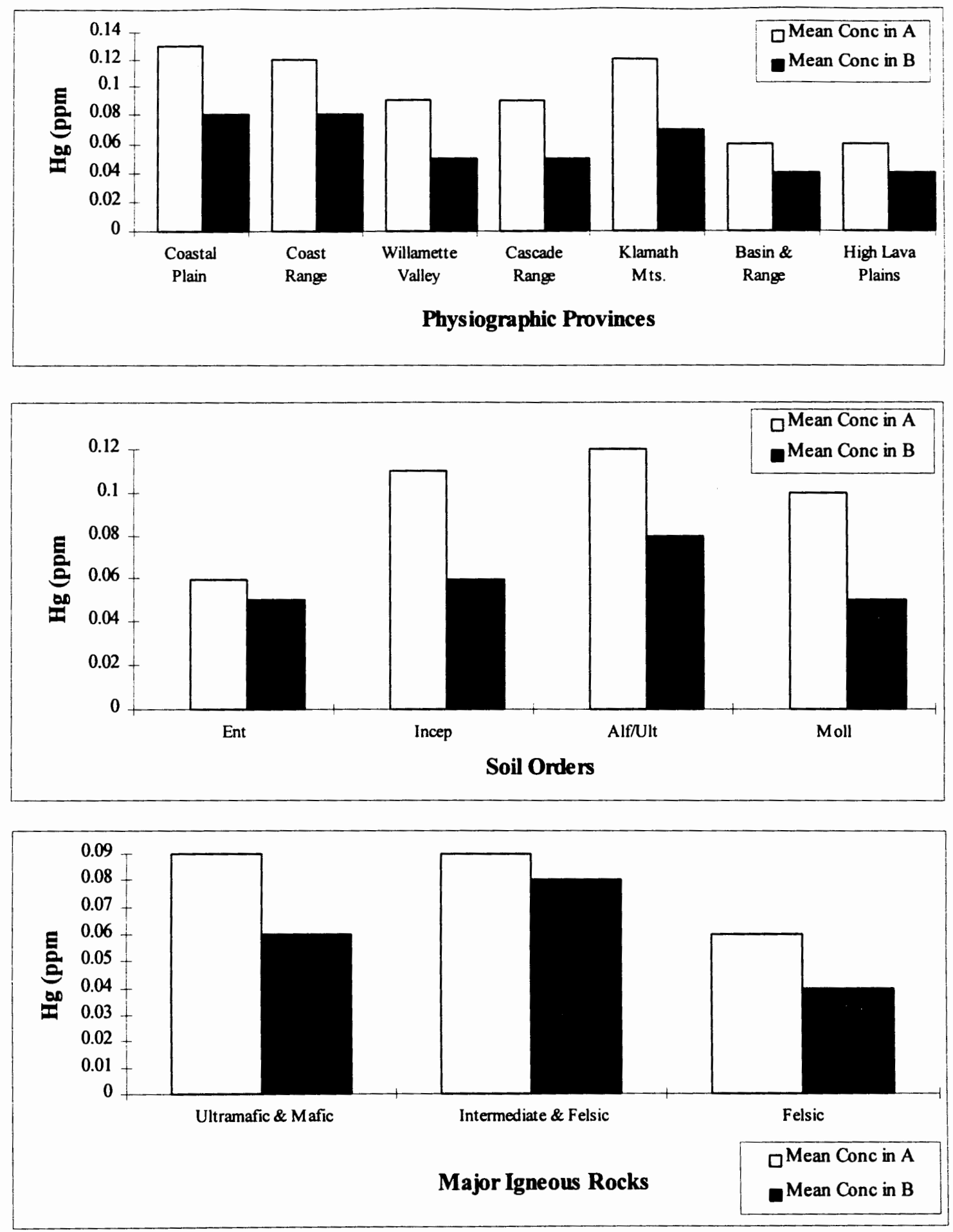

Figure 9 Soil Mercury $(\mathrm{Hg})$ concentrations in physiographic provinces, soil orders and major igneous rocks of Southwest Oregon 
Table 35. Distribution statistics for Nickel (Ni) content (ppm dry) in soils of Southwest Oregon.

\begin{tabular}{|c|c|c|c|c|c|c|c|}
\hline & $\begin{array}{l}\text { Hori- } \\
\text { zon }\end{array}$ & $\begin{array}{c}\text { Total } \\
\text { Sample } \\
\text { Number/ } \\
\text { Detects }^{1} \\
\end{array}$ & $\begin{array}{l}\text { Arith- } \\
\text { metic } \\
\text { Mean }\end{array}$ & $\begin{array}{l}\text { Mini- } \\
\text { mum }\end{array}$ & $\begin{array}{l}\text { Maxi- } \\
\text { mum }\end{array}$ & $\begin{array}{c}\text { Arith- } \\
\text { metic } \\
\text { Standard } \\
\text { Deviation } \\
\end{array}$ & Median \\
\hline \multicolumn{8}{|l|}{ For all sites } \\
\hline & A & $118 / 115$ & $<52$ & $<4$ & 1,132 & $>126$ & 22 \\
\hline & $\mathrm{B}$ & $118 / 115$ & $<71$ & $<4$ & 1,530 & $>201$ & 25 \\
\hline \multicolumn{8}{|c|}{ PhysiographicProvinces } \\
\hline \multirow[t]{2}{*}{ Coastal Plain } & $\mathrm{A}$ & $7 / 5$ & $<9$ & $<4$ & 25 & $>8$ & 4 \\
\hline & $\bar{B}$ & $7 / 5$ & $<13$ & $<4$ & 27 & $>10$ & 10 \\
\hline \multirow[t]{2}{*}{ Coast Range } & $\bar{A}$ & $16 / 16$ & 59 & 5 & 170 & 46 & 55 \\
\hline & B & $16 / 16$ & 73 & 5 & 163 & 54 & 63 \\
\hline \multirow{2}{*}{$\begin{array}{c}\text { Willamett } \\
\text { Valley }\end{array}$} & $\bar{A}$ & $2 / 2$ & 18 & 7 & 29 & 16 & 18 \\
\hline & $\bar{B}$ & $2 / 2$ & 22 & 9 & 35 & 18 & 22 \\
\hline \multirow{2}{*}{$\begin{array}{c}\text { Cascade } \\
\text { Range }\end{array}$} & $\overline{\mathrm{A}}$ & $39 / 38$ & $<18$ & $<4$ & 76 & $>16$ & 12 \\
\hline & B & $39 / 38$ & 21 & $<4$ & 86 & $>19$ & 13 \\
\hline \multirow{2}{*}{$\begin{array}{c}\text { Klamath } \\
\text { Mountains }\end{array}$} & $\mathrm{A}$ & $32 / 32$ & 120 & 6 & 1,132 & 225 & 50 \\
\hline & $\mathrm{B}$ & $32 / 32$ & 175 & 4 & 1,530 & 364 & 59 \\
\hline \multirow{2}{*}{$\begin{array}{c}\text { Basin and } \\
\text { Range }\end{array}$} & $\mathrm{A}$ & $18 / 18$ & 26 & 5 & 136 & 33 & 13 \\
\hline & $\mathrm{B}$ & $18 / 18$ & 32 & 5 & 154 & 38 & 18 \\
\hline \multirow{2}{*}{$\begin{array}{l}\text { High Lava } \\
\text { Plain }\end{array}$} & $\bar{A}$ & $4 / 4$ & 13 & 5 & 29 & 11 & 9 \\
\hline & $\bar{B}$ & $4 / 4$ & 15 & 7 & 33 & 12 & 10 \\
\hline \multicolumn{8}{|l|}{ Soil Orders } \\
\hline \multirow[t]{2}{*}{ Entisols } & $\mathrm{A}$ & $27 / 27$ & 10 & 4 & 43 & 7 & 8 \\
\hline & B & $27 / 26$ & $<13$ & $<4$ & 53 & $>11$ & 10 \\
\hline \multirow[t]{2}{*}{ Inceptisols } & $\bar{A}$ & $44 / 42$ & $<47$ & $<4$ & 371 & $>22$ & 27 \\
\hline & $\bar{B}$ & $44 / 42$ & $<60$ & $<4$ & 525 & $>85$ & 30 \\
\hline \multirow{2}{*}{$\begin{array}{l}\text { Alfisols/ } \\
\text { Ultisols }\end{array}$} & $\bar{A}$ & $31 / 31$ & 107 & 4 & 1,132 & 226 & 46 \\
\hline & $\mathrm{B}$ & $31 / 31$ & 160 & 5 & 1,530 & 366 & 56 \\
\hline \multirow[t]{2}{*}{ Mollisols } & $\mathrm{A}$ & $14 / 14$ & 32 & 7 & 76 & 20 & 28 \\
\hline & B & $14 / 14$ & 39 & 9 & 86 & 24 & 37 \\
\hline \multirow[t]{2}{*}{ Spodosol } & $\bar{A}$ & $1 / 0$ & $<4^{2}$ & -- & -- & -- & - \\
\hline & B & $1 / 1$ & $5^{a}$ & - & - & - & -- \\
\hline \multirow[t]{2}{*}{ Vertisol } & $\bar{A}$ & $1 / 1$ & $42^{2}$ & - & - & -- & - \\
\hline & B & $1 / 1$ & $48^{2}$ & - & -- & -- & -- \\
\hline
\end{tabular}

${ }^{1}$ Detects are the number of samples with concentrations equal to or greater than the laboratory's reporting limit.

a Only one concentration value is listed under arithmetic mean.

Note: Where the concentration of a metal in a sample is less than the laboratory's minimum reporting level, the minimum reporting level is used for calculating statistics, and the statistics are qualified as less than or greater than the value given. 
of the U.S., Ni content ranges from $<5$ to 200 ppm (Kabata-Pendias and Pendias, 1984) (Appendix 8.3). The surface soils of the study area are much richer in Ni than that of the U.S.

The analyzed samples from the Klamath Mountains have the highest soil Ni concentrations $(\mathrm{AM}$ for the $\mathrm{B}$ horizon $=175 \mathrm{ppm})$. Ni values in the analyzed samples from the Basin and Range $(\mathrm{AM}=32 \mathrm{ppm})$, Willamette Valley $(\mathrm{AM}=22 \mathrm{ppm})$ and Cascade Range $(\mathrm{AM}<21 \mathrm{ppm})$ are comparable. The lowest analyzed soil Ni values are in the High Lava Plains $(\mathrm{AM}=15 \mathrm{ppm})$ and Coastal Plain $(\mathrm{AM}<13 \mathrm{ppm})$. Among soil orders, Alfisols/Ultisols have the highest analyzed Ni value $(\mathrm{AM}=160 \mathrm{ppm})$. Entisols have the lowest analyzed $\mathrm{Ni}$ concentrations $(\mathrm{AM}<13 \mathrm{ppm})$. Figure 10 shows the graphic representations of soil Ni concentrations in physiographic provinces, soil orders and major igneous rocks of the study area. Ni values in the analyzed samples from the different physiographic provinces as well as from the different soil orders in the study area have very high standard deviations because these soils have been derived from rocks in which the Ni concentrations vary widely.

The Klamath Mountains have very high soil Ni concentrations compared to the U.S. The analyzed surface-soil samples from the Klamath Mountains contain an average of $120 \mathrm{ppm} \mathrm{Ni}$. This is more than four times the average Ni values (12-30 ppm; Appendix 8.3) reported by Kabata-Pendias and Pendias (1984) for surface soils of the U.S. The maximum analyzed Ni concentration of $1,132 \mathrm{ppm}$ in the A horizon of the 

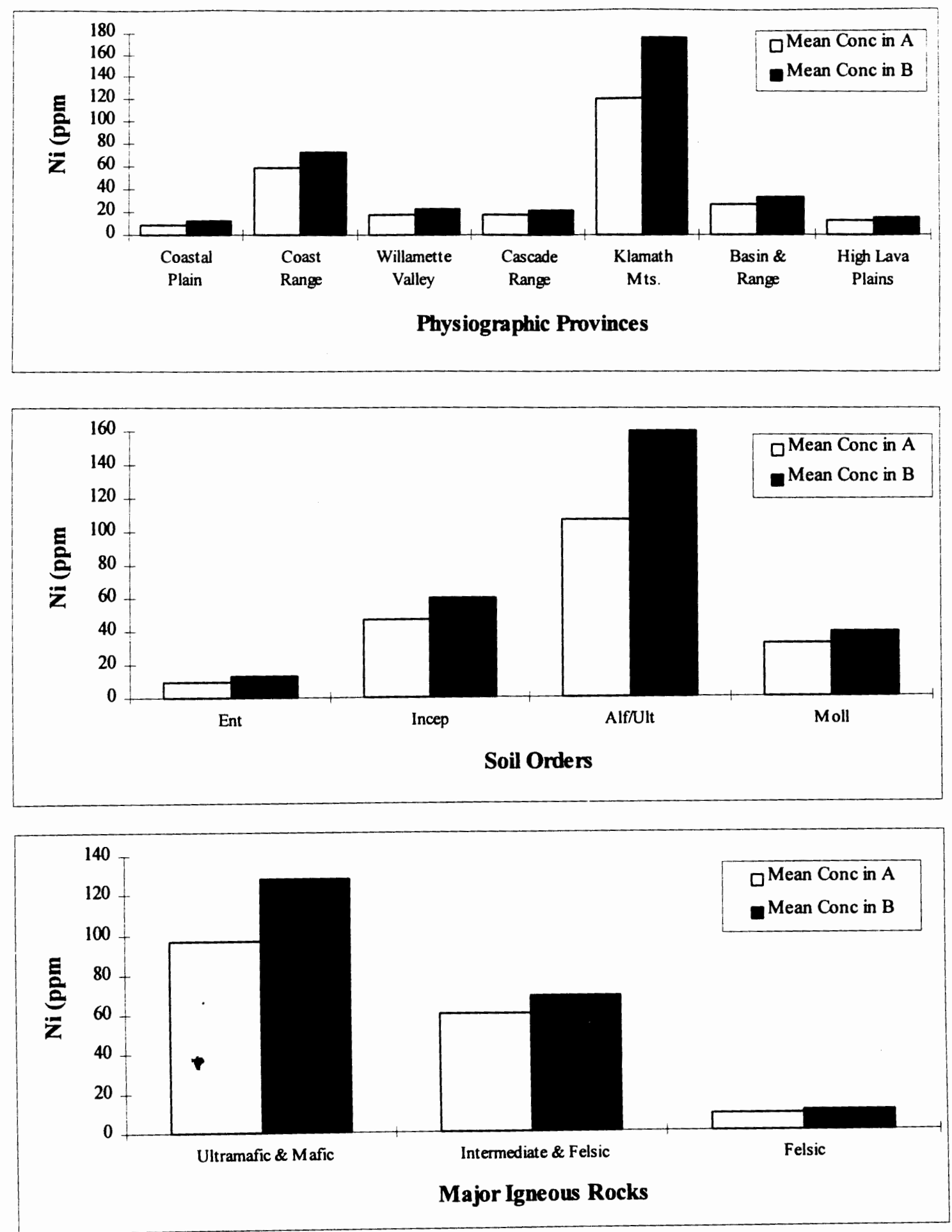

Figure 10. Soil Nickel (Ni) concentrations in physiographic provinces, soil orders and major igneous rocks of Southwest Oregon 
Klamath Mountains is nearly six times the highest value ( $200 \mathrm{ppm})$ reported by them for surface soils of the U.S.

Unusually high $\mathrm{Ni}$ concentrations have been found in soils derived from serpentinized ultramafic rocks. For example, samples from soils developed on Ju (at site KL16) and Jm (at site KL17) in the Klamath Mountains have Ni values of 2,662 ppm and 2,122 ppm (includes both the A and B horizons), respectively. As noted by Brooks (1987), soils on serpentinized ultramafiics (i.e. Jm and Ju) also contain exceptionally large concentrations of $\mathrm{Cr}, \mathrm{Fe}$ and $\mathrm{Mg}$ (see Appendix 6 for soil metal values). The other high analyzed Ni levels are found in soils formed over mafic rocks (bc and QTp), partly metamorphosed argillaceous sedimentary rocks (TrPzs) and landslide and debris flow deposits (QIs). The lowest analyzed Ni contents are found in soils derived from granitic rocks $(\mathrm{KJg})$, Mazama ash-flow and pumice deposits (Qma and Qmp) and sandy and silty rocks (Qd, Qt, Ts and Tss). Ni contents are highest in ultramafic rocks (1,400-2,000 ppm), and its concentrations decrease with increasing silica percentage in rocks down to 5 to $15 \mathrm{ppm}$ in granites (McGrath and Smith, 1993; Aubert and Pinta, 1980). The soil Ni level is highly influenced by parent rocks (KabataPendias and Pendias, 1984). In the study area, although there is an apparent increase in $\mathrm{Ni}$ concentrations in soils derived from felsic to mafic/ultramafic rocks (Figure 10), the equality of these values cannot be rejected at $95 \%$ confidence level. This is because the Ni concentrations in soils developed on ultramafic/mafic rocks in particular have an extremely large standard deviation (nearly three times the mean; Table 18). There is a 
distinct increase in soil Ni level with soil development (Table 19). The Klamath Mountains have such a high soil Ni content due to Alfisols/Ultisols developed on mafics/ultramafics, particularly on ultramafics.

In the study area the analyzed $\mathrm{Ni}$ concentrations in the $\mathrm{A}$ and $\mathrm{B}$ horizons have the pooled variance of 1.55 and the pooled standard deviation of 1.24. The null hypothesis Ho: $A=B$ can be rejected if $A-B$ is greater than $3.6(2.92 * 1.24)$. The results of the analysis for the Ni concentrations in the A horizon versus the B horizon at 118 sites investigated are as follows: $\mathrm{B}>\mathrm{A}$ in $48.3 \%$ of the profiles and $\mathrm{A}>\mathrm{B}$ in $7.6 \%$ of the profiles. In the rest of the profiles (44.1\%) we cannot reject the equality of the values in the two horizons. The concentration of $\mathrm{Ni}$ in the $\mathrm{B}$ horizon is more evident in Alfisols/Ultisols than in other soil orders.

\section{POTASSIUM (K)}

Distribution statistics for $\mathrm{K}$ content in soils of the study area are listed in Table 36. At all 118 sites investigated, the $\mathrm{K}$ concentrations in both the $\mathrm{A}$ and $\mathrm{B}$ horizons are greater than the laboratory's minimum reporting level of $50 \mathrm{ppm}$. The $\mathrm{K}$ concentrations range from 223 to $4,973 \mathrm{ppm}$ with an average of $1,266 \mathrm{ppm}$ in the A horizon and from 73 to $5,535 \mathrm{ppm}$ with an average of $1,083 \mathrm{ppm}$ in the B horizon.

The analyzed samples from the Coast Range and Klamath Mountains have the highest soil $\mathrm{K}$ levels ( $\mathrm{AM}$ for the $\mathrm{A}$ horizon =1,938 ppm and 1,636 ppm, respectively). The lowest analyzed soil $\mathrm{K}$ levels are in the Coastal Plain $(\mathrm{AM}=545 \mathrm{ppm})$ and High 
Table 36. Distribution statistics for Potassium (K) content (ppm dry) in soils of Southwest Oregon.

\begin{tabular}{|c|c|c|c|c|c|c|c|}
\hline & $\begin{array}{c}\text { Hori- } \\
\text { zon }\end{array}$ & $\begin{array}{c}\text { Total } \\
\text { Sample } \\
\text { Number/ } \\
\text { Detects }{ }^{1} \\
\end{array}$ & $\begin{array}{l}\text { Arith- } \\
\text { metic } \\
\text { Mean } \\
\end{array}$ & $\begin{array}{l}\text { Mini- } \\
\text { mum }\end{array}$ & $\begin{array}{l}\text { Maxi- } \\
\text { mum }\end{array}$ & $\begin{array}{c}\text { Arith- } \\
\text { metic } \\
\text { Standard } \\
\text { Deviation } \\
\end{array}$ & Median \\
\hline \multicolumn{8}{|l|}{ For all sites } \\
\hline & $\bar{A}$ & $118 / 118$ & 1,266 & 223 & 4,973 & 964 & 941 \\
\hline & $\mathrm{B}$ & $118 / 118$ & 1,083 & 73 & 5,535 & 941 & 780 \\
\hline \multicolumn{8}{|c|}{ Physiographic Provinces } \\
\hline \multirow[t]{2}{*}{ Coastal Plain } & $\mathrm{A}$ & $7 / 7$ & 545 & 298 & 896 & 209 & 501 \\
\hline & $\mathrm{B}$ & $7 / 7$ & 541 & 262 & 1,176 & 321 & 558 \\
\hline \multirow[t]{2}{*}{ Coast Range } & $\mathrm{A}$ & $16 / 16$ & 1,938 & 861 & 4,666 & 1,029 & 1,594 \\
\hline & $\mathrm{B}$ & $16 / 16$ & 1,838 & 518 & 5,022 & 1,177 & 1,494 \\
\hline \multirow{2}{*}{$\begin{array}{l}\text { Willamette } \\
\text { Valley }\end{array}$} & $\bar{A}$ & $2 / 2$ & 1,343 & 826 & 1,860 & 731 & 1,343 \\
\hline & $\bar{B}$ & $2 / 2$ & 951 & 780 & 1,121 & 242 & 951 \\
\hline \multirow{2}{*}{$\begin{array}{l}\text { Cascade } \\
\text { Range }\end{array}$} & $\bar{A}$ & $39 / 39$ & 1,043 & 223 & 4,541 & 909 & 669 \\
\hline & $\mathrm{B}$ & $39 / 39$ & 796 & 168 & 3,571 & 718 & 456 \\
\hline \multirow{2}{*}{$\begin{array}{c}\text { Klamath } \\
\text { Mountains }\end{array}$} & $\mathrm{A}$ & $32 / 32$ & 1,636 & 274 & 4,973 & 1,083 & 1,523 \\
\hline & B & $32 / 32$ & 1,406 & 73 & 5,535 & 1,111 & 1,115 \\
\hline \multirow{2}{*}{$\begin{array}{l}\text { Basin and } \\
\text { Range }\end{array}$} & $\bar{A}$ & $18 / 18$ & 931 & 476 & 1,771 & 410 & 821 \\
\hline & $\mathrm{B}$ & $18 / 18$ & 830 & 253 & 1,875 & 466 & 642 \\
\hline \multirow{2}{*}{$\begin{array}{c}\text { High Lava } \\
\text { Plain }\end{array}$} & $\mathrm{A}$ & $4 / 4$ & 526 & 391 & 615 & 106 & 549 \\
\hline & $\bar{B}$ & $4 / 4$ & 436 & 244 & 567 & 155 & 466 \\
\hline \multicolumn{8}{|l|}{ Soil Orders } \\
\hline \multirow[t]{2}{*}{ Entisols } & $\bar{A}$ & $27 / 27$ & 580 & 275 & 1,546 & 267 & 513 \\
\hline & $\bar{B}$ & $27 / 27$ & 493 & 234 & 1,421 & 308 & 426 \\
\hline \multirow[t]{2}{*}{ Inceptisols } & $\mathrm{A}$ & $44 / 44$ & 1,474 & 223 & 4,973 & 465 & 1,198 \\
\hline & $\bar{B}$ & $44 / 44$ & 1,338 & 163 & 5,535 & 1,176 & 970 \\
\hline \multirow{2}{*}{$\begin{array}{l}\text { Alfisols/ } \\
\text { Ultisols }\end{array}$} & $\bar{A}$ & $31 / 31$ & 1,353 & 286 & 3,881 & 801 & 1,065 \\
\hline & $\bar{B}$ & $31 / 31$ & 1,105 & 73 & 2,654 & 728 & 928 \\
\hline \multirow[t]{2}{*}{ Mollisols } & $\mathrm{A}$ & $14 / 14$ & 1,444 & 344 & 2,646 & 689 & 1,417 \\
\hline & $\mathrm{B}$ & $14 / 14$ & 1,202 & 248 & 2,948 & 738 & 1,096 \\
\hline \multirow[t]{2}{*}{ Spodosol } & $\bar{A}$ & $1 / 1$ & $530^{2}$ & - & - & - & - \\
\hline & $\mathrm{B}$ & $1 / 1$ & $262^{2}$ & - & - & - & - \\
\hline \multirow[t]{2}{*}{ Vertisol } & $\bar{A}$ & $1 / 1$ & $4,541^{2}$ & - & - & - & - \\
\hline & $\bar{B}$ & $1 / 1$ & $3,571^{2}$ & - & $=$ & $=$ & $=$ \\
\hline
\end{tabular}

'Detects are the number of samples with concentrations equal to or greater than the laboratory's reporting limit.

anly one concentration value is listed under arithmetic mean. 
Lava Plains $(A M=526 \mathrm{ppm})$. The analyzed $\mathrm{K}$ levels in Inceptisols $(\mathrm{AM}=1,474 \mathrm{ppm})$, Mollisols $(\mathrm{AM}=1,444 \mathrm{ppm})$ and Alfisols/Ultisols $(\mathrm{AM}=1,353 \mathrm{ppm})$ are comparable. Entisols have the lowest analyzed $\mathrm{K}$ values $(\mathrm{AM}=580 \mathrm{ppm}) . \mathrm{K}$ values in the analyzed samples from the different physiographic provinces as well as from the different soil orders in the study area have standard deviations close to the means. This is because these soils have been derived from rocks in which the $\mathrm{K}$ concentrations vary widely.

The highest analyzed $\mathrm{K}$ values are in soils developed over argillaceous rocks (geologic units $\mathrm{cm}, \mathrm{Tn}$, Jss and Ty), marine arkosic siltstone and sandstone (Tmsc, Tmsm, Tmss and $\mathrm{Tt})$, granitic $(\mathrm{KJg})$ and volcanic rocks ( $\mathrm{TrPv})$. The lowest analyzed $\mathrm{K}$ concentrations are in soils derived from ultramafic and mafic rocks (Jm, KJgu, mc, Qba, QTb and QTba) and sandy materials (Qd, Qt and Tss). K content in igneous rocks increases with increasing silica content, and the soil $\mathrm{K}$ levels are largely controlled by the associated parent rock materials (Fairbridge, 1972). In the study area, the equality of $\mathrm{K}$ concentrations in soils developed on major igneous rocks cannot be rejected. This is due to the large standard deviations of these values. The highest analyzed average soil $\mathrm{K}$ content in the Coast Range is due to Inceptisols formed on particularly feldspar-rich arkosic sandstones and siltstones. The humid, well-drained and developed Alfisols/Ultisols are expected to have low levels of $\mathrm{K}$ since the metal is highly mobile in soils (Birkeland, 1984). The comparable K values in Alfisols/Ultisols, Mollisols and Inceptisols indicate that $\mathrm{K}$ was not much leached out of the system, the reason of which cannot be found. The lowest analyzed average $\mathrm{K}$ content in Entisols could partly reflect 
their associated parent rocks as these soils are derived from $\mathrm{K}$-poor sandy materials at many sites.

In the study area the analyzed $\mathrm{K}$ concentrations in the $\mathrm{A}$ and $\mathrm{B}$ horizons have the pooled variance of 16,843 and the pooled standard deviation of 129.8 . The null hypothesis Ho: $\mathrm{A}=\mathrm{B}$ can be rejected if $\mathrm{A}-\mathrm{B}$ is greater than $379.0(2.92 * 129.8)$. The results of the analysis for the $\mathrm{K}$ concentrations in the $\mathrm{A}$ horizon versus the $\mathrm{B}$ horizon at 118 sites investigated are as follows: $A>B$ in $21.2 \%$ of the profiles and $B>A$ in $2.5 \%$ of the profiles. In the rest of the profiles (76.3\%) we cannot reject the equality of the values in the two horizons. $\mathrm{K}$ is concentrated in the B horizon of well-drained, humid soils of the Coastal Plain, Coast Range and Klamath Mountains.

\section{SELENIUM (SE)}

In the study area Se values in all the analyzed samples from both the A and B horizons are below the laboratory's minimum reporting level of $30 \mathrm{ppm}$. This is expected as the Se levels in soils are normally very low. Kabata-Pendias and Pendias (1984) reported surface soil Se of the U.S. to range from $<0.1$ to $4 \mathrm{ppm}$ with an average of $0.4 \mathrm{ppm}$ (Appendix 8.4).

\section{SILVER (AG)}

In the study area none of the analyzed samples in either the A or B horizon has a $\mathrm{Ag}$ value at or above the laboratory' minimum reporting level of one ppm. Normal $\mathrm{Ag}$ contents in soils vary from $<0.01$ to $5 \mathrm{ppm}$ with an average of about $0.1 \mathrm{ppm}$ (Boyle, 1972). 


\section{SODIUM (NA)}

Distribution statistics for Na content in soils of the study area are listed in Table 37. At all the 118 sites the $\mathrm{Na}$ concentrations in both the $\mathrm{A}$ and $\mathrm{B}$ horizons are greater than the laboratory's minimum reporting concentration of $50 \mathrm{ppm}$. The Na contents vary from 53 to $1,511 \mathrm{ppm}$ with an average of $346 \mathrm{ppm}$ in the A horizon and from 47 to $2,341 \mathrm{ppm}$ with an average of $419 \mathrm{ppm}$ in the $\mathrm{B}$ horizon.

The $\mathrm{Na}$ concentrations are generally greater in the soils sampled in semiarid eastern Oregon than in humid western Oregon. The analyzed soil Na values are high in the High Lava Plains (AM for the B horizon $=793 \mathrm{ppm}$ ) and Basin and Range (AM $=721 \mathrm{ppm}$ ). On the other hand, the Na levels are comparatively much lower in the analyzed samples from the Coast Range $(\mathrm{AM}=287 \mathrm{ppm})$, Coastal Plain $(\mathrm{AM}=150$ ppm) and Klamath Mountains $(\mathrm{AM}=163 \mathrm{ppm})$. The highest analyzed Na values (AM $=871 \mathrm{ppm}$ from only two sites) in the Willamette Valley are the exception. The $\mathrm{Na}$ levels in the Cascade Range ( $\mathrm{AM}=530 \mathrm{ppm})$ samples are in between the above two categories. Among soil orders, Entisols and Mollisols have the highest analyzed $\mathrm{Na}$ concentrations $(\mathrm{AM}=785 \mathrm{ppm}$ and $593 \mathrm{ppm}$, respectively). The Alfisols/Ultisols have the lowest analyzed $\mathrm{Na}$ values $(\mathrm{AM}=135 \mathrm{ppm}) . \mathrm{Na}$ values in the analyzed samples from the different physiographic provinces as well as from the different soil orders in the study area have very high standard deviations because these soils have been derived from rocks in which the Na concentrations vary widely. Climatic conditions have also greatly affected the soil $\mathrm{Na}$ concentrations in the region. 
Table 37. Distribution statistics for Sodium (Na) content (ppm dry) in soils of Southwest Oregon.

\begin{tabular}{|c|c|c|c|c|c|c|c|}
\hline & $\begin{array}{c}\text { Hori- } \\
\text { zon }\end{array}$ & $\begin{array}{c}\text { Total } \\
\text { Sample } \\
\text { Number/ } \\
\text { Detects } \\
\end{array}$ & $\begin{array}{l}\text { Arith- } \\
\text { metic } \\
\text { Mean }\end{array}$ & $\begin{array}{l}\text { Mini- } \\
\text { mum }\end{array}$ & $\begin{array}{l}\text { Maxi- } \\
\text { mum }\end{array}$ & $\begin{array}{c}\text { Arith- } \\
\text { metic } \\
\text { Standard } \\
\text { Deviation }\end{array}$ & Median \\
\hline \multicolumn{8}{|l|}{ For all sites } \\
\hline & $\mathrm{A}$ & $118 / 118$ & 346 & 53 & 1,511 & 318 & 216 \\
\hline & $\mathrm{B}$ & $118 / 118$ & 419 & 47 & 2,341 & $\overline{426}$ & 200 \\
\hline \multicolumn{8}{|c|}{ PhysiographicProvinces } \\
\hline \multirow[t]{2}{*}{ Coastal Plain } & $\mathrm{A}$ & $7 / 7$ & 215 & 129 & 362 & 81 & 206 \\
\hline & $\mathrm{B}$ & $7 / 7$ & 150 & 98 & 194 & $\overline{42}$ & 140 \\
\hline \multirow[t]{2}{*}{ Coast Range } & $\mathrm{A}$ & $16 / 16$ & 244 & 73 & 1,511 & 352 & 122 \\
\hline & $\mathrm{B}$ & $16 / 16$ & 287 & 59 & 2,341 & 557 & 137 \\
\hline \multirow{2}{*}{$\begin{array}{c}\text { Willamette } \\
\text { Valley }\end{array}$} & $\bar{A}$ & $2 / 2$ & 738 & 60 & $\overline{1,416}$ & 959 & 738 \\
\hline & $\bar{B}$ & $2 / 2$ & 871 & 53 & 1,689 & 1,157 & 871 \\
\hline \multirow{2}{*}{$\begin{array}{l}\text { Cascade } \\
\text { Range }\end{array}$} & $\bar{A}$ & $39 / 39$ & 425 & 61 & 1,353 & 319 & 371 \\
\hline & $\overline{\mathrm{B}}$ & $39 / 39$ & 530 & 57 & 1,708 & 427 & 502 \\
\hline \multirow{2}{*}{$\begin{array}{c}\text { Klamath } \\
\text { Mountains }\end{array}$} & $\bar{A}$ & $32 / 32$ & 148 & 53 & 494 & 89 & 128 \\
\hline & $\mathrm{B}$ & $32 / 32$ & 163 & 47 & 556 & 108 & 128 \\
\hline \multirow{2}{*}{$\begin{array}{l}\text { Basin and } \\
\text { Range }\end{array}$} & $\bar{A}$ & $18 / 18$ & 565 & 200 & 1,491 & 309 & 564 \\
\hline & $\bar{B}$ & $18 / 18$ & 721 & 171 & 1,739 & 339 & 661 \\
\hline \multirow{2}{*}{$\begin{array}{l}\text { High Lava } \\
\text { Plain }\end{array}$} & $\overline{\mathrm{A}}$ & $4 / 4$ & 614 & 470 & 767 & $\overline{146}$ & 611 \\
\hline & B & $4 / 4$ & 793 & 701 & 981 & 129 & 745 \\
\hline \multicolumn{8}{|l|}{ Soil Orders } \\
\hline \multirow[t]{2}{*}{ Entisols } & $\mathrm{A}$ & $27 / 27$ & 590 & 129 & 1,491 & 227 & 576 \\
\hline & $\bar{B}$ & $27 / 27$ & 785 & 129 & 1,739 & 273 & 761 \\
\hline \multirow[t]{2}{*}{ Inceptisols } & $\bar{A}$ & $44 / 44$ & 321 & 53 & 1,353 & 118 & 206 \\
\hline & $\overline{\mathrm{B}}$ & $44 / 44$ & $\overline{356}$ & 59 & 1,541 & 342 & 193 \\
\hline \multirow{2}{*}{$\begin{array}{l}\text { Alfisols/ } \\
\text { Ultisols }\end{array}$} & $\bar{A}$ & $31 / 31$ & 140 & 57 & 405 & 88 & 106 \\
\hline & $\bar{B}$ & $31 / 31$ & 135 & 47 & 384 & 84 & 90 \\
\hline \multirow[t]{2}{*}{ Mollisols } & $\mathrm{A}$ & $14 / 14$ & 435 & 60 & 1,511 & 522 & 208 \\
\hline & $\bar{B}$ & $14 / 14$ & 593 & 53 & 2,341 & $\overline{746}$ & 216 \\
\hline \multirow[t]{2}{*}{ Spodosol } & $\mathrm{A}$ & $1 / 1$ & $241^{2}$ & - & -- & - & - \\
\hline & $\bar{B}$ & $1 / 1$ & $105^{\mathrm{a}}$ & -- & - & $\cdots$ & -- \\
\hline \multirow[t]{2}{*}{ Vertisol } & $\mathrm{A}$ & $1 / 1$ & $168^{\mathrm{a}}$ & - & - & - & - \\
\hline & $\mathrm{B}$ & $1 / 1$ & $163^{2}$ & -- & $\because$ & $=$ & $=$ \\
\hline
\end{tabular}

'Detects are the number of samples with concentrations equal to or greater than the laboratory's reporting limit.

anly one concentration value is listed under arithmetic mean. 
The highest analyzed Na values are in soils derived from intermediate and felsic magmatic rocks (Qa, Qma, Qrd, QTps and Tat), alluvial deposits (Qal) and fanglomerate (Qf). The lowest analyzed Na concentrations are in soils on ultramafic and mafic rocks (bc, Ju, Jub, KJgu, QTb, QTvm). Na concentrations increase with increasing silica content of the magmatic rocks, and the soil Na content is inherited from parent rocks (Fairbridge, 1972). In the study area, the equality of the Na concentrations in soils developed on major igneous rocks cannot be rejected because these values have large standard deviations (Table 18). Surprisingly, at site LC6 in the Coast Range, the highest $\mathrm{Na}$ concentration of $3,852 \mathrm{ppm}(1,511 \mathrm{ppm}$ in the A horizon and 2,341 ppm in the B horizon) has been found in soil developed over the mafic Siletz River Volcanics (Tsr). The site LC6 is located east of Roseburg, Oregon, near a gravel pit. At two other sites (LC10A and LC19) in the Coast Range, soils on the same geologic unit contain Na concentrations of only $269 \mathrm{ppm}$ and $576 \mathrm{ppm}$ (includes both the A and B horizons), respectively. This shows that the unusually high soil Na content at site LC6 is likely due to anthropogenic contamination, and its value was not included in the averages. In the study area, the soil $\mathrm{Na}$ levels decrease with soil development (Table 19). Na is highly mobile in soil, being very soluble in water. Alfisols/Ultisols, formed on mafic/ultramafic rocks, are expected to be low in Na. These well developed soils in western Oregon have been extensively leached by groundwater resulting in further depletion of this metal. In general, leaching of $\mathrm{Na}$ downward through the profile has resulted in the low content of this metal in humid western Oregon. On the contrary, 
semiaridic condition of eastern Oregon is responsible for high soil Na levels there. Exceptionally Na-rich soils in the Willamette Valley, developed on the Holocene Missoula Floods sediments, are much younger than those in the rest of the study area. Brief time coupled with subhumid environment were responsible for little loss of this metal by leaching.

In the study area the analyzed $\mathrm{Na}$ concentrations in the $\mathrm{A}$ and $\mathrm{B}$ horizons have the pooled variance of 5,087 and the pooled standard deviation of 71.3 . The null hypothesis Ho: $A=B$ can be rejected if $A-B$ is greater than $208.3(2.92 * 71.3)$. The results of the analysis for the $\mathrm{Na}$ concentrations in the $\mathrm{A}$ horizon versus the $\mathrm{B}$ horizon at 118 sites investigated are as follows: $\mathrm{B}>\mathrm{A}$ in $16.9 \%$ of the profiles and $\mathrm{A}>\mathrm{B}$ in $0.8 \%$ of the profiles. In the rest of the profiles $(82.3 \%)$ we cannot reject the equality of the values in the two horizons. At a number of sites in the eastern Klamath Mountains, Basin and Range and High Lava Plains an accumulation of $\mathrm{Na}$ is found in the A horizon. These regions are characterized by a semiarid climate. Na has also accumulated in the $\mathrm{A}$ horizon at a few sites (LC14, LC16 and LC17) in the Coastal Plain. The latter is possibly due to an influence of the salt-rich air along the coast which overcomes the high rainfall that generally moves $\mathrm{Na}$ through the profile in this humid environment.

\section{THALLIUM (TL)}

In the study area none of the analyzed samples from either the A or B horizon contains $\mathrm{Tl}$ concentrations at or above the laboratory's minimum reporting level of 50 
ppm. Previous work (Smith and Carson, 1977) indicates that $\mathrm{Tl}$ contents in surface soils of the U.S. range from 0.02 to $2.8 \mathrm{ppm}$.

\section{$\operatorname{VANADIUM}(V)$}

Distribution statistics for $\mathrm{V}$ content in soils of the study area are listed in Table 38. At all the 118 sites the $\mathrm{V}$ concentrations in both the $\mathrm{A}$ and $\mathrm{B}$ horizons are greater than the laboratory's minimum reporting level of three $\mathrm{ppm}$. The $\mathrm{V}$ concentrations range from 6 to $374 \mathrm{ppm}$ with an average of $69 \mathrm{ppm}$ in the A horizon and from 4 to $409 \mathrm{ppm}$ with an average of $89 \mathrm{ppm}$ in the B horizon. The V contents in surface soils of the U.S. range from $<1$ to $300 \mathrm{ppm}$ with an average of $84 \mathrm{ppm}$ (Kabata-Pendias and Pendias, 1984) (Appendix 8.4). Soil V levels in the study area are similar to that of the U.S. The analyzed samples from the Klamath Mountains and Coast Range have the highest soil $\mathrm{V}$ contents (AM for the B horizon $=133 \mathrm{ppm}$ and $100 \mathrm{ppm}$, respectively). The lowest analyzed soil V levels are in the High Lava Plains $(\mathrm{AM}=39 \mathrm{ppm})$ and Coastal Plain $(\mathrm{AM}=38 \mathrm{ppm})$. Among major soil orders, Alfisols/Ultisols and Mollisols have the highest analyzed $\mathrm{V}$ concentrations ( $\mathrm{AM}=152 \mathrm{ppm}$ and $113 \mathrm{ppm}$, respectively). The lowest analyzed $\mathrm{V}$ values are in Entisols $(\mathrm{AM}=38 \mathrm{ppm}) . \mathrm{V}$ values in the analyzed samples from the different physiographic provinces as well as from the different soil orders in the study area have high standard deviations because these soils have been derived from rocks in which the $\mathrm{V}$ concentrations vary widely. 
Table 38. Distribution statistics for Vanadium (V) content (ppm dry) in soils of Southwest Oregon.

\begin{tabular}{|c|c|c|c|c|c|c|c|}
\hline & $\begin{array}{c}\text { Hori- } \\
\text { zon }\end{array}$ & $\begin{array}{c}\text { Total } \\
\text { Sample } \\
\text { Number/ } \\
\text { Detects }^{1} \\
\end{array}$ & $\begin{array}{l}\text { Arith- } \\
\text { metic } \\
\text { Mean } \\
\end{array}$ & $\begin{array}{l}\text { Mini- } \\
\text { mum }\end{array}$ & $\begin{array}{l}\text { Maxi- } \\
\text { mum }\end{array}$ & $\begin{array}{c}\text { Arith- } \\
\text { metic } \\
\text { Standard } \\
\text { Deviation } \\
\end{array}$ & Median \\
\hline \multicolumn{8}{|l|}{ For all sites } \\
\hline & $\mathrm{A}$ & $118 / 118$ & 69 & 6 & 374 & 56 & 55 \\
\hline & $\mathrm{B}$ & $118 / 118$ & 89 & 4 & 409 & 68 & 69 \\
\hline \multicolumn{8}{|c|}{ PhysiographicProvinces } \\
\hline \multirow[t]{2}{*}{ Coastal Plain } & $\mathrm{A}$ & $7 / 7$ & 23 & 6 & 65 & 21 & 20 \\
\hline & $\mathrm{B}$ & $7 / 7$ & 38 & 4 & 75 & 32 & 43 \\
\hline \multirow[t]{2}{*}{ Coast Range } & $\bar{A}$ & $16 / 16$ & 82 & 27 & 219 & 57 & 62 \\
\hline & $\bar{B}$ & $16 / 16$ & 100 & 43 & 248 & 67 & 73 \\
\hline \multirow{2}{*}{$\begin{array}{c}\text { Willamette } \\
\text { Valley }\end{array}$} & $\mathrm{A}$ & $2 / 2$ & 56 & 34 & 78 & 31 & 56 \\
\hline & $\mathrm{B}$ & $2 / 2$ & 66 & 44 & 89 & 31 & 66 \\
\hline \multirow{2}{*}{$\begin{array}{c}\text { Cascade } \\
\text { Range }\end{array}$} & $\bar{A}$ & $39 / 39$ & 64 & 14 & 212 & 50 & 39 \\
\hline & $\bar{B}$ & $39 / 39$ & 76 & 16 & 223 & 55 & 52 \\
\hline \multirow{2}{*}{$\begin{array}{c}\text { Klamath } \\
\text { Mountains }\end{array}$} & $\bar{A}$ & $32 / 32$ & 98 & 12 & 374 & 69 & 79 \\
\hline & $\mathrm{B}$ & $32 / 32$ & 133 & 12 & 409 & 84 & 114 \\
\hline \multirow{2}{*}{$\begin{array}{l}\text { Basin and } \\
\text { Range }\end{array}$} & $\mathrm{A}$ & $18 / 18$ & 46 & 18 & 107 & 28 & 34 \\
\hline & $\mathrm{B}$ & $18 / 18$ & 62 & 21 & 142 & 37 & 49 \\
\hline \multirow{2}{*}{$\begin{array}{l}\text { High Lava } \\
\text { Plain }\end{array}$} & $\bar{A}$ & $4 / 4$ & 29 & 21 & 39 & 9 & 28 \\
\hline & B & $4 / 4$ & 39 & 30 & 47 & 9 & 39 \\
\hline \multicolumn{8}{|l|}{ Soil Orders } \\
\hline \multirow[t]{2}{*}{ Entisols } & $\mathrm{A}$ & $27 / 27$ & 29 & 6 & 49 & 9 & 29 \\
\hline & $\overline{\mathrm{B}}$ & $27 / 27$ & 38 & $\overline{6}$ & 75 & 13 & 36 \\
\hline \multirow[t]{2}{*}{ Inceptisols } & $\mathrm{A}$ & $44 / 44$ & 57 & 8 & 182 & 19 & 54 \\
\hline & $\bar{B}$ & $44 / 44$ & 71 & 4 & 223 & 42 & 67 \\
\hline \multirow{2}{*}{$\begin{array}{l}\text { Alfisols/ } \\
\text { Ultisols }\end{array}$} & $\mathrm{A}$ & $31 / 31$ & 114 & 20 & 374 & 71 & 102 \\
\hline & $\mathrm{B}$ & $31 / 31$ & 152 & 44 & 409 & 82 & 140 \\
\hline \multirow[t]{2}{*}{ Mollisols } & $\bar{A}$ & $14 / 14$ & 88 & 34 & 219 & 53 & 78 \\
\hline & $\mathrm{B}$ & $14 / 14$ & 113 & 44 & 238 & 58 & 109 \\
\hline \multirow[t]{2}{*}{ Spodosol } & $\bar{A}$ & $1 / 1$ & $7^{2}$ & - & -- & -- & - \\
\hline & B & $1 / 1$ & $7^{\mathrm{a}}$ & - & -- & - & - \\
\hline \multirow[t]{2}{*}{ Vertisol } & $\mathrm{A}$ & $1 / 1$ & $75^{2}$ & - & - & -- & - \\
\hline & B & $1 / 1$ & $88^{2}$ & -- & -- & $\because$ & $\cdots$ \\
\hline
\end{tabular}

'Detects are the number of samples with concentrations equal to or greater than the laboratory's reporting limit.

a Only one concentration value is listed under arithmetic mean. 
The highest analyzed V levels are found in soils formed on ultramafic and mafic rocks (geologic units bc, cs, Ju, Jub, Jv, QTba and Tsr). The lowest analyzed V values are in soils derived from felsic rocks (KJg, Qrd and Tsv) and sandy materials (Qd, Qt, Tn and Tt). Earlier works (Jones and others, 1993; Kabata-Pendias and Pendias, 1984; Aubert and Pinta, 1980) indicate that the V concentrations increase with decreasing silica content in magmatic rocks, and the soil $\mathrm{V}$ contents are largely controlled by parent rock materials. In the study area, the average $\mathrm{V}$ contents increase in soils derived from felsic to mafic/ultramafic rocks (Table 18). Soil V contents also increase with soil development (Table 19), i.e. Alfisols/Ultisols > Inceptisols > Entisols. High V levels in the Klamath Mountains and Coast Range are mainly from Alfisols/Ultisols formed on mafic/ultramafic rocks.

In the study area the analyzed $\mathrm{V}$ concentrations in the $\mathrm{A}$ and $\mathrm{B}$ horizons have the pooled variance of 6.68 and the pooled standard deviation of 2.58 . The null hypothesis Ho: $A=B$ can be rejected if $A-B$ is greater than $7.5(2.92 * 2.58)$. The results of the analysis for the $\mathrm{V}$ concentrations in the $\mathrm{A}$ horizon versus the $\mathrm{B}$ horizon at 118 sites investigated are as follows: $\mathrm{B}>\mathrm{A}$ in $75.4 \%$ of the profiles. In the rest of the profiles (24.6\%) we cannot reject the equality of the values in the two horizons. The concentration of $\mathrm{V}$ in the $\mathrm{B}$ horizon is more apparent in well-drained, humid Alfisols/Ultisols than in others. 
ZINC (ZN)

Distribution statistics for $\mathrm{Zn}$ content in soils of the study area are listed in Table 39. $\mathrm{Zn}$ has detects in both the $\mathrm{A}$ and $\mathrm{B}$ horizons at all the 118 sites. The $\mathrm{Zn}$ concentrations range from 11 to $196 \mathrm{ppm}$ with an average of $74 \mathrm{ppm}$ in the A horizon and from 9 to 183 ppm with an average of $69 \mathrm{ppm}$ in the B horizon. Kabata-Pendias and Pendias (1984) reported values of 34-84 ppm $\mathrm{Zn}$ as background average contents of surface soils of the U.S. (Appendix 8.3). Soil $\mathrm{Zn}$ concentrations in the study area are within the range of that of the U.S.with the averages slightly higher than the national average.

The $\mathrm{Zn}$ concentrations in the analyzed samples from the Klamath Mountains (AM for the $\mathrm{A}$ horizon $=89 \mathrm{ppm})$, Coast Range $(\mathrm{AM}=83 \mathrm{ppm})$, Cascade Range $(\mathrm{AM}=75$ ppm), Basin and Range $(\mathrm{AM}=68 \mathrm{ppm})$ and Willamette Valley $(\mathrm{AM}=50 \mathrm{ppm})$ are comparable. The t-test indicates that the equality of the $\mathrm{Zn}$ values in these provinces cannot be rejected. The lowest analyzed soil $\mathrm{Zn}$ values are in the Coastal Plain (AM = $19 \mathrm{ppm})$. The analyzed $\mathrm{Zn}$ levels in Mollisols $(\mathrm{AM}=86 \mathrm{ppm})$, Alfisols/Ultisols ( $\mathrm{AM}=$ $85 \mathrm{ppm})$ and Inceptisols $(\mathrm{AM}=78 \mathrm{ppm})$ are comparable. Entisols have the lowest analyzed $\mathrm{Zn}$ concentrations $(\mathrm{AM}=49 \mathrm{ppm})$. Figure 11 shows the graphic representations of soil $\mathrm{Zn}$ concentrations in physiographic provinces, soil orders and major igneous rocks of the study area.

The highest analyzed $\mathrm{Zn}$ values are in soils developed on mafic rocks (bc, QTb, QTp, Tpb, Trb and Tu), argillaceous sediments (Jss, KJds and TrPzs) and landslide and debris flow deposits (Qls). The lowest analyzed $\mathrm{Zn}$ contents are in soils formed on 
Table 39. Distribution statistics for Zinc ( $\mathrm{Zn})$ content (ppm dry) in soils of Southwest Oregon.

\begin{tabular}{|c|c|c|c|c|c|c|c|}
\hline & $\begin{array}{l}\text { Hori- } \\
\text { zon }\end{array}$ & $\begin{array}{c}\text { Total } \\
\text { Sample } \\
\text { Number/ } \\
\text { Detects }^{1}\end{array}$ & $\begin{array}{l}\text { Arith- } \\
\text { metic } \\
\text { Mean }\end{array}$ & $\begin{array}{l}\text { Mini- } \\
\text { mum }\end{array}$ & $\begin{array}{c}\text { Maxi- } \\
\text { mum }\end{array}$ & $\begin{array}{c}\text { Arith- } \\
\text { metic } \\
\text { Standard } \\
\text { Deviation }\end{array}$ & Median \\
\hline \multicolumn{8}{|l|}{ For all sites } \\
\hline & $\mathrm{A}$ & $118 / 118$ & 74 & 11 & 196 & $\overline{38}$ & $\overline{70}$ \\
\hline & $\mathrm{B}$ & $118 / 118$ & 69 & 9 & 183 & 37 & 67 \\
\hline \multicolumn{8}{|c|}{ Physiographic Provinces } \\
\hline & & & & & & & \\
\hline \multirow[t]{2}{*}{ Coastal Plain } & $\overline{\mathrm{A}}$ & $7 / 7$ & 19 & 11 & 31 & 8 & 16 \\
\hline & $\bar{B}$ & $7 / 7$ & 29 & 9 & $\overline{82}$ & 27 & 19 \\
\hline \multirow[t]{2}{*}{ Coast Range } & $\overline{\mathrm{A}}$ & $16 / 16$ & 83 & 18 & 131 & 29 & $\overline{86}$ \\
\hline & $\overline{\mathrm{B}}$ & $16 / 16$ & 81 & 23 & 136 & 29 & 85 \\
\hline \multirow{2}{*}{$\begin{array}{c}\text { Willamette } \\
\text { Valley }\end{array}$} & $\mathrm{A}$ & $2 / 2$ & 50 & 27 & 74 & 34 & 50 \\
\hline & B & $2 / 2$ & 49 & 25 & 72 & 33 & 49 \\
\hline \multirow{2}{*}{$\begin{array}{c}\text { Cascade } \\
\text { Range }\end{array}$} & $\overline{\mathrm{A}}$ & $39 / 39$ & 75 & 17 & 153 & $\overline{34}$ & 68 \\
\hline & $\bar{B}$ & $39 / 39$ & 63 & 17 & 140 & 32 & 60 \\
\hline \multirow{2}{*}{$\begin{array}{l}\text { Klamath } \\
\text { Mountains }\end{array}$} & $\overline{\mathrm{A}}$ & $32 / 32$ & 89 & 25 & 196 & 39 & 81 \\
\hline & $\bar{B}$ & $32 / 32$ & 90 & 12 & 183 & 40 & 87 \\
\hline \multirow{2}{*}{$\begin{array}{c}\text { Basin and } \\
\text { Range }\end{array}$} & $\bar{A}$ & $18 / 18$ & 68 & 26 & 161 & 38 & 56 \\
\hline & B & $18 / 18$ & 56 & 21 & 113 & 29 & 50 \\
\hline \multirow{2}{*}{$\begin{array}{l}\text { High Lava } \\
\text { Plain }\end{array}$} & $\overline{\mathrm{A}}$ & $4 / 4$ & 45 & 32 & 61 & $\overline{14}$ & $\overline{44}$ \\
\hline & $\overline{\mathrm{B}}$ & $4 / 4$ & 34 & 24 & $\overline{46}$ & 10 & $\overline{32}$ \\
\hline \multicolumn{8}{|l|}{ Soil Orders } \\
\hline \multirow[t]{2}{*}{ Entisols } & $\overline{\mathrm{A}}$ & $27 / 27$ & 49 & 11 & 92 & 17 & $\overline{49}$ \\
\hline & $\mathrm{B}$ & $27 / 27$ & 38 & 19 & 91 & 14 & 35 \\
\hline \multirow[t]{2}{*}{ Inceptisols } & $A$ & $44 / 44$ & 78 & 11 & 168 & 15 & 73 \\
\hline & $\overline{\mathrm{B}}$ & $44 / 44$ & 76 & 9 & $\overline{183}$ & 40 & 71 \\
\hline \multirow{2}{*}{$\begin{array}{l}\text { Alfisols/ } \\
\text { Ultisols }\end{array}$} & $\bar{A}$ & $31 / 31$ & $\overline{85}$ & 16 & 196 & 42 & 85 \\
\hline & B & $31 / 31$ & 82 & 12 & 171 & 35 & 85 \\
\hline \multirow[t]{2}{*}{ Mollisol } & $\mathrm{A}$ & $14 / 14$ & 86 & 23 & 161 & 39 & 88 \\
\hline & B & $14 / 14$ & 78 & 23 & 140 & 32 & 83 \\
\hline \multirow[t]{2}{*}{ Spodosol } & $A$ & $1 / 1$ & $19^{\mathrm{a}}$ & $\cdots$ & - & - & - \\
\hline & B & $\overline{1 / 1}$ & $11^{\mathrm{a}}$ & $\overline{--}$ & - & -- & - \\
\hline \multirow[t]{2}{*}{ Vertisol } & $\mathrm{A}$ & $1 / 1$ & $80^{2}$ & - & -- & -- & $\cdots$ \\
\hline & $\mathrm{B}$ & $1 / 1$ & $75^{8}$ & -- & -- & - & $=$ \\
\hline
\end{tabular}

'Detects are the number of samples with concentrations equal to or greater than the laboratory's reporting limit.

anly one concentration value is listed under arithmetic mean. 

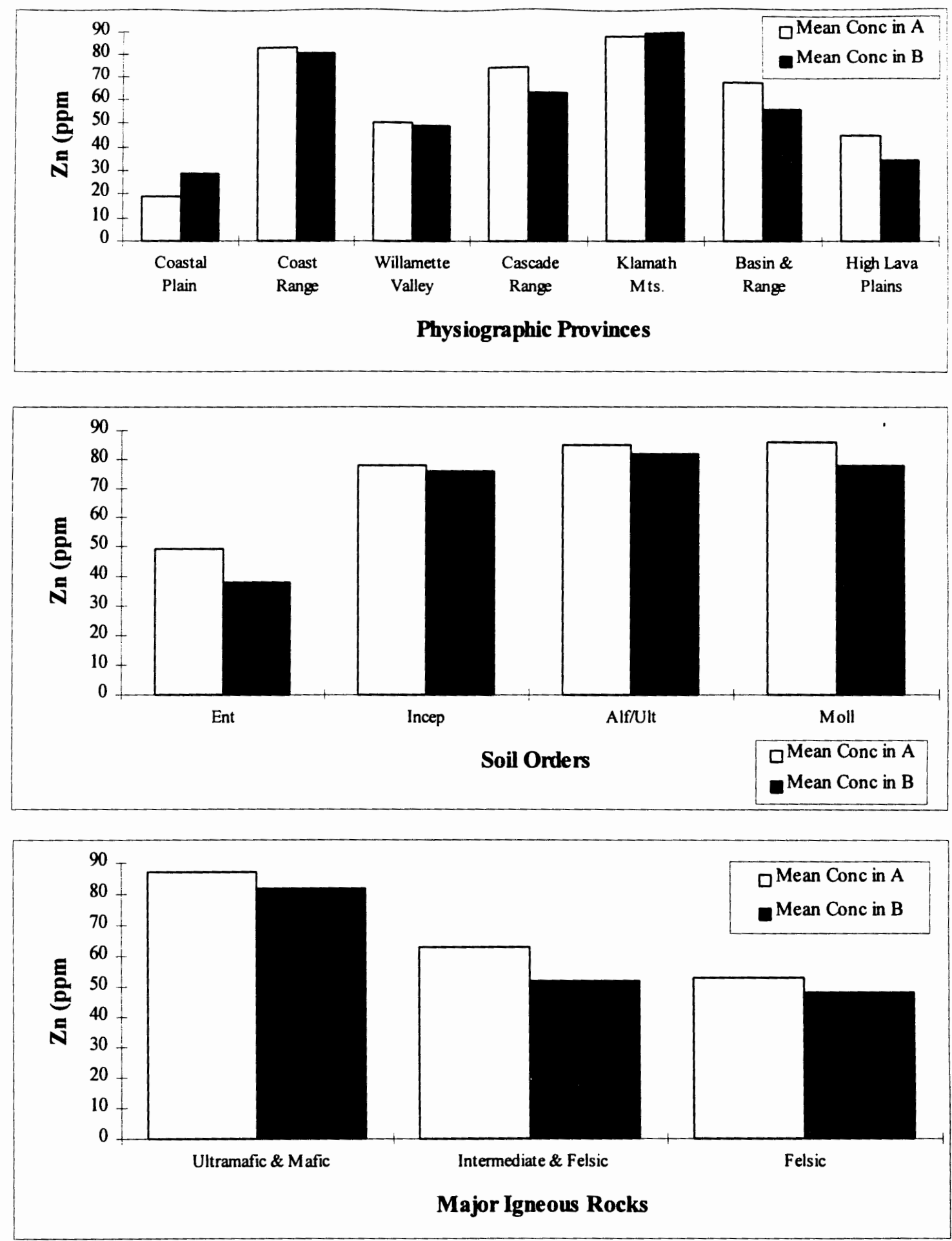

Figure 11. Soil Zinc (Zn) concentrations in physiographic provinces, soil orders and major igneous rocks of Southwest Oregon 
sandy materials ( $\mathrm{KJm}, \mathrm{Qd}, \mathrm{Qt}$ and Tss). The soil $\mathrm{Zn}$ content is mainly dependent on the composition of the parent rocks (Kabata-Pendias and Pendias, 1984). Previous works (Kabata-Pendias and Pendias, 1984; Aubert and Pinta, 1980; Krauskopf, 1972) indicate that $\mathrm{Zn}$ is rather uniformly distributed in magmatic rocks, with only slight increase in mafic rocks and slight decrease in felsic rocks. This is reflected in the similar average $\mathrm{Zn}$ contents in soils derived from felsic to mafic/ultramafic rocks in the study area (Table 18). The low arithmetic standard deviation (approximately half the arithmetic mean) (Table 39) is also indicative of less variability in soil $\mathrm{Zn}$ concentrations. Argillaceous sedimentary rocks have high $\mathrm{Zn}$ contents, while sandstones are very low in this metal (Aubert and Pinta, 1980). As expected, acid leached sandy soils of the Coastal Plain are Zn deficient. The young soils of the High Lava Plains are also $\mathrm{Zn}$ deficient. In the rest of the study area, the $\mathrm{Zn}$ concentrations are rather uniform, with a slight increase in the Klamath Mountains and Coast Range.

The highest analyzed $\mathrm{Zn}$ values are in soils developed on mafic rocks (bc, QTb, QTp, Tpb, Trb and Tu), argillaceous sediments (Jss, KJds and TrPzs) and landslide and debris flow deposits (Qls). The lowest analyzed $\mathrm{Zn}$ contents are in soils formed on sandy materials ( $\mathrm{KJm}, \mathrm{Qd}, \mathrm{Qt}$ and Tss). The soil $\mathrm{Zn}$ content is mainly dependent on the composition of the parent rocks (Kabata-Pendias and Pendias, 1984). Previous works (Kabata-Pendias and Pendias, 1984; Aubert and Pinta, 1980; Krauskopf, 1972) indicate that $\mathrm{Zn}$ is rather uniformly distributed in magmatic rocks, with only slight increase in mafic rocks and slight decrease in felsic rocks. This is reflected in the similar average 
$\mathrm{Zn}$ contents in soils derived from felsic to mafic/ultramafic rocks in the study area (Table 18). The low arithmetic standard deviation (approximately half the arithmetic mean) (Table 39) is also indicative of less variability in soil $\mathrm{Zn}$ concentrations. Argillaceous sedimentary rocks have high $\mathrm{Zn}$ contents, while sandstones are very low in this metal (Aubert and Pinta, 1980). As expected, acid leached sandy soils of the Coastal Plain are $\mathrm{Zn}$ deficient. The young soils of the High Lava Plains are also $\mathrm{Zn}$ deficient. In the rest of the study area, the $\mathrm{Zn}$ concentrations are rather uniform, with a slight increase in the Klamath Mountains and Coast Range.

In the study area the analyzed $\mathrm{Zn}$ concentrations in the $\mathrm{A}$ and $\mathrm{B}$ horizons have the pooled variance of 12.14 and the pooled standard deviation of 3.48 . The null hypothesis Ho: $A=B$ can be rejected if $A-B$ is greater than $10.2(2.92 * 3.48)$. The $\mathrm{Zn}$ concentrations in the A horizon versus the $\mathrm{B}$ horizon at 118 sites investigated are as follows: $\mathrm{A}>\mathrm{B}$ in $32.2 \%$ of the profiles and $\mathrm{B}>\mathrm{A}$ in $11.9 \%$ of the profiles. In the rest of the profiles (55.9\%) we cannot reject the equality of the values in the two horizons. The concentration of $\mathrm{Zn}$ in the $\mathrm{B}$ horizon is most evident in acid leached sandy soils of the Coastal Plain . 


\section{LIMITATIONS OF THE STUDY}

In a study of soils in Washington, Ames and Prych (1995) noted that, "Metal concentrations determined by the total-recoverable method (used in this study) do not correlate with either organic carbon content or fraction of fines in the sample ... the metal concentrations determined by the total-recoverable method are not simply dependent upon exchangeable metals concentrations, but also depend on the partial digestion of the various mineral phases present in the soils. Therefore, total-recoverable metals concentrations will vary between samples collected from soils that developed in different parent materials and in turn will depend on more subtle differences among different parent materials." The metal content of soil parent material corresponds closely to that of the different contributing rock types (Jenkins and Jones, 1980).

In this study soil sampling is based on geologic units. In most cases, individual geologic units are composed of various rock types. For example, the geologic unit Tn represents nonmarine sedimentary rocks consisting of sandstone, shale and conglomerate. Soils derived from different rock types of this geologic unit have different background metal distributions (see Appendix 5 for soil metal contents at sites R7, R8 and R9 over different rock types of geologic unit Tn). This can be of significance in determining if, and to what degree, soils were contaminated at a specific site where contamination is suspected. Soils developed on all rock types of a specific geologic unit have not been analyzed in this study. Also the site-specific petrographic details of the contributing rock types are not known in many cases. Local peculiarities 
of parent rocks may have a considerable effect on metal distribution in the derived soils. Nevertheless, the database will help to predict the 'first order' distribution of metals in soils of southwest Oregon.

To use the database generated from this study, find on the Geologic Map of Oregon (Walker and MacLeod, 1991) your geologic unit of the site and turn to Appendix 7 for metal concentration ranges in soils formed on that geologic unit. 


\section{CHAPTER VI: CONCLUSIONS}

A total of 248 samples from 118 sites on 71 geologic units in southwest Oregon were tested in this study. Eight of the 26 metals investigated have concentrations near or below the laboratory's reporting limits. The concentrations of $\mathrm{Ag}, \mathrm{Mo}, \mathrm{Sb}, \mathrm{Se}$ and $\mathrm{Tl}$ are below the laboratory's reporting limits at all sites (Tables 9 and 10). As has values above the laboratory's reporting limit at only two sites $(82.9 \mathrm{ppm}$ at $\mathrm{KL} 21$ and $29.7 \mathrm{ppm}$ at R13), both located in the Klamath Mountains. Higher than usual As concentrations at both the sites might be associated with sulfide-mineralization. Be has concentrations above laboratory's reporting limit at five sites located in the Klamath Mountains and Coast Range. The maximum concentration of $2.3 \mathrm{ppm} \mathrm{Be}$ is found at both sites LC9 and KL15 in the Coast Range and Klamath Mountains, respectively. Cd has concentrations above laboratory's reporting limit at 16 sites located mostly in the Klamath Mountains and Coast Range. The highest soil Cd content of 2.5 ppm occurs at site KL16 in the Klamath Mountains. The other notable Cd concentrations are 2.3 ppm at site LC6 (in the Coast Range) and 2.2 ppm at site KL30 (in the Klamath Mountains).

The Klamath Mountains, followed by the Coast Range, contain the highest soil concentrations of $\mathrm{Al}, \mathrm{Ca}, \mathrm{Co}, \mathrm{Cr}, \mathrm{Cu}, \mathrm{Fe}, \mathrm{K}, \mathrm{Mg}, \mathrm{Mn}, \mathrm{Ni}, \mathrm{V}$ and $\mathrm{Zn}$ (Tables 11 and 14). Soils of the Coastal Plain and High Lava Plains contain the lowest concentrations of these metals (Tables 10 and 16). Concentrations of these metals in the Willamette Valley, Cascade Range and Basin and Range (Tables 12, 13 and 15) fall generally between the above two categories. 
Soils of the Klamath Mountains and Coast Range are also comparatively richer in $\mathrm{Li}$ than the rest of the study area. Concentrations of $\mathrm{Ba}$ and $\mathrm{La}$ are rather uniform throughout the region. Soil concentrations of $\mathrm{Pb}$ are generally low, with a few exceptions in the Klamath Mountains, Coast and Cascade Ranges. Very high $\mathrm{Pb}$ values have been found at two sites ( $388 \mathrm{ppm}$ at KL14 and $159 \mathrm{ppm}$ at R12) in the Klamath Mountains. The region west of the Cascade Range has higher soil $\mathrm{Hg}$ levels (average $<0.14$ to $<0.21 \mathrm{ppm}$ ) than in the east (average $<0.10 \mathrm{ppm}$ ). Semiaridic soils in the regions east of the Cascade Range generally contain higher Na concentrations than humid soils in the west.

In general, $\mathrm{Al}, \mathrm{As}, \mathrm{Be}, \mathrm{Cd}, \mathrm{Co}, \mathrm{Cr}, \mathrm{Cu}, \mathrm{Fe}, \mathrm{La}, \mathrm{Li}, \mathrm{Mg}, \mathrm{Na}, \mathrm{Ni}$, and $\mathrm{V}$ are concentrated in the $\mathrm{B}$ horizon, while $\mathrm{Ba}, \mathrm{Ca}, \mathrm{Hg}, \mathrm{K}, \mathrm{Mn}, \mathrm{Pb}$ and $\mathrm{Zn}$ are concentrated in the A horizon. This has implications for sampling. One must sample both the surface and the B horizons to find the maximum concentration of the metals.

Soil concentrations of the metals studied are generally much higher in western Oregon, excluding the Coastal Plain, than in eastern Oregon. A notable exception to this trend is $\mathrm{Na}$ which has higher concentrations in eastern Oregon than in western Oregon. Both parent rocks and climatic conditions have affected the soil metal concentrations in the regions. In humid and mild environments of western Oregon, Alfisols/Ultisols developed on mafic/ultramafic rocks are very rich in $\mathrm{Co}, \mathrm{Cr}, \mathrm{Cu}, \mathrm{Mn}, \mathrm{Ni}, \mathrm{Fe}, \mathrm{Mg}$ and $\mathrm{V}$. This is particularly evident in the Klamath Mountains and Coast Range. Argillaceous sediments, containing high concentrations of $\mathrm{As}, \mathrm{Cd}, \mathrm{Cu}, \mathrm{K}, \mathrm{Pb}, \mathrm{V}$ and $\mathrm{Zn}$, are 
developed only in western Oregon. The subhumid and cold climate of eastern Oregon has influenced the development of Entisols and Inceptisols on predominantly basaltic rocks. These less developed soils appear to contain low concentrations of most of the metals studied. Coarse-textured, low-organic and acid-leached soils of the Coastal Plain have the lowest concentrations of all metals except $\mathrm{Li}$.

Metal concentration generally is related to soil development, i.e. highest in most developed and oldest soils (Alfisols and Ultisols) and lowest in the least developed soils (Entisols).

Table 40 shows the comparison of the concentration of metals in surface soils of the study area (from Table 9) with that of the rest of the U.S. (Kabata-Pendias and Pendias, 1984). The Oregon DEQ's soil cleanup level for various metals is also listed in Table 40. The comparison of the concentration of metals in subsoils (i.e. B horizon) of the study area (Table 10) with that of the rest of the U.S. is not possible because the latter is not available. The averages and ranges of soil $\mathrm{Co}, \mathrm{Mn}$ and $\mathrm{Ni}$ values found in this study are higher than those of the U.S. in general. The maximum concentrations found for $\mathrm{Pb}$ and $\mathrm{V}$ in this study are also higher than the reported values in the U.S. The Klamath Mountains province has exceptionally high $\mathrm{Cr}$ and $\mathrm{Cu}$ values compared to the rest of the U.S. The remainder of the metals in the study area have similar average and range of concentrations to those of the rest of the country. 
Table 40. Comparison of the concentration (in ppm dry; * in percent dry) of metals in surface soils of Southwest Oregon with that of the rest of the U.S. The DEQ's cleanup level for various metals is also listed.

\begin{tabular}{|c|c|c|c|c|c|c|c|c|}
\hline & \multicolumn{9}{|c|}{ Distribution statistics in the study area } & \multicolumn{2}{|c|}{ Values in the US $^{\text {a }}$} & \\
\hline Metal & $\begin{array}{c}\text { Arith- } \\
\text { metic } \\
\text { Mean }\end{array}$ & $\begin{array}{c}\text { Arith- } \\
\text { metic } \\
\text { St Dev }\end{array}$ & Median & $\begin{array}{c}\text { Mini- } \\
\text { mum }\end{array}$ & $\begin{array}{c}\text { Maxi } \\
- \\
\text { mum }\end{array}$ & $\begin{array}{c}\text { Arithmetic } \\
\text { Mean }^{c}\end{array}$ & Range & $\begin{array}{c}\text { DEQ's } \\
\text { Cleanup Level }\end{array}$ \\
\hline $\mathrm{Ag}$ & $<1$ & -- & $<1$ & $<1$ & $<1$ & NA $^{* *}$ & NA & 1,500 \\
\hline $\mathrm{Al}^{*}$ & 3.0 & 1.8 & 2.5 & 0.3 & 9.4 & NA & NA & na*** \\
\hline $\mathrm{As}$ & 20 & -- & $<20$ & $<20$ & 36.4 & $5.0-8.8$ & $<0.1-93.2$ & 0.4 \\
\hline $\mathrm{Ba}$ & 181 & 138 & 149 & 8 & 792 & $265-835$ & $10-3,000$ & 20,000 \\
\hline $\mathrm{Be}$ & $<1$ & -- & $<1$ & $<1$ & 1 & $1.2-2.1$ & $<1-15$ & 0.1 \\
\hline $\mathrm{Ca}$ & 5,741 & 3,970 & 4,793 & 638 & 18,68 & NA & NA & na \\
\hline $\mathrm{Cd}$ & $<1$ & -- & $<1$ & $<1$ & 1.2 & NA & NA & 100 \\
\hline $\mathrm{Co}$ & $<18$ & $>15$ & 13 & $<6$ & 95 & $3.5-17$ & $0.4-50$ & na \\
\hline $\mathrm{Cr}$ & 56 & 135 & 23 & 3 & 1,302 & $20-85$ & $1-1,500$ & 1,000 \\
\hline $\mathrm{Cu}$ & $<31$ & $>29$ & 22 & $<2$ & 148 & $14-41$ & $1-300$ & 10,000 \\
\hline $\mathrm{Fe}$ & 2.9 & 2.1 & 2.5 & 0.3 & 10.7 & NA & NA & na \\
\hline $\mathrm{Hg}$ & $<0.1$ & $>0.06$ & 0.08 & $<0.04$ & 0.37 & 0.11 & $<0.01-4.6$ & 80 \\
\hline $\mathrm{K}$ & 1,266 & 964 & 941 & 223 & 4,973 & NA & NA & na \\
\hline $\mathrm{La}$ & $<8$ & $>4.4$ & 5.5 & $<5$ & 26 & NA & NA & na \\
\hline $\mathrm{Li}$ & $<11$ & $>8.6$ & 7.6 & $<5$ & 48 & $13-34$ & $<5-120$ & na \\
\hline $\mathrm{Mg}$ & 4,431 & 3,844 & 3,124 & 545 & 16,42 & NA & NA & na \\
\hline $\mathrm{Mn}$ & 1,527 & 1,331 & 1,208 & 24 & 7,221 & $260-840$ & $7-3,000$ & 30,000 \\
\hline $\mathrm{Mo}$ & $<5$ & -- & $<5$ & $<5$ & $<5$ & $0.35-5.8$ & $0.08-17.8$ & na \\
\hline $\mathrm{Na}$ & 346 & 318 & 216 & 53 & 1,511 & NA & NA & na \\
\hline $\mathrm{Ni}$ & $<52$ & $>126$ & 22 & $<4$ & 1,132 & $12-30$ & $<5-200$ & 5,000 \\
\hline $\mathrm{Pb}$ & $<18$ & - & $<10$ & $<10$ & 378 & $17-26$ & $<10-70$ & 200 \\
\hline $\mathrm{Sb}$ & $<20$ & -- & $<20$ & $<20$ & $<20$ & NA & NA & na \\
\hline $\mathrm{Se}$ & $<30$ & -- & $<30$ & $<30$ & $<30$ & $0.19-0.5$ & $<0.1-4.0$ & na \\
\hline $\mathrm{Tl}$ & $<50$ & -- & $<50$ & $<50$ & $<50$ & NA & NA & na \\
\hline $\mathrm{V}$ & 69 & 56 & 55 & 6 & 374 & $38-136$ & $0.7-300$ & na \\
\hline $\mathrm{Zn}$ & 74 & 38 & 70 & 11 & 196 & $34-83.5$ & $<5-300$ & na \\
\hline
\end{tabular}

a from Kabata-Pendias and Pendias (1984).

b from Oregon DEQ (1994). The maximum allowable soil concentration given is for residential areas. For industrial sites the maximum allowable soil concentration is about an order of magnitude higher than that for residential area.

c Kabata-Pendias and Pendias (1984) reported arithmetic mean values of metals in various types of soils of the U.S. (see Appendix 1). Mean values for all soils are not available. Therefore, the range of mean concentrations is given. Hg data of the U.S. are from Steinnes (1993).

**not available; *** not assigned

--arithmetic standard deviation is not computed since most or all values are below laboratory's minimum reporting level. 
The Oregon DEQ (1994) has assigned soil cleanup level for only eleven of the 26 metals investigated in this study (Table 40). Except for $\mathrm{As}, \mathrm{Be}, \mathrm{Cr}$ and $\mathrm{Pb}$, the cleanup level for metals in residential areas is far higher (about 5 times in Ni to more than 1,500 times in $\mathrm{Ag}$ ) than their maximum background concentrations found in this study. Above the DEQ's maximum allowable soil concentration for residential areas, As has values from two sites (KL21 and R13) in the Klamath Mountains, Be has values from five sites (LC5, LC9, KL14, KL15 and R12) in the Klamath Mountains and Coast Range, $\mathrm{Cr}$ has values from two sites (KL16 and KL17) in the Klamath Mountains and $\mathrm{Pb}$ has a value from site $\mathrm{KL} 14$ in the Klamath Mountains. All soil metal concentrations found in this study are below the state cleanup levels for industrial sites which are about an order of magnitude higher than those for residential areas (Oregon DEQ, 1994).

\section{FUTURE WORK}

This reconnaissance study provides a foundation from which future studies may develop. Regionalized, detailed investigations should involve more sampling of soils to consider local peculiarities of the contributing rock types. DEQ's laboratory needs to lower the detection limit for environmentally significant trace elements like $\mathrm{Ag}, \mathrm{As}, \mathrm{Be}$, $\mathrm{Cd}, \mathrm{Mo}, \mathrm{Pb}, \mathrm{Sb}, \mathrm{Se}$ and $\mathrm{Tl}$ to obtain values in their natural occurrence ranges. The relationship between soil drainage classes (well drained, moderately drained and poorly drained) and metal distribution in soil profile can also be investigated. Finally, 
concentration maps for individual metals for the $\mathrm{A}$ and $\mathrm{B}$ horizons can be generated using GIS. 


\section{REFERENCES CITED}

Adriano, D.C., 1986, Trace Elements in the Terrestrial Environment: Springer-Verlag, New York, $533 \mathrm{p}$.

Alloway, B.J. , 1993a, Introduction, in Alloway, B.J., ed., Heavy Metals in Soils: John Wiley \& Sons, Inc., New York, p. 3-6.

Alloway, B.J., 1993b, The origins of heavy metals in soils, in Alloway, B.J, ed., Heavy Metals in Soils: John Wiley \& Sons, Inc., New York, chapter 3, p. 29-39.

Alloway, B.J., 1993c, Cadmium, in Alloway, B.J., ed., Heavy Metals in Soils: John Wiley \& Sons, Inc., New York, chapter 6, p. 100-124.

Ames, K.C. and Prych, E.A., 1995, Background concentrations of metals in soils from selected regions in the State of Washington: U.S. Geological Survey WaterResources Investigations Report 95-4018, Tacoma, Washington, 103 p.

Andersson, A., 1979, Mercury in Soils, in Nriagu, J.O., ed., Biogeochemistry of Mercury in the Environment: Elsevier, Amsterdam, chapter 4, p. 79-112.

Aubert, H. and Pinta, M., 1980, Trace Elements in Soils. Developments in Soil Science 7: Elsevier Scientific Publishing Company, Amsterdam, 395 p.

Baker, D.E., 1993, Copper, in Alloway, B.J., ed., Heavy Metals in Soils: John Wiley \& Sons, Inc., New York, chapter 8, p. 151-176.

Balashov, Yu. A., Ronov, A.B., Migdisov, A.A. and Turanskaya, N.V., 1964, The effects of climate and facies environment on the fractionation of the rare earths during sedimentation: Geochemistry International, v. 1, p. 951-969. (English translation)

Biddappa, C.C., Chino, M. and Kumazawa, K., 1982, Migration of heavy metals in two Japanese soils: Plant \& Soil, v. 66, p. 299-316.

Birkeland, P., 1984, Soils and Geomorphology: Oxford University Press, New York, $372 \mathrm{p}$.

Blackwell, D.D., Steele, J.L., Frohme, M.K., Murphey, C.F., Priest, G.R. and Black, G.L., 1990, Heat flow in the Oregon Cascade Range and its correlation with regional gravity, Curie point depths, and geology: Journal of Geophysical Research, v. 97, p. 4599-4627. 
Borine, R., 1983, Soil survey of Josephine County, Oregon: USDA, Soil Conservation Service, Washington, D.C., 258 p.

Bowen, H.J.M., 1966, Trace Elements in Biochemistry: Academic Press, New York, 234 p.

Bowen, H.J.M., 1979, Environmental Chemistry of the Elements: Academic Press, London, $333 \mathrm{p}$.

Boyle, R.W., 1972, The geology, geochemistry, and origin of the barite, manganese, and lead-zinc-copper-silver deposits of the Walton-Cheverie area, Nova Scotia: Bulletin of the Geological Survey of Canada, v. 166, 181p.

Boyle R.W. and Jonasson, I.R., 1973, The geochemistry of arsenic and its use as an indicator element in geochemical prospecting: Journal of Geochemical Exploration, v. 2, p. 251-296.

Brooks, R.R., 1987, Serpentine and its Vegetation: Dioscorides Press, Portland, Oregon, $454 \mathrm{p}$.

Burns, Scott .F., 1995, Personal communication: Geology Department, Portland State University, Oregon.

Buzzard, C.R. and Bowlsby, C.C., 1970, Soil survey of the Curry area, Oregon: USDA, Soil Conservation Service, Washington, D.C., 70 p.

Cahoon, J., 1985, Soil survey of Klamath County (southern part), Oregon: USDA, Soil Conservation Service, Washington, D.C., 269 p.

Cannon, H.L., 1978, Rocks: the geologic source of most trace elements: Geochemistry and the Environment, v. 3, p. 17-31.

Crecelius, E.A., Johnson, C.J. and Hofer, G.C., 1974, Contamination of soils near a copper smelter by arsenic, antimony and lead: Water, Air and Soil Pollution, v. 3, p. 337-342.

Davis, J. C., 1986, Statistics and Data Analysis in Geology, 2nd edition: Wiley, New York, $646 \mathrm{p}$. 
Davies, B.E., 1977, Heavy metal pollution of British agricultural soils with special reference to the role of lead and copper mining, in Proceeding, International Seminar on Soil Environment and Fertility Management in Intensive Agriculture, Tokyo: p. 394.

Davies, B.E., 1993, Lead, in Alloway, B.J., ed., Heavy Metals in Soils: John Wiley \& Sons, Inc., New York, chapter 9, p. 177-196.

Di Domenico, George., 1995, Personal communication: Department of Environmental Quality Laboratory, Portland State University Campus, Oregon.

Duncan, R.A., 1982, A captured island chain in the Coast Range of Oregon and Washington: Journal of Geophysical Research, v. 87B, p. 10827-10837.

Fairbridge, R.W., 1972, The Encyclopedia of Geochemistry and Environmental Sciences, Encyclopedia of Earth Sciences Series, v. IVA: Van Nostrand Reinhold, New York, 1321 p.

Fleming, G.A., 1962, Selenium in Irish soils and plants: Soil Science, v. 94, p. 28-35.

Frank, R., Ishida, K. and Suda, P., 1976, Metals in agricultural soils of Ontario: Canadian Journal of Soil Science, v. 56, p.181-196.

Guthrie, R.L. and Witty, J.E., 1982, New designations for soil horizons and layers and the new Soil Survey Manual: Soil Science Society of America Journal, v. 46, p. 443-444.

Hartford, William., 1993, Personal communication: Squier Associates, Portland, Oregon.

Heller, P.L., Tabor, R.W. and Suczek, C.A., 1987, Paleogeographic evolution of the United States Pacific Northwest during Paleogene time: Canadian Journal of Earth Sciences, v. 24, p. 1652-1667.

Holmgren, G.G.S., Meyer, M.W., Chaney, R.L. and Daniels, R.B., 1993, Cadmium, lead, zinc, copper, and nickel in agricultural soils of the United States of America: Journal of Environmental Quality, v. 22, p. 335-348.

Hopkins, L.L., Cannon, H.L., Meisch, A.T., Welch, R.M. and Nielson, P.M., 1977, Vanadium :Geochemistry and the Environment, v. 2, p. 93-107.

Hubbard, L.L., 1990, National water summary 1988-89 - floods and droughts: Oregon: U.S. Geological Survey Water-Supply Paper 2375, p. 459-465. 
Jenkins, D.A. and Jones, R.G., 1980, Trace elements in rocks, soils, plants, and animals, in Davies, B.E., ed., Applied Soil Trace Elements: John Wiley \& Sons Ltd., Chichester, chapter 1, p. 1-20.

Jenny, H., 1941, Factors of Soil Formation: McGraw Hill, New York, 281 p.

John, M.K., 1974, Extractable and plant-available zinc in horizons of several Fraser River alluvial soils: Canadian Journal of Soil Science, v. 54, p. 125-132.

John, M.K., van Laerhoven, C.J., Osborne, V.E. and Cotic, I., 1975, Mercury in soils of British Columbia, a mercuriferous region: Water, Air and Soil Pollution, v. 5, p. 213-220.

Johnson, D.M. and Dart, J.D., 1982, Variability of precipitation in the Pacific Northwest: spatial and temporal characteristics: Water Resources Research Institute WRRI77, Oregon State University, Corvallis, Oregon, 182 p.

Jones, K.C., Lepp, N.W. and Obbard, J.P., 1993, Other metals and metalloids, in Alloway, B.J., ed., Heavy Metals in Soils: John Wiley \& Sons, Inc., New York, chapter 14, p. 280-321.

Kabata-Pendias, A. and Pendias, H., 1984, Trace Elements in Soils and Plants: CRC Press, Inc., Boca Raton, Florida, 315 p.

Kelsey, H.M. and Bockheim, J.G., 1994, Coastal landscape evolution as a function of eustasy and surface uplift rate, Cascadia margin, southern Oregon: Geological Society of America Bulletin, v. 106, p. 840-854.

Knezek, B.D. and Ellis, B.G., 1980, Essential micronutrients IV: copper, iron, manganese, and zinc, in Davies, B.E., ed., Applied Soil Trace Elements: John Wiley \& Sons Ltd., Chichester, chapter 8, p. 259-286.

Krauskopf, K.B., 1972, Geochemistry of Micronutrients, in Mortvedt, J.J., Giordano, P.M. and Lindsay, W.L., eds., Micronutrients in Agriculture: Soil Science Society of America, Madison, Wisconsin, p. 7-40.

Kubota, J., 1980, Regional distribution of trace element problems in North America, in Davies, B.E., ed., Applied Soil Trace Elements: John Wiley \& Sons Ltd., Chichester, chapter 12, p. 441-466. 
Kubota, J. and Allaway, W.H., 1972, Geographic distribution of trace element problems, in Mortredt, J.J., ed., Micronutrients in Agriculture: Soil Science Society of America, Madison, Wisconsin, p. 523-553.

Larson, Donna., 1996, Personal and written communication: Department of Environmental Quality Laboratory, Portland State University Campus, Oregon.

Levesque, M., 1974, Selenium distribution in Canadian soil profiles: Canadian Journal of Soil Science, v. 54, p. 63-68.

Lindsay, W.L., 1972, Zinc in soils and plant nutrition: Advances in Agronomy, v. 24, p. 147-186.

McGrath, S.P. and Smith, S., 1993, Chromium and Nickel, in Alloway, B.J., ed., Heavy Metals in Soils: John Wiley \& Sons, Inc., New York, Chapter 7, p. 125-150.

Massey, H.F. and Lowe, R.H., 1961, High molybdenum content of certain Kentucky soils: Soil Science Society of America Proceeding, v. 25, p. 161-162.

McKeague, J.A. and Kloosterman, B., 1974, Mercury in horizons of some soil profiles in Canada: Canadian Journal of Soil Science, v. 54, p. 503-507.

McKnight, B.K., 1984, Stratigraphy and sedimentology of the Payne Cliffs Formation, southwestern Oregon, in Nilsen, T.H., ed., Geology of the upper Cretaceous Hornbrook Formation, Oregon and California: Society of Economic Paleontologists and Mineralogists, Pacific Section, p. 187-194.

Meriwether, J.R., Beck, J.N., Keeley, D.F., Langley, M.P., Thompson, R.H. and Young, J.C., 1988, Radionuclides in Louisiana soils: Journal of Environmental Quality, v. 17, n. 4, p. $562-568$.

Meriwether, J.R., Beck, J.N., Thompson, R.H. and Burns, S.F., 1992, Distribution, transport and deposition of radionuclides in Louisiana soils: Radionuclear Consortium, University of Southwestern Louisiana, unpaged.

Merry, R.H., Tiller, K.G. and Alston, A.M., 1983, Accumulation of copper, lead and arsenic in some Australian orchard soil: Australian Journal of Soil Research, v. 21, p. 549-561.

Mills, J.G. and Zwarich, M.A., 1975, Heavy metal content of agricultural soils in Manitoba: Canadian Journal of Soil Science, v. 55, p. 295-300. 
Mitchell, R.L., 1964, Soil Mineralogy, in Bear, F.E., ed., Chemistry of the Soil, 2nd edition: Van Nostrand Reinhold, New York, p. 320-368.

Moores, E.M., 1982, Origin and emplacement of ophiolites: Review Geophysics, v. 20, p. $735-760$.

Munsell Color Company, Inc., 1992, Munsell Soil Color Chart: Munsell Color Company, Inc., Baltimore.

Neal, R.H., 1993, Selenium, in Alloway, B.J., ed., Heavy Metals in Soils: John Wiley \& Sons, Inc., New York, chapter 12, p. 237-260.

Newton, V.C., 1969, Subsurface geology of the lower Columbia and Willamette basins, Oregon: Oregon Department of Geology and Mineral Industries, Oil and Gas Investigation, n. 2, $121 \mathrm{p}$.

Nriagu, J.O., 1978, Lead in soils, sediments and major rock types, in Nriagu, J.O., ed., The Biogeochemistry of Lead in the Environment: Elsevier/North Holland, Amsterdam, chapter 2, p. 15-54.

O’Neill, P., 1993, Arsenic, in Alloway, B.J., ed., Heavy Metals in Soils: John Wiley \& Sons, Inc., New York, chapter 5, p. 83-99.

Oregon Department of Environmental Quality (DEQ), 1994, Soil Cleanup Manual: OAR 340-122-045and 046, Waste Management and Cleanup Division, p. G 8-11.

Orr, E.L., Orr, W.N. and Baldwin, E.M., 1992, Geology of Oregon, 4th edition: Kendall/Hunt Publishing Company, Dubuque, Iowa, $254 \mathrm{p}$.

Pacific Northwest River Basins Commission, 1969, Columbia- North Pacific Region comprehensive framework study of water and related lands, the region: Pacific Northwest River Basins Commission, appendix II, 144 p.

Page, A.L., Chang, A.C. and Mohamed El-Amamy, 1987, Cadmium levels in soils and crops in the United States, in Hutchinson, T.C. and Meema, K.M., eds., Lead, Mercury, Cadmium and Arsenic in the Environment, SCOPE 31: John Wiley \& Sons Ltd., Chichester, p. 119-146.

Peterson, P.J. and Girling, C.A., 1981, Other Trace Metals, in Lepp, N.W., ed., Effect of Heavy Metal Pollution on Plants, v. 1: Applied Science Publishers, London, chapter 7, p. 213-278. 
Phipps, D.A., 1981, Chemistry and biochemistry of trace metals in biological systems, in Lepp, N.W., ed., Effect of Heavy Metal Pollution on Plants, v. 1: Applied Science Publishers, London, chapter 1, p. 1-54.

Presant, E.W. and Tupper, W.M., 1965, Trace elements in some New Brunswick soils: Canadian Journal of Soil Science, v. 45, p. 305-310.

Priest, G.R., 1990, Volcanic and tectonic evolution of the Cascade volcanic arc, central Oregon: Journal of Geophysical Research, v. 95, p. 19583-19599.

Rose, A.W., Hawkes, H.E. and Webb, J.S., 1979, Geochemistry in Mineral Exploration, 2nd edition: Academic Press, London, $657 \mathrm{p}$.

Rosenfeld, I. and Beath, O.A., 1964, Selenium: Geobotany, Biochemistry, Toxicity and Nutrition: Academic Press, New York, 411p.

Sargent-Welch Scientific Company, 1979, Periodic Table of the Elements: Skokie, Illinois.

Schoer, J., 1984, Thallium, in Hutzinger, O., ed., The Handbook of Environmental Chemistry, v. 3(C), p. 143-214: Springer-Verlag, Berlin.

Scokart, P.O., Meeus-Verdinne, K. and De Borger, R., 1983, Mobility of heavy metals in polluted soils near zinc smelters: Water, Air and Soil Pollution, v. 20, p. 451463.

Shacklette, H.T. and Boerngen, J.G., 1984, Element concentrations in soils and other surficial materials of the conterminous United States: U.S. Geological Survey Professional Paper 1270, Government Printing Office, Washington, D.C.

Smith, I.C. and Carson, B.L., 1977, Trace Metals in the Environment, v. 1: Ann Arbor Scientific Publications, Ann Arbor, Michigan, 394 p.

Smith, K.A., 1993, Manganese and Cobalt, in Alloway, B.J., ed., Heavy Metals in Soils: John Wiley \& Sons, Inc., New York, chapter 10, p. 197-221.

Soil Survey Staff, 1975, Soil Taxonomy: A basic system of soil classification for making and interpreting soil surveys: SCS, USDA Handbook 436.

Soil Survey Staff, 1992, Keys to Soil Taxonomy. SMSS Technical Monograph 19, 5th edition.: Pocahontas Press, Inc., Blacksburg, Virginia, 541 p. 
Soil Survey Staff, 1993, Soil Survey Manual: USDA Soil Conservation Service, Agricultural Handbook 18, Washington, D.C., 437 p.

Steinnes, E., 1993, Mercury, in Alloway, B.J., ed., Heavy Metals in Soils: John Wiley \& Sons, Inc., New York, Chapter, 11, p. 222-236.

Swaine, D.J. and Mitchell, R.L., 1960, Trace-element distribution in soil profiles: Journal of Soil Science, v. 11, p. 347-368.

U.S. Department of Agriculture (USDA), 1972, Soil Survey Laboratory Methods and Procedures for Collecting Soil Samples: USDA Soil Conservation Service, Soil Survey Illustrations Report No. 1, Procedure 8C1a.

U.S. Department of Agriculture (USDA), 1986, General Soil Map - State of Oregon (1:500, 000): USDA, Soil Conservation Service.

U.S. Environmental Protection Agency (EPA ), 1994, Test methods for evaluating solid wastes: SW-846, v. 1A, final update II, Office of Solid Waste and Emergency Response, Washington, D.C., methods 3050A and 6010A, unpaged.

U.S. Environmental Protection Agency (EPA), 1988, Code of Federal regulations: Federal Register, v. 40, part 401, p. 7-8.

Wacker, W.E.C., 1977, Magnesium: Geochemistry and the Environment, v. 2, p. 11-28.

Walker, G.W. and MacLeod, N.S., 1991, Geologic Map of Oregon (1: 500, 000): US Geological Survey, Denver, Colorado.

Wells, R.E., Engebretson, D.C., Snavely, P.D., Jr. and Coe, R.S., 1984, Cenozoic plate motions and the volcano-tectonic evolution of western Oregon and Washington: Tectonics, v. 3, p. 275-294.

Wright, J.E. and Wyld, S.J., 1994, The Rattlesnake Creek terrane, Klamath Mountains, California: An early Mesozoic volcanic arc and its basement of tectonically disrupted oceanic crust: Geological Society of America Bulletin, v. 106, p. 10331056.

Wright, J.R., Levick, R. and Atkinson, H.J., 1955, Trace-element distribution in virgin profiles representing four great soil groups: Soil Science Society of America Proceeding, v. 19, p. 340-344. 
Zimdahl, R.L. and Stogerboe, R.K., 1977, Behavior of lead in soil: Environmental Science \& Technology, v. 11, p. 1202-1207.

Zoback, M.L., McKee, E.H., Blakely, R.J. and Thompson, G.A., 1994, The northern Nevada rift: Regional tectonomagmatic relations and middle Miocene stress direction: Geological Society of America Bulletin, v. 106, p. 371-382. 


\section{Appendix 1. Previous Works on Metal Distributions in Rocks and Soils}

Aluminum (Al)

Parent Rocks: As one of the main constituents of the earth's crust, $\mathrm{Al}$ in rocks commonly ranges from 0.45 to $10 \%$ with the lowest value for ultramafics and highest for argillaceous sediments. In other types of magmatic rocks, $\mathrm{Al}$ is rather uniformly distributed, ranging between 6.9 and $8.8 \%$. In sandstones and carbonates, $\mathrm{Al}$ values are comparable to those in ultramafics (Kabata-Pendias and Pendias, 1984).

Aluminum Content of Soils: The total $\mathrm{Al}$ content of soils is inherited from parent rocks and ranges from $13.8 \%$ (for Aridisols) to $2.1 \%$ (for Spodosols) with an average of 7.1\% (includes both surface and $\mathrm{B}$ horizons) (Peterson and Girling, 1981). Al concentrates in the B horizon along with translocated clays and hydrous oxides (Bowen, 1979). The metal is highly mobile in acid soil solutions (Peterson and Girling, 1981).

Antimony $(\mathrm{Sb})$

Parent Rocks: The crustal abundance of $\mathrm{Sb}$ is approximately $1 \mathrm{ppm}$. Argillaceous sediments contain up to $2 \mathrm{ppm} \mathrm{Sb}$ (Kabata-Pendias and Pendias, 1984). Overall igneous rocks average $0.2 \mathrm{ppm}$ (Jones and others, 1993). Limestones and sandstones contain around $0.2 \mathrm{ppm}$ (Fairbridge, 1972).

Antimony Content of Soils: $\mathrm{Sb}$ is usually concentrated in soil relative to parent materials (Jones and others, 1993). The average for soil Sb is around $1 \mathrm{ppm}$ (Bowen, 1979), but wide ranges have been reported. Jones and others (1993) reported Sb contents of the U.S. soils to range from 2.3 to $9.5 \mathrm{ppm}$. Kabata-Pendias and Pendias 
(1984) reported values of $0.05-4.0 \mathrm{ppm} \mathrm{Sb}$ for a large number of surface soils of different countries. The highest values were found in forest soils, while the lowest values were found in Histosols, Spodosols and sandy soils. Within the soil profile the highest $\mathrm{Sb}$ values are commonly found in the humiferous surface horizons (Alloway, 1993a; Crecelius and others, 1974).

\section{Arsenic (As)}

Parent Rocks: There is little difference in the concentrations of As in rocks unless the levels have been raised by associated mineralization (Boyle and Jonasson, 1973). Higher levels of As are often associated with the presence of sulfide minerals such as pyrites. Mean values of $2 \mathrm{ppm}$ appear to be those most commonly found in igneous and sedimentary rocks, but finer-grained argillaceous rocks and phosphorites (sedimentary Ca sulfates) average 10-15 ppm As (O’Neill, 1993; Kabata-Pendias and Pendias, 1984).

Arsenic Content of Soils: In soils the natural As levels are dependent on the source rock type. The normal range is $1-40 \mathrm{ppm}$ with most soils being in the lower half of this range (O'Neill, 1993). Due to As pollution, the levels of this metal are likely to be increased in topsoils (Kabata-Pendias and Pendias, 1984). The range in As in various types of surface soils in the U.S. is broad, from $<0.1$ to $93.2 \mathrm{ppm}$ (Appendix 8.1) (Kabata-Pendias and Pendias, 1984) with a mean of $6.7 \mathrm{ppm}$. The lowest levels are found in sandy soils particularly derived from granites. Higher As concentrations are most often related to alluvial soils and soils rich in organic matter. Elevated levels of As are found in soils of sulfide-mineralized areas (Boyle and Jonasson, 1973). 
Arsenic migration in soil is limited due to its strong adsorption by clays, hydroxides and organic matter (O’Neill, 1993). In heavy gley soil, As is accumulated only in the top horizon and is readily leached from the subsurface layer with a high reduction potential. In well-drained soils with low organic matter the metal is usually concentrated in the B horizon (Kabata-Pendias and Pendias, 1984).

Barium (Ba)

Parent Rocks: In the earth's crust, $\mathrm{Ba}$ is likely to be concentrated in intermediate and felsic magmatic rocks and commonly ranges in concentration from 400 to 1,200 ppm (Kabata-Pendias and Pendias, 1984). Ultramafic rocks contain very little $\mathrm{Ba}(0.5$ $25 \mathrm{ppm})$. Among sedimentary rocks, shales and clays are richest in $\mathrm{Ba}(500-800 \mathrm{ppm})$ (Aubert and Pinta, 1980).

Barium Content of Soils: The concentration of $\mathrm{Ba}$ in soils depends mainly on the associated parent rocks. Kabata-Pendias and Pendias (1984) reported the U.S. surface soil $\mathrm{Ba}$ ranges from 10 to 3,000 ppm, with an average of 265-835 ppm (Appendix 8.1). The highest concentrations were found in desert soils and in soils developed over felsic magmatic rocks. The lowest values were in the low-organic soils.

In Spodosols and well-drained soils in humid environments, $\mathrm{Ba}$ accumulates in the lower horizons. In arid and semiarid regions the $\mathrm{Ba}$ enrichment is most often observed on the surface. Varnishes formed at the surface of aridic soils always have an enrichment in $\mathrm{Ba}$ (Aubert and Pinta, 1980; Kabata-Pendias and Pendias, 1984). 
Beryllium (Be)

Parent Rocks: Kabata-Pendias and Pendias (1984) reported concentrations of this metal to regularly increase from ultramafic, through mafic and intermediate, to felsic rocks which contain 2-6.5 ppm Be. They also reported that concentration of $\mathrm{Be}$ in argillaceous rocks was enriched (2-6 ppm), while sandstones and carbonates contained $0.2-2 \mathrm{ppm}$.

Beryllium Content of Soils: Kabata-Pendias and Pendias (1984) reported concentration of $\mathrm{Be}$ in various surface soils of the U.S. to range from $<1$ to $15 \mathrm{ppm}$ with an average of $1.6 \mathrm{ppm}$ (Appendix 8.1). During rock weathering Be usually remains behind. Organic substances are known to bind $\mathrm{Be}$, therefore, the metal is enriched in some coals and accumulates in organic soil horizons (Kabata-Pendias and Pendias, 1984). Most unleached soils usually have the highest Be levels in the surface horizons. In highly leached soils Be accumulates in the B horizon with organic matter (Adriano, 1986).

\section{Cadmium (Cd)}

Parent Rocks: Cd is mainly concentrated in argillaceous rocks, with phosphorites and marine black shales having the highest contents (0.3-980 ppm) (Alloway, 1993c). The abundance of this metal in other sedimentary and in magmatic rocks does not exceed 0.3 ppm (Kabata-Pendias and Pendias, 1984).

Cadmium Content of Soils: The main factor determining the Cd content of soil is the chemical composition of the parent rock. Most soils contain $<1 \mathrm{ppm}$, except those 
contaminated from discrete sources or developed on parent materials with high $\mathrm{Cd}$, such as black shales (Alloway, 1993c). Cd concentrations of $22 \mathrm{ppm}$ have been reported in uncontaminated soils developed on Monterey black shale at several locations in California (Page and others, 1987). Soils developed on Carboniferous black shales in Derbyshire, U.K. also have been found to contain $22 \mathrm{ppm} \mathrm{Cd}$ in the absence of anthropogenic contamination (Alloway, 1993c).

In the U.S., 3,305 samples collected from uncontaminated sites in 36 states revealed $\mathrm{Cd}$ from 0.005 to $2.4 \mathrm{ppm}$, with a mean of $0.27 \mathrm{ppm}$ (Holmgren and others, 1993). In general, Histosols (peats) contained the most Cd (Page and others, 1987).

Within soil profiles, $\mathrm{Cd}$ tends to be higher in the surface horizon which is a reflection of the relatively high humus content, inputs from atmospheric deposition, fertilizers and cycling through plants (Alloway, 1993c). Page and others (1987) referred to studies on Mollisols and Alfisols where mean concentrations of $0.39 \mathrm{ppm} \mathrm{Cd}$ were found in the surface horizons and $0.23 \mathrm{ppm} \mathrm{Cd}$ in the subsurface horizons. This may be reversed in more acidic soils, though (Alloway, 1993c).

$\mathrm{Cd}$ is most mobile in acidic soils within the range of $\mathrm{pH} 4.5$ to 5.5. In alkaline soil it is immobile (Kabata-Pendias and Pendias, 1984). Biddappa and others (1982) found that $\mathrm{Cd}, \mathrm{Ni}$ and $\mathrm{Zn}$ were more readily leached down columns of two Japanese soils than $\mathrm{Cu}$ and $\mathrm{Pb}$. In soils developed under the influence of humid climate, migration of $\mathrm{Cd}$ down the profile is more likely to occur than its accumulation in the surface horizon. 
The enrichment in Cd content observed in topsoils should be related to contamination effects (Kabata-Pendias and Pendias, 1984).

Calcium (Ca)

Parent Rocks: Ca is one of the most abundant elements in the earth's crust. Ca content in igneous rocks decreases with increasing silica content: dunite, $0.7 \%$; gabbros, 11\%; diorites, 6.7\%; granodiorites, $4.4 \%$; and granites, $2.0 \%$ (Fairbridge, 1972 ). The average shale contains $3.1 \%$, sandstone $5.5 \%$, and limestone $42.6 \% \mathrm{Ca}$ (Fairbridge, 1972).

Calcium Content of Soils: The soil Ca levels are controlled by parent rocks as well as by pedogenic processes. Ca is leached by the action of water or by reaction with dilute natural acids. Its concentration in soil as well as its distribution in the soil profile are controlled by its solubility and migration in aqueous solutions (Fairbridge, 1972). In arid and semiarid regions $\mathrm{Ca}$ concentrates in the $\mathrm{A}$ horizon, while in the humid areas leaching of Ca makes soils generally depleted of this metal (Fairbridge, 1972).

Chromium (Cr)

Parent Rocks: Ultramafic and mafic rocks are richest in $\mathrm{Cr}$, containing up to 3,400 ppm of this metal (McGrath and Smith, 1993; Kabata-Pendias and Pendias, 1984). The $\mathrm{Cr}$ content of felsic igneous and sedimentary rocks ranges from 2 to $590 \mathrm{ppm}$, being highest in argillaceous sediments (Cannon, 1978).

Chromium Content of Soils: The soil Cr is inherited from parent rocks, and therefore its highest concentration is in soils derived from ultramafic and mafic rocks. 
Soils on serpentines are known to contain as much as 2,000 to 4,000 ppm $\mathrm{Cr}$ (KabataPendias and Pendias, 1984). Chromite is resistant to weathering and therefore accounts for most of the $\mathrm{Cr}$ in residual material. The $\mathrm{Cr}$ contents of surface soils of the U.S. range from 3 to 1,500 ppm (Appendix 8.2) (Kabata-Pendias and Pendias, 1984) with an average of $54 \mathrm{ppm}$.

An increase in $\mathrm{Cr}$ content in the upper horizons of soils which are particularly humified (Mollisols) can be noticed. In Spodosols and well-drained humid soils, the accumulation of $\mathrm{Cr}$ takes place in illuvial or gley horizons. $\mathrm{Cr}$ content also varies with soil texture. Concentrations are higher in clayey soils than in easily leached sandy soils (Aubert and Pinta, 1980).

\section{Cobalt (Co)}

Parent Rocks: The Co values in ultramafic rocks varies from 100 to $220 \mathrm{ppm}$ and in felsic rocks from 1 to $15 \mathrm{ppm}$ (Kabata-Pendias and Pendias, 1984). The Co abundance in sedimentary rocks ranges from $<1$ to $50 \mathrm{ppm}$ with argillaceous sediments being the richest (Smith, 1993).

Cobalt Content of Soils: The Co concentration in soils is inherited from parent materials. Soils from mafic rocks and soils derived from clay deposits contain the highest amount of this metal (Smith, 1993). The normal Co content of surface soils of the U.S. ranges from $<1$ to $50 \mathrm{ppm}$ (Appendix 8.3) (Kabata-Pendias and Pendias, 1984), with the highest frequency in the range of 3 to $15 \mathrm{ppm}$ and with a mean of $8.2 \mathrm{ppm}$. In the U.S. higher Co contents are observed in soils of arid and semiarid regions. Low soil 
Co has been reported for soils of the lower Atlantic Coastal Plain and for soils of the glaciated region in the northeast (Kubota and Allaway, 1972). Coarse-textured soil parent materials of low Co content and podzolization are features of soils associated with Co deficiency in the eastern U.S. (Kubota, 1980).

Within a given soil profile, Co is generally concentrated in those horizons rich in organic material, humus and clays (Smith, 1993). In Spodosols Co accumulates in the illuvial B horizon, whereas the eluvial E horizon is generally depleted. In contrast, in Mollisols and Vertisols the distribution of Co is relatively uniform throughout the profile (Aubert and Pinta, 1980). Generally greater concentrations of Co are observed in alkaline than in acidic soils (Smith, 1993).

Copper (Cu)

Parent Rocks: $\mathrm{Cu}$ is most abundant in mafic rocks (30-160 ppm, with an average of $90 \mathrm{ppm}$ ) (Baker, 1993). Its concentration in granitic rocks ranges between 4 and 30 ppm (average $15 \mathrm{ppm}$ ). In sedimentary rocks, the argillaceous sediments are the richest, while carbonates are the poorest (Baker, 1993; Kabata-Pendias and Pendias, 1984).

Copper Content of Soils: Average background concentrations of 20-30 ppm Cu have been reported for soils of the world (Baker, 1993). The total Cu content of soils is influenced by the parent rock. In Scotland Spodosols on granite and sandstones are poor in $\mathrm{Cu}(3-5 \mathrm{ppm})$ and those on mica-schists and olivine gabbro have $25-30 \mathrm{ppm} \mathrm{Cu}$ (Aubert and Pinta, 1980). For surface soils of the U.S., Kabata-Pendias and Pendias (1984) reported the background $\mathrm{Cu}$ concentrations from 1 to $300 \mathrm{ppm}$ (Appendix 8.2), 
highest for soils over volcanic rocks and lowest for sandy and organic soils. Soils of arid and semiarid regions are often richer in $\mathrm{Cu}$ than those of other climatic zones.

$\mathrm{Cu}$ contents of soils are related to that of humus and organic matter. An accumulation of $\mathrm{Cu}$ in the upper humiferous horizons can often be observed (KabataPendias and Pendias, 1984). In Spodosols and well-drained humid soils the B horizons have been found to be richer in $\mathrm{Cu}$ than the $\mathrm{E}$ horizons, while in Mollisols $\mathrm{Cu}$ content variations between horizons are slight (Aubert and Pinta, 1980). Iron (Fe)

Parent Rocks: Fe is one of the major constituents of the lithosphere (approximately 5\%) and is concentrated mainly in the mafic rocks (Kabata-Pendias and Pendias, 1984).

Iron Content of Soils: The Fe content of soils is from parent rocks as well as the result of pedogenic processes. The most common range of $\mathrm{Fe}$ in soils is from 0.5 to $5 \%$ (Kabata-Pendias and Pendias, 1984). In Spodosois and well-drained humid soils Fe accumulates in the B horizon usually with organic matter (Knezek and Ellis, 1980). Lanthanum (La)

Parent Rocks: The concentrations of La increase from mafic to felsic igneous rocks. The La concentration averages $17 \mathrm{ppm}$ in basalts and $84 \mathrm{ppm}$ in granites (Fairbridge, 1972). The major source of La is from monazite in beach sands. The accessory monazite originally present in granitic rocks resists weathering and is 
concentrated by sedimentary processes. On average, sedimentary rocks have about 39 ppm La (Fairbridge, 1972).

Lanthanum Content of Soils: Data on La levels in soils are generally lacking. In a study of rare earths in Russian platform soils, Balashov and others (1964) found higher La concentrations in alkaline soils; lower concentrations were in acid soils, due to removal as soil organic complexes.

Lead $(\mathrm{Pb})$

Parent Rocks: There is a general increase in $\mathrm{Pb}$ concentrations from ultramafic to felsic igneous rocks. Nriagu (1978) calculated the mean $\mathrm{Pb}$ content of gabbro as 1.9 $\mathrm{ppm}$, andesite as $8.3 \mathrm{ppm}$ and granite as $22.7 \mathrm{ppm}$. $\mathrm{Pb}$ concentrations rise with increasing silica contents. Among sedimentary rocks, mudstones and shales have an average $\mathrm{Pb}$ content of $23 \mathrm{ppm}$; black shales are the richest. Sandstones contain an average of $10 \mathrm{ppm}$ while carbonates contain about $7 \mathrm{ppm}$ of $\mathrm{Pb}$ (Davies, 1993).

Lead Content of Soils: Soils are often richer in $\mathrm{Pb}$ than the rocks from which they are derived. Aubert and Pinta (1980) found that the average $\mathrm{Pb}$ concentration in soils was 15-25 ppm. Davies (1993) believed that in remote or recently settled areas soil $\mathrm{Pb}$ ranged between 10 and $30 \mathrm{ppm}$ but elsewhere a general, low-level contamination has raised concentrations to 30-100 ppm. Davies (1977) stated that an upper limit for $\mathrm{Pb}$ content of a 'normal' soil could be established as $70 \mathrm{ppm}$. The Pb content of surface soils of the U.S. averages 20 ppm (Appendix 8.2) (Kabata-Pendias and Pendias, 1984). 
Generally, soils of the temperate and boreal regions tend to have higher total $\mathrm{Pb}$ than those in other climatic areas (Aubert and Pinta, 1980).

$\mathrm{Pb}$ contents in soils vary in relation to humus and organic matter concentrations. Most of the time an accumulation of $\mathrm{Pb}$ is observed in surface horizons of soil. Wright and others (1955) noticed that $\mathrm{Pb}$ showed the greatest accumulation in surface horizons of soils in eastern Canada. Other authors have reported accumulations of $\mathrm{Pb}$ in surface horizons of uncontaminated soils (Merry and others, 1983). According to Aubert and Pinta (1980) this accumulation may be of biogenetic origin (accumulation by plants). There is little evidence that $\mathrm{Pb}$ is readily lost from soil profiles by leaching. Zimdahl and Skogerboe (1977) demonstrated that soils have rather large capacities for the immobilization of $\mathrm{Pb}$, that the organic fraction is largely responsible for the observed fixation of the metal, and $\mathrm{Pb}$ from vehicle exhausts tends to remain near the soil surface. Scokart and others (1983) investigated the mobility of $\mathrm{Pb}$ and other metals near Belgian $\mathrm{Zn}$ smelters and found that $\mathrm{Pb}$ and $\mathrm{Cu}$ remained in the upper layers of soil without regard to the type of soil.

\section{Lithium (Li)}

Parent Rocks: Li contents in magmatic rocks increase with an increase in silica, being highest in felsic rocks (15-45 ppm). The richest $\mathrm{Li}$ accumulation $(50-75 \mathrm{ppm})$ is observed in argillaceous sediments (Kabata-Pendias and Pendias, 1984).

Lithium Content of Soils: The Li content of soils is controlled mainly by pedogenic processes (Aubert and Pinta, 1980). The abundance of $\mathrm{Li}$ in surface soils of 
the U.S. (Appendix 8.5) (Kabata-Pendias and Pendias, 1984) is fairly uniform. The highest (average $34 \mathrm{ppm}$ ) is in alluvial soils and the lowest (average $13 \mathrm{ppm}$ ) in loworganic soils. Lower contents of $\mathrm{Li}$ have been reported for sandy soils, especially those derived from glacial drift in a humid climate (Kabata-Pendias and Pendias, 1984). In the arid climatic zones Li accumulates in the surface horizons, while in the humid regions the metal is enriched in the lower horizons of the soil profile (Kabata-Pendias and Pendias, 1984).

\section{Magnesium (Mg)}

$\mathrm{Mg}$ is among the most prevalent elements in the earth's crust (2\%) and is concentrated mainly in the mafic rocks (Wacker, 1977). Rocks usually contain a higher percentage of $\mathrm{Mg}$ than do soils, which reflects the loss of $\mathrm{Mg}$ during weathering. Bowen (1966) reports $\mathrm{Mg}$ concentrations for igneous rocks (2.33\%), shales (1.5\%), sandstones (1.1\%), limestones $(0.3 \%)$ and dolomites (20\%).

Soils have an average of $0.3 \% \mathrm{Mg}$. The $\mathrm{Mg}$ content of soils is both inherited from parent rocks and the result of pedogenic processes (Fairbridge, 1972). It is concentrated in the B horizon of the soil profile, associated with accumulations of translocated clays and hydrous oxides (Bowen, 1979).

Manganese (Mn)

Parent Rocks: $\mathrm{Mn}$ is one of the most abundant trace elements in the lithosphere. The highest concentrations (up to several thousand ppm) are found in mafic igneous rocks (Kabata-Pendias and Pendias, 1984). Mn contents in felsic rocks vary between 
200 and 1,000 ppm (Smith, 1993). The concentration range in argillaceous sediments and carbonates is about $400-600 \mathrm{ppm}$, but much lower concentrations are found in sandstones (20-500 ppm) (Mitchell, 1964; Aubert and Pinta, 1980).

Manganese Content of Soils: Soils derive virtually all their Mn content from parent materials. For example, in Scotland, total Mn content in Haplorthods developed on olivine gabbro till is 7,000 ppm, whereas that in Ferrods or Sideraquods on sandy materials is only $50 \mathrm{ppm}$ (Smith, 1993). Most soils contain, on an average, from 500 to 1,000 ppm of total Mn (Aubert and Pinta, 1980). Kabata-Pendias and Pendias (1984) reported Mn contents of a large number of surface soils of the U.S. to range between 7 and 3,000 ppm (Appendix 8.4); the mean content of these soils was $495 \mathrm{ppm}$. The variation of $\mathrm{Mn}$ concentration rarely seems to be correlated with soil typology. Higher Mn levels are often reported for soils over mafic rocks, for soils rich in organic matter, and for soils from arid or semiarid regions (Aubert and Pinta, 1980). Sandy soils are generally less rich in $\mathrm{Mn}$ than clayey soils. Mn concentrations follow the distribution of humus in the profile. In all climatic regions, an accumulation of $\mathrm{Mn}$ is usually observed in the humiferous surface horizons (Aubert and Pinta, 1980; Kabata-Pendias and Pendias, 1984; Adriano, 1986).

Mercury ( $\mathrm{Hg})$

Parent Rocks: In all types of magmatic rocks the $\mathrm{Hg}$ content is approximately 0.01 ppm (Steinnes, 1993). In sedimentary rocks, sandstones and limestones have slightly higher concentrations than the magmatic rocks, whereas shales cover a very wide range 
of $\mathrm{Hg}$ contents $(0.006-0.51 \mathrm{ppm})$. Elevated concentrations of this metal occur in rocks derived from volcanic debris or deposited in volcanic areas (Steinnes, 1993).

Mercury Content of Soils: Background levels of $\mathrm{Hg}$ in soils are not easy to estimate due to widespread $\mathrm{Hg}$ pollution. Data reported for various soils on a worldwide basis show that mean concentrations of $\mathrm{Hg}$ in surface soils do not exceed $0.4 \mathrm{ppm}$ (Kabata-Pendias and Pendias, 1984). Kabata-Pendias and Pendias (1984) reported Hg concentrations in surface soils of the U.S. to range from $<0.01$ to $4.6 \mathrm{ppm}$ (Appendix 8.5). The highest average concentration of $0.28 \mathrm{ppm}$ was found for Histosols followed by $0.13 \mathrm{ppm}$ for loamy soils This higher average $\mathrm{Hg}$ content in organic soils compared to mineral soils has been noted by many authors (John and others, 1975; Frank and others, 1976). Andersson (1979), in a study of $\mathrm{Hg}$ in profiles of virgin soils, demonstrated a very close correlation between $\mathrm{Hg}$ and organic matter content in acidic soils, whereas in neutral soils $(\mathrm{pH}>6)$ the co-variation between $\mathrm{Hg}$ and $\mathrm{Fe}$ was stronger than that of $\mathrm{Hg}$ and organic matter. The distinctly higher $\mathrm{Hg}$ content observed in soils in the eastern compared to the western U.S. (see Appendix 8.5) could in part be explained by differences in soil organic matter (Steinnes, 1993).

$\mathrm{Hg}$ is found in the surface soil at several times the concentration as in the subsoil (Kabata-Pendias and Pendias, 1984). McKeague and Kloosterman (1974) in an extensive survey of virgin soils from all the provinces of Canada, observed that in more than half of the samples, particularly Spodosols and Entisols on sandy materials, the highest $\mathrm{Hg}$ concentrations were present in the surface layer. In some cases however the 
$\mathrm{Hg}$ content in the surface horizon is similar to that of the subsoil (Mills and Zwarich, 1975). The removal of $\mathrm{Hg}$ from soils by leaching is in most cases insignificant (Steinnes, 1993).

Molybdenum (Mo)

Parent Rocks: Mo has its highest accumulation in organic-rich argillaceous sediments; black bituminous shales have concentrations up to $70 \mathrm{ppm}$ or higher (Jones and others, 1993). In magmatic rocks, Mo is more associated with felsic rocks (1-2 ppm). Ultramafic rocks as well as sandstones and carbonates have Mo contents in the range of 0.2-0.4 ppm (Aubert and Pinta, 1980; Kabata-Pendias and Pendias, 1984).

Molybdenum Content of Soils: Soil Mo contents average 1-2 ppm (Massey and Lowe, 1961; Kabata-Pendias and Pendias, 1984). The different types of soils in arid and semiarid regions generally have higher total Mo contents than those of other climatic zones (Aubert and Pinta, 1980).

Kabata-Pendias and Pendias (1984) reported the range of Mo in surface soils of the U.S. to be from 0.08 to $17.8 \mathrm{ppm}$ (Appendix 8.6) with the median concentration being slightly more than $1 \mathrm{ppm}$. Soils formed in coarse-textured glacial till and outwash have less Mo than soils formed in lacustrine deposits. Endemic areas of Mo toxicity in the U.S. occur principally in the west. Granitic rocks commonly occur where Mo-toxic areas are recognized. Shales are important rock sources of soil Mo in parts of northwestern Oregon. Histosols are the dominant soils associated with Mo toxicity on 
the broad basin-like lowlands in the Klamath area in southwestern Oregon (Kubota, 1980).

Generally, Mo accumulates in the upper soil horizons and, in particular, the humiferous horizons (Aubert and Pinta, 1980; Swaine and Mitchell, 1960). In Spodosols Mo accumulation occurs in the B illuvial horizon. Mo exists as an anion in soil and consequently shows increased solubility with increasing pH (Jones and others, 1993). Thus, the total Mo content is more in freely drained acidic soils than in poorly drained soils; in the latter case, the commonly high $\mathrm{pH}$ favors the mobilization of anions (Jones and others, 1993; Adriano, 1986).

Nickel (Ni)

Parent Rocks: Ni contents are highest in ultramafic rocks (1,400-2,000 ppm), and its concentrations decrease with increasing silica percentage in rocks down to 5 to 15 ppm in granites. Sedimentary rocks contain $\mathrm{Ni}$ in the range of 5 to $90 \mathrm{ppm}$, with the highest range being for argillaceous rocks and the lowest for sandstones (Aubert and Pinta, 1980; Kabata-Pendias and Pendias, 1984; McGrath and Smith, 1993).

Nickel Content of Soils: The average concentrations of $\mathrm{Ni}$ in world soils is 40 ppm (McGrath and Smith, 1993). The Ni status in soils is highly dependent on that of the parent rocks. Soils formed on serpentine can contain 100-7,000 ppm of Ni along with unusually large concentrations of $\mathrm{Cr}, \mathrm{Mg}$ and $\mathrm{Fe}$ (Brooks, 1987). Soils of arid and semiarid regions have Ni contents (5-300 ppm, with an average of about $50 \mathrm{ppm}$ ) which are generally higher than that of the temperate and boreal areas (Aubert and Pinta, 1980). 
In the surface soils of the U.S., Ni contents range from $<5$ to $200 \mathrm{ppm}$ (Appendix 8.3) (Kabata-Pendias and Pendias, 1984) with an average of $19 \mathrm{ppm}$. The higher Ni contents are in clay and loamy soils, in soils over mafic and volcanic rocks, in organic-rich soils, and in desert soils.

Depending on the origin of the soil and pedogenic processes, the surface or the subsoil may be relatively enriched in $\mathrm{Ni}$ concentrations. Generally, the distribution of $\mathrm{Ni}$ between the different horizons of soil profiles follows that of humus and organic matter. An accumulation of $\mathrm{Ni}$ is often observed in the humiferous surface horizons. $\mathrm{Ni}$ is uniformly distributed in Mollisols and Vertisols down the profiles, as is organic matter. In Spodosols and well-drained humid soils concentrations are higher in the B illuvial horizons. There also may be an accumulation of $\mathrm{Ni}$ in certain horizons very rich in $\mathrm{Fe}$ or Al sesquioxides (Aubert and Pinta, 1980; Adriano, 1986).

\section{Potassium (K)}

$\mathrm{K}$ is one of the major rock-forming elements of the earth's crust, and its concentration increases with increasing silica content of magmatic rocks. The terrestrial $\mathrm{K}$ abundance (in weight $\%$ ) are as follows: granite, 3.4 ; syenite, 3.73 ; diorite, 1.75 ; gabbro, 0.74; dunite, 0.033; shale, 2.66; sandstone, 1.07; and limestone, 0.27 (Fairbridge, 1972). The soil $\mathrm{K}$ contents are largely controlled by the associated parent rock materials as well as pedogenic processes. $\mathrm{K}$ is highly mobile in the soil (Birkeland, 1984). 


\section{Selenium (Se)}

Parent Rocks: In practice, Se tends to concentrate in sedimentary, rather than in magmatic rocks. Se contents in magmatic rocks rarely exceed 0.05 ppm (Neal, 1993; Kabata-Pendias and Pendias, 1984). Among the shales, those containing organic matter are generally richest in Se. In black shales, Se concentrations can range up to $675 \mathrm{ppm}$ (Adriano, 1986). Se is mostly found as an impurity in sulfide rocks. Primary sources of Se in nature are volcanic emissions and metallic sulfides associated with igneous activity (Neal, 1993). Volcanic tuffs and shales of Wyoming contain anomalously high Se, averaging $9.15 \mathrm{ppm}$ and $19.86 \mathrm{ppm}$, respectively (Rosenfeld and Beath, 1964). Elevated concentrations of Se are associated with some types of phosphatic rocks as well as with coal. Se can also occur in limestones and sandstones, but its content will likely be more related to the degree of carbonaceous debris present than to any other factor (Fleming, 1962).

Selenium Content of Soils: In the natural environment, elevated concentrations of Se in soils are associated primarily with volcanic materials, sulfide ore bodies, black shales and carbonaceous sandstones. The intensity of weathering and leaching processes on these parent materials will define the ultimate Se composition of associated soils (Neal, 1993).

The amount of Se present in most soils is detectable but highly variable. In the U.S., soil Se content ranges from trace amounts $(<0.1 \mathrm{ppm})$ up to areas of acute toxicity $(5,000 \mathrm{ppm})(\mathrm{Neal}, 1993)$. In general, surface soils of the U.S. contain an average of 0.4 
ppm Se (Appendix 8.4) ( Kabata-Pendias and Pendias, 1984). Kubota (1980) described the geographic distribution of Se in soils of the U.S. In the central U.S., areas of Se toxicity are in calcareous soils formed on seleniferous Cretaceous shales. In the Pacific northwest, most of the soils in the intermountain valleys contain small amounts of Se, contributed by volcanic ash which mantles much of the eastern slopes of the Cascades. The low Se area on the lower Atlantic Coastal Plain is an area of extremely acid soils formed in highly weathered Coastal Plain deposits. The seleniferous soil of San Joaquin Valley of California is believed to be of natural origin. The finer-textured alluvial soil was derived from the Jurassic-Cretaceous sedimentary rocks of the Coast Range, thought to have contained seleno-sulfides of $\mathrm{Fe}$ (Neal, 1993).

Levesque (1974) determined the distribution of Se in 54 soils (234 horizon samples) of northern Ontario, Canada. A general distribution pattern of Se decreasing with soil depth paralleled decreases in organic matter. Surface horizons of a wet soil had more Se (2.09 ppm) than surface horizons (0.41-0.64 ppm) of well-drained soils. In well-drained soils, the highest Mo levels were in the B horizon. In Ireland, the highest Se concentrations also have been found in surface horizons of poorly drained humic gley soils (Fleming, 1962).

Silver (Ag)

Parent Rocks: Igneous and sedimentary rocks contain, on an average, $0.1 \mathrm{ppm}$ of Ag. In organic-rich shales Ag content can be up to $1 \mathrm{ppm}$ (Aubert and Pinta, 1980; Jones and others, 1993). 
Silver Content of Soils: The normal range of $\mathrm{Ag}$ in soils varies from $<0.01$ to 5 ppm with an average of about $0.1 \mathrm{ppm}$ (Boyle, 1972). Data given by Shacklette and Boerngen (1984) for the U.S. show Ag in the plow zone of mineral soil to be $0.7 \mathrm{ppm}$ and in soils rich in organic matter to be from 2 to $5 \mathrm{ppm}$. Values established by Bowen (1979) range from 0.01 to $8 \mathrm{ppm}$. All higher values for $\mathrm{Ag}$ in soils are found in mineralized areas. The Ag content in soils derived from sandstones or limestones is very low (0.05-0.07 ppm) (Jones and others, 1993).

$\mathrm{Ag}$ tends to accumulate in the surface, organic-rich horizons (Presant and Tupper, 1965). Due to the comparative insolubility of $\mathrm{Ag}$, it is highly immobile in soils relative to other metals (Jones and others, 1993).

\section{Sodium $(\mathrm{Na})$}

Parent Rocks: $\mathrm{Na}$ is one of the most abundant of the elements in the earth's crust. In igneous rocks the $\mathrm{Na}$ concentrations increase with increasing silica content, resulting in Na enrichment especially in the feldspathoid-bearing rocks (e.g. nepheline syenite) and to a lesser extent in granites (Fairbridge, 1972). The average concentration of $\mathrm{Na}$ in magmatic rocks is $2.83 \%$ by weight, while that in sedimentary rocks is only about half as much (Fairbridge, 1972). The low content of $\mathrm{Na}$ in sedimentary rocks is probably because the continental sediments have been leached by groundwater.

Sodium Content of Soils: The Na content of soils is both inherited from parent rocks and the result of pedogenic processes. $\mathrm{Na}$ is highly mobile in the soil, being very soluble in water. The soil Na levels are high in the arid regions, and the metal 
accumulates in the surface horizons. The leaching of Na downward through the profile results in the low content of this metal in well-drained humid soils (Fairbridge, 1972).

\section{Thallium (TI)}

Parent Rocks: $\mathrm{Tl}$ is a rare and dispersed element in the earth's crust. Its concentration seems to increase with increasing silica content in magmatic rocks and with increasing clay content in sedimentary rocks. Common $\mathrm{Tl}$ contents of mafic rocks range from 0.05 to $0.4 \mathrm{ppm}$ and in felsic rocks from 0.5 to $2.3 \mathrm{ppm}$. Tl content in argillaceous rocks ranges from 0.5 to $2.0 \mathrm{ppm}$ and in carbonates as little as 0.01 to 0.14 ppm (Kabata-Pendias and Pendias, 1984). $\mathrm{Tl}$ is concentrated in certain sulfides, and deposits characteristically high in As are usually also high in $\mathrm{Tl}$ (Adriano, 1986).

Thallium Content of Soils: There is little information on the Tl status of soils. Smith and Carson (1977) widely reviewed environmental occurrences of $\mathrm{Tl}$ and cited its concentration to range from 0.02 to $2.8 \mathrm{ppm}$ in surface soils of the U.S. and enriched contents of $\mathrm{Tl}$ (up to about $5 \mathrm{ppm}$ ) in soils over sphalerite veins. Jones and others (1993) reported the total $\mathrm{Tl}$ levels in a range of British soils to range from 0.03 to $0.99 \mathrm{ppm}$. Soils sampled from the vicinity of a cement plant near Leimen, southwestern Germany had an average $\mathrm{Tl}$ contents of $3.6,0.7$, and $0.1 \mathrm{ppm}$ in the 0 to 10,40 to 50 , and 60 to 70 cm depths, respectively (Schoer, 1984). This indicates that although $\mathrm{Tl}$ is somewhat mobile in soil (Adriano, 1986), its mobility is limited. The above data also possibly indicate that $\mathrm{Tl}$ accumulates in the surface horizons. 


\section{Vanadium (V)}

Parent Rocks: V is concentrated mainly in ultramafic and mafic rocks and in shales (within the common range of 100 to $250 \mathrm{ppm}$ ). Concentrations are much lower in felsic igneous rocks ( $30-40 \mathrm{ppm}) . \mathrm{V}$ contents are particularly low in sandstones and carbonates (about 20 ppm) (Aubert and Pinta, 1980; Kabata-Pendias and Pendias, 1984; Jones and others, 1993).

Vanadium Content of Soils: Soils have V contents close to those of the rocks on which they were formed and sometimes even higher. The composition of parent material has less bearing on $\mathrm{V}$ content of mature, developed soils (Jones and others, 1993). Soils have a mean V concentration of $100 \mathrm{ppm}$ (Hopkins and others, 1977). The average V content of surface soils of the U.S. (Appendix 8.4) (Kabata-Pendias and Pendias, 1984) is $84 \mathrm{ppm}$. As evident from the Appendix 8.4, the highest values are found for soils over volcanic rocks (30-300 ppm, with an average of $136 \mathrm{ppm}$ ), while the lowest are for organic, and sandy soils and lithosols on sandstones. Silty soils also contain large amounts of V (20-300 ppm, with an average of $102 \mathrm{ppm})$. In arid and semiarid regions, soil V contents (particularly in Vertisols, saline and Mediterranean red soils) are often very high (Aubert and Pinta, 1980). V contents in surface horizons of desert soils in the U.S. range between 30 and $150 \mathrm{ppm}$ with an average of $93 \mathrm{ppm}$ (Appendix 8.4).

In general, $\mathrm{V}$ is distributed in soil profiles rather uniformly (Kabata-Pendias and Pendias, 1984). However, this element prefers to concentrate in the humiferous 
horizons. In temperate zones, the B horizon of leached soils and Spodosols is often richer in V than the surface horizon (Aubert and Pinta, 1980).

Zinc $(\mathrm{Zn})$

Parent Rocks: $\mathrm{Zn}$ seems to be distributed rather uniformly in magmatic rocks, and only its slight increase in mafic rocks (80-120 ppm) and its slight decrease in felsic rocks (40-60 ppm) is observed. The $\mathrm{Zn}$ concentrations in argillaceous sedimentary rocks is enhanced, ranging from 80 to $120 \mathrm{ppm}$, while in sandstones and carbonates concentrations of this metal range from 10 to 30 ppm (Krauskopf, 1972; Aubert and Pinta, 1980; Kabata-Pendias and Pendias, 1984).

Zinc Content of Soils: The total $\mathrm{Zn}$ content of soils is largely dependent on the composition of the parent rock material. The common total $\mathrm{Zn}$ contents of soils range from 10 to $300 \mathrm{ppm}$, with an average of $50 \mathrm{ppm}$ (Lindsay, 1972). Kabata-Pendias and Pendias (1984) reported values of 34-83.5 ppm $\mathrm{Zn}$ as background average contents of surface soils of the U.S. (Appendix 8.3). The highest values are found in Mollisols and dark prairie soils and in soils over volcanic rocks, while the lowest values are in felsic mineral and low-organic soils. Aubert and Pinta (1980) also noted that Mollisols and saline alkali soils of the arid and semiarid regions generally contain high quantities of $\mathrm{Zn}$.

In most soils, $\mathrm{Zn}$ accumulates in the humiferous surface horizon. $\mathrm{Zn}$ concentrations increase at the same time as those of humus and organic matter (John,1974). In Mollisols the distribution of this metal is uniform between different horizons (Aubert 
and Pinta, 1980). $\mathrm{Zn}$ is considered to be readily soluble relative to other heavy metals in soils. Acid leaching is very active in $\mathrm{Zn}$ mobilization; thus losses of this metal are observed in certain horizons, particularly in surface horizons of Spodosols and brown acid soils derived from sands (Kabata-Pendias and Pendias, 1984). The highly weathered, acid leached sandy soils of the lower Atlantic Coastal Plain appear to have uniformly low (20 to $30 \mathrm{ppm}$ ) $\mathrm{Zn}$ concentrations at the surface (Kubota, 1980). 


\section{Appendix 2: List of geologic units along with their associated soil sampling sites.} The geologic units and their description are from $W$ alker and MacLeod (1991). For location of the sampling sites, see Figure 5.

\begin{tabular}{|c|c|c|c|c|c|}
\hline $\begin{array}{l}\text { Geologic } \\
\text { Unit }\end{array}$ & Age & Description & Site \# & $\begin{array}{l}\text { Site }^{\mathrm{a}} \\
\text { Location } \\
\# \text { in } \\
\text { Fig.5 }\end{array}$ & $\begin{array}{l}\text { Physiographic } \\
\text { Province }\end{array}$ \\
\hline bc & $\begin{array}{l}\text { Mesozoic or } \\
\text { Paleozoic }\end{array}$ & Amphibolite of Briggs Creek & KL30 & 103 & $\begin{array}{l}\text { Klamath } \\
\text { Mountains }\end{array}$ \\
\hline $\mathrm{cm}$ & $\begin{array}{l}\text { Triassic \& } \\
\text { Permian }\end{array}$ & Condrey Mountain Schist & KL21 & 95 & $\begin{array}{l}\text { Klamath } \\
\text { Mountains }\end{array}$ \\
\hline cs & $\begin{array}{l}\text { Mesozoic or } \\
\text { Paleozoic }\end{array}$ & Colebrook Schist & $\begin{array}{l}\text { KL6, } \\
\text { KL12 }\end{array}$ & 80,86 & $\begin{array}{l}\text { Klamath } \\
\text { Mountains }\end{array}$ \\
\hline $\mathrm{Jm}$ & Jurassic & Melange & $\mathrm{KL17}$ & 91 & $\begin{array}{l}\text { Klamath } \\
\text { Mountains }\end{array}$ \\
\hline Jop & Jurassic & $\begin{array}{l}\text { Otter Point Formation \& related } \\
\text { rocks }\end{array}$ & KL13 & 87 & $\begin{array}{l}\text { Klamath } \\
\text { Mountains }\end{array}$ \\
\hline Js & Jurassic & Sedimentary rocks & $\begin{array}{l}\mathrm{KL1} \\
\mathrm{KL} 11\end{array}$ & 75,85 & $\begin{array}{l}\text { Klamath } \\
\text { Mountains }\end{array}$ \\
\hline Jss & Jurassic & Shale, mudstone \& sandstone & $\begin{array}{l}\text { KL14 } \\
\text { KL15 }\end{array}$ & 88,89 & $\begin{array}{l}\text { Klamath } \\
\text { Mountains }\end{array}$ \\
\hline JTrgd & $\begin{array}{l}\text { Jurassic \& } \\
\text { Triassic }\end{array}$ & Granite \& diorite & $\begin{array}{l}\text { KL9, } \\
\text { KL23 }\end{array}$ & 83,97 & $\begin{array}{l}\text { Klamath } \\
\text { Mountains }\end{array}$ \\
\hline $\mathrm{Ju}$ & Jurassic & $\begin{array}{l}\text { Ultramafic \& related rocks of } \\
\text { ophiolite sequences }\end{array}$ & KL16 & 90 & $\begin{array}{l}\text { Klamath } \\
\text { Mountains }\end{array}$ \\
\hline Jub & Jurassic & $\begin{array}{l}\text { Basaltic, volcanic \& sedimentary } \\
\text { rocks }\end{array}$ & $\begin{array}{l}\mathrm{R} 12, \\
\mathrm{R} 13\end{array}$ & 115,116 & $\begin{array}{l}\text { Klamath } \\
\text { Mountains }\end{array}$ \\
\hline Jv & Jurassic & Volcanic rocks & KL3 & 77 & $\begin{array}{l}\text { Klamath } \\
\text { Mountains }\end{array}$ \\
\hline$\overline{\mathrm{Kc}}$ & Cretaceous & Clastic sedimentary rocks & KL27 & 101 & $\begin{array}{l}\text { Klamath } \\
\text { Mountains }\end{array}$ \\
\hline KJds & $\begin{array}{l}\text { Cretaceous \& } \\
\text { Jurassic }\end{array}$ & $\begin{array}{l}\text { Sedimentary rocks of Dothan } \\
\text { Formation }\end{array}$ & $\overline{\mathrm{KL} 4}$ & 78 & $\begin{array}{l}\text { Klamath } \\
\text { Mountains }\end{array}$ \\
\hline$\overline{\mathrm{KJg}}$ & $\begin{array}{l}\text { Cretaceous \& } \\
\text { Jurassic }\end{array}$ & Granitic rocks & $\begin{array}{l}\text { KL2, } \\
\text { KL26 }\end{array}$ & 76,100 & $\begin{array}{l}\text { Klamath } \\
\text { Mountains }\end{array}$ \\
\hline KJgu & $\begin{array}{l}\text { Cretaceous \& } \\
\text { Jurassic }\end{array}$ & $\begin{array}{l}\text { Gabbro and ultramafic rocks } \\
\text { associated with granitic plutons }\end{array}$ & $\begin{array}{l}\mathrm{R} 10 \\
\mathrm{R} 11\end{array}$ & 113,114 & $\begin{array}{l}\text { Klamath } \\
\text { Mountains }\end{array}$ \\
\hline$\overline{\mathrm{KJm}}$ & $\begin{array}{l}\text { Cretaceous \& } \\
\text { Jurassic }\end{array}$ & $\begin{array}{l}\text { Myrtle Group conglomerate, } \\
\text { sandstone, siltstone \& limestone }\end{array}$ & $\begin{array}{l}\mathrm{R} 14, \\
\mathrm{R} 15\end{array}$ & 117,118 & $\begin{array}{l}\text { Klamath } \\
\text { Mountains }\end{array}$ \\
\hline
\end{tabular}


Appendix 2: List of geologic units along with their associated soil sampling sites. The geologic units and their description are from Walker and MacLeod (1991). For location of the sampling sites, see Figure 5 (continued).

\begin{tabular}{|c|c|c|c|c|c|}
\hline $\begin{array}{l}\text { Geologic } \\
\text { Unit }\end{array}$ & Age & Description & $\begin{array}{l}\text { Site } \\
\#(s)\end{array}$ & $\begin{array}{l}\text { Site }^{\mathrm{a}} \\
\text { Location } \\
\text { \# in Fig. } \\
5\end{array}$ & $\begin{array}{l}\text { Physiographic } \\
\text { Province }\end{array}$ \\
\hline Ks & Cretaceous & Sedimentary rocks & KL10 & 84 & $\begin{array}{l}\text { Klamath } \\
\text { Mountains }\end{array}$ \\
\hline $\mathrm{mc}$ & Paleozoic & May Creek Schist & KL28 & 102 & $\begin{array}{l}\text { Klamath } \\
\text { Mountains }\end{array}$ \\
\hline$\overline{Q a}$ & $\begin{array}{l}\text { Holocene \& } \\
\text { Pleistocene }\end{array}$ & Andesite & $\mathrm{R} 3, \mathrm{R} 4$ & 106,107 & $\begin{array}{l}\text { Cascade } \\
\text { Range } \\
\end{array}$ \\
\hline$\overline{Q a l}$ & Holocene & Alluvial deposits & $\begin{array}{l}\text { LC11, } \\
\text { LM7 } \\
\text { LM17 }\end{array}$ & $34,8,18$ & $\begin{array}{l}\text { Coast Range } \\
\text { Willamette } \\
\text { V.* }\end{array}$ \\
\hline$\overline{\mathrm{Qb}}$ & $\begin{array}{l}\text { Holocene \& } \\
\text { Pleistocene }\end{array}$ & Basalt \& basaltic andesite & $\mathrm{EO} 2$ & 47 & $\begin{array}{l}\text { High Lava } \\
\text { Plains }\end{array}$ \\
\hline Qba & $\begin{array}{l}\text { Holocene \& } \\
\text { Pleistocene }\end{array}$ & Basaltic andesite $\&$ basalt & $\begin{array}{l}\text { LM9, } \\
\text { LM16 }\end{array}$ & 10,17 & $\begin{array}{l}\text { Cascade } \\
\text { Range }\end{array}$ \\
\hline $\begin{array}{l}\mathrm{Qd} \\
\text { (young) }\end{array}$ & Holocene & Dune sand & $\mathrm{LC13}$ & 36 & Coastal Plain \\
\hline Qd (old) & Holocene & Dune sand & $\mathrm{LC} 14$ & 37 & Coastal Plain \\
\hline$\overline{Q f}$ & $\begin{array}{l}\text { Holocene \& } \\
\text { Pleistocene }\end{array}$ & Fanglomerate & $\mathrm{EO} 26$ & 66 & $\begin{array}{l}\text { Basin \& } \\
\text { Range } \\
\end{array}$ \\
\hline$\overline{Q g}$ & Pleistocene & Glacial deposits & $\begin{array}{l}\text { LM4, } \\
\text { LM10 }\end{array}$ & 5,11 & $\begin{array}{l}\text { Cascade } \\
\text { Range }\end{array}$ \\
\hline Qgf & Pleistocene & Glaciofluvial deposits & LM21 & 21 & $\begin{array}{l}\text { Cascade } \\
\text { Range }\end{array}$ \\
\hline$\overline{\text { Qls }}$ & $\begin{array}{l}\text { Holocene \& } \\
\text { Pleistocene }\end{array}$ & $\begin{array}{l}\text { Landslide \& debris flow } \\
\text { deposits }\end{array}$ & $\begin{array}{l}\text { LM1, } \\
\text { LC20 }\end{array}$ & 1,43 & Coast Range \\
\hline Qma & Holocene & Mazama ash-flow deposits & $\begin{array}{l}\text { LM5, } \\
\text { EO14 }\end{array}$ & 6,55 & $\begin{array}{l}\text { Cascade } \\
\text { Range }\end{array}$ \\
\hline Qmp & Holocene & Mazama pumice deposits & $\begin{array}{l}\text { LM6, } \\
\text { EO23 }\end{array}$ & 7,63 & $\begin{array}{l}\text { Cascade } \\
\text { Range }\end{array}$ \\
\hline Qrd & $\begin{array}{l}\text { Holocene \& } \\
\text { Pleistocene }\end{array}$ & Rhyolite \& dacite & $\begin{array}{l}\text { EO24, } \\
\text { EO25 }\end{array}$ & 64,65 & $\begin{array}{l}\text { Cascade } \\
\text { Range } \\
\end{array}$ \\
\hline$\overline{Q s}$ & Pleistocene & $\begin{array}{l}\text { Lacustrine \& fluvial } \\
\text { sedimentary rocks }\end{array}$ & $\begin{array}{l}\mathrm{LCl}, \\
\mathrm{EO} 15^{*}\end{array}$ & 23,56 & $\begin{array}{l}\text { Cascade } \\
\text { Range, Basin } \\
\text { \& Range* }\end{array}$ \\
\hline$\overline{\mathrm{Qt}}$ & $\begin{array}{l}\text { Holocene \& } \\
\text { Pleistocene }\end{array}$ & Terrace pediment \& lag gravels & $\begin{array}{l}\text { LC3*, } \\
\text { LC16, } \\
\text { LC17, } \\
\text { KL7, } \\
\text { KL8 }\end{array}$ & $\begin{array}{l}25,39 \\
40,81 \\
82\end{array}$ & $\begin{array}{l}\text { Willemette } \\
\text { V.* Coastal } \\
\text { Plain }\end{array}$ \\
\hline
\end{tabular}


Appendix 2: List of geologic units along with their associated soil sampling sites. The geologic units and their description are from Walker and MacLeod (1991). For location of the sampling sites, see Figure 5 (continued).

\begin{tabular}{|c|c|c|c|c|c|}
\hline $\begin{array}{l}\text { Geologic } \\
\text { Unit }\end{array}$ & Age & Description & Site \# & $\begin{array}{l}\text { Site }^{\mathrm{a}} \\
\text { Location } \\
\text { \# in Fig. } \\
5\end{array}$ & $\begin{array}{l}\text { Physiographic } \\
\text { Province }\end{array}$ \\
\hline$\overline{\mathrm{QTb}}$ & $\begin{array}{l}\text { Pleistocene \& } \\
\text { Pliocene }\end{array}$ & Basait & $\begin{array}{l}\text { EO8, } \\
\text { EO10 }\end{array}$ & 49,51 & $\begin{array}{l}\text { Basin \& } \\
\text { Range }\end{array}$ \\
\hline QTba & $\begin{array}{l}\text { Pleistocene \& } \\
\text { Pliocene }\end{array}$ & Basalt \& basaltic andesite & $\begin{array}{l}\text { LM3B, } \\
\text { LM15, } \\
\text { EO18, } \\
\text { EO21 }\end{array}$ & $\begin{array}{l}4,16,59, \\
61\end{array}$ & $\begin{array}{l}\text { Cascade } \\
\text { Range }\end{array}$ \\
\hline QTmv & $\begin{array}{l}\text { Pleistocene, } \\
\text { Pliocene, \& } \\
\text { Miocene? }\end{array}$ & Mafic vent complexes & $\begin{array}{l}\text { LM11, } \\
\text { EO20 }\end{array}$ & 12,60 & $\begin{array}{l}\text { Cascade } \\
\text { Range }\end{array}$ \\
\hline$\overline{\mathrm{QTp}}$ & $\begin{array}{l}\text { Holocene to } \\
\text { Miocene }\end{array}$ & Basaltic and andesitic ejecta & $\begin{array}{l}\text { EO22, } \\
\text { R5, R6 }\end{array}$ & $\begin{array}{l}62,108, \\
109\end{array}$ & $\begin{array}{l}\text { Basin \& } \\
\text { Range }\end{array}$ \\
\hline QTps & $\begin{array}{l}\text { Holocene to } \\
\text { Miocene? }\end{array}$ & $\begin{array}{l}\text { Subaqueous basaltic \& } \\
\text { andesitic ejecta }\end{array}$ & EO30 & 68 & $\begin{array}{l}\text { High Lava } \\
\text { Plains }\end{array}$ \\
\hline$\overline{\text { QTs }}$ & $\begin{array}{l}\text { Pleistocene \& } \\
\text { Pliocene }\end{array}$ & Sedimentary rocks & $\mathrm{EO13}$ & 54 & $\begin{array}{l}\text { Basin \& } \\
\text { Range } \\
\end{array}$ \\
\hline QTst & $\begin{array}{l}\text { Pleistocene } \\
\text { or Pliocene }\end{array}$ & $\begin{array}{l}\text { Tuffaceous sedimentary rocks } \\
\& \text { tuffs }\end{array}$ & $\begin{array}{l}\text { EO16, } \\
\text { EO17 }\end{array}$ & 57,58 & $\begin{array}{l}\text { High Lava } \\
\text { Plains }\end{array}$ \\
\hline QTVm & $\begin{array}{l}\text { Pleistocene, } \\
\text { Pliocene, \& } \\
\text { Miocene? }\end{array}$ & Mafic vent deposits & $\mathrm{EO} 35$ & 73 & $\begin{array}{l}\text { Basin \& } \\
\text { Range }\end{array}$ \\
\hline Tat & $\begin{array}{l}\text { Pliocene \& } \\
\text { Miocene }\end{array}$ & Silicic ash-flow tuff & EO31 & 69 & $\begin{array}{l}\text { Basin \& } \\
\text { Range }\end{array}$ \\
\hline $\mathrm{Tb}$ & Miocene & Basalt & E07 & 48 & $\begin{array}{l}\text { Basin \& } \\
\text { Range } \\
\end{array}$ \\
\hline Tbaa & Miocene & Basaltic \& andesitic rocks & $\bar{R} 1, \overline{R 2}$ & 104,105 & $\begin{array}{l}\text { Cascade } \\
\text { Range } \\
\end{array}$ \\
\hline Tfc & Miocene & $\begin{array}{l}\text { Flows \& clastic rocks, } \\
\text { undifferentiated }\end{array}$ & LM22 & 22 & $\begin{array}{l}\text { Cascade } \\
\text { Range } \\
\end{array}$ \\
\hline Tfe & $\begin{array}{l}\text { Oligocene \& } \\
\text { Eocene }\end{array}$ & $\begin{array}{l}\text { Fisher \& Eugene Fms. \& } \\
\text { correlative rocks }\end{array}$ & $\mathrm{LC} 22$ & $\overline{45}$ & $\begin{array}{l}\text { Cascade } \\
\text { Range }\end{array}$ \\
\hline Tfee & $\begin{array}{l}\text { Oligocene \& } \\
\text { Eocene }\end{array}$ & Marine Eugene Fm. & LC2 & 24 & $\begin{array}{l}\text { Cascade } \\
\text { Range } \\
\end{array}$ \\
\hline Tmsc & Eocene & $\begin{array}{l}\text { Marine siltstone, sandstone \& } \\
\text { conglomerate }\end{array}$ & LC7 & 29 & Coast Range \\
\hline
\end{tabular}


Appendix 2: List of geologic units along with their associated soil sampling sites. The geologic units and their description are from Walker and MacLeod (1991). For location of the sampling sites, see Figure 5 (continued).

\begin{tabular}{|c|c|c|c|c|c|}
\hline $\begin{array}{l}\text { Geologic } \\
\text { Unit }\end{array}$ & Age & Description & Site \# & $\begin{array}{l}\text { Site }^{2} \\
\text { Location } \\
\text { \# in Fig. } \\
5\end{array}$ & $\begin{array}{l}\text { Physiographic } \\
\text { Province }\end{array}$ \\
\hline Tmsm & $\begin{array}{l}\text { Paleocene \& } \\
\text { Eocene }\end{array}$ & $\begin{array}{l}\text { Marine siltstone, sandstone \& } \\
\text { conglomerate }\end{array}$ & $\overline{\mathrm{LC5}}$ & 27 & Coast Range \\
\hline Tmss & Eocene & Marine sandstone and siltstone & $\begin{array}{l}\text { LC8, } \\
\text { LC21, } \\
\text { KL5 }\end{array}$ & $\begin{array}{l}30,44 \\
79\end{array}$ & Coast Range \\
\hline Tmv & Miocene & Mafic vent complexes & EO32 & 70 & $\begin{array}{l}\text { Cascade } \\
\text { Range } \\
\end{array}$ \\
\hline Tn & Eocene & Nonmarine sedimentary rocks & $\begin{array}{l}\text { R7, R8, } \\
\text { R9 }\end{array}$ & $\begin{array}{l}110,111 \\
112\end{array}$ & $\begin{array}{l}\text { Cascade } \\
\text { Range }\end{array}$ \\
\hline Tob & $\begin{array}{l}\text { Pliocene \& } \\
\text { Miocene }\end{array}$ & Olivine basalt & $\begin{array}{l}\text { EO12, } \\
\text { EO27 }\end{array}$ & 53,67 & $\begin{array}{l}\text { Basin \& } \\
\text { Range }\end{array}$ \\
\hline $\mathrm{Tp}$ & $\begin{array}{l}\text { Pliocene \& } \\
\text { Miocene }\end{array}$ & Basaltic \& andesitic ejecta & EO33 & 71 & $\begin{array}{l}\text { Basin \& } \\
\text { Range }\end{array}$ \\
\hline $\mathrm{Tpb}$ & Eocene & Porphyritic basalt & LC23 & 46 & Coast Range \\
\hline Tps & $\begin{array}{l}\text { Pliocene \& } \\
\text { Miocene }\end{array}$ & $\begin{array}{l}\text { Subaqueous pyroclastic rocks } \\
\text { of basaitic cinder cones }\end{array}$ & $\mathrm{EO} 34$ & 72 & $\begin{array}{l}\text { Basin \& } \\
\text { Range } \\
\end{array}$ \\
\hline Trb & $\begin{array}{l}\text { Pliocene \& } \\
\text { Miocene }\end{array}$ & $\begin{array}{l}\text { Ridge capping basalt \& } \\
\text { basaltic andesite }\end{array}$ & LM14 & 15 & $\begin{array}{l}\text { Cascade } \\
\text { Range }\end{array}$ \\
\hline Trh & $\begin{array}{l}\text { Pliocene \& } \\
\text { Miocene }\end{array}$ & Rhyolite \& dacite & $\mathrm{EO} 36$ & 74 & $\begin{array}{l}\text { Basin \& } \\
\text { Range }\end{array}$ \\
\hline TrPv & $\begin{array}{l}\text { Triassic \& } \\
\text { Permian } \\
\end{array}$ & Volcanic rocks & $\begin{array}{l}\text { KL19, } \\
\text { KL22 } \\
\end{array}$ & 93,96 & $\begin{array}{l}\text { Klamath } \\
\text { Mountains }\end{array}$ \\
\hline TrPzm & $\begin{array}{l}\text { Triassic or } \\
\text { Paleozoic }\end{array}$ & Melange of Dutchmans Peak & $\begin{array}{l}\text { KL24, } \\
\text { KL25 }\end{array}$ & 98,99 & $\begin{array}{l}\text { Klamath } \\
\text { Mountains }\end{array}$ \\
\hline TrPzS & $\begin{array}{l}\text { Triassic \& } \\
\text { Paleozoic }\end{array}$ & $\begin{array}{l}\text { Sedimentary rocks, partly } \\
\text { metamorphosed }\end{array}$ & $\begin{array}{l}\text { KL18, } \\
\text { KL20 }\end{array}$ & 92,94 & $\begin{array}{l}\text { Klamath } \\
\text { Mountains }\end{array}$ \\
\hline Ts & $\begin{array}{l}\text { Pliocene \& } \\
\text { Miocene }\end{array}$ & $\begin{array}{l}\text { Tuffaceous sedimentary rocks } \\
\text { \& tuff }\end{array}$ & $\begin{array}{l}\text { EO9, } \\
\text { EO11 }\end{array}$ & 50,52 & $\begin{array}{l}\text { Basin \& } \\
\text { Range }\end{array}$ \\
\hline Tsr & $\begin{array}{l}\text { Eocene \& } \\
\text { Paleocene }\end{array}$ & $\begin{array}{l}\text { Siletz River Volcanics \& } \\
\text { related rocks }\end{array}$ & $\begin{array}{l}\text { LC6, } \\
\text { LC10A, } \\
\text { LC19 }\end{array}$ & $\begin{array}{l}28,32 \\
42\end{array}$ & Coast Range \\
\hline Tss & Eocene & $\begin{array}{l}\text { Tuffaceous siltstone \& } \\
\text { sandstone }\end{array}$ & $\begin{array}{l}\text { LC15, } \\
\text { LC18 }\end{array}$ & 38,41 & Coast Range \\
\hline Tsv & $\begin{array}{l}\text { Pliocene, } \\
\text { Miocene \& } \\
\text { Oligocene }\end{array}$ & Silica vent complexes & LM20 & 20 & $\begin{array}{l}\text { Cascade } \\
\text { Range }\end{array}$ \\
\hline
\end{tabular}


Appendix 2: List of geologic units along with their associated soil sampling sites. The geologic units and their description are from Walker and MacLeod (1991). For location of the sampling sites, see Figure 5 (continued).

\begin{tabular}{|c|c|c|c|c|c|}
\hline $\begin{array}{l}\text { Geologic } \\
\text { Unit }\end{array}$ & Age & Description & Site \# & $\begin{array}{l}\text { Site }^{\mathrm{a}} \\
\text { Location } \\
\text { \# in Fig. } \\
5\end{array}$ & $\begin{array}{l}\text { Physiographic } \\
\text { Province }\end{array}$ \\
\hline$\overline{\mathrm{Tt}}$ & Eocene & $\begin{array}{l}\text { Tyee Fm. (marine sandstone \& } \\
\text { siltstone) }\end{array}$ & $\begin{array}{l}\mathrm{LC4}, \\
\mathrm{LCl} 2\end{array}$ & 26,35 & Coast Range \\
\hline $\mathrm{Tu}$ & $\begin{array}{l}\text { Miocene \& } \\
\text { Oligocene }\end{array}$ & $\begin{array}{l}\text { Undifferentiated tuffaceous } \\
\text { sedimentary rocks, tuffs, \& } \\
\text { basalt }\end{array}$ & LM8 & 9 & $\begin{array}{l}\text { Cascade } \\
\text { Range }\end{array}$ \\
\hline Tub & Oligocene & Basaltic lava flows & LM12 & 13 & $\begin{array}{l}\text { Cascade } \\
\text { Range } \\
\end{array}$ \\
\hline Tus & $\begin{array}{l}\text { Miocene \& } \\
\text { Oligocene }\end{array}$ & $\begin{array}{l}\text { Sedimentary \& volcaniclastic } \\
\text { rocks }\end{array}$ & $\begin{array}{l}\text { LM2, } \\
\text { LM3A, } \\
\text { LM13 }\end{array}$ & $2,3,14$ & $\begin{array}{l}\text { Cascade } \\
\text { Range }\end{array}$ \\
\hline Tut & $\begin{array}{l}\text { Miocene \& } \\
\text { Oligocene }\end{array}$ & Tuff & LM19 & 19 & $\begin{array}{l}\text { Cascade } \\
\text { Range }\end{array}$ \\
\hline Ty & Eocene & Yamhill Fm. \& related rocks & $\begin{array}{l}\text { LC9, } \\
\text { LCIOB }\end{array}$ & 31,33 & Coast Range \\
\hline
\end{tabular}

${ }^{a}$ Our site numbers were simplified into one set of numbers for Figure 5. These new numbers are given in this column and they appear in the same order as the site numbers.

* Site corresponds to physiographic province. 


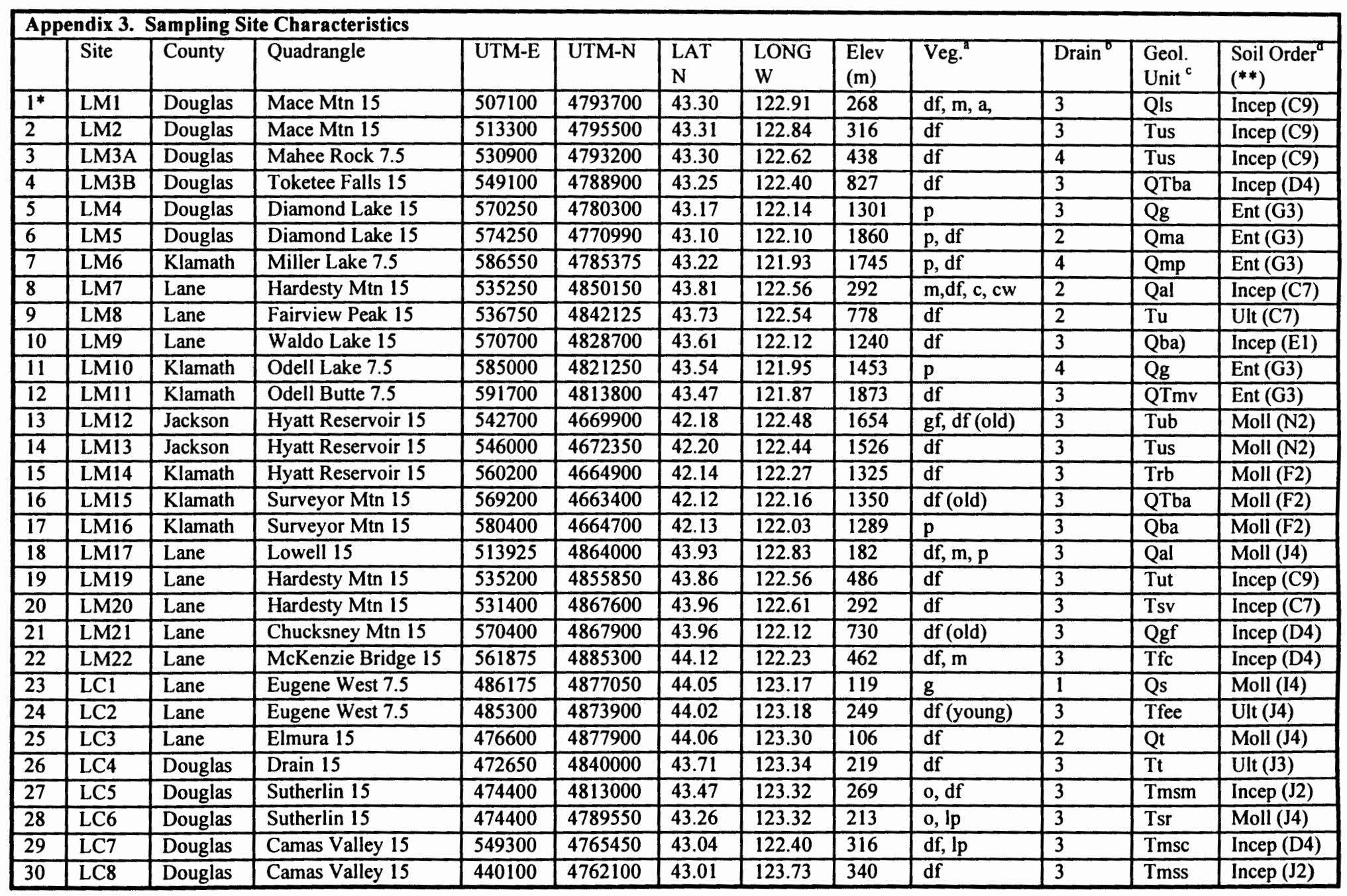




\begin{tabular}{|c|c|c|c|c|c|c|c|c|c|c|c|c|}
\hline & Site & County & Quadrangle & UTM-E & UTM-N & $\begin{array}{l}\text { LAT } \\
\mathrm{N}\end{array}$ & $\begin{array}{l}\text { LONG } \\
\text { W }\end{array}$ & $\begin{array}{l}\text { Elev } \\
.(\mathrm{m}) \\
\end{array}$ & Veg. & Drain & $\begin{array}{l}\text { Geol. } \\
\text { Unit }^{c}\end{array}$ & $\begin{array}{l}\text { Soil Order } \\
(* *)\end{array}$ \\
\hline 31 & LC9 & Douglas & Devils Graveyard 7.5 & 448625 & 4831700 & 43.64 & 123.64 & 134 & $\mathrm{df}, \mathrm{o}$ & 1 & Ty & Moll (I4) \\
\hline 32 & LC10A & Douglas & Sutherlin 15 & $4 8 \longdiv { 2 4 7 5 }$ & 4795800 & 43.32 & 123.22 & 182 & $\operatorname{lp}, \mathrm{f}, \mathrm{g}$ & 3 & Tsr & Uit (J4) \\
\hline 33 & $\mathrm{LC} 10 \mathrm{~B}$ & Douglas & Scottsburg 15 & 436800 & 4835330 & 43.67 & 123.78 & 24 & $\mathrm{~h}, \mathrm{c}$ & 3 & $\mathrm{Ty}$ & Ult (J3) \\
\hline 34 & LC11 & Douglas & Scottsburg 15 & 432600 & 4833000 & 43.65 & 123.84 & 0 & $w, m$ & 3 & Qal & Incep (C3) \\
\hline 35 & $\mathrm{LC12}$ & Douglas & Scottsburg 15 & 432700 & 4832950 & 43.65 & 123.83 & 24 & $m, f$ & 3 & $\mathrm{Tt}$ & Incep (C3) \\
\hline 36 & LC13 & Douglas & Reedsport 15 & 403250 & 4834800 & 43.66 & 124.20 & 0 & $\mathrm{mb}, \mathrm{sb}$ & 3 & $\overline{Q d}$ & Ent (A1) \\
\hline 37 & $\overline{\mathrm{LC14}}$ & Douglas & Reedsport 15 & 403675 & 4834500 & 43.66 & 124.19 & $\overline{0}$ & $\mathrm{df}, \mathrm{cs}, \mathrm{s}$ & 3 & Qd & Spodo (A1) \\
\hline 38 & LC15 & Coos & Reedsport 15 & 405450 & 4827250 & 43.59 & 124.17 & 24 & f, a & 3 & Tss & Incep (A2) \\
\hline 39 & $\overline{\mathrm{LC}} 16$ & Coos & Reedsport 15 & 404800 & 4827000 & 43.59 & 124.18 & 0 & f & 3 & $\mathrm{Qt}$ & Incep (?) \\
\hline 40 & LC17 & Coos & Cape Arago 7.5 & 388050 & 4797650 & 43.33 & 124.38 & 0 & $f($ old $)$ & 3 & $\overline{\mathrm{Qt}}$ & Ult (C3) \\
\hline 41 & $\overline{\mathrm{LC}} 18$ & Coos & Charleston 7.5 & 391150 & 4796850 & 43.32 & 124.34 & 109 & f(old) & 3 & Tss & Ult (C3) \\
\hline 42 & LC19 & Coos & Coquille 7.5 & 406530 & 4778150 & 43.15 & 124.15 & 27 & $f, m, a$ & 3 & Tsr & Uit (C3) \\
\hline 43 & LC20 & Coos & Bone Mtn 7.5 & 433180 & 4757150 & 42.97 & 123.82 & 170 & $\mathrm{a}, \mathrm{f}$ & 3 & $\overline{\text { Qls }}$ & Incep (C1) \\
\hline 44 & LC21 & Douglas & Bone Mtn 7.5 & 441500 & 4760700 & 43.00 & 123.72 & 334 & $\mathrm{f}, \mathrm{cs}$ & 3 & Tmss & Alf $(\mathrm{J} 2)$ \\
\hline 45 & LC22 & Lane & Fox Hollow 7.5 & 483970 & 4860480 & 43.90 & 123.20 & 489 & $f$ & 3 & $\mathrm{Tfe}$ & Ult (J4) \\
\hline 46 & LC23 & Lane & Heceta Head 15 & 414000 & 4891050 & 44.20 & 124.08 & 397 & $\mathrm{f}$ & 3 & $\mathrm{Tpb}$ & Incep (C1) \\
\hline 47 & $\mathrm{EO} 2$ & Deschutes & Lava Butte 7.5 & 631800 & 4862450 & 43.91 & 121.40 & 1368 & $\mathrm{p}$ & 4 & $\mathrm{Qb}$ & Incep (?) \\
\hline$\overline{48}$ & EO7 & Klamath & Swan Lake 15 & 619750 & 4694000 & 42.39 & 121.55 & 1398 & $p$ & 3 & $\mathrm{~Tb}$ & Moll (F2) \\
\hline$\overline{49}$ & $\overline{\mathrm{EO} 8}$ & Klamath & Swan Lake 15 & 610900 & 4696200 & 42.41 & 121.65 & 1885 & $f, p$ & 3 & QTb & Moll (F2) \\
\hline 50 & E09 & Klamath & Chiloquin 15 & 600600 & 4717150 & 42.60 & 121.77 & 1286 & p, br, g & 3 & Ts & Ent (G2) \\
\hline 51 & EO10 & Klamath & Culimus Butte 15 & 618400 & 4726600 & 42.68 & 121.55 & 1617 & $\mathrm{p}, \mathrm{br}$ & 3 & QTb & Ent (G2) \\
\hline$\overline{52}$ & E011 & Klamath & Klamath Marsh 15 & 620900 & 4738400 & 42.79 & 121.52 & 1447 & $p$ & 3 & Ts & Ent (G2) \\
\hline 53 & E012 & Klamath & Fuego Mtn 15 & 631900 & 4731150 & 42.72 & 121.39 & 1484 & $p$ & 4 & Tob & Ent (G2) \\
\hline$\overline{54}$ & EO13 & Klamath & Yamsay Mtn 15 & 625200 & 4759900 & 42.98 & 121.46 & 1423 & $p$ & 3 & QTs & Ent (G2) \\
\hline 55 & $\mathrm{E014}$ & Klamath & Lenz 15 & 597000 & $4 \overline{746950}$ & 42.87 & 121.81 & 1377 & $p$ & 3 & Qma & Incep (H1) \\
\hline$\overline{56}$ & E015 & Klamath & Odell Butte 7.5 & 599350 & 4812700 & 43.46 & 121.77 & 1392 & $p$ & 3 & Qs & Ent (G1) \\
\hline 57 & E016 & Deschutes & Firley Butte 7.5 & 630750 & 4839575 & 43.70 & 121.38 & 1435 & $\mathrm{p}$ & 3 & Q'Tst & Ent (G1) \\
\hline$\overline{58}$ & $\overline{E 017}$ & Deschutes & Paulina Peak 7.5 & 637000 & 4840100 & 43.70 & 121.30 & 1836 & $\mathrm{p}$ & 3 & QTst & Ent (G3) \\
\hline 59 & E018 & Deschutes & Davis Mtn 7.5 & 592350 & 4837800 & 43.69 & 121.85 & 1398 & $\mathrm{p}$ & 3 & QTba & Incep (G1) \\
\hline 60 & $\mathrm{EO} 20$ & Deschutes & Davis Mtn 7.5 & 598850 & 4830850 & 43.63 & 121.77 & 1824 & $f, p$ & 3 & QTmv & Ent (G1) \\
\hline
\end{tabular}




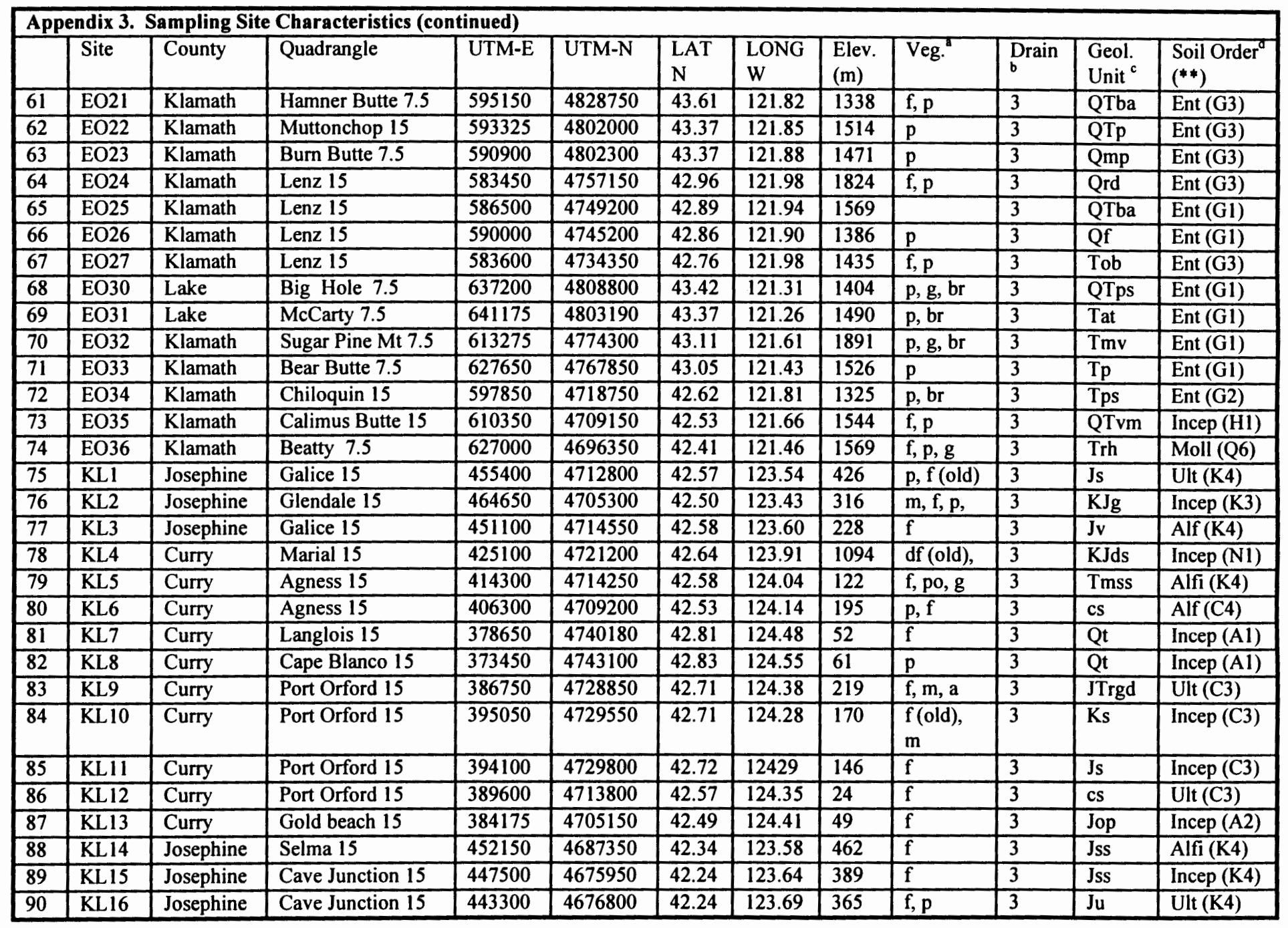




\begin{tabular}{|c|c|c|c|c|c|c|c|c|c|c|c|c|}
\hline & Site & County & Quadrangle & UTM-E & UTM-N & $\begin{array}{l}\text { LAT } \\
N\end{array}$ & $\begin{array}{l}\text { LONG } \\
\text { W }\end{array}$ & $\begin{array}{l}\text { Elev. } \\
\text { (m) }\end{array}$ & $\mathrm{Veg}^{2}$ & Drain $^{\circ}$ & Geol Unit $^{\circ}$ & $\begin{array}{l}\text { Soil Order } \\
\left({ }^{\circ *}\right)\end{array}$ \\
\hline 91 & $\overline{\mathrm{KL} 17}$ & Josephine & Cave Junction 15 & 452000 & 4655350 & 42.05 & 123.58 & 584 & $\bar{f}$ & 3 & $\mathrm{Jm}$ & Alf/Ult (K4) \\
\hline$\overline{92}$ & KL18 & Josephine & Oregon Caves 15 & 465750 & 4661100 & 42.10 & 123.41 & 1021 & f(old) & 3 & TrPzs & Alf $(\mathrm{K} 4)$ \\
\hline 93 & KL19 & Jackson & Ruch 15 & 482400 & 4669600 & 42.18 & 123.21 & 657 & $\mathrm{f}$ & 3 & $\overline{\operatorname{TrPv}}$ & Alf/Ult (K4) \\
\hline 94 & $\overline{\mathrm{KL} 20}$ & Josephine & Oregon Caves 15 & 475500 & 4653650 & 42.04 & 123.30 & 1386 & $\overline{f, p}$ & 3 & TrPzs & Incep (NI) \\
\hline 95 & KL21 & Jackson & Ruch 15 & 489000 & 4652250 & 42.02 & 123.13 & 657 & $f, p$ & 3 & $\mathrm{~cm}$ & Alf (K4) \\
\hline 96 & KL22 & Jackson & Ruch 15 & 495500 & 4662700 & 42.12 & 123.05 & $\overline{584}$ & $f, p$ & 3 & TrPv & Incep (K3) \\
\hline 97 & $\overline{\mathrm{KL} 23}$ & Josephine & Chetco Peak 15 & 430600 & 4655600 & 42.05 & 123.84 & 1143 & $\mathrm{f}, \mathrm{p}$ & $\overline{3}$ & JTrgd & Alf (K5) \\
\hline 98 & $\overline{K L 24}$ & Jackson & Talent 15 & 514000 & 4655250 & 42.05 & 122.83 & 2019 & f(old) & 3 & TrPzm & Alf $(\mathrm{N} 1)$ \\
\hline 99 & $\overline{K L 25}$ & Jackson & Talent 15 & 507350 & 4654250 & 42.04 & 122.91 & 1946 & $\mathrm{f}$ & 3 & TrPzm & Incep (N1) \\
\hline 100 & KL26 & Jackson & Ashland 15 & 523300 & 4658100 & 42.08 & 122.72 & 2043 & f & 3 & KJg & Incep (NI) \\
\hline 101 & KL27 & Jackson & Wimer 15 & 484000 & 4724200 & 42.67 & 123.20 & 778 & $\mathrm{f}$ & 3 & $\mathrm{Kc}$ & Alf/Ult (K4) \\
\hline 102 & KL28 & Jackson & Wimer 15 & 492200 & 4720500 & 42.64 & 123.10 & 754 & $\mathrm{f,p}$ & 3 & $\mathrm{mc}$ & Incep (K4) \\
\hline 103 & $\overline{K L} 30$ & Josephine & Galice 15 & 445600 & 4709150 & 42.53 & 123.66 & 745 & $0, f, p$ & 3 & bc & Alf $(\mathrm{K} 4)$ \\
\hline 104 & R1 & Lane & Waldo Lake 15 & 563400 & 4833650 & 43.66 & 122.21 & 803 & $\mathrm{df}(\mathrm{old})$ & 3 & Tbaa & Incep (D4) \\
\hline 105 & $\mathrm{R} 2$ & Lane & Waldo Lake 15 & 568550 & 4832300 & 43.64 & 122.15 & 1094 & $\mathrm{df}$ (old), vm & 3 & Tbaa & Incep (?) \\
\hline 106 & $\mathrm{R3}$ & Klamath & Pumice Desert 7.5 & 570480 & 4761300 & 43.00 & 122.14 & 1933 & $\mathrm{lp}, \mathrm{h}$ (old) & 3 & $\overline{Q a}$ & Incep (E1) \\
\hline 107 & $\overline{\mathrm{R} 4}$ & Klamath & Union Peak 7.5 & 570160 & 4746900 & 42.87 & 122.14 & 1885 & $\mathrm{~h}, \mathrm{lp}$ & 3 & $\mathrm{Qa}$ & Moll (G3) \\
\hline 108 & $\overline{\mathrm{R} 5}$ & Klamath & Lake $O^{\prime}$ Woods 15 & 572500 & 4698500 & 42.44 & 122.12 & 1277 & $\mathrm{pp}, \mathrm{df}(\mathrm{few})$ & 3 & QTp & Incep (F2) \\
\hline 109 & $\overline{R 6}$ & Klamath & Lake O' Woods 15 & 567500 & 4698800 & 42.44 & 122.18 & 1344 & $\mathrm{df}$ & 3 & QTp & Incep (F1) \\
\hline 110 & $\overline{\mathrm{R} 7}$ & Jackson & Trail 15 & 507250 & 4710500 & 42.55 & 122.91 & 456 & $\mathrm{md}, \mathrm{pp}, \mathrm{po}$ & 3 & Tn & Incep (K1) \\
\hline 111 & $\overline{\mathrm{R} 8}$ & Jackson & Medford 15 & 517000 & 4686400 & 42.33 & 122.79 & 608 & 0 & 2 & Tn & Vert (K1) \\
\hline 112 & R9 & Jackson & Medford 15 & 518130 & 4679550 & 42.27 & 122.78 & 547 & 0 & 3 & Tn & Incep (K1) \\
\hline 113 & $\bar{R} 10$ & Josephine & Grants Pass 15 & 471100 & 4688600 & 42.35 & 123.35 & 353 & md, po, pp & 3 & KJgu & Alf/Ult (K4) \\
\hline$\overline{114}$ & R11 & Josephine & Grants Pass 15 & 470900 & 4688150 & 42.35 & 123.35 & 353 & md, $p p, o$ & 3 & KJgu & Alf/Uit (K4) \\
\hline 115 & $\mathrm{R} 12$ & Josephine & Selma 15 & 452350 & 4687450 & 42.34 & 123.58 & 486 & $\mathrm{df}, \mathrm{md}, \mathrm{pi}$ & 3 & Jub & Incep (K4) \\
\hline 116 & $\mathrm{R} 13$ & Josephine & Wimer 15 & 480550 & 4721900 & 42.65 & 123.24 & 730 & df, md (few) & 3 & Jub & Alf/Ult (K4) \\
\hline 117 & R14 & Douglas & Canyonville 15 & 473700 & 4751400 & 42.92 & 123.32 & 340 & $\mathrm{df}, \mathrm{md}, \mathrm{pp}$ & 3 & $\mathrm{KJm}$ & Alf/Ult (K4) \\
\hline 118 & $\mathrm{R} 15$ & Douglas & Dixonville, 15 & 487100 & 4772500 & 43.11 & 123.16 & 271 & $\mathrm{df}, \mathrm{pp}, \mathrm{md}$ & 3 & $\mathrm{KJm}$ & Alf/Ult (K4) \\
\hline
\end{tabular}




\section{Appendix 3. Sampling Site Characteristics (continued)}

- $\quad$ Sampling Site Location \# in Figure 5.

** Soil Unit \# (from USDA, 1986) in Figure 3.

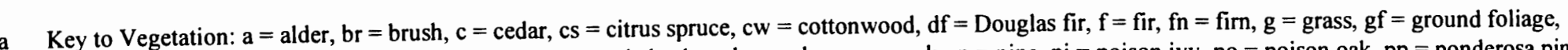

$\mathrm{h}=$ hemlock, $\mathrm{lp}=$ lodgepole pine, $\mathrm{m}=$ maple, $\mathrm{mb}=$ myrtle bush, $\mathrm{md}=$ madrone, $\mathrm{o}=\mathrm{oak}, \mathrm{p}=$ pine, $\mathrm{pi}=$ poison ivy, $\mathrm{po}=$ poison oak, $\mathrm{pp}=$ ponderosa pine, $\mathrm{s}=$ salal, $\mathrm{sb}=$ scotch broom, $\mathrm{vm}=$ vine maple, $\mathrm{w}=$ willow .

b Key to Drainage: $1=$ poorly drained, $2=$ moderately drained, $3=$ well drained, $4=$ very well drained.

c For description of geologic units see Appendix 2.

d Soil Orders from USDA (1986). These are in agreement with the respective soil characteristics listed in Appendix 4. Without data on base saturation (determination of which is beyond the scope of this study) distinction between Alfisols and Ultisols was not possible.

Note: Field inventory sheets of all sites except R1-R15 were from Bill Douglas (M.S. Geology student, Portland State University). 


\begin{tabular}{|c|c|c|c|c|c|c|c|c|}
\hline $\begin{array}{l}\text { Sample } \\
\text { number }\end{array}$ & $\begin{array}{l}\text { Hori- } \\
\text { zon }\end{array}$ & $\begin{array}{l}\text { Depth } \\
(\mathrm{cm})\end{array}$ & $\begin{array}{l}\text { Color } \\
\text { (dry) }\end{array}$ & $\begin{array}{l}\text { Color } \\
\text { (wet) }\end{array}$ & Texture & $\begin{array}{l}\text { Clay \% } \\
\text { (approx.) }\end{array}$ & Structure & $\mathrm{pH}$ \\
\hline LM1 & $\mathrm{A}$ & $0-8$ & 10 YR 4/3 & 10 YR $2 / 2$ & $\overline{\mathrm{SCL}}$ & 15 & $1 \mathrm{~m}, \mathrm{f}, \mathrm{sbk}$ & 5.9 \\
\hline LM1 & $\overline{B w}$ & $8-30+$ & 10 YR $5 / 4$ & $10 \mathrm{YR} 3 / 4$ & $\overline{\mathrm{SCL}}$ & 15 & $\mathrm{~lm}, \mathrm{f}, \mathrm{sbk}$ & 5.9 \\
\hline LM2 & $\mathrm{A}$ & $0-10$ & $10 \mathrm{YR} 4 / 2$ & $10 \mathrm{YR} 2 / 2$ & SL & 8 & $1 \mathrm{~m}, \mathrm{f}, \mathrm{sbk}$ & 6.1 \\
\hline$\overline{\mathrm{LM} 2}$ & $\overline{\mathrm{Bw}}$ & $10-25+$ & 10 YR $5 / 3$ & $10 \mathrm{YR} 3 / 3$ & $\overline{\mathrm{SL}}$ & 8 & $1 \mathrm{~m}, \mathrm{f}, \mathrm{sbk}$ & 6.0 \\
\hline LM3A & $\mathrm{A}$ & $0-15$ & $10 \mathrm{YR} .3 / 2$ & 10 YR. $2 / 2$ & $\mathrm{~S}$ & 0 & $\mathrm{sg}, \mathrm{f}, \mathrm{gr}$ & 5.4 \\
\hline LM3A & $\overline{B w}$ & $15-40+$ & 10 YR. $7 / 3$ & 10 YR. $5 / 4$ & $\mathrm{~S}$ & 0 & $\mathrm{sg}, \mathrm{f}, \mathrm{gr}$ & 6.3 \\
\hline LM3B & $\mathrm{A}$ & $0-3$ & 10 YR. $5 / 4$ & 10 YR. $3 / 3$ & $\mathrm{~S}$ & $<2$ & $\operatorname{lm}, \mathrm{f}, \mathrm{gr}$ & 6.6 \\
\hline LM3B & $\overline{B w}$ & $3-25+$ & 10 YR. $6 / 4$ & 10 YR. $4 / 4$ & $\overline{L S}$ & $<2$ & $\operatorname{lm}, \mathrm{f}, \mathrm{gr}$ & $\overline{6.3}$ \\
\hline LM4 & $\mathrm{A}$ & $0-4$ & $2.5 Y 4 / 3$ & $2.5 \mathrm{Y} 2.5 / 1$ & $\overline{\mathrm{LS}}$ & $<2$ & $\operatorname{lm}, \mathrm{f}, \mathrm{gr}$ & $\overline{4.8}$ \\
\hline LM4 & Bwj & $4-25$ & $2.5 \mathrm{Y} 6 / 4$ & 2.5 Y $3.5 / 2$ & LS & $<2$ & $\mathrm{~lm}, \mathrm{f}-\mathrm{m}, \mathrm{gr}$ & 5.6 \\
\hline$\overline{\text { LM5 }}$ & $\mathrm{A}$ & $0-3$ & 10 YR $3 / 2$ & 10 YR $2 / 2$ & LS & $<2$ & $\mathrm{~lm}, \mathrm{vf}, \mathrm{gr}$ & 4.0 \\
\hline LM5 & $\overline{B w j}$ & $3-20$ & 10 YR $6 / 4$ & $10 \mathrm{YR} 4 / 4$ & $\overline{\mathrm{LS}}$ & $<2$ & $1 \mathrm{~m}, \mathrm{f}, \mathrm{gr}$ & 5.7 \\
\hline LM6 & $\mathrm{A}$ & $0-2$ & $2.5 \mathrm{Y} 4 / 3$ & $2.5 \mathrm{Y} 3 / 2$ & LS & 0 & $\mathrm{sg}, \mathrm{f}, \mathrm{gr}$ & 4.7 \\
\hline$\overline{\mathrm{LM}}$ & $\overline{B w j}$ & $2-20$ & $2.5 Y 7 / 4$ & $2.5 Y 5 / 6$ & $\bar{S}$ & 0 & $\mathrm{sg}, \mathrm{m}, \mathrm{gr}$ & 5.8 \\
\hline LM7 & $\mathrm{A}$ & $0-8$ & $2.5 \mathrm{Y} 4 / 3$ & $2.5 \mathrm{Y} 3 / 3$ & $\overline{\mathrm{SL}}$ & 5 & $1 \mathrm{~m}, \mathrm{f}, \mathrm{sbk}$ & 6.1 \\
\hline$\overline{\mathrm{LM} 7}$ & $\bar{C}$ & $8-30+$ & $2.5 Y 5 / 3$ & $2.5 Y 3 / 3$ & $\overline{S L}$ & 5 & $1 \mathrm{~m}, \mathrm{f}, \mathrm{gr}$ & 6.0 \\
\hline LM8 & $\mathrm{A}$ & $0-6$ & $10 \mathrm{YR} 3 / 2$ & $10 Y \mathrm{YR} 2 / 2$ & SCL & 20 & $2 \mathrm{~m}, \mathrm{f}, \mathrm{sbk}$ & 5.9 \\
\hline LM8 & $\mathrm{Bt}$ & $6-20+$ & 10 YR $4 / 4$ & $10 \mathrm{YR} 3 / 4$ & $\mathrm{SCL}$ & 30 & $2 m, f, s b k$ & 4.8 \\
\hline LM9 & A & 0.8 & $10 \mathrm{YR} 3 / 2$ & 10 YR $2 / 2$ & LS & $<2$ & $1 \mathrm{~m}, \mathrm{f}, \mathrm{gr}$ & 4.5 \\
\hline LM9 & $\overline{\mathrm{Bwj}}$ & $8-25$ & 10 YR $6 / 3$ & 10 YR 4/3 & $\overline{L S}$ & $<2$ & $\operatorname{lm}, \mathrm{f}, \mathrm{gr}$ & 5.3 \\
\hline LM10 & $\mathrm{A}$ & $0-1$ & $10 \mathrm{YR} \mathrm{4/2}$ & 10 YR $2 / 2$ & $\mathrm{~S}$ & $<1$ & $1 \mathrm{~m}, \mathrm{f}, \mathrm{gr}$ & 4.9 \\
\hline LM10 & $\overline{\mathrm{Bwj}}$ & $1-20$ & $10 \mathrm{YR} 6 / 4$ & 10 YR 4/4 & $S$ & $<1$ & $1 \mathrm{~m}, \mathrm{~m}-\mathrm{c}, \mathrm{gr}$ & 5.8 \\
\hline LM11 & $\mathrm{A}$ & $0-6$ & 10 YR $3 / 2$ & $10 \mathrm{YR} 2 / 2$ & $\overline{\mathrm{S}}$ & $<1$ & $\mathrm{sg}, \mathrm{f}-\mathrm{m}, \mathrm{gr}$ & 4.8 \\
\hline LM11 & Bwj & $6-18$ & 10 YR $6 / 4$ & $10 \mathrm{YR} \mathrm{4/4}$ & $\bar{S}$ & $<1$ & $\mathrm{sg}, \mathrm{m}-\mathrm{c}, \mathrm{gr}$ & 5.6 \\
\hline LM12 & $\mathrm{A}$ & $0-10$ & $10 \mathrm{YR} 3 / 2$ & $10 \mathrm{YR} 2 / 1$ & $\overline{\mathrm{LS}}$ & 8 & $1 \mathrm{~m}, \mathrm{f}, \mathrm{sbk}$ & 5.9 \\
\hline LM12 & $\overline{\mathrm{Bw}}$ & $10-40+$ & $10 Y R 3 / 3$ & $10 \mathrm{YR} 2 / 1$ & $\overline{\mathrm{LS}}$ & 8 & $1 \mathrm{~m}, \mathrm{f}, \mathrm{sbk}$ & 6.2 \\
\hline LM13 & $\mathrm{A}$ & $0-8$ & $10 \mathrm{YR} 3 / 2$ & $10 \mathrm{YR} 2 / 2$ & $\mathrm{~L}$ & 12 & $1 \mathrm{~m}, \mathrm{f}, \mathrm{sbk}$ & 6.2 \\
\hline LM13 & $\overline{\mathrm{Bw}}$ & $8-35+$ & 10 YR 4/4 & $10 \mathrm{YR} 3 / 3$ & $\mathrm{~L}$ & 12 & $1 \mathrm{~m}, \mathrm{f}, \mathrm{sbk}$ & 5.6 \\
\hline LM14 & $\mathrm{A}$ & $0-8$ & $7.5 \mathrm{YR} 3 / 2$ & 7.5 YR $2 / 1$ & $\mathrm{~L}$ & 10 & $1 \mathrm{~m}, \mathrm{f}, \mathrm{sbk}$ & 6.6 \\
\hline LM14 & $\mathrm{Bw}$ & $8-30+$ & 7.5 YR 4/4 & 7.5 YR $3 / 3$ & $\bar{L}$ & 10 & $1 \mathrm{~m}, \mathrm{f}, \mathrm{sbk}$ & 6.4 \\
\hline LM15 & $\bar{A}$ & $0-15$ & $10 \mathrm{YR} 4 / 4$ & $10 \mathrm{YR} 3 / 3$ & $\overline{S L}$ & 8 & $1 \mathrm{~m}, \mathrm{f}, \mathrm{sbk}$ & 6.2 \\
\hline LM15 & $\mathrm{Bt}$ & $15-30+$ & $7.5 \mathrm{YR} \mathrm{4/4}$ & $7.5 \mathrm{YR} 3 / 3$ & $\mathrm{SCL}$ & 30 & $2 \mathrm{~m}, \mathrm{vf}, \mathrm{sbk}$ & 6.6 \\
\hline LM16 & $\mathrm{A}$ & $0-8$ & 10 YR. $4 / 3$ & 10 YR. $3 / 3$ & $\mathrm{~L}$ & 8 & $1 \mathrm{~m}, \mathrm{f}, \mathrm{sbk}$ & 5.3 \\
\hline LM16 & $\overline{\mathrm{Bt}}$ & $8-25+$ & 10 YR. $4 / 3$ & 10 YR. $3 / 3$ & $\mathrm{~L}$ & 15 & $1 \mathrm{~m}, \mathrm{f}, \mathrm{sbk}$ & 6.0 \\
\hline LM17 & $\bar{A}$ & $0-10$ & $10 \mathrm{YR} 4 / 3$ & $10 \mathrm{YR} 2 / 2$ & $\overline{\mathrm{SiL}}$ & 8 & $1 \mathrm{~m}, \mathrm{f}, \mathrm{sbk}$ & 6.8 \\
\hline LM17 & Bw & $10-35+$ & 10 YR $5 / 4$ & $10 \mathrm{YR} 3 / 2$ & SiL & 8 & $1 \mathrm{~m}, \mathrm{f}, \mathrm{sbk}$ & $\overline{6.4}$ \\
\hline LM19 & $\mathrm{A}$ & $0-5$ & $2.5 \mathrm{Y} \mathrm{4/2}$ & $2.5 \overline{Y 2.5 / 1}$ & $\mathrm{~L}$ & 8 & $1 \mathrm{~m}, \mathrm{f}, \mathrm{sbk}$ & 5.5 \\
\hline LM19 & $\mathrm{Bw}$ & $5-30+$ & $2.5 \mathrm{Y} 5 / 3$ & $2.5 \mathrm{Y} 3 / 2$ & $\mathrm{~L}$ & 8 & $1 \mathrm{~m}, \mathrm{f}, \mathrm{sbk}$ & 5.6 \\
\hline LM20 & $\bar{A}$ & $0-7$ & \multicolumn{2}{|c|}{ color not determined - } & $\mathrm{L}$ & 10 & $1 \mathrm{~m}, \mathrm{f}, \mathrm{sbk}$ & 5.3 \\
\hline LM20 & $\mathrm{Bw}$ & $7-30+$ & \multicolumn{2}{|c|}{ sample lost from lab } & SiL & 10 & $1 \mathrm{~m}, \mathrm{f}, \mathrm{sbk}$ & 5.6 \\
\hline LM21 & $\mathrm{A}$ & $0-4$ & $10 \mathrm{YR} 4 / 3$ & $10 \mathrm{YR} 3 / 2$ & $\mathrm{SL}$ & 5 & $1 \mathrm{~m}, \mathrm{f}, \mathrm{sbk}$ & 5.4 \\
\hline LM21 & $\overline{\mathrm{Bw}}$ & $4-30+$ & 10 YR $5 / 4$ & $10 \mathrm{YR} 4 / 3$ & $\mathrm{SL}$ & 5 & $1 \mathrm{~m}, \mathrm{f}, \mathrm{sbk}$ & 5.6 \\
\hline LM22 & $\mathrm{A}$ & $0-10$ & $10 \mathrm{YR} 3 / 2$ & $10 \mathrm{YR} 2 / 1$ & $\mathrm{SL}$ & 5 & $1 \mathrm{~m}, \mathrm{f}, \mathrm{sbk}$ & 5.4 \\
\hline LM22 & $\overline{\mathrm{Bw}}$ & $10-30+$ & 10 YR $6 / 4$ & 10 YR 3/3 & $\mathrm{SL}$ & 5 & $1 \mathrm{~m}, \mathrm{f}, \mathrm{sbk}$ & 5.6 \\
\hline $\mathrm{LCl}$ & $\mathrm{A}$ & $0-6$ & $2.5 \mathrm{Y} 5 / 2$ & $2.5 \mathrm{Y} 3 / 2$ & $\mathrm{C}$ & $>70$ & $1 \mathrm{~m}, \mathrm{vf}, \mathrm{sbk}$ & 5.3 \\
\hline
\end{tabular}




\begin{tabular}{|c|c|c|c|c|c|c|c|c|}
\hline \multicolumn{9}{|c|}{ Appendix 4.2. Selected physical and morphological properties of the soils studied } \\
\hline $\begin{array}{l}\text { Sample } \\
\# \\
\end{array}$ & $\begin{array}{l}\text { Hori- } \\
\text { zon }\end{array}$ & $\begin{array}{l}\text { Depth } \\
\text { (cm) }\end{array}$ & $\begin{array}{l}\text { Color } \\
\text { (dry) }\end{array}$ & $\begin{array}{l}\text { Color } \\
\text { (wet) }\end{array}$ & Texture & $\begin{array}{l}\text { Clay \% } \\
\text { (approx.) }\end{array}$ & Structure & $\overline{\mathrm{pH}}$ \\
\hline$\overline{\mathrm{LCl}}$ & $\mathrm{Bg}$ & $6-10+$ & $2.5 \mathrm{Y} 5 / 2$ & $2.5 \mathrm{Y} 3 / 2$ & $\bar{C}$ & 70 & $1 \mathrm{~m}, \mathrm{vf}, \mathrm{sbk}$ & 5.1 \\
\hline$\overline{\mathrm{LC} 2}$ & A & $0-7$ & $7.5 \mathrm{YR} 3 / 3$ & $7.5 \mathrm{YR} \mathrm{3/2}$ & $\overline{\mathrm{SCL}}$ & 30 & $1 \mathrm{~m}, \mathrm{f}, \mathrm{gr}$ & 5.5 \\
\hline$\overline{\mathrm{LC} 2}$ & $\overline{\mathrm{Bt}}$ & $7-28+$ & 7.5 YR $5 / 8$ & 7.5 YR 4/6 & $\overline{\mathrm{SCL}}$ & 40 & $2 \mathrm{~m}, \mathrm{f}, \mathrm{sbk}$ & 4.6 \\
\hline$\overline{L C 3}$ & $\overline{\mathrm{A}}$ & $0-16$ & $2.5 Y 5 / 3$ & 2.5 Y $2.5 / 2$ & $\overline{\mathrm{SL}}$ & 12 & $1 \mathrm{~m}, \mathrm{f}, \mathrm{sbk}$ & 5.5 \\
\hline$\overline{\mathrm{LC} 3}$ & $\overline{\mathrm{Bw}}$ & $16-22+$ & $2.5 Y 6 / 4$ & $2.5 \mathrm{Y} 4.5 / 4$ & $\overline{\mathrm{SL}}$ & 12 & $1 \mathrm{~m}, \mathrm{f}, \mathrm{sbk}$ & 4.8 \\
\hline$\overline{\mathrm{LC} 4}$ & $\mathrm{~A}$ & $0-20$ & 10 YR 5/4 & 10 YR 3/3 & $\overline{\mathrm{SL}}$ & 8 & $1 \mathrm{~m}, \mathrm{f}, \mathrm{sbk}$ & 5.7 \\
\hline LC4 & $\overline{\mathrm{Bt}}$ & $20-40+$ & 10 YR $5 / 4$ & 10 YR $3 / 4$ & $\overline{\mathrm{SCL}}$ & 15 & $1 \mathrm{~m}, \mathrm{f}, \mathrm{sbk}$ & 5.0 \\
\hline LC5 & $\mathrm{A}$ & $0-1$ & $2.5 \mathrm{Y} 4.5 / 4$ & $2.5 \mathrm{Y} 3 / 3$ & SiSL & 5 & $1 \mathrm{~m}, \mathrm{vf}, \mathrm{sbk}$ & 6.2 \\
\hline LC5 & $\overline{B w}$ & $1-28$ & 2.5 Y 5/4 & $2.5 \mathrm{Y} \mathrm{3/3}$ & $\overline{\text { SiSL }}$ & 5 & lm, vf, sbk & $\overline{6.4}$ \\
\hline LC6 & $\mathrm{A}$ & $0-10$ & $10 \mathrm{YR} 4 / 4$ & 10 YR $2 / 2$ & $\mathrm{SL}$ & 8 & $1 \mathrm{~m}, \mathrm{f}, \mathrm{sbk}$ & 6.0 \\
\hline LC6 & $\mathrm{Bw}$ & $10-28$ & 10 YR 4/4 & $10 \mathrm{YR} 3 / 3$ & $\overline{\mathrm{SL}}$ & 8 & $1 \mathrm{~m}, \mathrm{f}, \mathrm{sbk}$ & 6.2 \\
\hline LC7 & $A$ & $0-10$ & 10 YR 4/4 & 10 YR $3 / 3$ & $\overline{\mathrm{SiS}}$ & $\overline{<2}$ & $1 \mathrm{~m}, \mathrm{f}, \mathrm{gr}$ & 5.7 \\
\hline$\overline{\mathrm{LC} 7}$ & $\mathrm{Bw}$ & $10-25+$ & 10 YR $6 / 4$ & 10 YR 4/4 & $\overline{\text { SiS }}$ & $\overline{<2}$ & $\mathrm{~lm}, \mathrm{f}, \mathrm{gr}$ & $\overline{5.1}$ \\
\hline LC8 & $\mathrm{A}$ & $0-5$ & $10 \mathrm{YR} 4 / 2$ & $10 \mathrm{YR} 3 / 2$ & $\overline{\text { SSiL }}$ & 5 & $1 \mathrm{~m}, \mathrm{f}, \mathrm{sbk}$ & 5.7 \\
\hline$\overline{\mathrm{LC} 8}$ & $\overline{B w}$ & $5-30+$ & 10 YR $6 / 4$ & $10 \mathrm{YR} 3 / 3$ & $\overline{\text { SSiL }}$ & 5 & lm, f, sbk & $\overline{5.3}$ \\
\hline LC9 & $\mathrm{A}$ & $0-10$ & 1.5 Y $5.5 / 4$ & $1.5 \mathrm{Y} 4 / 3$ & $\overline{\mathrm{SCL}}$ & 8 & $1 \mathrm{~m}, \mathrm{f}, \mathrm{sbk}$ & 5.3 \\
\hline LC9 & $\overline{\mathrm{Bw}}$ & $10-25+$ & $1.5 \mathrm{Y} 6 / 6$ & $1.5 Y 5 / 4$ & $\overline{\mathrm{SCL}}$ & 8 & $1 \mathrm{~m}, \mathrm{f}, \mathrm{sbk}$ & 5.0 \\
\hline$\overline{\mathrm{LC} 10 \mathrm{~A}}$ & $\bar{A}$ & $0-5$ & 10 YR. $4 / 2$ & 10 YR. $3 / 2$ & $\overline{\mathrm{SCL}}$ & 15 & $\mathrm{~lm}, \mathrm{~m}, \mathrm{sbk}$ & $\overline{5.4}$ \\
\hline$\overline{\mathrm{LC} 10 \mathrm{~A}}$ & $\overline{\mathrm{Bt}}$ & $5-25$ & 10 YR. $4 / 3$ & 10 YR. $3 / 3$ & $\overline{\mathrm{SCL}}$ & 20 & $1 \mathrm{~m}, \mathrm{c}, \mathrm{sbk}$ & 5.8 \\
\hline$\overline{\mathrm{LC} 10 \mathrm{~B}}$ & $\mathrm{~A}$ & $\overline{0-6}$ & 10 YR. $4 / 4$ & 10 YR. $2 / 3$ & $\overline{\mathrm{SiCL}}$ & 30 & $\mathrm{~lm}, \mathrm{f}, \mathrm{cpr}$ & $\overline{5.6}$ \\
\hline$\overline{\mathrm{LC} 10 \mathrm{~B}}$ & $\overline{\mathrm{Bt}}$ & $6-14+$ & 10 YR. 4/4 & $7.5 Y R .3 / 3$ & $\overline{\mathrm{SiCL}}$ & 40 & $\operatorname{lm}, \mathrm{f}, \mathrm{sbk}$ & 5.4 \\
\hline $\mathrm{LC11}$ & $\overline{\mathrm{A}}$ & $0-4$ & 10 YR 5/4 & 10 YR 4/3 & $\mathrm{SL}$ & 10 & $\mathrm{~lm}, \mathrm{~m}, \mathrm{sbk}$ & 5.9 \\
\hline$\overline{\mathrm{LC} 11}$ & $\mathrm{Bw}$ & $4-12+$ & $10 \mathrm{YR} \mathrm{4/3}$ & $10 \mathrm{YR} 3 / 2$ & LS & 1 & $1 \mathrm{~m}, \mathrm{vc}, \mathrm{gr}$ & 5.8 \\
\hline$\overline{\mathrm{LC} 12}$ & $\mathrm{~A}$ & $0-4$ & $1.5 \mathrm{Y} 4 / 3$ & $1.5 \mathrm{Y} 2.5 / 2$ & $\overline{\mathrm{LS}}$ & 1 & $1 \mathrm{~m}, \mathrm{f}, \mathrm{sbk}$ & 6.0 \\
\hline$\overline{\mathrm{LC} 12}$ & $\mathrm{Bt}$ & $4-15+$ & $10 \mathrm{YR} 5 / 4$ & 10 YR $3 / 3$ & $\overline{\mathrm{SL}}$ & 15 & $1 \mathrm{~m}, \mathrm{f}, \mathrm{sbk}$ & 5.7 \\
\hline$\overline{\mathrm{LC} 13}$ & $\overline{\mathrm{A}}$ & $0-2$ & $2.5 \mathrm{Y} 5 / 2$ & $2.5 \mathrm{Y} 4 / 2$ & $S$ & 0 & $\mathrm{sg}, \mathrm{m}, \mathrm{gr}$ & 5.1 \\
\hline$\overline{\mathrm{LC} 13}$ & C & $2-20+$ & $2.5 \mathrm{Y} \mathrm{7/4}$ & $2.5 Y 5.5 / 4$ & $\mathrm{~S}$ & 0 & $\mathrm{sg}, \mathrm{m}, \mathrm{gr}$ & 5.4 \\
\hline$\overline{\mathrm{LC} 14}$ & $\bar{A}$ & $0-5$ & $10 \mathrm{YR} \mathrm{4/1}$ & $10 \mathrm{YR} 3 / 1$ & $\overline{\mathrm{LS}}$ & 7 & $1 \mathrm{~m}, \mathrm{f}, \mathrm{gr}$ & 4.0 \\
\hline LC14 & $E^{* *}$ & $5-50$ & & & $\overline{L S}$ & $<7$ & $1 \mathrm{~m}, \mathrm{f}, \mathrm{gr}$ & \\
\hline$\overline{\mathrm{LC14}}$ & $\mathrm{Bw}$ & $50-80+$ & 10 YR $6 / 7$ & 10 YR 5/6 & $\overline{\mathrm{LS}}$ & 7 & $1 \mathrm{~m}, \mathrm{f}, \mathrm{gr}$ & 5.5 \\
\hline LC15 & $\mathrm{A}$ & $0-10$ & $10 \mathrm{YR} 3 / 2$ & $10 \mathrm{YR} 4 / 4$ & $\mathrm{SL}$ & 10 & $1 \mathrm{~m}, \mathrm{f}, \mathrm{sbk}$ & 4.1 \\
\hline LC15 & $\mathrm{Bw}$ & $10-80+$ & $10 \mathrm{YR} 4 / 4$ & $10 \mathrm{YR} 3 / 3$ & $\overline{\mathrm{SL}}$ & 10 & $1 \mathrm{~m}, \mathrm{f}, \mathrm{sbk}$ & 4.9 \\
\hline LC16 & $\mathrm{A}^{*}$ & $0-5$ & color not de & rmined - & $S$ & $<1$ & $\mathrm{sg}, \mathrm{f}-\mathrm{m}, \mathrm{gr}$ & 4.0 \\
\hline$\overline{\mathrm{LC} 16}$ & $\overline{B w j}$ & $5-40+$ & sample lost & om lab & $\bar{S}$ & 0 & $\mathrm{sg}, \mathrm{f}-\mathrm{m}, \mathrm{gr}$ & 5.3 \\
\hline LC17 & $\mathrm{A}^{*}$ & $0-8$ & 10 YR $3 / 2$ & $10 \mathrm{YR} 2 / 2$ & SL & 10 & $1 \mathrm{~m}, \mathrm{f}, \mathrm{sbk}$ & 4.1 \\
\hline$\overline{\mathrm{LC} 17}$ & $\overline{\mathrm{Bt}}$ & $8-30+$ & 10 YR 5/4 & $10 \mathrm{YR} 3 / 3$ & SCL & 25 & $1 \mathrm{~m}, \mathrm{~m}, \mathrm{sbk}$ & 4.9 \\
\hline LC18 & $\bar{A}$ & $0-30$ & $10 \mathrm{YR} 3 / 2$ & $10 Y \mathrm{YR} 2 / 2$ & $\mathrm{SL}$ & 1 & $1 \mathrm{~m}, \mathrm{f}, \mathrm{sbk}$ & 4.0 \\
\hline LC18 & $\overline{\mathrm{Bt}}$ & $30-50+$ & 10 YR 4/4 & $10 Y R 3 / 2$ & $\overline{\mathrm{SCL}}$ & 25 & $2 m, f, s b k$ & 4.8 \\
\hline LC19 & $\bar{A}$ & $0-15$ & $10 Y \mathrm{YR} 4 / 4$ & 10 YR $3 / 3$ & $\overline{\mathrm{SiCl}}$ & 25 & $1 \mathrm{~m}, \mathrm{f}, \mathrm{sbk}$ & 5.7 \\
\hline LC19 & $\overline{\mathrm{Bt}}$ & $15-95+$ & $10 \mathrm{YR} 4 / 4$ & $10 \mathrm{YR} 3 / 3$ & $\overline{\mathrm{SiCL}}$ & 35 & $2 m, f, s b k$ & 5.0 \\
\hline LC20 & $\mathrm{A}$ & $0-2$ & $10 \mathrm{YR} 4 / 2$ & $10 \mathrm{YR} 3 / 2$ & $\mathrm{SL}$ & 18 & $1 \mathrm{~m}, \mathrm{f}, \mathrm{sbk}$ & 5.8 \\
\hline LC20 & $\mathrm{Bw}$ & $2-20+$ & $10 \mathrm{YR} 4 / 3$ & 10 YR $3 / 2$ & $\overline{\mathrm{SL}}$ & 18 & $1 \mathrm{~m}, \mathrm{f}, \mathrm{sbk}$ & 5.8 \\
\hline LC21 & $\mathrm{A}$ & $0-3$ & 7.5 YR 4/4 & 7.5 YR $2 / 2$ & $\overline{S L}$ & 10 & $1 \mathrm{~m}, \mathrm{f}, \mathrm{sbk}$ & 5.8 \\
\hline LC21 & $\mathrm{Bt}$ & $3-50+$ & 7.5 YR 5/8 & 7.5 YR 4/6 & $\overline{\mathrm{SCL}}$ & 25 & $2 \mathrm{~m}, \mathrm{f}, \mathrm{sbk}$ & 5.1 \\
\hline LC22 & $\mathrm{A}$ & $0-5$ & 6.5 YR 4/4 & $6.5 \mathrm{YR} 3 / 3$ & $\overline{\mathrm{CL}}$ & 20 & $1 \mathrm{~m}, \mathrm{vf}, \mathrm{sbk}$ & 5.9 \\
\hline
\end{tabular}


182

\begin{tabular}{|c|c|c|c|c|c|c|c|c|}
\hline $\begin{array}{l}\text { Sample } \\
\text { \# }\end{array}$ & $\begin{array}{l}\text { Hori- } \\
\text { zon }\end{array}$ & $\begin{array}{l}\text { Depth } \\
\text { (cm) }\end{array}$ & $\begin{array}{l}\text { Color } \\
\text { (dry) }\end{array}$ & $\begin{array}{l}\text { Color } \\
\text { (wet) }\end{array}$ & Texture & $\begin{array}{l}\text { Clay \% } \\
\text { (approx.) }\end{array}$ & Structure & $\mathrm{pH}$ \\
\hline $\mathrm{LC} 22$ & $\mathrm{Bt}$ & $5-30+$ & $4 \mathrm{YR} 4 / 4$ & $4 \mathrm{YR} 3 / 3$ & $\mathrm{CL}$ & $>20$ & $2 \mathrm{~m}, \mathrm{vf}, \mathrm{sbk}$ & 5.3 \\
\hline LC 23 & $\bar{A}$ & $0-4$ & 7.5 YR $4 / 4$ & 7.5 YR $3 / 3$ & $\overline{\mathrm{SiCL}}$ & 15 & $1 \mathrm{~m}, \mathrm{f}, \mathrm{sbk}$ & $\overline{5.2}$ \\
\hline LC23 & $\overline{B w}$ & $4-25+$ & $6.5 \mathrm{YR} 4 / 4$ & 6.5 YR 3/4 & $\overline{\mathrm{SiCL}}$ & 15 & $1 \mathrm{~m}, \mathrm{f}, \mathrm{sbk}$ & $\overline{5.5}$ \\
\hline $\mathrm{EO} 2$ & $\mathrm{~A}$ & $0-8$ & \multicolumn{2}{|c|}{ color not determined - } & LS & $<2$ & $\operatorname{lm}, \mathrm{f}, \mathrm{gr}$ & 5.1 \\
\hline $\mathrm{EO} 2$ & $\mathrm{Bw}$ & $8-35+$ & \multicolumn{2}{|c|}{ sample lost from lab } & $\bar{S}$ & 0 & $\mathrm{sg}, \mathrm{f}, \mathrm{gr}$ & 6.3 \\
\hline EO7 & $\mathrm{A}$ & $0-6$ & $10 \mathrm{YR} 4 / 3$ & $10 \mathrm{YR} 3 / 3$ & $\mathrm{~L}$ & 15 & $1 \mathrm{~m}, \mathrm{f}, \mathrm{sbk}$ & 5.7 \\
\hline$\overline{\mathrm{EO7}}$ & $\mathrm{Bw}$ & $6-30+$ & $10 \mathrm{YR} 4 / 4$ & $10 \mathrm{YR} 3 / 3$ & $\mathrm{~L}$ & 15 & $1 \mathrm{~m}, \mathrm{f}, \mathrm{sbk}$ & $\overline{6.3}$ \\
\hline E08 & $\mathrm{A}$ & $0-10$ & $10 \mathrm{YR} 4 / 2$ & $10 \mathrm{YR} 2 / 2$ & LS & 4 & $\operatorname{lm}, \mathrm{f}, \mathrm{gr}$ & 6.2 \\
\hline$\overline{E 08}$ & $\mathrm{Bw}$ & $10-35+$ & $10 \mathrm{YR} 6 / 5$ & 10 YR $3 / 4$ & $\overline{L S}$ & 4 & $\mathrm{~lm}, \mathrm{f}, \mathrm{gr}$ & 7.0 \\
\hline EO9 & $\mathrm{A}$ & $0-10$ & $10 \mathrm{YR} 5 / 2$ & $10 \mathrm{YR} 3 / 2$ & LS & 5 & $\mathrm{~lm}, \mathrm{f}, \mathrm{gr}$ & 5.0 \\
\hline$\overline{\mathrm{EO9}}$ & $\mathrm{C}$ & $10-40+$ & $10 \mathrm{YR} 5 / 2$ & $10 \mathrm{YR} 3 / 2$ & $\overline{\mathrm{LS}}$ & 5 & $1 \mathrm{~m}, \mathrm{f}, \mathrm{gr}$ & 6.3 \\
\hline EO10 & $\bar{A}$ & $0-10$ & $2.5 \mathrm{Y} 4 / 2$ & $2.5 \mathrm{Y} 2.5 / 1$ & $\overline{\mathrm{LS}}$ & 5 & $\mathrm{~lm}, \mathrm{f}, \mathrm{gr}$ & $\overline{5.6}$ \\
\hline EO10 & $\mathrm{C}$ & $10-30+$ & $2.5 \mathrm{Y} 6 / 4$ & $2.5 \mathrm{Y} 4 / 3$ & $S$ & $<5$ & $1 \mathrm{~m}, \mathrm{~m}-\mathrm{c}, \mathrm{gr}$ & 6.2 \\
\hline EO11 & A & $0-5$ & $2.5 \mathrm{Y} \mathrm{5/2}$ & $2.5 \mathrm{Y} 3 / 2$ & $\overline{\mathrm{LS}}$ & 5 & $1 \mathrm{~m}, \mathrm{f}, \mathrm{gr}$ & 5.2 \\
\hline E011 & $\bar{C}$ & $5-25+$ & $2.5 \mathrm{Y} 6 / 3$ & $2.5 \mathrm{Y} 4 / 3$ & $\mathrm{~S}$ & $<5$ & $1 \mathrm{~m}, \mathrm{f}, \mathrm{gr}$ & 6.2 \\
\hline E012 & $\bar{A}$ & $0-8$ & $2.5 Y 5 / 2$ & $2.5 \mathrm{Y} 3 / 2$ & $\overline{\mathrm{LS}}$ & 5 & $1 \mathrm{~m}, \mathrm{f}, \mathrm{gr}$ & 5.8 \\
\hline $\mathrm{EO} 12$ & $\bar{C}$ & $8-25+$ & $2.5 Y 6 / 4$ & $2.5 \mathrm{Y} 4 / 3$ & $S$ & $<5$ & $1 \mathrm{~m}, \mathrm{f}, \mathrm{gr}$ & 6.7 \\
\hline$\overline{\mathrm{EO} 13}$ & $\mathrm{~A}^{*}$ & $0-12$ & $2.5 \mathrm{Y} 5 / 3$ & $2.5 \mathrm{Y} 3 / 2$ & $\overline{\mathrm{LS}}$ & 8 & $1 \mathrm{~m}, \mathrm{vf}, \mathrm{gr}$ & 5.2 \\
\hline E013 & $\mathrm{C}$ & $12-30+$ & $2.5 \mathrm{Y} 6 / 3$ & $2.5 \mathrm{Y} 4 / 4$ & $S$ & 3 & $\operatorname{lm}, \mathrm{f}, \mathrm{gr}$ & 5.9 \\
\hline E014 & $\mathrm{A}$ & $0-8$ & $10 \mathrm{YR} 3 / 2$ & $10 \mathrm{YR} 3 / 2$ & $\overline{\mathrm{LS}}$ & 3 & $\mathrm{~lm}, \mathrm{f}, \mathrm{gr}$ & 4.9 \\
\hline E014 & $\mathrm{Bw}$ & $8-30+$ & 10 YR $6 / 4$ & $10 \mathrm{YR} 4 / 4$ & LS & 3 & $\mathrm{~lm}, \mathrm{f}, \mathrm{gr}$ & 6.2 \\
\hline EO15 & $\mathrm{A}$ & $0-10$ & $2.5 \mathrm{Y} 4 / 3$ & $2.5 \mathrm{Y} 3 / 1$ & $L S$ & 4 & $\mathrm{Im}, \mathrm{f}, \mathrm{gr}$ & 5.2 \\
\hline EO15 & $\bar{C}$ & $10-25+$ & $2.5 \mathrm{Y} 6 / 4$ & $2.5 \mathrm{Y} 4 / 3$ & $\mathrm{LS}$ & 4 & $1 \mathrm{~m}, \mathrm{f}, \mathrm{gr}$ & 6.1 \\
\hline E016 & $\mathrm{A}^{*}$ & $0-8$ & $2.5 \mathrm{Y} 4 / 2$ & $2.5 \mathrm{Y} 3 / 2$ & LS & 4 & $\mathrm{~lm}, \mathrm{f}, \mathrm{gr}$ & 5.4 \\
\hline E016 & $\mathrm{C}$ & $8-30+$ & $2.5 \mathrm{Y} 6 / 4$ & $2.5 \mathrm{Y} 4 / 4$ & $S$ & $<4$ & $\operatorname{lm}, \mathrm{f}, \mathrm{gr}$ & 6.2 \\
\hline$\overline{E 017}$ & $\bar{A}$ & $0-8$ & $2.5 \mathrm{Y} \mathrm{4/3}$ & $2.5 \mathrm{Y} 3 / 2$ & $\mathrm{LS}$ & 5 & $1 \mathrm{~m}, \mathrm{f}, \mathrm{gr}$ & 4.9 \\
\hline EO17 & $\overline{\mathrm{C}}$ & $8-30+$ & $2.5 Y 6 / 4$ & $2.5 \mathrm{Y} 4 / 4$ & $\mathrm{~S}$ & $<5$ & $\mathrm{~lm}, \mathrm{f}, \mathrm{gr}$ & 6.1 \\
\hline EO18 & $\mathrm{A}$ & $0-10$ & $2.5 \mathrm{Y} 4 / 3$ & $2.5 \mathrm{Y} 3 / 2$ & $\mathrm{LS}$ & 3 & $1 \mathrm{~m}, \mathrm{vf}, \mathrm{gr}$ & 5.2 \\
\hline E018 & $\mathrm{Bwj}$ & $10-25+$ & $2.5 \mathrm{Y} 6 / 4$ & $2.5 \mathrm{Y} 5 / 6$ & $\mathrm{LS}$ & 3 & $1 \mathrm{~m}, \mathrm{f}, \mathrm{gr}$ & 6.0 \\
\hline $\mathrm{EO} 20$ & $A$ & $0-5$ & $2.5 \mathrm{Y} 4 / 3$ & $2.5 \mathrm{Y} \mathrm{3/2}$ & LS & 2 & $\mathrm{~lm}, \mathrm{f}, \mathrm{gr}$ & 5.5 \\
\hline EO20 & $\bar{C}$ & $5-30+$ & $2.5 \times 6 / 6$ & $2.5 \mathrm{Y} 3 / 3$ & $\mathrm{~S}$ & $<2$ & $\mathrm{~lm}, \mathrm{f}, \mathrm{gr}$ & 6.3 \\
\hline EO21 & $\overline{\mathrm{A}}$ & $0-5$ & $2.5 \mathrm{Y} 4 / 2$ & $2.5 \mathrm{Y} 3 / 2$ & LS & 7 & $1 \mathrm{~m}, \mathrm{f}, \mathrm{sbk}$ & 4.8 \\
\hline $\mathrm{EO} 21$ & $\bar{C}$ & $5-30+$ & $2.5 \mathrm{Y} 6 / 4$ & $2.5 \mathrm{Y} 3 / 3$ & $S$ & $<5$ & $1 \mathrm{~m}, \mathrm{f}, \mathrm{gr}$ & 5.7 \\
\hline EO22 & $\mathrm{A}$ & $0-8$ & $2.5 \mathrm{Y} 5 / 3$ & $2.5 \mathrm{Y} 3 / 2$ & $\mathrm{LS}$ & 4 & $1 \mathrm{~m}, \mathrm{f}, \mathrm{sbk}$ & 5.1 \\
\hline EO22 & $\bar{C}$ & $8-30+$ & $2.5 \mathrm{Y} 7 / 3$ & $2.5 \mathrm{Y} 4 / 4$ & $S$ & $<2$ & $1 \mathrm{~m}, \mathrm{f}, \mathrm{gr}$ & 6.2 \\
\hline $\mathrm{EO} 23$ & $\mathrm{~A}$ & $0-5$ & $2.5 \mathrm{Y} \mathrm{4/2}$ & $2.5 \mathrm{Y} 3 / 2$ & $\mathrm{LS}$ & 5 & $1 \mathrm{~m}, \mathrm{f}, \mathrm{sbk}$ & 4.8 \\
\hline EO23 & $\bar{C}$ & $5-30+$ & $2.5 \mathrm{Y} 6 / 4$ & $2.5 \mathrm{Y} 4 / 6$ & $\mathrm{~S}$ & $<2$ & $\mathrm{~lm}, \mathrm{f}, \mathrm{gr}$ & 6.3 \\
\hline $\mathrm{EO} 24$ & $\bar{A}$ & $0-6$ & $2.5 \mathrm{Y} 4 / 3$ & $2.5 \mathrm{Y} 2 / 2$ & $\mathrm{SL}$ & 8 & lm, f, sbk & 5.4 \\
\hline$\overline{E O 24}$ & $\bar{C}$ & $6-30+$ & $10 \mathrm{YR} 6 / 4$ & $10 \mathrm{YR} 4 / 3$ & LS & $<5$ & $1 \mathrm{~m}, \mathrm{f}, \mathrm{gr}$ & 5.7 \\
\hline EO25 & $\bar{A}$ & $0-8$ & $2.5 Y .5 / 3$ & $2.5 \mathrm{Y} .3 / 2$ & LS & 4 & $\mathrm{~lm}, \mathrm{f}, \mathrm{gr}$ & 5.5 \\
\hline EO25 & $\bar{C}$ & $8-30+$ & $2.5 \mathrm{Y} 7 / 3$ & $2.5 \mathrm{Y} \mathrm{5/4}$ & $\mathrm{S}$ & $<4$ & $\mathrm{~lm}, \mathrm{f}, \mathrm{gr}$ & 5.6 \\
\hline EO26 & $\bar{A}$ & $0-10$ & $2.5 \mathrm{Y} 4 / 2$ & $2.5 \mathrm{Y} 3 / 2$ & $\mathrm{SL}$ & 6 & $1 \mathrm{~m}, \mathrm{f}, \mathrm{sbk}$ & 4.7 \\
\hline EO26 & $\mathrm{C}$ & $10-30+$ & $2.5 \mathrm{Y} 5 / 6$ & $2.5 \mathrm{Y} 3 / 2$ & LS & $<5$ & $1 \mathrm{~m}, \mathrm{f}, \mathrm{gr}$ & 5.6 \\
\hline EO27 & $\mathrm{A}^{*}$ & $0-7$ & $2.5 \mathrm{Y} 4 / 3$ & $2.5 \mathrm{Y} 3 / 2$ & $\mathrm{LS}$ & 4 & $\mathrm{~lm}, \mathrm{vf}, \mathrm{gr}$ & 5.7 \\
\hline $\mathrm{EO} 27$ & $\bar{C}$ & $7-30+$ & $2.5 \times 7 / 4$ & $2.5 \mathrm{Y} 4 / 6$ & $S$ & $<2$ & $\mathrm{sg}, \mathrm{vf}, \mathrm{gr}$ & 6.5 \\
\hline
\end{tabular}




\begin{tabular}{|c|c|c|c|c|c|c|c|c|}
\hline $\begin{array}{l}\text { Sample } \\
\#\end{array}$ & $\begin{array}{l}\text { Hori- } \\
\text { zon }\end{array}$ & $\begin{array}{l}\text { Depth } \\
\text { (cm) }\end{array}$ & $\begin{array}{l}\text { Color } \\
\text { (dry) }\end{array}$ & $\begin{array}{l}\text { Color } \\
\text { (wet) }\end{array}$ & Texture & $\begin{array}{l}\text { Clay \% } \\
\text { (approx.) }\end{array}$ & Structure & $\overline{\mathrm{pH}}$ \\
\hline EO 30 & $\mathrm{A}$ & $0-2$ & $2.5 \mathrm{Y} 7 / 4$ & $2.5 Y 4 / 4$ & $\bar{S}$ & $<1$ & $\mathrm{sg}, \mathrm{f}, \mathrm{gr}$ & 5.8 \\
\hline $\mathrm{EO} 30$ & $\overline{\mathrm{C}}$ & $2-40+$ & $2.5 Y 7 / 4$ & $2.5 \mathrm{Y} 4 / 4$ & $\bar{S}$ & $<1$ & $\mathrm{sg}, \mathrm{f}-\mathrm{m}, \mathrm{gr}$ & $\overline{6.2}$ \\
\hline EO31 & $\bar{A}$ & $0-8$ & $2.5 \mathrm{Y} 4 / 3$ & $2.5 \mathrm{Y} \mathrm{3/2}$ & $\bar{S}$ & $\overline{<2}$ & $\mathrm{sg}, \mathrm{m}-\mathrm{c}, \mathrm{gr}$ & $\overline{5.1}$ \\
\hline EO31 & $\overline{\mathrm{C}}$ & $8-25 t$ & $2.5 Y 7 / 3$ & $2.5 \mathrm{Y} \mathrm{5/4}$ & $\bar{S}$ & $<2$ & $\mathrm{sg}, \mathrm{m}-\mathrm{c}, \mathrm{gr}$ & 6.3 \\
\hline EO32 & $\overline{\mathrm{A}}$ & $0-5$ & $2.5 \mathrm{Y} 4 / 3$ & $2.5 \mathrm{Y} \mathrm{3/2}$ & $\bar{S}$ & $\overline{<2}$ & $\mathrm{sg}, \mathrm{m}-\mathrm{c}, \mathrm{gr}$ & 5.3 \\
\hline EO32 & $\bar{C}$ & $5-25+$ & $2.5 \mathrm{Y} 6 / 4$ & $2.5 Y 4 / 4$ & $\bar{S}$ & $<2$ & $\mathrm{sg}, \mathrm{m}-\mathrm{c}, \mathrm{gr}$ & 5.9 \\
\hline EO33 & $\mathrm{A}$ & $0-3$ & $2.5 \mathrm{Y} 4 / 3$ & $2.5 \mathrm{Y} 3 / 2$ & $\overline{\mathrm{LS}}$ & 5 & $1 \mathrm{~m}, \mathrm{~m}, \mathrm{sbk}$ & 5.3 \\
\hline$\overline{\mathrm{EO} 33}$ & $\bar{C}$ & $3-40+$ & $2.5 Y 6 / 4$ & $2.5 \mathrm{Y} 3 / 3$ & $\mathrm{~S}$ & $<5$ & $\mathrm{~lm}, \mathrm{~m}, \mathrm{sbk}$ & $\overline{6.4}$ \\
\hline$\overline{\mathrm{EO} 34}$ & $\bar{A}$ & $0-3$ & $2.5 \mathrm{Y} \mathrm{5/3}$ & $2.5 \mathrm{Y} 3 / 2$ & $\overline{\mathrm{LS}}$ & 5 & $1 \mathrm{~m}, \mathrm{f}, \mathrm{sbk}$ & $\overline{6.0}$ \\
\hline EO34 & $\mathrm{C}$ & $3-30+$ & $2.5 \mathrm{Y} 6 / 4$ & $2.5 \mathrm{Y} 4 / 4$ & $S$ & $<5$ & $1 \mathrm{~m}, \mathrm{~m}, \mathrm{sbk}$ & 6.5 \\
\hline EO35 & $\bar{A}$ & $0-3$ & 10 YR 5/4 & $10 \mathrm{YR} 3 / 3$ & $\overline{\mathrm{LS}}$ & 8 & $\mathrm{~lm}, \mathrm{~m}-\mathrm{c}, \mathrm{gr}$ & 6.8 \\
\hline EO35 & $\mathrm{Bw}$ & $3-10+$ & 9 YR 5/4 & 9 YR 3/4 & $\overline{L S}$ & 8 & $1 \mathrm{~m}, \mathrm{c}, \mathrm{sbk}$ & $\overline{6.8}$ \\
\hline EO36 & $\mathrm{A}$ & $0-12$ & $10 \mathrm{YR} 3 / 3$ & $10 \mathrm{YR} 3 / 2$ & $\overline{\mathrm{SL}}$ & 7 & $1 \mathrm{~m}, \mathrm{f}, \mathrm{sbk}$ & 6.4 \\
\hline$\overline{\mathrm{EO} 36}$ & $\overline{\mathrm{Bw}}$ & $12-30+$ & $10 \mathrm{YR} 5 / 4$ & $10 \mathrm{YR} 3 / 3$ & $\overline{\mathrm{SL}}$ & 7 & $1 \mathrm{~m}, \mathrm{f}, \mathrm{sbk}$ & $\overline{6.4}$ \\
\hline$\overline{\mathrm{KLl}}$ & A & $0-1$ & 10 YR 5/6 & $10 \mathrm{YR} 4 / 4$ & $\mathrm{~L}$ & 5 & $\mathrm{~lm}, \mathrm{f}, \mathrm{sbk}$ & 5.5 \\
\hline $\mathrm{KLI}$ & $\mathrm{Bt}$ & $1-20+$ & 7.5 YR $6 / 6$ & $7.54 / 6$ & $\mathrm{~L}$ & 15 & $2 \mathrm{~m}, \mathrm{f}, \mathrm{sbk}$ & 5.7 \\
\hline$\overline{\mathrm{KL2}}$ & $\mathrm{A}$ & $0-10$ & $2.5 \mathrm{Y} 4 / 3$ & $2.5 \mathrm{Y} \mathrm{3/2}$ & $\mathrm{LS}$ & 3 & $\mathrm{~lm}, \mathrm{f}, \mathrm{sbk}$ & 6.2 \\
\hline $\mathrm{KL2}$ & $\mathrm{Bw}$ & $10-45+$ & 10 YR $5 / 6$ & $10 \mathrm{YR} 4 / 4$ & $\overline{\mathrm{LS}}$ & 3 & $\operatorname{lm}, \mathrm{f}, \mathrm{sbk}$ & 6.3 \\
\hline $\mathrm{KL} 3$ & $\mathrm{~A}$ & $0-5$ & 10 YR $6 / 6$ & 10 YR $4 / 4$ & SL & 10 & $! \mathrm{m}, \mathrm{f}, \mathrm{sbk}$ & 6.3 \\
\hline$\overline{\mathrm{KL} 3}$ & $\overline{\mathrm{E}^{* *}}$ & $5-50$ & & & $\overline{\mathrm{SL}}$ & $<10$ & $1 \mathrm{~m}, \mathrm{f}, \mathrm{sbk}$ & \\
\hline $\mathrm{KL3}$ & $\overline{\mathrm{Bt}}$ & $50-200$ & $10 \mathrm{YR} 7 / 6$ & 7.5 YR 5/8 & $\overline{\mathrm{SCL}}$ & 30 & $2 \mathrm{~m}, \mathrm{f}, \mathrm{sbk}$ & 6.3 \\
\hline$\overline{\mathrm{KL} 4}$ & $\overline{\mathrm{A}}$ & $0-9$ & $10 \mathrm{YR} 4 / 4$ & 10 YR 3/3 & SL & 5 & $1 \mathrm{~m}, \mathrm{f}, \mathrm{sbk}$ & $\overline{4.5}$ \\
\hline$\overline{\mathrm{KL} 4}$ & $\overline{\mathrm{Bw}}$ & $9-30 t$ & 2.5 YR 5/4 & 2.5 YR $3 / 3$ & $\overline{\mathrm{SL}}$ & 5 & $1 \mathrm{~m}, \mathrm{f}, \mathrm{sbk}$ & 4.9 \\
\hline$\overline{\mathrm{KL5}}$ & $\mathrm{A}$ & $0-3$ & $10 \mathrm{YR} 4 / 3$ & $10 \mathrm{YR} 2 / 2$ & $\overline{\mathrm{LS}}$ & 5 & $\operatorname{lm}, \mathrm{f}, \mathrm{sbk}$ & 5.3 \\
\hline$\overline{K L 5}$ & $\overline{\mathrm{Bt}}$ & $3-25+$ & 10 YR $6 / 5$ & $10 Y R 4 / 4$ & $\overline{\mathrm{SL}}$ & 8 & $1 \mathrm{~m}, \mathrm{f}, \mathrm{sbk}$ & 5.4 \\
\hline$\overline{\mathrm{KL} 6}$ & $\bar{A}$ & $0-5$ & 7.5 YR $5 / 6$ & 7.5 YR 3/4 & $\overline{\mathrm{SL}}$ & 15 & $1 \mathrm{~m}, \mathrm{f}, \mathrm{sbk}$ & 5.0 \\
\hline KL6 & $\overline{\mathrm{Bt}}$ & $5-100+$ & 5 YR 5/6 & 5 YR 4/6 & $\overline{C L}$ & 40 & $\mathrm{~lm}, \mathrm{f}, \mathrm{sbk}$ & $\overline{5.6}$ \\
\hline$\overline{\text { KL7 }}$ & A & $0-12$ & $2.5 \mathrm{Y} \mathrm{3/1}$ & $2.5 \mathrm{Y} 2.5 / 1$ & $\overline{\mathrm{SiL}}$ & 5 & $\mathrm{Im}, \mathrm{f}, \mathrm{sbk}$ & 4.4 \\
\hline KL7 & $\mathrm{Bw}$ & $12-35+$ & $2.5 \mathrm{Y} 5 / 3$ & $2.5 \mathrm{Y} 3 / 2$ & SiL & 5 & $1 \mathrm{~m}, \mathrm{f}, \mathrm{sbk}$ & 5.0 \\
\hline KL8 & $\mathrm{A}$ & $0-20$ & $10 Y R 3 / 3$ & 10 YR $2 / 2$ & LS & 8 & $1 \mathrm{~m}, \mathrm{f}, \mathrm{sbk}$ & 4.7 \\
\hline$\overline{K L 8}$ & $\overline{\mathrm{Bw}}$ & $20-45+$ & $10 \mathrm{YR} 4 / 4$ & $10 \mathrm{YR} 3 / 4$ & $\overline{\mathrm{LS}}$ & 8 & $1 \mathrm{~m}, \mathrm{f}, \mathrm{sbk}$ & 5.2 \\
\hline KL9 & $\mathrm{A}$ & $0-5$ & 7.5 YR $5 / 6$ & $7.5 \mathrm{YR} 3 / 3$ & $\overline{\mathrm{SiCL}}$ & 20 & $1 \mathrm{~m}, \mathrm{f}, \mathrm{sbk}$ & 4.5 \\
\hline KL9 & $\mathrm{Bt}$ & $5-15+$ & 7.5 YR $5 / 6$ & 7.5 YR 4/6 & $\overline{\mathrm{SiCL}}$ & 30 & $2 \mathrm{~m}, \mathrm{f}, \mathrm{sbk}$ & 5.1 \\
\hline KL10 & $\bar{A}$ & $0-8$ & $10 \mathrm{YR} 4 / 3$ & $10 \mathrm{YR} 3 / 2$ & $\overline{\mathrm{SL}}$ & 10 & $\mathrm{~lm}, \mathrm{f}, \mathrm{sbk}$ & 4.8 \\
\hline KL10 & $\mathrm{Bw}$ & $8-30+$ & $10 \mathrm{YR} 5 / 3$ & $10 \mathrm{YR} 3 / 3$ & SL & 10 & $\mathrm{~lm}, \mathrm{f}, \mathrm{sbk}$ & 5.4 \\
\hline KL11 & $\mathrm{A}$ & $0-5$ & $10 \mathrm{YR} 4 / 4$ & 10 YR $3 / 2$ & LS & 4 & $1 \mathrm{~m}, \mathrm{f}, \mathrm{gr}$ & 4.3 \\
\hline KL11 & $\overline{B w}$ & $5-20+$ & 10 YR 5/4 & $10 \mathrm{YR} 3 / 4$ & $\overline{\mathrm{LS}}$ & 4 & $\mathrm{~lm}, \mathrm{f}, \mathrm{sbk}$ & 4.9 \\
\hline KL12 & $\mathrm{A}$ & $0-10$ & $10 \mathrm{YR} 4 / 4$ & $10 \mathrm{YR} 3 / 2$ & $\mathrm{SL}$ & 10 & $1 \mathrm{~m}, \mathrm{f}, \mathrm{sbk}$ & 5.8 \\
\hline $\mathrm{KL} 12$ & $\mathrm{Bt}$ & $10-40+$ & $10 Y R 6 / 6$ & $10 \mathrm{YR} 4 / 4$ & $\overline{\mathrm{SL}}$ & 15 & $1 \mathrm{~m}, \mathrm{f}, \mathrm{sbk}$ & 5.8 \\
\hline KLI3 & $\bar{A}$ & $0-2$ & $10 \mathrm{TR} 3 / 3$ & $10 \mathrm{YR} 2 / 3$ & $\mathrm{~L}$ & 10 & $1 \mathrm{~m}, \mathrm{f}, \mathrm{sbk}$ & 5.3 \\
\hline KL13 & $\overline{B w}$ & $2-25 t$ & $10 \mathrm{YR} 4 / 4$ & 10 YR $3 / 3$ & $\bar{L}$ & 10 & $\mathrm{~lm}, \mathrm{f}, \mathrm{sbk}$ & 5.5 \\
\hline KL14 & $A$ & $0-3$ & $10 \mathrm{YR} 4 / 3$ & 10 YR $3 / 2$ & $\mathrm{~L}$ & 10 & $1 \mathrm{~m}, \mathrm{f}, \mathrm{sbk}$ & 5.0 \\
\hline KL14 & $\overline{\mathrm{Bt}}$ & $3-20+$ & 10 YR $6 / 6$ & 10 YR $5 / 6$ & $\bar{L}$ & 15 & $\mathrm{~lm}, \mathrm{f}, \mathrm{sbk}$ & 5.3 \\
\hline KL15 & $\mathrm{A}$ & $0-10$ & $10 \mathrm{YR} 4 / 3$ & $10 \mathrm{YR} 3 / 2$ & $\overline{\mathrm{SL}}$ & 8 & $1 \mathrm{~m}, \mathrm{f}, \mathrm{gr}$ & $\overline{5.2}$ \\
\hline $\mathrm{KL15}$ & $\overline{\mathrm{Bw}}$ & $10-30+$ & 10 YR $5 / 4$ & $10 \mathrm{YR} 3 / 4$ & $\overline{\mathrm{SL}}$ & 8 & $1 \mathrm{~m}, \mathrm{f}, \mathrm{gr}$ & 5.2 \\
\hline
\end{tabular}




\begin{tabular}{|c|c|c|c|c|c|c|c|c|}
\hline $\begin{array}{l}\text { Sample } \\
\#\end{array}$ & $\begin{array}{l}\text { Hori- } \\
\text { zon }\end{array}$ & $\begin{array}{l}\text { Depth } \\
\text { (cm) }\end{array}$ & $\begin{array}{l}\text { Color } \\
\text { (dry) }\end{array}$ & $\begin{array}{l}\text { Color } \\
\text { (wet) }\end{array}$ & Texture & $\begin{array}{l}\text { Clay \% } \\
\text { (approx.) }\end{array}$ & Structure & $\mathrm{pH}$ \\
\hline$\overline{\mathrm{KL} 16}$ & A & $0-3$ & 5 YR 4/6 & $5 \mathrm{YR} 3 / 3$ & $\mathbf{L}$ & 20 & $1 \mathrm{~m}, \mathrm{f}, \mathrm{sbk}$ & 5.9 \\
\hline KL16 & $\overline{\mathrm{Bt}}$ & $3-25+$ & 2.5 YR $3 / 8$ & 2.5 YR $3 / 4$ & $\overline{C L}$ & 30 & $2 m, f, s b k$ & 5.9 \\
\hline $\mathrm{KL} 17$ & $\mathrm{~A}$ & $0-5$ & $10 \mathrm{YR} 4 / 4$ & 10 YR $3 / 3$ & $\mathrm{LS}$ & 8 & $\operatorname{lm}, \mathrm{f}, \mathrm{sbk}$ & 4.8 \\
\hline $\mathrm{KL} 17$ & $\overline{\mathrm{Bt}}$ & $5-20+$ & 7.5 YR 4/4 & 7.5 YR $3 / 3$ & $\overline{\mathrm{SCL}}$ & 25 & $2 \mathrm{~m}, \mathrm{f}, \mathrm{sbk}$ & 5.2 \\
\hline KL18 & $\bar{A}$ & $0-7$ & $2.5 \mathrm{Y} 5 / 3$ & $2.5 \mathrm{Y} 3 / 2$ & $\mathrm{~L}$ & 25 & $\mathrm{~lm}, \mathrm{f}, \mathrm{sbk}$ & 5.7 \\
\hline KL18 & $\overline{\mathrm{Bt}}$ & $7-20+$ & 10 YR $6 / 6$ & 10 YR 5/6 & $\mathrm{CL}$ & 35 & $2 m, f, s b k$ & 5.7 \\
\hline KL19 & $\mathrm{A}$ & $0-10$ & 10 YR $5 / 4$ & 10 YR $3 / 4$ & $\mathrm{~L}$ & 10 & $1 \mathrm{~m}, \mathrm{f}, \mathrm{sbk}$ & 6.8 \\
\hline KL19 & $\overline{\mathrm{Bt}}$ & $10-95+$ & 10 YR $6 / 6$ & 10 YR 4/6 & $\overline{C L}$ & 35 & lm, f, sbk & 6.1 \\
\hline KL20 & $\mathrm{A}$ & $0-10$ & $10 Y R 4 / 4$ & $10 Y R 3 / 3$ & $\mathrm{~L}$ & 15 & lm, f, sbk & 6.9 \\
\hline KL20 & $\overline{\mathrm{Bw}}$ & $10-30+$ & 7.5 YR 4/6 & $7.5 \mathrm{YR} \mathrm{3/3}$ & $\bar{L}$ & 15 & $\mathrm{~lm}, \mathrm{f}, \mathrm{sbk}$ & 6.9 \\
\hline KL21 & $\mathrm{A}$ & $0-2$ & 10 YR 4/4 & 10 YR $3 / 3$ & $\mathrm{~L}$ & 20 & $\mathrm{~lm}, \mathrm{f}, \mathrm{sbk}$ & 5.5 \\
\hline KL21 & $\mathrm{Bt}$ & $2-40$ & 7.5 YR $5 / 6$ & $7.5 \mathrm{YR} 4 / 6$ & $\mathrm{CL}$ & 30 & $2 m, f, s b k$ & $\overline{6.7}$ \\
\hline KL22 & $\mathrm{A}$ & $0-10$ & $10 \mathrm{YR} 4 / 3$ & $10 \mathrm{YR} 3 / 2$ & $\mathrm{SL}$ & 10 & $\mathrm{Im}, \mathrm{f}, \mathrm{sbk}$ & 5.4 \\
\hline KL22 & $\mathrm{Bw}$ & $10-40+$ & 10 YR $6 / 6$ & 10 YR 4/4 & $\overline{\mathrm{SL}}$ & 10 & $\mathrm{~lm}, \mathrm{f}, \mathrm{sbk}$ & $\overline{6.0}$ \\
\hline KL23 & $\mathrm{A}$ & $0-3$ & $2.5 \mathrm{Y} 5 / 3$ & $2.5 \mathrm{Y} 3 / 2$ & LS & 3 & $\mathrm{~lm}, \mathrm{f}, \mathrm{sbk}$ & 5.1 \\
\hline KL23 & $E^{* *}$ & $3-15$ & & & $\mathrm{SL}$ & 5 & $1 \mathrm{~m}, \mathrm{f}, \mathrm{sbk}$ & \\
\hline KL23 & $\overline{\mathrm{Bt}}$ & $15-40+$ & $2.5 \mathrm{Y} 5 / 4$ & $2.5 \mathrm{Y} \mathrm{4/4}$ & $\overline{\mathrm{SL}}$ & 10 & lm, f, sbk & 5.2 \\
\hline KL24 & $\mathrm{A}$ & $0-3$ & $10 \mathrm{YR} 3 / 2$ & $10 \mathrm{YR} 2 / 2$ & $\overline{S L}$ & $<5$ & $1 \mathrm{~m}, \mathrm{f}, \mathrm{sbk}$ & 5.2 \\
\hline KL24 & $E^{* *}$ & $3-8$ & & & $\mathrm{SL}$ & $<5$ & $1 \mathrm{~m}, \mathrm{f}, \mathrm{sbk}$ & \\
\hline KL24 & $\overline{\mathrm{Bt}}$ & $8-30+$ & $10 \mathrm{YR} \mathrm{4/4}$ & 10 YR $3 / 3$ & $\mathrm{~L}$ & $\overline{8}$ & $1 \mathrm{~m}, \mathrm{f}, \mathrm{sbk}$ & 4.9 \\
\hline KL25 & $\bar{A}$ & $0-6$ & $10 \mathrm{YR} 3 / 3$ & $10 \mathrm{YR} 2 / 2$ & $\overline{S L}$ & 5 & $\mathrm{~lm}, \mathrm{f}, \mathrm{sbk}$ & 5.2 \\
\hline KL25 & $\overline{\mathrm{Bw}}$ & $6-30+$ & $10 \overline{Y R} 4 / 4$ & $10 \mathrm{YR} 3 / 3$ & $\overline{\mathrm{SL}}$ & 5 & $\mathrm{~lm}, \mathrm{f}, \mathrm{sbk}$ & 5.2 \\
\hline KL26 & $\bar{A}$ & $0-5$ & $10 \mathrm{YR} 4 / 3$ & 10 YR $3 / 2$ & $\overline{L S}$ & 4 & $\operatorname{lm}, \mathrm{f}, \mathrm{sbk}$ & 5.1 \\
\hline KL26 & $\mathrm{Bw}$ & $5-25+$ & 10 YR 5/4 & $10 \mathrm{YR} 3 / 3$ & $\overline{\mathrm{LS}}$ & 4 & $1 \mathrm{~m}, \mathrm{f}, \mathrm{sbk}$ & 5.0 \\
\hline KL27 & $\mathrm{A}$ & $0-4$ & 7.5 YR 4/4 & $7.5 \mathrm{YR} \mathrm{3/3}$ & $\bar{L}$ & 10 & lm, f, sbk & 6.3 \\
\hline KL27 & $\overline{\mathrm{Bt}}$ & $4-25+$ & $7.5 \mathrm{YR} 5 / 6$ & 7.5 YR 4/4 & $\mathrm{L}$ & 25 & $1 \mathrm{~m}, \mathrm{f}, \mathrm{sbk}$ & 5.7 \\
\hline KL28 & $\bar{A}$ & $0-5$ & $2.5 \mathrm{Y} 4 / 3$ & $2.5 \mathrm{Y} 3 / 2$ & $\mathrm{~L}$ & 12 & $1 \mathrm{~m}, \mathrm{f}, \mathrm{sbk}$ & 5.9 \\
\hline KL28 & $\overline{B w}$ & $5-30+$ & $2.5 \mathrm{Y} \mathrm{5/3}$ & $2.5 \mathrm{Y} 3 / 3$ & $\mathrm{~L}$ & 12 & $1 \mathrm{~m}, \mathrm{f}, \mathrm{sbk}$ & 5.7 \\
\hline KL30 & $\mathrm{A}$ & $0-5$ & $5 \mathrm{YR} 3 / 3$ & 5 YR $2.5 / 2$ & $\mathrm{~L}$ & 18 & $1 \mathrm{~m}, \mathrm{f}, \mathrm{sbk}$ & 6.1 \\
\hline KL30 & $\overline{\mathrm{Bt}}$ & $5-25$ & 5 YR 4/6 & $5 \mathrm{YR} 3 / 3$ & $\mathrm{CL}$ & 30 & $2 \mathrm{~m}, \mathrm{f}, \mathrm{sbk}$ & 5.6 \\
\hline R1 & $\overline{A^{*}}$ & $0-7$ & $10 Y R 5 / 2$ & $10 \mathrm{YR} 3 / 2$ & $\overline{S L}$ & 10 & $1 \mathrm{~m}, \mathrm{f}, \mathrm{sbk}$ & 5.8 \\
\hline $\mathrm{R} 1$ & $\mathrm{Bw}$ & $7-35+$ & $10 \mathrm{YR} 6 / 2$ & $10 \mathrm{YR} 4 / 2$ & $\overline{\mathrm{SL}}$ & 10 & $1 \mathrm{~m}, \mathrm{f}, \mathrm{sbk}$ & 5.8 \\
\hline$\overline{\mathrm{R} 2}$ & $\mathrm{~A}$ & $0-7$ & 2.5 YR $3 / 2$ & 2.5 YR 3/1 & $\overline{S L}$ & 8 & $\operatorname{lm}, \mathrm{f}, \mathrm{gr}$ & 6.1 \\
\hline $\mathrm{R} 2$ & $\mathrm{Bw}$ & $7-35+$ & $2.5 \mathrm{YR} 7 / 2$ & $2.5 \mathrm{YR} 4 / 2$ & $\overline{\mathrm{SL}}$ & 8 & $\mathrm{~lm}, \mathrm{f}, \mathrm{gr}$ & 5.6 \\
\hline R3 & A & $0-35$ & $2.5 \mathrm{Y} 4 / 3$ & $2.5 \mathrm{Y} 3 / 2$ & $\overline{\mathrm{LS}}$ & 5 & $\operatorname{lm}, \mathrm{f}, \mathrm{sbk}$ & 5.0 \\
\hline $\mathrm{R} 3$ & $\mathrm{Bw}$ & $35-50+$ & 2.5 Y $6 / 4$ & $10 \mathrm{YR} 4 / 4$ & $\mathrm{LS}$ & 5 & $1 \mathrm{~m}, \mathrm{f}, \mathrm{gr}$ & 5.7 \\
\hline R4 & $\mathrm{A}^{*}$ & $0-4$ & $10 \mathrm{YR} 3 / 2$ & $10 \mathrm{YR} 2 / 1$ & $\overline{\mathrm{LS}}$ & 5 & $\mathrm{~lm}, \mathrm{f}, \mathrm{gr}$ & 4.3 \\
\hline$\overline{\mathrm{R} 4}$ & $\mathrm{Bw}$ & $4-65 t$ & 2.5 Y $5 / 4$ & $10 \mathrm{YR} 3 / 3$ & $\overline{\mathrm{LS}}$ & 5 & $\operatorname{lm}, \mathrm{f}, \mathrm{gr}$ & 4.9 \\
\hline$\overline{\mathrm{R} 5}$ & $\bar{A}$ & $0-4$ & $10 \mathrm{YR} 4 / 4$ & $7.5 \mathrm{YR} 3 / 3$ & $\overline{\mathrm{SL}}$ & 12 & $\mathrm{~lm}, \mathrm{f}, \mathrm{sbk}$ & 5.9 \\
\hline R5 & $\mathrm{Bw}$ & $4-35+$ & 9 YR 5/6 & 7 YR 3.5/4 & $\overline{\mathrm{SL}}$ & 12 & $\mathrm{~lm}, \mathrm{f}, \mathrm{sbk}$ & 6.6 \\
\hline$\overline{\mathrm{R} 6}$ & $\overline{A^{*}}$ & $0-4$ & 7.5 YR 4/4 & 7.5 YR 3/3 & $\overline{\mathrm{SL}}$ & 15 & $1 \mathrm{~m}, \mathrm{f}, \mathrm{sbk}$ & $\overline{6.8}$ \\
\hline $\mathrm{R} 6$ & $\mathrm{Bw}$ & $4-35$ & 7.5 YR $5 / 6$ & 5 YR 3/4 & SL & 15 & lm, f, sbk & 6.2 \\
\hline R7 & $\mathrm{A}$ & $0-4$ & $10 \mathrm{YR} 5 / 2$ & $10 \mathrm{YR} 3 / 2$ & $\mathrm{SL}$ & 10 & $1 \mathrm{~m}, \mathrm{f}, \mathrm{sbk}$ & 5.6 \\
\hline R7 & $\mathrm{Bw}$ & $4-40+$ & $10 \mathrm{YR} 6 / 4$ & 10 YR $5 / 4$ & $\overline{\mathrm{SL}}$ & 10 & $1 \mathrm{~m}, \mathrm{f}, \mathrm{sbk}$ & 6.0 \\
\hline $\mathrm{R} 8$ & $\mathrm{~A}$ & $0-8$ & N3 & N3 & $\mathrm{C}$ & $>60$ & $2 \mathrm{~m}, \mathrm{f}, \mathrm{sbk}$ & 6.8 \\
\hline
\end{tabular}




\begin{tabular}{|c|c|c|c|c|c|c|c|c|}
\hline Sample & $\begin{array}{l}\text { Hori- } \\
\text { zon }\end{array}$ & $\begin{array}{l}\text { Depth } \\
\text { (cm) }\end{array}$ & $\begin{array}{l}\text { Color } \\
\text { (dry) }\end{array}$ & $\begin{array}{l}\text { Color } \\
\text { (wet) }\end{array}$ & Texture & $\begin{array}{l}\text { Clay \% } \\
\text { (approx.) }\end{array}$ & Structure & $\mathrm{pH}$ \\
\hline R8 & $\mathrm{B}$ & $8-47+$ & N3 & N3 & $\bar{C}$ & $>60$ & $2 \mathrm{~m}, \mathrm{~m}, \mathrm{sbk}$ & 6.4 \\
\hline$\overline{\mathrm{R} 9}$ & $\overline{\mathrm{A}}$ & $0-6$ & 10 YR $5 / 3$ & $10 \mathrm{YR} 4 / 3$ & $\overline{\mathrm{SL}}$ & 12 & $\operatorname{lm}, f, g r$ & $\overline{6.8}$ \\
\hline R9 & $\mathrm{Bw}$ & $6-40$ & $10 \mathrm{YR} \mathrm{4/4}$ & $10 \mathrm{YR} 3 / 3$ & $\mathrm{SL}$ & 12 & $1 \mathrm{~m}, \mathrm{f}, \mathrm{sbk}$ & 6.5 \\
\hline$\overline{\mathrm{R} 10}$ & A & $0-4$ & 2.5 Y $6 / 3$ & $2.5 \mathrm{Y} 4 / 2$ & $\overline{\mathrm{SL}}$ & $\overline{15}$ & $1 \mathrm{~m}, \mathrm{f}, \mathrm{sbk}$ & $\overline{6.0}$ \\
\hline$\overline{\mathrm{R} 10}$ & $\mathrm{Bt}$ & $5-50+$ & $2.5 Y 5 / 4$ & $2.5 \mathrm{Y} 4 / 3$ & $\mathrm{C}$ & $>50$ & $2 m, m, s b k$ & 5.8 \\
\hline$\overline{\mathrm{R} 11}$ & $\bar{A}$ & $0-10$ & 10 YR $5 / 4$ & $10 \mathrm{YR} 3 / 2$ & $\overline{\mathrm{SL}}$ & 15 & $\mathrm{~lm}, \mathrm{f}, \mathrm{sbk}$ & 6.1 \\
\hline$\overline{\mathrm{R} 11}$ & $\overline{\mathrm{Bt}}$ & $10-50+$ & 10 YR 5/6 & 7.5 YR 4/6 & $\overline{\mathrm{SC}}$ & 50 & $2 \mathrm{~m}, \mathrm{~m}, \mathrm{sbk}$ & 6.1 \\
\hline$\overline{\mathrm{R} 12}$ & $A^{*}$ & $0-5$ & $10 \mathrm{YR} 5 / 3$ & $10 \mathrm{YR} 3 / 2$ & $\overline{\mathrm{SL}}$ & 18 & $1 \mathrm{~m}, \mathrm{f}, \mathrm{sbk}$ & 5.6 \\
\hline $\mathrm{R} 12$ & $\mathrm{Bw}$ & $5-25$ & 10 YR $6 / 4$ & 10 YR 5/4 & SL & 18 & $1 \mathrm{~m}, \mathrm{~m}, \mathrm{sbk}$ & 5.3 \\
\hline$\overline{\mathrm{R} 13}$ & $\overline{A^{*}}$ & $0-3$ & $10 \mathrm{YR} 3 / 3$ & $10 \mathrm{YR} 3 / 2$ & $\overline{\mathrm{SCL}}$ & 30 & $1 \mathrm{~m}, \mathrm{f}, \mathrm{sbk}$ & $\overline{5.0}$ \\
\hline R13 & $\mathrm{Bt}$ & $3-35+$ & $5 \mathrm{YR} 4 / 8$ & 5 YR 4/6 & $\overline{S C}$ & 50 & $2 m, f, s b k$ & 5.7 \\
\hline R14 & $\mathrm{A}$ & $0-4$ & $7.5 \mathrm{YR} 6 / 5$ & 7.5 YR 4/6 & $\overline{\mathrm{SCL}}$ & 20 & lm, f, sbk & 5.8 \\
\hline$\overline{\mathrm{R} 14}$ & $\mathrm{Bt}$ & $4-25$ & 7.5 YR 6/6 & 7.5 YR 5/6 & $\overline{\mathrm{SCL}}$ & 25 & $\mathrm{~lm}, \mathrm{f}, \mathrm{sbk}$ & $\overline{5.6}$ \\
\hline $\mathrm{R} 15$ & $\mathrm{~A}$ & $0-4$ & 10 YR 5/5 & 7.5 YR 4/4 & $\mathrm{SCL}$ & 20 & $1 \mathrm{~m}, \mathrm{f}, \mathrm{sbk}$ & 6.3 \\
\hline$\overline{\mathrm{R} 15}$ & $\overline{\mathrm{Bt}}$ & $4-50+$ & $9 \longdiv { Y R ~ 5 / 6 }$ & 9 YR 4/6 & $\overline{\mathrm{SCL}}$ & 30 & lm, f, sbk & 6.0 \\
\hline
\end{tabular}

* Has 1-4 cm of the $O$ horizon at the top. The $O$ and $A$ horizons were sampled together.

** The E horizon was identified and examined, but not sampled.

Key to soil texture determined in the field: $\mathrm{C}=$ clay, $\mathrm{L}=$ loam, $\mathrm{S}=$ sand, $\mathrm{Si}=$ silt.

Key to soil structure: $\mathrm{sg}=$ single grain, $\mathrm{m}=$ massive (modifiers 1,2,3 refer to weak, medium and strong, respectively); $\mathrm{vf}=$ very fine, $\mathrm{f}=$ fine, $\mathrm{m}=$ medium, $\mathrm{c}=$ coarse; $\mathrm{gr}=$ granular, sbk = subangular blocky (Soil Survey Staff, 1993). 


\section{APPENDIX 5. Quality Control/Quality Assurance data for Heavy Metals and Trace Elements in Soils of Southwest Oregon.}

Appendix 5.1 Percent difference of concentration of metals in laboratory duplicate samples analyzed by inductively-coupled plasma atomic emission spectroscopy (ICPAES).

\begin{tabular}{|l|l|l|l|l|l|l|l|l|l|l|l|}
\hline & Sample \# & EO8-B1 & EO13-B1 & EO18A1 & EO23-B1 & EO31A1 & EO34-B1 & EO35-B1 & KL2-A1 & KL8-B1 & KL12-B1 \\
\hline Metal & & & & & & & & & & & \\
\hline $\mathrm{Cd}$ & & 13.7 & -- & -- & 21.7 & -- & 3.0 & 1.4 & - & 21.4 & 11.1 \\
\hline $\mathrm{Ba}$ & & 2.6 & 0.71 & 0.4 & 0.2 & 6.6 & 0.9 & 15.7 & 0.8 & 3.4 & 0 \\
\hline $\mathrm{Ni}$ & & 0.4 & 13.2 & 0 & 13.1 & 3.3 & 3.6 & 8.2 & 4.4 & 8.4 & 1.7 \\
\hline $\mathrm{Co}$ & & 13.6 & 15.2 & 20.2 & 6.4 & 4.9 & 0.7 & 4.0 & 4.4 & 19.6 & 4.8 \\
\hline $\mathrm{Cr}$ & & 8.3 & 6.7 & 7.4 & 19.6 & 3.2 & 6.1 & 15.2 & 1.5 & 0.3 & 0.7 \\
\hline $\mathrm{V}$ & & 12.1 & 4.0 & 7.6 & 15.2 & 3.4 & 7.1 & 3.8 & 1.0 & 1.5 & 1.2 \\
\hline $\mathrm{Cu}$ & & 2.9 & 1.1 & 2.6 & 0.09 & 1.2 & 1.1 & 3.1 & 0.2 & 4.3 & 2.5 \\
\hline $\mathrm{Zn}$ & & 1.2 & 6.1 & 2.4 & 6.9 & 1.6 & 10.0 & 5.2 & 2.4 & 4.9 & 1.7 \\
\hline $\mathrm{Fe}$ & & 7.1 & 1.9 & 3.3 & 11.1 & 2.1 & 6.4 & 2.1 & 1.7 & 1.2 & 2.5 \\
\hline $\mathrm{Mn}$ & & 8.5 & 2.9 & 5.5 & 3.1 & 6.6 & 2.6 & 2.7 & 0.7 & 0.6 & 1.5 \\
\hline $\mathrm{K}$ & & 16.0 & 4.8 & 14.1 & 2.2 & 4.0 & 4.1 & 0.3 & 0.3 & 6.2 & 5.7 \\
\hline $\mathrm{Al}$ & & 0.3 & 1.4 & 0.4 & 0.8 & 1.5 & 4.7 & 5.2 & 0.3 & 0.7 & 2.4 \\
\hline $\mathrm{Li}$ & & 0 & 11.3 & 20.9 & 0 & 0 & 8.4 & 2.3 & 4.7 & 6.2 & 0.9 \\
\hline $\mathrm{Ca}$ & & 10.7 & 4.3 & 8.0 & 0.3 & 11.6 & 3.8 & 2.9 & 0.3 & 6.6 & 0.9 \\
\hline $\mathrm{Na}$ & & 37.9 & 4.3 & 9.4 & 4.8 & 4.9 & 2.4 & 2.2 & 7.2 & 5.8 & 0.1 \\
\hline $\mathrm{Mg}$ & & 6.7 & 14.0 & 1.9 & 15.4 & 1.4 & 2.1 & 4.8 & 0.8 & 1.3 & 1.6 \\
\hline $\mathrm{La}$ & & 14.6 & 2.1 & 0 & 11.5 & 6.1 & 0 & 4.1 & 3.8 & 2.4 & 7.0 \\
\hline
\end{tabular}

Note: Percent difference of concentration of a metal in a duplicate pair is not calculated if the concentration in one or both the digests is below the laboratory's minimum reporting level.

Duplicate values are grouped as follows: $84 \%$ of the values fall within $+/-10 \%$ difference (considered good), $14 \%$ of the values fall within $+/-20 \%$ difference (acceptable) and only $2 \%$ of the values are above $20 \%$ limit. Calculation done as follows: $\%$ Difference $=\left[\left(A_{1}-A_{2}\right) /\left(A_{1}+A_{2}\right) / 2\right]^{*} 100$, where $A_{1}$ and $\mathrm{A}_{2}$ are concentrations in duplicate pair. 
Appendix 5.2 Percent recovery in spiked samples analyzed by inductively-coupled plasma atomic emission spectroscopy (ICPAES).

\begin{tabular}{|l|l|l|l|l|l|l|l|l|l|l|l|}
\hline & Sample \# & EO8-B1 & EO13-B1 & EO18-A1 & EO23-B1 & EO31-A1 & EO35-B1 & KL2-A1 & KL8-B1 & KL12-B1 & $\begin{array}{l}\text { KL19 } \\
-A 1\end{array}$ \\
\hline Metal & & & & & & & & & & \\
\hline $\mathrm{Ag}$ & & 94.1 & 100 & 100.8 & 100.8 & 99.2 & 99.6 & 90 & 96.1 & 79.3 & 88.4 \\
\hline $\mathrm{Mo}$ & & 93.2 & 84.5 & 84.1 & 112.6 & 90.3 & 105.2 & 80.6 & 79.9 & 80.6 & 71.8 \\
\hline $\mathrm{Cd}$ & & 102.4 & 101.9 & 99.6 & 97.3 & 97 & 95.6 & 103.4 & 98.1 & 96 & 99.8 \\
\hline $\mathrm{Ba}$ & & 81.6 & 79.6 & 90.3 & 105.3 & 117.4 & 111.6 & 101.2 & 104.7 & 97.4 & 98.9 \\
\hline $\mathrm{Be}$ & & 106.4 & 113.7 & 106.7 & 96.7 & 97.2 & 96.3 & 101.7 & 104.1 & 104.5 & 106.7 \\
\hline $\mathrm{Ni}$ & & 97.5 & 97.1 & 97.7 & 103.3 & 100.3 & 103.7 & 98 & 100.6 & 94.3 & 104 \\
\hline $\mathrm{Co}$ & & 88.7 & 89.6 & 88.4 & 96.1 & 92.8 & 91.5 & 96.4 & 98.3 & 93.6 & 94.1 \\
\hline $\mathrm{Cr}$ & & 101.2 & 101.9 & 100 & 97.2 & 98.3 & 94.3 & 101.8 & 107.2 & 92.3 & 96.3 \\
\hline $\mathrm{V}$ & & 106.5 & 108.9 & 111.6 & 106.2 & 94.9 & 94.3 & 93.4 & 109.2 & 100.9 & 88.3 \\
\hline $\mathrm{Cu}$ & & 99.6 & 101.8 & 100.3 & 99.7 & 97.9 & 99.5 & 97.1 & 97.8 & 91.7 & 98.4 \\
\hline $\mathrm{Zn}$ & & 93.3 & 103.6 & 98 & 105.1 & 102 & 102.6 & 100.4 & 99.3 & 106.3 & 101.1 \\
\hline
\end{tabular}

Note: Spike recovery values are grouped as follows: $84 \%$ of the values fall within $90-110 \%$ recovery range (considered good), $15 \%$ of the values fall within $80-120 \%$ recovery range (acceptable) and only $1 \%$ (just one value) below $80 \%$ recovery .

Calculation done as follows: $\%$ Spike Recovery $=[\{(\mathrm{A}+\mathrm{S})-\mathrm{A}\} / \mathrm{S}]^{*} 100$, where $(\mathrm{A}+\mathrm{S})=$ concentration in spiked digest, $\mathrm{A}=$ concentration in unspiked digest, and $S=$ concentration of spike added.

Appendix 5.3 Percent recovery of metal concentrations in RCRA Study 22 (an EPA-approved standard material) analyzed by inductively-coupled plasma atomic emission spectroscopy (ICPAES).

\begin{tabular}{|l|l|l|l|l|l|l|l|l|l|l|l|l|l|l|}
\hline $\mathrm{Al}$ & $\mathrm{Ba}$ & $\mathrm{Cd}$ & $\mathrm{Ca}$ & $\mathrm{Cr}$ & $\mathrm{Cu}$ & $\mathrm{Fe}$ & $\mathrm{Pb}$ & $\mathrm{Mg}$ & $\mathrm{Mn}$ & $\mathrm{Ni}$ & $\mathrm{K}$ & $\mathrm{Ag}$ & $\mathrm{Na}$ & $\mathrm{Zn}$ \\
\hline 106.5 & 96.3 & 102.2 & 104.2 & 105.2 & 92.9 & 101.2 & 108.3 & 106.2 & 104 & 105.4 & 100.9 & 91.2 & 99.3 & 97.6 \\
\hline
\end{tabular}

Note: Recovery for all metals are within $90-110 \%$ which is considered good.

Calculation done as follows: $(100 / \mathrm{A})^{*} \mathrm{~B}$, where $\mathrm{A}=$ known concentration originally present and $\mathrm{B}=$ concentration recovered, 
Appendix 5.4 Percent difference of $\mathrm{Hg}$ concentrations in duplicate samples analyzed by cold vapor atomic absorption spectroscopy (CVAAS).

\begin{tabular}{|l|l|l|l|l|l|}
\hline Sample \# & $\begin{array}{l}\text { Percent } \\
\text { Differenc } \\
\text { e }\end{array}$ & Sample \# & $\begin{array}{l}\text { Percent } \\
\text { Difference }\end{array}$ & Sample \# & $\begin{array}{l}\text { Percent } \\
\text { Difference }\end{array}$ \\
\hline EO1-A2 & 11.8 & EO35-B1 & 9.1 & LC18-B1 & 1.8 \\
\hline EO2-B1 & 3.2 & KL1-A1 & 1.4 & LC19-A1 & 1.3 \\
\hline EO7-A1 & 12.2 & KL2-A1 & 8.4 & LM6-B1 & 2.1 \\
\hline EO8-A1 & 2.2 & KL3-B1 & 6.1 & LM8-A1 & 0 \\
\hline EO9-B2 & 19.4 & KL7-A1 & 0.4 & LM10-B1 & 2.5 \\
\hline EO10-B1 & 10.2 & KL8-B1 & 5.6 & LM13-A1 & 2.1 \\
\hline EO11-A1 & 5.6 & KL9-A2 & 0.9 & LM14-B1 & 8 \\
\hline EO11-B2 & 9.1 & KL10-B1 & 0 & LM16-A1 & 1.1 \\
\hline EO12-A2 & 14 & KL13-A1 & 2 & LM19-B1 & 1.5 \\
\hline EO13-B1 & 11.1 & KL18-A1 & 0.5 & LM20-B1 & 2.2 \\
\hline EO14-B1 & 0 & KL19-A1 & 2.1 & LM22-A1 & 0 \\
\hline EO16-A1 & 3.7 & KL20-B1 & 1.9 & R3-B1 & 12 \\
\hline EO18-A1 & 0 & KL23-A1 & 2.3 & R6-A1 & 1 \\
\hline EO20-B1 & 9.3 & KL26-B1 & 4.3 & R2-A1 & 0.7 \\
\hline EO21-B1 & 6.3 & KL28-A1 & 3.9 & LC7-B1 & 2.9 \\
\hline EO23-B1 & 3.3 & KL30-A1 & 1 & LC10B-A1 & 2.4 \\
\hline EO24-A1 & 1.7 & LC12-A1 & 0 & LC23-B1 & 3.3 \\
\hline EO26-B1 & 15.4 & LC12-B1 & 4.3 & LM1-B1 & 1 \\
\hline EO31-A1 & 11.9 & LC14-B1 & 8.7 & LM3B-A1 & 0 \\
\hline EO32-A1 & 10.4 & LC16-A1 & 2.6 & & \\
\hline & & & & & \\
\hline
\end{tabular}

Note: Duplicate values are grouped as follows: $\mathbf{8 8 \%}$ of the values fall within $+/-10 \%$ difference (considered good) and the remaining $12 \%$ of the values fall within $+1-20 \%$ difference (acceptable) 
Appendix 5.5 Percent recovery of $\mathrm{Hg}$ in spiked samples analyzed by cold vapor atomic absorption spectroscopy (CVAAS).

\begin{tabular}{|c|c|c|c|c|c|c|c|}
\hline Sample \# & $\begin{array}{l}\text { Percent } \\
\text { Recover } \\
y\end{array}$ & Sample \# & $\begin{array}{l}\text { Percent } \\
\text { Recover } \\
y\end{array}$ & Sample \# & $\begin{array}{l}\text { Percent } \\
\text { Recover } \\
\text { y }\end{array}$ & Sample \# & $\begin{array}{l}\text { Percent } \\
\text { Recover } \\
y\end{array}$ \\
\hline EO2-A1 & 104 & EO23-B1 & 103 & KL23-B1 & 110 & LM16-B1 & 103 \\
\hline EO2-B1 & 108 & EO26-A1 & 106 & KL27-A1 & 103 & LM17-B1 & 105 \\
\hline E07-B2 & 104 & EO31-B1 & 98 & KL30-B1 & 106 & LM20-A1 & 103 \\
\hline EO8-A2 & 104 & EO36-B1 & 100 & LC3-A1 & 106 & LM22-B1 & 100 \\
\hline EO9-B1 & 104 & KL1-B1 & 90 & LC12-B1 & 107 & R3-A1 & 106 \\
\hline EO10-B2 & 107 & KL3-A1 & 95 & LC14-AI & 102 & R6-B1 & 104 \\
\hline$\overline{\mathrm{EO}} 11-\mathrm{B} 1$ & 107 & KL7-B1 & 87 & LC16-B1 & 108 & $\overline{\mathrm{R} 12-\mathrm{B} 1}$ & 103 \\
\hline EO12-B1 & 107 & $\mathrm{KL} 11-\mathrm{Al}$ & 108 & LC19-B1 & 103 & LC4-B1 & 104 \\
\hline EO15-A1 & 97 & KL13-B1 & 103 & LM6-A1 & 99 & LC8-AI & 106 \\
\hline $\mathrm{EO} 17-\mathrm{B} 1$ & 99 & KL16-A1 & 113 & LM10-A1 & 102 & LC10B-B1 & 107 \\
\hline EO18-BI & 96 & KL18-B1 & 108 & LM13-B1 & 101 & LC23-Al & 103 \\
\hline$\overline{\mathrm{EO} 22-\overline{\mathrm{B}}}$ & 100 & KL20-A1 & 104 & LM14-A1 & 105 & LM3B-B & 106 \\
\hline
\end{tabular}

Note: Spiked recovery values are grouped as follows: $96 \%$ of the values fall within $90-110 \%$ recovery range (considered good) and the remaining $4 \%$ of the values fall within $80-120 \%$ recovery range (acceptable)

Appendix 5.6 Percent recovery of $\mathrm{Hg}$ in standard reference material (SRM) 2704 (from National Institute of Standards \& Technology) and in standard Hg solution analyzed by cold vapor atomic absorption spectroscopy (CVAAS).

\begin{tabular}{|l|l|l|l|l|l|l|l|l|l|l|l|l|}
\hline & Batch \# & 1 & 2 & 3 & 4 & 5 & 6 & 7 & 8 & 9 & 10 & 11 \\
\hline $\begin{array}{l}\text { Hg } \\
\text { Solution }\end{array}$ & & 98 & 98 & 98 & 98 & 99 & 98 & 101 & 100 & 98 & 101 & 98 \\
\hline SRM 2704 & & 101 & 102 & 104 & 98 & 104 & 92 & 101 & 100 & 104 & 101 & 103 \\
\hline
\end{tabular}

Note: Samples were analyzed for $\mathrm{Hg}$ in eleven batches. In each case the SRM 2704 and a standard $\mathrm{Hg}$ solution (with $2.5 \mathrm{ppb} \mathrm{Hg}$ ) were run. Recovery are as follows: for $\mathrm{Hg}$ solution, $100 \%$ of the values are within $95-105 \%$ recovery range (considered good); for SRM $2704,91 \%$ of the values are within 95 $105 \%$ recovery range (considered good) and the remaining $9 \%$ of the values (just one value) are within $90-110 \%$ recovery range (acceptable). 
Appendix 6.1 Database of Heavy Metals and Trace Elements (ppm) in Soils of Southwest Oregon.

\begin{tabular}{|c|c|c|c|c|c|c|c|c|c|c|c|c|}
\hline Site & Horizon & $C d$ & $B a$ & $B e$ & $\mid N i$ & Co & $C r$ & $V$ & $\mathrm{Cu}$ & $Z n$ & $\mathrm{Fe}$ & $M n$ \\
\hline LM1 & A & 1.0 & 300 & $<1.0$ & 25 & 35 & 99 & 182 & 46 & 152 & 57003 & 2540 \\
\hline LM1 & B & $<1.0$ & 212 & $<1.0$ & 27 & 42 & 122 & 223 & 48 & 140 & 68566 & 2055 \\
\hline LM2 & A & $<1.0$ & 249 & $<1.0$ & 17 & 19 & 28 & 129 & 21 & 102 & 43183 & 1913 \\
\hline LM2 & $B$ & $<1.0$ & 186 & $<1.0$ & 17 & 20 & 30 & 145 & 25 & 93 & 44720 & 1215 \\
\hline LM3A & A & $<1.0$ & 792 & $<1.0$ & 7 & $<6$ & 4 & 14 & 11 & 131 & 11248 & 2924 \\
\hline LM3A & B & $<1.0$ & 446 & $<1.0$ & 12 & 7 & 7 & 22 & 21 & 80 & 15469 & 450 \\
\hline LM3B & A & $<1.0$ & 309 & $<1.0$ & 27 & 14 & 23 & 48 & 27 & 62 & 25215 & 1185 \\
\hline LM3B & $B$ & $<1.0$ & 236 & $<1.0$ & 23 & 14 & 21 & 49 & 31 & 60 & 25997 & 1047 \\
\hline LM4 & $A$ & $<1.0$ & 82 & $<1.0$ & 8 & 6 & 6 & 27 & 16 & 56 & 13019 & 644 \\
\hline LM4 & B & $<1.0$ & 51 & $<1.0$ & 8 & 7 & 8 & 34 & 22 & 52 & 15918 & 443 \\
\hline LM5 & A & $<1.0$ & 44 & $<1.0$ & 6 & $<6$ & 6 & 31 & 8 & 33 & 10250 & 315 \\
\hline LM5 & $B$ & $<1.0$ & 25 & $<1.0$ & 11 & 9 & 10 & 49 & 29 & 37 & 17280 & 101 \\
\hline LM6 & A & $<1.0$ & 107 & $<1.0$ & 6 & $<6$ & 5 & 29 & 7 & 44 & 10212 & 695 \\
\hline LM6 & $B$ & $<1.0$ & 40 & $<1.0$ & 8 & 8 & 7 & 45 & 12 & 35 & 15880 & 195 \\
\hline LM7 & A & $<1.0$ & 155 & $<1.0$ & 35 & 17 & 30 & 83 & 30 & 71 & 34372 & 756 \\
\hline LM7 & B & $<1.0$ & 170 & $<1.0$ & 38 & 19 & 31 & 91 & 30 & 69 & 37932 & 789 \\
\hline LM8 & $A$ & $<1.0$ & 523 & $<1.0$ & 10 & 35 & 8 & 96 & 13 & 148 & 38650 & 5685 \\
\hline LM8 & $B$ & $<1.0$ & 206 & $<1.0$ & 6 & 15 & 13 & 138 & 31 & 108 & 63360 & 962 \\
\hline LM9 & $A$ & $<1.0$ & 39 & $<1.0$ & 8 & $<6$ & 4 & 28 & 7 & 27 & 8314 & 336 \\
\hline LM9 & B & $<1.0$ & 21 & $<1.0$ & 5 & 7 & 6 & 47 & 8 & 30 & 16001 & 246 \\
\hline LM10 & A & $<1.0$ & 46 & $<1.0$ & 8 & 6 & 5 & 39 & 11 & 38 & 14251 & 498 \\
\hline LM10 & B & $<1.0$ & 32 & $<1.0$ & 7 & 6 & 5 & 41 & 11 & 31 & 14274 & 279 \\
\hline LM11 & $A$ & $<1.0$ & 66 & $<1.0$ & 5 & 6 & 3 & 31 & 8 & 52 & 13087 & 2625 \\
\hline LM11 & $B$ & $<1.0$ & 27 & $<1.0$ & 4 & $<6$ & 4 & 31 & 8 & 40 & 12642 & 176 \\
\hline LM12 & $A$ & $<1.0$ & 272 & $<1.0$ & 28 & 23 & 21 & 95 & 70 & 94 & 41629 & 1596 \\
\hline LM12 & $B$ & $<1.0$ & 254 & $<1.0$ & 30 & 27 & 25 & 110 & 81 & 94 & 49622 & 1525 \\
\hline LM13 & $A$ & $<1.0$ & 306 & $<1.0$ & 27 & 19 & 23 & 67 & 28 & 85 & 27926 & 2774 \\
\hline LM13 & B & $<1.0$ & 194 & $<1.0$ & 41 & 32 & 41 & 118 & 48 & 75 & 48039 & 1465 \\
\hline
\end{tabular}


Appendix 6.2 Database of Heavy Metals and Trace Elements (ppm) in Soils of Southwest Oregon.

\begin{tabular}{|c|c|c|c|c|c|c|c|c|c|c|c|}
\hline Site & Horizon & $K$ & $A l$ & $L i$ & $C a$ & $N a$ & $M g$ & $L a$ & $P b$ & As & $\mathrm{Hg}$ \\
\hline LM1 & A & 1039 & 56999 & 10 & 6830 & 178 & 6232 & 8 & 104 & $<20$ & 0.15 \\
\hline LM1 & B & 924 & 71682 & 12 & 3322 & 136 & 7513 & 7 & 25 & $<20$ & 0.08 \\
\hline LM2 & A & 1346 & 50985 & 11 & 7893 & 171 & 5308 & 9 & 22 & $<20$ & 0.15 \\
\hline LM2 & B & 1170 & 54262 & 13 & 4202 & 170 & 5187 & 9 & $<10$ & $<20$ & 0.07 \\
\hline LM3A & $A$ & 888 & 18313 & 11 & 6773 & 338 & 1123 & 10 & 13 & $<20$ & 0.14 \\
\hline LM3A & B & 727 & 33387 & 23 & 2825 & 756 & 1448 & 15 & $<10$ & $<20$ & 0.05 \\
\hline LM3B & A & 1031 & 43002 & 13 & 6645 & 617 & 2563 & 13 & $<10$ & $<20$ & 0.10 \\
\hline LM3B & B & 664 & 49387 & 16 & 2350 & 694 & 1815 & 19 & $<10$ & $<20$ & 0.04 \\
\hline LM4 & A & 649 & 20954 & 5 & 1948 & 445 & 1520 & $<5$ & $<10$ & $<20$ & 0.06 \\
\hline LM4 & B & 438 & 27380 & 9 & 1598 & 640 & 2038 & 9 & 10 & $<20$ & 0.08 \\
\hline LM5 & A & 469 & 8580 & $<5$ & 2101 & 679 & 689 & $<5$ & 10 & $<20$ & 0.06 \\
\hline LM5 & B & 430 & 27338 & 6 & 3021 & 1188 & 1498 & $<5$ & $<10$ & $<20$ & 0.04 \\
\hline LM6 & $A$ & 452 & 13442 & $<5$ & 2254 & 478 & 841 & $<5$ & $<10$ & $<20$ & 0.06 \\
\hline LM6 & B & 394 & 23427 & 7 & 1396 & 768 & 1035 & $<5$ & $<10$ & $<20$ & 0.04 \\
\hline LM7 & A & 2285 & 32096 & 8 & 13066 & 1353 & 8385 & 11 & $<10$ & $<20$ & 0.08 \\
\hline LM7 & B & 1437 & 35235 & 8 & 9980 & 1357 & 9043 & 13 & $<10$ & $<20$ & 0.05 \\
\hline LM8 & A & 723 & 34515 & 6 & 9419 & 136 & 3419 & 5 & 20 & $<20$ & 0.17 \\
\hline LM8 & $B$ & 776 & 59463 & 8 & 5888 & 59 & 7446 & $<5$ & $<10$ & $<20$ & 0.09 \\
\hline LM9 & A & 373 & 4634 & $<5$ & 2194 & 357 & 545 & $<5$ & 20 & $<20$ & 0.14 \\
\hline LM9 & B & 214 & 12641 & $<5$ & 998 & 557 & 791 & $<5$ & 10 & $<20$ & 0.06 \\
\hline LM10 & A & 310 & 20868 & $<5$ & 2371 & 607 & 988 & 5 & $<10$ & $<20$ & 0.05 \\
\hline LM10 & B & 251 & 17406 & $<5$ & 2139 & 722 & 960 & 6 & $<10$ & $<20$ & $<0.04$ \\
\hline LM11 & A & 407 & 13415 & $<5$ & 1886 & 471 & 784 & $<5$ & $<10$ & $<20$ & 0.08 \\
\hline LM11 & B & 240 & 14925 & $<5$ & 1067 & 502 & 688 & $<5$ & 10 & $<20$ & 0.04 \\
\hline LM12 & $A$ & 2616 & 71482 & 11 & 14618 & 151 & 13829 & 7 & $<10$ & $<20$ & 0.14 \\
\hline LM12 & $B$ & 1774 & 79896 & 13 & 10812 & 157 & 15300 & 8 & $<10$ & $<20$ & 0.08 \\
\hline LM13 & A & 857 & 47688 & 5 & 17580 & 123 & 2665 & 5 & $<10$ & $<20$ & 0.26 \\
\hline LM13 & $B$ & 725 & 75682 & 9 & 3028 & 149 & 4499 & 11 & $<10$ & $<20$ & $<0.04$ \\
\hline
\end{tabular}


Appendix 6.3 Database of Heavy Metals and Trace Elements (ppm) in Soils of Southwest Oregon.

\begin{tabular}{|c|c|c|c|c|c|c|c|c|c|c|c|c|}
\hline Site & Horizon & $C d$ & $B a$ & $B e$ & $N i$ & $\mathrm{Co}$ & $\mathrm{Cr}$ & $V$ & $C u$ & $Z n$ & $\mathrm{Fe}$ & $M n$ \\
\hline LM14 & A & $<1.0$ & 475 & $<1.0$ & 63 & 31 & 63 & 116 & 52 & 151 & 55108 & 4571 \\
\hline LM14 & $B$ & 1.0 & 484 & $<1.0$ & 82 & 46 & 97 & 176 & 73 & 140 & 82430 & 2077 \\
\hline LM15 & A & $<1.0$ & 472 & $<1.0$ & 76 & 34 & 89 & 150 & 54 & 93 & 60452 & 2313 \\
\hline LM15 & B & $<1.0$ & 525 & $<1.0$ & 86 & 40 & 101 & 170 & 66 & 84 & 68459 & 1206 \\
\hline LM16 & A & $<1.0$ & 284 & $<1.0$ & 36 & 36 & 44 & 135 & 52 & 93 & 51558 & 1222 \\
\hline LM16 & $B$ & $<1.0$ & 356 & $<1.0$ & 43 & 39 & 51 & 150 & 66 & 87 & 59114 & 1223 \\
\hline LM17 & A & $<1.0$ & 136 & $<1.0$ & 29 & 18 & 26 & 78 & 28 & 74 & 31736 & 730 \\
\hline LM17 & B & $<1.0$ & 157 & $<1.0$ & 35 & 20 & 29 & 88 & 33 & 72 & 36824 & 783 \\
\hline LM19 & A & $<1.0$ & 246 & $<1.0$ & $<4$ & 6 & 4 & 14 & 7 & 68 & 20052 & 1209 \\
\hline LM19 & $B$ & $<1.0$ & 306 & 1.0 & $<4$ & 7 & 4 & 16 & 9 & 103 & 21199 & 2147 \\
\hline LM20 & A & $<1.0$ & 280 & $<1.0$ & 8 & 9 & 11 & 27 & 12 & 113 & 21970 & 2000 \\
\hline LM20 & B & $<1.0$ & 264 & $<1.0$ & 12 & 9 & 12 & 30 & 12 & 127 & 23409 & 1913 \\
\hline LM21 & A & $<1.0$ & 133 & $<1.0$ & 25 & 14 & 17 & 46 & 21 & 83 & 25539 & 2399 \\
\hline LM21 & B & $<1.0$ & 117 & $<1.0$ & 35 & 17 & 22 & 62 & 31 & 80 & 31065 & 1134 \\
\hline LM22 & A & $<1.0$ & 246 & $<1.0$ & 19 & 13 & 17 & 64 & 24 & 106 & 26162 & 2800 \\
\hline LM22 & B & $<1.0$ & 136 & $<1.0$ & 24 & 14 & 20 & 78 & 37 & 64 & 28580 & 639 \\
\hline LC1 & A & $<1.0$ & 98 & $<1.0$ & 15 & 29 & 36 & 82 & 30 & 42 & 30541 & 1276 \\
\hline LC1 & $B$ & $<1.0$ & 75 & $<1.0$ & 13 & 34 & 32 & 77 & 29 & 35 & 30496 & 1140 \\
\hline LC2 & A & $<1.0$ & 252 & $<1.0$ & 15 & 52 & 28 & 212 & 125 & 110 & 80890 & 2831 \\
\hline LC2 & $B$ & $<1.0$ & 162 & $<1.0$ & 10 & 17 & 24 & 220 & 150 & 81 & 79319 & 470 \\
\hline LC3 & A & $<1.0$ & 143 & $<1.0$ & 7 & 8 & 16 & 34 & 11 & 26 & 16789 & 1216 \\
\hline LC3 & B & $<1.0$ & 64 & $<1.0$ & 9 & 8 & 21 & 44 & 13 & 25 & 19378 & 187 \\
\hline LC4 & $A$ & $<1.0$ & 209 & $<1.0$ & 9 & 10 & 15 & 27 & 5 & 43 & 15727 & 730 \\
\hline LC4 & B & $<1.0$ & 128 & $<1.0$ & 12 & 7 & 30 & 44 & 12 & 42 & 25361 & 174 \\
\hline LC5 & A & $<1.0$ & 206 & 1.0 & 100 & 30 & 61 & 85 & 71 & 123 & 53454 & 5279 \\
\hline LC5 & $B$ & $<1.0$ & 188 & 1.0 & 104 & 32 & 68 & 97 & 78 & 132 & 57709 & 4951 \\
\hline LC6 & A & 1.2 & 68 & $<1.0$ & 56 & 47 & 37 & 218 & 148 & 101 & 74040 & 1248 \\
\hline LC6 & $B$ & 1.1 & 59 & $<1.0$ & 65 & 50 & 41 & 238 & 193 & 99 & 81995 & 1252 \\
\hline
\end{tabular}


Appendix 6.4 Database of Heavy Metals and Trace Elements (ppm) in Soils of Southwest Oregon.

\begin{tabular}{|c|c|c|c|c|c|c|c|c|c|c|c|}
\hline Site & |Horizon| & K & $A l$ & $\mid L i$ & $\mathrm{Ca}$ & $\mathrm{Na}$ & |Mg & $\mid L a$ & $\mid P b$ & As & $\mathrm{Hg}$ \\
\hline LM14 & $A$ & 1499 & 77558 & 9 & 15265 & 135 & 1612 & 11 & $<10$ & $<20$ & 0.17 \\
\hline LM14 & $B$ & 1071 & 103515 & 12 & 2913 & 122 & 1683 & 17 & $<10$ & $<20$ & 0.05 \\
\hline LM15 & A & 1712 & 85913 & 13 & 5748 & 206 & 2181 & 13 & $<10$ & $<20$ & 0.07 \\
\hline LM15 & $B$ & 1353 & 95618 & 16 & 3069 & 181 & 2396 & 16 & $<10$ & $<20$ & 0.04 \\
\hline LM16 & A & 1853 & 58412 & 11 & 3861 & 216 & 2893 & 17 & $<10$ & $<20$ & 0.07 \\
\hline LM16 & $B$ & 1861 & 74450 & 14 & 3879 & 250 & 3129 & 21 & $<10$ & $<20$ & $<0.04$ \\
\hline LM17 & A & 1860 & 30688 & 7 & 15923 & 1416 & 7817 & 10 & $<10$ & $<20$ & 0.08 \\
\hline LM17 & $B$ & 1121 & 34930 & 8 & 12209 & 1689 & 8823 & 12 & $<10$ & $<20$ & 0.06 \\
\hline LM19 & A & 941 & 18506 & $<5$ & 3552 & 117 & 1206 & 23 & 10 & $<20$ & 0.09 \\
\hline LM19 & B & 1050 & 24374 & 7 & 2653 & 114 & 1319 & 18 & $<10$ & $<20$ & 0.05 \\
\hline LM20 & A & 669 & 25643 & 8 & 3996 & 181 & 1517 & 7 & 18 & $<20$ & 0.10 \\
\hline LM20 & $B$ & 515 & 31016 & 12 & 1261 & 185 & 1605 & 9 & 12 & $<20$ & 0.07 \\
\hline LM21 & A & 520 & 31915 & 7 & 5110 & 409 & 4038 & 5 & $<10$ & $<20$ & 0.17 \\
\hline LM21 & $B$ & 390 & 44482 & 8 & 2780 & 603 & 5277 & 13 & $<10$ & $<20$ & 0.06 \\
\hline LM22 & A & 470 & 31486 & 8 & 3389 & 371 & 2375 & 6 & $<10$ & $<20$ & 0.08 \\
\hline LM22 & B & 344 & 42274 & 9 & 2192 & 393 & 3456 & 5 & $<10$ & $k 20$ & 0.06 \\
\hline LC1 & A & 766 & 32045 & 6 & 3042 & 141 & 2565 & 20 & $<10$ & $<20$ & $<0.04$ \\
\hline LC1 & B & 446 & 29862 & 5 & 2575 & 127 & 2316 & 17 & $<10$ & $<20$ & $<0.04$ \\
\hline LC2 & A & 963 & 56248 & 6 & 4589 & 92 & 6134 & 20 & $<10$ & $<20$ & 0.05 \\
\hline LC2 & $B$ & 517 & 82482 & 5 & 4183 & 82 & 10958 & 8 & $<10$ & $<20$ & $<0.04$ \\
\hline LC3 & A & 826 & 14574 & 5 & 3081 & 60 & 1317 & 13 & 40 & $<20$ & 0.09 \\
\hline LC3 & B & 780 & 21008 & 8 & 134 & 53 & 1520 & 15 & $<10$ & $<20$ & $<0.04$ \\
\hline LC4 & A & 890 & 18856 & 8 & 2906 & 73 & 1328 & 10 & $<10$ & $<20$ & 0.06 \\
\hline LC4 & $B$ & 1105 & 41695 & 15 & 952 & 59 & 2088 & 10 & 10 & $<20$ & 0.05 \\
\hline LC5 & A & 4666 & 35246 & 48 & 5209 & 88 & 10561 & 9 & 16 & $<20$ & 0.07 \\
\hline LC5 & B & 5022 & 40154 & 54 & 4073 & 97 & |11308 & 10 & 14 & $<20$ & 0.06 \\
\hline LC6 & A & 1335 & 38245 & 5 & 15137 & 1511 & 11419 & 5 & $<10$ & $<20$ & 0.06 \\
\hline LC6 & ${ }_{B}$ & 518 & 48781 & 5 & 14619 & 2341 & 13405 & 6 & $<10$ & $<20$ & $<0.04$ \\
\hline
\end{tabular}


Appendix 6.5 Database of Heavy Metals and Trace Elements (ppm) in Soils of Southwest Oregon.

\begin{tabular}{|c|c|c|c|c|c|c|c|c|c|c|c|c|}
\hline Site & Horizon & $C d$ & $\boldsymbol{B a}$ & $B e$ & $N i$ & Co & $\mathrm{Cr}$ & $\boldsymbol{V}$ & $C u$ & $Z n$ & $\mathrm{Fe}$ & $M n$ \\
\hline LC7 & A & $<1.0$ & 148 & $<1.0$ & 91 & 22 & 74 & 59 & 28 & 63 & 32465 & 1522 \\
\hline LC7 & $B$ & $<1.0$ & 118 & $<1.0$ & 121 & 30 & 99 & 69 & 35 & 71 & 42182 & 1228 \\
\hline LC8 & A & 1.0 & 281 & $<1.0$ & 54 & 16 & 51 & 39 & 17 & 87 & 28374 & 1454 \\
\hline LC8 & $B$ & 1.0 & 190 & $<1.0$ & 61 & 19 & 62 & 48 & 20 & 82 & 32982 & 922 \\
\hline LC9 & A & $<1.0$ & 232 & & 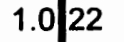 & 19 & 30 & 33 & 27 & 85 & 30787 & 728 \\
\hline LC9 & B & $<1.0$ & 176 & & \begin{tabular}{l|l|l}
1.325
\end{tabular} & 22 & 39 & 44 & 35 & 95 & 38071 & 525 \\
\hline LC10A & A & 1.0 & 193 & $<1.0$ & 22 & 25 & 37 & 110 & 31 & 73 & 37471 & 1631 \\
\hline LC10A & B & 1.1 & 196 & $<1.0$ & 30 & 38 & 58 & 171 & 44 & 85 & 59116 & 1857 \\
\hline LC10B & A & $<1.0$ & 218 & $<1.0$ & 23 & 7 & 46 & 65 & 17 & 76 & 35558 & 803 \\
\hline LC10B & $B$ & $<1.0$ & 150 & $<1.0$ & 27 & 8 & 54 & 78 & 19 & 78 & 41380 & 500 \\
\hline LC11 & A & $<1.0$ & 119 & $<1.0$ & 38 & 15 & 38 & 57 & 25 & 131 & 28956 & 941 \\
\hline LC11 & B & $<1.0$ & 99 & $<1.0$ & 32 & 13 & 33 & 54 & 20 & 86 & 26666 & 732 \\
\hline LC12 & A & $<1.0$ & 125 & $<1.0$ & 17 & 9 & 34 & 40 & 11 & 67 & 21565 & 353 \\
\hline LC12 & B & $<1.0$ & 108 & $<1.0$ & 17 & 10 & 37 & 43 & 9 & 60 & 23045 & 287 \\
\hline LC13 & A & $<1.0$ & 8 & $<1.0$ & 4 & $<6$ & 8 & 6 & $<2$ & 10 & 3844 & 41 \\
\hline LC13 & B & $<1.0$ & 34 & $<1.0$ & $<4$ & $<6$ & 9 & 6 & 4 & 19 & 3846 & 30 \\
\hline LC14 & A & $<1.0$ & 34 & $<1.0$ & $<4$ & $<6$ & 9 & 7 & 4 & 19 & 2648 & 52 \\
\hline LC14 & B & $<1.0$ & 10 & $<1.0$ & 5 & $<6$ & 9 & 7 & $<2$ & 11 & 4538 & 32 \\
\hline LC15 & A & $<1.0$ & 36 & $<1.0$ & 11 & $<6$ & 28 & 34 & 19 & 31 & 17366 & 235 \\
\hline LC15 & B & $<1.0$ & 73 & $<1.0$ & 27 & 11 & 57 & 74 & 33 & 81 & 40980 & 1363 \\
\hline LC16 & A & $<1.0$ & 14 & $<1.0$ & $<4$ & $<6$ & 7 & 8 & 2 & 15 & 3985 & 24 \\
\hline LC16 & B & $<1.0$ & 7 & $<1.0$ & $<4$ & $<6$ & 6 & 4 & $<2$ & 8 & 3066 & 21 \\
\hline LC17 & A & $<1.0$ & 24 & $<1.0$ & 4 & $<6$ & 12 & 20 & 9 & 16 & 7685 & 62 \\
\hline LC17 & B & $<1.0$ & 36 & $<1.0$ & 13 & 8 & 39 & 55 & 21 & 48 & 29401 & 186 \\
\hline LC18 & A & $<1.0$ & 22 & $<1.0$ & 5 & $<6$ & 28 & 57 & 12 & 18 & 20720 & 31 \\
\hline LC18 & B & $\mid<1.0$ & 23 & $\mid<1.0$ & 5 & $<6$ & 53 & 72 & 7 & 23 & 35875 & 49 \\
\hline
\end{tabular}


Appendix 6.6 Database of Heavy Metals and Trace Elements (ppm) in Soils of Southwest Oregon.

\begin{tabular}{|c|c|c|c|c|c|c|c|c|c|c|c|}
\hline Site & Horizon & $K$ & $A l$ & $L i$ & $\mathrm{Ca}$ & $\mathrm{Na}$ & $M g$ & $L a$ & $P b$ & As & $\mathrm{Hg}$ \\
\hline LC7 & A & 2289 & 24623 & 23 & 6822 & 109 & 6508 & 8 & $<10$ & $<20$ & 0.08 \\
\hline LC7 & B & 2515 & 34060 & 31 & 877 & 94 & 6845 & 11 & $<10$ & $<20$ & $<0.04$ \\
\hline LC8 & A & 2782 & 24526 & 27 & 6109 & 124 & 6850 & 13 & $<10$ & $<20$ & 0.06 \\
\hline LC8 & B & 2488 & 29474 & 34 & 2942 & 130 & 7881 & 15 & 10 & $<20$ & 0.04 \\
\hline LC9 & A & 2646 & 26201 & 22 & 4148 & 96 & 4926 & 26 & 12 & $<20$ & 0.09 \\
\hline LC9 & B & 2948 & 35519 & 25 & 1789 & 84 & 5632 & 33 & 16 & $<20$ & 0.08 \\
\hline LC10A & A & 1567 & 23752 & 5 & 8279 & 120 & 3186 & 8 & $<10$ & $<20$ & 0.16 \\
\hline LC10A & B & 1704 & 35983 & 8 & 4369 & 149 & 4191 & 11 & $<10$ & $<20$ & 0.10 \\
\hline LC10B & A & 1132 & 56172 & 28 & 1604 & 78 & 2284 & 16 & $<10$ & $<20$ & 0.06 \\
\hline LC10B & B & 1025 & 67634 & 33 & 793 & 81 & 2457 & 13 & $<10$ & $<20$ & 0.05 \\
\hline LC11 & A & 1544 & 21845 & 16 & 6197 & 350 & 7059 & 13 & 16 & $<20$ & 0.08 \\
\hline LC11 & B & 1137 & 19743 & 13 & 5933 & 444 & 6266 & 11 & 11 & $<20$ & 0.04 \\
\hline LC12 & A & 2099 & 23010 & 19 & 4505 & 183 & 6629 & 14 & 25 & $<20$ & 0.07 \\
\hline LC12 & B & 2016 & 26359 & 23 & 2384 & 156 & 7088 & 17 & $<10$ & $<20$ & 0.04 \\
\hline LC13 & A & 298 & 2689 & 6 & 640 & 129 & 895 & $<5$ & $<10$ & $<20$ & $<0.04$ \\
\hline LC13 & $B$ & 315 & 2752 & 7 & 576 & 129 & 821 & $<5$ & $<10$ & $<20$ & $<0.04$ \\
\hline LC14 & A & 530 & 2541 & $<5$ & 1888 & 241 & 704 & $<5$ & 10 & $<20$ & 0.14 \\
\hline LC14 & B & 262 & 5001 & 9 & 465 & 105 & 756 & $<5$ & $<10$ & $<20$ & $<0.04$ \\
\hline LC15 & A & 475 & 16442 & 5 & 1068 & 206 & 1187 & 5 & 10 & $<20$ & 0.17 \\
\hline LC15 & $B$ & 605 & 55751 & 26 & 587 & 194 & 2063 & 13 & $<10$ & $<20$ & 0.14 \\
\hline LC16 & A & 369 & 4016 & $<5.0$ & 1151 & 138 & 620 & $<5$ & $<10$ & $<20$ & 0.06 \\
\hline LC16 & B & 264 & 2586 & 6 & 411 & 98 & 591 & $<5$ & $<10$ & $<20$ & $<0.04$ \\
\hline LC17 & A & 896 & 6246 & $<5$ & 1553 & 362 & 1419 & 7 & $<10$ & $<20$ & 0.19 \\
\hline LC17 & $B$ & 1176 & 29679 & 33 & 292 & 190 & 2935 & 14 & $<10$ & $<20$ & 0.14 \\
\hline LC18 & A & 861 & 17362 & 7 & 638 & 405 & 1551 & 7 & 14 & $<20$ & 0.37 \\
\hline LC18 & $B$ & 818 & 41250 & 22 & 429 & 175 & 1655 & 9 & $\mid<10$ & $<20$ & 0.25 \\
\hline
\end{tabular}


Appendix 6.7 Database of Heavy Metals and Trace Elements (ppm) in Soils of Southwest Oregon.

\begin{tabular}{|c|c|c|c|c|c|c|c|c|c|c|c|c|}
\hline Site & Horizon & $C d$ & $B a$ & $\mathrm{Be}$ & $N i$ & Co & $\mathrm{Cr}$ & $\boldsymbol{V}$ & $\mathrm{Cu}$ & $Z n$ & $\mathrm{Fe}$ & $M n$ \\
\hline LC19 & A & $<1.0$ & 138 & $<1.0$ & 71 & 60 & 95 & 207 & 134 & 100 & 72999 & 1442 \\
\hline LC19 & $B$ & 1.1 & 159 & $<1.0$ & 122 & 51 & 159 & 248 & 188 & 86 & 97686 & 922 \\
\hline LC20 & A & $<1.0$ & 152 & $<1.0$ & 170 & 26 & 111 & 69 & 43 & 105 & 35746 & 598 \\
\hline LC20 & $B$ & $<1.0$ & 137 & $<1.0$ & 154 & 27 & 107 & 69 & 37 & 85 & 32746 & 654 \\
\hline LC21 & A & $<1.0$ & 285 & $<1.0$ & 81 & 17 & 96 & 74 & 22 & 66 & 33971 & 2408 \\
\hline LC21 & B & $<1.0$ & 124 & $<1.0$ & 112 & 22 & 135 & 94 & 25 & 51 & 45439 & 413 \\
\hline LC22 & A & $<1.0$ & 193 & $<1.0$ & 9 & 22 & 21 & 133 & 51 & 62 & 78726 & 3495 \\
\hline LC22 & B & $<1.0$ & 124 & $<1.0$ & 9 & 23 & 22 & 142 & 61 & 60 & 82363 & 2555 \\
\hline LC23 & A & $<1.0$ & 118 & $<1.0$ & 117 & 45 & 120 & 117 & 65 & 105 & 78302 & 1988 \\
\hline LC23 & $B$ & 1.0 & 91 & $<1.0$ & 163 & 56 & 161 & 150 & 90 & 136 & 98169 & 1765 \\
\hline EO2 & A & $<1.0$ & 105 & $<1.0$ & 29 & 11 & 12 & 38 & 15 & 61 & 19180 & 559 \\
\hline EO2 & B & $<1.0$ & 133 & $<1.0$ & 33 & 13 & 14 & 47 & 18 & 46 & 23288 & 430 \\
\hline EO7 & A & $<1.0$ & 234 & $<1.0$ & 23 & 17 & 20 & 79 & 29 & 83 & 27200 & 779 \\
\hline EO7 & B & 1.0 & 256 & $<1.0$ & 40 & 28 & 36 & 142 & 51 & 82 & 45716 & 943 \\
\hline EO8 & A & $<1.0$ & 350 & $<1.0$ & 19 & 8 & 7 & 40 & 16 & 161 & 15618 & 4600 \\
\hline EO8 & $B$ & $<1.0$ & 109 & $<1.0$ & 24 & 12 & 11 & 56 & 24 & 104 & 22707 & 581 \\
\hline EO9 & A & $<1.0$ & 92 & $<1.0$ & 10 & 8 & 10 & 48 & 13 & 59 & 14220 & 699 \\
\hline EO9 & $B$ & $<1.0$ & 148 & $<1.0$ & 15 & 11 & 16 & 75 & 24 & 45 & 21466 & 421 \\
\hline E010 & A & $<1.0$ & 100 & $<1.0$ & 5 & $<6$ & 3 & 18 & 8 & 36 & 7034 & 327 \\
\hline EO10 & B & $<1.0$ & 73 & $<1.0$ & 5 & $<6$ & 4 & 31 & 11 & 30 & 10417 & 145 \\
\hline E011 & A & $<1.0$ & 70 & $<1.0$ & 5 & $<6$ & 4 & 23 & 10 & 38 & 8190 & 292 \\
\hline E011 & B & $<1.0$ & 76 & $<1.0$ & 5 & $<6$ & 4 & 27 & 12 & 29 & 9475 & 196 \\
\hline E012 & A & $<1.0$ & 67 & $<1.0$ & 6 & $<6$ & 4 & 24 & 9 & 32 & 8340 & 287 \\
\hline E012 & B & $<1.0$ & 71 & $<1.0$ & 5 & $<6$ & 4 & 25 & 10 & 91 & 8615 & 135 \\
\hline E013 & A & $<1.0$ & 85 & $<1.0$ & 9 & $<6$ & 5 & 31 & 11 & 52 & 9812 & 533 \\
\hline E013 & B & $<1.0$ & 112 & $<1.0$ & 12 & 6 & 7 & 42 & 15 & 35 & 13010 & 214 \\
\hline EO14 & A & $<1.0$ & 96 & $<1.0$ & 7 & $<6$ & 5 & 18 & 18 & 27 & 8402 & 232 \\
\hline EO14 & B & $<1.0$ & 106 & $<1.0$ & 8 & $<6$ & 5 & 21 & 20 & 21 & 10204 & 210 \\
\hline
\end{tabular}


Appendix 6.8 Database of Heavy Metals and Trace Elements (ppm) in Soils of Southwest Oregon.

\begin{tabular}{|c|c|c|c|c|c|c|c|c|c|c|c|}
\hline Site & Horizon & $K$ & $A l$ & $L i$ & $\mathrm{Ca}$ & $N a$ & $M g$ & $L a$ & $P b$ & As & $H g$ \\
\hline LC19 & A & 1622 & 73145 & 14 & 5534 & 265 & 11425 & 7 & $<10$ & $<20$ & 0.11 \\
\hline LC19 & B & 688 & 100324 & 18 & 1012 & 311 & 13848 & 5 & $<10$ & $<20$ & 0.06 \\
\hline LC20 & A & 3124 & 33024 & 21 & 8191 & 152 & 10809 & 10 & 51 & $<20$ & 0.14 \\
\hline LC20 & B & 2666 & 32262 & 21 & 5931 & 145 & 10175 & 11 & 40 & $<20$ & 0.13 \\
\hline LC21 & A & 1065 & 35732 & 20 & 4972 & 75 & 4714 & 8 & 10 & $<20$ & 0.10 \\
\hline LC21 & B & 1284 & 52244 & 26 & 376 & 82 & 6420 & 13 & $<10$ & $<20$ & 0.08 \\
\hline LC22 & A & 631 & 53649 & 5 & 3884 & 61 & 1498 & 11 & $<10$ & $<20$ & 0.10 \\
\hline LC22 & B & 379 & 61317 & 6 & 2031 & 57 & 1468 & 12 & $<10$ & $<20$ & 0.07 \\
\hline LC23 & A & 947 & 61316 & 18 & 3051 & 198 & 7410 & 21 & $<10$ & $<20$ & 0.21 \\
\hline LC23 & B & 822 & 85402 & 25 & 608 & 163 & 8673 & 27 & $<10$ & $<20$ & 0.11 \\
\hline EO2 & A & 607 & 21690 & 6 & 3642 & 710 & 3924 & 6 & 10 & $<20$ & 0.05 \\
\hline EO2 & B & 567 & 25605 & 8 & 3137 & 719 & 4798 & 8 & $<10$ & $<20$ & $<0.04$ \\
\hline EO7 & A & 1317 & 31794 & 8 & 7077 & 328 & 2565 & 9 & $<10$ & $<20$ & 0.07 \\
\hline EO7 & B & 1875 & 58961 & 14 & 5061 & 560 & 3570 & 15 & $<10$ & $<20$ & $<0.04$ \\
\hline EO8 & A & 807 & 24723 & 5 & 12354 & 268 & 2202 & $<5$ & 10 & $<20$ & 0.17 \\
\hline EO8 & B & 623 & 38927 & 8 & 2531 & 531 & 2531 & 6 & $<10$ & $<20$ & $<0.04$ \\
\hline EO9 & A & 1042 & 14861 & $<5$ & 3976 & 330 & 1282 & $<5$ & 10 & $<20$ & 0.09 \\
\hline EO9 & B & 1094 & 25721 & 7 & 3768 & 691 & 1567 & 7 & $<10$ & $<20$ & $<0.04$ \\
\hline E010 & A & 513 & 13198 & $<5$ & 2787 & 446 & 879 & $<5$ & 10 & $<20$ & 0.04 \\
\hline E010 & B & 336 & 18549 & 6 & 1937 & 601 & 972 & 5 & $<10$ & $<20$ & $<0.04$ \\
\hline EO11 & A & 616 & 13820 & $<5$ & 2642 & 519 & 1003 & $<5$ & $<10$ & $<20$ & 0.04 \\
\hline E011 & B & 449 & 17247 & 5 & 2292 & 627 & 1148 & 5 & $<10$ & $<20$ & $<0.04$ \\
\hline E012 & A & 541 & 13830 & $<5$ & 3341 & 628 & 1164 & $<5$ & $<10$ & $<20$ & 0.04 \\
\hline E012 & B & 404 & 13989 & $<5$ & 2523 & 600 & 967 & $<5$ & 10 & $<20$ & $<0.04$ \\
\hline E013 & A & 691 & 14823 & $<5$ & 4001 & 625 & 1210 & $<5$ & 10 & $<20$ & 0.07 \\
\hline E013 & B & 660 & 20113 & 5 & 3831 & 914 & 1595 & 5 & $<10$ & $<20$ & $<0.04$ \\
\hline EO14 & A & 560 & 16879 & 6 & 3281 & 666 & 1564 & 5 & $<10$ & $<20$ & 0.04 \\
\hline EO14 & B & 513 & 20453 & 6 & 3168 & 1040 & 1846 & 6 & $<10$ & $<20$ & $<0.04$ \\
\hline
\end{tabular}


Appendix 6.9 Database of Heavy Metals and Trace Elements (ppm) in Soils of Southwest Oregon.

\begin{tabular}{|c|c|c|c|c|c|c|c|c|c|c|c|c|}
\hline Site & Horizon & $C d$ & $B a$ & Be & $N i$ & Co & $\mathrm{Cr}$ & $V$ & $C u$ & $Z n$ & $\mathrm{Fe}$ & $M n$ \\
\hline E015 & $A$ & $<1.0$ & 95 & $<1.0$ & 8 & $<6$ & 5 & 31 & 8 & 49 & 9874 & 709 \\
\hline E015 & $B$ & $<1.0$ & 49 & $<1.0$ & 8 & $<6$ & 5 & 34 & 13 & 29 & 10583 & 182 \\
\hline E016 & A & $<1.0$ & 74 & $<1.0$ & 6 & 6 & 5 & 35 & 10 & 53 & 12226 & 673 \\
\hline E016 & $B$ & $<1.0$ & 85 & $<1.0$ & 7 & 7 & 6 & 47 & 14 & 36 & 15507 & 251 \\
\hline E017 & A & $<1.0$ & 54 & $<1.0$ & 5 & $<6$ & 5 & 22 & 10 & 35 & 8317 & 514 \\
\hline E017 & $B$ & $<1.0$ & 36 & $<1.0$ & 7 & $<6$ & 5 & 30 & 13 & 28 & 10359 & 236 \\
\hline E018 & A & $<1.0$ & 45 & $<1.0$ & 7 & $<6$ & 5 & 38 & 6 & 41 & 11326 & 383 \\
\hline E018 & B & $<1.0$ & 29 & $<1.0$ & 7 & 6 & 5 & 38 & 13 & 30 & 11704 & 157 \\
\hline EO20 & A & $<1.0$ & 183 & $<1.0$ & 7 & $<6$ & 3 & 20 & 7 & 48 & 6965 & 907 \\
\hline EO20 & B & $<1.0$ & 68 & $<1.0$ & 8 & $<6$ & 5 & 31 & 12 & 30 & 9857 & 163 \\
\hline EO21 & A & $<1.0$ & 58 & $<1.0$ & 11 & $<6$ & 4 & 20 & 9 & 46 & 9170 & 369 \\
\hline EO21 & $B$ & $<1.0$ & 143 & $<1.0$ & 17 & 7 & 6 & 27 & 14 & 43 & 12944 & 352 \\
\hline EO22 & A & $<1.0$ & 123 & $<1.0$ & 8 & 6 & 4 & 26 & 8 & 64 & 9755 & 976 \\
\hline EO22 & B & $<1.0$ & 97 & $<1.0$ & 10 & 6 & 5 & 32 & 12 & 35 & 11430 & 137 \\
\hline EO23 & A & $<1.0$ & 84 & $<1.0$ & 9 & 6 & 5 & 35 & 9 & 43 & 11824 & 485 \\
\hline EO23 & $B$ & $<1.0$ & 46 & $<1.0$ & 12 & 7 & 7 & 45 & 10 & 34 & 14524 & 178 \\
\hline EO24* & A1 & $<1.0$ & 105 & $<1.0$ & 12 & 6 & 5 & 31 & 19 & 92 & 11783 & 3235 \\
\hline EO24 & A2 & $<1.0$ & 116 & $<1.0$ & 11 & 7 & 6 & 32 & 18 & 89 & 13079 & 2854 \\
\hline EO24 & B1 & $<1.0$ & 81 & $<1.0$ & 19 & 9 & 10 & 46 & 36 & 42 & 16346 & 143 \\
\hline EO24 & B2 & $<1.0$ & 69 & $<1.0$ & 20 & 10 & 10 & 51 & 38 & 39 & 18016 & 172 \\
\hline EO25 & $A$ & $<1.0$ & 148 & $<1.0$ & 7 & $<6$ & 4 & 23 & 10 & 66 & 9654 & 851 \\
\hline EO25 & $B$ & $<1.0$ & 95 & $<1.0$ & 8 & $<6$ & 5 & 24 & 13 & 45 & 10041 & 153 \\
\hline EO26* & A1 & $<1.0$ & 52 & $<1.0$ & 15 & 6 & 6 & 29 & 22 & 26 & 10219 & 451 \\
\hline EO26 & A2 & $<1.0$ & 52 & $<1.0$ & 14 & 6 & 7 & 30 & 23 & 24 & 11505 & 465 \\
\hline EO26 & B1 & $<1.0$ & 61 & $<1.0$ & 20 & 7 & 8 & 37 & 27 & 23 & 12490 & 165 \\
\hline EO26 & B2 & $<1.0$ & 49 & $<1.0$ & 21 & 7 & 8 & 37 & 25 & 21 & 13894 & 184 \\
\hline EO27 & A & $<1.0$ & 122 & $<1.0$ & 13 & 7 & 4 & 36 & 27 & 49 & 12603 & 3049 \\
\hline EO27 & $B$ & $<1.0$ & 122 & $<1.0$ & 13 & 7 & 7 & 35 & 27 & 49 & 14215 & 124 \\
\hline EO30* & A1 & $<1.0$ & 86 & $<1.0$ & 11 & $<6$ & 5 & 21 & 11 & 32 & 8793 & 248 \\
\hline
\end{tabular}


Appendix 6.10 Database of Heavy Metals and Trace Elements (ppm) in Soils of Southwest Oregon.

\begin{tabular}{|c|c|c|c|c|c|c|c|c|c|c|c|}
\hline Site & Horizon & $\boldsymbol{K}$ & $A l$ & $L i$ & $\mathrm{Ca}$ & $N a$ & $M g$ & $L a$ & $P b$ & As & $H g$ \\
\hline E015 & A & 476 & 14709 & $<5$ & 3944 & 601 & 993 & $<5$ & 10 & $<20$ & 0.06 \\
\hline E015 & B & 253 & 16323 & 5 & 2493 & 666 & 939 & 6 & $<10$ & $<20$ & $<0.04$ \\
\hline E016 & A & 615 & 13953 & $<5$ & 3180 & 511 & 1148 & $<5$ & $<10$ & $<20$ & 0.06 \\
\hline E016 & B & 555 & 17556 & 5 & 2868 & 770 & 1360 & 6 & $<10$ & $<20$ & $<0.04$ \\
\hline E017 & A & 391 & 16465 & $<5$ & 2314 & 470 & 805 & $<5$ & $<10$ & $<20$ & 0.09 \\
\hline E017 & $B$ & 244 & 20011 & 5 & 2372 & 701 & 1017 & 5 & $<10$ & $<20$ & $<0.04$ \\
\hline E018 & A & 247 & 15862 & $<5$ & 1997 & 475 & 867 & $<5$ & $<10$ & $<20$ & $<0.04$ \\
\hline E018 & B & 178 & 17933 & $<5$ & 1950 & 606 & 1030 & 6 & $<10$ & $<20$ & $<0.04$ \\
\hline EO20 & A & 301 & 11973 & $<5$ & 4500 & 643 & 776 & $<5$ & $<10$ & $<20$ & 0.06 \\
\hline EO20 & B & 273 & 19287 & 5 & 3742 & 936 & 1026 & $<5$ & $<10$ & $<20$ & $<0.04$ \\
\hline EO21 & A & 513 & 11116 & $<5$ & 3657 & 612 & 1108 & $<5$ & $<10$ & $<20$ & 0.08 \\
\hline EO21 & B & 346 & 17218 & 7 & 2647 & 781 & 1867 & 6 & $<10$ & $<20$ & $<0.04$ \\
\hline EO22 & A & 562 & 14818 & 5 & 3757 & 747 & 987 & $<5$ & $<10$ & $<20$ & 0.04 \\
\hline EO22 & $B$ & 397 & 16822 & 6 & 3261 & 864 & 1080 & 5 & $<10$ & $<20$ & $<0.04$ \\
\hline EO23 & A & 275 & 15015 & 5 & 3108 & 576 & 1217 & $<5$ & 10 & $<20$ & 0.04 \\
\hline EO23 & B & 234 & 19087 & 6 & 2823 & 786 & 1544 & 5 & $<10$ & $<20$ & $<0.04$ \\
\hline EO24* & A1 & 660 & 14629 & $<5$ & 5630 & 638 & 1718 & $<5$ & 14 & $<20$ & 0.09 \\
\hline EO24 & A2 & 775 & 14950 & 5 & 5136 & 609 & 1845 & 5 & 12 & $<20$ & 0.09 \\
\hline EO24 & B1 & 456 & 23871 & 6 & 4354 & 947 & 2513 & 6 & $<10$ & $<20$ & 0.12 \\
\hline EO24 & B2 & 398 & 24430 & 6 & 4421 & 1055 & 2473 & 6 & $<10$ & $<20$ & 0.11 \\
\hline EO25 & A & 457 & 13875 & 7 & 2282 & 410 & 912 & $<5$ & 10 & $<20$ & 0.04 \\
\hline EO25 & B & 426 & 14857 & 7 & 1480 & 635 & 916 & $<5$ & $<10$ & $<20$ & 0.04 \\
\hline EO26* & A1 & 513 & 20340 & $<5$ & 9111 & 1491 & 2514 & $<5$ & $<10$ & $<20$ & 0.07 \\
\hline EO26 & A2 & 618 & 22611 & $<5$ & 9696 & 1675 & 2892 & 5 & $<10$ & $<20$ & 0.08 \\
\hline EO26 & B1 & 472 & 25175 & $<5$ & 9234 & 1739 & 3173 & $<5$ & $<10$ & $<20$ & $<0.04$ \\
\hline EO26 & B2 & 445 & 26237 & $<5$ & 9542 & 1835 & 3681 & 5 & $<10$ & $<20$ & $<0.04$ \\
\hline EO27 & A & 836 & 17095 & 8 & 4664 & 561 & 2055 & 5 & $<10$ & $<20$ & 0.06 \\
\hline EO27 & B & 506 & 18256 & 10 & 3432 & 655 & 1915 & 10 & $<10$ & $<20$ & 0.06 \\
\hline EO30* & A1 & 492 & 13597 & $<5$ & 3968 & 767 & 1313 & $<5$ & $<10$ & $\mid<20$ & $<0.04$ \\
\hline
\end{tabular}


Appendix 6.11 Database of Heavy Metals and Trace Elements (ppm) in Soils of Southwest Oregon.

\begin{tabular}{|c|c|c|c|c|c|c|c|c|c|c|c|c|}
\hline Site & Horizon & $C d$ & $B a$ & $B e$ & Ni & $\mathrm{Co}$ & $C r$ & $V$ & $C u$ & $Z n$ & $\mathrm{Fe}$ & $M n$ \\
\hline EO30 & $\overline{A 2}$ & $<1.0$ & 102 & $<1.0$ & 11 & $<6$ & 5 & 19 & 12 & 30 & 8654 & 277 \\
\hline EO30 & B1 & $<1.0$ & 97 & $<1.0$ & 13 & 6 & 7 & 31 & 15 & 24 & 10912 & 137 \\
\hline EO30 & B2 & $<1.0$ & 100 & $<1.0$ & 12 & 6 & 6 & 30 & 15 & 26 & 11228 & 151 \\
\hline EO31 & $A$ & $<1.0$ & 203 & $<1.0$ & 8 & $<6$ & 4 & 25 & 9 & 51 & 8708 & 677 \\
\hline EO31 & $B$ & $<1.0$ & 77 & $<1.0$ & 11 & 7 & 8 & 46 & 17 & 32 & 13675 & 164 \\
\hline EO32* & A1 & $<1.0$ & 198 & $<1.0$ & 10 & 6 & 5 & 29 & 11 & 63 & 10938 & 1010 \\
\hline EO32 & A2 & $<1.0$ & 162 & $<1.0$ & 6 & 5 & 4 & 25 & 11 & 70 & 10744 & 1244 \\
\hline EO32 & B1 & $<1.0$ & 138 & $<1.0$ & 13 & 7 & 7 & 37 & 20 & 41 & 13445 & 191 \\
\hline EO32 & $B 2$ & $<1.0$ & 111 & $<1.0$ & 11 & 8 & 7 & 40 & 20 & 38 & 15088 & 211 \\
\hline EO33 & A & $<1.0$ & 113 & $<1.0$ & 14 & 6 & 8 & 32 & 13 & 68 & 11845 & 757 \\
\hline EO33 & B & $<1.0$ & 189 & $<1.0$ & 44 & 15 & 30 & 51 & 30 & 50 & 26278 & 473 \\
\hline E034 & A & $<1.0$ & 182 & $<1.0$ & 43 & 15 & 28 & 49 & 28 & 74 & 25527 & 635 \\
\hline EO34 & B & $<1.0$ & 205 & $<1.0$ & 52 & 18 & 34 & 62 & 30 & 52 & 29284 & 438 \\
\hline EO35* & A1 & $<1.0$ & 388 & $<1.0$ & 29 & 19 & 12 & 83 & 47 & 78 & 36177 & 1220 \\
\hline EO35 & A2 & $<1.0$ & 439 & $<1.0$ & 28 & 21 & 12 & 77 & 48 & 91 & 34962 & 1544 \\
\hline EO35 & B1 & $<1.0$ & 358 & $<1.0$ & 30 & 23 & 14 & 93 & 56 & 66 & 39721 & 774 \\
\hline EO35 & B2 & $<1.0$ & 331 & $<1.0$ & 32 & 23 & 18 & 100 & 55 & 67 & 40669 & 657 \\
\hline EO36 & $A$ & $<1.0$ & 432 & $<1.0$ & 31 & 18 & 22 & 69 & 37 & 92 & 29298 & 1380 \\
\hline EO36 & B & 1.0 & 456 & $<1.0$ & 42 & 26 & 34 & 109 & 53 & 78 & 42238 & 894 \\
\hline KL1 & A & $<1.0$ & 174 & $<1.0$ & 28 & 25 & 24 & 136 & 35 & 95 & 46241 & 2096 \\
\hline KL1 & B & 1.0 & 172 & $<1.0$ & 22 & 34 & 32 & 188 & 51 & 89 & 62989 & 1643 \\
\hline $\mathrm{KL2}$ & A & $<1.0$ & 343 & $<1.0$ & 22 & 7 & 23 & 29 & 7 & 61 & 14538 & 2261 \\
\hline $\mathrm{KL} 2$ & B & $<1.0$ & 115 & $<1.0$ & 19 & 9 & 31 & 42 & 11 & 47 & 18333 & 741 \\
\hline KL3 & A & $<1.0$ & 138 & $<1.0$ & 8 & 25 & 12 & 169 & 111 & 87 & 48823 & 1825 \\
\hline KL3 & B & $<1.0$ & 59 & $<1.0$ & 7 & 25 & 17 & 202 & 136 & 72 & 57995 & 848 \\
\hline KL4 & A & $<1.0$ & 185 & $<1.0$ & 34 & 13 & 40 & 57 & 32 & 100 & 33887 & 2328 \\
\hline KL4 & $B$ & $<1.0$ & 172 & $<1.0$ & 42 & 17 & 55 & 72 & 57 & 139 & 40417 & 1738 \\
\hline KL5 & A & $<1.0$ & 287 & $<1.0$ & 77 & 17 & 67 & 52 & 16 & 89 & 29774 & 2857 \\
\hline
\end{tabular}


Appendix 6.12 Database of Heavy Metals and Trace Elements (ppm) in Soils of Southwest Oregon.

\begin{tabular}{|c|c|c|c|c|c|c|c|c|c|c|c|}
\hline Site & Horizon & $\boldsymbol{K}$ & $A l$ & $L i$ & $\mathrm{Ca}$ & $N a$ & $M g$ & $L a$ & $P b$ & As & $\mathrm{Hg}$ \\
\hline EO30 & $A 2$ & 521 & 13791 & $<5$ & 3502 & 604 & 1314 & $<5$ & $<10$ & $<20$ & $<0.04$ \\
\hline EO30 & B1 & 378 & 14848 & $<5$ & 3947 & 981 & 1447 & $<5$ & $<10$ & $<20$ & $<0.04$ \\
\hline EO30 & $\mathrm{B} 2$ & 375 & 15009 & $<5$ & 3777 & 944 & 1607 & $<5$ & $<10$ & $<20$ & $<0.04$ \\
\hline EO31 & $A$ & 941 & 12544 & 5 & 5261 & 566 & 1223 & $<5$ & $<10$ & $<20$ & 0.06 \\
\hline EO31 & $B$ & 564 & 17901 & 6 & 3800 & 1039 & 1279 & 5 & 10 & $<20$ & $<0.04$ \\
\hline EO32* & A1 & 453 & 14686 & 7 & 3181 & 538 & 1120 & $<5$ & 10 & $<20$ & 0.07 \\
\hline EO32 & A2 & 414 & 16309 & 7 & 2832 & 493 & 990 & $<5$ & $<10$ & $<20$ & 0.06 \\
\hline EO32 & B1 & 438 & 18999 & 9 & 2516 & 762 & 1507 & 8 & $<10$ & $<20$ & $<0.04$ \\
\hline EO32 & $\mathrm{B} 2$ & 465 & 21346 & 11 & 2867 & 904 & 1555 & 10 & $<10$ & $<20$ & $<0.04$ \\
\hline EO33 & A & 634 & 16525 & 5 & 4436 & 655 & 1333 & $<5$ & $<10$ & $<20$ & 0.06 \\
\hline EO33 & $B$ & 1341 & 34967 & 9 & 3880 & 730 & 5079 & 7 & $<10$ & $<20$ & 0.04 \\
\hline EO34 & $A$ & 1546 & 34073 & 9 & 4366 & 778 & 4927 & 6 & $<10$ & $<20$ & $<0.04$ \\
\hline EO34 & $B$ & 1421 & 38105 & 10 & 4136 & 830 & 5988 & 8 & $<10$ & $<20$ & $<0.04$ \\
\hline EO35* & A1 & 1481 & 44100 & 12 & 6559 & 320 & 1960 & 10 & $<10$ & $<20$ & 0.04 \\
\hline EO35 & A2 & 2009 & 42637 & 11 & 5977 & 299 & 2094 & 10 & $<10$ & $<20$ & 0.04 \\
\hline EO35 & B1 & 970 & 49053 & 13 & 3118 & 397 & 2217 & 12 & $<10$ & $<20$ & $<0.04$ \\
\hline EO35 & B2 & 891 & 51378 & 13 & 3067 & 458 & 2321 & 12 & $<10$ & $<20$ & $<0.04$ \\
\hline EO36 & $A$ & 1771 & 42986 & 10 & 8838 & 210 & 2373 & 9 & 10 & $<20$ & 0.06 \\
\hline EO36 & $B$ & 1489 & 60563 & 13 & 3586 & 347 & 2893 & 13 & $<10$ & $<20$ & $<0.04$ \\
\hline KL1 & A & 1775 & 46228 & 10 & 7698 & 100 & 4827 & 9 & $<10$ & $<20$ & 0.11 \\
\hline KL-1 & B & 1706 & 64041 & 14 & 4418 & 123 & 6039 & 14 & $<10$ & $<20$ & 0.08 \\
\hline $\mathrm{KL2}$ & A & 1085 & 26399 & 9 & 5430 & 106 & 2119 & 16 & $<10$ & $<20$ & 0.05 \\
\hline $\mathrm{KL} 2$ & $B$ & 1141 & 35349 & 11 & 1997 & 124 & 2414 & 13 & $<10$ & $<20$ & $<0.04$ \\
\hline KL3 & A & 1549 & 47179 & 8 & 17184 & 106 & 5536 & $<5$ & $<10$ & $<20$ & 0.05 \\
\hline $\mathrm{KL} 3$ & B & 928 & 59727 & 11 & 12457 & 168 & 6327 & $<5$ & $<10$ & $<20$ & $<0.04$ \\
\hline KL44 & A & 1721 & 37090 & 28 & 1700 & 84 & 5305 & 5 & 14 & $<20$ & 0.17 \\
\hline KL4 & $B$ & 1534 & 54063 & 41 & 1116 & 96 & 6571 & 6 & $<10$ & $<20$ & 0.18 \\
\hline KL5 & A & 2445 & 24253 & 25 & 5281 & 81 & 8116 & 5 & $<10$ & $<20$ & 0.12 \\
\hline
\end{tabular}


Appendix 6.13 Database of Heavy Metals and Trace Elements (ppm) in Soils of Southwest Oregon.

\begin{tabular}{|c|c|c|c|c|c|c|c|c|c|c|c|c|c|}
\hline Site & Horizon & $C d$ & $B a$ & $B e$ & & $\mathrm{Ni}$ & Co & $\mathrm{Cr}$ & $V$ & $C u$ & $Z n$ & $\mathrm{Fe}$ & $M n$ \\
\hline KL5 & $B$ & $<1.0$ & 145 & $<1.0$ & & 112 & 24 & 96 & 73 & 26 & 88 & 42675 & 1368 \\
\hline KL6 & $A$ & 1.0 & 163 & $<1.0$ & & 57 & 30 & 87 & 225 & 67 & 100 & 71957 & 3088 \\
\hline KL6 & $B$ & $<1.0$ & 165 & $<1.0$ & & 86 & 43 & 167 & 281 & 112 & 128 & 96329 & 1871 \\
\hline $\mathrm{KL} 7^{*}$ & A1 & $<1.0$ & 65 & $<1.0$ & & 10 & $<6$ & 19 & 23 & 8 & 11 & 5600 & 36 \\
\hline $\mathrm{KL7}$ & A2 & $<1.0$ & 78 & $<1.0$ & & 12 & $<6$ & 21 & 24 & 11 & 12 & 6019 & 54 \\
\hline KL7 & B1 & $<1.0$ & 63 & $<1.0$ & & 10 & $<6$ & 33 & 43 & 7 & 11 & 9925 & 42 \\
\hline KL7 & $B 2$ & $<1.0$ & 62 & $<1.0$ & & 10 & $<6$ & 36 & 45 & 7 & 13 & 10511 & 48 \\
\hline KL8 & $A$ & $<1.0$ & 34 & $<1.0$ & & 25 & 6 & 77 & 65 & 13 & 29 & 25055 & 196 \\
\hline KL8 & $B$ & $<1.0$ & 36 & $<1.0$ & & 26 & $<6$ & 81 & 74 & 9 & 24 & 28679 & 127 \\
\hline KL9 & A & $<1.0$ & 87 & $<1.0$ & & 322 & 31 & 228 & 103 & 27 & 89 & 61486 & 327 \\
\hline KL9 & B & 1.0 & 80 & $<1.0$ & & 351 & 31 & 252 & 163 & 43 & 87 & 73605 & 270 \\
\hline KL10 & A & $<1.0$ & 137 & $<1.0$ & & 94 & 22 & 104 & 76 & 45 & 78 & 30964 & 1036 \\
\hline KL10 & B & $<1.0$ & 141 & $<1.0$ & & 116 & 22 & 124 & 78 & 53 & 99 & 39984 & 729 \\
\hline KL11 & A & $<1.0$ & 174 & $<1.0$ & & 54 & 14 & 70 & 76 & 28 & 73 & 30281 & 1408 \\
\hline KL11 & B & $<1.0$ & 160 & $<1.0$ & & 100 & 23 & 108 & 113 & 57 & 112 & 43822 & 1450 \\
\hline KL12 & A & 1.0 & 219 & $<1.0$ & & 51 & 26 & 52 & 157 & 59 & 91 & 49606 & 1226 \\
\hline KL12 & B & $<1.0$ & 246 & $<1.0$ & & 56 & 26 & 61 & 173 & 61 & 97 & 56487 & 1122 \\
\hline KL13 & A & $<1.0$ & 235 & $<1.0$ & & 47 & 8 & 117 & 74 & 8 & 48 & 27436 & 636 \\
\hline $\mathrm{KL} 13$ & B & $<1.0$ & 181 & $<1.0$ & & 60 & 12 & 149 & 95 & 9 & 53 & 34681 & 454 \\
\hline KL14 & A & $<1.0$ & 350 & $<1.0$ & & 46 & 12 & 44 & 32 & 18 & 106 & 19102 & 2872 \\
\hline KL14 & $B$ & $<1.0$ & 202 & $<1.0$ & & 35 & 6 & 54 & 47 & 22 & 62 & 25646 & 526 \\
\hline KL15 & A & $<1.0$ & 436 & & 1.0 & 48 & 11 & 35 & 39 & 31 & 131 & 24581 & 1609 \\
\hline KL15 & $B$ & $<1.0$ & 311 & & 1.3 & 58 & 18 & 52 & 66 & 63 & 140 & 37107 & 601 \\
\hline KL16 & A & 1.0 & 187 & $<1.0$ & & 1132 & 95 & 1302 & 155 & 53 & 98 & 98652 & 3676 \\
\hline KL16 & B & 1.5 & 146 & $<1.0$ & & 1530 & 135 & 1814 & 215 & 81 & 119 & 137939 & 3345 \\
\hline KL.17 & A & $<1.0$ & 55 & $<1.0$ & & 641 & 66 & 562 & 78 & 28 & 75 & 46415 & 1144 \\
\hline KL17 & B & 1.1 & 32 & $<1.0$ & & 1481 & 175 & 1226 & 151 & 51 & 75 & 94215 & 1472 \\
\hline KL18 & A & $<1.0$ & 404 & $<1.0$ & & 61 & 33 & 33 & 145 & 47 & 196 & 42255 & 4535 \\
\hline
\end{tabular}


Appendix 6.14 Database of Heavy Metals and Trace Elements (ppm) in Soils of Southwest Oregon.

\begin{tabular}{|c|c|c|c|c|c|c|c|c|c|c|c|}
\hline Site & Horizon & $K$ & $A l$ & $L i$ & $C a$ & $\mathrm{Na}$ & $M g$ & $L a$ & $P b$ & As & $H g$ \\
\hline KL5 & $B$ & 2649 & 36493 & 35 & 1140 & 82 & 10379 & 9 & $<10$ & $<20$ & 0.04 \\
\hline KL6 & A & 698 & 57938 & 23 & 4024 & 83 & 4468 & $<5$ & $<10$ & $<20$ & 0.19 \\
\hline KL6 & $B$ & 584 & 97974 & 41 & 1740 & 83 & 4142 & 6 & $<10$ & $<20$ & 0.06 \\
\hline $\mathrm{KL} 7^{\star}$ & A1 & 501 & 7474 & $<5$ & 1906 & 260 & 1123 & 6 & 25 & $<20$ & 0.17 \\
\hline $\mathrm{KL} 7$ & A2 & 601 & 8430 & $<5$ & 2603 & 301 & 1370 & 7 & 28 & $<20$ & 0.16 \\
\hline KL7 & B1 & 558 & 21398 & 15 & 524 & 140 & 951 & 9 & $<10$ & $<20$ & 0.06 \\
\hline KL7 & $\mathrm{B} 2$ & 768 & 23764 & 14 & 550 & 159 & 1003 & 11 & $<10$ & $<20$ & 0.06 \\
\hline KL8 & $A$ & 745 & 29237 & 23 & 1914 & 169 & 3314 & 5 & $<10$ & $<20$ & 0.14 \\
\hline KL8 & $B$ & 604 & 31173 & 24 & 1117 & 193 & 2336 & 9 & $<10$ & $<20$ & 0.11 \\
\hline KL9 & A & 512 & 43065 & 48 & 1027 & 107 & 14470 & 5 & $<10$ & $<20$ & 0.17 \\
\hline KL9 & $B$ & 779 & 69670 & 52 & 726 & 90 & 16352 & 6 & $<10$ & $<20$ & 0.10 \\
\hline KL10 & A & 1608 & 27195 & 22 & 6694 & 144 & 14216 & 9 & $<10$ & $<20$ & 0.11 \\
\hline KL10 & $B$ & 2014 & 35663 & 35 & 3277 & 127 & 16633 & 13 & $<10$ & $<20$ & 0.07 \\
\hline KL11 & A & 1419 & 24499 & 18 & 4680 & 119 & 9937 & 6 & $<10$ & $<20$ & 0.14 \\
\hline KL11 & $B$ & 1850 & 42084 & 34 & 4540 & 150 & 14555 & 9 & $<10$ & $<20$ & 0.10 \\
\hline KL12 & A & 1596 & 41497 & 19 & 5636 & 273 & 14187 & 15 & $<10$ & $<20$ & 0.23 \\
\hline $\mathrm{KL} 12$ & $B$ & 1112 & 47073 & 23 & 3711 & 292 & 16076 & 13 & $<10$ & $<20$ & 0.24 \\
\hline $\mathrm{KL} 13$ & A & 811 & 26229 & 17 & 4356 & 242 & 3532 & 7 & 11 & $<20$ & 0.14 \\
\hline KL13 & $B$ & 788 & 35427 & 21 & 2722 & 218 & 3866 & 11 & $<10$ & $<20$ & 0.05 \\
\hline KL14 & A & 1834 & 18276 & 9 & 6466 & 96 & 3061 & $<5$ & 378 & $<20$ & 0.16 \\
\hline KL14 & $B$ & 2070 & 29872 & 17 & 1045 & 61 & 2344 & $<5$ & 10 & $<20$ & 0.06 \\
\hline KL15 & $A$ & 3902 & 26180 & 15 & 5699 & 95 & 3944 & $<5$ & 35 & $<20$ & 0.11 \\
\hline KL15 & $B$ & 5535 & 45888 & 35 & 1235 & 118 & 5680 & 12 & 12 & $<20$ & 0.09 \\
\hline$K L 16$ & A & 783 & 54559 & 12 & 6174 & 57 & 6604 & 5 & 10 & $<20$ & 0.11 \\
\hline KL16 & B & 731 & 75800 & 16 & 1777 & 47 & 7805 & 7 & $<10$ & $<20$ & 0.07 \\
\hline KL17 & A & 862 & 23249 & $<5$ & 7117 & 146 & 11805 & $<5$ & 10 & $<20$ & 0.17 \\
\hline $\mathrm{KL} 17$ & $B$ & 219 & 46498 & 6 & 6111 & 129 & 21446 & $<5$ & $<10$ & $<20$ & 0.05 \\
\hline KL18 & A & 965 & 45086 & 22 & 5928 & 103 & 14242 & $<5$ & $<10$ & $<20$ & 0.14 \\
\hline
\end{tabular}


Appendix 6.15 Database of Heavy Metals and Trace Elements (ppm) in Soils of Southwest Oregon.

\begin{tabular}{|c|c|c|c|c|c|c|c|c|c|c|c|c|}
\hline Site & Horizon & $C d$ & $B a$ & Be & $N i$ & Co & $\mathrm{Cr}$ & $V$ & $C u$ & $Z n$ & $\mathrm{Fe}$ & $M n$ \\
\hline KL18 & $B$ & $<1.0$ & 261 & $<1.0$ & 64 & 35 & 34 & 191 & 68 & 164 & 50229 & 1358 \\
\hline KL19 & A & $<1.0$ & 105 & $<1.0$ & 22 & 24 & 36 & 106 & 100 & 77 & 37017 & 1046 \\
\hline KL19 & B & $<1.0$ & 44 & $<1.0$ & 22 & 19 & 53 & 136 & 165 & 55 & 40741 & 426 \\
\hline KL20 & A & $<1.0$ & 736 & $<1.0$ & 371 & 33 & 273 & 78 & 51 & 168 & 35594 & 7221 \\
\hline KL20 & B & $<1.0$ & 491 & $<1.0$ & 525 & 51 & 390 & 115 & 74 & 183 & 52646 & 3062 \\
\hline KL21 & A & $<1.0$ & 178 & $<1.0$ & 108 & 30 & 92 & 109 & 89 & 125 & 44399 & 1943 \\
\hline$K L 21$ & B & $<1.0$ & 125 & $<1.0$ & 149 & 36 & 122 & 140 & 128 & 128 & 55190 & 1684 \\
\hline $\mathrm{KL} 22$ & A & $<1.0$ & 147 & $<1.0$ & 36 & 21 & 69 & 80 & 63 & 71 & 28428 & 917 \\
\hline $\mathrm{KL22}$ & $B$ & $<1.0$ & 79 & $<1.0$ & 48 & 29 & 109 & 128 & 105 & 68 & 40371 & 769 \\
\hline$K L 23$ & A & $<1.0$ & 128 & $<1.0$ & 22 & 13 & 26 & 61 & 22 & 64 & 25616 & 2412 \\
\hline$K L 23$ & B & $<1.0$ & 110 & $<1.0$ & 26 & 14 & 33 & 71 & 19 & 71 & 29983 & 971 \\
\hline$K L 24$ & A & $<1.0$ & 73 & $<1.0$ & 54 & 15 & 84 & 88 & 49 & 85 & 22280 & 1535 \\
\hline$K L 24$ & $B$ & $<1.0$ & 68 & $<1.0$ & 62 & 19 & 115 & 114 & 62 & 88 & 28079 & 1076 \\
\hline KL25 & A & $<1.0$ & 173 & $<1.0$ & 37 & 15 & 67 & 58 & 50 & 70 & 25055 & 1855 \\
\hline $\mathrm{KL25}$ & B & $<1.0$ & 125 & $<1.0$ & 35 & 17 & 71 & 67 & 54 & 64 & 28275 & 1278 \\
\hline$K L 26$ & A & $<1.0$ & 93 & $<1.0$ & 6 & $<6$ & 4 & 12 & 5 & 54 & 13667 & 1207 \\
\hline $\mathrm{KL26}$ & B & $<1.0$ & 92 & $<1.0$ & 4 & $<6$ & 4 & 12 & 3 & 49 & 14946 & 394 \\
\hline KL27 & A & $<1.0$ & 503 & $<1.0$ & 75 & 20 & 83 & 102 & 55 & 125 & 46659 & 3718 \\
\hline$K L 27$ & $B$ & $<1.0$ & 356 & $<1.0$ & 82 & 23 & 94 & 114 & 69 & 119 & 51633 & 2196 \\
\hline$K L 28$ & A & $<1.0$ & 64 & $<1.0$ & 52 & 25 & 71 & 48 & 38 & 61 & 21477 & 1330 \\
\hline$K L 28$ & $B$ & $<1.0$ & 33 & $<1.0$ & 51 & 25 & 77 & 53 & 50 & 41 & 23727 & 554 \\
\hline KL30 & A & 1.0 & 149 & $<1.0$ & 164 & 75 & 313 & 374 & 136 & 185 & 107317 & 4509 \\
\hline KL30 & $B$ & 1.2 & 91 & $<1.0$ & 178 & 84 & 341 & 409 & 185 & 171 & 120278 & 2718 \\
\hline R1 & A & $<1.0$ & 214 & $<1.0$ & 23 & 14 & 17 & 54 & 23 & 86 & 27635 & 1567 \\
\hline R1 & B & $<1.0$ & 184 & $<1.0$ & 26 & 18 & 24 & 74 & 28 & 71 & 34311 & 522 \\
\hline R2 & A & $<1.0$ & 161 & $<1.0$ & 15 & 11 & 12 & 38 & 19 & 74 & 18185 & 2404 \\
\hline R2 & B & $<1.0$ & 76 & $<1.0$ & 11 & 14 & 18 & 63 & 21 & 74 & 29347 & 699 \\
\hline R3 & A & $<1.0$ & 34 & $<1.0$ & 13 & 6 & 9 & 52 & 14 & 17 & 13492 & 129 \\
\hline
\end{tabular}


Appendix 6.16 Database of Heavy Metals and Trace Elements (ppm) in Soils of Southwest Oregon.

\begin{tabular}{|c|c|c|c|c|c|c|c|c|c|c|c|}
\hline Site & Horizon & $K$ & $A l$ & $L i$ & $\mathrm{Ca}$ & $N a$ & $M g$ & $L a$ & $P b$ & As & $\mathrm{Hg}$ \\
\hline KL18 & $B$ & 799 & 60659 & 27 & 3172 & 103 & 18551 & $<5$ & $<10$ & $<20$ & 0.05 \\
\hline KL19 & A & 3881 & 45373 & 8 & 14223 & 156 & 10037 & 8 & $<10$ & $<20$ & 0.04 \\
\hline KL19 & B & 853 & 51007 & 10 & 15173 & 206 & 12919 & 5 & $<10$ & $<20$ & 0.04 \\
\hline$K L 20$ & A & 1510 & 36989 & 21 & 18682 & 176 & 16424 & 9 & $<10$ & $<20$ & 0.29 \\
\hline$K L 20$ & B & 1035 & 52737 & 31 & 8178 & 223 & 23606 & 12 & $<10$ & $<20$ & 0.12 \\
\hline$K L 21$ & A & 3138 & 26607 & 16 & 8072 & 235 & 11541 & 8 & $<10$ & 36 & 0.05 \\
\hline KL21 & B & 2654 & 33290 & 21 & 6527 & 189 & 13551 & 11 & $<10$ & 47 & 0.06 \\
\hline$K L 22$ & A & 4973 & 34601 & 10 & 11246 & 222 & 12975 & 6 & $<10$ & $<20$ & 0.04 \\
\hline$K L 22$ & B & 3043 & 48844 & 15 & 9701 & 219 & 17873 & 9 & $<10$ & $<20$ & $<0.04$ \\
\hline $\mathrm{KL} 23$ & A & 1398 & 49514 & 16 & 1404 & 60 & 3754 & 5 & $<10$ & $<20$ & 0.13 \\
\hline KL23 & B & 1234 & 66872 & 21 & 691 & 56 & 3949 & $<5$ & $<10$ & $<20$ & 0.14 \\
\hline$K L 24$ & A & 1535 & 22216 & 11 & 6700 & 139 & 8809 & $<5$ & $<10$ & $<20$ & 0.18 \\
\hline$K L 24$ & B & 1117 & 29711 & 14 & 2780 & 217 & 10850 & $<5$ & $<10$ & $<20$ & 0.07 \\
\hline KL25 & A & 1463 & 26792 & 11 & 9675 & 264 & 7303 & $<5$ & $<10$ & $<20$ & 0.17 \\
\hline$K L 25$ & B & 937 & 30484 & 12 & 5778 & 306 & 7662 & $<5$ & $<10$ & $<20$ & 0.07 \\
\hline $\mathrm{KL26}$ & A & 2234 & 17715 & 23 & 1902 & 137 & 2398 & 10 & $<10$ & $<20$ & 0.06 \\
\hline $\mathrm{KL26}$ & $B$ & 2345 & 22420 & 29 & 913 & 162 & 2600 & 14 & $<10$ & $<20$ & 0.04 \\
\hline$K L 27$ & A & 2165 & 50626 & 47 & 4907 & 84 & 4750 & 12 & $<10$ & $<20$ & 0.06 \\
\hline KL27 & $B$ & 2170 & 58980 & 52 & 1407 & 84 & 5245 & 12 & $<10$ & $<20$ & 0.05 \\
\hline$K L 28$ & A & 274 & 35554 & $<5$ & 8943 & 494 & 5779 & $<5$ & $<10$ & $<20$ & 0.06 \\
\hline$K L 28$ & B & 163 & 39845 & $<5$ & 7833 & 556 & 6473 & $<5$ & $<10$ & $<20$ & $<0.04$ \\
\hline KL30 & A & 806 & 55984 & 8 & 5923 & 149 & 6389 & 9 & $<10$ & $<20$ & 0.07 \\
\hline$K L 30$ & B & 344 & 67663 & 9 & 3018 & 107 & 6801 & 13 & $<10$ & $<20$ & 0.07 \\
\hline R1 & A & 669 & 39053 & 7 & 5025 & 317 & 3903 & 5 & $<10$ & $<20$ & 0.08 \\
\hline $\mathrm{R} 1$ & B & 612 & 48870 & 7 & 3928 & 319 & 5266 & 7 & $<10$ & $<20$ & 0.06 \\
\hline R2 & A & 1733 & | 19971 & $<5$ & 17394 & 442 & 7569 & 6 & 133 & $<20$ & 0.22 \\
\hline $\mathrm{R} 2$ & $B$ & 1232 & 30418 & 9 & 6653 & 343 & 9982 & 5 & $<10$ & $<20$ & $<0.04$ \\
\hline R3 & A & 223 & 19768 & $<5$ & 4370 & 1294 & 1616 & $<5$ & $\mid<10$ & $<20$ & 0.07 \\
\hline
\end{tabular}


Appendix 6.17 Database of Heavy Metals and Trace Elements (ppm) in Soils of Southwest Oregon.

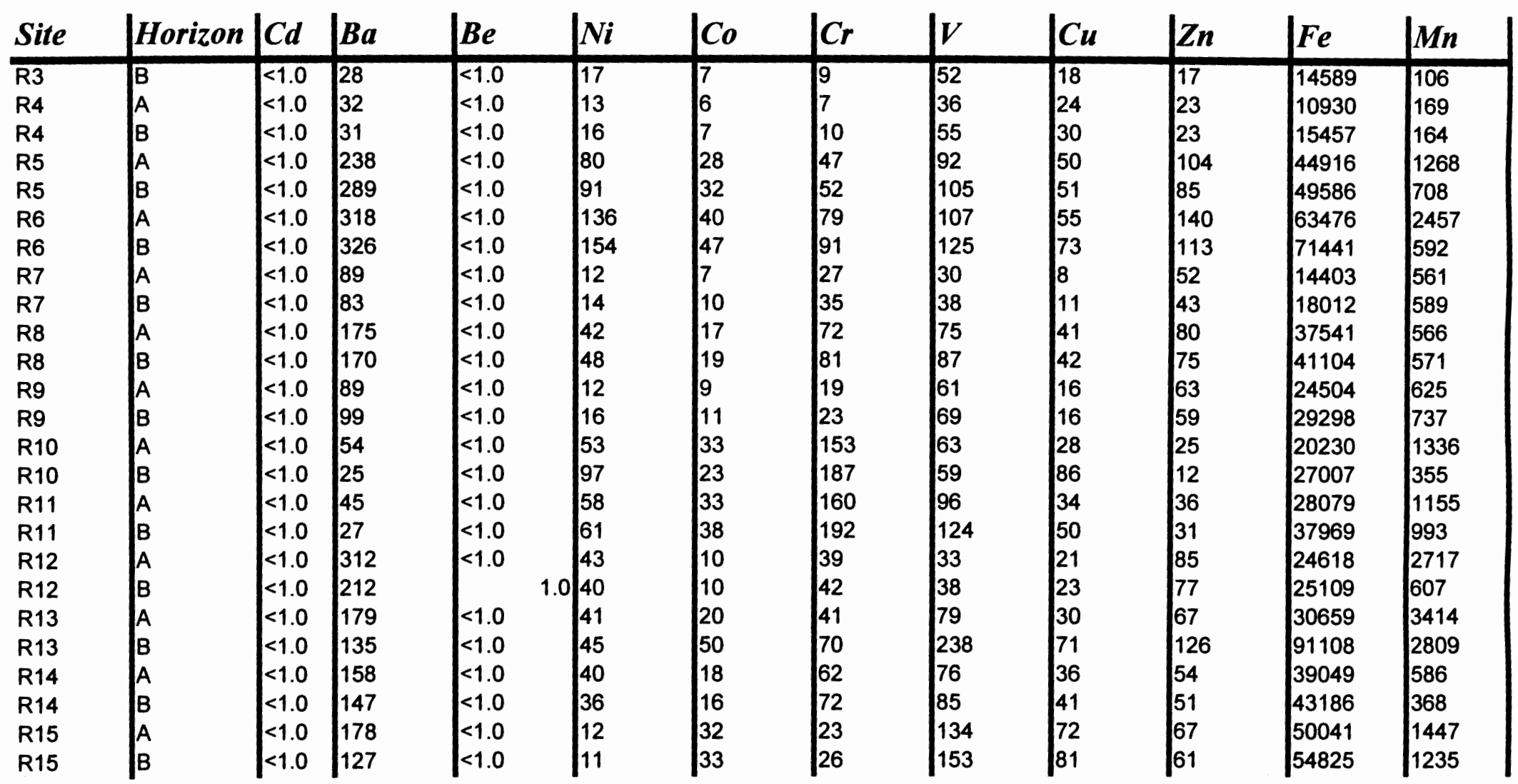




\section{Appendix 6.18 Database of Heavy Metals and Trace Elements (ppm) in Soils of Southwest Oregon.}

\begin{tabular}{|c|c|c|c|c|c|c|c|c|c|c|c|}
\hline Site & Horizon & $\boldsymbol{K}$ & $A l$ & $L i$ & $\mathrm{Ca}$ & $N a$ & $M g$ & $L a$ & $P b$ & As & $\mathrm{Hg}$ \\
\hline R3 & B & 168 & 23013 & $<5$ & 5323 & 1541 & 2284 & $<5$ & $<10$ & $<20$ & 0.05 \\
\hline R4 & A & 344 & 18926 & $<5$ & 5107 & 1224 & 1748 & $<5$ & 11 & $<20$ & 0.06 \\
\hline R4 & $B$ & 248 & 27537 & $<5$ & 6422 & 1708 & 2216 & $<5$ & $<10$ & $<20$ & 0.04 \\
\hline R5 & A & 1198 & 63332 & 10 & 5533 & 968 & 6079 & 10 & $<10$ & $<20$ & 0.04 \\
\hline R5 & B & 1113 & 70569 & 11 & 4122 & 837 & 6727 & 11 & $<10$ & $<20$ & $<0.04$ \\
\hline R6 & $A$ & 1282 & 93717 & 12 & 5605 & 200 & 6756 & 16 & $<10$ & $<20$ & 0.08 \\
\hline R6 & $B$ & 851 & 102212 & 14 & 2108 & 171 & 7988 & 26 & $<10$ & $<20$ & $<0.04$ \\
\hline R7 & A & 2296 & 9909 & 5 & 3446 & 158 & 3463 & 11 & 11 & $<20$ & $<0.04$ \\
\hline R7 & $B$ & 2360 & 13527 & 6 & 1900 & 161 & 4174 & 15 & $<10$ & $<20$ & $<0.04$ \\
\hline R8 & A & 4541 & 51739 & 15 & 13409 & 168 & 6914 & 15 & $<10$ & $<20$ & $<0.04$ \\
\hline R8 & $B$ & 3571 & 56018 & 16 & 12246 & 163 & 7317 & 16 & $<10$ & $<20$ & $<0.04$ \\
\hline R9 & $A$ & 2864 & 17850 & 9 & 6150 & 220 & 4553 & 18 & 21 & $<20$ & $<0.04$ \\
\hline R9 & $B$ & 2025 & 25484 & 11 & 5924 & 157 & 5028 & 23 & 12 & $<20$ & $<0.04$ \\
\hline R10 & A & 286 & 21990 & $<5$ & 8850 & 185 & 4667 & $<5$ & 13 & $<20$ & 0.06 \\
\hline R10 & B & 73 & 72785 & 8 & 5092 & 384 & 6290 & $<5$ & $<10$ & $<20$ & 0.08 \\
\hline R11 & $A$ & 436 & 30010 & $<5$ & 6143 & 206 & 2725 & $<5$ & $<10$ & $<20$ & 0.07 \\
\hline R11 & B & 170 & 39467 & 5 & 4046 & 156 & 4418 & 5 & $<10$ & $<20$ & 0.04 \\
\hline $\mathrm{R} 12$ & A & 2206 & 24718 & 13 & 3753 & 53 & 3559 & 10 & 146 & $<20$ & 0.07 \\
\hline R12 & $B$ & 2445 & 32761 & 19 & 951 & 59 & 3742 & 12 & 13 & $<20$ & 0.04 \\
\hline R13 & $A$ & 885 & 20991 & 6 & 7517 & 76 & 4476 & 5 & 13 & $<20$ & 0.19 \\
\hline R13 & $B$ & 622 & 57490 & 13 & 1471 & 66 & 5401 & 11 & $<10$ & 29 & 0.06 \\
\hline R14 & A & 1893 & 28984 & 17 & 1493 & 57 & 4080 & 10 & 12 & $<20$ & 0.07 \\
\hline R14 & B & 2092 & 37561 & 22 & 1154 & 64 & 3878 & 8 & $<10$ & $<20$ & 0.09 \\
\hline R15 & $A$ & 2158 & 37259 & $<5$ & 7757 & 166 & 8778 & 5 & $<10$ & $<20$ & $<0.04$ \\
\hline R15 & B & 1526 & 43532 & $<5$ & 7486 & 216 & 9983 & 5 & $<10$ & $<20$ & $\mid<0.04$ \\
\hline
\end{tabular}


Appendix 7. Distribution statistics for concentrations of metals in soils developed on individual geologic units in southwest Oregon.

Appendix 7.1. Distribution statistics for concentrations (in ppm of dry soil) of metals in soils on geologic unit "bc" (Amphibolite of Briggs Creek; Mesozoic or Paleozoic). For sampling site \#(s) and physiographic province(s) see Appendix 2.

In A Horizon

Metal

\section{In B Horizon}

\begin{tabular}{|c|c|c|c|c|c|c|c|c|}
\hline $\begin{array}{l}\text { Total } \\
\text { sample } \\
\text { number/ } \\
\text { detects }\end{array}$ & $\begin{array}{l}\text { Arith- } \\
\text { metic } \\
\text { mean }^{2}\end{array}$ & $\begin{array}{l}\text { Mini- } \\
\text { mum }\end{array}$ & $\begin{array}{l}\text { Maxi- } \\
\text { mum }\end{array}$ & Metal & $\begin{array}{l}\text { Total } \\
\text { sample } \\
\text { number/ } \\
\text { detects }\end{array}$ & $\begin{array}{l}\text { Arith- } \\
\text { metic } \\
\text { mean }^{2}\end{array}$ & $\begin{array}{l}\text { Mini- } \\
\text { mum }\end{array}$ & $\begin{array}{l}\text { Maxi- } \\
\text { mum }\end{array}$ \\
\hline
\end{tabular}

\begin{tabular}{|c|c|c|c|c|c|c|c|c|c|}
\hline Ag & $1 / 0$ & $<1$ & -- & -- & $\mathrm{Ag}$ & $1 / 0$ & $<1$ & - & -- \\
\hline Mo & $1 / 0$ & $<5$ & -- & -- & Mo & $1 / 0$ & $<5$ & -- & - \\
\hline $\mathrm{Cd}$ & $1 / 1$ & 1 & - & -. & $\mathrm{Cd}$ & $1 / 1$ & 1.2 & -- & -- \\
\hline $\mathrm{Ba}$ & $1 / 1$ & 149 & -- & - & $\mathrm{Ba}$ & $1 / 1$ & 91 & -- & -- \\
\hline $\mathrm{Be}$ & $1 / 0$ & $<1$ & -- & - & $\mathrm{Be}$ & $1 / 0$ & $<1$ & - & -. \\
\hline $\mathrm{Ni}$ & $1 / 1$ & 164 & - & - & $\mathrm{Ni}$ & $1 / 1$ & 178 & - & -- \\
\hline Co & $1 / 1$ & 75 & - & -- & Co & $1 / 1$ & 84 & -- & -- \\
\hline $\mathrm{Cr}$ & $1 / 1$ & 313 & -. & -- & $\mathrm{Cr}$ & $1 / 1$ & 341 & -. & -- \\
\hline V & $1 / 1$ & 374 & - & $\cdots$ & $\mathrm{V}$ & $1 / 1$ & 409 & -- & - \\
\hline $\mathrm{Cu}$ & $1 / 1$ & 136 & - & - & $\mathrm{Cu}$ & $1 / 1$ & 185 & - & - \\
\hline $\mathrm{Zn}$ & $1 / 1$ & 185 & - & - & $\mathrm{Zn}$ & $1 / 1$ & 171 & - & -- \\
\hline $\mathrm{Fe}$ & $1 / 1$ & 107,317 & -. & -- & $\mathrm{Fe}$ & $1 / 1$ & 120,278 & -- & -- \\
\hline $\mathrm{Mn}$ & $1 / 1$ & 4,509 & - & - & $\mathrm{Mn}$ & $1 / 1$ & 2,718 & - & - \\
\hline K & $1 / 1$ & 809 & -- & -- & $\mathrm{K}$ & $1 / 1$ & 344 & -- & -- \\
\hline $\mathrm{Al}$ & $1 / 1$ & 55,984 & - & - & Al & $1 / 1$ & 67,663 & -- & -- \\
\hline $\mathrm{Li}$ & $1 / 1$ & 8 & -. & -- & $\mathrm{Li}$ & $1 / 1$ & 9 & -- & -- \\
\hline $\mathrm{Ca}$ & $1 / 1$ & 5,923 & -- & - & $\mathrm{Ca}$ & $1 / 1$ & 3,018 & -- & -- \\
\hline $\mathrm{Na}$ & $1 / 1$ & 149 & - & -- & $\mathrm{Na}$ & $1 / 1$ & 107 & - & -- \\
\hline $\mathrm{Mg}$ & $1 / 1$ & 6,389 & -- & -- & $\mathrm{Mg}$ & $1 / 1$ & 6,801 & -- & - \\
\hline $\mathrm{La}$ & $1 / 1$ & 9 & - & - & $\mathrm{La}$ & $1 / 1$ & 13 & -- & -- \\
\hline $\mathrm{Sb}$ & $1 / 0$ & $<20$ & -- & -- & $\mathrm{Sb}$ & $1 / 0$ & $<20$ & - & -- \\
\hline $\mathrm{Pb}$ & $1 / 0$ & $<10$ & - & - & $\mathrm{Pb}$ & $1 / 0$ & $<10$ & -- & -- \\
\hline $\mathrm{Tl}$ & $1 / 0$ & $<50$ & - & - & $\mathrm{Tl}$ & $1 / 0$ & $<50$ & - & -- \\
\hline As & $1 / 0$ & $<20$ & -- & - & As & $1 / 0$ & $<20$ & -- & - \\
\hline $\mathrm{Se}$ & $1 / 0$ & $<30$ & - & - & $\mathrm{Se}$ & $1 / 0$ & $<30$ & -- & -- \\
\hline $\mathrm{Hg}$ & $1 / 1$ & 0.07 & -- & -- & $\mathrm{Hg}$ & $1 / 1$ & 0.07 & -- & -- \\
\hline
\end{tabular}

${ }^{1}$ Detects are the number of samples with concentrations equal to or greater than the laboratory reporting limit.

${ }^{2}$ Only one concentration value for the soils is listed under arithmetic mean. 
Appendix 7.2. Distribution statistics for concentrations (in ppm of dry soil) of metals in soils on geologic unit "cm" (Condrey Mountain Schist, derived possibly from shales of the Galice Formation; Triassic and Permian). For sampling site \#(s) and physiographic province(s) see Appendix 2.

In A Horizon

In B Horizon

$\begin{array}{llllllllll}\text { Metal } & \text { Total } & \text { Arith- } & \text { Mini- } & \text { Maxi- } & \text { Metal } & \text { Total } & \text { Arith- } & \text { Mini- } & \text { Maxi- } \\ & \begin{array}{l}\text { sample } \\ \text { number/ } \\ \text { detects }\end{array} & \begin{array}{l}\text { metic } \\ \text { mean }^{2}\end{array} & \text { mum } & \text { mum } & & \begin{array}{l}\text { sample } \\ \text { number/ } \\ \text { metic } \\ \text { mean }\end{array} & \text { mum } & \text { mum } \\ & & & & & & \end{array}$

\begin{tabular}{|c|c|c|c|c|c|c|c|c|c|}
\hline Ag & $1 / 0$ & $<1$ & -- & - & $\mathrm{Ag}$ & $1 / 0$ & $<1$ & -- & -- \\
\hline Mo & $1 / 0$ & $<5$ & -- & -- & Mo & $1 / 0$ & $<5$ & -- & -- \\
\hline $\mathrm{Cd}$ & $1 / 0$ & $<1$ & -- & -- & $\mathrm{Cd}$ & $1 / 0$ & $<1$ & - & -- \\
\hline $\mathrm{Ba}$ & $1 / 1$ & 178 & -- & -- & $\mathrm{Ba}$ & $1 / 1$ & 125 & -- & -- \\
\hline $\mathrm{Be}$ & $1 / 0$ & $<1$ & - & -- & $\mathrm{Be}$ & $1 / 0$ & $<1$ & - & - \\
\hline $\mathrm{Ni}$ & $1 / 1$ & 108 & -- & -- & $\mathrm{Ni}$ & $1 / 1$ & 149 & - & -- \\
\hline Co & $1 / 1$ & 30 & - & -- & Co & $1 / 1$ & 36 & - & -- \\
\hline $\mathrm{Cr}$ & $1 / 1$ & 92 & -- & -- & $\mathrm{Cr}$ & $1 / 1$ & 122 & -- & -- \\
\hline V & $1 / 1$ & 109 & -- & -- & V & $1 / 1$ & 140 & -- & -- \\
\hline $\mathrm{Cu}$ & $1 / 1$ & 89 & - & -- & $\mathrm{Cu}$ & $1 / 1$ & 128 & - & -- \\
\hline $\mathrm{Zn}$ & $1 / 1$ & 125 & -- & -- & $\mathrm{Zn}$ & $1 / 1$ & 128 & -- & -- \\
\hline $\mathrm{Fe}$ & $1 / 1$ & 44,399 & - & -- & $\mathrm{Fe}$ & $1 / 1$ & 55,190 & - & -- \\
\hline $\mathrm{Mn}$ & $1 / 1$ & 1,943 & - & -. & $\mathrm{Mn}$ & $1 / 1$ & 1,684 & -- & - \\
\hline K & $1 / 1$ & 3,138 & -- & -- & $\mathrm{K}$ & $1 / 1$ & 2,654 & -- & -- \\
\hline $\mathrm{Al}$ & $1 / 1$ & 26,607 & -- & -- & $\mathrm{Al}$ & $1 / 1$ & 33,290 & -- & -- \\
\hline $\mathrm{Li}$ & $1 / 1$ & 16 & -- & - & $\mathrm{Li}$ & $1 / 1$ & 21 & - & - \\
\hline $\mathrm{Ca}$ & $1 / 1$ & 8,072 & - & - & $\mathrm{Ca}$ & $1 / 1$ & 6,527 & - & -- \\
\hline $\mathrm{Na}$ & $1 / 1$ & 235 & -- & - & $\mathrm{Na}$ & $1 / 1$ & 189 & -- & $\cdots$ \\
\hline $\mathrm{Mg}$ & $1 / 1$ & 11,541 & -- & -- & $\mathrm{Mg}$ & $1 / 1$ & 13,551 & -- & - \\
\hline $\mathrm{La}$ & $1 / 1$ & 8 & -- & -- & $\mathrm{La}$ & $1 / 1$ & 11 & - & -- \\
\hline$S b$ & $1 / 0$ & $<20$ & -- & -- & $\mathrm{Sb}$ & $1 / 0$ & $<20$ & -- & -- \\
\hline $\mathrm{Pb}$ & $1 / 0$ & $<10$ & -- & -- & $\mathrm{Pb}$ & $1 / 0$ & $<10$ & - & -- \\
\hline $\mathrm{Tl}$ & $1 / 0$ & $<50$ & -- & $\cdots$ & $\mathrm{Tl}$ & $1 / 0$ & $<50$ & -- & - \\
\hline As & $1 / 1$ & 36 & -- & -- & As & $1 / 1$ & 47 & -- & -- \\
\hline $\mathrm{Se}$ & $1 / 0$ & $<30$ & - & -- & $\mathrm{Se}$ & $1 / 0$ & $<30$ & -- & -- \\
\hline $\mathrm{Hg}$ & $1 / 1$ & 0.05 & -- & - & $\mathrm{Hg}$ & $1 / 1$ & 0.06 & -- & - \\
\hline
\end{tabular}

${ }^{1}$ Detects are the number of samples with concentrations equal to or greater than the laboratory reporting limit.

${ }^{2}$ Only one concentration value for the soils is listed under arithmetic mean. 
Appendix 7.3. Distribution statistics for concentrations (in ppm of dry soil) of metals in soils on geologic unit "cs" (Colebrook Schist - originally tuffs, cherts and pillow lavas in deep sea; Mesozoic or Paleozoic). For sampling site \#(s) and physiographic province(s) see Appendix 2.

In A Horizon

\section{In B Horizon}

\begin{tabular}{|c|c|c|c|c|c|c|c|c|c|}
\hline Metal & $\begin{array}{l}\text { Total } \\
\text { sample } \\
\text { number/ } \\
\text { detects }{ }^{1}\end{array}$ & $\begin{array}{l}\text { Arith- } \\
\text { metic } \\
\text { mean }\end{array}$ & $\begin{array}{l}\text { Mini- } \\
\text { mum }\end{array}$ & $\begin{array}{l}\text { Maxi- } \\
\text { mum }\end{array}$ & Metal & $\begin{array}{l}\text { Total } \\
\text { sample } \\
\text { number/ } \\
\text { detects }^{\prime}\end{array}$ & $\begin{array}{l}\text { Arith- } \\
\text { metic } \\
\text { mean }\end{array}$ & $\begin{array}{l}\text { Mini- } \\
\text { mum }\end{array}$ & $\begin{array}{l}\text { Maxi- } \\
\text { mum }\end{array}$ \\
\hline $\mathrm{Ag}$ & $2 / 0$ & $<1$ & $<1$ & $<1$ & $\mathrm{Ag}$ & $2 / 0$ & $<1$ & $<1$ & $<1$ \\
\hline Mo & $2 / 0$ & $<5$ & $<5$ & $<5$ & Mo & $2 / 0$ & $<5$ & $<5$ & $<5$ \\
\hline $\mathrm{Cd}$ & $2 / 2$ & 1 & 1 & 1 & $\mathrm{Cd}$ & $2 / 1$ & $<1$ & $<1$ & 1 \\
\hline $\mathrm{Ba}$ & $2 / 2$ & 191 & 163 & 219 & $\mathrm{Ba}$ & $2 / 2$ & 205 & 165 & 246 \\
\hline $\mathrm{Be}$ & $2 / 0$ & $<1$ & $<1$ & $<1$ & $\mathrm{Be}$ & $2 / 0$ & $<1$ & $<1$ & $<1$ \\
\hline $\mathrm{Ni}$ & $2 / 2$ & 54 & 51 & 57 & $\mathrm{Ni}$ & $2 / 2$ & 71 & 56 & 86 \\
\hline Co & $2 / 2$ & 28 & 26 & 30 & Co & $2 / 2$ & 34 & 26 & 43 \\
\hline $\mathrm{Cr}$ & $2 / 2$ & 70 & 52 & 87 & $\mathrm{Cr}$ & $2 / 2$ & 114 & 61 & 167 \\
\hline V & $2 / 2$ & 191 & 157 & 225 & $\mathrm{~V}$ & $2 / 2$ & 227 & 173 & 281 \\
\hline $\mathrm{Cu}$ & $2 / 2$ & 63 & 59 & 67 & $\mathrm{Cu}$ & $2 / 2$ & 87 & 61 & 112 \\
\hline $\mathrm{Zn}$ & $2 / 2$ & 96 & 91 & 100 & $\mathrm{Zn}$ & $2 / 2$ & 112 & 97 & 128 \\
\hline $\mathrm{Fe}$ & $2 / 2$ & 60,782 & 49,606 & 71,957 & $\mathrm{Fe}$ & $2 / 2$ & 76,408 & 56,487 & 96,329 \\
\hline $\mathrm{Mn}$ & $2 / 2$ & 2,157 & 1,226 & 3,088 & $\mathrm{Mn}$ & $2 / 2$ & 1,497 & 1,123 & 1,871 \\
\hline K & $2 / 2$ & 1,147 & 698 & 1,596 & $\mathrm{~K}$ & $2 / 2$ & 848 & 584 & 1,112 \\
\hline Al & $2 / 2$ & 49,717 & 41,497 & 57,938 & $\mathrm{Al}$ & $2 / 2$ & 72,524 & 47,073 & 97,974 \\
\hline $\mathrm{Li}$ & $2 / 2$ & 21 & 19 & 23 & $\mathrm{Li}$ & $2 / 2$ & 32 & 23 & 41 \\
\hline $\mathrm{Ca}$ & $2 / 2$ & 4,830 & 4,024 & 5,636 & $\mathrm{Ca}$ & $2 / 2$ & 2,725 & 1,740 & 3,711 \\
\hline $\mathrm{Na}$ & $2 / 2$ & 178 & 83 & 273 & $\mathrm{Na}$ & $2 / 2$ & 188 & 83 & 292 \\
\hline $\mathrm{Mg}$ & $2 / 2$ & 9,327 & 4,468 & 14,187 & $\mathrm{Mg}$ & $2 / 2$ & 10,109 & 4,142 & 16,076 \\
\hline $\mathrm{La}$ & $2 / 1$ & $<10^{*}$ & $<5$ & 15 & $\mathrm{La}$ & $2 / 2$ & 9 & 6 & 13 \\
\hline $\mathrm{Sb}$ & $2 / 0$ & $<20$ & $<20$ & $<20$ & $\mathrm{Sb}$ & $2 / 0$ & $<20$ & $<20$ & $<20$ \\
\hline $\mathrm{Pb}$ & $2 / 0$ & $<10$ & $<10$ & $<10$ & $\mathrm{~Pb}$ & $2 / 0$ & $<10$ & $<10$ & $<10$ \\
\hline $\mathrm{Tl}$ & $2 / 0$ & $<50$ & $<50$ & $<50$ & $\mathrm{Tl}$ & $2 / 0$ & $<50$ & $<50$ & $<50$ \\
\hline As & $2 / 0$ & $<20$ & $<20$ & $<20$ & As & $2 / 0$ & $<20$ & $<20$ & $<20$ \\
\hline $\mathrm{Se}$ & $2 / 0$ & $<30$ & $<30$ & $<30$ & $\mathrm{Se}$ & $2 / 0$ & $<30$ & $<30$ & $<30$ \\
\hline $\mathrm{Hg}$ & $2 / 2$ & 0.21 & 0.19 & 0.23 & $\mathrm{Hg}$ & $2 / 2$ & 0.15 & 0.06 & 0.24 \\
\hline
\end{tabular}

${ }^{1}$ Detects are the number of samples with concentrations equal to or greater than the laboratory reporting limit.

* Where the concentration of a metal in a sample is less than the laboratory minimum reporting level, the minimum reporting level is used for calculating arithmetic mean, and the arithmetic mean is qualified as less than the value given. 
Appendix 7.4. Distribution statistics for concentrations (in ppm of dry soil) of metals in soils on geologic unit “Jm" (Melange; Jurassic). For sampling site \#(s) and physiographic province(s) see Appendix 2.

In A Horizon

In B Horizon

\begin{tabular}{|c|c|c|c|c|c|c|c|c|}
\hline Metal & $\begin{array}{l}\text { Total } \\
\text { sample } \\
\text { number/ } \\
\text { detects }\end{array}$ & $\begin{array}{l}\text { Arith- } \\
\text { metic } \\
\text { mean }^{2}\end{array}$ & $\begin{array}{l}\text { Mini- } \\
\text { mum }\end{array}$ & $\begin{array}{l}\text { Maxi- } \\
\text { mum }\end{array}$ & Metal & $\begin{array}{l}\text { Total } \\
\text { sample } \\
\text { number/ } \\
\text { detects }^{1}\end{array}$ & $\begin{array}{l}\text { Arith- } \\
\text { metic } \\
\text { mean }^{2}\end{array}$ & $\begin{array}{l}\text { Mini- } \\
\text { mum }\end{array}$ \\
\hline
\end{tabular}

\begin{tabular}{|c|c|c|c|c|c|c|c|c|c|}
\hline $\mathrm{Ag}$ & $1 / 0$ & $<1$ & -- & -- & $\mathrm{Ag}$ & $1 / 0$ & $<1$ & -- & -- \\
\hline Mo & $1 / 0$ & $<5$ & -- & -- & Mo & $1 / 0$ & $<5$ & - & -- \\
\hline $\mathrm{Cd}$ & $1 / 0$ & $<1$ & - & - & $\mathrm{Cd}$ & $1 / 1$ & 1.1 & -- & -- \\
\hline $\mathrm{Ba}$ & $1 / 1$ & 55 & -- & -- & $\mathrm{Ba}$ & $1 / 1$ & 32 & -- & -- \\
\hline $\mathrm{Be}$ & $1 / 0$ & $<1$ & - & -- & $\mathrm{Be}$ & $1 / 0$ & $<1$ & - & -- \\
\hline $\mathrm{Ni}$ & $1 / 1$ & 641 & - & -- & $\mathrm{Ni}$ & $1 / 1$ & 1,481 & -- & -- \\
\hline Co & $1 / 1$ & 67 & -- & -- & Co & $1 / 1$ & 175 & -- & -- \\
\hline $\mathrm{Cr}$ & $1 / 1$ & 562 & -- & -- & $\mathrm{Cr}$ & $1 / 1$ & 1,226 & -- & -- \\
\hline V & $1 / 1$ & 78 & - & - & V & $1 / 1$ & 151 & -- & - \\
\hline $\mathrm{Cu}$ & $1 / 1$ & 28 & -- & - & $\mathrm{Cu}$ & $1 / 1$ & 51 & -- & - \\
\hline $\mathrm{Zn}$ & $1 / 1$ & 75 & -- & -- & $\mathrm{Zn}$ & $1 / 1$ & 75 & -- & -- \\
\hline $\mathrm{Fe}$ & $1 / 1$ & 46,415 & -- & -- & $\mathrm{Fe}$ & $1 / 1$ & 94,215 & -- & -- \\
\hline Mn & $1 / 1$ & 1,144 & -- & - & $\mathrm{Mn}$ & $1 / 1$ & 1,472 & -- & -- \\
\hline K & $1 / 1$ & 862 & -- & -- & $\mathrm{K}$ & $1 / 1$ & 219 & - & -- \\
\hline $\mathrm{Al}$ & $1 / 1$ & 23,249 & - & -- & $\mathrm{Al}$ & $1 / 1$ & 46,498 & -- & -- \\
\hline $\mathrm{Li}$ & $1 / 0$ & $<5$ & -- & -- & $\mathrm{Li}$ & $1 / 1$ & 6 & -- & - \\
\hline $\mathrm{Ca}$ & $1 / 1$ & 7,117 & -- & -- & $\mathrm{Ca}$ & $1 / 1$ & 6,111 & -- & -- \\
\hline $\mathrm{Na}$ & $1 / 1$ & 146 & -- & - & $\mathrm{Na}$ & $1 / 1$ & 129 & -- & - \\
\hline $\mathrm{Mg}$ & $1 / 1$ & 11,805 & -- & - & $\mathrm{Mg}$ & $1 / 1$ & 21,446 & -- & -- \\
\hline $\mathrm{La}$ & $1 / 0$ & $<5$ & -- & - & $\mathrm{La}$ & $1 / 0$ & $<5$ & -- & -- \\
\hline $\mathrm{Sb}$ & $1 / 0$ & $<20$ & -- & -. & $\mathrm{Sb}$ & $1 / 0$ & $<20$ & -- & -- \\
\hline $\mathrm{Pb}$ & $1 / 1$ & 10 & -- & - & $\mathrm{Pb}$ & $1 / 0$ & $<10$ & -- & -- \\
\hline $\mathrm{Tl}$ & $1 / 0$ & $<50$ & -- & -- & $\mathrm{Tl}$ & $1 / 0$ & $<50$ & -- & -- \\
\hline As & $1 / 0$ & $<20$ & - & -- & As & $1 / 0$ & $<20$ & -- & -- \\
\hline $\mathrm{Se}$ & $1 / 0$ & $<30$ & -- & -- & $\mathrm{Se}$ & $1 / 0$ & $<30$ & -- & - \\
\hline $\mathrm{Hg}$ & $1 / 1$ & 0.17 & -- & -- & $\mathrm{Hg}$ & $1 / 1$ & 0.05 & -- & -- \\
\hline
\end{tabular}

${ }^{1}$ Detects are the number of samples with concentrations equal to or greater than the laboratory reporting limit.

${ }^{2}$ Only one concentration value for the soils is listed under arithmetic mean. 
Appendix 7.5. Distribution statistics for concentrations (in ppm of dry soil) of metals in soils on geologic unit "Jop" (Silts and sands of the Otter Point Formation \& related rocks; Jurassic). For sampling site \#(s) and physiographic province(s) see Appendix 2.

In A Horizon

In B Horizon

\begin{tabular}{|c|c|c|c|c|c|c|c|c|}
\hline Metal & $\begin{array}{l}\text { Total } \\
\text { sample } \\
\text { number/ } \\
\text { detects }^{1}\end{array}$ & $\begin{array}{l}\text { Arith- } \\
\text { metic } \\
\text { mean }^{2}\end{array}$ & $\begin{array}{l}\text { Mini- } \\
\text { mum }\end{array}$ & $\begin{array}{l}\text { Maxi- } \\
\text { mum }\end{array}$ & Metal & $\begin{array}{l}\text { Total } \\
\text { sample } \\
\text { number/ } \\
\text { detects }^{1}\end{array}$ & $\begin{array}{l}\text { Arith- } \\
\text { metic } \\
\text { mean }^{2}\end{array}$ & $\begin{array}{l}\text { Mini- } \\
\text { mum }\end{array}$ \\
\hline $\mathrm{Ag}$ & $1 / 0$ & $<1$ & - & - & $\mathrm{Ag}$ & $1 / 0$ & $<1$ & - \\
\hline Mo & $1 / 0$ & $<5$ & - & -- & Mo & $1 / 0$ & $<5$ & -- \\
\hline $\mathrm{Cd}$ & $1 / 0$ & $<1$ & -- & -- & $\mathrm{Cd}$ & $1 / 0$ & $<1$ & - \\
\hline $\mathrm{Ba}$ & $1 / 1$ & 235 & -- & -- & $\mathrm{Ba}$ & $1 / 1$ & 181 & -- \\
\hline $\mathrm{Be}$ & $1 / 0$ & $<1$ & -- & -- & $\mathrm{Be}$ & $1 / 0$ & $<1$ & -- \\
\hline $\mathrm{Ni}$ & $1 / 1$ & 47 & - & - & $\mathrm{Ni}$ & $1 / 1$ & 60 & -- \\
\hline Co & $1 / 1$ & 8 & -- & -- & Co & $1 / 1$ & 12 & -- \\
\hline $\mathrm{Cr}$ & $1 / 1$ & 117 & -- & -- & $\mathrm{Cr}$ & $1 / 1$ & 149 & -- \\
\hline V & $1 / 1$ & 74 & -- & -- & $\mathrm{V}$ & $1 / 1$ & 95 & - \\
\hline $\mathrm{Cu}$ & $1 / 1$ & 8 & -- & -. & $\mathrm{Cu}$ & $1 / 1$ & 9 & -- \\
\hline $\mathrm{Zn}$ & $1 / 1$ & 48 & -- & - & $\mathrm{Zn}$ & $1 / 1$ & 53 & -- \\
\hline $\mathrm{Fe}$ & $1 / 1$ & 27,436 & - & -- & $\mathrm{Fe}$ & $1 / 1$ & 34,681 & -- \\
\hline $\mathrm{Mn}$ & $1 / 1$ & 636 & -- & -- & $\mathrm{Mn}$ & $1 / 1$ & 454 & - \\
\hline K & $1 / 1$ & 811 & - & -- & K & $1 / 1$ & 788 & -- \\
\hline $\mathrm{Al}$ & $1 / 1$ & 26,229 & - & -- & $\mathrm{Al}$ & $1 / 1$ & 35,427 & -- \\
\hline $\mathrm{Li}$ & $1 / 1$ & 17 & -- & -- & $\mathrm{Li}$ & $1 / 1$ & 21 & -- \\
\hline $\mathrm{Ca}$ & $1 / 1$ & 4,356 & - & -- & $\mathrm{Ca}$ & $1 / 1$ & 2,722 & - \\
\hline $\mathrm{Na}$ & $1 / 1$ & 242 & - & -- & $\mathrm{Na}$ & $1 / 1$ & 218 & -- \\
\hline $\mathrm{Mg}$ & $1 / 1$ & 3,532 & -- & - & $\mathrm{Mg}$ & $1 / 1$ & 3,866 & - \\
\hline $\mathrm{La}$ & $1 / 1$ & 7 & -- & -- & $\mathrm{La}$ & $1 / 1$ & 11 & -- \\
\hline $\mathrm{Sb}$ & $1 / 0$ & $<20$ & -- & -- & Sb & $1 / 0$ & $<20$ & - \\
\hline $\mathrm{Pb}$ & $1 / 1$ & 11 & -- & -- & $\mathrm{Pb}$ & $1 / 0$ & $<10$ & - \\
\hline $\mathrm{Tl}$ & $1 / 0$ & $<50$ & -- & - & $\mathrm{Tl}$ & $1 / 0$ & $<50$ & -- \\
\hline As & $1 / 0$ & $<20$ & -- & - & As & $1 / 0$ & $<20$ & -- \\
\hline $\mathrm{Se}$ & $1 / 0$ & $<30$ & -. & - & $\mathrm{Se}$ & $1 / 0$ & $<30$ & -- \\
\hline $\mathrm{Hg}$ & $1 / 1$ & 0.14 & - & -- & $\mathrm{Hg}$ & $1 / 1$ & 0.05 & -- \\
\hline
\end{tabular}

${ }^{1}$ Detects are the number of samples with concentrations equal to or greater than the laboratory reporting limit.

${ }^{2}$ Only one concentration value for the soils is listed under arithmetic mean. 
Appendix 7.6. Distribution statistics for concentrations (in ppm of dry soil) of metals in soils on geologic unit "Js" (Sedimentary rocks; Jurassic). For sampling site \#(s) and physiographic province(s) see Appendix 2.

In A Horizon

In B Horizon

\begin{tabular}{|c|c|c|c|c|c|c|c|c|c|}
\hline Metal & $\begin{array}{l}\text { Total } \\
\text { sample } \\
\text { number/ } \\
\text { detects }^{1}\end{array}$ & $\begin{array}{l}\text { Arith- } \\
\text { metic } \\
\text { mean }\end{array}$ & $\begin{array}{l}\text { Mini- } \\
\text { mum }\end{array}$ & $\begin{array}{l}\text { Maxi- } \\
\text { mum }\end{array}$ & Metal & $\begin{array}{l}\text { Total } \\
\text { sample } \\
\text { number/ } \\
\text { detects }^{1}\end{array}$ & $\begin{array}{l}\text { Arith- } \\
\text { metic } \\
\text { mean }\end{array}$ & $\begin{array}{l}\text { Mini- } \\
\text { mum }\end{array}$ & $\begin{array}{l}\text { Maxi- } \\
\text { mum }\end{array}$ \\
\hline $\mathrm{Ag}$ & $2 / 0$ & $<1$ & $<1$ & $<1$ & $\mathrm{Ag}$ & $2 / 0$ & $<1$ & $<1$ & $<1$ \\
\hline Mo & $2 / 0$ & $<5$ & $<5$ & $<5$ & Mo & $2 / 0$ & $<5$ & $<5$ & $<5$ \\
\hline $\mathrm{Cd}$ & $2 / 0$ & $<1$ & $<1$ & $<1$ & $\mathrm{Cd}$ & $2 / 1$ & $<1^{*}$ & $<1$ & 1 \\
\hline $\mathrm{Ba}$ & $2 / 2$ & 174 & 174 & 175 & $\mathrm{Ba}$ & $2 / 2$ & 166 & 160 & 172 \\
\hline $\mathrm{Be}$ & $2 / 0$ & $<1$ & $<1$ & $<1$ & $\mathrm{Be}$ & $2 / 0$ & $<1$ & $<1$ & $<1$ \\
\hline $\mathrm{Ni}$ & $2 / 2$ & 41 & 28 & 54 & $\mathrm{Ni}$ & $2 / 2$ & 61 & 22 & 100 \\
\hline Co & $2 / 2$ & 19 & 14 & 25 & Co & $2 / 2$ & 29 & 23 & 35 \\
\hline $\mathrm{Cr}$ & $2 / 2$ & 47 & 24 & 70 & $\mathrm{Cr}$ & $2 / 2$ & 70 & 32 & 108 \\
\hline V & $2 / 2$ & 106 & 76 & 136 & $\mathrm{~V}$ & $2 / 2$ & 151 & 113 & 188 \\
\hline $\mathrm{Cu}$ & $2 / 2$ & 32 & 28 & 35 & $\mathrm{Cu}$ & $2 / 2$ & 54 & 51 & 57 \\
\hline $\mathrm{Zn}$ & $2 / 2$ & 84 & 73 & 95 & $\mathrm{Zn}$ & $2 / 2$ & 111 & 90 & 112 \\
\hline $\mathrm{Fe}$ & $2 / 2$ & 38,261 & 30,281 & 46,241 & $\mathrm{Fe}$ & $2 / 2$ & 53,406 & 43,822 & 62,989 \\
\hline $\mathrm{Mn}$ & $2 / 2$ & 1,752 & 1,408 & 2,096 & $\mathrm{Mn}$ & $2 / 2$ & 1,546 & 1,450 & 1,643 \\
\hline K & $2 / 2$ & 1,597 & 1,419 & 1,775 & $\mathbf{K}$ & $2 / 2$ & 1,778 & 1,706 & 1,850 \\
\hline $\mathrm{Al}$ & $2 / 2$ & 35,363 & 24,499 & 46,228 & $\mathrm{Al}$ & $2 / 2$ & 53,062 & 42,084 & 64,041 \\
\hline $\mathrm{Li}$ & $2 / 2$ & 14 & 10 & 18 & $\mathrm{Li}$ & $2 / 2$ & 24 & 14 & 34 \\
\hline $\mathrm{Ca}$ & $2 / 2$ & 6,189 & 4,678 & 7,698 & $\mathrm{Ca}$ & $2 / 2$ & 4,479 & 4,418 & 4,540 \\
\hline $\mathrm{Na}$ & $2 / 2$ & 109 & 100 & 119 & $\mathrm{Na}$ & $2 / 2$ & 136 & 123 & 150 \\
\hline $\mathrm{Mg}$ & $2 / 2$ & 7,382 & 4,827 & 9,937 & $\mathrm{Mg}$ & $2 / 2$ & 10,297 & 6,039 & 14,555 \\
\hline $\mathrm{La}$ & $2 / 2$ & 8 & 6 & 9 & $\mathrm{La}$ & $2 / 2$ & 12 & 9 & 14 \\
\hline $\mathrm{Sb}$ & $2 / 0$ & $<20$ & $<20$ & $<20$ & $\mathrm{Sb}$ & $2 / 0$ & $<20$ & $<20$ & $<20$ \\
\hline $\mathrm{Pb}$ & $2 / 0$ & $<10$ & $<10$ & $<10$ & $\mathrm{~Pb}$ & $2 / 0$ & $<10$ & $<10$ & $<10$ \\
\hline $\mathrm{Tl}$ & $2 / 0$ & $<50$ & $<50$ & $<50$ & $\mathrm{Tl}$ & $2 / 0$ & $<50$ & $<50$ & $<50$ \\
\hline As & $2 / 0$ & $<20$ & $<20$ & $<20$ & As & $2 / 0$ & $<20$ & $<20$ & $<20$ \\
\hline $\mathrm{Se}$ & $2 / 0$ & $<30$ & $<30$ & $<30$ & $\mathrm{Se}$ & $2 / 0$ & $<30$ & $<30$ & $<30$ \\
\hline $\mathrm{Hg}$ & $2 / 2$ & 0.13 & 0.11 & 0.14 & $\mathrm{Hg}$ & $2 / 2$ & 0.09 & 0.08 & 0.1 \\
\hline
\end{tabular}

${ }^{1}$ Detects are the number of samples with concentrations equal to or greater than the laboratory reporting limit.

* Where the concentration of a metal in a sample is less than the laboratory minimum reporting level, the minimum reporting level is used for calculating arithmetic mean, and the arithmetic mean is qualified as less than the value given. 
Appendix 7.7. Distribution statistics for concentrations (in ppm of dry soil) of metals in soils on geologic unit "Jss" (Shale, mudstone \& sandstone; Jurassic). For sampling site \#(s) and physiographic province(s) see Appendix 2.

In A Horizon

In B Horizon

\begin{tabular}{|c|c|c|c|c|c|c|c|c|c|}
\hline Metal & $\begin{array}{l}\text { Total } \\
\text { sample } \\
\text { number/ } \\
\text { detects }^{1}\end{array}$ & $\begin{array}{l}\text { Arith- } \\
\text { metic } \\
\text { mean }\end{array}$ & $\begin{array}{l}\text { Mini- } \\
\text { mum }\end{array}$ & $\begin{array}{l}\text { Maxi- } \\
\text { mum }\end{array}$ & Metal & $\begin{array}{l}\text { Total } \\
\text { sample } \\
\text { number/ } \\
\text { detects }^{\prime}\end{array}$ & $\begin{array}{l}\text { Arith- } \\
\text { metic } \\
\text { mean }\end{array}$ & $\begin{array}{l}\text { Mini- } \\
\text { mum }\end{array}$ & $\begin{array}{l}\text { Maxi- } \\
\text { mum }\end{array}$ \\
\hline $\mathrm{Ag}$ & $2 / 0$ & $<1$ & $<1$ & $<1$ & $\mathrm{Ag}$ & $2 / 0$ & $<1$ & $<1$ & $<1$ \\
\hline Mo & $2 / 0$ & $<5$ & $<5$ & $<5$ & Mo & $2 / 0$ & $<5$ & $<5$ & $<5$ \\
\hline $\mathrm{Cd}$ & $2 / 0$ & $<1$ & $<1$ & $<1$ & $\mathrm{Cd}$ & $2 / 0$ & $<1$ & $<1$ & $<1$ \\
\hline $\mathrm{Ba}$ & $2 / 2$ & 393 & 350 & 436 & $\mathrm{Ba}$ & $2 / 2$ & 257 & 202 & 311 \\
\hline $\mathrm{Be}$ & $2 / 1$ & $<1^{*}$ & $<1$ & 1 & $\mathrm{Be}$ & $2 / 2$ & 1.1 & 1 & 1.3 \\
\hline $\mathrm{Ni}$ & $2 / 2$ & 47 & 46 & 48 & $\mathrm{Ni}$ & $2 / 2$ & 47 & 35 & 58 \\
\hline Co & $2 / 2$ & 12 & 11 & 12 & Co & $2 / 2$ & 12 & 6 & 18 \\
\hline $\mathrm{Cr}$ & $2 / 2$ & 39 & 35 & 44 & $\mathrm{Cr}$ & $2 / 2$ & 53 & 52 & 54 \\
\hline V & $2 / 2$ & 35 & 32 & 39 & $\mathrm{~V}$ & $2 / 2$ & 57 & 48 & 66 \\
\hline $\mathrm{Cu}$ & $2 / 2$ & 25 & 18 & 31 & $\mathrm{Cu}$ & $2 / 2$ & 43 & 22 & 63 \\
\hline $\mathrm{Zn}$ & $2 / 2$ & 118 & 106 & 131 & $\mathrm{Zn}$ & $2 / 2$ & 111 & 62 & 140 \\
\hline $\mathrm{Fe}$ & $2 / 2$ & 21,841 & 19,102 & 24,581 & $\mathrm{Fe}$ & $2 / 2$ & 31,377 & 25,646 & 37,107 \\
\hline $\mathrm{Mn}$ & $2 / 2$ & 2,240 & 1,609 & 2,872 & $\mathrm{Mn}$ & $2 / 2$ & 564 & 526 & 601 \\
\hline K & $2 / 2$ & 2,868 & 1,834 & 3,902 & $\mathrm{~K}$ & $2 / 2$ & 3,803 & 2,070 & 5,535 \\
\hline $\mathrm{Al}$ & $2 / 2$ & 22,228 & 18,276 & 26,180 & $\mathrm{Al}$ & $2 / 2$ & 37,880 & 29,872 & 45,888 \\
\hline $\mathrm{Li}$ & $2 / 2$ & 12 & 9 & 15 & $\mathrm{Li}$ & $2 / 2$ & 26 & 17 & 35 \\
\hline $\mathrm{Ca}$ & $2 / 2$ & 6,082 & 5,699 & 6,466 & $\mathrm{Ca}$ & $2 / 2$ & 1,140 & 1,045 & 1,235 \\
\hline $\mathrm{Na}$ & $2 / 2$ & 96 & 95 & 96 & $\mathrm{Na}$ & $2 / 2$ & 89 & 61 & 118 \\
\hline $\mathrm{Mg}$ & $2 / 2$ & 3,503 & 3,061 & 3,944 & $\mathrm{Mg}$ & $2 / 2$ & 4,012 & 2,344 & 5,680 \\
\hline $\mathrm{La}$ & $2 / 0$ & $<5$ & $<5$ & $<5$ & $\mathrm{La}$ & $2 / 1$ & $<9 *$ & $<5$ & 12 \\
\hline $\mathrm{Sb}$ & $2 / 0$ & $<20$ & $<20$ & $<20$ & $\mathrm{Sb}$ & $2 / 0$ & $<20$ & $<20$ & $<20$ \\
\hline $\mathrm{Pb}$ & $2 / 2$ & 206 & 35 & 378 & $\mathrm{~Pb}$ & $2 / 2$ & 11 & 10 & 12 \\
\hline $\mathrm{Tl}$ & $2 / 0$ & $<50$ & $<50$ & $<50$ & $\mathrm{Tl}$ & $2 / 0$ & $<50$ & $<50$ & $<50$ \\
\hline As & $2 / 0$ & $<20$ & $<20$ & $<20$ & As & $2 / 0$ & $<20$ & $<20$ & $<20$ \\
\hline $\mathrm{Se}$ & $2 / 0$ & $<30$ & $<30$ & $<30$ & $\mathrm{Se}$ & $2 / 0$ & $<30$ & $<30$ & $<30$ \\
\hline $\mathrm{Hg}$ & $2 / 2$ & 0.14 & 0.11 & 0.16 & $\mathrm{Hg}$ & $2 / 2$ & 0.08 & 0.06 & 0.09 \\
\hline
\end{tabular}

${ }^{1}$ Detects are the number of samples with concentrations equal to or greater than the laboratory reporting limit.

* Where the concentration of a metal in a sample is less than the laboratory minimum reporting level, the minimum reporting level is used for calculating arithmetic mean, and the arithmetic mean is qualified as less than the value given. 
Appendix 7.8. Distribution statistics for concentrations (in ppm of dry soil) of metals in soils on geologic unit "JTrgd" (Granite \& diorite; Jurassic and Triassic). For sampling site \#(s) and physiographic province(s) see Appendix 2.

In A Horizon

In B Horizon

\begin{tabular}{|c|c|c|c|c|c|c|c|c|c|}
\hline Metal & $\begin{array}{l}\text { Total } \\
\text { sample } \\
\text { number/ } \\
\text { detects }{ }^{1}\end{array}$ & $\begin{array}{l}\text { Arith- } \\
\text { metic } \\
\text { mean }\end{array}$ & $\begin{array}{l}\text { Mini- } \\
\text { mum }\end{array}$ & $\begin{array}{l}\text { Maxi- } \\
\text { mum }\end{array}$ & Metal & $\begin{array}{l}\text { Total } \\
\text { sample } \\
\text { number/ } \\
\text { detects }{ }^{1}\end{array}$ & $\begin{array}{l}\text { Arith- } \\
\text { metic } \\
\text { mean }\end{array}$ & $\begin{array}{l}\text { Mini- } \\
\text { mum }\end{array}$ & $\begin{array}{l}\text { Maxi- } \\
\text { mum }\end{array}$ \\
\hline $\mathrm{Ag}$ & $2 / 0$ & $<1$ & $<1$ & $<1$ & $\mathrm{Ag}$ & $2 / 0$ & $<1$ & $<1$ & $<1$ \\
\hline Mo & $2 / 0$ & $<5$ & $<5$ & $<5$ & Mo & $2 / 0$ & $<5$ & $<5$ & $<5$ \\
\hline $\mathrm{Cd}$ & $2 / 0$ & $<1$ & $<1$ & $<1$ & $\mathrm{Cd}$ & $2 / 1$ & $<1^{*}$ & $<1$ & 1 \\
\hline $\mathrm{Ba}$ & $2 / 2$ & 107 & 87 & 128 & $\mathrm{Ba}$ & $2 / 2$ & 95 & 80 & 110 \\
\hline $\mathrm{Be}$ & $2 / 0$ & $<1$ & $<1$ & $<1$ & $\mathrm{Be}$ & $2 / 0$ & $<1$ & $<1$ & $<1$ \\
\hline $\mathrm{Ni}$ & $2 / 2$ & 172 & 22 & 322 & $\mathrm{Ni}$ & $2 / 2$ & 189 & 26 & 351 \\
\hline Co & $2 / 2$ & 22 & 13 & 31 & Co & $2 / 2$ & 23 & 14 & 32 \\
\hline $\mathrm{Cr}$ & $2 / 2$ & 127 & 26 & 228 & $\mathrm{Cr}$ & $2 / 2$ & 142 & 33 & 252 \\
\hline V & $2 / 2$ & 82 & 61 & 103 & $\mathrm{~V}$ & $2 / 2$ & 117 & 71 & 164 \\
\hline $\mathrm{Cu}$ & $2 / 2$ & 25 & 22 & 27 & $\mathrm{Cu}$ & $2 / 2$ & 31 & 19 & 43 \\
\hline $\mathrm{Zn}$ & $2 / 2$ & 76 & 64 & 89 & $\mathrm{Zn}$ & $2 / 2$ & 79 & 71 & 87 \\
\hline $\mathrm{Fe}$ & $2 / 2$ & 43,551 & 25,616 & 61,486 & $\mathrm{Fe}$ & $2 / 2$ & 51,794 & 29,983 & 73,605 \\
\hline $\mathrm{Mn}$ & $2 / 2$ & 1,369 & 327 & 2,412 & $\mathrm{Mn}$ & $2 / 2$ & 620 & 270 & 971 \\
\hline $\mathrm{K}$ & $2 / 2$ & 955 & 512 & 1,398 & $\mathrm{~K}$ & $2 / 2$ & 1,007 & 779 & 1,234 \\
\hline $\mathrm{Al}$ & $2 / 2$ & 46,289 & 43,065 & 49,514 & $\mathrm{Al}$ & $2 / 2$ & 68,271 & 66,872 & 69,670 \\
\hline $\mathrm{Li}$ & $2 / 2$ & 32 & 16 & 48 & $\mathrm{Li}$ & $2 / 2$ & 36 & 21 & 52 \\
\hline $\mathrm{Ca}$ & $2 / 2$ & 1,215 & 1,027 & 1,404 & $\mathrm{Ca}$ & $2 / 2$ & 709 & 691 & 726 \\
\hline $\mathrm{Na}$ & $2 / 2$ & 84 & 60 & 107 & $\mathrm{Na}$ & $2 / 2$ & 73 & 56 & 90 \\
\hline $\mathrm{Mg}$ & $2 / 2$ & 9,112 & 3,754 & 14,470 & $\mathrm{Mg}$ & $2 / 2$ & 10,151 & 3,949 & 16,352 \\
\hline $\mathrm{La}$ & $2 / 2$ & 5 & 5 & 5 & $\mathrm{La}$ & $2 / 1$ & $<5^{*}$ & $<5$ & 6 \\
\hline $\mathrm{Sb}$ & $2 / 0$ & $<20$ & $<20$ & $<20$ & $\mathrm{Sb}$ & $2 / 0$ & $<20$ & $<20$ & $<20$ \\
\hline $\mathrm{Pb}$ & $2 / 0$ & $<10$ & $<10$ & $<10$ & $\mathrm{~Pb}$ & $2 / 0$ & $<10$ & $<10$ & $<10$ \\
\hline $\mathrm{Tl}$ & $2 / 0$ & $<50$ & $<50$ & $<50$ & $\mathrm{Tl}$ & $2 / 0$ & $<50$ & $<50$ & $<50$ \\
\hline As & $2 / 0$ & $<20$ & $<20$ & $<20$ & As & $2 / 0$ & $<20$ & $<20$ & $<20$ \\
\hline $\mathrm{Se}$ & $2 / 0$ & $<30$ & $<30$ & $<30$ & $\mathrm{Se}$ & $2 / 0$ & $<30$ & $<30$ & $<30$ \\
\hline $\mathrm{Hg}$ & $2 / 2$ & 0.15 & 0.13 & 0.17 & $\mathrm{Hg}$ & $2 / 2$ & 0.12 & 0.10 & 0.14 \\
\hline
\end{tabular}

${ }^{1}$ Detects are the number of samples with concentrations equal to or greater than the laboratory reporting limit.

* Where the concentration of a metal in a sample is less than the laboratory minimum reporting level, the minimum reporting level is used for calculating arithmetic mean, and the arithmetic mean is qualified as less than the value given. 
Appendix 7.9. Distribution statistics for concentrations (in ppm of dry soil) of metals in soils on geologic unit "Ju" (Ultramafic \& related rocks of ophiolite sequences; Jurassic). For sampling site \#(s) and physiographic province(s) see Appendix 2.

In AHorizon

$\underline{\text { In B Horizon }}$

\begin{tabular}{|c|c|c|c|c|c|c|c|c|c|}
\hline Metal & $\begin{array}{l}\text { Total } \\
\text { sample } \\
\text { number/ } \\
\text { detects }\end{array}$ & $\begin{array}{l}\text { Arith- } \\
\text { metic } \\
\text { mean }^{2}\end{array}$ & $\begin{array}{l}\text { Mini- } \\
\text { mum }\end{array}$ & $\begin{array}{l}\text { Maxi- } \\
\text { mum }\end{array}$ & Metal & $\begin{array}{l}\text { Total } \\
\text { sample } \\
\text { number/ } \\
\text { detects }\end{array}$ & $\begin{array}{l}\text { Arith- } \\
\text { metic } \\
\text { mean }^{2}\end{array}$ & $\begin{array}{l}\text { Mini- } \\
\text { mum }\end{array}$ & $\begin{array}{l}\text { Maxi- } \\
\text { mum }\end{array}$ \\
\hline
\end{tabular}

\begin{tabular}{|c|c|c|c|c|c|c|c|c|c|}
\hline $\mathrm{Ag}$ & $1 / 0$ & $<1$ & -- & -- & $\mathrm{Ag}$ & $1 / 0$ & $<1$ & -- & -- \\
\hline Mo & $1 / 0$ & $<5$ & -- & - & Mo & $1 / 0$ & $<5$ & -- & -- \\
\hline $\mathrm{Cd}$ & $1 / 1$ & 1 & -- & -- & $\mathrm{Cd}$ & $1 / 1$ & 1.5 & -- & -- \\
\hline $\mathrm{Ba}$ & $1 / 1$ & 187 & -- & -- & $\mathrm{Ba}$ & $1 / 1$ & 146 & -- & -- \\
\hline $\mathrm{Be}$ & $1 / 0$ & $<1$ & -- & -- & $\mathrm{Be}$ & $1 / 0$ & $<1$ & -- & -- \\
\hline $\mathrm{Ni}$ & $1 / 1$ & 1,132 & -- & -- & $\mathrm{Ni}$ & $1 / 1$ & 1,530 & -- & -- \\
\hline Co & $1 / 1$ & 95 & -- & - & Co & $1 / 1$ & 135 & -- & -- \\
\hline $\mathrm{Cr}$ & $1 / 1$ & 1,302 & -- & -- & $\mathrm{Cr}$ & $1 / 1$ & 1,815 & -- & -- \\
\hline V & $1 / 1$ & 155 & -- & -- & V & $1 / 1$ & 215 & -- & -- \\
\hline $\mathrm{Cu}$ & $1 / 1$ & 53 & -- & -- & $\mathrm{Cu}$ & $1 / 1$ & 81 & -- & -- \\
\hline $\mathrm{Zn}$ & $1 / 1$ & 98 & - & -- & $\mathrm{Zn}$ & $1 / 1$ & 119 & -- & -- \\
\hline $\mathrm{Fe}$ & $1 / 1$ & 98,652 & -- & -- & $\mathrm{Fe}$ & $1 / 1$ & 137,939 & -- & -- \\
\hline $\mathrm{Mn}$ & $1 / 1$ & 3,676 & -- & -- & $\mathrm{Mn}$ & $1 / 1$ & 3,345 & -- & -- \\
\hline K & $1 / 1$ & 783 & -- & -- & K & $1 / 1$ & 731 & -- & -- \\
\hline $\mathrm{Al}$ & $1 / 1$ & 54,559 & -- & -- & $\mathrm{Al}$ & $1 / 1$ & 75,800 & -- & -- \\
\hline $\mathrm{Li}$ & $1 / 1$ & 12 & -- & -- & $\mathrm{Li}$ & $1 / 1$ & 16 & -- & -- \\
\hline $\mathrm{Ca}$ & $1 / 1$ & 6,174 & -- & -- & $\mathrm{Ca}$ & $1 / 1$ & 1,777 & -- & -- \\
\hline $\mathrm{Na}$ & $1 / 1$ & 57 & -- & -- & $\mathrm{Na}$ & $1 / 1$ & 47 & -- & -- \\
\hline $\mathrm{Mg}$ & $1 / 1$ & 6,604 & -- & -- & $\mathrm{Mg}$ & $1 / 1$ & 7,805 & -- & -. \\
\hline $\mathrm{La}$ & $1 / 1$ & 5 & -- & -- & $\mathrm{La}$ & $1 / 1$ & 7 & -- & -- \\
\hline $\mathrm{Sb}$ & $1 / 0$ & $<20$ & -- & -- & $\mathrm{Sb}$ & $1 / 0$ & $<20$ & -- & -- \\
\hline $\mathrm{Pb}$ & $1 / 1$ & 10 & -- & -- & $\mathrm{Pb}$ & $1 / 0$ & $<10$ & -- & -- \\
\hline $\mathrm{Tl}$ & $1 / 0$ & $<50$ & -- & -- & $\mathrm{Tl}$ & $1 / 0$ & $<50$ & -- & -- \\
\hline As & $1 / 0$ & $<20$ & -- & -- & As & $1 / 0$ & $<20$ & -- & -- \\
\hline $\mathrm{Se}$ & $1 / 0$ & $<30$ & -- & -- & $\mathrm{Se}$ & $1 / 0$ & $<30$ & -- & -. \\
\hline $\mathrm{Hg}$ & $1 / 1$ & 0.11 & -- & -- & $\mathrm{Hg}$ & $1 / 1$ & 0.07 & -- & -- \\
\hline
\end{tabular}

${ }^{1}$ Detects are the number of samples with concentrations equal to or greater than the laboratory reporting limit.

${ }^{2}$ Only one concentration value for the soils is listed under arithmetic mean. 
Appendix 7.10. Distribution statistics for concentrations (in ppm of dry soil) of metals in soils on geologic unit "Jub" (Basaltic, volcanic \& sedimentary rocks; Jurassic). For sampling site $\#(s)$ and physiographic province(s) see Appendix 2.

In A Horizon

\begin{tabular}{|c|c|c|c|c|c|c|c|c|c|}
\hline Metal & $\begin{array}{l}\text { Total } \\
\text { sample } \\
\text { number/ } \\
\text { detects }{ }^{1}\end{array}$ & $\begin{array}{l}\text { Arith- } \\
\text { metic } \\
\text { mean }\end{array}$ & $\begin{array}{l}\text { Mini- } \\
\text { mum }\end{array}$ & $\begin{array}{l}\text { Maxi- } \\
\text { mum }\end{array}$ & Metal & $\begin{array}{l}\text { Total } \\
\text { sample } \\
\text { number/ } \\
\text { detects }^{1}\end{array}$ & $\begin{array}{l}\text { Arith- } \\
\text { metic } \\
\text { mean }\end{array}$ & $\begin{array}{l}\text { Mini- } \\
\text { mum }\end{array}$ & $\begin{array}{l}\text { Maxi- } \\
\text { mum }\end{array}$ \\
\hline $\mathrm{Ag}$ & $2 / 0$ & $<1$ & $<1$ & $<1$ & $\mathrm{Ag}$ & $2 / 0$ & $<1$ & $<1$ & $<1$ \\
\hline Mo & $2 / 0$ & $<5$ & $<5$ & $<5$ & Mo & $2 / 0$ & $<5$ & $<5$ & $<5$ \\
\hline $\mathrm{Cd}$ & $2 / 0$ & $<1$ & $<1$ & $<1$ & $\mathrm{Cd}$ & $2 / 1$ & $<1^{*}$ & $<1$ & 1 \\
\hline $\mathrm{Ba}$ & $2 / 2$ & 246 & 179 & 312 & $\mathrm{Ba}$ & $2 / 2$ & 174 & 135 & 212 \\
\hline $\mathrm{Be}$ & $2 / 0$ & $<1$ & $<1$ & $<1$ & $\mathrm{Be}$ & $2 / 1$ & $<1^{*}$ & $<1$ & 1 \\
\hline $\mathrm{Ni}$ & $2 / 2$ & 42 & 41 & 43 & $\mathrm{Ni}$ & $2 / 2$ & 43 & 40 & 45 \\
\hline Co & $2 / 2$ & 15 & 10 & 20 & Co & $2 / 2$ & 30 & 10 & 50 \\
\hline $\mathrm{Cr}$ & $2 / 2$ & 40 & 39 & 41 & $\mathrm{Cr}$ & $2 / 2$ & 56 & 42 & 70 \\
\hline $\mathrm{V}$ & $2 / 2$ & 56 & 33 & 79 & $\mathrm{~V}$ & $2 / 2$ & 138 & 38 & 239 \\
\hline $\mathrm{Cu}$ & $2 / 2$ & 25 & 21 & 30 & $\mathrm{Cu}$ & $2 / 2$ & 47 & 23 & 71 \\
\hline $\mathrm{Zn}$ & $2 / 2$ & 76 & 67 & 85 & $\mathrm{Zn}$ & $2 / 2$ & 102 & 78 & 126 \\
\hline $\mathrm{Fe}$ & $2 / 2$ & 27,639 & 24,618 & 30,659 & $\mathrm{Fe}$ & $2 / 2$ & 58,108 & 25,110 & 91,108 \\
\hline $\mathrm{Mn}$ & $2 / 2$ & 3,066 & 2,717 & 3,414 & $\mathrm{Mn}$ & $2 / 2$ & 1,708 & 607 & 2,809 \\
\hline $\mathrm{K}$ & $2 / 2$ & 1,546 & 885 & 2,206 & $\mathrm{~K}$ & $2 / 2$ & 1,533 & 622 & 2,445 \\
\hline $\mathrm{Al}$ & $2 / 2$ & 22,855 & 20,991 & 24,718 & $\mathrm{Al}$ & $2 / 2$ & 45,126 & 32,761 & 57,490 \\
\hline $\mathrm{Li}$ & $2 / 2$ & 9 & 6 & 13 & $\mathrm{Li}$ & $2 / 2$ & 16 & 13 & 19 \\
\hline $\mathrm{Ca}$ & $2 / 2$ & 5,635 & 3,753 & 7,517 & $\mathrm{Ca}$ & $2 / 2$ & 1,211 & 951 & 1,471 \\
\hline $\mathrm{Na}$ & $2 / 2$ & 64 & 53 & 76 & $\mathrm{Na}$ & $2 / 2$ & 63 & 59 & 66 \\
\hline $\mathrm{Mg}$ & $2 / 2$ & 4,018 & 3,559 & 4,476 & $\mathrm{Mg}$ & $2 / 2$ & 4,571 & 3,742 & 5,401 \\
\hline $\mathrm{La}$ & $2 / 2$ & 7 & 5 & 10 & $\mathrm{La}$ & $2 / 2$ & 12 & 11 & 12 \\
\hline $\mathrm{Sb}$ & $2 / 0$ & $<20$ & $<20$ & $<20$ & $\mathrm{Sb}$ & $2 / 0$ & $<20$ & $<20$ & $<20$ \\
\hline $\mathrm{Pb}$ & $2 / 2$ & 79 & 13 & 146 & $\mathrm{~Pb}$ & $2 / 1$ & $<11^{*}$ & $<10$ & 13 \\
\hline $\mathrm{Tl}$ & $2 / 0$ & $<50$ & $<50$ & $<50$ & $\mathrm{Tl}$ & $2 / 0$ & $<50$ & $<50$ & $<50$ \\
\hline As & $2 / 0$ & $<20$ & $<20$ & $<20$ & As & $2 / 1$ & $<25^{*}$ & $<20$ & 29 \\
\hline $\mathrm{Se}$ & $2 / 0$ & $<30$ & $<30$ & $<30$ & $\mathrm{Se}$ & $2 / 0$ & $<30$ & $<30$ & $<30$ \\
\hline $\mathrm{Hg}$ & $2 / 2$ & 0.13 & 0.07 & 0.19 & $\mathrm{Hg}$ & $2 / 2$ & 0.05 & 0.04 & 0.06 \\
\hline
\end{tabular}

\section{In B Horizon}


Appendix 7.11. Distribution statistics for concentrations (in ppm of dry soil) of metals in soils on geologic unit “Jv" (Volcanic rocks; Jurassic). For sampling site \#(s) and physiographic province(s) see Appendix 2.

In A Horizon

In B Horizon

\begin{tabular}{|c|c|c|c|c|c|c|c|c|}
\hline Metal & $\begin{array}{l}\text { Total } \\
\text { sample } \\
\text { number/ } \\
\text { detects }{ }^{1}\end{array}$ & $\begin{array}{l}\text { Arith- } \\
\text { metic } \\
\text { mean }^{2}\end{array}$ & $\begin{array}{l}\text { Mini- } \\
\text { mum }\end{array}$ & $\begin{array}{l}\text { Maxi- } \\
\text { mum }\end{array}$ & Metal & $\begin{array}{l}\text { Total } \\
\text { sample } \\
\text { number/ } \\
\text { detects }{ }^{1}\end{array}$ & $\begin{array}{l}\text { Arith- } \\
\text { metic } \\
\text { mean }^{2}\end{array}$ & $\begin{array}{l}\text { Mini- } \\
\text { mum }\end{array}$ \\
\hline
\end{tabular}

\begin{tabular}{|c|c|c|c|c|c|c|c|c|c|}
\hline $\mathrm{Ag}$ & $1 / 0$ & $<1$ & -- & -- & $\mathrm{Ag}$ & $1 / 0$ & $<1$ & - & -- \\
\hline Mo & $1 / 0$ & $<5$ & -- & -- & Mo & $1 / 0$ & $<5$ & -- & -- \\
\hline $\mathrm{Cd}$ & $1 / 0$ & $<1$ & -- & -- & $\mathrm{Cd}$ & $1 / 0$ & $<1$ & -- & -- \\
\hline $\mathrm{Ba}$ & $1 / 1$ & 138 & -- & -- & $\mathrm{Ba}$ & $1 / 1$ & 59 & -- & \\
\hline $\mathrm{Be}$ & $1 / 0$ & $<1$ & -- & -- & $\mathrm{Be}$ & $1 / 0$ & $<1$ & -- & -- \\
\hline $\mathrm{Ni}$ & $1 / 1$ & 8 & -- & -- & $\mathrm{Ni}$ & $1 / 1$ & 7 & -- & -- \\
\hline Co & $1 / 1$ & 25 & -- & - & $\mathrm{Co}$ & $1 / 1$ & 25 & -- & -- \\
\hline $\mathrm{Cr}$ & $1 / 1$ & 12 & -- & -- & $\mathrm{Cr}$ & $1 / 1$ & 17 & -- & -- \\
\hline V & $1 / 1$ & 169 & -- & -- & V & $1 / 1$ & 202 & -- & -- \\
\hline $\mathrm{Cu}$ & $1 / 1$ & 111 & -- & -- & $\mathrm{Cu}$ & $1 / 1$ & 136 & - & - \\
\hline $\mathrm{Zn}$ & $1 / 1$ & 87 & -- & -- & $\mathrm{Zn}$ & $1 / 1$ & 72 & -- & -- \\
\hline $\mathrm{Fe}$ & $1 / 1$ & 48,823 & -- & -- & $\mathrm{Fe}$ & $1 / 1$ & 57,995 & -- & -- \\
\hline Mn & $1 / 1$ & 1,825 & -- & -- & $\mathrm{Mn}$ & $1 / 1$ & 848 & -- & -- \\
\hline $\mathrm{K}$ & $1 / 1$ & 1,549 & -- & -- & K & $1 / 1$ & 928 & -- & -- \\
\hline Al & $1 / 1$ & 47,179 & -- & -- & $\mathrm{Al}$ & $1 / 1$ & 59,727 & -- & -- \\
\hline $\mathrm{Li}$ & $1 / 1$ & 8 & -- & -- & $\mathrm{Li}$ & $1 / 1$ & 11 & -- & -- \\
\hline $\mathrm{Ca}$ & $1 / 1$ & 17,184 & -- & -- & $\mathrm{Ca}$ & $1 / 1$ & 12,457 & -- & -- \\
\hline $\mathrm{Na}$ & $1 / 1$ & 106 & -- & -- & $\mathrm{Na}$ & $1 / 1$ & 168 & -- & -- \\
\hline $\mathrm{Mg}$ & $1 / 1$ & 5,536 & -- & - & $\mathrm{Mg}$ & $1 / 1$ & 6,327 & -- & -- \\
\hline $\mathrm{La}$ & $1 / 0$ & $<5$ & -- & -- & $\mathrm{La}$ & $1 / 0$ & $<5$ & -- & -- \\
\hline $\mathrm{Sb}$ & $1 / 0$ & $<20$ & -- & -- & $\mathrm{Sb}$ & $1 / 0$ & $<20$ & -- & -- \\
\hline $\mathrm{Pb}$ & $1 / 0$ & $<10$ & -- & -- & $\mathrm{Pb}$ & $1 / 0$ & $<10$ & -- & -- \\
\hline $\mathrm{Tl}$ & $1 / 0$ & $<50$ & -- & -- & $\mathrm{Tl}$ & $1 / 0$ & $<50$ & -- & -- \\
\hline As & $1 / 0$ & $<20$ & -- & -- & As & $1 / 0$ & $<20$ & -- & -- \\
\hline $\mathrm{Se}$ & $1 / 0$ & $<30$ & -- & -- & $\mathrm{Se}$ & $1 / 0$ & $<30$ & -- & - \\
\hline $\mathrm{Hg}$ & $1 / 1$ & 0.05 & - & -- & $\mathrm{Hg}$ & $1 / 0$ & $<0.04$ & -- & -- \\
\hline
\end{tabular}

${ }^{1}$ Detects are the number of samples with concentrations equal to or greater than the laboratory reporting limit.

${ }^{2}$ Only one concentration value for the soils is listed under arithmetic mean. 
Appendix 7.12. Distribution statistics for concentrations (in ppm of dry soil) of metals in soils on geologic unit "Kc" (Clastic sedimentary rocks; Cretaceous). For sampling site \#(s) and physiographic province(s) see Appendix 2.

In A Horizon

In B Horizon

$\begin{array}{llllllllll}\text { Metal } & \begin{array}{l}\text { Total } \\ \text { sample }\end{array} & \begin{array}{l}\text { Arith- } \\ \text { metic }\end{array} & \text { Mini- } & \text { mum } & \text { Maxi- } & \text { Mum } & & \begin{array}{l}\text { Total } \\ \text { sample } \\ \text { number/ } \\ \text { mean }^{2}\end{array} & \end{array}$

\begin{tabular}{|c|c|c|c|c|c|c|c|c|c|}
\hline $\mathrm{Ag}$ & $1 / 0$ & $<1$ & -- & -- & $\mathrm{Ag}$ & $1 / 0$ & $<1$ & -- & -- \\
\hline Mo & $1 / 0$ & $<5$ & -- & - & Mo & $1 / 0$ & $<5$ & -- & -- \\
\hline $\mathrm{Cd}$ & $1 / 0$ & $<1$ & -- & -- & $\mathrm{Cd}$ & $1 / 0$ & $<1$ & -- & -- \\
\hline $\mathrm{Ba}$ & $1 / 1$ & 503 & -- & -- & $\mathrm{Ba}$ & $1 / 1$ & 356 & -- & -- \\
\hline $\mathrm{Be}$ & $1 / 0$ & $<1$ & -- & -- & $\mathrm{Be}$ & $1 / 0$ & $<1$ & -- & -- \\
\hline $\mathrm{Ni}$ & $1 / 1$ & 76 & -- & -- & $\mathrm{Ni}$ & $1 / 1$ & 82 & -- & -- \\
\hline Co & $1 / 1$ & 20 & -- & -- & Co & $1 / 1$ & 23 & -- & -- \\
\hline $\mathrm{Cr}$ & $1 / 1$ & 83 & -- & -- & $\mathrm{Cr}$ & $1 / 1$ & 94 & -- & -- \\
\hline V & $1 / 1$ & 102 & -- & -- & $\mathrm{V}$ & $1 / 1$ & 114 & -- & -- \\
\hline $\mathrm{Cu}$ & $1 / 1$ & 55 & -- & -- & $\mathrm{Cu}$ & $1 / 1$ & 69 & - & -- \\
\hline $\mathrm{Zn}$ & $1 / 1$ & 125 & -- & -- & $\mathrm{Zn}$ & $1 / 1$ & 119 & -- & -- \\
\hline $\mathrm{Fe}$ & $1 / 1$ & 46,659 & -- & -- & $\mathrm{Fe}$ & $1 / 1$ & 51,633 & -- & -- \\
\hline $\mathrm{Mn}$ & $1 / 1$ & 3,718 & -- & -- & $\mathrm{Mn}$ & $1 / 1$ & 2,196 & -- & -- \\
\hline $\mathrm{K}$ & $1 / 1$ & 2,165 & -- & -- & K & $1 / 1$ & 2,170 & -- & -- \\
\hline $\mathrm{Al}$ & $1 / 1$ & 50,626 & -- & -- & $\mathrm{Al}$ & $1 / 1$ & 58,980 & -- & \\
\hline $\mathrm{Li}$ & $1 / 1$ & 47 & -- & -- & $\mathrm{Li}$ & $1 / 1$ & 52 & -- & -- \\
\hline $\mathrm{Ca}$ & $1 / 1$ & 4,907 & -- & -- & $\mathrm{Ca}$ & $1 / 1$ & 1,407 & -- & -- \\
\hline $\mathrm{Na}$ & $1 / 1$ & 84 & -- & -- & $\mathrm{Na}$ & $1 / 1$ & 84 & -- & -- \\
\hline $\mathrm{Mg}$ & $1 / 1$ & 4,750 & -- & - & $\mathrm{Mg}$ & $1 / 1$ & 5,245 & -- & -- \\
\hline $\mathrm{La}$ & $1 / 1$ & 12 & -- & -- & $\mathrm{La}$ & $1 / 1$ & 12 & -- & -- \\
\hline $\mathrm{Sb}$ & $1 / 0$ & $<20$ & -- & -- & $\mathrm{Sb}$ & $1 / 0$ & $<20$ & -- & -- \\
\hline $\mathrm{Pb}$ & $1 / 0$ & $<10$ & -- & -- & $\mathrm{Pb}$ & $1 / 0$ & $<10$ & -- & -- \\
\hline $\mathrm{Tl}$ & $1 / 0$ & $<50$ & -- & -- & $\mathrm{Tl}$ & $1 / 0$ & $<50$ & - & -- \\
\hline As & $1 / 0$ & $<20$ & -- & -- & As & $1 / 0$ & $<20$ & -- & - \\
\hline $\mathrm{Se}$ & $1 / 0$ & $<30$ & -- & -- & $\mathrm{Se}$ & $1 / 0$ & $<30$ & -- & -- \\
\hline $\mathrm{Hg}$ & $1 / 1$ & 0.06 & -- & -- & $\mathrm{Hg}$ & $1 / 1$ & 0.05 & -- & -- \\
\hline
\end{tabular}

${ }^{1}$ Detects are the number of samples with concentrations equal to or greater than the laboratory reporting limit.

${ }^{2}$ Only one concentration value for the soils is listed under arithmetic mean. 
Appendix 7.13. Distribution statistics for concentrations (in ppm of dry soil) of metals in soils on geologic unit "KJds" (Turbidite sands and muds with some deep water cherts of Dothan Formation; Cretaceous \& Jurassic). For sampling site \#(s) and physiographic province(s) see Appendix 2.

In A Horizon

\section{In B Horizon}

\begin{tabular}{|c|c|c|c|c|c|c|c|c|}
\hline Metal & $\begin{array}{l}\text { Total } \\
\text { sample } \\
\text { number/ } \\
\text { detects }\end{array}$ & $\begin{array}{l}\text { Arith- } \\
\text { metic } \\
\text { mean }^{2}\end{array}$ & $\begin{array}{l}\text { Mini- } \\
\text { mum }\end{array}$ & $\begin{array}{l}\text { Maxi- } \\
\text { mum }\end{array}$ & Metal & $\begin{array}{l}\text { Total } \\
\text { sample } \\
\text { number/ } \\
\text { detects }\end{array}$ & $\begin{array}{l}\text { Arith- } \\
\text { metic } \\
\text { mean }^{2}\end{array}$ & $\begin{array}{l}\text { Mini- } \\
\text { mum }\end{array}$ \\
\hline $\mathrm{Ag}$ & $1 / 0$ & $<1$ & -- & -- & $\mathrm{Ag}$ & $1 / 0$ & $<1$ & -- \\
\hline Mo & $1 / 0$ & $<5$ & -- & -- & Mo & $1 / 0$ & $<5$ & -- \\
\hline $\mathrm{Cd}$ & $1 / 0$ & $<1$ & - & -- & $\mathrm{Cd}$ & $1 / 0$ & $<1$ & -- \\
\hline $\mathrm{Ba}$ & $1 / 1$ & 186 & -- & -- & $\mathrm{Ba}$ & $1 / 0$ & 172 & -- \\
\hline $\mathrm{Be}$ & $1 / 0$ & $<1$ & -- & -- & $\mathrm{Be}$ & $1 / 0$ & $<1$ & -- \\
\hline $\mathrm{Ni}$ & $1 / 1$ & 34 & - & -- & $\mathrm{Ni}$ & $1 / 1$ & 42 & -- \\
\hline Co & $1 / 1$ & 13 & -- & -- & Co & $1 / 1$ & 17 & -- \\
\hline $\mathrm{Cr}$ & $1 / 1$ & 40 & -- & - & $\mathrm{Cr}$ & $1 / 1$ & 55 & -- \\
\hline V & $1 / 1$ & 57 & -- & -- & $\mathrm{V}$ & $1 / 1$ & 72 & -- \\
\hline $\mathrm{Cu}$ & $1 / 1$ & 32 & - & -- & $\mathrm{Cu}$ & $1 / 1$ & 57 & -- \\
\hline $\mathrm{Zn}$ & $1 / 1$ & 100 & -- & -- & $\mathrm{Zn}$ & $1 / 1$ & 140 & - \\
\hline $\mathrm{Fe}$ & $1 / 1$ & 33,887 & -- & -- & $\mathrm{Fe}$ & $1 / 1$ & 40,417 & -- \\
\hline $\mathrm{Mn}$ & $1 / 1$ & 2,328 & -- & -- & $\mathrm{Mn}$ & $1 / 1$ & 1,738 & -- \\
\hline K & $1 / 1$ & 1,721 & -- & - & $\mathrm{K}$ & $1 / 1$ & 1,534 & - \\
\hline Al & $1 / 1$ & 37,090 & -- & -- & $\mathrm{Al}$ & $1 / 1$ & 54,063 & -- \\
\hline $\mathrm{Li}$ & $1 / 1$ & 28 & - & -- & $\mathrm{Li}$ & $1 / 1$ & 41 & -- \\
\hline $\mathrm{Ca}$ & $1 / 1$ & 1,700 & -- & -- & $\mathrm{Ca}$ & $1 / 1$ & 1,116 & -- \\
\hline $\mathrm{Na}$ & $1 / 1$ & 84 & -- & -- & $\mathrm{Na}$ & $1 / 1$ & 96 & -- \\
\hline $\mathrm{Mg}$ & $1 / 1$ & 5,305 & - & -- & $\mathrm{Mg}$ & $1 / 1$ & 6,571 & -- \\
\hline $\mathrm{La}$ & $1 / 1$ & 5 & -- & -- & $\mathrm{La}$ & $1 / 1$ & 6 & -- \\
\hline $\mathrm{Sb}$ & $1 / 0$ & $<20$ & -- & - & $\mathrm{Sb}$ & $1 / 0$ & $<20$ & -- \\
\hline $\mathrm{Pb}$ & $1 / 1$ & 14 & -- & -- & $\mathrm{Pb}$ & $1 / 0$ & $<10$ & -- \\
\hline $\mathrm{Tl}$ & $1 / 0$ & $<50$ & - & -- & $\mathrm{Tl}$ & $1 / 0$ & $<50$ & -- \\
\hline As & $1 / 0$ & $<20$ & -- & -- & As & $1 / 0$ & $<20$ & -- \\
\hline $\mathrm{Se}$ & $1 / 0$ & $<30$ & -- & -- & $\mathrm{Se}$ & $1 / 0$ & $<30$ & -- \\
\hline $\mathrm{Hg}$ & $1 / 1$ & 0.17 & -- & - & $\mathrm{Hg}$ & $1 / 1$ & 0.18 & -- \\
\hline
\end{tabular}

'Detects are the number of samples with concentrations equal to or greater than the laboratory reporting limit.

${ }^{2}$ Only one concentration value for the soils is listed under arithmetic mean. 
Appendix 7.14. Distribution statistics for concentrations (in ppm of dry soil) of metals in soils on geologic unit "KJg" (Granitic rocks; Cretaceous \& Jurassic). For sampling site \#(s) and physiographic province(s) see Appendix 2.

In A Horizon

\begin{tabular}{|c|c|c|c|c|c|c|c|c|c|}
\hline Metal & $\begin{array}{l}\text { Total } \\
\text { sample } \\
\text { number/ } \\
\text { detects }^{1}\end{array}$ & $\begin{array}{l}\text { Arith- } \\
\text { metic } \\
\text { mean }\end{array}$ & $\begin{array}{l}\text { Mini- } \\
\text { mum }\end{array}$ & $\begin{array}{l}\text { Maxi- } \\
\text { mum }\end{array}$ & Metal & $\begin{array}{l}\text { Total } \\
\text { sample } \\
\text { number/ } \\
\text { detects }^{1}\end{array}$ & $\begin{array}{l}\text { Arith- } \\
\text { metic } \\
\text { mean }\end{array}$ & $\begin{array}{l}\text { Mini- } \\
\text { mum }\end{array}$ & $\begin{array}{l}\text { Maxi- } \\
\text { mum }\end{array}$ \\
\hline $\mathrm{Ag}$ & $2 / 0$ & $<1$ & $<1$ & $<1$ & $\mathrm{Ag}$ & $2 / 0$ & $<1$ & $<1$ & $<1$ \\
\hline Mo & $2 / 0$ & $<5$ & $<5$ & $<5$ & Mo & $2 / 0$ & $<5$ & $<5$ & $<5$ \\
\hline $\mathrm{Cd}$ & $2 / 0$ & $<1$ & $<1$ & $<1$ & $\mathrm{Cd}$ & $2 / 0$ & $<1$ & $<1$ & $<1$ \\
\hline $\mathrm{Ba}$ & $2 / 2$ & 218 & 93 & 343 & $\mathrm{Ba}$ & $2 / 2$ & 103 & 92 & 115 \\
\hline $\mathrm{Be}$ & $2 / 0$ & $<1$ & $<1$ & $<1$ & $\mathrm{Be}$ & $2 / 0$ & $<1$ & $<1$ & $<1$ \\
\hline $\mathrm{Ni}$ & $2 / 2$ & 14 & 6 & 22 & $\mathrm{Ni}$ & $2 / 2$ & 11 & 4 & 19 \\
\hline Co & $2 / 1$ & $<7^{*}$ & $<6$ & 7 & Co & $2 / 1$ & $<8^{*}$ & $<6$ & 9 \\
\hline $\mathrm{Cr}$ & $2 / 2$ & 14 & 5 & 23 & $\mathrm{Cr}$ & $2 / 2$ & 17 & 4 & 31 \\
\hline V & $2 / 2$ & 21 & 12 & 29 & $\mathrm{~V}$ & $2 / 2$ & 27 & 12 & 42 \\
\hline $\mathrm{Cu}$ & $2 / 2$ & 6 & 5 & 7 & $\mathrm{Cu}$ & $2 / 2$ & 7 & 3 & 11 \\
\hline $\mathrm{Zn}$ & $2 / 2$ & 58 & 55 & 61 & $\mathrm{Zn}$ & $2 / 2$ & 48 & 47 & 49 \\
\hline $\mathrm{Fe}$ & $2 / 2$ & 14,103 & 13,667 & 14,538 & $\mathrm{Fe}$ & $2 / 2$ & 16,640 & 14,946 & 18,333 \\
\hline Mn & $2 / 2$ & 1,734 & 1,207 & 2,261 & Mn & $2 / 2$ & 568 & 394 & 741 \\
\hline $\mathrm{K}$ & $2 / 2$ & 1,659 & 1,085 & 2,234 & $\mathrm{~K}$ & $2 / 2$ & 1,743 & 1,141 & 2,345 \\
\hline $\mathrm{Al}$ & $2 / 2$ & 22,057 & 17,715 & 26,399 & $\mathrm{Al}$ & $2 / 2$ & 28,885 & 22,420 & 35,349 \\
\hline $\mathrm{Li}$ & $2 / 2$ & 16 & 9 & 23 & $\mathrm{Li}$ & $2 / 2$ & 20 & 11 & 29 \\
\hline $\mathrm{Ca}$ & $2 / 2$ & 3,666 & 1,902 & 5,430 & $\mathrm{Ca}$ & $2 / 2$ & 1,455 & 913 & 1,997 \\
\hline $\mathrm{Na}$ & $2 / 2$ & 121 & 106 & 137 & $\mathrm{Na}$ & $2 / 2$ & 143 & 124 & 162 \\
\hline $\mathrm{Mg}$ & $2 / 2$ & 2,259 & 2,119 & 2,398 & $\mathrm{Mg}$ & $2 / 2$ & 2,507 & 2,414 & 2,600 \\
\hline $\mathrm{La}$ & $2 / 2$ & 13 & 10 & 16 & $\mathrm{La}$ & $2 / 2$ & 14 & 13 & 14 \\
\hline $\mathrm{Sb}$ & $2 / 0$ & $<20$ & $<20$ & $<20$ & $\mathrm{Sb}$ & $2 / 0$ & $<20$ & $<20$ & $<20$ \\
\hline $\mathrm{Pb}$ & $2 / 0$ & $<10$ & $<10$ & $<10$ & $\mathrm{~Pb}$ & $2 / 0$ & $<10$ & $<10$ & $<10$ \\
\hline $\mathrm{Tl}$ & $2 / 0$ & $<50$ & $<50$ & $<50$ & $\mathrm{Tl}$ & $2 / 0$ & $<50$ & $<50$ & $<50$ \\
\hline As & $2 / 0$ & $<20$ & $<20$ & $<20$ & As & $2 / 0$ & $<20$ & $<20$ & $<20$ \\
\hline $\mathrm{Se}$ & $2 / 0$ & $<30$ & $<30$ & $<30$ & $\mathrm{Se}$ & $2 / 0$ & $<30$ & $<30$ & $<30$ \\
\hline $\mathrm{Hg}$ & $2 / 2$ & 0.06 & 0.05 & 0.06 & $\mathrm{Hg}$ & $2 / 1$ & $<0.04$ & $<0.04$ & 0.04 \\
\hline
\end{tabular}

${ }^{1}$ Detects are the number of samples with concentrations equal to or greater than the laboratory reporting limit.

* Where the concentration of a metal in a sample is less than the laboratory minimum reporting level, the minimum reporting level is used for calculating arithmetic mean, and the arithmetic mean is qualified as less than the value given. 
Appendix 7.15. Distribution statistics for concentrations (in ppm of dry soil) of metals in soils on geologic unit "KJgu" (Gabbro \& ultramafic rocks associated with granitic plutons; Cretaceous \& Jurassic). For sampling site \#(s) and physiographic province(s) see Appendix 2.

In A Horizon

In B Horizon

\begin{tabular}{|c|c|c|c|c|c|c|c|c|c|}
\hline Metal & $\begin{array}{l}\text { Total } \\
\text { sample } \\
\text { number/ } \\
\text { detects }\end{array}$ & $\begin{array}{l}\text { Arith- } \\
\text { metic } \\
\text { mean }\end{array}$ & $\begin{array}{l}\text { Mini- } \\
\text { mum }\end{array}$ & $\begin{array}{l}\text { Maxi- } \\
\text { mum }\end{array}$ & Metal & $\begin{array}{l}\text { Total } \\
\text { sample } \\
\text { number/ } \\
\text { detects }{ }^{\prime}\end{array}$ & $\begin{array}{l}\text { Arith- } \\
\text { metic } \\
\text { mean }\end{array}$ & $\begin{array}{l}\text { Mini- } \\
\text { mum }\end{array}$ & $\begin{array}{l}\text { Maxi- } \\
\text { mum }\end{array}$ \\
\hline $\mathrm{Ag}$ & $2 / 0$ & $<1$ & $<1$ & $<1$ & $\mathrm{Ag}$ & $2 / 0$ & $<1$ & $<1$ & $<1$ \\
\hline Mo & $2 / 0$ & $<5$ & $<5$ & $<5$ & Mo & $2 / 0$ & $<5$ & $<5$ & $<5$ \\
\hline $\mathrm{Cd}$ & $2 / 0$ & $<1$ & $<1$ & $<1$ & $\mathrm{Cd}$ & $2 / 0$ & $<1$ & $<1$ & $<1$ \\
\hline $\mathrm{Ba}$ & $2 / 2$ & 50 & 45 & 55 & $\mathrm{Ba}$ & $2 / 2$ & 26 & 25 & 27 \\
\hline $\mathrm{Be}$ & $2 / 0$ & $<1$ & $<1$ & $<1$ & $\mathrm{Be}$ & $2 / 0$ & $<1$ & $<1$ & $<1$ \\
\hline $\mathrm{Ni}$ & $2 / 2$ & 56 & 53 & 58 & $\mathrm{Ni}$ & $2 / 2$ & 79 & 61 & 97 \\
\hline Co & $2 / 2$ & 33 & 33 & 34 & Co & $2 / 2$ & 30 & 23 & 38 \\
\hline $\mathrm{Cr}$ & $2 / 2$ & 156 & 153 & 160 & $\mathrm{Cr}$ & $2 / 2$ & 190 & 187 & 192 \\
\hline V & $2 / 2$ & 79 & 63 & 96 & V & $2 / 2$ & 91 & 59 & 124 \\
\hline $\mathrm{Cu}$ & $2 / 2$ & 31 & 28 & 34 & $\mathrm{Cu}$ & $2 / 2$ & 68 & 50 & 86 \\
\hline $\mathrm{Zn}$ & $2 / 2$ & 30 & 25 & 36 & $\mathrm{Zn}$ & $2 / 2$ & 22 & 12 & 31 \\
\hline $\mathrm{Fe}$ & $2 / 2$ & 24,155 & 20,230 & 28,079 & $\mathrm{Fe}$ & $2 / 2$ & 32,488 & 27,007 & 37,969 \\
\hline $\mathrm{Mn}$ & $2 / 2$ & 1,246 & 1,155 & 1,336 & $\mathrm{Mn}$ & $2 / 2$ & 674 & 355 & 993 \\
\hline K & $2 / 2$ & 361 & 286 & 436 & $\mathrm{~K}$ & $2 / 2$ & 121 & 73 & 170 \\
\hline $\mathrm{Al}$ & $2 / 2$ & 26,000 & 21,990 & 30,010 & $\mathrm{Al}$ & $2 / 2$ & 56,126 & 39,467 & 72,785 \\
\hline $\mathrm{Li}$ & $2 / 0$ & $<5$ & $<5$ & $<5$ & $\mathrm{Li}$ & $2 / 2$ & 7 & 5 & 8 \\
\hline $\mathrm{Ca}$ & $2 / 2$ & 7,497 & 6,143 & 8,850 & $\mathrm{Ca}$ & $2 / 2$ & 4,569 & 4,046 & 5,092 \\
\hline $\mathrm{Na}$ & $2 / 2$ & 196 & 185 & 206 & $\mathrm{Na}$ & $2 / 2$ & 270 & 156 & 384 \\
\hline $\mathrm{Mg}$ & $2 / 2$ & 3,696 & 2,725 & 4,667 & $\mathrm{Mg}$ & $2 / 2$ & 5,354 & 4,418 & 6,290 \\
\hline $\mathrm{La}$ & $2 / 0$ & $<5$ & $<5$ & $<5$ & $\mathrm{La}$ & $2 / 1$ & $<5^{*}$ & $<5$ & 5 \\
\hline $\mathrm{Sb}$ & $2 / 0$ & $<20$ & $<20$ & $<20$ & $\mathrm{Sb}$ & $2 / 0$ & $<20$ & $<20$ & $<20$ \\
\hline $\mathrm{Pb}$ & $2 / 1$ & $<11^{*}$ & $<10$ & 13 & $\mathrm{~Pb}$ & $2 / 0$ & $<10$ & $<10$ & $<10$ \\
\hline $\mathrm{Tl}$ & $2 / 0$ & $<50$ & $<50$ & $<50$ & $\mathrm{Tl}$ & $2 / 0$ & $<50$ & $<50$ & $<50$ \\
\hline As & $2 / 0$ & $<20$ & $<20$ & $<20$ & As & $2 / 0$ & $<20$ & $<20$ & $<20$ \\
\hline $\mathrm{Se}$ & $2 / 0$ & $<30$ & $<30$ & $<30$ & $\mathrm{Se}$ & $2 / 0$ & $<30$ & $<30$ & $<30$ \\
\hline $\mathrm{Hg}$ & $2 / 2$ & 0.07 & 0.06 & 0.07 & $\mathrm{Hg}$ & $2 / 2$ & 0.06 & 0.04 & 0.08 \\
\hline
\end{tabular}

${ }^{1}$ Detects are the number of samples with concentrations equal to or greater than the laboratory reporting limit.

* Where the concentration of a metal in a sample is less than the laboratory minimum reporting level, the minimum reporting level is used for calculating arithmetic mean, and the arithmetic mean is qualified as less than the value given. 
Appendix 7.16. Distribution statistics for concentrations (in ppm of dry soil) of metals in soils on geologic unit "KJm" (Myrtle Group conglomerate, sandstone, siltstone \& limestone;

Cretaceous \& Jurassic). For sampling site \#(s) and physiographic province(s) see Appendix 2.

In A Horizon

In B Horizon

\begin{tabular}{|c|c|c|c|c|c|c|c|c|c|}
\hline Metal & $\begin{array}{l}\text { Total } \\
\text { sample } \\
\text { number/ } \\
\text { detects }^{1}\end{array}$ & $\begin{array}{l}\text { Arith- } \\
\text { metic } \\
\text { mean }\end{array}$ & $\begin{array}{l}\text { Mini- } \\
\text { mum }\end{array}$ & $\begin{array}{l}\text { Maxi- } \\
\text { mum }\end{array}$ & Metal & $\begin{array}{l}\text { Total } \\
\text { sample } \\
\text { number/ } \\
\text { detects }^{1}\end{array}$ & $\begin{array}{l}\text { Arith- } \\
\text { metic } \\
\text { mean }\end{array}$ & $\begin{array}{l}\text { Mini- } \\
\text { mum }\end{array}$ & $\begin{array}{l}\text { Maxi- } \\
\text { mum }\end{array}$ \\
\hline $\mathrm{Ag}$ & $2 / 0$ & $<1$ & $<1$ & $<1$ & $\mathrm{Ag}$ & $2 / 0$ & $<1$ & $<1$ & $<1$ \\
\hline Mo & $2 / 0$ & $<5$ & $<5$ & $<5$ & Mo & $2 / 0$ & $<5$ & $<5$ & $<5$ \\
\hline $\mathrm{Cd}$ & $2 / 0$ & $<1$ & $<1$ & $<1$ & $\mathrm{Cd}$ & $2 / 0$ & $<1$ & $<1$ & $<1$ \\
\hline $\mathrm{Ba}$ & $2 / 2$ & 168 & 158 & 178 & $\mathrm{Ba}$ & $2 / 2$ & 137 & 127 & 147 \\
\hline $\mathrm{Be}$ & $2 / 0$ & $<1$ & $<1$ & $<1$ & $\mathrm{Be}$ & $2 / 0$ & $<1$ & $<1$ & $<1$ \\
\hline $\mathrm{Ni}$ & $2 / 2$ & 26 & 12 & 40 & $\mathrm{Ni}$ & $2 / 2$ & 24 & 11 & 36 \\
\hline Co & $2 / 2$ & 25 & 18 & 32 & Co & $2 / 2$ & 24 & 16 & 33 \\
\hline $\mathrm{Cr}$ & $2 / 2$ & 43 & 23 & 62 & $\mathrm{Cr}$ & $2 / 2$ & 49 & 26 & 72 \\
\hline V & $2 / 2$ & 105 & 76 & 134 & $\mathrm{~V}$ & $2 / 2$ & 119 & 85 & 153 \\
\hline $\mathrm{Cu}$ & $2 / 2$ & 54 & 36 & 72 & $\mathrm{Cu}$ & $2 / 2$ & 61 & 41 & 81 \\
\hline $\mathrm{Zn}$ & $2 / 2$ & 61 & 54 & 67 & $\mathrm{Zn}$ & $2 / 2$ & 56 & 51 & 61 \\
\hline $\mathrm{Fe}$ & $2 / 2$ & 44,545 & 39,049 & 50,041 & $\mathrm{Fe}$ & $2 / 2$ & 49,005 & 43,186 & 54,825 \\
\hline $\mathrm{Mn}$ & $2 / 2$ & 1,016 & 586 & 1,447 & $\mathrm{Mn}$ & $2 / 2$ & 801 & 368 & 1,235 \\
\hline K & $2 / 2$ & 2,025 & 1,893 & 2,158 & $\mathrm{~K}$ & $2 / 2$ & 1,809 & 1,526 & 2,092 \\
\hline $\mathrm{Al}$ & $2 / 2$ & 33,121 & 28,984 & 37,259 & $\mathrm{Al}$ & $2 / 2$ & 40,546 & 37,561 & 43,532 \\
\hline $\mathrm{Li}$ & $2 / 1$ & $<11^{*}$ & $<5$ & 17 & $\mathrm{Li}$ & $2 / 1$ & $<14^{*}$ & $<5$ & 22 \\
\hline $\mathrm{Ca}$ & $2 / 2$ & 4,625 & 1,493 & 7,757 & $\mathrm{Ca}$ & $2 / 2$ & 4,320 & 1,154 & 7,486 \\
\hline $\mathrm{Na}$ & $2 / 2$ & 112 & 57 & 166 & $\mathrm{Na}$ & $2 / 2$ & 140 & 64 & 216 \\
\hline Mg & $2 / 2$ & 6,429 & 4,080 & 8,778 & $\mathrm{Mg}$ & $2 / 2$ & 6,930 & 3,878 & 9,983 \\
\hline $\mathrm{La}$ & $2 / 2$ & 8 & 5 & 10 & $\mathrm{La}$ & $2 / 2$ & 7 & 5 & 8 \\
\hline $\mathrm{Sb}$ & $2 / 0$ & $<20$ & $<20$ & $<20$ & $\mathrm{Sb}$ & $2 / 0$ & $<20$ & $<20$ & $<20$ \\
\hline $\mathrm{Pb}$ & $2 / 1$ & $<11^{*}$ & $<10$ & 12 & $\mathrm{~Pb}$ & $2 / 0$ & $<10$ & $<10$ & $<10$ \\
\hline $\mathrm{Tl}$ & $2 / 0$ & $<50$ & $<50$ & $<50$ & $\mathrm{Tl}$ & $2 / 0$ & $<50$ & $<50$ & $<50$ \\
\hline As & $2 / 0$ & $<20$ & $<20$ & $<20$ & As & $2 / 0$ & $<20$ & $<20$ & $<20$ \\
\hline $\mathrm{Se}$ & $2 / 0$ & $<30$ & $<30$ & $<30$ & $\mathrm{Se}$ & $2 / 0$ & $<30$ & $<30$ & $<30$ \\
\hline $\mathrm{Hg}$ & $2 / 1$ & $<0.06^{*}$ & $<0.04$ & 0.07 & $\mathrm{Hg}$ & $2 / 1$ & $<0.07^{*}$ & $<0.04$ & 0.09 \\
\hline
\end{tabular}

Detects are the number of samples with concentrations equal to or greater than the laboratory reporting limit.

* Where the concentration of a metal in a sample is less than the laboratory minimum reporting level, the minimum reporting level is used for calculating arithmetic mean, and the arithmetic mean is qualified as less than the value given. 
Appendix 7.17. Distribution statistics for concentrations (in ppm of dry soil) of metals in soils on geologic unit "Ks" (Sedimentary rocks; Cretaceous). For sampling site \#(s) and physiographic province(s) see Appendix 2.

In A Horizon

In B Horizon

\begin{tabular}{|c|c|c|c|c|c|c|c|c|c|}
\hline Metal & $\begin{array}{l}\text { Total } \\
\text { sample } \\
\text { number/ } \\
\text { detects }\end{array}$ & $\begin{array}{l}\text { Arith- } \\
\text { metic } \\
\text { mean }\end{array}$ & $\begin{array}{l}\text { Mini- } \\
\text { mum }\end{array}$ & $\begin{array}{l}\text { Maxi- } \\
\text { mum }\end{array}$ & Metal & $\begin{array}{l}\text { Total } \\
\text { sample } \\
\text { number/ } \\
\text { detects }\end{array}$ & $\begin{array}{l}\text { Arith- } \\
\text { metic } \\
\text { mean }^{2}\end{array}$ & $\begin{array}{l}\text { Mini- } \\
\text { mum }\end{array}$ & $\begin{array}{l}\text { Maxi- } \\
\text { mum }\end{array}$ \\
\hline
\end{tabular}

\begin{tabular}{|c|c|c|c|c|c|c|c|c|c|}
\hline Ag & $1 / 0$ & $<1$ & -- & -- & $\mathrm{Ag}$ & $1 / 0$ & $<1$ & -- & - \\
\hline Mo & $1 / 0$ & $<5$ & -- & - & Mo & $1 / 0$ & $<5$ & -- & -- \\
\hline $\mathrm{Cd}$ & $1 / 0$ & $<1$ & -- & -- & $\mathrm{Cd}$ & $1 / 0$ & $<1$ & -- & -- \\
\hline $\mathrm{Ba}$ & $1 / 1$ & 137 & -- & -- & $\mathrm{Ba}$ & $1 / 1$ & 141 & -- & -- \\
\hline $\mathrm{Be}$ & $1 / 0$ & $<1$ & -- & -- & $\mathrm{Be}$ & $1 / 0$ & $<1$ & -- & -- \\
\hline $\mathrm{Ni}$ & $1 / 1$ & 94 & - & -- & $\mathrm{Ni}$ & $1 / 1$ & 116 & -- & - \\
\hline Co & $1 / 1$ & 22 & -- & -- & Co & $1 / 1$ & 22 & -- & -- \\
\hline $\mathrm{Cr}$ & $1 / 1$ & 104 & -- & -- & $\mathrm{Cr}$ & $1 / 1$ & 124 & -- & -- \\
\hline V & $1 / 1$ & 76 & -- & -- & V & $1 / 1$ & 78 & - & -- \\
\hline $\mathrm{Cu}$ & $1 / 1$ & 45 & -- & -- & $\mathrm{Cu}$ & $1 / 1$ & 53 & -- & -- \\
\hline $\mathrm{Zn}$ & $1 / 1$ & 78 & -- & -- & $\mathrm{Zn}_{\mathbf{n}}$ & $1 / 1$ & 99 & -- & -- \\
\hline $\mathrm{Fe}$ & $1 / 1$ & 30,964 & -- & -- & $\mathrm{Fe}$ & $1 / 1$ & 39,984 & -- & - \\
\hline $\mathrm{Mn}$ & $1 / 1$ & 1,036 & - & -- & $\mathrm{Mn}$ & $1 / 1$ & 729 & -- & -- \\
\hline $\mathrm{K}$ & $1 / 1$ & 1,608 & -- & -- & K & $1 / 1$ & 2,014 & -- & -- \\
\hline $\mathrm{Al}$ & $1 / 1$ & 27,195 & -- & -- & $\mathrm{Al}$ & $1 / 1$ & 35,663 & -- & -- \\
\hline $\mathrm{Li}$ & $1 / 1$ & 22 & -- & -- & $\mathrm{Li}$ & $1 / 1$ & 35 & -- & -- \\
\hline $\mathrm{Ca}$ & $1 / 1$ & 6,694 & -- & -- & $\mathrm{Ca}$ & $1 / 1$ & 3,277 & -- & -- \\
\hline $\mathrm{Na}$ & $1 / 1$ & 144 & -- & -- & $\mathrm{Na}$ & $1 / 1$ & 127 & -- & -- \\
\hline $\mathrm{Mg}$ & $1 / 1$ & 14,216 & -- & -- & $\mathrm{Mg}$ & $1 / 1$ & 16,633 & -- & -- \\
\hline $\mathrm{La}$ & $1 / 1$ & 9 & -- & -- & $\mathrm{La}$ & $1 / 1$ & 13 & -- & -- \\
\hline $\mathrm{Sb}$ & $1 / 0$ & $<20$ & -- & -- & $\mathrm{Sb}$ & $1 / 0$ & $<20$ & -- & -- \\
\hline $\mathrm{Pb}$ & $1 / 0$ & $<10$ & -- & -. & $\mathrm{Pb}$ & $1 / 0$ & $<10$ & -- & -- \\
\hline $\mathrm{Tl}$ & $1 / 0$ & $<50$ & -- & -- & $\mathrm{Tl}$ & $1 / 0$ & $<50$ & -- & -- \\
\hline As & $1 / 0$ & $<20$ & -- & -- & As & $1 / 0$ & $<20$ & -- & - \\
\hline $\mathrm{Se}$ & $1 / 0$ & $<30$ & -- & -- & $\mathrm{Se}$ & $1 / 0$ & $<30$ & -- & -- \\
\hline $\mathrm{Hg}$ & $1 / 1$ & 0.11 & -- & -- & $\mathrm{Hg}$ & $1 / 1$ & 0.07 & -- & -- \\
\hline
\end{tabular}

${ }^{I}$ Detects are the number of samples with concentrations equal to or greater than the laboratory reporting limit.

${ }^{2}$ Only one concentration value for the soils is listed under arithmetic mean. 
Appendix 7.18. Distribution statistics for concentrations (in ppm of dry soil) of metals in soils on geologic unit “mc" (May Creek Schist; Paleozoic). For sampling site \#(s) and physiographic province(s) see Appendix 2.

In A Horizon

$\underline{\text { In B Horizon }}$

\begin{tabular}{|c|c|c|c|c|c|c|c|c|}
\hline Metal & $\begin{array}{l}\text { Total } \\
\text { sample } \\
\text { number/ } \\
\text { detects' }\end{array}$ & $\begin{array}{l}\text { Arith- } \\
\text { metic } \\
\text { mean }^{2}\end{array}$ & $\begin{array}{l}\text { Mini- } \\
\text { mum }\end{array}$ & $\begin{array}{l}\text { Maxi- } \\
\text { mum }\end{array}$ & Metal & $\begin{array}{l}\text { Total } \\
\text { sample } \\
\text { number/ } \\
\text { detects }^{1}\end{array}$ & $\begin{array}{l}\text { Arith- } \\
\text { metic } \\
\text { mean }\end{array}$ & $\begin{array}{l}\text { Mini- } \\
\text { mum }\end{array}$ \\
\hline $\mathrm{Ag}$ & $1 / 0$ & $<1$ & -- & -- & $\mathrm{Ag}$ & $1 / 0$ & $<1$ & -- \\
\hline Mo & $1 / 0$ & $<5$ & -- & -- & Mo & $1 / 0$ & $<5$ & -- \\
\hline $\mathrm{Cd}$ & $1 / 0$ & $<1$ & -- & -- & $\mathrm{Cd}$ & $1 / 0$ & $<1$ & -- \\
\hline $\mathrm{Ba}$ & $1 / 1$ & 64 & -- & - & $\mathrm{Ba}$ & $1 / 1$ & 33 & -- \\
\hline $\mathrm{Be}$ & $1 / 0$ & $<1$ & -- & -- & $\mathrm{Be}$ & $1 / 0$ & $<1$ & - \\
\hline $\mathrm{Ni}$ & $1 / 1$ & 52 & -- & -- & $\mathrm{Ni}$ & $1 / 1$ & 51 & -- \\
\hline Co & $1 / 1$ & 25 & -- & -- & Co & $1 / 1$ & 25 & - \\
\hline $\mathrm{Cr}$ & $1 / 1$ & 71 & -- & -- & $\mathrm{Cr}$ & $1 / 1$ & 77 & -- \\
\hline V & $1 / 1$ & 48 & -- & -- & $\mathrm{V}$ & $1 / 1$ & 53 & -- \\
\hline $\mathrm{Cu}$ & $1 / 1$ & 38 & -- & -- & $\mathrm{Cu}$ & $1 / 1$ & 50 & - \\
\hline $\mathrm{Zn}$ & $1 / 1$ & 61 & -- & -- & $\mathrm{Zn}$ & $1 / 1$ & 41 & -- \\
\hline $\mathrm{Fe}$ & $1 / 1$ & 21,477 & -- & -- & $\mathrm{Fe}$ & $1 / 1$ & 23,727 & - \\
\hline $\mathrm{Mn}$ & $1 / 1$ & 1,330 & -- & -- & $\mathrm{Mn}$ & $1 / 1$ & 554 & -- \\
\hline $\mathrm{K}$ & $1 / 1$ & 274 & -- & -- & K & $1 / 1$ & 163 & -- \\
\hline $\mathrm{Al}$ & $1 / 1$ & 35,554 & -- & -- & $\mathrm{Al}$ & $1 / 1$ & 39,845 & -- \\
\hline $\mathrm{Li}$ & $1 / 0$ & $<5$ & -- & -- & $\mathrm{Li}$ & $1 / 0$ & $<5$ & - \\
\hline $\mathrm{Ca}$ & $1 / 1$ & 8,943 & - & -- & $\mathrm{Ca}$ & $1 / 1$ & 7,833 & -- \\
\hline $\mathrm{Na}$ & $1 / 1$ & 494 & -- & -- & $\mathrm{Na}$ & $1 / 1$ & 556 & -- \\
\hline $\mathrm{Mg}$ & $1 / 1$ & 5,779 & -- & -- & $\mathrm{Mg}$ & $1 / 1$ & 6,473 & -- \\
\hline $\mathrm{La}$ & $1 / 0$ & $<5$ & -- & -- & $\mathrm{La}$ & $1 / 0$ & $<5$ & -- \\
\hline $\mathrm{Sb}$ & $1 / 0$ & $<20$ & -- & -- & $\mathrm{Sb}$ & $1 / 0$ & $<20$ & - \\
\hline $\mathrm{Pb}$ & $1 / 0$ & $<10$ & -- & -- & $\mathrm{Pb}$ & $1 / 0$ & $<10$ & -- \\
\hline $\mathrm{Tl}$ & $1 / 0$ & $<50$ & -- & -- & $\mathrm{Tl}$ & $1 / 0$ & $<50$ & -- \\
\hline As & $1 / 0$ & $<20$ & -- & - & As & $1 / 0$ & $<20$ & -- \\
\hline $\mathrm{Se}$ & $1 / 0$ & $<30$ & -- & -- & $\mathrm{Se}$ & $1 / 0$ & $<30$ & -- \\
\hline $\mathrm{Hg}$ & $1 / 1$ & 0.06 & -- & -- & $\mathrm{Hg}$ & $1 / 0$ & $<0.04$ & -- \\
\hline
\end{tabular}

${ }^{1}$ Detects are the number of samples with concentrations equal to or greater than the laboratory reporting limit.

${ }^{2}$ Only one concentration value for the soils is listed under arithmetic mean. 
Appendix 7.19. Distribution statistics for concentrations (in ppm of dry soil) of metals in soils on geologic unit "Qa" (Andesite; Holocene \& Pleistocene). For sampling site \#(s) and physiographic province(s) see Appendix 2.

In A Horizon

In B Horizon

\begin{tabular}{|c|c|c|c|c|c|c|c|c|c|}
\hline Metal & $\begin{array}{l}\text { Total } \\
\text { sample } \\
\text { number/ } \\
\text { detects }^{1}\end{array}$ & $\begin{array}{l}\text { Arith- } \\
\text { metic } \\
\text { mean }\end{array}$ & $\begin{array}{l}\text { Mini- } \\
\text { mum }\end{array}$ & $\begin{array}{l}\text { Maxi- } \\
\text { mum }\end{array}$ & Metal & $\begin{array}{l}\text { Total } \\
\text { sample } \\
\text { number/ } \\
\text { detects }^{1}\end{array}$ & $\begin{array}{l}\text { Arith- } \\
\text { metic } \\
\text { mean }\end{array}$ & $\begin{array}{l}\text { Mini- } \\
\text { mum }\end{array}$ & $\begin{array}{l}\text { Maxi- } \\
\text { mum }\end{array}$ \\
\hline $\mathrm{Ag}$ & $2 / 0$ & $<1$ & $<1$ & $<1$ & $\mathrm{Ag}$ & $2 / 0$ & $<1$ & $<1$ & $<1$ \\
\hline Mo & $2 / 0$ & $<5$ & $<5$ & $<5$ & Mo & $2 / 0$ & $<5$ & $<5$ & $<5$ \\
\hline $\mathrm{Cd}$ & $2 / 0$ & $<1$ & $<1$ & $<1$ & $\mathrm{Cd}$ & $2 / 0$ & $<1$ & $<1$ & $<1$ \\
\hline $\mathrm{Ba}$ & $2 / 2$ & 33 & 32 & 34 & $\mathrm{Ba}$ & $2 / 2$ & 29 & 28 & $312 / 0$ \\
\hline $\mathrm{Be}$ & $2 / 0$ & $<1$ & $<1$ & $<1$ & $\mathrm{Be}$ & $2 / 0$ & $<1$ & $<1$ & $<1$ \\
\hline $\mathrm{Ni}$ & $2 / 2$ & 13 & 13 & 13 & $\mathrm{Ni}$ & $2 / 2$ & 17 & 16 & 17 \\
\hline Co & $2 / 2$ & 6 & 6 & 6 & Co & $2 / 2$ & 7 & 7 & 7 \\
\hline $\mathrm{Cr}$ & $2 / 2$ & 8 & 7 & 9 & $\mathrm{Cr}$ & $2 / 2$ & 10 & 9 & 10 \\
\hline V & $2 / 2$ & 44 & 36 & 52 & V & $2 / 2$ & 54 & 52 & 55 \\
\hline $\mathrm{Cu}$ & $2 / 2$ & 19 & 14 & 24 & $\mathrm{Cu}$ & $2 / 2$ & 24 & 18 & 30 \\
\hline $\mathrm{Zn}$ & $2 / 2$ & 20 & 17 & 23 & $\mathrm{Zn}$ & $2 / 2$ & 20 & 17 & 23 \\
\hline $\mathrm{Fe}$ & $2 / 2$ & 12,211 & 10,930 & 13,492 & $\mathrm{Fe}$ & $2 / 2$ & 15,023 & 14,589 & 15,457 \\
\hline $\mathrm{Mn}$ & $2 / 2$ & 149 & 129 & 169 & $\mathrm{Mn}$ & $2 / 2$ & 135 & 106 & 164 \\
\hline K & $2 / 2$ & 284 & 223 & 344 & K & $2 / 2$ & 208 & 168 & 248 \\
\hline $\mathrm{Al}$ & $2 / 2$ & 19,347 & 18,926 & 19,768 & $\mathrm{Al}$ & $2 / 2$ & 25,275 & 23,013 & 27,537 \\
\hline $\mathrm{Li}$ & $2 / 0$ & $<5$ & $<5$ & $<5$ & $\mathrm{Li}$ & $2 / 0$ & $<5$ & $<5$ & $<5$ \\
\hline $\mathrm{Ca}$ & $2 / 2$ & 4,739 & 4,370 & 5,107 & $\mathrm{Ca}$ & $2 / 2$ & 5,873 & 5,323 & 6,422 \\
\hline $\mathrm{Na}$ & $2 / 2$ & 1,259 & 1,224 & 1,294 & $\mathrm{Na}$ & $2 / 2$ & 1,625 & 1,541 & 1,708 \\
\hline $\mathrm{Mg}$ & $2 / 2$ & 1,682 & 1,616 & 1,748 & $\mathrm{Mg}$ & $2 / 2$ & 2,250 & 2,216 & 2,284 \\
\hline $\mathrm{La}$ & $2 / 0$ & $<5$ & $<5$ & $<5$ & $\mathrm{La}$ & $2 / 0$ & $<5$ & $<5$ & $<5$ \\
\hline $\mathrm{Sb}$ & $2 / 0$ & $<20$ & $<20$ & $<20$ & $\mathrm{Sb}$ & $2 / 0$ & $<20$ & $<20$ & $<20$ \\
\hline $\mathrm{Pb}$ & $2 / 1$ & $<11^{*}$ & $<10$ & 12 & $\mathrm{~Pb}$ & $2 / 0$ & $<10$ & $<10$ & $<10$ \\
\hline $\mathrm{Tl}$ & $2 / 0$ & $<50$ & $<50$ & $<50$ & $\mathrm{Tl}$ & $2 / 0$ & $<50$ & $<50$ & $<50$ \\
\hline As & $2 / 0$ & $<20$ & $<20$ & $<20$ & As & $2 / 0$ & $<20$ & $<20$ & $<20$ \\
\hline $\mathrm{Se}$ & $2 / 0$ & $<30$ & $<30$ & $<30$ & $\mathrm{Se}$ & $2 / 0$ & $<30$ & $<30$ & $<30$ \\
\hline $\mathrm{Hg}$ & $2 / 2$ & 0.07 & 0.06 & 0.07 & $\mathrm{Hg}$ & $2 / 2$ & 0.05 & 0.04 & 0.05 \\
\hline
\end{tabular}

Detects are the number of samples with concentrations equal to or greater than the laboratory reporting limit.

* Where the concentration of a metal in a sample is less than the laboratory minimum reporting level, the minimum reporting level is used for calculating arithmetic mean, and the arithmetic mean is qualified as less than the value given. 
Appendix 7.20. Distribution statistics for concentrations (in ppm of dry soil) of metals in soils on geologic unit “Qal” (Alluvial deposits; Holocene). For sampling site \#(s) and physiographic province(s) see Appendix 2.

In A Horizon

$\begin{array}{lllll}\text { Metal } & \begin{array}{l}\text { Total } \\ \text { sample } \\ \text { number/ } \\ \text { detects }\end{array} & \begin{array}{l}\text { Arith- } \\ \text { metic }\end{array} & \begin{array}{l}\text { Mini- } \\ \text { mean }\end{array} & \begin{array}{l}\text { Maxi- } \\ \text { mum }\end{array} \\ & & & \\ & & & \end{array}$

$\begin{array}{lll}\mathrm{Ag} & 3 / 0 & <1 \\ \mathrm{Mo} & 3 / 0 & <5 \\ \mathrm{Cd} & 3 / 0 & <1\end{array}$

$\mathrm{Ba} \quad 3 / 3$

$\mathrm{Be} \quad 3 / 0$

$\mathrm{Ni} \quad 3 / 3$

Co $3 / 3$

$\mathrm{Cr} \quad 3 / 3$

$\mathrm{V} \quad 3 / 3$

$\mathrm{Cu} \quad 3 / 3$

$\mathrm{Zn} \quad 3 / 3$

$\mathrm{Fe} \quad 3 / 3$

Mn $\quad 3 / 3$

$\mathrm{K} \quad 3 / 3$

$\mathrm{Al} \quad 3 / 3$

$\mathrm{Li} \quad 3 / 3$

$\mathrm{Ca} \quad 3 / 3$

$\mathrm{Na} \quad 3 / 3$

$\mathrm{Mg} \quad 3 / 3$

$\mathrm{La} \quad 3 / 3$

$\mathrm{Sb} \quad 3 / 0$

$\mathrm{Pb} \quad 3 / 1$

Tl $\quad 3 / 0$

As $\quad 3 / 0$

Se $\quad 3 / 0$

$\mathrm{Hg} \quad 3 / 3$

\begin{tabular}{|c|c|}
\hline$<1$ & $<1$ \\
\hline$<5$ & $<5$ \\
\hline$<1$ & $<10$ \\
\hline 137 & 119 \\
\hline$<1$ & $<1$ \\
\hline 34 & 29 \\
\hline 17 & 16 \\
\hline 31 & 26 \\
\hline 73 & 57 \\
\hline 28 & 25 \\
\hline
\end{tabular}

$$
92
$$$$
31,688
$$$$
809
$$$$
1,897
$$$$
28,210
$$$$
10
$$$$
11,729
$$$$
1,040
$$$$
7,754
$$$$
12
$$$$
<20
$$$$
<12 *
$$$$
<50
$$$$
<20
$$$$
<30
$$

0.08

\section{In B Horizon}

$\begin{array}{llllll}<1 & \mathrm{Ag} & 3 / 0 & <1 & <1 & <1 \\ <5 & \mathrm{Mo} & 3 / 0 & <5 & <5 & <5 \\ <1 & \mathrm{Cd} & 3 / 0 & <1 & <1 & <1 \\ 155 & \mathrm{Ba} & 3 / 3 & 142 & 99 & 170 \\ <1 & \mathrm{Be} & 3 / 0 & <1 & <1 & <1 \\ 38 & \mathrm{Ni} & 3 / 3 & 35 & 32 & 38 \\ 18 & \mathrm{Co} & 3 / 3 & 18 & 13 & 20 \\ 38 & \mathrm{Cr} & 3 / 3 & 31 & 29 & 33 \\ 83 & \mathrm{~V} & 3 / 3 & 77 & 54 & 91 \\ 30 & \mathrm{Cu} & 3 / 3 & 27 & 20 & 33 \\ 131 & \mathrm{Zn} & 3 / 3 & 76 & 69 & 86 \\ 34,372 & \mathrm{Fe} & 3 / 3 & 33,808 & 26,666 & 37,932 \\ 941 & \mathrm{Mn} & 3 / 3 & 768 & 732 & 789 \\ 2,285 & \mathrm{~K} & 3 / 3 & 1,232 & 1,121 & 1,437 \\ 32,096 & \mathrm{Al} & 3 / 3 & 29,969 & 19,743 & 35,235 \\ 16 & \mathrm{Li} & 3 / 3 & 10 & 8 & 13 \\ 15,923 & \mathrm{Ca} & 3 / 3 & 9,374 & 5,933 & 12,209 \\ 1,416 & \mathrm{Na} & 3 / 3 & 1,163 & 444 & 1,689 \\ 8,385 & \mathrm{Mg} & 3 / 3 & 8,044 & 6,266 & 9,043 \\ 13 & \mathrm{La} & 3 / 3 & 12 & 11 & 13 \\ <20 & \mathrm{Sb} & 3 / 0 & <20 & <20 & <20 \\ 16 & \mathrm{~Pb} & 3 / 1 & <10^{*} & <10 & 11 \\ <50 & \mathrm{Tl} & 3 / 0 & <50 & <50 & <50 \\ <20 & \mathrm{As} & 3 / 0 & <20 & <20 & <20 \\ <30 & \mathrm{Se} & 3 / 0 & <30 & <30 & <30 \\ 0.08 & \mathrm{Hg} & 3 / 3 & 0.05 & 0.04 & 0.06\end{array}$

${ }^{1}$ Detects are the number of samples with concentrations equal to or greater than the laboratory reporting limit.

* Where the concentration of a metal in a sample is less than the laboratory minimum reporting level, the minimum reporting level is used for calculating arithmetic mean, and the arithmetic mean is qualified as less than the value given. 
Appendix 7.21. Distribution statistics for concentrations (in ppm of dry soil) of metals in soils on geologic unit "Qb" (Basalt \& basaltic andesite; Holocene \& Pleistocene ). For sampling site \#(s) and physiographic province(s) see Appendix 2.

In A Horizon

In B Horizon

$\begin{array}{llllllllll}\text { Metal } & \begin{array}{l}\text { Total } \\ \text { sample }\end{array} & \text { Arith- } & \text { Mini- } & \text { Maxi- } & \text { Metal } & \text { Total } & \text { Arith- } & \text { Mini- } & \text { Maxi- } \\ \text { number/ } & \text { mean }^{2} & \text { mum } & \text { mum } & & \begin{array}{l}\text { sample } \\ \text { number/ } /\end{array} & \begin{array}{l}\text { metic } \\ \text { mean }\end{array} & \text { mum } & \text { mum } \\ \text { detects }^{1} & & & & & & & \end{array}$

\begin{tabular}{|c|c|c|c|c|c|c|c|c|c|}
\hline $\mathrm{Ag}$ & $1 / 0$ & $<1$ & -- & -- & $\mathrm{Ag}$ & $1 / 0$ & $<1$ & -- & -- \\
\hline Mo & $1 / 0$ & $<5$ & - & -- & Mo & $1 / 0$ & $<5$ & - & -- \\
\hline $\mathrm{Cd}$ & $1 / 0$ & $<1$ & -- & -- & $\mathrm{Cd}$ & $1 / 0$ & $<1$ & -- & .- \\
\hline $\mathrm{Ba}$ & $1 / 1$ & 105 & -- & - & $\mathrm{Ba}$ & $1 / 1$ & 133 & -- & -- \\
\hline $\mathrm{Be}$ & $1 / 0$ & $<1$ & -- & -- & $\mathrm{Be}$ & $1 / 0$ & $<1$ & -- & -- \\
\hline $\mathrm{Ni}$ & $1 / 1$ & 29 & -- & -. & $\mathrm{Ni}$ & $1 / 1$ & 33 & -- & -- \\
\hline Co & $1 / 1$ & 11 & -- & -- & Co & $1 / 1$ & 14 & -- & -- \\
\hline $\mathrm{Cr}$ & $1 / 1$ & 12 & -- & -- & $\mathrm{Cr}$ & $1 / 1$ & 14 & -- & -- \\
\hline V & $1 / 1$ & 39 & -- & -- & V & $1 / 1$ & 47 & -- & -- \\
\hline $\mathrm{Cu}$ & $1 / 1$ & 15 & -- & -- & $\mathrm{Cu}$ & $1 / 1$ & 18 & -- & -. \\
\hline $\mathrm{Zn}$ & $1 / 1$ & 61 & -- & -- & $\mathrm{Zn}$ & $1 / 1$ & 46 & -- & -- \\
\hline $\mathrm{Fe}$ & $1 / 1$ & 19,180 & -- & -- & $\mathrm{Fe}$ & $1 / 1$ & 23,288 & - & -- \\
\hline Mn & $1 / 1$ & 559 & - & - & $\mathrm{Mn}$ & $1 / 1$ & 430 & -- & -- \\
\hline K & $1 / 1$ & 607 & -- & -- & $\mathrm{K}$ & $1 / 1$ & 567 & - & -- \\
\hline $\mathrm{Al}$ & $1 / 1$ & 21,690 & -- & -- & $\mathrm{Al}$ & $1 / 1$ & 25,605 & -- & -- \\
\hline $\mathrm{Li}$ & $1 / 1$ & 7 & -- & -- & $\mathrm{Li}$ & $1 / 1$ & 8 & -- & -- \\
\hline $\mathrm{Ca}$ & $1 / 1$ & 3,642 & -- & -- & $\mathrm{Ca}$ & $1 / 1$ & 3,137 & -- & -- \\
\hline $\mathrm{Na}$ & $1 / 1$ & 710 & -- & -- & $\mathrm{Na}$ & $1 / 1$ & 719 & -- & -- \\
\hline $\mathrm{Mg}$ & $1 / 1$ & 3,924 & -- & -- & $\mathrm{Mg}$ & $1 / 1$ & 4,798 & -- & -- \\
\hline $\mathrm{La}$ & $1 / 1$ & 6 & -- & - & $\mathrm{La}$ & $1 / 1$ & 8 & -- & -- \\
\hline $\mathrm{Sb}$ & $1 / 0$ & $<20$ & -. & -- & $\mathrm{Sb}$ & $1 / 0$ & $<20$ & -- & - \\
\hline $\mathrm{Pb}$ & $1 / 1$ & 10 & - & -- & $\mathrm{Pb}$ & $1 / 0$ & $<10$ & -- & -- \\
\hline $\mathrm{Tl}$ & $1 / 0$ & $<50$ & -- & -- & $\mathrm{Tl}$ & $1 / 0$ & $<50$ & - & -- \\
\hline As & $1 / 0$ & $<20$ & - & -- & As & $1 / 0$ & $<20$ & -- & -- \\
\hline $\mathrm{Se}$ & $1 / 0$ & $<30$ & -- & -- & $\mathrm{Se}$ & $1 / 0$ & $<30$ & -- & -- \\
\hline $\mathrm{Hg}$ & $1 / 1$ & 0.05 & - & -- & $\mathrm{Hg}$ & $1 / 0$ & $<0.04$ & -- & - \\
\hline
\end{tabular}

${ }^{1}$ Detects are the number of samples with concentrations equal to or greater than the laboratory reporting limit.

${ }^{2}$ Only one concentration value for the soils is listed under arithmetic mean. 
Appendix 7.22. Distribution statistics for concentrations (in ppm of dry soil) of metals in soils on geologic unit “Qba” (Basaltic andesite \& basalt; Holocene \& Pleistocene). For sampling site \#(s) and physiographic province(s) see Appendix 2.

In A Horizon

\begin{tabular}{|c|c|c|c|c|c|c|c|c|c|}
\hline Metal & $\begin{array}{l}\text { Total } \\
\text { sample } \\
\text { number/ } \\
\text { detects }\end{array}$ & $\begin{array}{l}\text { Arith- } \\
\text { metic } \\
\text { mean }\end{array}$ & $\begin{array}{l}\text { Mini- } \\
\text { mum }\end{array}$ & $\begin{array}{l}\text { Maxi- } \\
\text { mum }\end{array}$ & Metal & $\begin{array}{l}\text { Total } \\
\text { sample } \\
\text { number/ } \\
\text { detects }{ }^{1}\end{array}$ & $\begin{array}{l}\text { Arith- } \\
\text { metic } \\
\text { mean }\end{array}$ & $\begin{array}{l}\text { Mini- } \\
\text { mum }\end{array}$ & $\begin{array}{l}\text { Maxi- } \\
\text { mum }\end{array}$ \\
\hline $\mathrm{Ag}$ & $2 / 0$ & $<1$ & $<1$ & $<1$ & $\mathrm{Ag}$ & $2 / 0$ & $<1$ & $<1$ & $<1$ \\
\hline Mo & $2 / 0$ & $<5$ & $<5$ & $<5$ & Mo & $2 / 0$ & $<5$ & $<5$ & $<5$ \\
\hline $\mathrm{Cd}$ & $2 / 0$ & $<1$ & $<1$ & $<1$ & $\mathrm{Cd}$ & $2 / 0$ & $<1$ & $<1$ & $<1$ \\
\hline $\mathrm{Ba}$ & $2 / 2$ & 161 & 39 & 284 & $\mathrm{Ba}$ & $2 / 2$ & 189 & 21 & 356 \\
\hline $\mathrm{Be}$ & $2 / 0$ & $<1$ & $<1$ & $<1$ & $\mathrm{Be}$ & $2 / 0$ & $<1$ & $<1$ & $<1$ \\
\hline $\mathrm{Ni}$ & $2 / 2$ & 22 & 8 & 36 & $\mathrm{Ni}$ & $2 / 2$ & 24 & 5 & 44 \\
\hline Co & $2 / 1$ & $<21^{*}$ & $<6$ & 36 & Co & $2 / 2$ & 23 & 7 & 39 \\
\hline $\mathrm{Cr}$ & $2 / 2$ & 24 & 4 & 45 & $\mathrm{Cr}$ & $2 / 2$ & 29 & 6 & 52 \\
\hline V & $2 / 2$ & 81 & 28 & 135 & V & $2 / 2$ & 99 & 47 & 150 \\
\hline $\mathrm{Cu}$ & $2 / 2$ & 30 & 7 & 52 & $\mathrm{Cu}$ & $2 / 2$ & 37 & 8 & 66 \\
\hline $\mathrm{Zn}$ & $2 / 2$ & 60 & 27 & 93 & $\mathrm{Zn}$ & $2 / 2$ & 59 & 30 & 87 \\
\hline $\mathrm{Fe}$ & $2 / 2$ & 29,936 & 8,314 & 51,558 & $\mathrm{Fe}$ & $2 / 2$ & 37,558 & 16,001 & 59,114 \\
\hline $\mathrm{Mn}$ & $2 / 2$ & 779 & 336 & 1,222 & $\mathrm{Mn}$ & $2 / 2$ & 734 & 246 & 1,223 \\
\hline K & $2 / 2$ & 1,113 & 373 & 1,853 & K & $2 / 2$ & 1,038 & 214 & 1,861 \\
\hline $\mathrm{Al}$ & $2 / 2$ & 31,523 & 4,634 & 58,412 & $\mathrm{Al}$ & $2 / 2$ & 43,545 & 12,641 & 74,450 \\
\hline $\mathrm{Li}$ & $2 / 1$ & $<8^{*}$ & $<5$ & 11 & $\mathrm{Li}$ & $2 / 1$ & $<10^{*}$ & $<5$ & 14 \\
\hline $\mathrm{Ca}$ & $2 / 2$ & 3,028 & 2,194 & 3,861 & $\mathrm{Ca}$ & $2 / 2$ & 2,439 & 998 & 3,879 \\
\hline $\mathrm{Na}$ & $2 / 2$ & 287 & 216 & 357 & $\mathrm{Na}$ & $2 / 2$ & 404 & 250 & 557 \\
\hline $\mathrm{Mg}$ & $2 / 2$ & 1,719 & 545 & 2,893 & $\mathrm{Mg}$ & $2 / 2$ & 1,960 & 791 & 3,129 \\
\hline $\mathrm{La}$ & $2 / 1$ & $<11$ & $<5$ & 17 & $\mathrm{La}$ & $2 / 1$ & $<13^{*}$ & $<5$ & 21 \\
\hline $\mathrm{Sb}$ & $2 / 0$ & $<20$ & $<20$ & $<20$ & $\mathrm{Sb}$ & $2 / 0$ & $<20$ & $<20$ & $<20$ \\
\hline $\mathrm{Pb}$ & $2 / 1$ & $<15^{*}$ & $<10$ & 20 & $\mathrm{~Pb}$ & $2 / 1$ & $<10$ & $<10$ & 10 \\
\hline $\mathrm{TI}$ & $2 / 0$ & $<50$ & $<50$ & $<50$ & $\mathrm{Tl}$ & $2 / 0$ & $<50$ & $<50$ & $<50$ \\
\hline As & $2 / 0$ & $<20$ & $<20$ & $<20$ & As & $2 / 0$ & $<20$ & $<20$ & $<20$ \\
\hline $\mathrm{Se}$ & $2 / 0$ & $<30$ & $<30$ & $<30$ & $\mathrm{Se}$ & $2 / 0$ & $<30$ & $<30$ & $<30$ \\
\hline $\mathrm{Hg}$ & $2 / 2$ & 0.11 & 0.07 & 0.14 & $\mathrm{Hg}$ & $2 / 1$ & $<0.05$ & $<0.04$ & 0.06 \\
\hline
\end{tabular}

${ }^{1}$ Detects are the number of samples with concentrations equal to or greater than the laboratory reporting limit.

* Where the concentration of a metal in a sample is less than the laboratory minimum reporting level, the minimum reporting level is used for calculating arithmetic mean, and the arithmetic mean is qualified as less than the value given. 
Appendix 7.23. Distribution statistics for concentrations (in ppm of dry soil) of metals in soils on geologic unit "Qd" (young) (Dune sand; Holocene). For sampling site \#(s) and physiographic province(s) see Appendix 2.

In A Horizon

In B Horizon

\begin{tabular}{|c|c|c|c|c|c|c|c|c|c|}
\hline Metal & $\begin{array}{l}\text { Total } \\
\text { sample } \\
\text { number/ } \\
\text { detects }\end{array}$ & $\begin{array}{l}\text { Arith- } \\
\text { metic } \\
\text { mean }^{2}\end{array}$ & $\begin{array}{l}\text { Mini- } \\
\text { mum }\end{array}$ & $\begin{array}{l}\text { Maxi- } \\
\text { mum }\end{array}$ & Metal & $\begin{array}{l}\text { Total } \\
\text { sample } \\
\text { number/ }\end{array}$ & $\begin{array}{l}\text { Arith- } \\
\text { metic } \\
\text { mean }^{2}\end{array}$ & $\begin{array}{l}\text { Mini- } \\
\text { mum }\end{array}$ & $\begin{array}{l}\text { Maxi- } \\
\text { mum }\end{array}$ \\
\hline
\end{tabular}

\begin{tabular}{|c|c|c|c|c|c|c|c|c|c|}
\hline $\mathrm{Ag}$ & $1 / 0$ & $<1$ & -- & -- & $\mathrm{Ag}$ & $1 / 1$ & 1 & -- & -- \\
\hline Mo & $1 / 1$ & $<5$ & -- & -- & Mo & $1 / 0$ & $<5$ & - & -- \\
\hline $\mathrm{Cd}$ & $1 / 0$ & $<1$ & -- & -- & $\mathrm{Cd}$ & $1 / 0$ & $<1$ & -- & -- \\
\hline $\mathrm{Ba}$ & $1 / 1$ & 8 & - & - & $\mathrm{Ba}$ & $1 / 1$ & 34 & -- & -- \\
\hline $\mathrm{Be}$ & $1 / 0$ & $<1$ & -- & -- & $\mathrm{Be}$ & $1 / 0$ & $<1$ & -- & -- \\
\hline $\mathrm{Ni}$ & $1 / 1$ & 4 & -- & -- & $\mathrm{Ni}$ & $1 / 0$ & $<4$ & -- & -- \\
\hline Co & $1 / 0$ & $<6$ & - & -- & Co & $1 / 0$ & $<6$ & -- & -- \\
\hline $\mathrm{Cr}$ & $1 / 1$ & 9 & -- & -- & $\mathrm{Cr}$ & $1 / 1$ & 9 & -- & -- \\
\hline V & $1 / 1$ & 6 & -- & - & $\mathrm{V}$ & $1 / 1$ & 6 & -- & -- \\
\hline $\mathrm{Cu}$ & $1 / 0$ & $<2$ & -- & -- & $\mathrm{Cu}$ & $1 / 1$ & 5 & -- & -- \\
\hline $\mathrm{Zn}$ & $1 / 1$ & 11 & -- & -- & $\mathrm{Zn}$ & $1 / 1$ & 19 & -- & -- \\
\hline $\mathrm{Fe}$ & $1 / 1$ & 3,844 & -- & -- & $\mathrm{Fe}$ & $1 / 1$ & 3,846 & -- & -- \\
\hline $\mathrm{Mn}$ & $1 / 1$ & 41 & -- & -- & $\mathrm{Mn}$ & $1 / 1$ & 30 & -- & -- \\
\hline K & $1 / 1$ & 298 & -- & -- & $\mathrm{K}$ & $1 / 1$ & 315 & -- & -- \\
\hline $\mathrm{Al}$ & $1 / 1$ & 2,689 & -- & -- & $\mathrm{Al}$ & $1 / 1$ & 2,752 & -- & -- \\
\hline $\mathrm{Li}$ & $1 / 1$ & 6 & -- & -- & $\mathrm{Li}$ & $1 / 1$ & 7 & -- & -- \\
\hline $\mathrm{Ca}$ & $1 / 1$ & 640 & -- & -- & $\mathrm{Ca}$ & $1 / 1$ & 576 & -- & -- \\
\hline $\mathrm{Na}$ & $1 / 1$ & 129 & -- & -- & $\mathrm{Na}$ & $1 / 1$ & 129 & -- & -- \\
\hline $\mathrm{Mg}$ & $1 / 1$ & 895 & -- & -- & $\mathrm{Mg}$ & $1 / 1$ & 821 & -- & -- \\
\hline $\mathrm{La}$ & $1 / 0$ & $<5$ & - & -- & $\mathrm{La}$ & $1 / 0$ & $<5$ & -- & -- \\
\hline $\mathrm{Sb}$ & $1 / 0$ & $<20$ & -- & -- & $\mathrm{Sb}$ & $1 / 0$ & $<20$ & -- & -- \\
\hline $\mathrm{Pb}$ & $1 / 0$ & $<10$ & -- & - & $\mathrm{Pb}$ & $1 / 0$ & $<10$ & -- & - \\
\hline $\mathrm{Tl}$ & $1 / 0$ & $<50$ & -- & -- & $\mathrm{Tl}$ & $1 / 0$ & $<50$ & -- & -- \\
\hline As & $1 / 0$ & $<20$ & -- & -- & As & $1 / 0$ & $<20$ & -- & -- \\
\hline $\mathrm{Se}$ & $1 / 0$ & $<30$ & -- & -- & $\mathrm{Se}$ & $1 / 0$ & $<30$ & - & -- \\
\hline $\mathrm{Hg}$ & $1 / 0$ & $<0.04$ & -- & -- & $\mathrm{Hg}$ & $1 / 0$ & $<0.04$ & - & -- \\
\hline
\end{tabular}

${ }^{1}$ Detects are the number of samples with concentrations equal to or greater than the laboratory reporting limit.

${ }^{2}$ Only one concentration value for the soils is listed under arithmetic mean. 
Appendix 7.24. Distribution statistics for concentrations (in ppm of dry soil) of metals in soils on geologic unit “Qd" (old) (Dune sand; Holocene). For sampling site \#(s) and physiographic province(s) see Appendix 2.

In A Horizon

In B Horizon

\begin{tabular}{|c|c|c|c|c|c|c|c|c|}
\hline Metal & $\begin{array}{l}\text { Total } \\
\text { sample } \\
\text { number/ } \\
\text { detects }\end{array}$ & $\begin{array}{l}\text { Arith- } \\
\text { metic } \\
\text { mean }^{2}\end{array}$ & $\begin{array}{l}\text { Mini- } \\
\text { mum }\end{array}$ & $\begin{array}{l}\text { Maxi- } \\
\text { mum }\end{array}$ & Metal & $\begin{array}{l}\text { Total } \\
\text { sample } \\
\text { number/ } \\
\text { detects }{ }^{1}\end{array}$ & $\begin{array}{l}\text { Arith- } \\
\text { metic } \\
\text { mean }^{2}\end{array}$ & $\begin{array}{l}\text { Mini- } \\
\text { mum }\end{array}$ \\
\hline
\end{tabular}

\begin{tabular}{|c|c|c|c|c|c|c|c|c|c|}
\hline $\mathrm{Ag}$ & $1 / 1$ & 1 & - & -- & $\mathrm{Ag}$ & $1 / 0$ & $<1$ & -- & -- \\
\hline Mo & $1 / 0$ & $<5$ & - & -- & Mo & $1 / 0$ & $<5$ & -- & -- \\
\hline $\mathrm{Cd}$ & $1 / 0$ & $<1$ & -- & -- & $\mathrm{Cd}$ & $1 / 0$ & $<1$ & -- & -- \\
\hline $\mathrm{Ba}$ & $1 / 1$ & 34 & -- & -- & $\mathrm{Ba}$ & $1 / 1$ & 10 & -- & -- \\
\hline $\mathrm{Be}$ & $1 / 0$ & $<1$ & -- & -- & $\mathrm{Be}$ & $1 / 0$ & $<1$ & - & -- \\
\hline $\mathrm{Ni}$ & $1 / 0$ & $<4$ & - & -- & $\mathrm{Ni}$ & $1 / 1$ & 5 & -- & -- \\
\hline Co & $1 / 0$ & $<6$ & -- & - & Co & $1 / 0$ & $<6$ & -- & -- \\
\hline $\mathrm{Cr}$ & $1 / 1$ & 9 & - & -- & $\mathrm{Cr}$ & $1 / 1$ & 9 & -- & -- \\
\hline V & $1 / 1$ & 7 & -- & -- & V & $1 / 1$ & 7 & -- & -- \\
\hline $\mathrm{Cu}$ & $1 / 1$ & 5 & - & -- & $\mathrm{Cu}$ & $1 / 0$ & $<2$ & -- & -- \\
\hline $\mathrm{Zn}$ & $1 / 1$ & 19 & - & -- & $\mathrm{Zn}$ & $1 / 1$ & 11 & -- & \\
\hline $\mathrm{Fe}$ & $1 / 1$ & 2,648 & -- & -- & $\mathrm{Fe}$ & $1 / 1$ & 4,538 & -- & -- \\
\hline $\mathrm{Mn}$ & $1 / 1$ & 52 & - & -- & $\mathrm{Mn}$ & $1 / 1$ & 32 & -- & -- \\
\hline $\mathrm{K}$ & $1 / 1$ & 530 & -- & - & $\mathrm{K}$ & $1 / 1$ & 262 & - & -- \\
\hline $\mathrm{Al}$ & $1 / 1$ & 2,541 & -- & -- & $\mathrm{Al}$ & $1 / 1$ & 5,001 & -- & -- \\
\hline $\mathrm{Li}$ & $1 / 0$ & $<5$ & -- & -- & $\mathrm{Li}$ & 11 & 9 & - & -- \\
\hline $\mathrm{Ca}$ & $1 / 1$ & 1,888 & -- & -- & $\mathrm{Ca}$ & $1 / 1$ & 465 & -- & -- \\
\hline $\mathrm{Na}$ & $1 / 1$ & 241 & - & -- & $\mathrm{Na}$ & $1 / 1$ & 105 & -- & -- \\
\hline $\mathrm{Mg}$ & $1 / 1$ & 704 & -- & -- & $\mathrm{Mg}$ & $1 / 1$ & 756 & -- & -- \\
\hline $\mathrm{La}$ & $1 / 0$ & $<5$ & -- & -- & $\mathrm{La}$ & $1 / 0$ & $<5$ & -- & -- \\
\hline $\mathrm{Sb}$ & $1 / 0$ & $<20$ & -- & -- & $\mathrm{Sb}$ & $1 / 0$ & $<20$ & -- & -- \\
\hline $\mathrm{Pb}$ & $1 / 1$ & 10 & -- & -- & $\mathrm{Pb}$ & $1 / 0$ & $<10$ & -- & -- \\
\hline $\mathrm{Tl}$ & $1 / 0$ & $<50$ & -- & -- & $\mathrm{Tl}$ & $1 / 0$ & $<50$ & -- & -- \\
\hline As & $1 / 0$ & $<20$ & -- & - & As & $1 / 0$ & $<20$ & -- & -- \\
\hline $\mathrm{Se}$ & $1 / 0$ & $<30$ & -- & -- & $\mathrm{Se}$ & $1 / 0$ & $<30$ & -- & -- \\
\hline $\mathrm{Hg}$ & $1 / 1$ & 0.14 & -- & -- & $\mathrm{Hg}$ & $1 / 0$ & $<0.04$ & -- & -- \\
\hline
\end{tabular}

${ }^{1}$ Detects are the number of samples with concentrations equal to or greater than the laboratory reporting limit.

${ }^{2}$ Only one concentration value for the soils is listed under arithmetic mean. 
Appendix 7.25. Distribution statistics for concentrations (in ppm of dry soil) of metals in soils on geologic unit “Qf” (Fanglomerate; Holocene \& Pleistocene). For sampling site \#(s) and physiographic province(s) see Appendix 2.

In A Horizon

In B Horizon

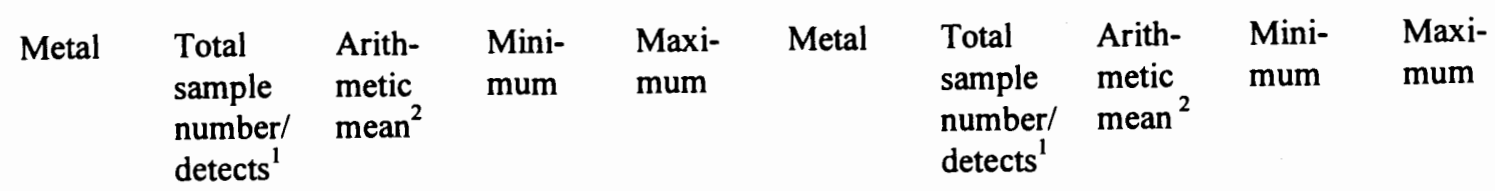

\begin{tabular}{|c|c|c|c|c|c|c|c|c|c|}
\hline $\mathrm{Ag}$ & $1 / 0$ & $<1$ & -- & -- & $\mathrm{Ag}$ & $1 / 0$ & $<1$ & -- & -- \\
\hline Mo & $1 / 0$ & $<5$ & -- & -- & Mo & $1 / 0$ & $<5$ & -- & -- \\
\hline $\mathrm{Cd}$ & $1 / 0$ & $<1$ & -- & -- & $\mathrm{Cd}$ & $1 / 0$ & $<1$ & -- & -- \\
\hline $\mathrm{Ba}$ & $1 / 1$ & 52 & - & -- & $\mathrm{Ba}$ & $1 / 1$ & 61 & -- & -- \\
\hline $\mathrm{Be}$ & $1 / 0$ & $<1$ & -- & -- & $\mathrm{Be}$ & $1 / 0$ & $<1$ & -- & -- \\
\hline $\mathrm{Ni}$ & $1 / 1$ & 15 & -- & -- & $\mathrm{Ni}$ & $1 / 1$ & 20 & -- & -- \\
\hline Co & $1 / 1$ & 6 & -- & - & $\mathrm{Co}$ & $1 / 1$ & 7 & -- & -- \\
\hline $\mathrm{Cr}$ & $1 / 1$ & 6 & -- & -- & $\mathrm{Cr}$ & $1 / 1$ & 8 & -- & -- \\
\hline V & $1 / 1$ & 29 & -- & -- & V & $1 / 1$ & 37 & -- & -- \\
\hline $\mathrm{Cu}$ & $1 / 1$ & 22 & -- & -- & $\mathrm{Cu}$ & $1 / 1$ & 27 & -- & -- \\
\hline $\mathrm{Zn}$ & $1 / 1$ & 26 & -- & -- & $\mathrm{Zn}$ & $1 / 1$ & 23 & - & -- \\
\hline $\mathrm{Fe}$ & $1 / 1$ & 10,219 & -- & -- & $\mathrm{Fe}$ & $1 / 1$ & 12,490 & -- & -- \\
\hline $\mathrm{Mn}$ & $1 / 1$ & 451 & -- & -- & $\mathrm{Mn}$ & $1 / 1$ & 165 & -- & -- \\
\hline K & $1 / 1$ & 513 & -- & -- & $\mathrm{K}$ & $1 / 1$ & 472 & -- & - \\
\hline Al & $1 / 1$ & 20,340 & -- & -- & $\mathrm{Al}$ & $1 / 1$ & 25,175 & -- & -- \\
\hline $\mathrm{Li}$ & $1 / 0$ & $<5$ & -- & - & $\mathrm{Li}$ & $1 / 0$ & $<5$ & -- & -- \\
\hline $\mathrm{Ca}$ & $1 / 1$ & 9,111 & -- & -- & $\mathrm{Ca}$ & $1 / 1$ & 9,234 & -- & -- \\
\hline $\mathrm{Na}$ & $1 / 1$ & 1,491 & -- & -- & $\mathrm{Na}$ & $1 / 1$ & 1,739 & -- & -- \\
\hline $\mathbf{M g}$ & $1 / 1$ & 2,514 & -- & -- & $\mathrm{Mg}$ & $1 / 1$ & 3,173 & -- & -- \\
\hline $\mathrm{La}$ & $1 / 0$ & $<5$ & -- & -- & $\mathrm{La}$ & $1 / 0$ & $<5$ & -- & -- \\
\hline $\mathrm{Sb}$ & $1 / 0$ & $<20$ & -- & -- & $\mathrm{Sb}$ & $1 / 0$ & $<20$ & -- & - \\
\hline $\mathrm{Pb}$ & $1 / 0$ & $<10$ & -- & -- & $\mathrm{Pb}$ & $1 / 0$ & $<10$ & -- & -- \\
\hline $\mathrm{Tl}$ & $1 / 0$ & $<50$ & -- & -- & $\mathrm{Tl}$ & $1 / 0$ & $<50$ & -- & -- \\
\hline As & $1 / 0$ & $<20$ & -- & -- & As & $1 / 0$ & $<20$ & -- & -- \\
\hline $\mathrm{Se}$ & $1 / 0$ & $<30$ & -- & -- & $\mathrm{Se}$ & $1 / 0$ & $<30$ & - & -- \\
\hline $\mathrm{Hg}$ & $1 / 1$ & 0.07 & -- & -- & $\mathrm{Hg}$ & $1 / 0$ & $<0.04$ & -- & -- \\
\hline
\end{tabular}

${ }^{1}$ Detects are the number of samples with concentrations equal to or greater than the laboratory reporting limit.

${ }^{2}$ Only one concentration value for the soils is listed under arithmetic mean. 
Appendix 7.26. Distribution statistics for concentrations (in ppm of dry soil) of metals in soils on geologic unit "Qg" (Glacial deposits; Pleistocene). For sampling site \#(s) and physiographic province(s) see Appendix 2.

In A Horizon

In B Horizon

$\begin{array}{llllllllll}\text { Metal } & \begin{array}{l}\text { Total } \\ \text { sample } \\ \text { number/ } \\ \text { detects }^{\prime}\end{array} & \begin{array}{l}\text { Arith- } \\ \text { metic }\end{array} & \begin{array}{l}\text { Mini- } \\ \text { mum }\end{array} & & \begin{array}{l}\text { Maxi- } \\ \text { mum }\end{array} & \begin{array}{l}\text { Metal } \\ \text { Total } \\ \text { sample } \\ \text { number/ } \\ \text { detects }\end{array} & \begin{array}{l}\text { Arith- } \\ \text { metic } \\ \text { mean }\end{array} & \begin{array}{l}\text { Mini- } \\ \text { mum }\end{array} & \begin{array}{l}\text { Maxi- } \\ \text { mum }\end{array} \\ & & & & & & & & \\ \mathrm{Ag} & 2 / 0 & <1 & <1 & <1 & \mathrm{Ag} & 2 / 0 & <1 & <1 & <1 \\ \mathrm{Mo} & 2 / 0 & <5 & <5 & <5 & \mathrm{Mo} & 2 / 0 & <5 & <5 & <5 \\ \mathrm{Cd} & 2 / 0 & <1 & <1 & <1 & \mathrm{Cd} & 2 / 0 & <1 & <1 & <1 \\ \mathrm{Ba} & 2 / 2 & 64 & 47 & 82 & \mathrm{Ba} & 2 / 2 & 41 & 32 & 51 \\ \mathrm{Be} & 2 / 0 & <1 & <1 & <1 & \mathrm{Be} & 2 / 0 & <1 & <1 & <1 \\ \mathrm{Ni} & 2 / 2 & 8 & 8 & 8 & \mathrm{Ni} & 2 / 2 & 8 & 7 & 8 \\ \mathrm{Co} & 2 / 2 & 6 & 6 & 6 & \mathrm{Co} & 2 / 2 & 7 & 6 & 7 \\ \mathrm{Cr} & 2 / 2 & 6 & 5 & 6 & \mathrm{Cr} & 2 / 2 & 6 & 5 & 8 \\ \mathrm{~V} & 2 / 2 & 33 & 27 & 39 & \mathrm{~V} & 2 / 2 & 37 & 34 & 41 \\ \mathrm{Cu} & 2 / 2 & 14 & 11 & 16 & \mathrm{Cu} & 2 / 2 & 17 & 11 & 22 \\ \mathrm{Zn} & 2 / 2 & 47 & 38 & 56 & \mathrm{Zn} & 2 / 2 & 42 & 31 & 52 \\ \mathrm{Fe} & 2 / 2 & 13,635 & 13,019 & 14,251 & \mathrm{Fe} & 2 / 2 & 15,096 & 14,274 & 15,918 \\ \mathrm{Mn} & 2 / 2 & 571 & 498 & 644 & \mathrm{Mn} & 2 / 2 & 361 & 279 & 443 \\ \mathrm{~K} & 2 / 2 & 480 & 310 & 649 & \mathrm{~K} & 2 / 2 & 345 & 251 & 438 \\ \mathrm{Al} & 2 / 2 & 20,911 & 20,868 & 20,954 & \mathrm{Al} & 2 / 2 & 22,393 & 17,406 & 27,380 \\ \mathrm{Li} & 2 / 1 & <5 * & <5 & 5 & \mathrm{Li} & 2 / 1 & <7^{*} & <5 & 9 \\ \mathrm{Ca} & 2 / 2 & 2,160 & 1,948 & 2,371 & \mathrm{Ca} & 2 / 2 & 1,869 & 1,598 & 2,139 \\ \mathrm{Na} & 2 / 2 & 526 & 445 & 607 & \mathrm{Na} & 2 / 2 & 681 & 640 & 722 \\ \mathrm{Mg} & 2 / 2 & 1,254 & 988 & 1,520 & \mathrm{Mg} & 2 / 2 & 1,499 & 960 & 2,038 \\ \mathrm{La} & 2 / 2 & 5 & 5 & 5 & \mathrm{La} & 2 / 2 & 7 & 6 & 9 \\ \mathrm{Sb} & 2 / 0 & <20 & <20 & <20 & \mathrm{Sb} & 2 / 0 & <20 & <20 & <20 \\ \mathrm{~Pb} & 2 / 0 & <10 & <10 & <10 & \mathrm{~Pb} & 2 / 1 & <10 & <10 & 10 \\ \mathrm{Tl} & 2 / 0 & <50 & <50 & <50 & \mathrm{Tl} & 2 / 0 & <50 & <50 & <50 \\ \mathrm{As} & 2 / 0 & <20 & <20 & <20 & \mathrm{As} & 2 / 0 & <20 & <20 & <20 \\ \mathrm{Se} & 2 / 0 & <30 & <30 & <30 & \mathrm{Se} & 2 / 0 & <30 & <30 & <30 \\ \mathrm{Hg} & 2 / 2 & 0.06 & 0.05 & 0.06 & \mathrm{Hg} & 2 / 1 & <0.06 * & <0.04 & 0.08\end{array}$

${ }^{1}$ Detects are the number of samples with concentrations equal to or greater than the laboratory reporting limit.

* Where the concentration of a metal in a sample is less than the laboratory minimum reporting level, the minimum reporting level is used for calculating arithmetic mean, and the arithmetic mean is qualified as less than the value given. 
Appendix 7.27. Distribution statistics for concentrations (in ppm of dry soil) of metals in soils on geologic unit "Qgf” (Glaciofluvial deposits; Pleistocene). For sampling site \#(s) and physiographic province(s) see Appendix 2.

In A Horizon

In B Horizon

\begin{tabular}{|c|c|c|c|c|c|c|c|c|}
\hline Metal & $\begin{array}{l}\text { Total } \\
\text { sample } \\
\text { number/ } \\
\text { detects }\end{array}$ & $\begin{array}{l}\text { Arith- } \\
\text { metic } \\
\text { mean }^{2}\end{array}$ & $\begin{array}{l}\text { Mini- } \\
\text { mum }\end{array}$ & $\begin{array}{l}\text { Maxi- } \\
\text { mum }\end{array}$ & Metal & $\begin{array}{l}\text { Total } \\
\text { sample } \\
\text { number/ } \\
\text { detects }^{1}\end{array}$ & $\begin{array}{l}\text { Arith- } \\
\text { metic } \\
\text { mean }^{2}\end{array}$ & $\begin{array}{l}\text { Mini- } \\
\text { mum }\end{array}$ \\
\hline
\end{tabular}

\begin{tabular}{|c|c|c|c|c|c|c|c|c|c|}
\hline $\mathrm{Ag}$ & $1 / 0$ & $<1$ & -- & - & $\mathrm{Ag}$ & $1 / 0$ & $<1$ & -- & - \\
\hline Mo & $1 / 0$ & $<5$ & -- & - & Mo & $1 / 0$ & $<5$ & -- & -- \\
\hline $\mathrm{Cd}$ & $1 / 0$ & $<1$ & - & -- & $\mathrm{Cd}$ & $1 / 0$ & $<1$ & -- & -- \\
\hline $\mathrm{Ba}$ & $1 / 1$ & 133 & -- & -- & $\mathrm{Ba}$ & $1 / 1$ & 117 & - & -- \\
\hline $\mathrm{Be}$ & $1 / 0$ & $<1$ & -- & -- & $\mathrm{Be}$ & $1 / 0$ & $<1$ & - & -- \\
\hline $\mathrm{Ni}$ & $1 / 1$ & 25 & -- & - & $\mathrm{Ni}$ & $1 / 1$ & 35 & - & -- \\
\hline Co & $1 / 1$ & 14 & -- & - & Co & $1 / 1$ & 17 & - & - \\
\hline $\mathrm{Cr}$ & $1 / 1$ & 17 & -- & $\cdots$ & $\mathrm{Cr}$ & $1 / 1$ & 22 & - & - \\
\hline V & $1 / 1$ & 46 & -- & - & V & $1 / 1$ & 62 & -- & $\cdots$ \\
\hline $\mathrm{Cu}$ & $1 / 1$ & 21 & -- & - & $\mathrm{Cu}$ & $1 / 1$ & 31 & -- & - \\
\hline $\mathrm{Zn}$ & $1 / 1$ & 83 & -- & -- & $\mathrm{Zn}$ & $1 / 1$ & 80 & -- & -- \\
\hline $\mathrm{Fe}$ & $1 / 1$ & 25,539 & -- & -- & $\mathrm{Fe}$ & $1 / 1$ & 31,065 & -- & -- \\
\hline $\mathrm{Mn}$ & $1 / 1$ & 2,399 & -- & -- & $\mathrm{Mn}$ & $1 / 1$ & 1,134 & - & -- \\
\hline $\mathrm{K}$ & $1 / 1$ & 520 & -- & -- & $\mathrm{K}$ & $1 / 1$ & 390 & - & -- \\
\hline $\mathrm{Al}$ & $1 / 1$ & 31,915 & -- & -- & $\mathrm{Al}$ & $1 / 1$ & 44,482 & -- & - \\
\hline $\mathrm{Li}$ & $1 / 1$ & 7 & -- & - & $\mathrm{Li}$ & $1 / 1$ & 8 & - & - \\
\hline $\mathrm{Ca}$ & $1 / 1$ & 5,110 & -- & -- & $\mathrm{Ca}$ & $1 / 1$ & 2,780 & - & -- \\
\hline $\mathrm{Na}$ & $1 / 1$ & 409 & -- & -- & $\mathrm{Na}$ & $1 / 1$ & 603 & -- & - \\
\hline $\mathrm{Mg}$ & $1 / 1$ & 4,038 & -- & -- & $\mathrm{Mg}$ & $1 / 1$ & 5,277 & -- & - \\
\hline $\mathrm{La}$ & $1 / 1$ & 5 & - & -- & $\mathrm{La}$ & $1 / 1$ & 13 & -- & -- \\
\hline $\mathrm{Sb}$ & $1 / 0$ & $<20$ & - & -- & $\mathrm{Sb}$ & $1 / 0$ & $<20$ & -- & -- \\
\hline $\mathrm{Pb}$ & $1 / 0$ & $<10$ & -- & -- & $\mathrm{Pb}$ & $1 / 0$ & $<10$ & -- & -- \\
\hline $\mathrm{Tl}$ & $1 / 0$ & $<50$ & -- & -- & $\mathrm{Tl}$ & $1 / 0$ & $<50$ & -- & -- \\
\hline As & $1 / 0$ & $<20$ & -- & -- & As & $1 / 0$ & $<20$ & -- & - \\
\hline $\mathrm{Se}$ & $1 / 0$ & $<30$ & -- & - & $\mathrm{Se}$ & $1 / 0$ & $<30$ & -- & -- \\
\hline $\mathrm{Hg}$ & $1 / 1$ & 0.17 & -- & - & $\mathrm{Hg}$ & $1 / 1$ & 0.06 & -- & - \\
\hline
\end{tabular}

'Detects are the number of samples with concentrations equal to or greater than the laboratory reporting limit.

${ }^{2}$ Only one concentration value for the soils is listed under arithmetic mean. 
Appendix 7.28. Distribution statistics for concentrations (in ppm of dry soil) of metals in soils on geologic unit "Qls" (Landslide \& debris flow deposits; Holocene \& Pleistocene). For sampling site \#(s) and physiographic province(s) see Appendix 2.

In A Horizon

In B Horizon

\begin{tabular}{|c|c|c|c|c|c|c|c|c|c|}
\hline Metal & $\begin{array}{l}\text { Total } \\
\text { sample } \\
\text { number/ } \\
\text { detects }^{1}\end{array}$ & $\begin{array}{l}\text { Arith- } \\
\text { metic } \\
\text { mean }\end{array}$ & $\begin{array}{l}\text { Mini- } \\
\text { mum }\end{array}$ & $\begin{array}{l}\text { Maxi- } \\
\text { mum }\end{array}$ & Metal & $\begin{array}{l}\text { Total } \\
\text { sample } \\
\text { number/ } \\
\text { detects }{ }^{1}\end{array}$ & $\begin{array}{l}\text { Arith- } \\
\text { metic } \\
\text { mean }\end{array}$ & $\begin{array}{l}\text { Mini- } \\
\text { mum }\end{array}$ & $\begin{array}{l}\text { Maxi- } \\
\text { mum }\end{array}$ \\
\hline $\mathrm{Ag}$ & $2 / 0$ & $<1$ & $<1$ & $<1$ & $\mathrm{Ag}$ & $2 / 0$ & $<1$ & $<1$ & $<1$ \\
\hline Mo & $2 / 0$ & $<5$ & $<5$ & $<5$ & Mo & $2 / 0$ & $<5$ & $<5$ & $<5$ \\
\hline $\mathrm{Cd}$ & $2 / 1$ & $<1$ & $<1$ & 1 & $\mathrm{Cd}$ & $2 / 0$ & $<1$ & $<1$ & $<1$ \\
\hline $\mathrm{Ba}$ & $2 / 2$ & 226 & 153 & 300 & $\mathrm{Ba}$ & $2 / 2$ & 175 & 138 & 212 \\
\hline $\mathrm{Be}$ & $2 / 0$ & $<1$ & $<1$ & $<1$ & $\mathrm{Be}$ & $2 / 0$ & $<1$ & $<1$ & $<1$ \\
\hline $\mathrm{Ni}$ & $2 / 2$ & 98 & 25 & 170 & $\mathrm{Ni}$ & $2 / 2$ & 91 & 27 & 154 \\
\hline Co & $2 / 2$ & 30 & 26 & 35 & Co & $2 / 2$ & 34 & 27 & 42 \\
\hline $\mathrm{Cr}$ & $2 / 2$ & 105 & 99 & 111 & $\mathrm{Cr}$ & $2 / 2$ & 115 & 107 & 122 \\
\hline V & $2 / 2$ & 126 & 69 & 182 & $\mathrm{~V}$ & $2 / 2$ & 146 & 69 & 223 \\
\hline $\mathrm{Cu}$ & $2 / 2$ & 44 & 43 & 46 & $\mathrm{Cu}$ & $2 / 2$ & 42 & 37 & 48 \\
\hline $\mathrm{Zn}$ & $2 / 2$ & 129 & 105 & 153 & $\mathrm{Zn}$ & $2 / 2$ & 113 & 85 & 140 \\
\hline $\mathrm{Fe}$ & $2 / 2$ & 46,374 & 35,746 & 57,003 & $\mathrm{Fe}$ & $2 / 2$ & 50,656 & 32,746 & 68,566 \\
\hline $\mathrm{Mn}$ & $2 / 2$ & 1,569 & 598 & 2,540 & $\mathrm{Mn}$ & $2 / 2$ & 1,354 & 654 & 2,055 \\
\hline K & $2 / 2$ & 2,081 & 1,039 & 3,124 & K & $2 / 2$ & 1,795 & 924 & 2,666 \\
\hline $\mathrm{Al}$ & $2 / 2$ & 45,012 & 33,024 & 56,999 & $\mathrm{Al}$ & $2 / 2$ & 51,972 & 32,262 & 71,682 \\
\hline $\mathrm{Li}$ & $2 / 2$ & 16 & 10 & 21 & $\mathrm{Li}$ & $2 / 2$ & 16 & 12 & 21 \\
\hline $\mathrm{Ca}$ & $2 / 2$ & 7,511 & 6,831 & 8,191 & $\mathrm{Ca}$ & $2 / 2$ & 4,626 & 3,322 & 5,931 \\
\hline $\mathrm{Na}$ & $2 / 2$ & 165 & 152 & 178 & $\mathrm{Na}$ & $2 / 2$ & 140 & 136 & 145 \\
\hline $\mathrm{Mg}$ & $2 / 2$ & 8,520 & 6,232 & 10,809 & $\mathrm{Mg}$ & $2 / 2$ & 8,844 & 7,514 & 10,175 \\
\hline $\mathrm{La}$ & $2 / 2$ & 9 & 8 & 10 & $\mathrm{La}$ & $2 / 2$ & 9 & 8 & 11 \\
\hline $\mathrm{Sb}$ & $2 / 0$ & $<20$ & $<20$ & $<20$ & $\mathrm{Sb}$ & $2 / 0$ & $<20$ & $<20$ & $<20$ \\
\hline $\mathrm{Pb}$ & $2 / 2$ & 77 & 51 & 104 & $\mathrm{~Pb}$ & $2 / 2$ & 32 & 25 & 40 \\
\hline $\mathrm{TI}$ & $2 / 0$ & $<50$ & $<50$ & $<50$ & $T 1$ & $2 / 0$ & $<50$ & $<50$ & $<50$ \\
\hline As & $2 / 0$ & $<20$ & $<20$ & $<20$ & As & $2 / 0$ & $<20$ & $<20$ & $<20$ \\
\hline $\mathrm{Se}$ & $2 / 0$ & $<30$ & $<30$ & $<30$ & $\mathrm{Se}$ & $2 / 0$ & $<30$ & $<30$ & $<30$ \\
\hline $\mathrm{Hg}$ & $2 / 2$ & 0.15 & 0.14 & 0.15 & $\mathrm{Hg}$ & $2 / 2$ & 0.11 & 0.08 & 0.13 \\
\hline
\end{tabular}

${ }^{1}$ Detects are the number of samples with concentrations equal to or greater than the laboratory reporting limit.

* Where the concentration of a metal in a sample is less than the laboratory minimum reporting level, the minimum reporting level is used for calculating arithmetic mean, and the arithmetic mean is qualified as less than the value given. 
Appendix 7.29. Distribution statistics for concentrations (in ppm of dry soil) of metals in soils on geologic unit "Qma" (Mazama ash-flow deposits; Holocene). For sampling site \#(s) and physiographic province(s) see Appendix 2.

In A Horizon

Metal

\begin{tabular}{|c|c|c|c|c|c|c|c|}
\hline $\begin{array}{l}\text { Total } \\
\text { sample } \\
\text { number/ } \\
\text { detects }\end{array}$ & $\begin{array}{l}\text { Arith- } \\
\text { metic } \\
\text { mean }\end{array}$ & $\begin{array}{l}\text { Mini- } \\
\text { mum }\end{array}$ & $\begin{array}{l}\text { Maxi- } \\
\text { mum }\end{array}$ & Metal & $\begin{array}{l}\text { Total } \\
\text { sample } \\
\text { number/ } \\
\text { detects }^{1}\end{array}$ & $\begin{array}{l}\text { Arith- } \\
\text { metic } \\
\text { mean }\end{array}$ & $\begin{array}{l}\text { Mini- } \\
\text { mum }\end{array}$ \\
\hline
\end{tabular}

$\begin{array}{llllllllll}\mathrm{Ag} & 2 / 0 & <1 & <1 & <1 & \mathrm{Ag} & 2 / 0 & <1 & <1 & <1 \\ \mathrm{Mo} & 2 / 0 & <5 & <5 & <5 & \mathrm{Mo} & 2 / 0 & <5 & <5 & <5 \\ \mathrm{Cd} & 2 / 0 & <1 & <1 & <1 & \mathrm{Cd} & 2 / 0 & <1 & <1 & <1 \\ \mathrm{Ba} & 2 / 2 & 70 & 44 & 96 & \mathrm{Ba} & 2 / 2 & 66 & 25 & 106 \\ \mathrm{Be} & 2 / 0 & <1 & <1 & <1 & \mathrm{Be} & 2 / 0 & <1 & <1 & <1 \\ \mathrm{Ni} & 2 / 2 & 6 & 6 & 7 & \mathrm{Ni} & 2 / 2 & 10 & 8 & 11 \\ \mathrm{Co} & 2 / 0 & <6 & <6 & <6 & \mathrm{Co} & 2 / 1 & <8^{*} & <6 & 9 \\ \mathrm{Cr} & 2 / 2 & 6 & 5 & 6 & \mathrm{Cr} & 2 / 2 & 8 & 5 & 10 \\ \mathrm{~V} & 2 / 2 & 24 & 18 & 31 & \mathrm{~V} & 2 / 2 & 35 & 21 & 49 \\ \mathrm{Cu} & 2 / 2 & 13 & 8 & 18 & \mathrm{Cu} & 2 / 2 & 25 & 20 & 29 \\ \mathrm{Zn} & 2 / 2 & 30 & 27 & 33 & \mathrm{Zn} & 2 / 2 & 29 & 21 & 37 \\ \mathrm{Fe} & 2 / 2 & 9,326 & 8,402 & 10,250 & \mathrm{Fe} & 2 / 2 & 13,742 & 10,204 & 17,280 \\ \mathrm{Mn} & 2 / 2 & 273 & 232 & 315 & \mathrm{Mn} & 2 / 2 & 155 & 101 & 210 \\ \mathrm{~K} & 2 / 2 & 515 & 469 & 560 & \mathrm{~K} & 2 / 2 & 471 & 430 & 513 \\ \mathrm{Al} & 2 / 2 & 12,729 & 8,580 & 16,879 & \mathrm{Al} & 2 / 2 & 23,896 & 20,453 & 27,338 \\ \mathrm{Li} & 2 / 1 & <5 & <5 & 6 & \mathrm{Li} & 2 / 2 & 6 & 6 & 6 \\ \mathrm{Ca} & 2 / 2 & 2,691 & 2,101 & 3,281 & \mathrm{Ca} & 2 / 2 & 3,094 & 3,021 & 3,168 \\ \mathrm{Na} & 2 / 2 & 673 & 666 & 679 & \mathrm{Na} & 2 / 2 & 1,114 & 1,040 & 1,188 \\ \mathrm{Mg} & 2 / 2 & 1,127 & 689 & 1,564 & \mathrm{Mg} & 2 / 2 & 1,672 & 1,498 & 1,846 \\ \mathrm{La} & 2 / 1 & <5 & <5 & 5 & \mathrm{La} & 2 / 1 & <5 * & <5 & 6 \\ \mathrm{Sb} & 2 / 0 & <20 & <20 & <20 & \mathrm{Sb} & 2 / 0 & <20 & <20 & <20 \\ \mathrm{~Pb} & 2 / 1 & <10 & <10 & 10 & \mathrm{~Pb} & 2 / 0 & <10 & <10 & <10 \\ \mathrm{Tl} & 2 / 0 & <50 & <50 & <50 & \mathrm{Tl} & 2 / 0 & <50 & <50 & <50 \\ \mathrm{As} & 2 / 0 & <20 & <20 & <20 & \mathrm{As} & 2 / 0 & <20 & <20 & <20 \\ \mathrm{Se} & 2 / 0 & <30 & <30 & <30 & \mathrm{Se} & 2 / 0 & <30 & <30 & <30 \\ \mathrm{Hg} & 2 / 2 & 0.05 & 0.04 & 0.06 & \mathrm{Hg} & 2 / 1 & <0.04 & <0.04 & 0.04\end{array}$

${ }^{1}$ Detects are the number of samples with concentrations equal to or greater than the laboratory reporting limit.

* Where the concentration of a metal in a sample is less than the laboratory minimum reporting level, the minimum reporting level is used for calculating arithmetic mean, and the arithmetic mean is qualified as less than the value given. 
Appendix 7.30. Distribution statistics for concentrations (in ppm of dry soil) of metals in soils on geologic unit “Qmp" (Mazama pumice deposits; Holocene). For sampling site \#(s) and physiographic province(s) see Appendix 2.

In A Horizon

In B Horizon

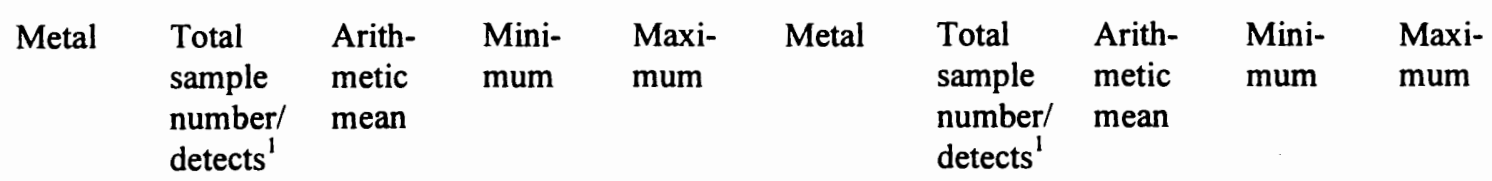

$\begin{array}{llllllllll}\mathrm{Ag} & 2 / 0 & <1 & <1 & <1 & \mathrm{Ag} & 2 / 0 & <1 & <1 & <1 \\ \mathrm{Mo} & 2 / 0 & <5 & <5 & <5 & \mathrm{Mo} & 2 / 0 & <5 & <5 & <5 \\ \mathrm{Cd} & 2 / 0 & <1 & <1 & <1 & \mathrm{Cd} & 2 / 0 & <1 & <1 & <1 \\ \mathrm{Ba} & 2 / 2 & 96 & 84 & 107 & \mathrm{Ba} & 2 / 2 & 43 & 40 & 47 \\ \mathrm{Be} & 2 / 0 & <1 & <1 & <1 & \mathrm{Be} & 2 / 0 & <1 & <1 & <1 \\ \mathrm{Ni} & 2 / 2 & 8 & 6 & 9 & \mathrm{Ni} & 2 / 2 & 10 & 8 & 12 \\ \mathrm{Co} & 2 / 1 & <6^{*} & <6 & 6 & \mathrm{Co} & 2 / 2 & 7 & 7 & 8 \\ \mathrm{Cr} & 2 / 2 & 5 & 5 & 5 & \mathrm{Cr} & 2 / 2 & 7 & 7 & 7 \\ \mathrm{~V} & 2 / 2 & 32 & 29 & 35 & \mathrm{~V} & 2 / 2 & 45 & 45 & 45 \\ \mathrm{Cu} & 2 / 2 & 8 & 7 & 9 & \mathrm{Cu} & 2 / 2 & 11 & 10 & 12 \\ \mathrm{Zn} & 2 / 2 & 44 & 43 & 44 & \mathrm{Zn} & 2 / 2 & 34 & 34 & 35 \\ \mathrm{Fe} & 2 / 2 & 11,018 & 10,212 & 11,824 & \mathrm{Fe} & 2 / 2 & 15,202 & 14,524 & 15,880 \\ \mathrm{Mn} & 2 / 2 & 590 & 485 & 695 & \mathrm{Mn} & 2 / 2 & 186 & 178 & 195 \\ \mathrm{~K} & 2 / 2 & 364 & 275 & 452 & \mathrm{~K} & 2 / 2 & 314 & 234 & 394 \\ \mathrm{Al} & 2 / 2 & 14,229 & 13,442 & 15,015 & \mathrm{Al} & 2 / 2 & 21,257 & 19,087 & 23,427 \\ \mathrm{Li} & 2 / 1 & <5^{*} & <5 & 5 & \mathrm{Li} & 2 / 2 & 7 & 6 & 7 \\ \mathrm{Ca} & 2 / 2 & 2,681 & 2,254 & 3,108 & \mathrm{Ca} & 2 / 2 & 2,109 & 1,396 & 2,823 \\ \mathrm{Na} & 2 / 2 & 527 & 478 & 576 & \mathrm{Na} & 2 / 2 & 777 & 768 & 786 \\ \mathrm{Mg} & 2 / 2 & 1,029 & 841 & 1,217 & \mathrm{Mg} & 2 / 2 & 1,290 & 1,035 & 1,544 \\ \mathrm{La} & 2 / 0 & <5 & <5 & <5 & \mathrm{La} & 2 / 1 & <5^{*} & <5 & 5 \\ \mathrm{Sb} & 2 / 0 & <20 & <20 & <20 & \mathrm{Sb} & 2 / 0 & <20 & <20 & <20 \\ \mathrm{~Pb} & 2 / 1 & <10 & <10 & 10 & \mathrm{~Pb} & 2 / 0 & <10 & <10 & <10 \\ \mathrm{Tl} & 2 / 0 & <50 & <50 & <50 & \mathrm{Tl} & 2 / 0 & <50 & <50 & <50 \\ \mathrm{As} & 2 / 0 & <20 & <20 & <20 & \mathrm{As} & 2 / 0 & <20 & <20 & <20 \\ \mathrm{Se} & 2 / 0 & <30 & <30 & <30 & \mathrm{Se} & 2 / 0 & <30 & <30 & <30 \\ \mathrm{Hg} & 2 / 2 & 0.05 & 0.04 & 0.06 & \mathrm{Hg} & 2 / 1 & <0.04^{*} & <0.04 & 0.04\end{array}$

${ }^{1}$ Detects are the number of samples with concentrations equal to or greater than the laboratory reporting limit.

* Where the concentration of a metal in a sample is less than the laboratory minimum reporting level, the minimum reporting level is used for calculating arithmetic mean, and the arithmetic mean is qualified as less than the value given. 
Appendix 7.31. Distribution statistics for concentrations (in ppm of dry soil) of metals in soils on geologic unit "Qrd" (Rhyolite \& dacite; Holocene \& Pleistocene). For sampling site \#(s) and physiographic province(s) see Appendix 2.

In A Horizon

In B Horizon

Metal Total Arith- Mini- Maxi- Metal Total Arith- Mini- Maxisample metic mum mum sample metic mum mum number/ mean ${ }^{2}$ number/ mean ${ }^{2}$ detects $^{1} \quad \operatorname{detects}^{1}$

\begin{tabular}{|c|c|c|c|c|c|c|c|c|c|}
\hline $\mathrm{Ag}$ & $1 / 0$ & $<1$ & -- & -- & $\mathrm{Ag}$ & $1 / 0$ & $<1$ & -- & -- \\
\hline Mo & $1 / 0$ & $<5$ & -- & -- & Mo & $1 / 0$ & $<5$ &.- & -- \\
\hline $\mathrm{Cd}$ & $1 / 0$ & $<1$ & - & -- & $\mathrm{Cd}$ & $1 / 0$ & $<1$ & - & - \\
\hline $\mathrm{Ba}$ & $1 / 1$ & 105 & -- & -- & $\mathrm{Ba}$ & $1 / 1$ & 81 & - & - \\
\hline $\mathrm{Be}$ & $1 / 0$ & $<1$ & -- & - & $\mathrm{Be}$ & $1 / 0$ & $<1$ & - & -- \\
\hline $\mathrm{Ni}$ & $1 / 1$ & 13 & -- & - & $\mathrm{Ni}$ & $1 / 1$ & 19 & -- & -- \\
\hline Co & $1 / 1$ & 6 & -- & -- & Co & $1 / 1$ & 9 & -- & - \\
\hline $\mathrm{Cr}$ & $1 / 1$ & 5 & -- & -- & $\mathrm{Cr}$ & $1 / 1$ & 10 & -- & -- \\
\hline V & $1 / 1$ & 32 & - & -- & $\mathrm{V}$ & $1 / 1$ & 46 & -- & -- \\
\hline $\mathrm{Cu}$ & $1 / 1$ & 19 & -- & -- & $\mathrm{Cu}$ & $1 / 1$ & 36 & -- & -- \\
\hline $\mathrm{Zn}$ & $1 / 1$ & 92 & -- & -- & $\mathrm{Zn}$ & $1 / 1$ & 42 & - & -- \\
\hline $\mathrm{Fe}$ & $1 / 1$ & 11,783 & -- & -- & $\mathrm{Fe}$ & $1 / 1$ & 16,346 & -- & -- \\
\hline $\mathrm{Mn}$ & $1 / 1$ & 3,235 & -- & - & $\mathrm{Mn}$ & $1 / 1$ & 143 & - & - \\
\hline K & $1 / 1$ & 660 & - & -- & $\mathrm{K}$ & $1 / 1$ & 456 & -- & -- \\
\hline $\mathrm{Al}$ & $1 / 1$ & 14,629 & -- & - & $\mathrm{Al}$ & $1 / 1$ & 23,871 & -- & - \\
\hline $\mathrm{Li}$ & $1 / 0$ & $<5$ & -- & -- & $\mathrm{Li}$ & $1 / 1$ & 6 & -- & -- \\
\hline $\mathrm{Ca}$ & $1 / 1$ & 5,630 & -- & -- & $\mathrm{Ca}$ & $1 / 1$ & 4,354 & - & - \\
\hline $\mathrm{Na}$ & $1 / 1$ & 638 & -- & - & $\mathrm{Na}$ & $1 / 1$ & 947 & -- & -. \\
\hline $\mathrm{Mg}$ & $1 / 1$ & 1,718 & - & -- & $\mathrm{Mg}$ & $1 / 1$ & 2,513 & -- & -- \\
\hline $\mathrm{La}$ & $1 / 0$ & $<5$ & - & -- & $\mathrm{La}$ & $1 / 1$ & 6 & - & -- \\
\hline $\mathrm{Sb}$ & $1 / 0$ & $<20$ & - & -- & $\mathrm{Sb}$ & $1 / 0$ & $<20$ & $\cdots$ & -- \\
\hline $\mathrm{Pb}$ & $1 / 1$ & 14 & -- & -- & $\mathrm{Pb}$ & $1 / 0$ & $<10$ & - & -- \\
\hline $\mathrm{Tl}$ & $1 / 0$ & $<50$ & -- & - & $\mathrm{Tl}$ & $1 / 0$ & $<50$ & -- & -- \\
\hline As & $1 / 0$ & $<20$ & - & -- & As & $1 / 0$ & $<20$ & -- & - \\
\hline $\mathrm{Se}$ & $1 / 0$ & $<30$ & -- & -- & $\mathrm{Se}$ & $1 / 0$ & $<30$ & -- & -- \\
\hline $\mathrm{Hg}$ & $1 / 1$ & 0.09 & -- & -- & $\mathrm{Hg}$ & $1 / 1$ & 0.12 & -- & -- \\
\hline
\end{tabular}

'Detects are the number of samples with concentrations equal to or greater than the laboratory reporting limit.

${ }^{2}$ Only one concentration value for the soils is listed under arithmetic mean. 
Appendix 7.32. Distribution statistics for concentrations (in ppm of dry soil) of metals in soils on geologic unit “Qs" (Lacustrine \& fluvial sedimentary rocks; Pleistocene). For sampling site \#(s) and physiographic province(s) see Appendix 2.

In A Horizon

In B Horizon

\begin{tabular}{|c|c|c|c|c|c|c|c|c|c|}
\hline Metal & $\begin{array}{l}\text { Total } \\
\text { sample } \\
\text { number/ } \\
\text { detects }\end{array}$ & $\begin{array}{l}\text { Arith- } \\
\text { metic } \\
\text { mean }\end{array}$ & $\begin{array}{l}\text { Mini- } \\
\text { mum }\end{array}$ & $\begin{array}{l}\text { Maxi- } \\
\text { mum }\end{array}$ & Metal & $\begin{array}{l}\text { Total } \\
\text { sample } \\
\text { number' } \\
\text { detects }^{1}\end{array}$ & $\begin{array}{l}\text { Arith- } \\
\text { metic } \\
\text { mean }\end{array}$ & $\begin{array}{l}\text { Mini- } \\
\text { mum }\end{array}$ & $\begin{array}{l}\text { Maxi- } \\
\text { mum }\end{array}$ \\
\hline $\mathrm{Ag}$ & $2 / 0$ & $<1$ & $<1$ & $<1$ & $\mathrm{Ag}$ & $2 / 0$ & $<1$ & $<1$ & $<1$ \\
\hline Mo & $2 / 0$ & $<5$ & $<5$ & $<5$ & Mo & $2 / 0$ & $<5$ & $<5$ & $<5$ \\
\hline $\mathrm{Cd}$ & $2 / 0$ & $<1$ & $<1$ & $<1$ & $\mathrm{Cd}$ & $2 / 0$ & $<1$ & $<1$ & $<1$ \\
\hline $\mathrm{Ba}$ & $2 / 2$ & 97 & 95 & 99 & $\mathrm{Ba}$ & $2 / 2$ & 62 & 49 & 75 \\
\hline $\mathrm{Be}$ & $2 / 0$ & $<1$ & $<1$ & $<1$ & $\mathrm{Be}$ & $2 / 0$ & $<1$ & $<1$ & $<1$ \\
\hline $\mathrm{Ni}$ & $2 / 2$ & 12 & 8 & 15 & $\mathrm{Ni}$ & $2 / 2$ & 10 & 8 & 13 \\
\hline Co & $2 / 1$ & $<18^{*}$ & $<6$ & 29 & Co & $2 / 1$ & $<20^{*}$ & $<6$ & 34 \\
\hline $\mathrm{Cr}$ & $2 / 2$ & 21 & 5 & 36 & $\mathrm{Cr}$ & $2 / 2$ & 18 & 5 & 32 \\
\hline V & $2 / 2$ & 57 & 31 & 82 & $\mathrm{~V}$ & $2 / 2$ & 56 & 34 & 77 \\
\hline $\mathrm{Cu}$ & $2 / 2$ & 19 & 8 & 30 & $\mathrm{Cu}$ & $2 / 2$ & 21 & 13 & 29 \\
\hline $\mathrm{Zn}$ & $2 / 2$ & 45 & 42 & 49 & $\mathrm{Zn}$ & $2 / 2$ & 32 & 29 & 36 \\
\hline $\mathrm{Fe}$ & $2 / 2$ & 20,208 & 9,874 & 30,541 & $\mathrm{Fe}$ & $2 / 2$ & 20,540 & 10,583 & 30,496 \\
\hline Mn & $2 / 2$ & 993 & 709 & 1,276 & $\mathrm{Mn}$ & $2 / 2$ & 661 & 182 & 1,140 \\
\hline $\mathrm{K}$ & $2 / 2$ & 621 & 476 & 766 & K & $2 / 2$ & 350 & 253 & 446 \\
\hline $\mathrm{Al}$ & $2 / 2$ & 23,377 & 14,709 & 32,045 & Al & $2 / 2$ & 23,093 & 16,323 & 29,862 \\
\hline $\mathrm{Li}$ & $2 / 1$ & $<5^{*}$ & $<5$ & 6 & $\mathrm{Li}$ & $2 / 2$ & 5 & 5 & 5 \\
\hline $\mathrm{Ca}$ & $2 / 2$ & 3,493 & 3,042 & 3,944 & $\mathrm{Ca}$ & $2 / 2$ & 2,534 & 2,493 & 2,575 \\
\hline $\mathrm{Na}$ & $2 / 2$ & 371 & 141 & 601 & $\mathrm{Na}$ & $2 / 2$ & 396 & 127 & 666 \\
\hline $\mathrm{Mg}$ & $2 / 2$ & 1,779 & 993 & 2,565 & $\mathrm{Mg}$ & $2 / 2$ & 1,627 & 939 & 2,316 \\
\hline $\mathrm{La}$ & $2 / 1$ & $<13^{*}$ & $<5$ & 20 & $\mathrm{La}$ & $2 / 2$ & 11 & 6 & 17 \\
\hline $\mathrm{Sb}$ & $2 / 0$ & $<20$ & $<20$ & $<20$ & $\mathrm{Sb}$ & $2 / 0$ & $<20$ & $<20$ & $<20$ \\
\hline $\mathrm{Pb}$ & $2 / 1$ & $<10^{*}$ & $<10$ & 10 & $\mathrm{~Pb}$ & $2 / 0$ & $<10$ & $<10$ & $<10$ \\
\hline $\mathrm{Tl}$ & $2 / 0$ & $<50$ & $<50$ & $<50$ & $\mathrm{Tl}$ & $2 / 0$ & $<50$ & $<50$ & $<50$ \\
\hline As & $2 / 0$ & $<20$ & $<20$ & $<20$ & As & $2 / 0$ & $<20$ & $<20$ & $<20$ \\
\hline $\mathrm{Se}$ & $2 / 0$ & $<30$ & $<30$ & $<30$ & $\mathrm{Se}$ & $2 / 0$ & $<30$ & $<30$ & $<30$ \\
\hline $\mathrm{Hg}$ & $2 / 0$ & $<0.05^{*}$ & $<0.04$ & 0.06 & $\mathrm{Hg}$ & $2 / 0$ & $<0.04$ & $<0.04$ & $<0.04$ \\
\hline
\end{tabular}

${ }^{1}$ Detects are the number of samples with concentrations equal to or greater than the laboratory reporting limit.

* Where the concentration of a metal in a sample is less than the laboratory minimum reporting level, the minimum reporting level is used for calculating arithmetic mean, and the arithmetic mean is qualified as less than the value given. 
Appendix 7.33. Distribution statistics for concentrations (in ppm of dry soil) of metals in soils on geologic unit “Qt" (Terrace pediment \& lag gravels; Holocene \& Pleistocene). For sampling site \#(s) and physiographic province(s) see Appendix 2.

In A Horizon

In B Horizon

\begin{tabular}{|c|c|c|c|c|c|c|c|c|c|}
\hline Metal & $\begin{array}{l}\text { Total } \\
\text { sample } \\
\text { number/ } \\
\text { detects' }\end{array}$ & $\begin{array}{l}\text { Arith- } \\
\text { metic } \\
\text { mean }\end{array}$ & $\begin{array}{l}\text { Mini- } \\
\text { mum }\end{array}$ & $\begin{array}{l}\text { Maxi- } \\
\text { mum }\end{array}$ & Metal & $\begin{array}{l}\text { Total } \\
\text { sample } \\
\text { number/ } \\
\text { detects }^{\prime}\end{array}$ & $\begin{array}{l}\text { Arith- } \\
\text { metic } \\
\text { mean }\end{array}$ & $\begin{array}{l}\text { Mini- } \\
\text { mum }\end{array}$ & $\begin{array}{l}\text { Maxi- } \\
\text { mum }\end{array}$ \\
\hline $\mathrm{Ag}$ & $5 / 0$ & $<1$ & $<1$ & $<1$ & $\mathrm{Ag}$ & $5 / 0$ & $<1$ & $<1$ & $<1$ \\
\hline Mo & $5 / 0$ & $<5$ & $<5$ & $<5$ & Mo & $5 / 0$ & $<5$ & $<5$ & $<5$ \\
\hline $\mathrm{Cd}$ & $5 / 0$ & $<1$ & $<1$ & $<1$ & $\mathrm{Cd}$ & $5 / 0$ & $<1$ & $<1$ & $<1$ \\
\hline $\mathrm{Ba}$ & $5 / 5$ & 56 & 14 & 143 & $\mathrm{Ba}$ & $5 / 5$ & 41 & 7 & 64 \\
\hline $\mathrm{Be}$ & $5 / 0$ & $<1$ & $<1$ & $<1$ & $\mathrm{Be}$ & $5 / 0$ & $<1$ & $<1$ & $<1$ \\
\hline $\mathrm{Ni}$ & $5 / 4$ & $<10^{*}$ & $<4$ & 25 & $\mathrm{Ni}$ & $5 / 4$ & $<12^{*}$ & $<4$ & 26 \\
\hline Co & $5 / 2$ & $<6^{*}$ & $<6$ & 8 & $\mathrm{Co}$ & $5 / 2$ & $<7^{*}$ & $<6$ & 8 \\
\hline $\mathrm{Cr}$ & $5 / 5$ & 26 & 7 & 77 & $\mathrm{Cr}$ & $5 / 5$ & 36 & 6 & 81 \\
\hline $\mathrm{V}$ & $5 / 5$ & 30 & 8 & 65 & $\mathrm{~V}$ & $5 / 5$ & 44 & 4 & 74 \\
\hline $\mathrm{Cu}$ & $5 / 5$ & 9 & 2 & 13 & $\mathrm{Cu}$ & $5 / 4$ & $<11^{*}$ & $<2$ & 21 \\
\hline $\mathrm{Zn}$ & $5 / 5$ & 20 & 11 & 29 & $\mathrm{Zn}$ & $5 / 5$ & 23 & 9 & 48 \\
\hline $\mathrm{Fe}$ & $5 / 5$ & 11,823 & 3,985 & 25,055 & $\mathrm{Fe}$ & $5 / 5$ & 18,090 & 3,066 & 29,401 \\
\hline $\mathrm{Mn}$ & $5 / 5$ & 307 & 24 & 1,216 & $\mathrm{Mn}$ & $5 / 5$ & 113 & 21 & 187 \\
\hline K & $5 / 5$ & 668 & 369 & 896 & $\mathrm{~K}$ & $5 / 5$ & 676 & 264 & 1,176 \\
\hline $\mathrm{Al}$ & $5 / 5$ & 12,309 & 4,016 & 29,237 & $\mathrm{Al}$ & $5 / 5$ & 21,169 & 2,586 & 31,173 \\
\hline $\mathrm{Li}$ & $5 / 2$ & $<9^{*}$ & $<5$ & 23 & $\mathrm{Li}$ & $5 / 5$ & 17 & 6 & 33 \\
\hline $\mathrm{Ca}$ & $5 / 5$ & 1,921 & 1,151 & 3,081 & $\mathrm{Ca}$ & $5 / 5$ & 496 & 134 & 1,117 \\
\hline $\mathrm{Na}$ & $5 / 5$ & 198 & 60 & 362 & $\mathrm{Na}$ & $5 / 5$ & 135 & 53 & 193 \\
\hline $\mathrm{Mg}$ & $5 / 5$ & 1,559 & 620 & 3,314 & $\mathrm{Mg}$ & $5 / 5$ & 1,666 & 591 & 2,935 \\
\hline $\mathrm{La}$ & $5 / 4$ & $<8^{*}$ & $<5$ & 13 & $\mathrm{La}$ & $5 / 4$ & $<11^{*}$ & $<5$ & 15 \\
\hline $\mathrm{Sb}$ & $5 / 0$ & $<20$ & $<20$ & $<20$ & $\mathrm{Sb}$ & $5 / 0$ & $<20$ & $<20$ & $<20$ \\
\hline $\mathrm{Pb}$ & $5 / 2$ & $<19^{*}$ & $<10$ & 40 & $\mathrm{~Pb}$ & $5 / 0$ & $<10$ & $<10$ & $<10$ \\
\hline $\mathrm{Tl}$ & $5 / 0$ & $<50$ & $<50$ & $<50$ & $\mathrm{Tl}$ & $5 / 0$ & $<50$ & $<50$ & $<50$ \\
\hline As & $5 / 0$ & $<20$ & $<20$ & $<20$ & As & $5 / 0$ & $<20$ & $<20$ & $<20$ \\
\hline $\mathrm{Se}$ & $5 / 0$ & $<30$ & $<30$ & $<30$ & $\mathrm{Se}$ & $5 / 0$ & $<30$ & $<30$ & $<30$ \\
\hline $\mathrm{Hg}$ & $5 / 5$ & 0.13 & 0.06 & 0.19 & $\mathrm{Hg}$ & $5 / 3$ & $<0.08^{*}$ & $<0.04$ & 0.14 \\
\hline
\end{tabular}

${ }^{1}$ Detects are the number of samples with concentrations equal to or greater than the laboratory reporting limit.

* Where the concentration of a metal in a sample is less than the laboratory minimum reporting level, the minimum reporting level is used for calculating arithmetic mean, and the arithmetic mean is qualified as less than the value given. 
Appendix 7.34. Distribution statistics for concentrations (in ppm of dry soil) of metals in soils on geologic unit “QTb" (Basalt; Pleistocene \& Pliocene). For sampling site \#(s) and physiographic province(s) see Appendix 2.

In A Horizon

In B Horizon

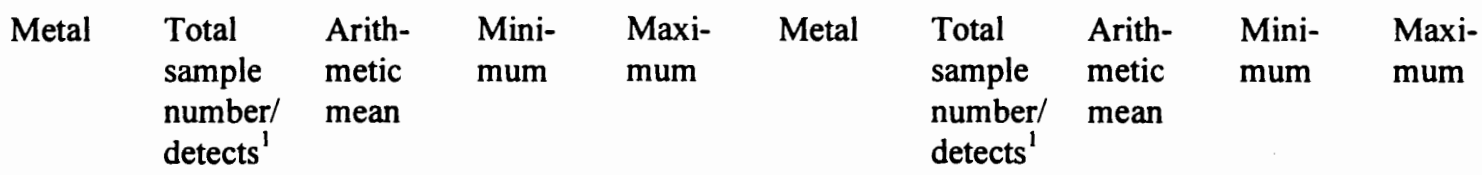

$\begin{array}{llllllllll}\mathrm{Ag} & 2 / 0 & <1 & <1 & <1 & \mathrm{Ag} & 2 / 0 & <1 & <1 & <1 \\ \mathrm{Mo} & 2 / 0 & <5 & <5 & <5 & \mathrm{Mo} & 2 / 0 & <5 & <5 & <5 \\ \mathrm{Cd} & 2 / 0 & <1 & <1 & <1 & \mathrm{Cd} & 2 / 0 & <1 & <1 & <1 \\ \mathrm{Ba} & 2 / 2 & 225 & 100 & 350 & \mathrm{Ba} & 2 / 2 & 91 & 74 & 109 \\ \mathrm{Be} & 2 / 0 & <1 & <1 & <1 & \mathrm{Be} & 2 / 0 & <1 & <1 & <1 \\ \mathrm{Ni} & 2 / 2 & 12 & 5 & 19 & \mathrm{Ni} & 2 / 2 & 15 & 5 & 25 \\ \mathrm{Co} & 2 / 1 & <7^{*} & <6 & 8 & \mathrm{Co} & 2 / 1 & <9 * & <6 & 12 \\ \mathrm{Cr} & 2 / 2 & 5 & 3 & 7 & \mathrm{Cr} & 2 / 2 & 8 & 4 & 12 \\ \mathrm{~V} & 2 / 2 & 29 & 18 & 40 & \mathrm{~V} & 2 / 2 & 43 & 31 & 56 \\ \mathrm{Cu} & 2 / 2 & 12 & 8 & 16 & \mathrm{Cu} & 2 / 2 & 17 & 11 & 24 \\ \mathrm{Zn} & 2 / 2 & 99 & 36 & 161 & \mathrm{Zn} & 2 / 2 & 67 & 30 & 105 \\ \mathrm{Fe} & 2 / 2 & 11,326 & 7,034 & 15,618 & \mathrm{Fe} & 2 / 2 & 16,562 & 10,417 & 22,707 \\ \mathrm{Mn} & 2 / 2 & 2,463 & 327 & 4,600 & \mathrm{Mn} & 2 / 2 & 363 & 145 & 581 \\ \mathrm{~K} & 2 / 2 & 660 & 513 & 807 & \mathrm{~K} & 2 / 2 & 479 & 336 & 623 \\ \mathrm{Al} & 2 / 2 & 18,961 & 13,198 & 24,723 & \mathrm{Al} & 2 / 2 & 28,738 & 18,549 & 38,927 \\ \mathrm{Li} & 2 / 1 & <5 * & <5 & 5 & \mathrm{Li} & 2 / 2 & 7 & 6 & 8 \\ \mathrm{Ca} & 2 / 2 & 7,571 & 2,787 & 12,354 & \mathrm{Ca} & 2 / 2 & 2,234 & 1,937 & 2,531 \\ \mathrm{Na} & 2 / 2 & 357 & 268 & 446 & \mathrm{Na} & 2 / 2 & 566 & 531 & 601 \\ \mathrm{Mg} & 2 / 2 & 1,540 & 879 & 2,202 & \mathrm{Mg} & 2 / 2 & 1,752 & 972 & 2,531 \\ \mathrm{La} & 2 / 0 & <5 & <5 & <5 & \mathrm{La} & 2 / 2 & 6 & 5 & 6 \\ \mathrm{Sb} & 2 / 0 & <20 & <20 & <20 & \mathrm{Sb} & 2 / 0 & <20 & <20 & <20 \\ \mathrm{~Pb} & 2 / 2 & 10 & 10 & 10 & \mathrm{~Pb} & 2 / 0 & <10 & <10 & <10 \\ \mathrm{Tl} & 2 / 0 & <50 & <50 & <50 & \mathrm{Tl} & 2 / 0 & <50 & <50 & <50 \\ \mathrm{As} & 2 / 0 & <20 & <20 & <20 & \mathrm{As} & 2 / 0 & <20 & <20 & <20 \\ \mathrm{Se} & 2 / 0 & <30 & <30 & <30 & \mathrm{Se} & 2 / 0 & <30 & <30 & <30 \\ \mathrm{Hg} & 2 / 2 & 0.11 & 0.04 & 0.17 & \mathrm{Hg} & 2 / 0 & <0.04 & <0.04 & <0.4\end{array}$

'Detects are the number of samples with concentrations equal to or greater than the laboratory reporting limit.

* Where the concentration of a metal in a sample is less than the laboratory minimum reporting level, the minimum reporting level is used for calculating arithmetic mean, and the arithmetic mean is qualified as less than the value given. 
Appendix 7.35. Distribution statistics for concentrations (in ppm of dry soil) of metals in soils on geologic unit “QTba" (Basalt \& basaltic andesite; Pleistocene \& Pliocene). For sampling site \#(s) and physiographic province(s) see Appendix 2.

In A Horizon

In B Horizon

\begin{tabular}{|c|c|c|c|c|c|c|c|c|c|}
\hline Metal & $\begin{array}{l}\text { Total } \\
\text { sample } \\
\text { number/ } \\
\text { detects }^{1}\end{array}$ & $\begin{array}{l}\text { Arith- } \\
\text { metic } \\
\text { mean }\end{array}$ & $\begin{array}{l}\text { Mini- } \\
\text { mum }\end{array}$ & $\begin{array}{l}\text { Maxi- } \\
\text { mum }\end{array}$ & Metal & $\begin{array}{l}\text { Total } \\
\text { sample } \\
\text { number/ } \\
\text { detects }^{1}\end{array}$ & $\begin{array}{l}\text { Arith- } \\
\text { metic } \\
\text { mean }\end{array}$ & $\begin{array}{l}\text { Mini- } \\
\text { mum }\end{array}$ & $\begin{array}{l}\text { Maxi- } \\
\text { mum }\end{array}$ \\
\hline $\mathrm{Ag}$ & $5 / 0$ & $<1$ & $<1$ & $<1$ & $\mathrm{Ag}$ & $5 / 0$ & $<1$ & $<1$ & $<1$ \\
\hline Mo & $5 / 0$ & $<5$ & $<5$ & $<5$ & Mo & $5 / 0$ & $<5$ & $<5$ & $<5$ \\
\hline $\mathrm{Cd}$ & $5 / 0$ & $<1$ & $<1$ & $<1$ & $\mathrm{Cd}$ & $5 / 0$ & $<1$ & $<1$ & $<1$ \\
\hline $\mathrm{Ba}$ & $5 / 5$ & 207 & 45 & 472 & $\mathrm{Ba}$ & $5 / 5$ & 206 & 29 & 525 \\
\hline $\mathrm{Be}$ & $5 / 0$ & $<1$ & $<1$ & $<1$ & $\mathrm{Be}$ & $5 / 0$ & $<1$ & $<1$ & $<1$ \\
\hline $\mathrm{Ni}$ & $5 / 5$ & 26 & 7 & 76 & $\mathrm{Ni}$ & $5 / 5$ & 28 & 7 & 86 \\
\hline Co & $2 / 5$ & $<14^{*}$ & $<6$ & 34 & Co & $5 / 4$ & $<15^{*}$ & $<6$ & 40 \\
\hline $\mathrm{Cr}$ & $5 / 5$ & 25 & 4 & 89 & $\mathrm{Cr}$ & $5 / 5$ & 28 & 5 & 101 \\
\hline V & $5 / 5$ & 56 & 20 & 150 & $\mathrm{~V}$ & $5 / 5$ & 62 & 24 & 170 \\
\hline $\mathrm{Cu}$ & $5 / 5$ & 21 & 6 & 54 & $\mathrm{Cu}$ & $5 / 5$ & 27 & 13 & 66 \\
\hline $\mathrm{Zn}$ & $5 / 5$ & 62 & 41 & 93 & $\mathrm{Zn}$ & $5 / 5$ & 52 & 30 & 84 \\
\hline $\mathrm{Fe}$ & $5 / 5$ & 23,163 & 9,170 & 60,452 & $\mathrm{Fe}$ & $5 / 5$ & 25,829 & 10,041 & 68,459 \\
\hline Mn & $5 / 5$ & 1,020 & 369 & 2,313 & $\mathrm{Mn}$ & $5 / 5$ & 583 & 153 & 1,206 \\
\hline K & $5 / 5$ & 792 & 248 & 1,712 & K & $5 / 5$ & 593 & 178 & 1,353 \\
\hline $\mathrm{Al}$ & $5 / 5$ & 33,954 & 11,116 & 85,913 & $\mathrm{Al}$ & $5 / 5$ & 39,003 & 14,857 & 95,618 \\
\hline $\mathrm{Li}$ & $5 / 3$ & $<9^{*}$ & $<5$ & 13 & $\mathrm{Li}$ & $5 / 4$ & $<10^{*}$ & $<5$ & 16 \\
\hline $\mathrm{Ca}$ & $5 / 5$ & 4,066 & 1,997 & 6,645 & $\mathrm{Ca}$ & $5 / 5$ & 2,299 & 1,480 & 3,069 \\
\hline $\mathrm{Na}$ & $5 / 5$ & 464 & 206 & 617 & $\mathrm{Na}$ & $5 / 5$ & 580 & 181 & 781 \\
\hline $\mathrm{Mg}$ & $5 / 5$ & 1,526 & 868 & 2,563 & $\mathrm{Mg}$ & $5 / 5$ & 1,605 & 916 & 2,396 \\
\hline $\mathrm{La}$ & $5 / 2$ & $<8^{*}$ & $<5$ & 13 & $\mathrm{La}$ & $5 / 4$ & $<11^{*}$ & $<5$ & 19 \\
\hline $\mathrm{Sb}$ & $5 / 0$ & $<20$ & $<20$ & $<20$ & $\mathrm{Sb}$ & $5 / 0$ & $<20$ & $<20$ & $<20$ \\
\hline $\mathrm{Pb}$ & $5 / 1$ & $<10$ & $<10$ & 10 & $\mathrm{~Pb}$ & $5 / 0$ & $<10$ & $<10$ & $<10$ \\
\hline $\mathrm{Tl}$ & $5 / 0$ & $<50$ & $<50$ & $<50$ & $\mathrm{Tl}$ & $5 / 0$ & $<50$ & $<50$ & $<50$ \\
\hline As & $5 / 0$ & $<20$ & $<20$ & $<20$ & As & $5 / 0$ & $<20$ & $<20$ & $<20$ \\
\hline $\mathrm{Se}$ & $5 / 0$ & $<30$ & $<30$ & $<30$ & Se & $5 / 0$ & $<30$ & $<30$ & $<30$ \\
\hline $\mathrm{Hg}$ & $5 / 4$ & $<0.07$ & $<0.04$ & 0.10 & $\mathrm{Hg}$ & $5 / 3$ & $<0.04$ & $<0.04$ & 0.04 \\
\hline
\end{tabular}

${ }^{1}$ Detects are the number of samples with concentrations equal to or greater than the laboratory reporting limit.

* Where the concentration of a metal in a sample is less than the laboratory minimum reporting level, the minimum reporting level is used for calculating arithmetic mean, and the arithmetic mean is qualified as less than the value given. 
Appendix 7.36. Distribution statistics for concentrations (in ppm of dry soil) of metals in soils on geologic unit "QTmv" (Mafic vent complexes; Pleistocene, Pliocene \& Miocene ?). For sampling site \#(s) and physiographic province(s) see Appendix 2.

In A Horizon

In B Horizon

\begin{tabular}{|c|c|c|c|c|c|c|c|c|c|}
\hline Metal & $\begin{array}{l}\text { Total } \\
\text { sample } \\
\text { number/ } \\
\text { detects }{ }^{1}\end{array}$ & $\begin{array}{l}\text { Arith- } \\
\text { metic } \\
\text { mean }\end{array}$ & $\begin{array}{l}\text { Mini- } \\
\text { mum }\end{array}$ & $\begin{array}{l}\text { Maxi- } \\
\text { mum }\end{array}$ & Metal & $\begin{array}{l}\text { Total } \\
\text { sample } \\
\text { number/ } \\
\text { detects }{ }^{\prime}\end{array}$ & $\begin{array}{l}\text { Arith- } \\
\text { metic } \\
\text { mean }\end{array}$ & $\begin{array}{l}\text { Mini- } \\
\text { mum }\end{array}$ & $\begin{array}{l}\text { Maxi- } \\
\text { mum }\end{array}$ \\
\hline $\mathrm{Ag}$ & $2 / 0$ & $<1$ & $<1$ & $<1$ & $\mathrm{Ag}$ & $2 / 0$ & $<1$ & $<1$ & $<1$ \\
\hline Mo & $2 / 0$ & $<5$ & $<5$ & $<5$ & Mo & $2 / 0$ & $<5$ & $<5$ & $<5$ \\
\hline $\mathrm{Cd}$ & $2 / 0$ & $<1$ & $<1$ & $<1$ & $\mathrm{Cd}$ & $2 / 0$ & $<1$ & $<1$ & $<1$ \\
\hline $\mathrm{Ba}$ & $2 / 2$ & 124 & 66 & 183 & $\mathrm{Ba}$ & $2 / 2$ & 48 & 28 & 68 \\
\hline $\mathrm{Be}$ & $2 / 0$ & $<1$ & $<1$ & $<1$ & $\mathrm{Be}$ & $2 / 0$ & $<1$ & $<1$ & $<1$ \\
\hline $\mathrm{Ni}$ & $2 / 2$ & 6 & 5 & 7 & $\mathrm{Ni}$ & $2 / 2$ & 6 & 4 & 8 \\
\hline Co & $2 / 1$ & $<6^{*}$ & $<6$ & 6 & Co & $2 / 0$ & $<6$ & $<6$ & $<6$ \\
\hline $\mathrm{Cr}$ & $2 / 2$ & 3 & 3 & 3 & $\mathrm{Cr}$ & $2 / 2$ & 5 & 4 & 5 \\
\hline V & $2 / 2$ & 26 & 20 & 31 & $\mathrm{~V}$ & $2 / 2$ & 31 & 31 & 31 \\
\hline $\mathrm{Cu}$ & $2 / 2$ & 8 & 7 & 8 & $\mathrm{Cu}$ & $2 / 2$ & 10 & 8 & 12 \\
\hline $\mathrm{Zn}$ & $2 / 2$ & 50 & 48 & 52 & $\mathrm{Zn}$ & $2 / 2$ & 35 & 30 & 40 \\
\hline $\mathrm{Fe}$ & $2 / 2$ & 10,026 & 6,965 & 13,087 & $\mathrm{Fe}$ & $2 / 2$ & 11,250 & 9,857 & 12,642 \\
\hline $\mathrm{Mn}$ & $2 / 2$ & 1,766 & 907 & 2,625 & $\mathrm{Mn}$ & $2 / 2$ & 169 & 163 & 176 \\
\hline $\mathrm{K}$ & $2 / 2$ & 354 & 301 & 407 & K & $2 / 2$ & 257 & 240 & 273 \\
\hline $\mathrm{Al}$ & $2 / 2$ & 12,694 & 11,973 & 13,415 & $\mathrm{Al}$ & $2 / 2$ & 17,106 & 14,925 & 19,287 \\
\hline $\mathrm{Li}$ & $2 / 0$ & $<5$ & $<5$ & $<5$ & $\mathrm{Li}$ & $2 / 1$ & $<5^{*}$ & $<5$ & 5 \\
\hline $\mathrm{Ca}$ & $2 / 2$ & 3,193 & 1,886 & 4,500 & $\mathrm{Ca}$ & $2 / 2$ & 2,405 & 1,067 & 3,742 \\
\hline $\mathrm{Na}$ & $2 / 2$ & 557 & 471 & 643 & $\mathrm{Na}$ & $2 / 2$ & 719 & 502 & 936 \\
\hline $\mathrm{Mg}$ & $2 / 2$ & 780 & 776 & 784 & $\mathrm{Mg}$ & $2 / 2$ & 857 & 688 & 1,026 \\
\hline $\mathrm{La}$ & $2 / 0$ & $<5$ & $<5$ & $<5$ & $\mathrm{La}$ & $2 / 0$ & $<5$ & $<5$ & $<5$ \\
\hline $\mathrm{Sb}$ & $2 / 0$ & $<20$ & $<20$ & $<20$ & $\mathrm{Sb}$ & $2 / 0$ & $<20$ & $<20$ & $<20$ \\
\hline $\mathrm{Pb}$ & $2 / 0$ & $<10$ & $<10$ & $<10$ & $\mathrm{~Pb}$ & $2 / 1$ & $<10^{*}$ & $<10$ & 10 \\
\hline $\mathrm{Tl}$ & $2 / 0$ & $<50$ & $<50$ & $<50$ & $\mathrm{Tl}$ & $2 / 0$ & $<50$ & $<50$ & $<50$ \\
\hline As & $2 / 0$ & $<20$ & $<20$ & $<20$ & As & $2 / 0$ & $<20$ & $<20$ & $<20$ \\
\hline $\mathrm{Se}$ & $2 / 0$ & $<30$ & $<30$ & $<30$ & $\mathrm{Se}$ & $2 / 0$ & $<30$ & $<30$ & $<30$ \\
\hline $\mathrm{Hg}$ & $2 / 2$ & 0.07 & 0.06 & 0.08 & $\mathrm{Hg}$ & $2 / 1$ & $<0.04^{*}$ & $<0.04$ & 0.04 \\
\hline
\end{tabular}

${ }^{1}$ Detects are the number of samples with concentrations equal to or greater than the laboratory reporting limit.

* Where the concentration of a metal in a sample is less than the laboratory minimum reporting level, the minimum reporting level is used for calculating arithmetic mean, and the arithmetic mean is qualified as less than the value given. 
Appendix 7.37. Distribution statistics for concentrations (in ppm of dry soil) of metals in soils on geologic unit “QTp" (Basaltic \& andesitic ejecta; Holocene to Miocene). For sampling site \#(s) and physiographic province(s) see Appendix 2.

In A Horizon

\begin{tabular}{|c|c|c|c|c|c|c|c|c|c|}
\hline Metal & $\begin{array}{l}\text { Total } \\
\text { sample } \\
\text { number/ } \\
\text { detects }{ }^{1}\end{array}$ & $\begin{array}{l}\text { Arith- } \\
\text { metic } \\
\text { mean }\end{array}$ & $\begin{array}{l}\text { Mini- } \\
\text { mum }\end{array}$ & $\begin{array}{l}\text { Maxi- } \\
\text { mum }\end{array}$ & Metal & $\begin{array}{l}\text { Total } \\
\text { sample } \\
\text { number/ } \\
\text { detects }^{1}\end{array}$ & $\begin{array}{l}\text { Arith- } \\
\text { metic } \\
\text { mean }\end{array}$ & $\begin{array}{l}\text { Mini- } \\
\text { mum }\end{array}$ & $\begin{array}{l}\text { Maxi- } \\
\text { mum }\end{array}$ \\
\hline $\mathrm{Ag}$ & $3 / 0$ & $<1$ & $<1$ & $<1$ & $\mathrm{Ag}$ & $3 / 0$ & $<1$ & $<1$ & $<1$ \\
\hline Mo & $3 / 0$ & $<5$ & $<5$ & $<5$ & Mo & $3 / 0$ & $<5$ & $<5$ & $<5$ \\
\hline $\mathrm{Cd}$ & $3 / 0$ & $<1$ & $<1$ & $<1$ & $\mathrm{Cd}$ & $3 / 0$ & $<1$ & $<1$ & $<1$ \\
\hline $\mathrm{Ba}$ & $3 / 3$ & 226 & 123 & 318 & $\mathrm{Ba}$ & $3 / 3$ & 238 & 97 & 326 \\
\hline $\mathrm{Be}$ & $3 / 0$ & $<1$ & $<1$ & $<1$ & $\mathrm{Be}$ & $3 / 0$ & $<1$ & $<1$ & $<1$ \\
\hline $\mathrm{Ni}$ & $3 / 3$ & 75 & 8 & 136 & $\mathrm{Ni}$ & $3 / 3$ & 85 & 10 & 154 \\
\hline Co & $3 / 3$ & 25 & 6 & 41 & Co & $3 / 3$ & 28 & 6 & 47 \\
\hline $\mathrm{Cr}$ & $3 / 3$ & 43 & 4 & 79 & $\mathrm{Cr}$ & $3 / 3$ & 49 & 5 & 91 \\
\hline V & $3 / 3$ & 75 & 26 & 107 & $\mathrm{~V}$ & $3 / 3$ & 87 & 32 & 125 \\
\hline $\mathrm{Cu}$ & $3 / 3$ & 38 & 8 & 56 & $\mathrm{Cu}$ & $3 / 3$ & 45 & 12 & 73 \\
\hline $\mathrm{Zn}$ & $3 / 3$ & 103 & 64 & 140 & $\mathrm{Zn}$ & $3 / 3$ & 78 & 35 & 113 \\
\hline $\mathrm{Fe}$ & $3 / 3$ & 39,382 & 9,755 & 63,476 & $\mathrm{Fe}$ & $3 / 3$ & 44,152 & 11,430 & 71,441 \\
\hline $\mathrm{Mn}$ & $3 / 3$ & 1,567 & 976 & 2,457 & $\mathrm{Mn}$ & $3 / 3$ & 479 & 137 & 708 \\
\hline K & $3 / 3$ & 1,014 & 562 & 1,282 & $\mathrm{~K}$ & $3 / 3$ & 787 & 397 & 1,113 \\
\hline $\mathrm{Al}$ & $3 / 3$ & 57,289 & 14,818 & 93,717 & Al & $3 / 3$ & 63,201 & 16,822 & 102,212 \\
\hline $\mathrm{Li}$ & $3 / 3$ & 9 & 5 & 12 & $\mathrm{Li}$ & $3 / 3$ & 10 & 6 & 14 \\
\hline $\mathrm{Ca}$ & $3 / 3$ & 4,965 & 3,757 & 5,605 & $\mathrm{Ca}$ & $3 / 3$ & 3,164 & 2,108 & 4,122 \\
\hline $\mathrm{Na}$ & $3 / 3$ & 639 & 200 & 968 & $\mathrm{Na}$ & $3 / 3$ & 624 & 171 & 864 \\
\hline $\mathrm{Mg}$ & $3 / 3$ & 4,607 & 987 & 6,756 & $\mathrm{Mg}$ & $3 / 3$ & 5,265 & 1,080 & 7,988 \\
\hline $\mathrm{La}$ & $3 / 2$ & $<11^{*}$ & $<5$ & 16 & $\mathbf{L a}$ & $3 / 3$ & 14 & 5 & 26 \\
\hline $\mathrm{Sb}$ & $3 / 0$ & $<20$ & $<20$ & $<20$ & $\mathrm{Sb}$ & $3 / 0$ & $<20$ & $<20$ & $<20$ \\
\hline $\mathrm{Pb}$ & $3 / 0$ & $<10$ & $<10$ & $<10$ & $\mathrm{~Pb}$ & $3 / 0$ & $<10$ & $<10$ & $<10$ \\
\hline $\mathrm{Tl}$ & $3 / 0$ & $<50$ & $<50$ & $<50$ & $\mathrm{Tl}$ & $3 / 0$ & $<50$ & $<50$ & $<50$ \\
\hline As & $3 / 0$ & $<20$ & $<20$ & $<20$ & As & $3 / 0$ & $<20$ & $<20$ & $<20$ \\
\hline $\mathrm{Se}$ & $3 / 0$ & $<30$ & $<30$ & $<30$ & $\mathrm{Se}$ & $3 / 0$ & $<30$ & $<30$ & $<30$ \\
\hline $\mathrm{Hg}$ & $3 / 3$ & 0.05 & 0.04 & 0.08 & $\mathrm{Hg}$ & $3 / 0$ & $<0.04$ & $<0.04$ & $<0.04$ \\
\hline
\end{tabular}

${ }^{1}$ Detects are the number of samples with concentrations equal to or greater than the laboratory reporting limit.

* Where the concentration of a metal in a sample is less than the laboratory minimum reporting level, the minimum reporting level is used for calculating arithmetic mean, and the arithmetic mean is qualified as less than the value given. 
Appendix 7.38. Distribution statistics for concentrations (in ppm of dry soil) of metals in soils on geologic unit "QTps" (Subaqueous basaltic \& andesitic ejecta; Holocene to Miocene?).

For sampling site \#(s) and physiographic province(s) see Appendix 2.

In A Horizon

In B Horizon

\begin{tabular}{|c|c|c|c|c|c|c|c|c|c|}
\hline Metal & $\begin{array}{l}\text { Total } \\
\text { sample } \\
\text { number/ } \\
\text { detects }\end{array}$ & $\begin{array}{l}\text { Arith- } \\
\text { metic } \\
\text { mean }^{2}\end{array}$ & $\begin{array}{l}\text { Mini- } \\
\text { mum }\end{array}$ & $\begin{array}{l}\text { Maxi- } \\
\text { mum }\end{array}$ & Metal & $\begin{array}{l}\text { Total } \\
\text { sample } \\
\text { number/ } \\
\text { detects }^{1}\end{array}$ & $\begin{array}{l}\text { Arith- } \\
\text { metic } \\
\text { mean }^{2}\end{array}$ & $\begin{array}{l}\text { Mini- } \\
\text { mum }\end{array}$ & $\begin{array}{l}\text { Maxi- } \\
\text { mum }\end{array}$ \\
\hline
\end{tabular}

\begin{tabular}{|c|c|c|c|c|c|c|c|c|c|}
\hline $\mathrm{Ag}$ & $1 / 0$ & $<1$ & -- & - & $\mathrm{Ag}$ & $1 / 0$ & $<1$ & -- & -- \\
\hline Mo & $1 / 0$ & $<5$ & -- & -- & Mo & $1 / 0$ & $<5$ & -- & -- \\
\hline $\mathrm{Cd}$ & $1 / 0$ & $<1$ & -- & -- & $\mathrm{Cd}$ & $1 / 0$ & $<1$ & -- & -- \\
\hline $\mathrm{Ba}$ & $1 / 1$ & 86 & -- & - & $\mathrm{Ba}$ & $1 / 1$ & 97 & -- & -- \\
\hline $\mathrm{Be}$ & $1 / 0$ & $<1$ & -- & -- & $\mathrm{Be}$ & $1 / 0$ & $<1$ & -- & -- \\
\hline $\mathrm{Ni}$ & $1 / 1$ & 11 & -- & -- & $\mathrm{Ni}$ & $1 / 1$ & 13 & -- & -- \\
\hline Co & $1 / 0$ & $<6$ &.- & -- & Co & $1 / 1$ & 6 & -- & -- \\
\hline $\mathrm{Cr}$ & $1 / 1$ & 5 & - & -- & $\mathrm{Cr}$ & $1 / 1$ & 7 & -- & -- \\
\hline V & $1 / 1$ & 21 & -- & -- & V & $1 / 1$ & 31 & -- & -- \\
\hline $\mathrm{Cu}$ & $1 / 1$ & 11 & -- & -- & $\mathrm{Cu}$ & $1 / 1$ & 15 & -- & -- \\
\hline $\mathrm{Zn}$ & $1 / 1$ & 32 & -- & -- & $\mathrm{Zn}$ & $1 / 1$ & 24 & - & -- \\
\hline $\mathrm{Fe}$ & $1 / 1$ & 8,793 & -- & -- & $\mathrm{Fe}$ & $1 / 1$ & 10,912 & -- & -- \\
\hline Mn & $1 / 1$ & 248 & -- & -- & $\mathrm{Mn}$ & $1 / 1$ & 137 & -- & - \\
\hline K & $1 / 1$ & 492 & -- & -- & $\mathrm{K}$ & $1 / 1$ & 378 & - & -- \\
\hline $\mathrm{Al}$ & $1 / 1$ & 13,597 & -- & -- & $\mathrm{Al}$ & $1 / 1$ & 14,848 & - & -- \\
\hline $\mathrm{Li}$ & $1 / 0$ & $<5$ & -- & -- & $\mathrm{Li}$ & $1 / 0$ & $<5$ & -- & - \\
\hline $\mathrm{Ca}$ & $1 / 1$ & 3,968 & -- & -- & $\mathrm{Ca}$ & $1 / 1$ & 3,947 & -- & -- \\
\hline $\mathrm{Na}$ & $1 / 1$ & 767 & -- & -- & $\mathrm{Na}$ & $1 / 1$ & 981 & - & -- \\
\hline $\mathrm{Mg}$ & $1 / 1$ & 1,313 & -- & -- & $\mathrm{Mg}$ & $1 / 1$ & 1,447 & - & -- \\
\hline $\mathrm{La}$ & $1 / 0$ & $<5$ & -- & -- & $\mathrm{La}$ & $1 / 0$ & $<5$ & -- & - \\
\hline $\mathrm{Sb}$ & $1 / 0$ & $<20$ & -- & -- & $\mathrm{Sb}$ & $1 / 0$ & $<20$ & - & -- \\
\hline $\mathrm{Pb}$ & $1 / 0$ & $<10$ & -- & - & $\mathrm{Pb}$ & $1 / 0$ & $<10$ & -- & - \\
\hline $\mathrm{Tl}$ & $1 / 0$ & $<50$ & - & -- & $\mathrm{Tl}$ & $1 / 0$ & $<50$ & -- & - \\
\hline As & $1 / 0$ & $<20$ & -- & -- & As & $1 / 0$ & $<20$ & -- & -- \\
\hline $\mathrm{Se}$ & $1 / 0$ & $<30$ & -- & - & $\mathrm{Se}$ & $1 / 0$ & $<30$ & -- & -- \\
\hline $\mathrm{Hg}$ & $1 / 0$ & $<0.04$ & - & -- & $\mathrm{Hg}$ & $1 / 0$ & $<0.04$ & -- & -- \\
\hline
\end{tabular}

${ }^{1}$ Detects are the number of samples with concentrations equal to or greater than the laboratory reporting limit.

${ }^{2}$ Only one concentration value for the soils is listed under arithmetic mean. 
Appendix 7.39. Distribution statistics for concentrations (in ppm of dry soil) of metals in soils on geologic unit "QTs" (Sedimentary rocks; Pleistocene \& Pliocene). For sampling site \#(s) and physiographic province(s) see Appendix 2.

In A Horizon

In B Horizon

Metal Total Arith- Mini- Maxi- Metal Total Arith- Mini- Maxi$\begin{array}{llllll}\text { sample } & \text { metic } & \text { mum } & \text { mum } & \text { sample metic } & \text { mum mum } \\ \text { number/ } & \text { mean }^{2} & & & \text { number/ } & \text { mean }\end{array}$ $\operatorname{detects}^{1} \operatorname{detects}^{1}$

\begin{tabular}{|c|c|c|c|c|c|c|c|c|c|}
\hline $\mathrm{Ag}$ & $1 / 0$ & $<1$ & -- & -- & $\mathrm{Ag}$ & $1 / 0$ & $<1$ & -- & -- \\
\hline Mo & $1 / 0$ & $<5$ & - & -- & Mo & $1 / 0$ & $<5$ & -- & - \\
\hline $\mathrm{Cd}$ & $1 / 0$ & $<1$ & -- & - & $\mathrm{Cd}$ & $1 / 0$ & $<1$ & -- & -- \\
\hline $\mathrm{Ba}$ & $1 / 1$ & 85 & -- & - & $\mathrm{Ba}$ & $1 / 1$ & 112 & -- & -- \\
\hline $\mathrm{Be}$ & $1 / 0$ & $<1$ & -- & -- & $\mathrm{Be}$ & $1 / 0$ & $<1$ & -- & -- \\
\hline $\mathrm{Ni}$ & $1 / 1$ & 9 & -- & -- & $\mathrm{Ni}$ & $1 / 1$ & 12 & - & -- \\
\hline Co & $1 / 0$ & $<6$ & - & -- & Co & $1 / 1$ & 6 & -- & -- \\
\hline $\mathrm{Cr}$ & $1 / 1$ & 5 & -- & - & $\mathrm{Cr}$ & $1 / 1$ & 8 & -- & -- \\
\hline V & $1 / 1$ & 31 & -- & -- & V & $1 / 1$ & 42 & -- & -- \\
\hline $\mathrm{Cu}$ & $1 / 1$ & 11 & -- & -- & $\mathrm{Cu}$ & $1 / 1$ & 15 & -- & -- \\
\hline $\mathrm{Zn}$ & $1 / 1$ & 52 & -- & -- & $\mathrm{Zn}$ & $1 / 1$ & 35 & $\cdots$ & -- \\
\hline $\mathrm{Fe}$ & $1 / 1$ & 9,812 & -- & -- & $\mathrm{Fe}$ & $1 / 1$ & 13,010 & -- & -- \\
\hline Mn & $1 / 1$ & 533 & -- & -- & $\mathrm{Mn}$ & $1 / 1$ & 214 & -- & -- \\
\hline K & $1 / 1$ & 691 & -- & - & K & $1 / 1$ & 660 & -- & -- \\
\hline $\mathrm{Al}$ & $1 / 1$ & 14,823 & -- & -- & $\mathrm{Al}$ & $1 / 1$ & 20,113 & - & -- \\
\hline $\mathrm{Li}$ & $1 / 0$ & $<5$ & -- & -- & $\mathrm{Li}$ & $1 / 1$ & 5 & -- & -- \\
\hline $\mathrm{Ca}$ & $1 / 1$ & 4,001 & - & -- & $\mathrm{Ca}$ & $1 / 1$ & 3,831 & -- & -- \\
\hline $\mathrm{Na}$ & $1 / 1$ & 625 & -- & -- & $\mathrm{Na}$ & $1 / 1$ & 914 & -- & -- \\
\hline $\mathrm{Mg}$ & $1 / 1$ & 1,210 & -- & -- & $\mathrm{Mg}$ & $1 / 1$ & 1,595 & -- & -- \\
\hline $\mathrm{La}$ & $1 / 0$ & $<5$ & -- & -- & $\mathrm{La}$ & $1 / 1$ & 5 & -- & -- \\
\hline $\mathrm{Sb}$ & $1 / 0$ & $<20$ & -- & - & $\mathrm{Sb}$ & $1 / 0$ & $<20$ & $-\cdots$ & -- \\
\hline $\mathrm{Pb}$ & $1 / 0$ & $<10$ & - & -- & $\mathrm{Pb}$ & $1 / 0$ & $<10$ & - & -- \\
\hline $\mathrm{Tl}$ & $1 / 0$ & $<50$ & -- & -- & $\mathrm{Tl}$ & $1 / 0$ & $<50$ & -- & -. \\
\hline As & $1 / 0$ & $<20$ & -- & -- & As & $1 / 0$ & $<20$ & -- & -- \\
\hline $\mathrm{Se}$ & $1 / 0$ & $<30$ & -- & -- & $\mathrm{Se}$ & $1 / 0$ & $<30$ & -- & -- \\
\hline $\mathrm{Hg}$ & $1 / 1$ & 0.07 & -- & -- & $\mathrm{Hg}$ & $1 / 0$ & $<0.04$ & -- & -- \\
\hline
\end{tabular}

${ }^{1}$ Detects are the number of samples with concentrations equal to or greater than the laboratory reporting limit.

${ }^{2}$ Only one concentration value for the soils is listed under arithmetic mean. 
Appendix 7.40. Distribution statistics for concentrations (in ppm of dry soil) of metals in soils on geologic unit "QTst" (Tuffaceous sedimentary rocks \& tuffs; Pleistocene or Pliocene). For sampling site \#(s) and physiographic province(s) see Appendix 2.

\section{In A Horizon}

\begin{tabular}{|c|c|c|c|c|c|c|c|c|c|}
\hline Metal & $\begin{array}{l}\text { Total } \\
\text { sample } \\
\text { number/ } \\
\text { detects }^{1}\end{array}$ & $\begin{array}{l}\text { Arith- } \\
\text { metic } \\
\text { mean }\end{array}$ & $\begin{array}{l}\text { Mini- } \\
\text { mum }\end{array}$ & $\begin{array}{l}\text { Maxi- } \\
\text { mum }\end{array}$ & Metal & $\begin{array}{l}\text { Total } \\
\text { sample } \\
\text { number/ } \\
\text { detects }^{1}\end{array}$ & $\begin{array}{l}\text { Arith- } \\
\text { metic } \\
\text { mean }\end{array}$ & $\begin{array}{l}\text { Mini- } \\
\text { mum }\end{array}$ & $\begin{array}{l}\text { Maxi- } \\
\text { mum }\end{array}$ \\
\hline $\mathrm{Ag}$ & $2 / 0$ & $<1$ & $<1$ & $<1$ & $\mathrm{Ag}$ & $2 / 0$ & $<1$ & $<1$ & $<1$ \\
\hline Mo & $2 / 0$ & $<5$ & $<5$ & $<5$ & Mo & $2 / 0$ & $<5$ & $<5$ & $<5$ \\
\hline $\mathrm{Cd}$ & $2 / 0$ & $<1$ & $<1$ & $<1$ & $\mathrm{Cd}$ & $2 / 0$ & $<1$ & $<1$ & $<1$ \\
\hline $\mathrm{Ba}$ & $2 / 2$ & 64 & 54 & 74 & $\mathrm{Ba}$ & $2 / 2$ & 61 & 36 & 85 \\
\hline $\mathrm{Be}$ & $2 / 0$ & $<1$ & $<1$ & $<1$ & $\mathrm{Be}$ & $2 / 0$ & $<1$ & $<1$ & $<1$ \\
\hline $\mathrm{Ni}$ & $2 / 2$ & 6 & 5 & 6 & $\mathrm{Ni}$ & $2 / 2$ & 7 & 7 & 7 \\
\hline Co & $2 / 1$ & $<6^{*}$ & $<6$ & 6 & Co & $1 / 1$ & $<7^{*}$ & $<6$ & 7 \\
\hline $\mathrm{Cr}$ & $2 / 2$ & 5 & 5 & 5 & $\mathrm{Cr}$ & $2 / 2$ & 6 & 5 & 6 \\
\hline V & $2 / 2$ & 28 & 22 & 35 & $\mathrm{~V}$ & $2 / 2$ & 39 & 30 & 47 \\
\hline $\mathrm{Cu}$ & $2 / 2$ & 10 & 10 & 11 & $\mathrm{Cu}$ & $2 / 2$ & 14 & 13 & 14 \\
\hline $\mathrm{Zn}$ & $2 / 2$ & 44 & 35 & 53 & $\mathrm{Zn}$ & $2 / 2$ & 32 & 28 & 36 \\
\hline $\mathrm{Fe}$ & $2 / 2$ & 10,272 & 8,317 & 12,226 & $\mathrm{Fe}$ & $2 / 2$ & 12,933 & 10,359 & 15,507 \\
\hline $\mathrm{Mn}$ & $2 / 2$ & 593 & 514 & 673 & $\mathrm{Mn}$ & $2 / 2$ & 243 & 236 & 251 \\
\hline $\mathrm{K}$ & $2 / 2$ & 503 & 391 & 615 & $\mathrm{~K}$ & $2 / 2$ & 399 & 244 & 555 \\
\hline $\mathrm{Al}$ & $2 / 2$ & 15,209 & 13,953 & 16,465 & $\mathrm{Al}$ & $2 / 2$ & 18,783 & 17,556 & 20,011 \\
\hline $\mathrm{Li}$ & $2 / 0$ & $<5$ & $<5$ & $<5$ & $\mathrm{Li}$ & $2 / 2$ & 5 & 5 & 5 \\
\hline $\mathrm{Ca}$ & $2 / 2$ & 2,747 & 2,314 & 3,180 & $\mathrm{Ca}$ & $2 / 2$ & 2,620 & 2,372 & 2,868 \\
\hline $\mathrm{Na}$ & $2 / 2$ & 490 & 470 & 511 & $\mathrm{Na}$ & $2 / 2$ & 735 & 701 & 770 \\
\hline $\mathrm{Mg}$ & $2 / 2$ & 977 & 805 & 1,148 & $\mathrm{Mg}$ & $2 / 2$ & 1,188 & 1,017 & 1,360 \\
\hline $\mathrm{La}$ & $2 / 0$ & $<5$ & $<5$ & $<5$ & $\mathrm{La}$ & $2 / 2$ & 5 & 5 & 6 \\
\hline $\mathrm{Sb}$ & $2 / 0$ & $<20$ & $<20$ & $<20$ & $\mathrm{Sb}$ & $2 / 0$ & $<20$ & $<20$ & $<20$ \\
\hline $\mathrm{Pb}$ & $2 / 0$ & $<10$ & $<10$ & $<10$ & $\mathrm{~Pb}$ & $2 / 0$ & $<10$ & $<10$ & $<10$ \\
\hline $\mathrm{TI}$ & $2 / 0$ & $<50$ & $<50$ & $<50$ & $\mathrm{Tl}$ & $2 / 0$ & $<50$ & $<50$ & $<50$ \\
\hline As & $2 / 0$ & $<20$ & $<20$ & $<20$ & As & $2 / 0$ & $<20$ & $<20$ & $<20$ \\
\hline $\mathrm{Se}$ & $2 / 0$ & $<30$ & $<30$ & $<30$ & $\mathrm{Se}$ & $2 / 0$ & $<30$ & $<30$ & $<30$ \\
\hline $\mathrm{Hg}$ & $2 / 2$ & 0.08 & 0.06 & 0.09 & $\mathrm{Hg}$ & $2 / 0$ & $<0.04$ & $<0.04$ & $<0.04$ \\
\hline
\end{tabular}

\section{In B Horizon}

\footnotetext{
${ }^{1}$ Detects are the number of samples with concentrations equal to or greater than the laboratory reporting limit.
}

* Where the concentration of a metal in a sample is less than the laboratory minimum reporting level, the minimum reporting level is used for calculating arithmetic mean, and the arithmetic mean is qualified as less than the value given. 
Appendix 7.41. Distribution statistics for concentrations (in ppm of dry soil) of metals in soils on geologic unit “QTvm” (Mafic vent deposits; Pleistocene, Pliocene \& Miocene ?). For sampling site \#(s) and physiographic province(s) see Appendix 2.

In A Horizon

Metal

In B Horizon

\begin{tabular}{|c|c|c|c|c|c|c|c|c|}
\hline $\begin{array}{l}\text { Total } \\
\text { sample } \\
\text { number/ } \\
\text { detects }^{1}\end{array}$ & $\begin{array}{l}\text { Arith- } \\
\text { metic } \\
\text { mean }^{2}\end{array}$ & $\begin{array}{l}\text { Mini- } \\
\text { mum }\end{array}$ & $\begin{array}{l}\text { Maxi- } \\
\text { mum }\end{array}$ & Metal & $\begin{array}{l}\text { Total } \\
\text { sample } \\
\text { number/ } \\
\text { detects }\end{array}$ & $\begin{array}{l}\text { Arith- } \\
\text { metic } \\
\text { mean }^{2}\end{array}$ & $\begin{array}{l}\text { Mini- } \\
\text { mum }\end{array}$ & $\begin{array}{l}\text { Maxi- } \\
\text { mum }\end{array}$ \\
\hline
\end{tabular}

\begin{tabular}{|c|c|c|c|c|c|c|c|c|c|}
\hline $\mathrm{Ag}$ & $1 / 0$ & $<1$ & -- & -- & $\mathrm{Ag}$ & $1 / 0$ & $<1$ & - & -- \\
\hline Mo & $1 / 0$ & $<5$ & -- & -- & Mo & $1 / 0$ & $<5$ & - & -- \\
\hline $\mathrm{Cd}$ & $1 / 0$ & $<1$ & -- & - & $\mathrm{Cd}$ & $1 / 0$ & $<1$ & -- & -- \\
\hline $\mathrm{Ba}$ & $1 / 1$ & 388 & -- & -- & $\mathrm{Ba}$ & $1 / 1$ & 358 & -- & -- \\
\hline $\mathrm{Be}$ & $1 / 0$ & $<1$ & -- & -- & $\mathrm{Be}$ & $1 / 0$ & $<1$ & - & - \\
\hline $\mathrm{Ni}$ & $1 / 1$ & 29 & -- & - & $\mathrm{Ni}$ & $1 / 1$ & 30 & -- & - \\
\hline Co & $1 / 1$ & 19 & -- & -- & Co & $1 / 1$ & 23 &.- & -- \\
\hline $\mathrm{Cr}$ & $1 / 1$ & 12 & -- & -- & $\mathrm{Cr}$ & $1 / 1$ & 14 & -- & -- \\
\hline V & $1 / 1$ & 83 & -- & -- & V & $1 / 1$ & 93 & -- & -- \\
\hline $\mathrm{Cu}$ & $1 / 1$ & 47 & -- & -- & $\mathrm{Cu}$ & $1 / 1$ & 56 & -- & -- \\
\hline $\mathrm{Zn}$ & $1 / 1$ & 78 & -- & - & $\mathrm{Zn}$ & $1 / 1$ & 66 & -- & -- \\
\hline $\mathrm{Fe}$ & $1 / 1$ & 36,177 & - & -- & $\mathrm{Fe}$ & $1 / 1$ & 39,721 & - & -- \\
\hline $\mathrm{Mn}$ & $1 / 1$ & 1,220 & - & -- & $\mathrm{Mn}$ & $1 / 1$ & 774 & -- & -- \\
\hline K & $1 / 1$ & 1,481 & -- & -- & $\mathrm{K}$ & $1 / 1$ & 970 & -- & -- \\
\hline $\mathrm{Al}$ & $1 / 1$ & 44,100 & - & -- & $\mathrm{Al}$ & $1 / 1$ & 49,053 & -- & -- \\
\hline $\mathrm{Li}$ & $1 / 1$ & 12 & -- & -- & $\mathrm{Li}$ & $1 / 1$ & 13 & - & -- \\
\hline $\mathrm{Ca}$ & $1 / 1$ & 6,559 & -- & -- & $\mathrm{Ca}$ & $1 / 1$ & 3,118 & -- & -- \\
\hline $\mathrm{Na}$ & $1 / 1$ & 320 & -- & -- & $\mathrm{Na}$ & $1 / 1$ & 397 & -- & -- \\
\hline Mg & $1 / 1$ & 1,960 & -- & -- & $\mathrm{Mg}$ & 2,217 & - & -- & \\
\hline $\mathrm{La}$ & $1 / 1$ & 10 & -- & -- & $\mathrm{La}$ & $1 / 1$ & 12 & -- & - \\
\hline $\mathrm{Sb}$ & $1 / 0$ & $<20$ & -- & - & $\mathrm{Sb}$ & $1 / 0$ & $<20$ & -- & - \\
\hline $\mathrm{Pb}$ & $1 / 0$ & $<10$ & -- & - & $\mathrm{Pb}$ & $1 / 0$ & $<10$ & -- & -- \\
\hline $\mathrm{Tl}$ & $1 / 0$ & $<50$ & - & -- & $\mathrm{Tl}$ & $1 / 0$ & $<50$ & - & -- \\
\hline As & $1 / 0$ & $<20$ & - & - & As & $1 / 0$ & $<20$ & - & -- \\
\hline $\mathrm{Se}$ & $1 / 0$ & $<30$ & -- & -- & $\mathrm{Se}$ & $1 / 0$ & $<30$ & -- & -- \\
\hline $\mathrm{Hg}$ & $1 / 1$ & 0.04 & -- & -- & $\mathrm{Hg}$ & $1 / 0$ & $<0.04$ & -- & -- \\
\hline
\end{tabular}

${ }^{1}$ Detects are the number of samples with concentrations equal to or greater than the laboratory reporting limit.

${ }^{2}$ Only one concentration value for the soils is listed under arithmetic mean. 
Appendix 7.42. Distribution statistics for concentrations (in ppm of dry soil) of metals in soils on geologic unit "Tat" (Silicic ash-flow tuff; Pliocene \& Miocene). For sampling site \#(s) and physiographic province(s) see Appendix 2.

In A Horizon

\begin{tabular}{|c|c|c|c|c|c|c|c|c|}
\hline Metal & $\begin{array}{l}\text { Total } \\
\text { sample } \\
\text { number/ } \\
\text { detects }^{1}\end{array}$ & $\begin{array}{l}\text { Arith- } \\
\text { metic } \\
\text { mean }^{2}\end{array}$ & $\begin{array}{l}\text { Mini- } \\
\text { mum }\end{array}$ & $\begin{array}{l}\text { Maxi- } \\
\text { mum }\end{array}$ & Metal & $\begin{array}{l}\text { Total } \\
\text { sample } \\
\text { number/ } \\
\text { detects }{ }^{1}\end{array}$ & $\begin{array}{l}\text { Arith- } \\
\text { metic } \\
\text { mean }\end{array}$ & $\begin{array}{l}\text { Mini- } \\
\text { mum }\end{array}$ \\
\hline $\mathrm{Ag}$ & $1 / 0$ & $<1$ & -- & -- & $\mathrm{Ag}$ & $1 / 0$ & $<1$ & -- \\
\hline Mo & $1 / 0$ & $<5$ & - & -- & Mo & $1 / 0$ & $<5$ & -- \\
\hline $\mathrm{Cd}$ & $1 / 0$ & $<1$ & -- & -- & $\mathrm{Cd}$ & $1 / 0$ & $<1$ & -- \\
\hline $\mathrm{Ba}$ & $1 / 1$ & 204 & - & -- & $\mathrm{Ba}$ & $1 / 1$ & 77 & -- \\
\hline $\mathrm{Be}$ & $1 / 0$ & $<1$ & - & -- & $\mathrm{Be}$ & $1 / 0$ & $<1$ & -- \\
\hline $\mathrm{Ni}$ & $1 / 1$ & 8 & - & -- & $\mathrm{Ni}$ & $1 / 1$ & 11 & -- \\
\hline Co & $1 / 0$ & $<6$ & - & - & Co & $1 / 1$ & 7 & -- \\
\hline $\mathrm{Cr}$ & $1 / 1$ & 4 & -- & - & $\mathrm{Cr}$ & $1 / 1$ & 8 & -. \\
\hline V & $1 / 1$ & 25 & -- & - & $\mathrm{V}$ & $1 / 1$ & 46 & -- \\
\hline $\mathrm{Cu}$ & $1 / 1$ & 9 & -- & - & $\mathrm{Cu}$ & $1 / 1$ & 17 & -- \\
\hline $\mathrm{Zn}$ & $1 / 1$ & 51 & -- & - & $\mathrm{Zn}$ & $1 / 1$ & 32 & -- \\
\hline $\mathrm{Fe}$ & $1 / 1$ & 8,708 & - & - & $\mathrm{Fe}$ & $1 / 1$ & 13,675 & -- \\
\hline $\mathrm{Mn}$ & $1 / 1$ & 678 & -- & -. & $\mathrm{Mn}$ & $1 / 1$ & 164 & -- \\
\hline $\mathrm{K}$ & $1 / 1$ & 941 & -- & -- & $\mathrm{K}$ & $1 / 1$ & 564 & - \\
\hline $\mathrm{Al}$ & $1 / 1$ & 12,544 & - & - & $\mathrm{Al}$ & $1 / 1$ & 17,901 & - \\
\hline $\mathrm{Li}$ & $1 / 1$ & 5 & -- & -- & $\mathrm{Li}$ & $1 / 1$ & 6 & -- \\
\hline $\mathrm{Ca}$ & $1 / 1$ & 5,261 & -- & -- & $\mathrm{Ca}$ & $1 / 1$ & 3,800 & $\cdots$ \\
\hline $\mathrm{Na}$ & $1 / 1$ & 566 & -- & -- & $\mathrm{Na}$ & $1 / 1$ & 1,039 & - \\
\hline $\mathrm{Mg}$ & $1 / 1$ & 1,223 & - & - & $\mathrm{Mg}$ & $1 / 1$ & 1,279 & - \\
\hline $\mathrm{La}$ & $1 / 0$ & $<5$ & -- & -- & $\mathrm{La}$ & $1 / 1$ & 5 & -- \\
\hline $\mathrm{Sb}$ & $1 / 0$ & $<20$ & -- & - & $\mathrm{Sb}$ & $1 / 0$ & $<20$ & -- \\
\hline $\mathrm{Pb}$ & $1 / 0$ & $<10$ & -- & - & $\mathrm{Pb}$ & $1 / 0$ & $<10$ & -- \\
\hline $\mathrm{Tl}$ & $1 / 0$ & $<50$ & -- & -- & $\mathrm{Tl}$ & $1 / 0$ & $<50$ & -- \\
\hline As & $1 / 0$ & $<20$ & -- & -- & As & $1 / 0$ & $<20$ & - \\
\hline $\mathrm{Se}$ & $1 / 0$ & $<30$ & -- & -- & $\mathrm{Se}$ & $1 / 0$ & $<30$ & - \\
\hline $\mathrm{Hg}$ & $1 / 1$ & 0.06 & - & -- & $\mathrm{Hg}$ & $1 / 0$ & $<0.04$ & - \\
\hline
\end{tabular}

${ }^{1}$ Detects are the number of samples with concentrations equal to or greater than the laboratory reporting limit.

${ }^{2}$ Only one concentration value for the soils is listed under arithmetic mean. 
Appendix 7.43. Distribution statistics for concentrations (in ppm of dry soil) of metals in soils on geologic unit "Tb" (Basalt; Miocene). For sampling site \#(s) and physiographic province(s) see Appendix 2.

In A Horizon

In B Horizon

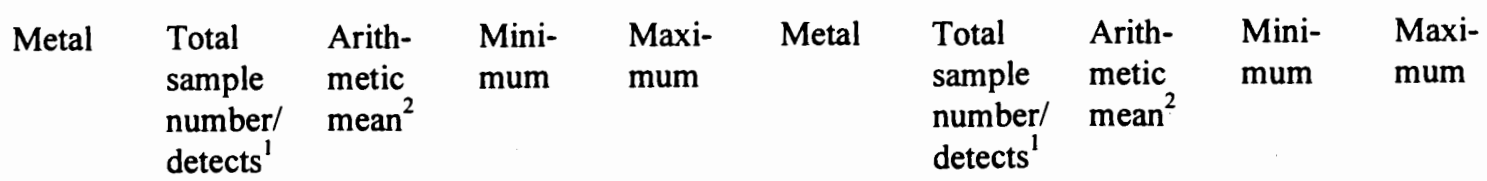

\begin{tabular}{|c|c|c|c|c|c|c|c|c|c|}
\hline $\mathrm{Ag}$ & $1 / 0$ & $<1$ & -- & -- & $\mathrm{Ag}$ & $1 / 0$ & $<1$ & -- & -- \\
\hline Mo & $1 / 0$ & $<5$ & -- & -- & Mo & $1 / 0$ & $<5$ & -- & -- \\
\hline $\mathrm{Cd}$ & $1 / 0$ & $<1$ & -- & -- & $\mathrm{Cd}$ & $1 / 1$ & 1 & - & -- \\
\hline $\mathrm{Ba}$ & $1 / 1$ & 234 & -- & - & $\mathrm{Ba}$ & $1 / 1$ & 256 & -- & -- \\
\hline $\mathrm{Be}$ & $1 / 1$ & $<1$ & -- & -- & $\mathrm{Be}$ & $1 / 0$ & $<1$ & -- & - \\
\hline $\mathrm{Ni}$ & $1 / 1$ & 23 & -- & -- & $\mathrm{Ni}$ & $1 / 1$ & 40 & -- & - \\
\hline Co & $1 / 1$ & 17 & -- & -- & Co & $1 / 1$ & 28 & -- & -- \\
\hline $\mathrm{Cr}$ & $1 / 1$ & 20 & -- & -- & $\mathrm{Cr}$ & $1 / 1$ & 36 & -- & - \\
\hline V & $1 / 1$ & 79 & - & -- & $\mathrm{V}$ & $1 / 1$ & 142 & -- & -- \\
\hline $\mathrm{Cu}$ & $1 / 1$ & 30 & $\cdots$ & -- & $\mathrm{Cu}$ & $1 / 1$ & 51 & -- & -- \\
\hline $\mathrm{Zn}$ & $1 / 1$ & 83 & $\cdots$ & -- & $\mathrm{Zn}$ & $1 / 1$ & 82 & -- & - \\
\hline $\mathrm{Fe}$ & $1 / 1$ & 27,200 & -- & -- & $\mathrm{Fe}$ & $1 / 1$ & 45,716 & -- & -- \\
\hline Mn & $1 / 1$ & 779 & -- & - & $\mathrm{Mn}$ & $1 / 1$ & 943 & -- & -- \\
\hline $\mathrm{K}$ & $1 / 1$ & 1,317 & -- & - & $\mathrm{K}$ & $1 / 1$ & 1,875 & -- & -- \\
\hline $\mathrm{Al}$ & $1 / 1$ & 31,794 & -- & - & Al & $1 / 1$ & 58,961 & -- & -- \\
\hline $\mathrm{Li}$ & $1 / 1$ & 8 & -- & - & $\mathrm{Li}$ & $1 / 1$ & 14 & -- & -- \\
\hline $\mathrm{Ca}$ & $1 / 1$ & 7.077 & -- & - & $\mathrm{Ca}$ & $1 / 1$ & 5,061 & -- & -- \\
\hline $\mathrm{Na}$ & $1 / 1$ & 328 & -- & -- & $\mathrm{Na}$ & $1 / 1$ & 560 & -- & -- \\
\hline $\mathrm{Mg}$ & $1 / 1$ & 2,565 & -- & -- & $\mathrm{Mg}$ & $1 / 1$ & 3,570 & - & -- \\
\hline $\mathbf{L a}$ & $1 / 1$ & 9 & -- & -- & $\mathrm{La}$ & $1 / 1$ & 15 & -- & -- \\
\hline $\mathrm{Sb}$ & $1 / 0$ & $<20$ & - & -- & $\mathrm{Sb}$ & $1 / 0$ & $<20$ & -- & -- \\
\hline $\mathrm{Pb}$ & $1 / 0$ & $<10$ & - & -- & $\mathrm{Pb}$ & $1 / 0$ & $<10$ & - & -- \\
\hline $\mathrm{Tl}$ & $1 / 0$ & $<50$ & - & -- & $\mathrm{Tl}$ & $1 / 0$ & $<50$ & - & -- \\
\hline As & $1 / 0$ & $<20$ & -- & - & As & $1 / 0$ & $<20$ & - & -- \\
\hline $\mathrm{Se}$ & $1 / 0$ & $<30$ & -- & -- & $\mathrm{Se}$ & $1 / 0$ & $<30$ & -- & -- \\
\hline $\mathrm{Hg}$ & $1 / 1$ & 0.07 & -- & - & $\mathrm{Hg}$ & $1 / 0$ & $<0.04$ & -- & - \\
\hline
\end{tabular}

${ }^{1}$ Detects are the number of samples with concentrations equal to or greater than the laboratory reporting limit.

${ }^{2}$ Only one concentration value for the soils is listed under arithmetic mean. 
Appendix 7.44. Distribution statistics for concentrations (in ppm of dry soil) of metals in soils on geologic unit "Tbaa" (Basaltic \& andesitic rocks;Miocene). For sampling site \#(s) and physiographic province(s) see Appendix 2.

In A Horizon

\begin{tabular}{|c|c|c|c|c|c|c|c|c|c|}
\hline Metal & $\begin{array}{l}\text { Total } \\
\text { sample } \\
\text { number/ } \\
\text { detects }^{1}\end{array}$ & $\begin{array}{l}\text { Arith- } \\
\text { metic } \\
\text { mean }\end{array}$ & $\begin{array}{l}\text { Mini- } \\
\text { mum }\end{array}$ & $\begin{array}{l}\text { Maxi- } \\
\text { mum }\end{array}$ & Metal & $\begin{array}{l}\text { Total } \\
\text { sample } \\
\text { number/ } \\
\text { detects }{ }^{1}\end{array}$ & $\begin{array}{l}\text { Arith- } \\
\text { metic } \\
\text { mean }\end{array}$ & $\begin{array}{l}\text { Mini- } \\
\text { mum }\end{array}$ & $\begin{array}{l}\text { Maxi- } \\
\text { mum }\end{array}$ \\
\hline $\mathrm{Ag}$ & $2 / 0$ & $<1$ & $<1$ & $<1$ & $\mathrm{Ag}$ & $2 / 0$ & $<1$ & $<1$ & $<1$ \\
\hline Mo & $2 / 0$ & $<5$ & $<5$ & $<5$ & Mo & $2 / 0$ & $<5$ & $<5$ & $<5$ \\
\hline $\mathrm{Cd}$ & $2 / 0$ & $<1$ & $<1$ & $<1$ & $\mathrm{Cd}$ & $2 / 0$ & $<1$ & $<1$ & $<1$ \\
\hline $\mathrm{Ba}$ & $2 / 2$ & 188 & 161 & 215 & $\mathrm{Ba}$ & $2 / 2$ & 130 & 76 & 184 \\
\hline $\mathrm{Be}$ & $2 / 0$ & $<1$ & $<1$ & $<1$ & $\mathrm{Be}$ & $2 / 2$ & $<1$ & $<1$ & $<1$ \\
\hline $\mathrm{Ni}$ & $2 / 2$ & 19 & 15 & 23 & $\mathrm{Ni}$ & $2 / 2$ & 19 & 11 & 26 \\
\hline Co & $2 / 2$ & 12 & 11 & 14 & Co & $2 / 2$ & 16 & 14 & 18 \\
\hline $\mathrm{Cr}$ & $2 / 2$ & 14 & 12 & 17 & $\mathrm{Cr}$ & $2 / 2$ & 21 & 18 & 24 \\
\hline V & $2 / 2$ & 46 & 38 & 54 & $\mathrm{~V}$ & $2 / 2$ & 68 & 63 & 74 \\
\hline $\mathrm{Cu}$ & $2 / 2$ & 21 & 19 & 23 & $\mathrm{Cu}$ & $2 / 2$ & 25 & 21 & 28 \\
\hline $\mathrm{Zn}$ & $2 / 2$ & 80 & 75 & 86 & $\mathrm{Zn}$ & $2 / 2$ & 72 & 71 & 74 \\
\hline $\mathrm{Fe}$ & $2 / 2$ & 22,910 & 18,185 & 27,635 & $\mathrm{Fe}$ & $2 / 2$ & 31,829 & 29,347 & 34,311 \\
\hline $\mathrm{Mn}$ & $2 / 2$ & 1,985 & 1,567 & 2,404 & $\mathrm{Mn}$ & $2 / 2$ & 610 & 522 & 699 \\
\hline K & $2 / 2$ & 1,201 & 669 & 1,733 & $\mathrm{~K}$ & $2 / 2$ & 922 & 612 & 1,232 \\
\hline $\mathrm{Al}$ & $2 / 2$ & 29,512 & 19,971 & 39,053 & $\mathrm{Al}$ & $2 / 2$ & 39,644 & 30,418 & 48,870 \\
\hline $\mathrm{Li}$ & $2 / 1$ & $<6^{*}$ & $<5$ & 7 & $\mathrm{Li}$ & $2 / 2$ & 8 & 7 & 9 \\
\hline $\mathrm{Ca}$ & $2 / 2$ & 11,210 & 5,025 & 17,394 & $\mathrm{Ca}$ & $2 / 2$ & 5,291 & 3,928 & 6,653 \\
\hline $\mathrm{Na}$ & $2 / 2$ & 379 & 317 & 442 & $\mathrm{Na}$ & $2 / 2$ & 331 & 319 & 343 \\
\hline $\mathrm{Mg}$ & $2 / 2$ & 5,736 & 3,903 & 7,569 & $\mathrm{Mg}$ & $2 / 2$ & 7,624 & 5,266 & 9,982 \\
\hline $\mathrm{La}$ & $2 / 2$ & 5 & 5 & 6 & $\mathrm{La}$ & $2 / 2$ & 6 & 5 & 7 \\
\hline $\mathrm{Sb}$ & $2 / 0$ & $<20$ & $<20$ & $<20$ & $\mathrm{Sb}$ & $2 / 0$ & $<20$ & $<20$ & $<20$ \\
\hline $\mathrm{Pb}$ & $2 / 1$ & $<72^{*}$ & $<10$ & 133 & $\mathrm{~Pb}$ & $2 / 0$ & $<10$ & $<10$ & $<10$ \\
\hline $\mathrm{Tl}$ & $2 / 0$ & $<50$ & $<50$ & $<50$ & $\mathrm{Tl}$ & $2 / 0$ & $<50$ & $<50$ & $<50$ \\
\hline As & $2 / 0$ & $<20$ & $<20$ & $<20$ & As & $2 / 0$ & $<20$ & $<20$ & $<20$ \\
\hline $\mathrm{Se}$ & $2 / 0$ & $<30$ & $<30$ & $<30$ & $\mathrm{Se}$ & $2 / 0$ & $<30$ & $<30$ & $<30$ \\
\hline $\mathrm{Hg}$ & $2 / 2$ & 0.15 & 0.08 & 0.22 & $\mathrm{Hg}$ & $2 / 1$ & $0.05^{*}$ & $<0.04$ & 0.06 \\
\hline
\end{tabular}

\section{In B Horizon}

${ }^{1}$ Detects are the number of samples with concentrations equal to or greater than the laboratory reporting limit.

* Where the concentration of a metal in a sample is less than the laboratory minimum reporting level, the minimum reporting level is used for calculating arithmetic mean, and the arithmetic mean is qualified as less than the value given. 
Appendix 7.45. Distribution statistics for concentrations (in ppm of dry soil) of metals in soils on geologic unit "T fc" (Flows \& clastic rocks, undifferentiated; Miocene). For sampling site $\#(s)$ and physiographic province(s) see Appendix 2.

In A Horizon

In B Horizon

\begin{tabular}{|c|c|c|c|c|c|c|c|c|}
\hline Metal & $\begin{array}{l}\text { Total } \\
\text { sample } \\
\text { number/ } \\
\text { detects }^{1}\end{array}$ & $\begin{array}{l}\text { Arith- } \\
\text { metic } \\
\text { mean }\end{array}$ & $\begin{array}{l}\text { Mini- } \\
\text { mum }\end{array}$ & $\begin{array}{l}\text { Maxi- } \\
\text { mum }\end{array}$ & Metal & $\begin{array}{l}\text { Total } \\
\text { sample } \\
\text { number/ } \\
\text { detects }\end{array}$ & $\begin{array}{l}\text { Arith- } \\
\text { metic } \\
\text { mean }^{2}\end{array}$ & $\begin{array}{l}\text { Mini- } \\
\text { mum }\end{array}$ \\
\hline $\mathrm{Ag}$ & $1 / 0$ & $<1$ & - & -- & $\mathrm{Ag}$ & $1 / 0$ & $<1$ & -- \\
\hline Mo & $1 / 0$ & $<5$ & - & - & Mo & $1 / 0$ & $<5$ & - \\
\hline $\mathrm{Cd}$ & $1 / 0$ & $<1$ & -- & - & $\mathrm{Cd}$ & $1 / 0$ & $<1$ & -- \\
\hline $\mathrm{Ba}$ & $1 / 1$ & 246 & -- & - & $\mathrm{Ba}$ & $1 / 1$ & 136 & -- \\
\hline $\mathrm{Be}$ & $1 / 0$ & $<1$ & -- & -- & $\mathrm{Be}$ & $1 / 0$ & $<1$ & -- \\
\hline $\mathrm{Ni}$ & $1 / 1$ & 19 & -- & - & $\mathrm{Ni}$ & $1 / 1$ & 24 & -- \\
\hline Co & $1 / 1$ & 13 & -- & -- & Co & $1 / 1$ & 14 & -- \\
\hline $\mathrm{Cr}$ & $1 / 1$ & 17 & - & -- & $\mathrm{Cr}$ & $1 / 1$ & 20 & - \\
\hline V & $1 / 1$ & 64 & - & -- & $\mathrm{V}$ & $1 / 1$ & 78 & - \\
\hline $\mathrm{Cu}$ & $1 / 1$ & 24 & -- & -- & $\mathrm{Cu}$ & $1 / 1$ & 37 & -- \\
\hline $\mathrm{Zn}$ & $1 / 1$ & 106 & -- & - & $\mathrm{Zn}$ & $1 / 1$ & 64 & -- \\
\hline $\mathrm{Fe}$ & $1 / 1$ & 26,162 & -- & -- & $\mathrm{Fe}$ & $1 / 1$ & 28,580 & -- \\
\hline $\mathrm{Mn}$ & $1 / 1$ & 2,800 & - & - & $\mathrm{Mn}$ & $1 / 1$ & 639 & - \\
\hline K & $1 / 1$ & 470 & -- & - & $\mathrm{K}$ & $1 / 1$ & 344 & -- \\
\hline $\mathrm{Al}$ & $1 / 1$ & 31,486 & -- & -- & $\mathrm{Al}$ & $1 / 1$ & 42,274 & -- \\
\hline $\mathrm{Li}$ & $1 / 1$ & 8 & - & -- & $\mathrm{Li}$ & $1 / 1$ & 9 & -- \\
\hline $\mathrm{Ca}$ & $1 / 1$ & 3,389 & -- & - & $\mathrm{Ca}$ & $1 / 1$ & 2,192 & -- \\
\hline $\mathrm{Na}$ & $1 / 1$ & 371 & - & -- & $\mathrm{Na}$ & $1 / 1$ & 393 & -- \\
\hline $\mathrm{Mg}$ & $1 / 1$ & 2,375 & -- & -- & $\mathrm{Mg}$ & $1 / 1$ & 3,456 & - \\
\hline $\mathrm{La}$ & $1 / 1$ & 6 & -- & -- & $\mathrm{La}$ & $1 / 1$ & 5 & -- \\
\hline $\mathrm{Sb}$ & $1 / 0$ & $<20$ & -- & -- & $\mathrm{Sb}$ & $1 / 0$ & $<20$ & - \\
\hline $\mathrm{Pb}$ & $1 / 0$ & $<10$ & - & -- & $\mathrm{Pb}$ & $1 / 0$ & $<10$ & - \\
\hline $\mathrm{Tl}$ & $1 / 0$ & $<50$ & -- & -- & $\mathrm{Tl}$ & $1 / 0$ & $<50$ & - \\
\hline As & $1 / 0$ & $<20$ & -- & -- & As & $1 / 0$ & $<20$ & -- \\
\hline $\mathrm{Se}$ & $1 / 0$ & $<30$ & -- & - & $\mathrm{Se}$ & $1 / 0$ & $<30$ & -- \\
\hline $\mathrm{Hg}$ & $1 / 1$ & 0.08 & -- & -- & $\mathrm{Hg}$ & $1 / 1$ & 0.06 & -- \\
\hline
\end{tabular}

${ }^{1}$ Detects are the number of samples with concentrations equal to or greater than the laboratory reporting limit.

${ }^{2}$ Only one concentration value for the soils is listed under arithmetic mean. 
Appendix 7.46. Distribution statistics for concentrations (in ppm of dry soil) of metals in soils on geologic unit "Tfe" (Tuffs, conglomerates, silts \& sands of the Fisher \& Eugene Formations \& correlative rocks; Oligocene \& Eocene ). For sampling site \#(s) and physiographic province(s) see Appendix 2.

In A Horizon

In B Horizon

\begin{tabular}{|c|c|c|c|c|c|c|c|c|c|}
\hline Metal & $\begin{array}{l}\text { Total } \\
\text { sample } \\
\text { number/ } \\
\text { detects }^{1}\end{array}$ & $\begin{array}{l}\text { Arith- } \\
\text { metic } \\
\text { mean }^{2}\end{array}$ & $\begin{array}{l}\text { Mini- } \\
\text { mum }\end{array}$ & $\begin{array}{l}\text { Maxi- } \\
\text { mum }\end{array}$ & Metal & $\begin{array}{l}\text { Total } \\
\text { sample } \\
\text { number/ } \\
\text { detects }\end{array}$ & $\begin{array}{l}\text { Arith- } \\
\text { metic } \\
\text { mean }^{2}\end{array}$ & $\begin{array}{l}\text { Mini- } \\
\text { mum }\end{array}$ & $\begin{array}{l}\text { Maxi- } \\
\text { mum }\end{array}$ \\
\hline $\mathrm{Ag}$ & $1 / 0$ & $<1$ & - & - & $\mathrm{Ag}$ & $1 / 0$ & $<1$ & - & -. \\
\hline Mo & $1 / 0$ & $<5$ & - & -- & Mo & $1 / 0$ & $<5$ & -- & - \\
\hline $\mathrm{Cd}$ & $1 / 0$ & $<1$ & -- & - & $\mathrm{Cd}$ & $1 / 0$ & $<1$ & -- & -- \\
\hline $\mathrm{Ba}$ & $1 / 1$ & 193 & - & -- & $\mathrm{Ba}$ & $1 / 1$ & 124 & -. & -- \\
\hline $\mathrm{Be}$ & $1 / 0$ & $<1$ & -- & - & $\mathrm{Be}$ & $1 / 0$ & $<1$ & - & - \\
\hline $\mathrm{Ni}$ & $1 / 1$ & 9 & -- & - & $\mathrm{Ni}$ & $1 / 1$ & 10 & -- & -- \\
\hline Co & $1 / 1$ & 22 & - & -- & Co & $1 / 1$ & 23 & -- & -- \\
\hline $\mathrm{Cr}$ & $1 / 1$ & 21 & -- & -- & $\mathrm{Cr}$ & $1 / 1$ & 22 & - & -- \\
\hline V & $1 / 1$ & 133 & - & -- & $\mathrm{V}$ & $1 / 1$ & 142 & - & -- \\
\hline $\mathrm{Cu}$ & $1 / 1$ & 51 & -- & -- & $\mathrm{Cu}$ & $1 / 1$ & 61 & -- & -- \\
\hline $\mathrm{Zn}$ & $1 / 1$ & 62 & -- & -- & $\mathrm{Zn}$ & $1 / 1$ & 60 & -- & - \\
\hline $\mathrm{Fe}$ & $1 / 1$ & 78,726 & -- & -- & $\mathrm{Fe}$ & $1 / 1$ & 82,363 & -- & - \\
\hline $\mathrm{Mn}$ & $1 / 1$ & 3,495 & -- & -- & $\mathrm{Mn}$ & $1 / 1$ & 2,555 & -- & -- \\
\hline $\mathrm{K}$ & $1 / 1$ & 631 & -- & - & K & $1 / 1$ & 379 & -- & -- \\
\hline $\mathrm{Al}$ & $1 / 1$ & 53,649 & -- & -- & $\mathrm{Al}$ & $1 / 1$ & 61,317 & -- & - \\
\hline $\mathrm{Li}$ & $1 / 1$ & 5 & -- & -- & $\mathrm{Li}$ & $1 / 1$ & 6 & - & - \\
\hline $\mathrm{Ca}$ & $1 / 1$ & 3,884 & -- & - & $\mathrm{Ca}$ & $1 / 1$ & 2,031 & -- & -- \\
\hline $\mathrm{Na}$ & $1 / 1$ & 61 & - & -- & $\mathrm{Na}$ & $1 / 1$ & 57 & - & -- \\
\hline $\mathrm{Mg}$ & $1 / 1$ & 1,498 & -- & -- & $\mathrm{Mg}$ & $1 / 1$ & 1,468 & - & -- \\
\hline $\mathrm{La}$ & $1 / 1$ & 11 & - & - & $\mathrm{La}$ & $1 / 1$ & 12 & -- & - \\
\hline $\mathrm{Sb}$ & $1 / 0$ & $<20$ & -- & -- & $\mathrm{Sb}$ & $1 / 0$ & $<20$ & -- & -- \\
\hline $\mathrm{Pb}$ & $1 / 0$ & $<10$ & - & -- & $\mathrm{Pb}$ & $1 / 0$ & 10 & -- & - \\
\hline $\mathrm{Tl}$ & $1 / 0$ & $<50$ & - & - & $\mathrm{Tl}$ & $1 / 0$ & $<50$ & - & -- \\
\hline As & $1 / 0$ & $<20$ & - & -- & As & $1 / 0$ & $<20$ & -- & - \\
\hline $\mathrm{Se}$ & $1 / 0$ & $<30$ & -- & - & $\mathrm{Se}$ & $1 / 0$ & $<30$ & -- & -- \\
\hline $\mathrm{Hg}$ & $1 / 1$ & 0.10 & -- & -- & $\mathrm{Hg}$ & $1 / 1$ & 0.07 & -- & - \\
\hline
\end{tabular}

${ }^{1}$ Detects are the number of samples with concentrations equal to or greater than the laboratory reporting limit.

${ }^{2}$ Only one concentration value for the soils is listed under arithmetic mean. 
Appendix 7.47. Distribution statistics for concentrations (in ppm of dry soil) of metals in soils on geologic unit "Tfee" (Silts \& sands of the marine Eugene Formation; Oligocene \& Eocene). For sampling site \#(s) and physiographic province(s) see Appendix 2.

In A Horizon

Metal

$\begin{array}{lll}\text { Total } & \text { Arith- } & \text { Mini- } \\ \text { sample } & \text { metic } & \text { mum } \\ \text { number/ } & \text { mean }^{2} & \\ \text { detects } & & \end{array}$

$\begin{array}{ll}\mathrm{Ag} & 1 / 0 \\ \mathrm{Mo} & 1 / 0 \\ \mathrm{Cd} & 1 / 0 \\ \mathrm{Ba} & 1 / 1 \\ \mathrm{Be} & 1 / 0 \\ \mathrm{Ni} & 1 / 1 \\ \mathrm{Co} & 1 / 1 \\ \mathrm{Cr} & 1 / 1 \\ \mathrm{~V} & 1 / 1 \\ \mathrm{Cu} & 1 / 1 \\ \mathrm{Zn} & 1 / 1 \\ \mathrm{Fe} & 1 / 1 \\ \mathrm{Mn} & 1 / 1 \\ \mathrm{~K} & 1 / 1 \\ \mathrm{Al} & 1 / 1 \\ \mathrm{Li} & 1 / 1 \\ \mathrm{Ca} & 1 / 1 \\ \mathrm{Na} & 1 / 1 \\ \mathrm{Mg} & 1 / 1 \\ \mathrm{La} & 1 / 1 \\ \mathrm{Sb} & 1 / 0 \\ \mathrm{~Pb} & 1 / 0 \\ \mathrm{Tl} & 1 / 0 \\ \mathrm{As} & 1 / 0 \\ \mathrm{Se} & 1 / 0 \\ \mathrm{Hg} & 1 / 1\end{array}$

$<1 \quad--$

$\begin{array}{lll}<1 & -- & - \\ <5 & -- & -\end{array}$

$<1 \quad$--

$252 \quad--\quad$ -

$<1 \quad--\quad \quad-$

$52 \quad$-.

$\begin{array}{lll}28 & - & \end{array}$

$212 \quad--\quad$--

$125 \quad--\quad$--

$110 \quad--\quad-$

$80,890 \quad--\quad$--

$963 \quad--\quad--$

$56,248 \quad--\quad$-.

$4,589 \quad--\quad--$

$6,134 \quad--\quad$--

$20 \quad-\quad--$

$<20 \quad--\quad--$

$<50 \quad--\quad$-.

$<30 \quad--\quad$--

$0.05 \quad--\quad-$
$15 \quad--\quad$ -

$2,831 \quad--\quad$-.

$6 \quad--\quad--$

$92 \quad--\quad$

$<10 \quad--\quad$-.

$<20 \quad--\quad$--

\section{In B Horizon}

\begin{tabular}{|c|c|c|c|}
\hline $\begin{array}{l}\text { Maxi- } \quad \text { Metal } \\
\text { num }\end{array}$ & $\begin{array}{l}\text { Total } \\
\text { sample } \\
\text { number/ }\end{array}$ & $\begin{array}{l}\text { Arith- } \\
\text { metic } \\
\text { mean }^{2}\end{array}$ & $\begin{array}{l}\text { Mini- } \\
\text { mum }\end{array}$ \\
\hline
\end{tabular}

\begin{tabular}{|c|c|c|c|c|}
\hline $\mathrm{Ag}$ & $1 / 0$ & $<1$ & -- & - \\
\hline Mo & $1 / 0$ & $<5$ & -- & -- \\
\hline $\mathrm{Cd}$ & $1 / 0$ & $<1$ & -- & -- \\
\hline $\mathrm{Ba}$ & $1 / 1$ & 162 & -- & - \\
\hline $\mathrm{Be}$ & $1 / 0$ & $<1$ & -- & -- \\
\hline $\mathrm{Ni}$ & $1 / 1$ & 10 & - & -- \\
\hline Co & $1 / 1$ & 17 & - & -- \\
\hline $\mathrm{Cr}$ & $1 / 1$ & 24 & -- & -- \\
\hline V & $1 / 1$ & 220 & -- & -- \\
\hline $\mathrm{Cu}$ & $1 / 1$ & 150 & - & - \\
\hline $\mathrm{Zn}$ & $1 / 1$ & 81 & -- & - \\
\hline $\mathrm{Fe}$ & $1 / 1$ & 79,319 & -- & -- \\
\hline $\mathrm{Mn}$ & $1 / 1$ & 470 & -- & -- \\
\hline K & $1 / 1$ & 517 & -- & -- \\
\hline $\mathrm{Al}$ & $1 / 1$ & 82,482 & -- & -- \\
\hline $\mathrm{Li}$ & $1 / 1$ & 5 & - & -- \\
\hline $\mathrm{Ca}$ & $1 / 1$ & 4,183 & - & -- \\
\hline $\mathrm{Na}$ & $1 / 1$ & 82 & - & -- \\
\hline $\mathrm{Mg}$ & $1 / 1$ & 10,958 & -- & -- \\
\hline $\mathrm{La}$ & $1 / 1$ & 8 & - & -- \\
\hline Sb & $1 / 0$ &, 20 & - & - \\
\hline $\mathrm{Pb}$ & $1 / 0$ & $<10$ & -- & - \\
\hline $\mathrm{Tl}$ & $1 / 0$ & $<50$ & - & -- \\
\hline As & $1 / 0$ & $<20$ & -- & -- \\
\hline $\mathrm{Se}$ & $1 / 0$ & $<30$ & -- & - \\
\hline $\mathrm{Hg}$ & $1 / 0$ & $<0.04$ & -- & -- \\
\hline
\end{tabular}

${ }^{1}$ Detects are the number of samples with concentrations equal to or greater than the laboratory reporting limit.

${ }^{2}$ Only one concentration value for the soils is listed under arithmetic mean. 
Appendix 7.48. Distribution statistics for concentrations (in ppm of dry soil) of metals in soils on geologic unit "Tmsc" (Marine siltstone, sandstone \& conglomerate; Eocene ). For sampling site \#(s) and physiographic province(s) see Appendix 2.

In A Horizon

In B Horizon

\begin{tabular}{|c|c|c|c|c|c|c|c|c|}
\hline Metal & $\begin{array}{l}\text { Total } \\
\text { sample } \\
\text { number/ } \\
\text { detects }^{1}\end{array}$ & $\begin{array}{l}\text { Arith- } \\
\text { metic } \\
\text { mean }^{2}\end{array}$ & $\begin{array}{l}\text { Mini- } \\
\text { mum }\end{array}$ & $\begin{array}{l}\text { Maxi- } \\
\text { mum }\end{array}$ & Metal & $\begin{array}{l}\text { Total } \\
\text { sample } \\
\text { number/ } \\
\text { detects }^{1}\end{array}$ & $\begin{array}{l}\text { Arith- } \\
\text { metic } \\
\text { mean }^{2}\end{array}$ & $\begin{array}{l}\text { Mini- } \\
\text { mum }\end{array}$ \\
\hline $\mathrm{Ag}$ & $1 / 0$ & $<1$ & -- & - & $\mathrm{Ag}$ & $1 / 0$ & $<1$ & -- \\
\hline Mo & $1 / 0$ & $<5$ & - & -- & Mo & $1 / 0$ & $<5$ & -- \\
\hline $\mathrm{Cd}$ & $1 / 0$ & $<1$ & -- & -- & $\mathrm{Cd}$ & $1 / 0$ & $<1$ & -- \\
\hline $\mathrm{Ba}$ & $1 / 1$ & 148 & - & -- & $\mathrm{Ba}$ & $1 / 1$ & 118 & - \\
\hline $\mathrm{Be}$ & $1 / 0$ & $<1$ & -- & - & $\mathrm{Be}$ & $1 / 0$ & $<1$ & -- \\
\hline $\mathrm{Ni}$ & $1 / 1$ & 91 & -- & - & $\mathrm{Ni}$ & $1 / 1$ & 121 & -- \\
\hline Co & $1 / 1$ & 22 & - & -- & Co & $1 / 1$ & 30 & -- \\
\hline $\mathrm{Cr}$ & $1 / 1$ & 74 & -- & -- & $\mathrm{Cr}$ & $1 / 1$ & 99 & - \\
\hline V & $1 / 1$ & 59 & - & -- & $\mathrm{V}$ & $1 / 1$ & 69 & -- \\
\hline $\mathrm{Cu}$ & $1 / 1$ & 28 & -- & - & $\mathrm{Cu}$ & $1 / 1$ & 35 & - \\
\hline $\mathrm{Zn}$ & $1 / 1$ & 63 & -- & -- & $\mathrm{Zn}$ & $1 / 1$ & 71 & -- \\
\hline $\mathrm{Fe}$ & $1 / 1$ & 32,465 & -- & - & $\mathrm{Fe}$ & $1 / 1$ & 42,182 & - \\
\hline $\mathrm{Mn}$ & $1 / 1$ & 1,522 & -- & -- & $\mathrm{Mn}$ & $1 / 1$ & 1,228 & -- \\
\hline $\mathrm{K}$ & $1 / 1$ & 2,289 & -- & - & $\mathrm{K}$ & $1 / 1$ & 2,515 & -- \\
\hline $\mathrm{Al}$ & $1 / 1$ & 24,623 & -- & -- & $\mathrm{Al}$ & $1 / 1$ & 34,060 & -- \\
\hline $\mathrm{Li}$ & $1 / 1$ & 23 & -- & -- & $\mathrm{Li}$ & $1 / 1$ & 31 & -- \\
\hline $\mathrm{Ca}$ & $1 / 1$ & 6,822 & -- & -- & $\mathrm{Ca}$ & $1 / 1$ & 877 & - \\
\hline $\mathrm{Na}$ & $1 / 1$ & 109 & -- & -- & $\mathrm{Na}$ & $1 / 1$ & 94 & -- \\
\hline $\mathrm{Mg}$ & $1 / 1$ & 6,508 & -- & - & $\mathrm{Mg}$ & $1 / 1$ & 6,845 & - \\
\hline $\mathrm{La}$ & $1 / 1$ & 8 & - & -- & $\mathrm{La}$ & $1 / 1$ & 11 & -- \\
\hline $\mathrm{Sb}$ & $1 / 0$ & $<20$ & -- & -- & $\mathrm{Sb}$ & $1 / 0$ & $<20$ & -- \\
\hline $\mathrm{Pb}$ & $1 / 1$ & 10 & - & -- & $\mathrm{Pb}$ & $1 / 0$ & $<10$ & -- \\
\hline $\mathrm{Tl}$ & $1 / 0$ & $<50$ & -- & -- & $\mathrm{Tl}$ & $1 / 0$ & $<50$ & -- \\
\hline As & $1 / 0$ & $<20$ & -- & -- & As & $1 / 0$ & $<20$ & -- \\
\hline $\mathrm{Se}$ & $1 / 0$ & $<30$ & -- & -- & $\mathrm{Se}$ & $1 / 0$ & $<30$ & - \\
\hline $\mathrm{Hg}$ & $1 / 1$ & 0.08 & -- & -- & $\mathrm{Hg}$ & $1 / 0$ & $<0.04$ & -- \\
\hline
\end{tabular}

${ }^{1}$ Detects are the number of samples with concentrations equal to or greater than the laboratory reporting limit.

${ }^{2}$ Only one concentration value for the soils is listed under arithmetic mean. 
Appendix 7.49. Distribution statistics for concentrations (in ppm of dry soil) of metals in soils on geologic unit "Tmsm" (Marine siltstone, sandstone \& conglomerate; Paleocene \& Eocene). For sampling site \#(s) and physiographic province(s) see Appendix 2.

In A Horizon

In B Horizon

\begin{tabular}{|c|c|c|c|c|c|c|c|c|}
\hline Metal & $\begin{array}{l}\text { Total } \\
\text { sample } \\
\text { number/ } \\
\text { detects }^{1}\end{array}$ & $\begin{array}{l}\text { Arith- } \\
\text { metic } \\
\text { mean }^{2}\end{array}$ & $\begin{array}{l}\text { Mini- } \\
\text { mum }\end{array}$ & $\begin{array}{l}\text { Maxi- } \\
\text { mum }\end{array}$ & Metal & $\begin{array}{l}\text { Total } \\
\text { sample } \\
\text { number/d } \\
\text { etects }^{1}\end{array}$ & $\begin{array}{l}\text { Arith- } \\
\text { metic } \\
\text { mean }^{2}\end{array}$ & $\begin{array}{l}\text { Mini- } \\
\text { mum }\end{array}$ \\
\hline $\mathrm{Ag}$ & $1 / 0$ & $<1$ & -- & -- & $\mathrm{Ag}$ & $1 / 0$ & $<1$ & -- \\
\hline Mo & $1 / 0$ & $<5$ & - & -- & Mo & $1 / 0$ & $<5$ & - \\
\hline $\mathrm{Cd}$ & $1 / 0$ & $<1$ & -- & -- & $\mathrm{Cd}$ & $1 / 0$ & $<1$ & -- \\
\hline $\mathrm{Ba}$ & $1 / 1$ & 206 & -- & -- & $\mathrm{Ba}$ & $1 / 1$ & 188 & - \\
\hline $\mathrm{Be}$ & $1 / 1$ & 1 & -- & - & $\mathrm{Be}$ & $1 / 1$ & 1 & -- \\
\hline $\mathrm{Ni}$ & $1 / 1$ & 100 & - & -- & $\mathrm{Ni}$ & $1 / 1$ & 104 & -- \\
\hline Co & $1 / 1$ & 30 & -- & -- & Co & $1 / 1$ & 32 & -- \\
\hline $\mathrm{Cr}$ & $1 / 1$ & 61 & -- & -- & $\mathrm{Cr}$ & $1 / 1$ & 68 & - \\
\hline V & $1 / 1$ & 85 & -- & -- & $\mathrm{V}$ & $1 / 1$ & 97 & -- \\
\hline $\mathrm{Cu}$ & $1 / 1$ & 71 & -- & -- & $\mathrm{Cu}$ & $1 / 1$ & 78 & -- \\
\hline $\mathrm{Zn}$ & $1 / 1$ & 123 & -- & -- & $\mathrm{Zn}$ & $1 / 1$ & 132 & -- \\
\hline $\mathrm{Fe}$ & $1 / 1$ & 53,454 & - & - & $\mathrm{Fe}$ & $1 / 1$ & 57,709 & -- \\
\hline $\mathrm{Mn}$ & $1 / 1$ & 5,279 & - & -- & $\mathrm{Mn}$ & $1 / 1$ & 4,951 & -- \\
\hline $\mathrm{K}$ & $1 / 1$ & 4,666 & -- & -- & $\mathrm{K}$ & $1 / 1$ & 5,022 & -- \\
\hline $\mathrm{Al}$ & $1 / 1$ & 35,246 & -- & -- & $\mathrm{Al}$ & $1 / 1$ & 40,154 & -- \\
\hline $\mathrm{Li}$ & $1 / 1$ & 48 & -- & -- & $\mathrm{Li}$ & $1 / 1$ & 54 & -- \\
\hline $\mathrm{Ca}$ & $1 / 1$ & 5,209 & -- & - & $\mathrm{Ca}$ & $1 / 1$ & 4,073 & - \\
\hline $\mathrm{Na}$ & $1 / 1$ & 88 & -- & - & $\mathrm{Na}$ & $1 / 1$ & 97 & -- \\
\hline $\mathrm{Mg}$ & $1 / 1$ & 10,561 & -- & -- & $\mathrm{Mg}$ & $1 / 1$ & 11,308 & -- \\
\hline $\mathbf{L a}$ & $1 / 1$ & 9 & -- & -- & $\mathrm{La}$ & $1 / 1$ & 10 & -- \\
\hline $\mathrm{Sb}$ & $1 / 0$ & $<20$ & - & - & $\mathrm{Sb}$ & $1 / 0$ & $<20$ & -- \\
\hline $\mathrm{Pb}$ & $1 / 1$ & 16 & $\cdots$ & -- & $\mathrm{Pb}$ & $1 / 1$ & 14 & -- \\
\hline $\mathrm{Tl}$ & $1 / 0$ & $<50$ & -- & -- & $\mathrm{Tl}$ & $1 / 0$ & $<50$ & - \\
\hline As & $1 / 0$ & $<20$ & -- & -- & As & $1 / 0$ & $<20$ & -- \\
\hline $\mathrm{Se}$ & $1 / 0$ & $<30$ & -- & -- & $\mathrm{Se}$ & $1 / 0$ & $<30$ & -- \\
\hline $\mathrm{Hg}$ & $1 / 1$ & 0.07 & -- & -- & $\mathrm{Hg}$ & $1 / 1$ & 0.06 & -- \\
\hline
\end{tabular}

${ }^{\mathrm{I}}$ Detects are the number of samples with concentrations equal to or greater than the laboratory reporting limit.

${ }^{2}$ Only one concentration value for the soils is listed under arithmetic mean. 
Appendix 7.50. Distribution statistics for concentrations (in ppm of dry soil) of metals in soils on geologic unit "Tmss" (Marine sandstone \& siltstone; Eocene ). For sampling site \#(s) and physiographic province(s) see Appendix 2.

In A Horizon

In B Horizon

\begin{tabular}{|c|c|c|c|c|c|c|c|c|c|}
\hline Metal & $\begin{array}{l}\text { Total } \\
\text { sample } \\
\text { number/ } \\
\text { detects }{ }^{\prime}\end{array}$ & $\begin{array}{l}\text { Arith- } \\
\text { metic } \\
\text { mean }\end{array}$ & $\begin{array}{l}\text { Mini- } \\
\text { mum }\end{array}$ & $\begin{array}{l}\text { Maxi- } \\
\text { mum }\end{array}$ & Metal & $\begin{array}{l}\text { Total } \\
\text { sample } \\
\text { number/ } \\
\text { detects }^{1}\end{array}$ & $\begin{array}{l}\text { Arith- } \\
\text { metic } \\
\text { mean }\end{array}$ & $\begin{array}{l}\text { Mini- } \\
\text { mum }\end{array}$ & $\begin{array}{l}\text { Maxi- } \\
\text { mum }\end{array}$ \\
\hline $\mathrm{Ag}$ & $3 / 0$ & $<1$ & $<1$ & $<1$ & $\mathrm{Ag}$ & $3 / 0$ & $<1$ & $<1$ & $<1$ \\
\hline Mo & $3 / 0$ & $<5$ & $<5$ & $<5$ & Mo & $3 / 0$ & $<5$ & $<5$ & $<5$ \\
\hline $\mathrm{Cd}$ & $3 / 1$ & $<1^{*}$ & $<1$ & 1 & $\mathrm{Cd}$ & $3 / 0$ & $<1$ & $<1$ & $<1$ \\
\hline $\mathrm{Ba}$ & $3 / 3$ & 284 & 281 & 287 & $\mathrm{Ba}$ & $3 / 3$ & 153 & 124 & 190 \\
\hline $\mathrm{Be}$ & $3 / 0$ & $<1$ & $<1$ & $<1$ & $\mathrm{Be}$ & $3 / 0$ & $<1$ & $<1$ & $<1$ \\
\hline $\mathrm{Ni}$ & $3 / 3$ & 70 & 54 & 81 & $\mathrm{Ni}$ & $3 / 0$ & 95 & 61 & 112 \\
\hline Co & $3 / 3$ & 17 & 16 & 17 & Co & $3 / 3$ & 22 & 19 & 24 \\
\hline $\mathrm{Cr}$ & $3 / 3$ & 72 & 51 & 96 & $\mathrm{Cr}$ & $3 / 3$ & 98 & 62 & 135 \\
\hline V & $3 / 3$ & 55 & 39 & 74 & $\mathrm{~V}$ & $3 / 3$ & 71 & 48 & 94 \\
\hline $\mathrm{Cu}$ & $3 / 3$ & 18 & 16 & 22 & $\mathrm{Cu}$ & $3 / 3$ & 24 & 20 & 26 \\
\hline $\mathrm{Zn}$ & $3 / 3$ & 81 & 66 & 89 & $\mathrm{Zn}$ & $3 / 3$ & 74 & 51 & 88 \\
\hline $\mathrm{Fe}$ & $3 / 3$ & 30,706 & 28,374 & 33,971 & $\mathrm{Fe}$ & $3 / 3$ & 40,365 & 32,982 & 45,439 \\
\hline $\mathrm{Mn}$ & $3 / 3$ & 2,240 & 1,454 & 2,857 & $\mathrm{Mn}$ & $3 / 3$ & 901 & 413 & 1,368 \\
\hline $\mathrm{K}$ & $3 / 3$ & 2,097 & 1,065 & 2,782 & $\mathrm{~K}$ & $3 / 3$ & 2,140 & 1,284 & 2,649 \\
\hline $\mathrm{Al}$ & $3 / 3$ & 28,170 & 24,253 & 35,732 & $\mathrm{Al}$ & $3 / 3$ & 39,404 & 29,474 & 52,244 \\
\hline $\mathrm{Li}$ & $3 / 3$ & 24 & 20 & 27 & $\mathrm{Li}$ & $3 / 3$ & 32 & 26 & 35 \\
\hline $\mathrm{Ca}$ & $3 / 3$ & 5,454 & 4,972 & 6,109 & $\mathrm{Ca}$ & $3 / 3$ & 1,486 & 376 & 2,942 \\
\hline $\mathrm{Na}$ & $3 / 3$ & 93 & 75 & 124 & $\mathrm{Na}$ & $3 / 3$ & 98 & 82 & 130 \\
\hline $\mathrm{Mg}$ & $3 / 3$ & 6,560 & 4,714 & 8,116 & $\mathrm{Mg}$ & $3 / 3$ & 8,227 & 6,420 & 10,379 \\
\hline $\mathrm{La}$ & $3 / 3$ & 9 & 5 & 13 & $\mathrm{La}$ & $3 / 3$ & 12 & 9 & 15 \\
\hline $\mathrm{Sb}$ & $3 / 0$ & $<20$ & $<20$ & $<20$ & $\mathrm{Sb}$ & $3 / 0$ & $<20$ & $<20$ & $<20$ \\
\hline $\mathrm{Pb}$ & $3 / 1$ & $<10^{*}$ & $<10$ & 10 & $\mathrm{~Pb}$ & $3 / 1$ & $<10^{*}$ & $<10$ & 10 \\
\hline $\mathrm{Tl}$ & $3 / 0$ & $<50$ & $<50$ & $<50$ & $\mathrm{Tl}$ & $3 / 0$ & $<50$ & $<50$ & $<50$ \\
\hline As & $3 / 0$ & $<20$ & $<20$ & $<20$ & As & $3 / 0$ & $<20$ & $<20$ & $<20$ \\
\hline $\mathrm{Se}$ & $3 / 0$ & $<30$ & $<30$ & $<30$ & $\mathrm{Se}$ & $3 / 0$ & $<30$ & $<30$ & $<30$ \\
\hline $\mathrm{Hg}$ & $3 / 3$ & 0.09 & 0.06 & 0.12 & $\mathrm{Hg}$ & $3 / 3$ & 0.05 & 0.04 & 0.08 \\
\hline
\end{tabular}

${ }^{1}$ Detects are the number of samples with concentrations equal to or greater than the laboratory reporting limit.

* Where the concentration of a metal in a sample is less than the laboratory minimum reporting level, the minimum reporting level is used for calculating arithmetic mean, and the arithmetic mean is qualified as less than the value given. 
Appendix 7.51. Distribution statistics for concentrations (in ppm of dry soil) of metals in soils on geologic unit "Tmv" (Mafic vent complexes; Miocene). For sampling site \#(s) and physiographic province(s) see Appendix 2.

In A Horizon

In B Horizon

\begin{tabular}{|c|c|c|c|c|c|c|c|c|}
\hline Metal & $\begin{array}{l}\text { Total } \\
\text { sample } \\
\text { number/ } \\
\text { detects }{ }^{1}\end{array}$ & $\begin{array}{l}\text { Arith- } \\
\text { metic } \\
\text { mean }^{2}\end{array}$ & $\begin{array}{l}\text { Mini- } \\
\text { mum }\end{array}$ & $\begin{array}{l}\text { Maxi- } \\
\text { mum }\end{array}$ & Metal & $\begin{array}{l}\text { Total } \\
\text { sample } \\
\text { number/ } \\
\text { detects }\end{array}$ & $\begin{array}{l}\text { Arith- } \\
\text { metic } \\
\text { mean }\end{array}$ & $\begin{array}{l}\text { Mini- } \\
\text { mum }\end{array}$ \\
\hline
\end{tabular}

\begin{tabular}{|c|c|c|c|c|c|c|c|c|c|}
\hline $\mathrm{Ag}$ & $1 / 0$ & $<1$ & -- & -- & $\mathrm{Ag}$ & $1 / 0$ & $<1$ & -- & -- \\
\hline Mo & $1 / 0$ & $<5$ & -- & -- & Mo & $1 / 0$ & $<5$ & -- & -- \\
\hline $\mathrm{Cd}$ & $1 / 0$ & $<1$ & -- & -- & $\mathrm{Cd}$ & $1 / 0$ & $<1$ & -- & -- \\
\hline $\mathrm{Ba}$ & $1 / 1$ & 199 & -- & -- & $\mathrm{Ba}$ & $1 / 1$ & 138 & -- & -- \\
\hline $\mathrm{Be}$ & $1 / 0$ & $<1$ & -- & -- & $\mathrm{Be}$ & $1 / 0$ & $<1$ & - & -- \\
\hline $\mathrm{Ni}$ & $1 / 1$ & 10 & -- & -- & $\mathrm{Ni}$ & $1 / 1$ & 13 & - & -- \\
\hline Co & $1 / 1$ & 6 & -- & -- & Co & $1 / 1$ & 7 & -- & -- \\
\hline $\mathrm{Cr}$ & $1 / 1$ & 5 & -- & -- & $\mathrm{Cr}$ & $1 / 1$ & 7 & -- & -- \\
\hline $\mathrm{V}$ & $1 / 1$ & 29 & - & -- & $\mathrm{V}$ & $1 / 1$ & 37 & - & - \\
\hline $\mathrm{Cu}$ & $1 / 1$ & 11 & -- & - & $\mathrm{Cu}$ & $1 / 1$ & 20 & -- & -- \\
\hline $\mathrm{Zn}$ & $1 / 1$ & 63 & -- & -- & $\mathrm{Zn}$ & $1 / 1$ & 41 & -- & -- \\
\hline $\mathrm{Fe}$ & $1 / 1$ & 10,938 & -- & - & $\mathrm{Fe}$ & $1 / 1$ & 13,445 & -- & -- \\
\hline $\mathrm{Mn}$ & $1 / 1$ & 1,010 & -- & -- & $\mathrm{Mn}$ & $1 / 1$ & 191 & -- & -- \\
\hline $\mathrm{K}$ & $1 / 1$ & 453 & -- & - & $\mathrm{K}$ & $1 / 1$ & 438 & -- & -- \\
\hline Al & $1 / 1$ & 14,686 & - & -- & $\mathrm{Al}$ & $1 / 1$ & 18,999 & - & -- \\
\hline $\mathrm{Li}$ & $1 / 1$ & 7 & -- & -- & $\mathrm{Li}$ & $1 / 1$ & 9 & $\cdots$ & -- \\
\hline $\mathrm{Ca}$ & $1 / 1$ & 3,181 & -- & -- & $\mathrm{Ca}$ & $1 / 1$ & 2,516 & -- & -- \\
\hline $\mathrm{Na}$ & $1 / 1$ & 538 & -- & -- & $\mathrm{Na}$ & $1 / 1$ & 762 & -- & - \\
\hline $\mathrm{Mg}$ & $1 / 1$ & 1,120 & -- & - & $\mathrm{Mg}$ & $1 / 1$ & 1,507 & - & -- \\
\hline $\mathrm{La}$ & $1 / 0$ & $<5$ & - & - & $\mathrm{La}$ & $1 / 1$ & 8 & -- & - \\
\hline $\mathrm{Sb}$ & $1 / 0$ & $<20$ & -- & -- & $\mathrm{Sb}$ & $1 / 0$ & $<20$ & -- & -- \\
\hline $\mathrm{Pb}$ & $1 / 1$ & 10 & -- & - & $\mathrm{Pb}$ & $1 / 0$ & $<10$ & -- & - \\
\hline $\mathrm{Tl}$ & $1 / 0$ & $<50$ & - & -- & $\mathrm{TI}$ & $1 / 0$ & $<50$ & -- & - \\
\hline As & $1 / 0$ & $<20$ & -- & - & As & $1 / 0$ & $<20$ & -- & -- \\
\hline $\mathrm{Se}$ & $1 / 0$ & $<30$ & - & - & $\mathrm{Se}$ & $1 / 0$ & $<30$ & - & -- \\
\hline $\mathrm{Hg}$ & $1 / 1$ & 0.07 & - & -- & $\mathrm{Hg}$ & $1 / 0$ & $<0.04$ & -- & -- \\
\hline
\end{tabular}

${ }^{1}$ Detects are the number of samples with concentrations equal to or greater than the laboratory reporting limit.

${ }^{2}$ Only one concentration value for the soils is listed under arithmetic mean. 
Appendix 7.52. Distribution statistics for concentrations (in ppm of dry soil) of metals in soils on geologic unit "Tn" (Non-marine sedimentary rocks; Eocene). For sampling site \#(s) and physiographic province(s) see Appendix 2.

In A Horizon

In B Horizon

\begin{tabular}{|c|c|c|c|c|c|c|c|c|c|}
\hline Metal & $\begin{array}{l}\text { Total } \\
\text { sample } \\
\text { number/ } \\
\text { detects }^{1}\end{array}$ & $\begin{array}{l}\text { Arith- } \\
\text { metic } \\
\text { mean }\end{array}$ & $\begin{array}{l}\text { Mini- } \\
\text { mum }\end{array}$ & $\begin{array}{l}\text { Maxi- } \\
\text { mum }\end{array}$ & Metal & $\begin{array}{l}\text { Total } \\
\text { sample } \\
\text { number/ } \\
\text { detects }^{1}\end{array}$ & $\begin{array}{l}\text { Arith- } \\
\text { metic } \\
\text { mean }\end{array}$ & $\begin{array}{l}\text { Mini- } \\
\text { mum }\end{array}$ & $\begin{array}{l}\text { Maxi- } \\
\text { mum }\end{array}$ \\
\hline $\mathrm{Ag}$ & $3 / 0$ & $<1$ & $<1$ & $<1$ & $\mathrm{Ag}$ & $3 / 0$ & $<1$ & $<1$ & $<1$ \\
\hline Mo & $3 / 0$ & $<5$ & $<5$ & $<5$ & Mo & $3 / 0$ & $<5$ & $<5$ & $<5$ \\
\hline $\mathrm{Cd}$ & $3 / 0$ & $<1$ & $<1$ & $<1$ & $\mathrm{Cd}$ & $3 / 0$ & $<1$ & $<1$ & $<1$ \\
\hline $\mathrm{Ba}$ & $3 / 3$ & 118 & 89 & 175 & $\mathrm{Ba}$ & $3 / 3$ & 117 & 83 & 170 \\
\hline $\mathrm{Be}$ & $3 / 0$ & $<1$ & $<1$ & $<1$ & $\mathrm{Be}$ & $3 / 0$ & $<1$ & $<1$ & $<1$ \\
\hline $\mathrm{Ni}$ & $3 / 3$ & 22 & 12 & 42 & $\mathrm{Ni}$ & $3 / 3$ & 26 & 14 & 48 \\
\hline Co & $3 / 3$ & 11 & 7 & 17 & $\mathrm{Co}$ & $3 / 3$ & 13 & 10 & 19 \\
\hline $\mathrm{Cr}$ & $3 / 3$ & 39 & 19 & 72 & $\mathrm{Cr}$ & $3 / 3$ & 46 & 23 & 81 \\
\hline V & $3 / 3$ & 55 & 30 & 75 & $\mathrm{~V}$ & $3 / 3$ & 65 & 38 & 88 \\
\hline $\mathrm{Cu}$ & $3 / 3$ & 22 & 8 & 41 & $\mathrm{Cu}$ & $3 / 3$ & 23 & 11 & 42 \\
\hline $\mathrm{Zn}$ & $3 / 3$ & 65 & 52 & 80 & $\mathrm{Zn}$ & $3 / 3$ & 59 & 43 & 75 \\
\hline $\mathrm{Fe}$ & $3 / 3$ & 25,483 & 14,403 & 37,541 & $\mathrm{Fe}$ & $3 / 3$ & 29,472 & 18,012 & 41,104 \\
\hline $\mathrm{Mn}$ & $3 / 3$ & 584 & 561 & 625 & $\mathrm{Mn}$ & $3 / 3$ & 633 & 571 & 737 \\
\hline K & $3 / 3$ & 3,234 & 2,296 & 4,541 & $\mathrm{~K}$ & $3 / 3$ & 2,652 & 2,025 & 3,571 \\
\hline $\mathrm{Al}$ & $3 / 3$ & 26,499 & 9,909 & 51,739 & $\mathrm{Al}$ & $3 / 3$ & 31,676 & 13,527 & 56,018 \\
\hline $\mathrm{Li}$ & $3 / 3$ & 10 & 5 & 15 & $\mathrm{Li}$ & $3 / 3$ & 11 & 6 & 16 \\
\hline $\mathrm{Ca}$ & $3 / 3$ & 7,668 & 3,446 & 13,409 & $\mathrm{Ca}$ & $3 / 3$ & 6,690 & 1,900 & 12,246 \\
\hline $\mathrm{Na}$ & $3 / 3$ & 182 & 158 & 220 & $\mathrm{Na}$ & $3 / 3$ & 160 & 157 & 163 \\
\hline $\mathrm{Mg}$ & $3 / 3$ & 4,977 & 3,463 & 6,914 & $\mathrm{Mg}$ & $3 / 3$ & 5,507 & 4,174 & 7,317 \\
\hline $\mathrm{La}$ & $3 / 3$ & 15 & 11 & 18 & $\mathrm{La}$ & $3 / 3$ & 18 & 15 & 23 \\
\hline $\mathrm{Sb}$ & $3 / 0$ & $<20$ & $<20$ & $<20$ & $\mathrm{Sb}$ & $3 / 0$ & $<20$ & $<20$ & $<20$ \\
\hline $\mathrm{Pb}$ & $3 / 2$ & $<14^{*}$ & $<10$ & 21 & $\mathrm{~Pb}$ & $3 / 1$ & $<11^{*}$ & $<10$ & 12 \\
\hline $\mathrm{Tl}$ & $3 / 0$ & $<50$ & $<50$ & $<50$ & $\mathrm{Tl}$ & $3 / 0$ & $<50$ & $<50$ & $<50$ \\
\hline As & $3 / 0$ & $<20$ & $<20$ & $<20$ & As & $3 / 0$ & $<20$ & $<20$ & $<20$ \\
\hline $\mathrm{Se}$ & $3 / 0$ & $<30$ & $<30$ & $<30$ & $\mathrm{Se}$ & $3 / 0$ & $<30$ & $<30$ & $<30$ \\
\hline $\mathrm{Hg}$ & $3 / 0$ & $<0.04$ & $<0.04$ & $<0.04$ & $\mathrm{Hg}$ & $3 / 0$ & $<0.04$ & $<0.04$ & $<0.04$ \\
\hline
\end{tabular}

${ }^{1}$ Detects are the number of samples with concentrations equal to or greater than the laboratory reporting limit.

* Where the concentration of a metal in a sample is less than the laboratory minimum reporting level, the minimum reporting level is used for calculating arithmetic mean, and the arithmetic mean is qualified as less than the value given. 
Appendix 7.53. Distribution statistics for concentrations (in ppm of dry soil) of metals in soils on geologic unit "Tob" (Olivine basalt; Pliocene \& Miocene). For sampling site \#(s) and physiographic province(s) see Appendix 2.

In A Horizon

In B Horizon

\begin{tabular}{|c|c|c|c|c|c|c|c|c|c|}
\hline Metal & $\begin{array}{l}\text { Total } \\
\text { sample } \\
\text { number/ } \\
\text { detects }{ }^{1}\end{array}$ & $\begin{array}{l}\text { Arith- } \\
\text { metic } \\
\text { mean }\end{array}$ & $\begin{array}{l}\text { Mini- } \\
\text { mum }\end{array}$ & $\begin{array}{l}\text { Maxi- } \\
\text { mum }\end{array}$ & Metal & $\begin{array}{l}\text { Total } \\
\text { sample } \\
\text { number/ } \\
\text { detects }\end{array}$ & $\begin{array}{l}\text { Arith- } \\
\text { metic } \\
\text { mean }\end{array}$ & $\begin{array}{l}\text { Mini- } \\
\text { mum }\end{array}$ & $\begin{array}{l}\text { Maxi- } \\
\text { mum }\end{array}$ \\
\hline
\end{tabular}

\begin{tabular}{|c|c|c|c|c|c|c|c|c|c|}
\hline $\mathrm{Ag}$ & $2 / 0$ & $<1$ & $<1$ & $<1$ & $\mathrm{Ag}$ & $2 / 0$ & $<1$ & $<1$ & $<1$ \\
\hline Mo & $2 / 0$ & $<5$ & $<5$ & $<5$ & Mo & $2 / 0$ & $<5$ & $<5$ & $<5$ \\
\hline $\mathrm{Cd}$ & $2 / 0$ & $<1$ & $<1$ & $<1$ & $\mathrm{Cd}$ & $2 / 0$ & $<1$ & $<1$ & $<1$ \\
\hline $\mathrm{Ba}$ & $2 / 2$ & 94 & 67 & 122 & $\mathrm{Ba}$ & $2 / 2$ & 97 & 71 & 122 \\
\hline $\mathrm{Be}$ & $2 / 0$ & $<1$ & $<1$ & $<1$ & $\mathrm{Be}$ & $2 / 0$ & $<1$ & $<1$ & $<1$ \\
\hline $\mathrm{Ni}$ & $2 / 2$ & 9 & 6 & 13 & $\mathrm{Ni}$ & $2 / 2$ & 9 & 5 & 13 \\
\hline Co & $2 / 1$ & $<7^{*}$ & $<6$ & 7 & Co & $2 / 1$ & $<7^{*}$ & $<6$ & 7 \\
\hline $\mathrm{Cr}$ & $2 / 2$ & 5 & 4 & 5 & $\mathrm{Cr}$ & $2 / 2$ & 6 & 4 & 7 \\
\hline V & $2 / 2$ & 30 & 24 & 36 & $\mathrm{~V}$ & $2 / 2$ & 30 & 25 & 36 \\
\hline $\mathrm{Cu}$ & $2 / 2$ & 18 & 9 & 27 & $\mathrm{Cu}$ & $2 / 2$ & 18 & 10 & 27 \\
\hline $\mathrm{Zn}$ & $2 / 2$ & 41 & 32 & 50 & $\mathrm{Zn}$ & $2 / 2$ & 70 & 50 & 91 \\
\hline $\mathrm{Fe}$ & $2 / 2$ & 10,472 & 8,340 & 12,603 & $\mathrm{Fe}$ & $2 / 2$ & 11,415 & 8,615 & 14,215 \\
\hline $\mathrm{Mn}$ & $2 / 2$ & 1,668 & 287 & 3,049 & $\mathrm{Mn}$ & $2 / 2$ & 130 & 124 & 135 \\
\hline K & $2 / 2$ & 688 & 541 & 836 & $\mathrm{~K}$ & $2 / 2$ & 455 & 404 & 506 \\
\hline $\mathrm{Al}$ & $2 / 2$ & 15,462 & 13,830 & 17,095 & $\mathrm{Al}$ & $2 / 2$ & 16,123 & 13,989 & 18,256 \\
\hline $\mathrm{Li}$ & $2 / 1$ & $<7^{*}$ & $<5$ & 8 & $\mathrm{Li}$ & $2 / 1$ & $<8^{*}$ & 5 & 10 \\
\hline $\mathrm{Ca}$ & $2 / 2$ & 4,003 & 3,341 & 4,664 & $\mathrm{Ca}$ & $2 / 2$ & 2,978 & 2,523 & 3,432 \\
\hline $\mathrm{Na}$ & $2 / 2$ & 595 & 561 & 628 & $\mathrm{Na}$ & 628 & 600 & 655 & \\
\hline $\mathrm{Mg}$ & $2 / 2$ & 1,609 & 1,164 & 2,055 & $\mathrm{Mg}$ & $2 / 2$ & 1,441 & 967 & 1,915 \\
\hline $\mathrm{La}$ & $2 / 1$ & $<5^{*}$ & $<5$ & 5 & $\mathrm{La}$ & $2 / 1$ & $<8^{*}$ & 5 & 10 \\
\hline $\mathrm{Sb}$ & $2 / 0$ & $<20$ & $<20$ & $<20$ & $\mathrm{Sb}$ & $2 / 0$ & $<20$ & $<20$ & $<20$ \\
\hline $\mathrm{Pb}$ & $2 / 0$ & $<10$ & $<10$ & $<10$ & $\mathrm{~Pb}$ & $2 / 1$ & $<10^{*}$ & $<10$ & 10 \\
\hline $\mathrm{Tl}$ & $2 / 0$ & $<50$ & $<50$ & $<50$ & $\mathrm{TI}$ & $2 / 0$ & $<50$ & $<50$ & $<50$ \\
\hline As & $2 / 0$ & $<20$ & $<20$ & $<20$ & As & $2 / 0$ & $<20$ & $<20$ & $<20$ \\
\hline $\mathrm{Se}$ & $2 / 0$ & $<30$ & $<30$ & $<30$ & Se & $2 / 0$ & $<30$ & $<30$ & $<30$ \\
\hline $\mathrm{Hg}$ & $2 / 2$ & 0.05 & 0.04 & 0.06 & $\mathrm{Hg}$ & $2 / 1$ & $<0.05^{*}$ & $<0.04$ & 0.06 \\
\hline
\end{tabular}

${ }^{1}$ Detects are the number of samples with concentrations equal to or greater than the laboratory reporting limit.

* Where the concentration of a metal in a sample is less than the laboratory minimum reporting level, the minimum reporting level is used for calculating arithmetic mean, and the arithmetic mean is qualified as less than the value given. 
Appendix 7.54. Distribution statistics for concentrations (in ppm of dry soil) of metals in soils on geologic unit "Tp" (Basaltic \& andesitic ejecta; Pliocene \& Miocene). For sampling site \#(s) and physiographic province(s) see Appendix 2.

In A Horizon

In B Horizon

\begin{tabular}{|c|c|c|c|c|c|c|c|c|}
\hline Metal & $\begin{array}{l}\text { Total } \\
\text { sample } \\
\text { number/ } \\
\text { detects }^{1}\end{array}$ & $\begin{array}{l}\text { Arith- } \\
\text { metic } \\
\text { mean }^{2}\end{array}$ & $\begin{array}{l}\text { Mini- } \\
\text { mum }\end{array}$ & $\begin{array}{l}\text { Maxi- } \\
\text { mum }\end{array}$ & Metal & $\begin{array}{l}\text { Total } \\
\text { sample } \\
\text { number/ } \\
\text { detects }^{1}\end{array}$ & $\begin{array}{l}\text { Arith- } \\
\text { metic } \\
\text { mean }^{2}\end{array}$ & $\begin{array}{l}\text { Mini- } \\
\text { mum }\end{array}$ \\
\hline $\mathrm{Ag}$ & $1 / 0$ & $<1$ & -- & -- & $\mathrm{Ag}$ & $1 / 0$ & $<1$ & -- \\
\hline Mo & $1 / 0$ & $<5$ & -- & -- & Mo & $1 / 0$ & $<5$ & -- \\
\hline $\mathrm{Cd}$ & $1 / 0$ & $<1$ & -- & -- & $\mathrm{Cd}$ & $1 / 0$ & $<1$ & -- \\
\hline $\mathrm{Ba}$ & $1 / 1$ & 113 & - & -- & $\mathrm{Ba}$ & $1 / 1$ & 189 & -- \\
\hline $\mathrm{Be}$ & $1 / 0$ & $<1$ & - & -- & $\mathrm{Be}$ & $1 / 0$ & $<1$ & - \\
\hline $\mathrm{Ni}$ & $1 / 1$ & 14 & -- & -- & $\mathrm{Ni}$ & $1 / 1$ & 44 & -- \\
\hline Co & $1 / 1$ & 6 & -- & -- & Co & $1 / 1$ & 15 & - \\
\hline $\mathrm{Cr}$ & $1 / 1$ & 8 & -- & -- & $\mathrm{Cr}$ & $1 / 1$ & 30 & -- \\
\hline $\mathrm{V}$ & $1 / 1$ & 32 & -- & -- & $\mathrm{V}$ & $1 / 1$ & 51 & -- \\
\hline $\mathrm{Cu}$ & $1 / 1$ & 13 & -- & -- & $\mathrm{Cu}$ & $1 / 1$ & 30 & -- \\
\hline $\mathrm{Zn}$ & 68 & -- & -- & & $\mathrm{Zn}$ & $1 / 1$ & 50 & -- \\
\hline $\mathrm{Fe}$ & $1 / 1$ & 11,845 & -- & - & $\mathrm{Fe}$ & $1 / 1$ & 26,278 & - \\
\hline $\mathrm{Mn}$ & $1 / 1$ & 757 & -- & -- & $\mathrm{Mn}$ & $1 / 1$ & 473 & -- \\
\hline K & $1 / 1$ & 634 & -- & -- & $\mathrm{K}$ & $1 / 1$ & 1,341 & -- \\
\hline $\mathrm{Al}$ & $1 / 1$ & 16,529 & -- & - & $\mathrm{Al}$ & $1 / 1$ & 34,967 & -- \\
\hline $\mathrm{Li}$ & $1 / 1$ & 5 & -- & -- & $\mathrm{Li}$ & $1 / 1$ & 9 & -- \\
\hline $\mathrm{Ca}$ & $1 / 1$ & 4,436 & -- & -- & $\mathrm{Ca}$ & $1 / 1$ & 3,880 & -- \\
\hline $\mathrm{Na}$ & $1 / 1$ & 655 & - & - & $\mathrm{Na}$ & $1 / 1$ & 730 & -- \\
\hline $\mathrm{Mg}$ & $1 / 1$ & 1,333 & -- & -- & $\mathrm{Mg}$ & $1 / 1$ & 5,079 & -- \\
\hline $\mathrm{La}$ & $1 / 0$ & $<5$ & -- & -- & $\mathrm{La}$ & $1 / 1$ & 7 & -- \\
\hline $\mathrm{Sb}$ & $1 / 0$ & $<20$ & - & - & $\mathrm{Sb}$ & $1 / 0$ & $<20$ & -- \\
\hline $\mathrm{Pb}$ & $1 / 0$ & $<10$ & -- & -- & $\mathrm{Pb}$ & $1 / 0$ & $<10$ & -- \\
\hline $\mathrm{Tl}$ & $1 / 0$ & $<50$ & -- & -- & $\mathrm{Tl}$ & $1 / 0$ & $<50$ & -- \\
\hline As & $1 / 0$ & $<20$ & -- & -- & As & $1 / 0$ & $<20$ & -- \\
\hline $\mathrm{Se}$ & $1 / 0$ & $<30$ & -- & -- & $\mathrm{Se}$ & $1 / 0$ & $<30$ & -- \\
\hline $\mathrm{Hg}$ & $1 / 1$ & 0.06 & -- & -- & $\mathrm{Hg}$ & $1 / 1$ & 0.04 & -- \\
\hline
\end{tabular}

${ }^{1}$ Detects are the number of samples with concentrations equal to or greater than the laboratory reporting limit.

${ }^{2}$ Only one concentration value for the soils is listed under arithmetic mean. 
Appendix 7.55. Distribution statistics for concentrations (in ppm of dry soil) of metals in soils on geologic unit "Tpb" (Porphyritic basalt; Eocene). For sampling site \#(s) and physiographic province(s) see Appendix 2.

In A Horizon

In B Horizon

\begin{tabular}{|c|c|c|c|c|c|c|c|c|c|}
\hline Metal & $\begin{array}{l}\text { Total } \\
\text { sample } \\
\text { number/ } \\
\text { detects }^{1}\end{array}$ & $\begin{array}{l}\text { Arith- } \\
\text { metic } \\
\text { mean }\end{array}$ & $\begin{array}{l}\text { Mini- } \\
\text { mum }\end{array}$ & $\begin{array}{l}\text { Maxi- } \\
\text { mum }\end{array}$ & Metal & $\begin{array}{l}\text { Total } \\
\text { sample } \\
\text { number/ } \\
\text { detects }^{1}\end{array}$ & $\begin{array}{l}\text { Arith- } \\
\text { metic } \\
\text { mean }^{2}\end{array}$ & $\begin{array}{l}\text { Mini- } \\
\text { mum }\end{array}$ & $\begin{array}{l}\text { Maxi- } \\
\text { mum }\end{array}$ \\
\hline $\mathrm{Ag}$ & $1 / 0$ & $<1$ & -. & -- & $\mathrm{Ag}$ & $1 / 0$ & $<1$ & -- & -- \\
\hline Mo & $1 / 0$ & $<5$ & - & -- & Mo & $1 / 0$ & $<5$ & -- & -- \\
\hline $\mathrm{Cd}$ & $1 / 1$ & 1 & - & -- & $\mathrm{Cd}$ & $1 / 1$ & 1 & - & - \\
\hline $\mathrm{Ba}$ & $1 / 1$ & 118 & - & - & $\mathrm{Ba}$ & $1 / 1$ & 91 & - & -- \\
\hline $\mathrm{Be}$ & $1 / 0$ & $<1$ & -- & -- & $\mathrm{Be}$ & $1 / 0$ & $<1$ & - & -- \\
\hline $\mathrm{Ni}$ & $1 / 1$ & 117 & -- & - & $\mathrm{Ni}$ & $1 / 1$ & 163 & -- & -- \\
\hline Co & $1 / 1$ & 45 & -. & -- & Co & $1 / 1$ & 56 & -- & -- \\
\hline $\mathrm{Cr}$ & $1 / 1$ & 120 & -- & -- & $\mathrm{Cr}$ & $1 / 1$ & 161 & - & - \\
\hline V & $1 / 1$ & 117 & -- & - & $\mathrm{V}$ & $1 / 1$ & 150 & - & - \\
\hline $\mathrm{Cu}$ & $1 / 1$ & 65 & -- & -- & $\mathrm{Cu}$ & $1 / 1$ & 90 & -- & -- \\
\hline $\mathrm{Zn}$ & $1 / 1$ & 105 & -- & -- & $\mathrm{Zn}$ & $1 / 1$ & 136 & -- & -- \\
\hline $\mathrm{Fe}$ & $1 / 1$ & 78,302 & - & -- & $\mathrm{Fe}$ & $1 / 1$ & 98,169 & -- & -- \\
\hline $\mathrm{Mn}$ & $1 / 1$ & 1,988 & - & -- & $\mathrm{Mn}$ & $1 / 1$ & 1,765 & -- & -- \\
\hline K & $1 / 1$ & 947 & -- & -- & $\mathrm{K}$ & $1 / 1$ & 822 & $\cdots$ & - \\
\hline $\mathrm{Al}$ & $1 / 1$ & 61,316 & -- & -- & $\mathrm{Al}$ & $1 / 1$ & 85,402 & -- & -- \\
\hline $\mathrm{Li}$ & $1 / 1$ & 18 & -- & -- & $\mathrm{Li}$ & $1 / 1$ & 25 & -- & -- \\
\hline $\mathrm{Ca}$ & $1 / 1$ & 3,051 & - & - & $\mathrm{Ca}$ & $1 / 1$ & 608 & -- & -- \\
\hline $\mathrm{Na}$ & $1 / 1$ & 198 & -- & -- & $\mathrm{Na}$ & $1 / 1$ & 163 & -. & - \\
\hline $\mathrm{Mg}$ & $1 / 1$ & 7,410 & -- & - & $\mathrm{Mg}$ & $1 / 1$ & 8,673 & - & - \\
\hline $\mathrm{La}$ & $1 / 1$ & 21 & -- & -- & $\mathrm{La}$ & $1 / 1$ & 27 & -- & -- \\
\hline $\mathrm{Sb}$ & $1 / 0$ & $<20$ & - & - & $\mathrm{Sb}$ & $1 / 0$ & $<20$ & -- & -- \\
\hline $\mathrm{Pb}$ & $1 / 0$ & $<10$ & -- & -- & $\mathrm{Pb}$ & $1 / 0$ & $<10$ & -- & - \\
\hline $\mathrm{Tl}$ & $1 / 0$ & $<50$ & -- & - & $\mathbf{T l}$ & $1 / 0$ & $<50$ & -- & -- \\
\hline As & $1 / 0$ & $<20$ & -- & - & As & $1 / 0$ & $<20$ & -- & - \\
\hline $\mathrm{Se}$ & $1 / 0$ & $<30$ & -- & -- & $\mathrm{Se}$ & $1 / 0$ & $<30$ & -- & -- \\
\hline $\mathrm{Hg}$ & $1 / 1$ & 0.21 & -- & - & $\mathrm{Hg}$ & $1 / 1$ & 0.11 & - & -- \\
\hline
\end{tabular}

'Detects are the number of samples with concentrations equal to or greater than the laboratory reporting limit.

${ }^{2}$ Only one concentration value for the soils is listed under arithmetic mean. 
Appendix 7.56. Distribution statistics for concentrations (in ppm of dry soil) of metals in soils on geologic unit "Tps" (Subaqueous pyroclastic rocks of basaltic cinder cones; Pliocene \& Miocene). For sampling site \#(s) and physiographic province(s) see Appendix 2.

In A Horizon

In B Horizon

\begin{tabular}{|c|c|c|c|c|c|c|c|c|c|}
\hline Metal & $\begin{array}{l}\text { Total } \\
\text { sample } \\
\text { number/ } \\
\text { detects }^{1}\end{array}$ & $\begin{array}{l}\text { Arith- } \\
\text { metic } \\
\text { mean }^{2}\end{array}$ & $\begin{array}{l}\text { Mini- } \\
\text { mum }\end{array}$ & $\begin{array}{l}\text { Maxi- } \\
\text { mum }\end{array}$ & Metal & $\begin{array}{l}\text { Total } \\
\text { sample } \\
\text { number/ } \\
\text { detects }^{\prime}\end{array}$ & $\begin{array}{l}\text { Arith- } \\
\text { metic } \\
\text { mean }^{2}\end{array}$ & $\begin{array}{l}\text { Mini- } \\
\text { mum }\end{array}$ & $\begin{array}{l}\text { Maxi } \\
\text { mum }\end{array}$ \\
\hline $\mathrm{Ag}$ & $1 / 0$ & $<1$ & -- & -- & $\mathrm{Ag}$ & $1 / 0$ & $<1$ & -- & -- \\
\hline Mo & $1 / 0$ & $<5$ & -- & -- & Mo & $1 / 0$ & $<5$ & -- & -- \\
\hline $\mathrm{Cd}$ & $1 / 0$ & $<1$ & -- & -- & $\mathrm{Cd}$ & $1 / 0$ & $<1$ & - & -- \\
\hline $\mathrm{Ba}$ & $1 / 1$ & 182 & -- & -- & $\mathrm{Ba}$ & $1 / 1$ & 205 & -- & -- \\
\hline $\mathrm{Be}$ & $1 / 0$ & $<1$ & -- & -- & $\mathrm{Be}$ & $1 / 0$ & $<1$ & - & -- \\
\hline $\mathrm{Ni}$ & $1 / 1$ & 43 & -- & -- & $\mathrm{Ni}$ & $1 / 1$ & 53 & -- & -- \\
\hline Co & $1 / 1$ & 15 & -- & -- & Co & $1 / 1$ & 18 & -- & -- \\
\hline $\mathrm{Cr}$ & $1 / 1$ & $28-$ & -- & & $\mathrm{Cr}$ & $1 / 1$ & 34 & - & -- \\
\hline V & $1 / 1$ & 49 & -- & -- & V & $1 / 1$ & 63 & -- & -- \\
\hline $\mathrm{Cu}$ & $1 / 1$ & 28 & -- & -- & $\mathrm{Cu}$ & $1 / 1$ & 30 & -- & -- \\
\hline $\mathrm{Zn}$ & $1 / 1$ & 74 & -- & - & $\mathrm{Zn}$ & $1 / 1$ & 52 & -- & -- \\
\hline $\mathrm{Fe}$ & $1 / 1$ & 25,527 & - & - & $\mathrm{Fe}$ & $1 / 1$ & 29,284 & -- & -- \\
\hline $\mathrm{Mn}$ & $1 / 1$ & 635 & -- & -- & $\mathrm{Mn}$ & $1 / 1$ & 438 & -- & -- \\
\hline $\mathrm{K}$ & $1 / 1$ & 1,546 & -- & - & $\mathrm{K}$ & $1 / 1$ & 1,421 & - & -- \\
\hline $\mathrm{Al}$ & $1 / 1$ & 34,073 & -- & -- & $\mathrm{Al}$ & $1 / 1$ & 38,105 & -- & - \\
\hline $\mathrm{Li}$ & $1 / 1$ & 9 & -- & -- & $\mathrm{Li}$ & $1 / 1$ & 10 & -- & -- \\
\hline $\mathrm{Ca}$ & $1 / 1$ & 4,366 & -- & -- & $\mathrm{Ca}$ & $1 / 1$ & 4,137 & -- & -- \\
\hline $\mathrm{Na}$ & $1 / 1$ & 778 & - & -- & $\mathrm{Na}$ & $1 / 1$ & 830 & -- & -- \\
\hline $\mathrm{Mg}$ & $1 / 1$ & 4,927 & -- & - & $\mathrm{Mg}$ & $1 / 1$ & 5,989 & - & -- \\
\hline $\mathrm{La}$ & $1 / 1$ & 6 & -- & -- & La & $1 / 1$ & 8 & -- & -- \\
\hline $\mathrm{Sb}$ & $1 / 0$ & $<20$ & -- & -- & $\mathrm{Sb}$ & $1 / 0$ & $<20$ & -- & -- \\
\hline $\mathrm{Pb}$ & $1 / 0$ & $<10$ & - & - & $\mathrm{Pb}$ & $1 / 0$ & $<10$ & - & - \\
\hline $\mathrm{Tl}$ & $1 / 1$ & $<50$ & -- & - & $\mathrm{Tl}$ & $1 / 0$ & $<50$ & -- & -- \\
\hline As & $1 / 0$ & $<20$ & -- & - & As & $1 / 0$ & $<20$ & -- & -- \\
\hline $\mathrm{Se}$ & $1 / 0$ & $<30$ & -- & -- & $\mathrm{Se}$ & $1 / 0$ & $<30$ & -- & -- \\
\hline $\mathrm{Hg}$ & $1 / 0$ & $<0.04$ & - & -- & $\mathrm{Hg}$ & $1 / 0$ & $<0.04$ & -- & -- \\
\hline
\end{tabular}

${ }^{1}$ Detects are the number of samples with concentrations equal to or greater than the laboratory reporting limit.

${ }^{2}$ Only one concentration value for the soils is listed under arithmetic mean. 
Appendix 7.57. Distribution statistics for concentrations (in ppm of dry soil) of metals in soils on geologic unit "Trb" (Ridge capping basalt \& basaltic andesite; Pliocene \& Miocene). For sampling site \#(s) and physiographic province(s) see Appendix 2.

In A Horizon

In B Horizon

\begin{tabular}{|c|c|c|c|c|c|c|c|c|}
\hline Metal & $\begin{array}{l}\text { Total } \\
\text { sample } \\
\text { number/ } \\
\text { detects }^{1}\end{array}$ & $\begin{array}{l}\text { Arith- } \\
\text { metic } \\
\text { mean }^{2}\end{array}$ & $\begin{array}{l}\text { Mini- } \\
\text { mum }\end{array}$ & $\begin{array}{l}\text { Maxi- } \\
\text { mum }\end{array}$ & Metal & $\begin{array}{l}\text { Total } \\
\text { sample } \\
\text { number/ } \\
\text { detects }\end{array}$ & $\begin{array}{l}\text { Arith- } \\
\text { metic } \\
\text { mean }^{2}\end{array}$ & $\begin{array}{l}\text { Mini- } \\
\text { mum }\end{array}$ \\
\hline $\mathrm{Ag}$ & $1 / 0$ & $<1$ & -- & - & $\mathrm{Ag}$ & $1 / 0$ & $<1$ & -- \\
\hline Mo & $1 / 0$ & $<5$ & -- & -- & Mo & $1 / 0$ & $<5$ & - \\
\hline $\mathrm{Cd}$ & $1 / 0$ & $<1$ & - & -- & $\mathrm{Cd}$ & $1 / 1$ & 1 & - \\
\hline $\mathrm{Ba}$ & $1 / 1$ & 475 & -- & -- & $\mathrm{Ba}$ & $1 / 1$ & 484 & - \\
\hline $\mathrm{Be}$ & $1 / 0$ & $<1$ & -- & -- & $\mathrm{Be}$ & $1 / 0$ & $<1$ & -- \\
\hline $\mathrm{Ni}$ & $1 / 1$ & 63 & -- & -- & $\mathrm{Ni}$ & $1 / 1$ & 82 & -- \\
\hline Co & $1 / 1$ & 31 & - & -- & Co & $1 / 1$ & 46 & -- \\
\hline $\mathrm{Cr}$ & $1 / 1$ & 63 & -- & - & $\mathrm{Cr}$ & $1 / 1$ & 97 & -- \\
\hline V & $1 / 1$ & 116 & -- & -- & $\mathrm{V}$ & $1 / 1$ & 176 & -- \\
\hline $\mathrm{Cu}$ & $1 / 1$ & 52 & -- & -- & $\mathrm{Cu}$ & $1 / 1$ & 73 & -- \\
\hline $\mathrm{Zn}$ & $1 / 1$ & 151 & -- & -- & $\mathrm{Zn}$ & $1 / 1$ & 140 & -- \\
\hline $\mathrm{Fe}$ & $1 / 1$ & 55,108 & -- & -- & $\mathrm{Fe}$ & $1 / 1$ & 82,430 & -- \\
\hline $\mathrm{Mn}$ & $1 / 1$ & 4,571 & -- & -- & Mn & $1 / 1$ & 2,077 & - \\
\hline $\mathrm{K}$ & $1 / 1$ & 1,499 & -- & -- & $\mathrm{K}$ & $1 / 1$ & 1,072 & -- \\
\hline $\mathrm{Al}$ & $1 / 1$ & 77,558 & - & -- & Al & $1 / 1$ & 103,515 & -- \\
\hline $\mathrm{Li}$ & $1 / 1$ & 9 & -- & - & $\mathrm{Li}$ & $1 / 1$ & 12 & -- \\
\hline $\mathrm{Ca}$ & $1 / 1$ & 15,265 & - & -- & $\mathrm{Ca}$ & $1 / 1$ & 2,913 & - \\
\hline $\mathrm{Na}$ & $1 / 1$ & 135 & $\ldots$ & -- & $\mathrm{Na}$ & $1 / 1$ & 122 & - \\
\hline $\mathrm{Mg}$ & $1 / 1$ & 1,612 & -- & -- & $\mathrm{Mg}$ & $1 / 1$ & 1,683 & -- \\
\hline $\mathrm{La}$ & $1 / 1$ & 11 & -- & -- & $\mathrm{La}$ & $1 / 1$ & 17 & -- \\
\hline $\mathrm{Sb}$ & $1 / 0$ & $<20$ & -- & -- & $\mathrm{Sb}$ & $1 / 1$ & 20 & -- \\
\hline $\mathrm{Pb}$ & $1 / 0$ & $<10$ & - & -- & $\mathrm{Pb}$ & $1 / 0$ & $<10$ & -- \\
\hline $\mathrm{Tl}$ & $1 / 0$ & $<50$ & - & -- & $\mathrm{Tl}$ & $1 / 0$ & $<50$ & -- \\
\hline As & $1 / 0$ & $<20$ & -- & -- & As & $1 / 0$ & $<20$ & -- \\
\hline $\mathrm{Se}$ & $1 / 0$ & $<30$ & -. & - & $\mathrm{Se}$ & $1 / 0$ & $<30$ & -- \\
\hline $\mathrm{Hg}$ & $1 / 1$ & 0.17 & -- & -- & $\mathrm{Hg}$ & $1 / 1$ & 0.05 & -- \\
\hline
\end{tabular}

${ }^{1}$ Detects are the number of samples with concentrations equal to or greater than the laboratory reporting limit.

${ }^{2}$ Only one concentration value for the soils is listed under arithmetic mean. 
Appendix 7.58. Distribution statistics for concentrations (in ppm of dry soil) of metals in soils on geologic unit "Trh" (Rhyolite \& dacite; Pliocene \& Miocene). For sampling site \#(s) and physiographic province(s) see Appendix 2.

In A Horizon

\section{In B Horizon}

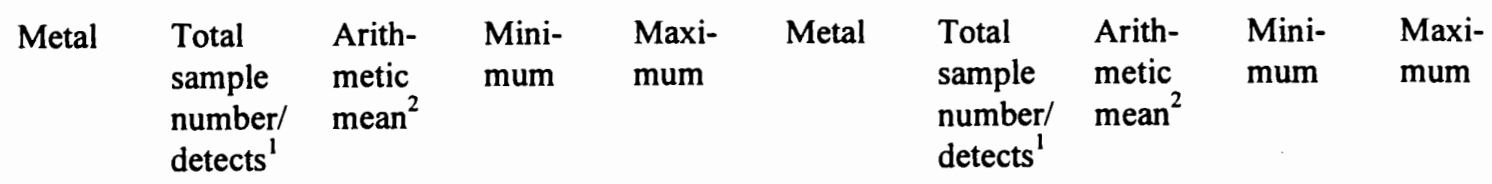

\begin{tabular}{|c|c|c|c|c|c|c|c|c|c|}
\hline $\mathrm{Ag}$ & $1 / 0$ & $<1$ & -- & -- & $\mathrm{Ag}$ & $1 / 0$ & $<1$ & -- & - \\
\hline Mo & $1 / 0$ & $<5$ & -- & -- & Mo & $1 / 0$ & $<5$ & -- & -- \\
\hline $\mathrm{Cd}$ & $1 / 0$ & $<1$ & -- & -- & $\mathrm{Cd}$ & $1 / 0$ & $<1$ & -- & -- \\
\hline $\mathrm{Ba}$ & $1 / 1$ & 432 & -- & -- & $\mathrm{Ba}$ & $1 / 1$ & 456 & -- & -- \\
\hline $\mathrm{Be}$ & $1 / 0$ & $<1$ & -- & -- & $\mathrm{Be}$ & $1 / 0$ & $<1$ & -- & -- \\
\hline $\mathrm{Ni}$ & $1 / 1$ & 31 & -- & -- & $\mathrm{Ni}$ & $1 / 1$ & 42 & - & -- \\
\hline Co & $1 / 1$ & 18 & -- & -- & Co & $1 / 1$ & 27 & -- & -- \\
\hline $\mathrm{Cr}$ & $1 / 1$ & 22 & - & -- & $\mathrm{Cr}$ & $1 / 1$ & 34 & -- & -- \\
\hline V & $1 / 1$ & 69 & -- & - & $\mathrm{V}$ & $1 / 1$ & 109 & - & -- \\
\hline $\mathrm{Cu}$ & $1 / 1$ & 37 & -- & - & $\mathrm{Cu}$ & $1 / 1$ & 53 & - & -- \\
\hline $\mathrm{Zn}$ & $1 / 1$ & 92 & - & -- & $\mathrm{Zn}$ & $1 / 1$ & 78 & - & -- \\
\hline $\mathrm{Fe}$ & $1 / 1$ & 29,298 & -- & -- & $\mathrm{Fe}$ & $1 / 1$ & 42,238 & -- & -- \\
\hline Mn & $1 / 1$ & 1,380 & -- & -- & $\mathrm{Mn}$ & $1 / 1$ & 894 & -- & -- \\
\hline K & $1 / 1$ & 1,771 & -- & -- & $\mathrm{K}$ & $1 / 1$ & 1,489 & - & -- \\
\hline $\mathrm{Al}$ & $1 / 1$ & 42,986 & - & -- & $\mathrm{Al}$ & $1 / 1$ & 60,563 & - & -- \\
\hline $\mathrm{Li}$ & $1 / 1$ & 10 & - & -- & $\mathrm{Li}$ & $1 / 1$ & 13 & -- & - \\
\hline $\mathrm{Ca}$ & $1 / 1$ & 8,838 & -- & -- & $\mathrm{Ca}$ & $1 / 1$ & 3,586 & -- & -- \\
\hline $\mathrm{Na}$ & $1 / 1$ & 210 & -- & -- & $\mathrm{Na}$ & $1 / 1$ & 347 & -- & -- \\
\hline $\mathrm{Mg}$ & $1 / 1$ & 2,373 & - & -- & $\mathrm{Mg}$ & $1 / 1$ & 2,893 & -- & - \\
\hline $\mathrm{La}$ & $1 / 1$ & 9 & -- & - & $\mathrm{La}$ & $1 / 1$ & 13 & -- & -- \\
\hline $\mathrm{Sb}$ & $1 / 0$ & $<20$ & -- & -- & $\mathrm{Sb}$ & $1 / 0$ & $<20$ & - & -- \\
\hline $\mathrm{Pb}$ & $1 / 1$ & 10 & -- & -- & $\mathrm{Pb}$ & $1 / 0$ & $<10$ & -- & -- \\
\hline $\mathrm{Tl}$ & $1 / 0$ & $<50$ & -- & - & $\mathrm{Tl}$ & $1 / 0$ & $<50$ & -- & -- \\
\hline As & $1 / 0$ & $<20$ & -- & - & As & $1 / 0$ & $<20$ & -- & -- \\
\hline $\mathrm{Se}$ & $1 / 0$ & $<30$ & -- & - & $\mathrm{Se}$ & $1 / 0$ & $<30$ & $\cdots$ & -- \\
\hline $\mathrm{Hg}$ & $1 / 1$ & 0.06 & -- & -- & $\mathrm{Hg}$ & $1 / 0$ & $<0.04$ & -- & -- \\
\hline
\end{tabular}

${ }^{1}$ Detects are the number of samples with concentrations equal to or greater than the laboratory reporting limit.

${ }^{2}$ Only one concentration value for the soils is listed under arithmetic mean. 
Appendix 7.59. Distribution statistics for concentrations (in ppm of dry soil) of metals in soils on geologic unit "TrPv"(Volcanic rocks; Triassic \& Permian). For sampling site \#(s) and physiographic province(s) see Appendix 2.

In A Horizon

In B Horizon

\begin{tabular}{|c|c|c|c|c|c|c|c|c|}
\hline Metal & $\begin{array}{l}\text { Total } \\
\text { sample } \\
\text { number/ } \\
\text { detects }{ }^{1}\end{array}$ & $\begin{array}{l}\text { Arith- } \\
\text { metic } \\
\text { mean }\end{array}$ & $\begin{array}{l}\text { Mini- } \\
\text { mum }\end{array}$ & $\begin{array}{l}\text { Maxi- } \\
\text { mum }\end{array}$ & Metal & $\begin{array}{l}\text { Total } \\
\text { sample } \\
\text { number/ } \\
\text { detects }\end{array}$ & $\begin{array}{l}\text { Arith } \\
\text { metic } \\
\text { mean }\end{array}$ & $\begin{array}{l}\text { Mini- } \\
\text { mum }\end{array}$ \\
\hline
\end{tabular}

$\begin{array}{llllllllll}\mathrm{Ag} & 2 / 0 & <1 & <1 & <1 & \mathrm{Ag} & 2 / 0 & <1 & <1 & <1 \\ \mathrm{Mo} & 2 / 0 & <5 & <5 & <5 & \mathrm{Mo} & 2 / 0 & <5 & <5 & <5 \\ \mathrm{Cd} & 2 / 0 & <1 & <1 & <1 & \mathrm{Cd} & 2 / 0 & <1 & <1 & <1 \\ \mathrm{Ba} & 2 / 2 & 126 & 105 & 148 & \mathrm{Ba} & 2 / 2 & 61 & 44 & 79 \\ \mathrm{Be} & 2 / 0 & <1 & <1 & <1 & \mathrm{Be} & 2 / 0 & <1 & <1 & <1 \\ \mathrm{Ni} & 2 / 2 & 29 & 22 & 36 & \mathrm{Ni} & 2 / 2 & 35 & 22 & 48 \\ \mathrm{Co} & 2 / 2 & 23 & 21 & 24 & \mathrm{Co} & 2 / 2 & 24 & 19 & 29 \\ \mathrm{Cr} & 2 / 2 & 52 & 36 & 69 & \mathrm{Cr} & 2 / 2 & 81 & 53 & 109 \\ \mathrm{~V} & 2 / 2 & 93 & 80 & 106 & \mathrm{~V} & 2 / 2 & 132 & 128 & 136 \\ \mathrm{Cu} & 2 / 2 & 82 & 63 & 100 & \mathrm{Cu} & 2 / 2 & 135 & 105 & 165 \\ \mathrm{Zn} & 2 / 2 & 74 & 71 & 77 & \mathrm{Zn} & 2 / 2 & 62 & 55 & 68 \\ \mathrm{Fe} & 2 / 2 & 32,723 & 28,428 & 37,017 & \mathrm{Fe} & 2 / 2 & 40,556 & 40,371 & 40,741 \\ \mathrm{Mn} & 2 / 2 & 981 & 917 & 1,046 & \mathrm{Mn} & 2 / 2 & 598 & 426 & 769 \\ \mathrm{~K} & 2 / 2 & 4,427 & 3,881 & 4,973 & \mathrm{~K} & 2 / 2 & 1,948 & 853 & 3,043 \\ \mathrm{Al} & 2 / 2 & 39,987 & 34,601 & 45,373 & \mathrm{Al} & 2 / 2 & 49,925 & 48,844 & 51,007 \\ \mathrm{Li} & 2 / 2 & 9 & 8 & 10 & \mathrm{Li} & 2 / 2 & 13 & 10 & 15 \\ \mathrm{Ca} & 2 / 2 & 12,734 & 11,246 & 14,223 & \mathrm{Ca} & 2 / 2 & 12,437 & 9,701 & 15,173 \\ \mathrm{Na} & 2 / 2 & 189 & 157 & 222 & \mathrm{Na} & 2 / 2 & 213 & 206 & 219 \\ \mathrm{Mg} & 2 / 2 & 11,506 & 10,037 & 12,975 & \mathrm{Mg} & 2 / 2 & 15,396 & 12,919 & 17,873 \\ \mathrm{La} & 2 / 2 & 7 & 6 & 8 & \mathrm{La} & 2 / 2 & 7 & 5 & 9 \\ \mathrm{Sb} & 2 / 0 & <20 & <20 & <20 & \mathrm{Sb} & 2 / 0 & <20 & <20 & <20 \\ \mathrm{~Pb} & 2 / 0 & <10 & <10 & <10 & \mathrm{~Pb} & 2 / 0 & <10 & <10 & <10 \\ \mathrm{Tl} & 2 / 0 & <50 & <50 & <50 & \mathrm{Tl} & 2 / 0 & <50 & <50 & <50 \\ \mathrm{As} & 2 / 0 & <20 & <20 & <20 & \mathrm{As} & 2 / 0 & <20 & <20 & <20 \\ \mathrm{Se} & 2 / 0 & <30 & <30 & <30 & \mathrm{Se} & 2 / 0 & <30 & <30 & <30 \\ \mathrm{Hg} & 2 / 2 & 0.04 & 0.04 & 0.04 & \mathrm{Hg} & 2 / 1 & <0.04 * & <0.04 & 0.04\end{array}$

${ }^{1}$ Detects are the number of samples with concentrations equal to or greater than the laboratory reporting limit.

* Where the concentration of a metal in a sample is less than the laboratory minimum reporting level, the minimum reporting level is used for calculating arithmetic mean, and the arithmetic mean is qualified as less than the value given. 
Appendix 7.60. Distribution statistics for concentrations (in ppm of dry soil) of metals in soils on geologic unit "TrPzm"(Melange of Dutchmans Peak; Triassic or Paleozoic). For sampling site \#(s) and physiographic province(s) see Appendix 2.

In A Horizon

In B Horizon

$\begin{array}{llllllllll}\text { Metal } & \begin{array}{l}\text { Total } \\ \text { sample }\end{array} & \begin{array}{l}\text { Arith- } \\ \text { metic }\end{array} & \text { Mini- } & \text { mum } & \text { Maxi- } & \text { Mum } & \text { Metal } & \begin{array}{l}\text { Total } \\ \text { number/ } \\ \text { detects }\end{array} & \text { mean }\end{array}$

$\begin{array}{llllllllll}\mathrm{Ag} & 2 / 0 & <1 & <1 & <1 & \mathrm{Ag} & 2 / 0 & <1 & <1 & <1 \\ \mathrm{Mo} & 2 / 0 & <5 & <5 & <5 & \mathrm{Mo} & 2 / 0 & <5 & <5 & <5 \\ \mathrm{Cd} & 2 / 0 & <1 & <1 & <1 & \mathrm{Cd} & 2 / 0 & <1 & <1 & <1 \\ \mathrm{Ba} & 2 / 2 & 123 & 73 & 173 & \mathrm{Ba} & 2 / 2 & 96 & 68 & 125 \\ \mathrm{Be} & 2 / 0 & <1 & <1 & <1 & \mathrm{Be} & 2 / 0 & <1 & <1 & <1 \\ \mathrm{Ni} & 2 / 2 & 46 & 37 & 54 & \mathrm{Ni} & 2 / 2 & 49 & 35 & 63 \\ \mathrm{Co} & 2 / 2 & 15 & 15 & 15 & \mathrm{Co} & 2 / 2 & 18 & 17 & 19 \\ \mathrm{Cr} & 2 / 2 & 76 & 67 & 84 & \mathrm{Cr} & 2 / 2 & 93 & 71 & 115 \\ \mathrm{~V} & 2 / 2 & 73 & 58 & 88 & \mathrm{~V} & 2 / 2 & 91 & 67 & 114 \\ \mathrm{Cu} & 2 / 2 & 49 & 49 & 50 & \mathrm{Cu} & 2 / 2 & 58 & 54 & 62 \\ \mathrm{Zn} & 2 / 2 & 78 & 70 & 85 & \mathrm{Zn} & 2 / 2 & 76 & 64 & 88 \\ \mathrm{Fe} & 2 / 2 & 23,668 & 22,280 & 25,055 & \mathrm{Fe} & 2 / 2 & 28,177 & 28,079 & 28,275 \\ \mathrm{Mn} & 2 / 2 & 1,695 & 1,535 & 1,855 & \mathrm{Mn} & 2 / 2 & 1,177 & 1,076 & 1,278 \\ \mathrm{~K} & 2 / 2 & 1,499 & 1,463 & 1,535 & \mathrm{~K} & 2 / 2 & 1,027 & 937 & 1,117 \\ \mathrm{Al} & 2 / 2 & 24,509 & 22,216 & 26,792 & \mathrm{Al} & 2 / 2 & 30,097 & 29,711 & 30,484 \\ \mathrm{Li} & 2 / 2 & 11 & 11 & 11 & \mathrm{Li} & 2 / 2 & 13 & 12 & 14 \\ \mathrm{Ca} & 2 / 2 & 8,188 & 6,700 & 9,675 & \mathrm{Ca} & 2 / 2 & 4,279 & 2,780 & 5,778 \\ \mathrm{Na} & 2 / 2 & 202 & 139 & 264 & \mathrm{Na} & 2 / 2 & 262 & 217 & 306 \\ \mathrm{Mg} & 2 / 2 & 8,056 & 7,303 & 8,809 & \mathrm{Mg} & 2 / 2 & 9,256 & 7,662 & 10,850 \\ \mathrm{La} & 2 / 0 & <5 & <5 & <5 & \mathrm{La} & 2 / 0 & <5 & <5 & <5 \\ \mathrm{Sb} & 2 / 0 & <20 & <20 & <20 & \mathrm{Sb} & 2 / 0 & <20 & <20 & <20 \\ \mathrm{~Pb} & 2 / 0 & <10 & <10 & <10 & \mathrm{~Pb} & 2 / 0 & <10 & <10 & <10 \\ \mathrm{Tl} & 2 / 0 & <50 & <50 & <50 & \mathrm{Tl} & 2 / 0 & <50 & <50 & <50 \\ \mathrm{As} & 2 / 0 & <20 & <20 & <20 & \mathrm{As} & 2 / 0 & <20 & <20 & <20 \\ \mathrm{Se} & 2 / 0 & <30 & <30 & <30 & \mathrm{Se} & 2 / 0 & <30 & <30 & <30 \\ \mathrm{Hg} & 2 / 2 & 0.18 & 0.17 & 0.18 & \mathrm{Hg} & 2 / 2 & 0.07 & 0.07 & 0.07\end{array}$

${ }^{1}$ Detects are the number of samples with concentrations equal to or greater than the laboratory reporting limit.

* Where the concentration of a metal in a sample is less than the laboratory minimum reporting level, the minimum reporting level is used for calculating arithmetic mean, and the arithmetic mean is qualified as less than the value given. 
Appendix 7.61. Distribution statistics for concentrations (in ppm of dry soil) of metals in soils on geologic unit "TrPzs"(Sedimentary rocks, partly metamorphosed; Triassic \& Paleozoic). For sampling site \#(s) and physiographic province(s) see Appendix 2.

In A Horizon

In B Horizon

\begin{tabular}{|c|c|c|c|c|c|c|c|c|c|}
\hline Metal & $\begin{array}{l}\text { Total } \\
\text { sample } \\
\text { number/ } \\
\text { detects }^{1}\end{array}$ & $\begin{array}{l}\text { Arith- } \\
\text { metic } \\
\text { mean }\end{array}$ & $\begin{array}{l}\text { Mini- } \\
\text { mum }\end{array}$ & $\begin{array}{l}\text { Maxi- } \\
\text { mum }\end{array}$ & Metal & $\begin{array}{l}\text { Total } \\
\text { sample } \\
\text { number/ } \\
\text { detects }{ }^{1}\end{array}$ & $\begin{array}{l}\text { Arith- } \\
\text { metic } \\
\text { mean }\end{array}$ & $\begin{array}{l}\text { Mini- } \\
\text { mum }\end{array}$ & $\begin{array}{l}\text { Maxi- } \\
\text { mum }\end{array}$ \\
\hline $\mathrm{Ag}$ & $2 / 0$ & $<1$ & $<1$ & $<1$ & $\mathrm{Ag}$ & $2 / 0$ & $<1$ & $<1$ & $<1$ \\
\hline Mo & $2 / 0$ & $<5$ & $<5$ &, 5 & Mo & $2 / 0$ & $<5$ & $<5$ & $<5$ \\
\hline $\mathrm{Cd}$ & $2 / 0$ & $<1$ & $<1$ & $<1$ & $\mathrm{Cd}$ & $2 / 0$ & $<1$ & $<1$ & $<1$ \\
\hline $\mathrm{Ba}$ & $2 / 2$ & 570 & 404 & 736 & $\mathrm{Ba}$ & $2 / 2$ & 376 & 261 & 491 \\
\hline $\mathrm{Be}$ & $2 / 0$ & $<1$ & $<1$ & $<1$ & $\mathrm{Be}$ & $2 / 0$ & $<1$ & $<1$ & $<1$ \\
\hline $\mathrm{Ni}$ & $2 / 2$ & 217 & 62 & 372 & $\mathrm{Ni}$ & $2 / 2$ & 295 & 64 & 525 \\
\hline Co & $2 / 2$ & 33 & 33 & 33 & Co & $2 / 2$ & 43 & 35 & 51 \\
\hline $\mathrm{Cr}$ & $2 / 2$ & 153 & 33 & 273 & $\mathrm{Cr}$ & $2 / 2$ & 212 & 35 & 390 \\
\hline $\mathrm{V}$ & $2 / 2$ & 112 & 78 & 145 & $\mathrm{~V}$ & $2 / 2$ & 153 & 115 & 191 \\
\hline $\mathrm{Cu}$ & $2 / 2$ & 49 & 47 & 51 & $\mathrm{Cu}$ & $2 / 2$ & 71 & 68 & 74 \\
\hline $\mathrm{Zn}$ & $2 / 2$ & 182 & 168 & 196 & $\mathrm{Zn}$ & $2 / 2$ & 173 & 164 & 183 \\
\hline $\mathrm{Fe}$ & $2 / 2$ & 38,924 & 35,594 & 42,255 & $\mathrm{Fe}$ & $2 / 2$ & 51,437 & 50,229 & 52,646 \\
\hline $\mathrm{Mn}$ & $2 / 2$ & 5,878 & 4,535 & 7,221 & $\mathrm{Mn}$ & $2 / 2$ & 2,210 & 1,358 & 3,062 \\
\hline K & $2 / 2$ & 1,238 & 9,65 & 1,510 & $\mathrm{~K}$ & $2 / 2$ & 917 & 799 & 1,035 \\
\hline $\mathrm{Al}$ & $2 / 2$ & 41,037 & 36,989 & 45,086 & Al & $2 / 2$ & 56,698 & 52,737 & 60,659 \\
\hline $\mathrm{Li}$ & $2 / 2$ & 22 & 21 & 22 & $\mathrm{Li}$ & $2 / 2$ & 29 & 27 & 31 \\
\hline $\mathrm{Ca}$ & $2 / 2$ & 12,305 & 5,928 & 18,682 & $\mathrm{Ca}$ & $2 / 2$ & 5,675 & 3,172 & 8,178 \\
\hline $\mathrm{Na}$ & $2 / 2$ & 140 & 103 & 176 & $\mathrm{Na}$ & $2 / 2$ & 163 & 103 & 223 \\
\hline $\mathrm{Mg}$ & $2 / 2$ & 15,333 & 14,242 & 16,424 & $\mathrm{Mg}$ & $2 / 2$ & 21,078 & 18,551 & 23,606 \\
\hline $\mathrm{La}$ & $2 / 1$ & $<7^{*}$ & $<5$ & 9 & $\mathrm{La}$ & $2 / 1$ & $<9^{*}$ & $<5$ & 12 \\
\hline $\mathrm{Sb}$ & $2 / 0$ & $<20$ & $<20$ & $<20$ & $\mathrm{Sb}$ & $2 / 0$ & $<20$ & $<20$ & $<20$ \\
\hline $\mathrm{Pb}$ & $2 / 0$ & $<10$ & $<10$ & $<10$ & $\mathrm{~Pb}$ & $2 / 0$ & $<10$ & $<10$ & $<10$ \\
\hline $\mathrm{Tl}$ & $2 / 0$ & $<50$ & $<50$ & $<50$ & $\mathrm{Tl}$ & $2 / 0$ & $<50$ & $<50$ & $<50$ \\
\hline As & $2 / 0$ & $<20$ & $<20$ & $<20$ & As & $2 / 0$ & $<20$ & $<20$ & $<20$ \\
\hline $\mathrm{Se}$ & $2 / 0$ & $<30$ & $<30$ & $<30$ & $\mathrm{Se}$ & $2 / 0$ & $<30$ & $<30$ & $<30$ \\
\hline $\mathrm{Hg}$ & $2 / 2$ & 0.22 & 0.14 & 0.29 & $\mathrm{Hg}$ & $2 / 2$ & 0.09 & 0.05 & 0.12 \\
\hline
\end{tabular}

${ }^{1}$ Detects are the number of samples with concentrations equal to or greater than the laboratory reporting limit.

* Where the concentration of a metal in a sample is less than the laboratory minimum reporting level, the minimum reporting level is used for calculating arithmetic mean, and the arithmetic mean is qualified as less than the value given. 
Appendix 7.62. Distribution statistics for concentrations (in ppm of dry soil) of metals in soils on geologic unit “Ts"(Tuffaceous sedimentary rocks \& tuff; Pliocene \& Miocene). For sampling site \#(s) and physiographic province(s) see Appendix 2.

In A Horizon

\begin{tabular}{|c|c|c|c|c|c|c|c|c|c|}
\hline Metal & $\begin{array}{l}\text { Total } \\
\text { sample } \\
\text { number/ } \\
\text { detects }{ }^{1}\end{array}$ & $\begin{array}{l}\text { Arith- } \\
\text { metic } \\
\text { mean }\end{array}$ & $\begin{array}{l}\text { Mini- } \\
\text { mum }\end{array}$ & $\begin{array}{l}\text { Maxi- } \\
\text { mum }\end{array}$ & Metal & $\begin{array}{l}\text { Total } \\
\text { sample } \\
\text { number/ } \\
\text { detects }^{1}\end{array}$ & $\begin{array}{l}\text { Arith- } \\
\text { metic } \\
\text { mean }\end{array}$ & $\begin{array}{l}\text { Mini- } \\
\text { mum }\end{array}$ & $\begin{array}{l}\text { Maxi- } \\
\text { mum }\end{array}$ \\
\hline $\mathrm{Ag}$ & $2 / 0$ & $<1$ & $<1$ & $<1$ & $\mathrm{Ag}$ & $2 / 0$ & $<1$ & $<1$ & $<1$ \\
\hline Mo & $2 / 0$ & $<5$ & $<5$ & $<5$ & Mo & $2 / 0$ & $<5$ & $<5$ & $<5$ \\
\hline $\mathrm{Cd}$ & $2 / 0$ & $<1$ & $<1$ & $<1$ & $\mathrm{Cd}$ & $2 / 0$ & $<1$ & $<1$ & $<1$ \\
\hline $\mathrm{Ba}$ & $2 / 2$ & 81 & 70 & 92 & $\mathrm{Ba}$ & $2 / 2$ & 112 & 76 & 148 \\
\hline $\mathrm{Be}$ & $2 / 0$ & $<1$ & $<1$ & $<1$ & $\mathrm{Be}$ & $2 / 0$ & $<1$ & $<1$ & $<1$ \\
\hline $\mathrm{Ni}$ & $2 / 2$ & 7 & 5 & 10 & $\mathrm{Ni}$ & $2 / 2$ & 10 & 5 & 15 \\
\hline Co & $2 / 1$ & $<7^{*}$ & $<6$ & 8 & Co & $2 / 1$ & $<9^{*}$ & $<6$ & 12 \\
\hline $\mathrm{Cr}$ & $2 / 2$ & 7 & 4 & 10 & $\mathrm{Cr}$ & $2 / 2$ & 10 & 4 & 16 \\
\hline $\mathrm{V}$ & $2 / 2$ & 36 & 23 & 48 & $\mathrm{~V}$ & $2 / 2$ & 51 & 27 & 75 \\
\hline $\mathrm{Cu}$ & $2 / 2$ & 12 & 10 & 13 & $\mathrm{Cu}$ & $2 / 2$ & 18 & 12 & 24 \\
\hline $\mathrm{Zn}$ & $2 / 2$ & 48 & 38 & 59 & $\mathrm{Zn}$ & $2 / 2$ & 37 & 29 & 45 \\
\hline $\mathrm{Fe}$ & $2 / 2$ & 11,205 & 8,190 & 14,220 & $\mathrm{Fe}$ & $2 / 2$ & 15,471 & 9,475 & 21,466 \\
\hline $\mathrm{Mn}$ & $2 / 2$ & 496 & 292 & 699 & $\mathrm{Mn}$ & $2 / 2$ & 308 & 196 & 421 \\
\hline K & $2 / 2$ & 829 & 616 & 1,042 & $\mathrm{~K}$ & $2 / 2$ & 772 & 449 & 1,094 \\
\hline $\mathrm{Al}$ & $2 / 2$ & 14,340 & 13,820 & 14,861 & $\mathrm{Al}$ & $2 / 2$ & 21,484 & 17,247 & 25,721 \\
\hline $\mathrm{Li}$ & $2 / 0$ & $<5$ & $<5$ & $<5$ & $\mathrm{Li}$ & $2 / 2$ & 6 & 5 & 7 \\
\hline $\mathrm{Ca}$ & $2 / 2$ & 3,309 & 2,642 & 3,976 & $\mathrm{Ca}$ & $2 / 2$ & 3,030 & 2,292 & 3,768 \\
\hline $\mathrm{Na}$ & $2 / 2$ & 425 & 330 & 519 & $\mathrm{Na}$ & $2 / 2$ & 659 & 627 & 691 \\
\hline $\mathrm{Mg}$ & $2 / 2$ & 1,142 & 1,003 & 1,282 & $\mathrm{Mg}$ & $2 / 2$ & 1,357 & 1,148 & 1,567 \\
\hline $\mathrm{La}$ & $2 / 0$ & $<5$ & $<5$ & $<5$ & $\mathrm{La}$ & $2 / 2$ & 6 & 5 & 7 \\
\hline $\mathrm{Sb}$ & $2 / 0$ & $<20$ & $<20$ & $<20$ & $\mathrm{Sb}$ & $2 / 0$ & $<20$ & $<20$ & $<20$ \\
\hline $\mathrm{Pb}$ & $2 / 1$ & $<10^{*}$ & $<10$ & 10 & $\mathrm{~Pb}$ & $2 / 0$ & $<10$ & $<10$ & $<10$ \\
\hline $\mathrm{Tl}$ & $2 / 0$ & $<50$ & $<50$ & $<50$ & $\mathrm{Tl}$ & $2 / 0$ & $<50$ & $<50$ & $<50$ \\
\hline As & $2 / 0$ & $<20$ & $<20$ & $<20$ & As & $2 / 0$ & $<20$ & $<20$ & $<20$ \\
\hline $\mathrm{Se}$ & $2 / 0$ & $<30$ & $<30$ & $<30$ & $\mathrm{Se}$ & $2 / 0$ & $<30$ & $<30$ & $<30$ \\
\hline $\mathrm{Hg}$ & $2 / 2$ & 0.07 & 0.04 & 0.09 & $\mathrm{Hg}$ & $2 / 0$ & $<0.04$ & $<0.04$ & $<0.04$ \\
\hline
\end{tabular}

${ }^{1}$ Detects are the number of samples with concentrations equal to or greater than the laboratory reporting limit.

* Where the concentration of a metal in a sample is less than the laboratory minimum reporting level, the minimum reporting level is used for calculating arithmetic mean, and the arithmetic mean is qualified as less than the value given. 
Appendix 7.63. Distribution statistics for concentrations (in ppm of dry soil) of metals in soils on geologic unit “Tsr"(Siletz River Volcanics \& related rocks; Eocene \& Paleocene). For' sampling site \#(s) and physiographic province(s) see Appendix 2.

In A Horizon

In B Horizon

$\begin{array}{llllllllll}\text { Metal } & \text { Total } & \text { Arith- } & \text { Mini- } & \text { Maxi- } & \text { Metal } & \text { Total } & \text { Arith- } & \text { Mini- } & \text { Maxi- } \\ & \begin{array}{l}\text { sample } \\ \text { number/ } \\ \text { detects }\end{array} & \text { metic } & \text { mum } & \text { mum } & & & \begin{array}{l}\text { sample } \\ \text { number/ } / \\ \text { mean } \\ \text { metects }\end{array} & \text { mum } & \text { mum }\end{array}$

$\begin{array}{llllllllll}\mathrm{Ag} & 3 / 0 & <1 & <1 & <1 & \mathrm{Ag} & 3 / 0 & <1 & <1 & <1 \\ \mathrm{Mo} & 3 / 0 & <5 & <5 & <5 & \mathrm{Mo} & 3 / 0 & <5 & <5 & <5 \\ \mathrm{Cd} & 3 / 2 & <1.1^{*} & <1 & 1.2 & \mathrm{Cd} & 3 / 3 & 1.1 & 1.1 & 1.1 \\ \mathrm{Ba} & 3 / 3 & 133 & 68 & 193 & \mathrm{Ba} & 3 / 3 & 138 & 59 & 196 \\ \mathrm{Be} & 3 / 0 & <1 & <1 & <1 & \mathrm{Be} & 3 / 0 & <1 & <1 & <1 \\ \mathrm{Ni} & 3 / 3 & 50 & 22 & 72 & \mathrm{Ni} & 3 / 3 & 72 & 30 & 122 \\ \mathrm{Co} & 3 / 3 & 44 & 25 & 60 & \mathrm{Co} & 3 / 3 & 46 & 38 & 51 \\ \mathrm{Cr} & 3 / 3 & 57 & 37 & 95 & \mathrm{Cr} & 3 / 3 & 86 & 41 & 159 \\ \mathrm{~V} & 3 / 3 & 179 & 111 & 219 & \mathrm{~V} & 3 / 3 & 219 & 172 & 248 \\ \mathrm{Cu} & 3 / 3 & 104 & 31 & 148 & \mathrm{Cu} & 3 / 3 & 142 & 44 & 193 \\ \mathrm{Zn} & 3 / 3 & 91 & 73 & 101 & \mathrm{Zn} & 3 / 3 & 90 & 85 & 99 \\ \mathrm{Fe} & 3 / 3 & 61,503 & 37,471 & 74,040 & \mathrm{Fe} & 3 / 3 & 79,599 & 59,116 & 97,686 \\ \mathrm{Mn} & 3 / 3 & 1,440 & 1,248 & 1,631 & \mathrm{Mn} & 3 / 3 & 1,344 & 922 & 1,857 \\ \mathrm{~K} & 3 / 3 & 1,508 & 1,335 & 1,622 & \mathrm{~K} & 3 / 3 & 970 & 518 & 1,704 \\ \mathrm{Al} & 3 / 3 & 45,047 & 23,752 & 73,145 & \mathrm{Al} & 3 / 3 & 61,696 & 35,983 & 100,324 \\ \mathrm{Li} & 3 / 3 & 8 & 5 & 14 & \mathrm{Li} & 3 / 3 & 10 & 5 & 18 \\ \mathrm{Ca} & 3 / 3 & 9,650 & 5,534 & 15,137 & \mathrm{Ca} & 3 / 3 & 6,667 & 1,012 & 14,619 \\ \mathrm{Na} & 3 / 3 & 632 & 120 & 1,511 & \mathrm{Na} & 3 / 3 & 934 & 149 & 2,341 \\ \mathrm{Mg} & 3 / 3 & 8,677 & 3,186 & 11,425 & \mathrm{Mg} & 3 / 3 & 10,481 & 4,191 & 13,848 \\ \mathrm{La} & 3 / 3 & 6 & 5 & 8 & \mathrm{La} & 3 / 3 & 7 & 5 & 11 \\ \mathrm{Sb} & 3 / 0 & <20 & <20 & <20 & \mathrm{Sb} & 3 / 0 & <20 & <20 & <20 \\ \mathrm{~Pb} & 3 / 0 & <10 & <10 & <10 & \mathrm{~Pb} & 3 / 0 & <10 & <10 & <10 \\ \mathrm{Tl} & 3 / 0 & <50 & <50 & <50 & \mathrm{Tl} & 3 / 0 & <50 & <50 & <50 \\ \mathrm{As} & 3 / 0 & <20 & <20 & <20 & \mathrm{As} & 3 / 0 & <20 & <20 & <20 \\ \mathrm{Se} & 3 / 0 & <30 & <30 & <30 & \mathrm{Se} & 3 / 0 & <30 & <30 & <30 \\ \mathrm{Hg} & 3 / 3 & 0.11 & 0.06 & 0.16 & \mathrm{Hg} & 3 / 2 & <0.07 * & <0.04 & 0.10\end{array}$

${ }^{1}$ Detects are the number of samples with concentrations equal to or greater than the laboratory reporting limit.

* Where the concentration of a metal in a sample is less than the laboratory minimum reporting level, the minimum reporting level is used for calculating arithmetic mean, and the arithmetic mean is qualified as less than the value given. 
Appendix 7.64. Distribution statistics for concentrations (in ppm of dry soil) of metals in soils on geologic unit "Tss"(Tuffaceous siltstone \& sandstone; Eocene). For sampling site \#(s) and physiographic province(s) see Appendix 2.

In A Horizon

Metal Total Arith- Mini- Maxi- Metal

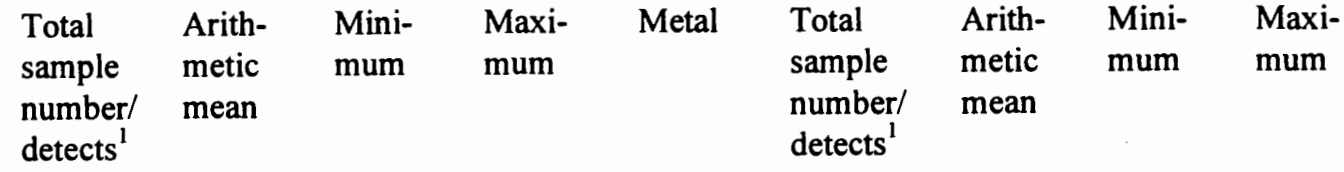

$\begin{array}{llllllllll}\mathrm{Ag} & 2 / 0 & <1 & <1 & <1 & \mathrm{Ag} & 2 / 0 & <1 & <1 & <1 \\ \mathrm{Mo} & 2 / 0 & <5 & <5 & <5 & \mathrm{Mo} & 2 / 0 & <5 & <5 & <5 \\ \mathrm{Cd} & 2 / 0 & <1 & <1 & <1 & \mathrm{Cd} & 2 / 0 & <1 & <1 & <1 \\ \mathrm{Ba} & 2 / 2 & 29 & 22 & 36 & \mathrm{Ba} & 2 / 2 & 48 & 23 & 73 \\ \mathrm{Be} & 2 / 0 & <1 & <1 & <1 & \mathrm{Be} & 2 / 0 & <1 & <1 & <1 \\ \mathrm{Ni} & 2 / 2 & 8 & 5 & 11 & \mathrm{Ni} & 2 / 2 & 16 & 5 & 27 \\ \mathrm{Co} & 2 / 0 & <6 & <6 & <6 & \mathrm{Co} & 2 / 1 & <9 * & <6 & 11 \\ \mathrm{Cr} & 2 / 2 & 28 & 28 & 28 & \mathrm{Cr} & 2 / 2 & 55 & 53 & 57 \\ \mathrm{~V} & 2 / 2 & 46 & 34 & 57 & \mathrm{~V} & 2 / 2 & 73 & 72 & 75 \\ \mathrm{Cu} & 2 / 2 & 15 & 12 & 19 & \mathrm{Cu} & 2 / 2 & 20 & 7 & 33 \\ \mathrm{Zn} & 2 / 2 & 25 & 18 & 31 & \mathrm{Zn} & 2 / 2 & 52 & 23 & 82 \\ \mathrm{Fe} & 2 / 2 & 19,043 & 17,366 & 20,720 & \mathrm{Fe} & 2 / 2 & 38,428 & 35,875 & 40,980 \\ \mathrm{Mn} & 2 / 2 & 133 & 31 & 235 & \mathrm{Mn} & 2 / 2 & 706 & 49 & 1,363 \\ \mathrm{~K} & 2 / 2 & 668 & 475 & 861 & \mathrm{~K} & 2 / 2 & 712 & 605 & 818 \\ \mathrm{Al} & 2 / 2 & 16,902 & 16,442 & 17,362 & \mathrm{Al} & 2 / 2 & 48,501 & 41,250 & 55,751 \\ \mathrm{Li} & 2 / 2 & 6 & 5 & 7 & \mathrm{Li} & 2 / 2 & 24 & 22 & 26 \\ \mathrm{Ca} & 2 / 2 & 853 & 638 & 1,068 & \mathrm{Ca} & 2 / 2 & 508 & 429 & 587 \\ \mathrm{Na} & 2 / 2 & 306 & 206 & 405 & \mathrm{Na} & 2 / 2 & 184 & 175 & 194 \\ \mathrm{Mg} & 2 / 2 & 1,369 & 1,187 & 1,551 & \mathrm{Mg} & 2 / 2 & 1,859 & 1,655 & 2,063 \\ \mathrm{La} & 2 / 2 & 6 & 5 & 7 & \mathrm{La} & 2 / 2 & 11 & 9 & 13 \\ \mathrm{Sb} & 2 / 0 & <20 & <20 & <20 & \mathrm{Sb} & 2 / 0 & <20 & <20 & <20 \\ \mathrm{~Pb} & 2 / 2 & 12 & 10 & 14 & \mathrm{~Pb} & 2 / 0 & <10 & <10 & <10 \\ \mathrm{Tl} & 2 / 0 & <50 & <50 & <50 & \mathrm{Tl} & 2 / 0 & <50 & <50 & <50 \\ \mathrm{As} & 2 / 0 & <20 & <20 & <20 & \mathrm{As} & 2 / 0 & <20 & <20 & <20 \\ \mathrm{Se} & 2 / 0 & <30 & <30 & <30 & \mathrm{Se} & 2 / 0 & <30 & <30 & <30 \\ \mathrm{Hg} & 2 / 2 & 0.27 & 0.17 & 0.37 & \mathrm{Hg} & 2 / 2 & 0.20 & 0.14 & 0.25\end{array}$

${ }^{1}$ Detects are the number of samples with concentrations equal to or greater than the laboratory reporting limit.

* Where the concentration of a metal in a sample is less than the laboratory minimum reporting level, the minimum reporting level is used for calculating arithmetic mean, and the arithmetic mean is qualified as less than the value given. 
Appendix 7.65. Distribution statistics for concentrations (in ppm of dry soil) of metals in soils on geologic unit "Tsv"(Silica vent complexes; Pliocene, Miocene \& Oligocene). For sampling site \#(s) and physiographic province(s) see Appendix 2.

In A Horizon

In B Horizon

\begin{tabular}{|c|c|c|c|c|c|c|c|c|}
\hline Metal & $\begin{array}{l}\text { Total } \\
\text { sample } \\
\text { number/ } \\
\text { detects }^{1}\end{array}$ & $\begin{array}{l}\text { Arith- } \\
\text { metic } \\
\text { mean }^{2}\end{array}$ & $\begin{array}{l}\text { Mini- } \\
\text { mum }\end{array}$ & $\begin{array}{l}\text { Maxi- } \\
\text { mum }\end{array}$ & Metal & $\begin{array}{l}\text { Total } \\
\text { sample } \\
\text { number/ } \\
\text { detects }^{1}\end{array}$ & $\begin{array}{l}\text { Arith- } \\
\text { metic } \\
\text { mean }^{2}\end{array}$ & $\begin{array}{l}\text { Mini- } \\
\text { mum }\end{array}$ \\
\hline $\mathrm{Ag}$ & $1 / 0$ & $<1$ & -- & - & $\mathrm{Ag}$ & $1 / 0$ & $<1$ & -- \\
\hline Mo & $1 / 0$ & $<5$ & -- & -- & Mo & $1 / 0$ & $<5$ & - \\
\hline $\mathrm{Cd}$ & $1 / 0$ & $<1$ & -- & -- & $\mathrm{Cd}$ & $1 / 0$ & $<1$ & - \\
\hline $\mathrm{Ba}$ & $1 / 1$ & 280 & -- & -- & $\mathrm{Ba}$ & $1 / 1$ & 264 & -- \\
\hline $\mathrm{Be}$ & $1 / 0$ & $<1$ & -- & -- & $\mathrm{Be}$ & $1 / 0$ & $<1$ & - \\
\hline $\mathrm{Ni}$ & $1 / 1$ & 8 & -- & -- & $\mathrm{Ni}$ & $1 / 1$ & 12 & -- \\
\hline Co & $1 / 1$ & 9 & -- & - & Co & $1 / 1$ & 10 & - \\
\hline $\mathrm{Cr}$ & $1 / 1$ & 11 & -- & -- & $\mathrm{Cr}$ & $1 / 1$ & 12 & -- \\
\hline V & $1 / 1$ & 27 & -- & - & $\mathrm{V}$ & $1 / 1$ & 30 & - \\
\hline $\mathrm{Cu}$ & $1 / 1$ & 12 & -- & - & $\mathrm{Cu}$ & $1 / 1$ & 12 & -- \\
\hline $\mathrm{Zn}$ & $1 / 1$ & 113 & -- & - & $\mathrm{Zn}$ & $1 / 1$ & 127 &.- \\
\hline $\mathrm{Fe}$ & $1 / 1$ & 21,970 & -- & -- & $\mathrm{Fe}$ & $1 / 1$ & 23,409 & -- \\
\hline $\mathrm{Mn}$ & $1 / 1$ & 2,000 & -- & -- & $\mathrm{Mn}$ & $1 / 1$ & 1,913 & - \\
\hline $\mathrm{K}$ & $1 / 1$ & 669 & - & -- & $\mathrm{K}$ & $1 / 1$ & 515 & - \\
\hline $\mathrm{Al}$ & 25,643 & -- & -- & & Al & $1 / 1$ & 31,016 & -- \\
\hline $\mathrm{Li}$ & $1 / 1$ & 8 & -- & -- & $\mathrm{Li}$ & $1 / 1$ & 12 & -- \\
\hline $\mathrm{Ca}$ & $1 / 1$ & 3,996 & -- & -- & $\mathrm{Ca}$ & $1 / 1$ & 1,261 & - \\
\hline $\mathrm{Na}$ & $1 / 1$ & 181 & - & -- & $\mathrm{Na}$ & $1 / 1$ & 185 & -- \\
\hline $\mathrm{Mg}$ & $1 / 1$ & 1,517 & -- & - & $\mathrm{Mg}$ & $1 / 1$ & 1,605 & - \\
\hline $\mathrm{La}$ & $1 / 1$ & 7 & -- & -- & $\mathrm{La}$ & $1 / 1$ & 9 & -- \\
\hline $\mathrm{Sb}$ & $1 / 0$ & $<20$ & -- & - & $\mathrm{Sb}$ & $1 / 0$ & $<20$ & - \\
\hline $\mathrm{Pb}$ & $1 / 1$ & 18 & -- & -- & $\mathrm{Pb}$ & $1 / 1$ & 12 & -- \\
\hline $\mathrm{Tl}$ & $1 / 0$ & $<50$ & -- & -- & $\mathrm{Tl}$ & $1 / 0$ & $<50$ & - \\
\hline As & $1 / 0$ & $<20$ & -- & -- & As & $1 / 0$ & $<20$ & -- \\
\hline $\mathrm{Se}$ & $1 / 0$ & $<30$ & -- & -- & $\mathrm{Se}$ & $1 / 0$ & $<30$ & - \\
\hline $\mathrm{Hg}$ & $1 / 1$ & 0.10 & -- & -- & $\mathrm{Hg}$ & $1 / 1$ & 0.07 & -- \\
\hline
\end{tabular}

${ }^{1}$ Detects are the number of samples with concentrations equal to or greater than the laboratory reporting limit.

${ }^{2}$ Only one concentration value for the soils is listed under arithmetic mean. 
Appendix 7.66. Distribution statistics for concentrations (in ppm of dry soil) of metals in soils on geologic unit "Tt"(Marine sandstone \& siltstone of the Tyee Formation; Eocene). For sampling site \#(s) and physiographic province(s) see Appendix 2.

In A Horizon

In B Horizon

\begin{tabular}{|c|c|c|c|c|c|c|c|c|c|}
\hline Metal & $\begin{array}{l}\text { Total } \\
\text { sample } \\
\text { number/ } \\
\text { detects' }\end{array}$ & $\begin{array}{l}\text { Arith- } \\
\text { metic } \\
\text { mean }\end{array}$ & $\begin{array}{l}\text { Mini- } \\
\text { mum }\end{array}$ & $\begin{array}{l}\text { Maxi- } \\
\text { mum }\end{array}$ & Metal & $\begin{array}{l}\text { Total } \\
\text { sample } \\
\text { number/ } \\
\text { detects }^{1}\end{array}$ & $\begin{array}{l}\text { Arith- } \\
\text { metic } \\
\text { mean }\end{array}$ & $\begin{array}{l}\text { Mini- } \\
\text { mum }\end{array}$ & $\begin{array}{l}\text { Maxi- } \\
\text { mum }\end{array}$ \\
\hline $\mathrm{Ag}$ & $2 / 0$ & $<1$ & $<1$ & $<1$ & Ag & $2 / 0$ & $<1$ & $<1$ & $<1$ \\
\hline Mo & $2 / 0$ & $<5$ & $<5$ & $<5$ & Mo & $2 / 0$ & $<5$ & $<5$ & $<5$ \\
\hline $\mathrm{Cd}$ & $2 / 0$ & $<1$ & $<1$ & $<1$ & $\mathrm{Cd}$ & $2 / 0$ & $<1$ & $<1$ & $<1$ \\
\hline $\mathrm{Ba}$ & $2 / 2$ & 167 & 125 & 210 & $\mathrm{Ba}$ & $2 / 2$ & 118 & 108 & 128 \\
\hline $\mathrm{Be}$ & $2 / 0$ & $<1$ & $<1$ & $<1$ & $\mathrm{Be}$ & $2 / 0$ & $<1$ & $<1$ & $<1$ \\
\hline $\mathrm{Ni}$ & $2 / 2$ & 13 & 9 & 17 & $\mathrm{Ni}$ & $2 / 2$ & 15 & 12 & 18 \\
\hline Co & $2 / 2$ & 10 & 9 & 10 & Co & $2 / 2$ & 9 & 8 & 10 \\
\hline $\mathrm{Cr}$ & $2 / 2$ & 24 & 15 & 34 & $\mathrm{Cr}$ & $2 / 2$ & 33 & 30 & 37 \\
\hline $\mathrm{V}$ & $2 / 2$ & 34 & 27 & 40 & V & $2 / 2$ & 44 & 43 & 44 \\
\hline $\mathrm{Cu}$ & $2 / 2$ & 8 & 5 & 11 & $\mathrm{Cu}$ & $2 / 2$ & 10 & 9 & 12 \\
\hline $\mathrm{Zn}$ & $2 / 2$ & 55 & 43 & 67 & $\mathrm{Zn}$ & $2 / 2$ & 51 & 42 & 61 \\
\hline $\mathrm{Fe}$ & $2 / 2$ & 18,646 & 15,727 & 21,565 & $\mathrm{Fe}$ & $2 / 2$ & 24,203 & 23,045 & 25,361 \\
\hline $\mathrm{Mn}$ & $2 / 2$ & 542 & 353 & 730 & $\mathrm{Mn}$ & $2 / 2$ & 231 & 174 & 287 \\
\hline $\mathrm{K}$ & $2 / 2$ & 1,495 & 890 & 2,099 & K & $2 / 2$ & 1,561 & 1,105 & 2,016 \\
\hline $\mathrm{Al}$ & $2 / 2$ & 20,933 & 18,856 & 23,010 & Al & $2 / 2$ & 34,027 & 26,359 & 41,695 \\
\hline $\mathrm{Li}$ & $2 / 2$ & 14 & 8 & 19 & $\mathrm{Li}$ & $2 / 2$ & 19 & 15 & 23 \\
\hline $\mathrm{Ca}$ & $2 / 2$ & 3,705 & 2,906 & 4,505 & $\mathrm{Ca}$ & $2 / 2$ & 1,668 & 952 & 2,384 \\
\hline $\mathrm{Na}$ & $2 / 2$ & 128 & 73 & 183 & $\mathrm{Na}$ & $2 / 2$ & 108 & 59 & 156 \\
\hline $\mathrm{Mg}$ & $2 / 2$ & 3,978 & 1,328 & 6,629 & $\mathrm{Mg}$ & $2 / 2$ & 4,588 & 2,088 & 7,088 \\
\hline $\mathrm{La}$ & $2 / 2$ & 12 & 10 & 14 & $\mathrm{La}$ & $2 / 2$ & 13 & 10 & 17 \\
\hline $\mathrm{Sb}$ & $2 / 0$ & $<20$ & $<20$ & $<20$ & $\mathrm{Sb}$ & $2 / 0$ & $<20$ & $<20$ & $<20$ \\
\hline $\mathrm{Pb}$ & $2 / 1$ & $<18^{*}$ & $<10$ & 25 & $\mathrm{~Pb}$ & $2 / 1$ & $<10^{*}$ & $<10$ & 10 \\
\hline $\mathrm{Tl}$ & $2 / 0$ & $<50$ & $<50$ & $<50$ & $\mathrm{Tl}$ & $2 / 0$ & $<50$ & $<50$ & $<50$ \\
\hline As & $2 / 0$ & $<20$ & $<20$ & $<20$ & As & $2 / 0$ & $<20$ & $<20$ & $<20$ \\
\hline $\mathrm{Se}$ & $2 / 0$ & $<30$ & $<30$ & $<30$ & $\mathrm{Se}$ & $2 / 0$ & $<30$ & $<30$ & $<30$ \\
\hline $\mathrm{Hg}$ & $2 / 2$ & 0.07 & 0.06 & 0.07 & $\mathrm{Hg}$ & $2 / 2$ & 0.05 & 0.04 & 0.05 \\
\hline
\end{tabular}

${ }^{1}$ Detects are the number of samples with concentrations equal to or greater than the laboratory reporting limit.

* Where the concentration of a metal in a sample is less than the laboratory minimum reporting level, the minimum reporting level is used for calculating arithmetic mean, and the arithmetic mean is qualified as less than the value given. 
Appendix 7.67. Distribution statistics for concentrations (in ppm of dry soil) of metals in soils on geologic unit "Tu"(Undifferentiated tuffaceous sedimentary rocks, tuffs $\&$ basalt; Miocene \& Oligocene). For sampling site \#(s) and physiographic province(s) see Appendix 2.

In A Horizon

In B Horizon

\begin{tabular}{|c|c|c|c|c|c|c|c|c|}
\hline Metal & $\begin{array}{l}\text { Total } \\
\text { sample } \\
\text { number/ } \\
\text { detects }^{1}\end{array}$ & $\begin{array}{l}\text { Arith- } \\
\text { metic } \\
\text { mean }^{2}\end{array}$ & $\begin{array}{l}\text { Mini- } \\
\text { mum }\end{array}$ & $\begin{array}{l}\text { Maxi- } \\
\text { mum }\end{array}$ & Metal & $\begin{array}{l}\text { Total } \\
\text { sample } \\
\text { number/ } \\
\text { detects }^{1}\end{array}$ & $\begin{array}{l}\text { Arith- } \\
\text { metic } \\
\text { mean }^{2}\end{array}$ & $\begin{array}{l}\text { Mini- } \\
\text { mum }\end{array}$ \\
\hline $\mathrm{Ag}$ & $1 / 0$ & $<1$ & -- & -- & $\mathrm{Ag}$ & $1 / 0$ & $<1$ & -- \\
\hline Mo & $1 / 0$ & $<5$ & -- & -- & Mo & $1 / 0$ & $<5$ & - \\
\hline $\mathrm{Cd}$ & $1 / 0$ & $<1$ & -- & -- & $\mathrm{Cd}$ & $1 / 0$ & $<1$ & -- \\
\hline $\mathrm{Ba}$ & $1 / 1$ & 523 & -- & -- & $\mathrm{Ba}$ & $1 / 1$ & 206 & -- \\
\hline $\mathrm{Be}$ & $1 / 0$ & $<1$ & -- & -- & $\mathrm{Be}$ & $1 / 0$ & $<1$ & -- \\
\hline $\mathrm{Ni}$ & $1 / 1$ & 10 & - & -- & $\mathrm{Ni}$ & $1 / 1$ & 6 & -- \\
\hline Co & $1 / 1$ & 35 & -- & - & Co & $1 / 1$ & 15 & -- \\
\hline $\mathrm{Cr}$ & $1 / 1$ & 8 & -- & -- & $\mathrm{Cr}$ & $1 / 1$ & 13 & -- \\
\hline V & $1 / 1$ & 97 & -- & - & $\mathrm{V}$ & $1 / 1$ & 138 & - \\
\hline $\mathrm{Cu}$ & $1 / 1$ & 13 & -- & -- & $\mathrm{Cu}$ & $1 / 1$ & 31 & -- \\
\hline $\mathrm{Zn}$ & $1 / 1$ & 148 & -- & - & $\mathrm{Zn}$ & $1 / 1$ & 108 & -- \\
\hline $\mathrm{Fe}$ & $1 / 1$ & 38,650 & -- & -- & $\mathrm{Fe}$ & $1 / 1$ & 63,360 & -- \\
\hline $\mathrm{Mn}$ & $1 / 1$ & 5,685 & -- & -- & $\mathrm{Mn}$ & $1 / 1$ & 962 & -- \\
\hline K & $1 / 1$ & 723 & -- & -- & $\mathrm{K}$ & $1 / 1$ & 776 & - \\
\hline $\mathrm{Al}$ & $1 / 1$ & 34,515 & -- & -- & $\mathrm{Al}$ & $1 / 1$ & 59,463 & -- \\
\hline $\mathrm{Li}$ & $1 / 1$ & 6 & -- & -- & $\mathrm{Li}$ & $1 / 1$ & 8 & -- \\
\hline $\mathrm{Ca}$ & $1 / 1$ & 9,419 & -- & - & $\mathrm{Ca}$ & $1 / 1$ & 5,888 & -- \\
\hline $\mathrm{Na}$ & $1 / 1$ & 136 & -- & - & $\mathrm{Na}$ & $1 / 1$ & 59 & -. \\
\hline $\mathrm{Mg}$ & $1 / 1$ & 3,419 & - & -- & $\mathrm{Mg}$ & $1 / 1$ & 7,446 & - \\
\hline $\mathrm{La}$ & $1 / 1$ & 5 & -- & -- & $\mathrm{La}$ & $1 / 1$ & 5 & -- \\
\hline $\mathrm{Sb}$ & $1 / 0$ & $<20$ & -- & -- & $\mathrm{Sb}$ & $1 / 0$ & $<20$ & -- \\
\hline $\mathrm{Pb}$ & $1 / 1$ & 20 & - & -- & $\mathrm{Pb}$ & $1 / 0$ & $<10$ & -- \\
\hline $\mathrm{Tl}$ & $1 / 0$ & $<50$ & -- & -- & $\mathrm{Tl}$ & $1 / 0$ & $<50$ & -- \\
\hline As & $1 / 0$ & $<20$ & -- & -- & As & $1 / 0$ & $<20$ & -- \\
\hline $\mathrm{Se}$ & $1 / 0$ & $<30$ & -- & -- & $\mathrm{Se}$ & $1 / 0$ & $<30$ & -- \\
\hline $\mathrm{Hg}$ & $1 / 1$ & 0.17 & -- & -- & $\mathrm{Hg}$ & $1 / 1$ & 0.09 & -- \\
\hline
\end{tabular}

${ }^{1}$ Detects are the number of samples with concentrations equal to or greater than the laboratory reporting limit.

${ }^{2}$ Only one concentration value for the soils is listed under arithmetic mean. 
Appendix 7.68. Distribution statistics for concentrations (in ppm of dry soil) of metals in soils on geologic unit "Tub"(Basaltic lava flows; Oligocene). For sampling site \#(s) and physiographic province(s) see Appendix 2.

In A Horizon

In B Horizon

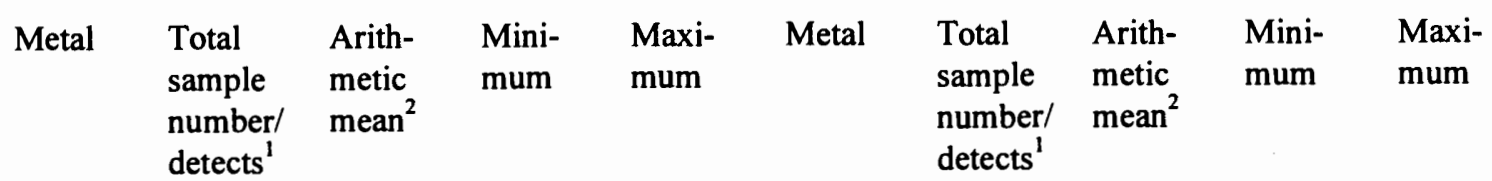

\begin{tabular}{|c|c|c|c|c|c|c|c|c|c|}
\hline $\mathrm{Ag}$ & $1 / 0$ & $<1$ & -- & -- & $\mathrm{Ag}$ & $1 / 0$ & $<1$ & -- & -- \\
\hline Mo & $1 / 0$ & $<5$ & -- & -- & Mo & $1 / 0$ & $<5$ & -- & -- \\
\hline $\mathrm{Cd}$ & $1 / 0$ & $<1$ & -- & -- & $\mathrm{Cd}$ & $1 / 0$ & $<1$ & -- & -- \\
\hline $\mathrm{Ba}$ & $1 / 1$ & 272 & -- & -- & $\mathrm{Ba}$ & $1 / 1$ & 254 & -- & -- \\
\hline $\mathrm{Be}$ & 10 & $<1$ & -- & -- & $\mathrm{Be}$ & $1 / 0$ & $<1$ & $\ldots$ & -- \\
\hline $\mathrm{Ni}$ & $1 / 1$ & 28 & -- & -- & $\mathrm{Ni}$ & $1 / 1$ & 30 & -- & -- \\
\hline Co & $1 / 1$ & 23 & -- & -- & Co & $1 / 1$ & 27 & -- & -- \\
\hline $\mathrm{Cr}$ & $1 / 1$ & 21 & -- & -- & $\mathrm{Cr}$ & $1 / 1$ & 25 & -- & -- \\
\hline V & $1 / 1$ & 95 & -- & -- & $\mathrm{V}$ & $1 / 1$ & 110 & -- & -- \\
\hline $\mathrm{Cu}$ & $1 / 1$ & 70 & -- & -- & $\mathrm{Cu}$ & $1 / 1$ & 81 & - & -- \\
\hline $\mathrm{Zn}$ & $1 / 1$ & 94 & -- & -- & $\mathrm{Zn}$ & $1 / 1$ & 94 & -- & -- \\
\hline $\mathrm{Fe}$ & $1 / 1$ & 41,629 & -- & -- & $\mathrm{Fe}$ & $1 / 1$ & 49,622 & -- & -- \\
\hline $\mathrm{Mn}$ & $1 / 1$ & 1,596 & -- & -- & $\mathrm{Mn}$ & $1 / 1$ & 1,525 & -- & -- \\
\hline K & $1 / 1$ & 2,616 & -- & -- & $\mathrm{K}$ & $1 / 1$ & 1,774 & -- & -- \\
\hline $\mathrm{Al}$ & $1 / 1$ & 71,482 & -- & -- & $\mathrm{Al}$ & $1 / 1$ & 79,896 & -- & - \\
\hline $\mathrm{Li}$ & $1 / 1$ & 11 & -- & -- & $\mathrm{Li}$ & $1 / 1$ & 13 & -- & -- \\
\hline $\mathrm{Ca}$ & $1 / 1$ & 14,618 & -- & -- & $\mathrm{Ca}$ & $1 / 1$ & 10,812 & -- & -- \\
\hline $\mathrm{Na}$ & $1 / 1$ & 151 & -- & -- & $\mathrm{Na}$ & $1 / 1$ & 157 & -- & -- \\
\hline $\mathrm{Mg}$ & $1 / 1$ & 13,829 & - & -- & $\mathrm{Mg}$ & $1 / 1$ & 15,300 & -- & -- \\
\hline $\mathrm{La}$ & $1 / 1$ & 7 & -- & -- & $\mathrm{La}$ & $1 / 1$ & 8 & -- & -- \\
\hline $\mathrm{Sb}$ & $1 / 0$ & $<20$ & -- & - & $\mathrm{Sb}$ & $1 / 0$ & $<20$ & -- & -- \\
\hline $\mathrm{Pb}$ & $1 / 0$ & $<10$ & - & -- & $\mathrm{Pb}$ & $1 / 0$ & $<10$ & -- & -- \\
\hline $\mathrm{Tl}$ & $1 / 0$ & $<50$ & -- & -- & $\mathrm{Tl}$ & $1 / 0$ & $<50$ & -- & -- \\
\hline As & $1 / 0$ & $<20$ & -- & -- & As & $1 / 0$ & $<20$ & -- & -- \\
\hline $\mathrm{Se}$ & $1 / 0$ & $<30$ & -- & -- & $\mathrm{Se}$ & $1 / 0$ & $<30$ & -- & -- \\
\hline $\mathrm{Hg}$ & $1 / 1$ & 0.14 & -- & -- & $\mathrm{Hg}$ & $1 / 1$ & 0.08 & -- & -- \\
\hline
\end{tabular}

${ }^{1}$ Detects are the number of samples with concentrations equal to or greater than the laboratory reporting limit.

${ }^{2}$ Only one concentration value for the soils is listed under arithmetic mean. 
Appendix 7.69. Distribution statistics for concentrations (in ppm of dry soil) of metals in soils on geologic unit “Tus"(Sedimentary \& volcaniclastic rocks; Miocene \& Oligocene). For sampling site \#(s) and physiographic province(s) see Appendix 2.

In A Horizon

In B Horizon

\begin{tabular}{|c|c|c|c|c|c|c|c|c|c|}
\hline Metal & $\begin{array}{l}\text { Total } \\
\text { sample } \\
\text { number/ } \\
\text { detects }^{1}\end{array}$ & $\begin{array}{l}\text { Arith- } \\
\text { metic } \\
\text { mean }\end{array}$ & $\begin{array}{l}\text { Mini- } \\
\text { mum }\end{array}$ & $\begin{array}{l}\text { Maxi- } \\
\text { mum }\end{array}$ & Metal & $\begin{array}{l}\text { Total } \\
\text { sample } \\
\text { number/ } \\
\text { detects }^{1}\end{array}$ & $\begin{array}{l}\text { Arith- } \\
\text { metic } \\
\text { mean }\end{array}$ & $\begin{array}{l}\text { Mini- } \\
\text { mum }\end{array}$ & $\begin{array}{l}\text { Maxi- } \\
\text { mum }\end{array}$ \\
\hline $\mathrm{Ag}$ & $3 / 0$ & $<1$ & $<1$ & $<1$ & $\mathrm{Ag}$ & $3 / 0$ & $<1$ & $<1$ & $<1$ \\
\hline Mo & $3 / 0$ & $<5$ & $<5$ & $<5$ & Mo & $3 / 1$ & $<5^{*}$ & $<5$ & 5 \\
\hline $\mathrm{Cd}$ & $3 / 0$ & $<1$ & $<1$ & $<1$ & $\mathrm{Cd}$ & $3 / 0$ & $<1$ & $<1$ & $<1$ \\
\hline $\mathrm{Ba}$ & $3 / 3$ & 449 & 249 & 792 & $\mathrm{Ba}$ & $3 / 3$ & 275 & 186 & 446 \\
\hline $\mathrm{Be}$ & $3 / 0$ & $<1$ & $<1$ & $<1$ & $\mathrm{Be}$ & $3 / 0$ & $<1$ & $<1$ & $<1$ \\
\hline $\mathrm{Ni}$ & $3 / 3$ & 17 & 7 & 27 & $\mathrm{Ni}$ & $3 / 3$ & 23 & 12 & 41 \\
\hline Co & $3 / 2$ & $<15^{*}$ & $<6$ & 19 & Co & $3 / 3$ & 20 & 7 & 32 \\
\hline $\mathrm{Cr}$ & $3 / 3$ & 18 & 4 & 28 & $\mathrm{Cr}$ & $3 / 3$ & 26 & 7 & 41 \\
\hline V & $3 / 3$ & 70 & 14 & 129 & V & $3 / 3$ & 95 & 22 & 145 \\
\hline $\mathrm{Cu}$ & $3 / 3$ & 20 & 11 & 28 & $\mathrm{Cu}$ & $3 / 3$ & 31 & 21 & 48 \\
\hline $\mathrm{Zn}$ & $3 / 3$ & 106 & 85 & $\cdot 131$ & $\mathrm{Zn}$ & $3 / 3$ & 83 & 75 & 93 \\
\hline $\mathrm{Fe}$ & $3 / 3$ & 27,452 & 11,248 & 43,183 & $\mathrm{Fe}$ & $3 / 3$ & 36,076 & 15,469 & 48,039 \\
\hline $\mathrm{Mn}$ & $3 / 3$ & 2,537 & 1,913 & 2,924 & $\mathrm{Mn}$ & $3 / 3$ & 1,043 & 450 & 1,465 \\
\hline $\mathrm{K}$ & $3 / 3$ & 1,030 & 857 & 1,346 & K & $3 / 3$ & 874 & 725 & 1,170 \\
\hline $\mathrm{Al}$ & $3 / 3$ & 38,995 & 18,313 & 50,985 & $\mathrm{Al}$ & $3 / 3$ & 54,444 & 33,387 & 75,682 \\
\hline $\mathrm{Li}$ & $3 / 3$ & 9 & 5 & 11 & $\mathrm{Li}$ & $3 / 3$ & 15 & 9 & 23 \\
\hline $\mathrm{Ca}$ & $3 / 3$ & 10,749 & 6,773 & 17,580 & $\mathrm{Ca}$ & $3 / 3$ & 3,352 & 2,825 & 4,202 \\
\hline $\mathrm{Na}$ & $3 / 3$ & 211 & 123 & 338 & $\mathrm{Na}$ & $3 / 3$ & 359 & 149 & 756 \\
\hline $\mathrm{Mg}$ & $3 / 3$ & 3,032 & 1,123 & 5,308 & $\mathrm{Mg}$ & $3 / 3$ & 3,712 & 1,448 & 5,187 \\
\hline $\mathrm{La}$ & $3 / 3$ & 8 & 5 & 10 & $\mathrm{La}$ & $3 / 3$ & 12 & 9 & 15 \\
\hline $\mathrm{Sb}$ & $3 / 0$ & $<20$ & $<20$ & $<20$ & $\mathrm{Sb}$ & $3 / 0$ & $<20$ & $<20$ & $<20$ \\
\hline $\mathrm{Pb}$ & $3 / 2$ & $<15^{*}$ & $<10$ & 22 & $\mathrm{~Pb}$ & $3 / 0$ & $<10$ & $<10$ & $<10$ \\
\hline $\mathrm{Tl}$ & $3 / 0$ & $<50$ & $<50$ & $<50$ & $\mathrm{Tl}$ & $3 / 0$ & $<50$ & $<50$ & $<50$ \\
\hline As & $3 / 0$ & $<20$ & $<20$ & $<20$ & As & $3 / 0$ & $<20$ & $<20$ & $<20$ \\
\hline Se & $3 / 0$ & $<30$ & $<30$ & $<30$ & $\mathrm{Se}$ & $3 / 0$ & $<30$ & $<30$ & $<30$ \\
\hline $\mathrm{Hg}$ & $3 / 3$ & 0.18 & 0.14 & 0.26 & $\mathrm{Hg}$ & $3 / 2$ & $<0.05^{*}$ & $<0.04$ & 0.07 \\
\hline
\end{tabular}

${ }^{1}$ Detects are the number of samples with concentrations equal to or greater than the laboratory reporting limit.

* Where the concentration of a metal in a sample is less than the laboratory minimum reporting level, the minimum reporting level is used for calculating arithmetic mean, and the arithmetic mean is qualified as less than the value given. 
Appendix 7.70. Distribution statistics for concentrations (in ppm of dry soil) of metals in soils on geologic unit "Tut"(Tuff; Miocene \& Oligocene). For sampling site \#(s) and physiographic province(s) see Appendix 2.

In A Horizon

In B Horizon

\begin{tabular}{|c|c|c|c|c|c|c|c|c|}
\hline Metal & $\begin{array}{l}\text { Total } \\
\text { sample } \\
\text { number/ } \\
\text { detects }\end{array}$ & $\begin{array}{l}\text { Arith- } \\
\text { metic } \\
\text { mean }^{2}\end{array}$ & $\begin{array}{l}\text { Mini- } \\
\text { mum }\end{array}$ & $\begin{array}{l}\text { Maxi- } \\
\text { mum }\end{array}$ & Metal & $\begin{array}{l}\text { Total } \\
\text { sample } \\
\text { number/ } \\
\text { detects }^{1}\end{array}$ & $\begin{array}{l}\text { Arith- } \\
\text { metic } \\
\text { mean }^{2}\end{array}$ & $\begin{array}{l}\text { Mini- } \\
\text { mum }\end{array}$ \\
\hline $\mathrm{Ag}$ & $1 / 0$ & $<1$ & -- & -- & $\mathrm{Ag}$ & $1 / 0$ & $<1$ & -- \\
\hline Mo & $1 / 0$ & $<5$ & -- & -- & Mo & $1 / 0$ & $<5$ & -- \\
\hline $\mathrm{Cd}$ & $1 / 0$ & $<1$ & - & -- & $\mathrm{Cd}$ & $1 / 0$ & $<1$ & -- \\
\hline $\mathrm{Ba}$ & $1 / 1$ & 246 & -- & - & $\mathrm{Ba}$ & $1 / 1$ & 306 & -- \\
\hline $\mathrm{Be}$ & $1 / 0$ & $<1$ & - & -- & $\mathrm{Be}$ & $1 / 0$ & $<1$ & -- \\
\hline $\mathrm{Ni}$ & $1 / 0$ & $<4$ & -- & -- & $\mathrm{Ni}$ & $1 / 0$ & $<4$ & - \\
\hline Co & $1 / 1$ & 6 & - & -- & Co & $1 / 1$ & 7 & -- \\
\hline $\mathrm{Cr}$ & $1 / 1$ & 4 & -- & -- & $\mathrm{Cr}$ & $1 / 1$ & 4 & -- \\
\hline V & $1 / 1$ & 14 & -- & -. & $\mathrm{V}$ & $1 / 1$ & 16 & -- \\
\hline $\mathrm{Cu}$ & $1 / 1$ & 7 & -- & -- & $\mathrm{Cu}$ & $1 / 1$ & 9 & -- \\
\hline $\mathrm{Zn}$ & $1 / 1$ & 68 & -- & -- & $\mathrm{Zn}$ & $1 / 1$ & 103 & -. \\
\hline $\mathrm{Fe}$ & $1 / 1$ & 20,052 & -- & -- & $\mathrm{Fe}$ & $1 / 1$ & 21,199 & -- \\
\hline $\mathrm{Mn}$ & $1 / 1$ & 1,209 & -- & -- & $\mathrm{Mn}$ & $1 / 1$ & 2,147 & -- \\
\hline $\mathrm{K}$ & $1 / 1$ & 941 & -- & -- & $\mathrm{K}$ & $1 / 1$ & 1,050 & -- \\
\hline $\mathrm{Al}$ & $1 / 1$ & 18,506 & -- & $\cdots$ & $\mathrm{Al}$ & $1 / 1$ & 24,374 & -- \\
\hline $\mathrm{Li}$ & $1 / 1$ & 5 & -- & -- & $\mathrm{Li}$ & $1 / 1$ & 7 & -- \\
\hline $\mathrm{Ca}$ & $1 / 1$ & 3,552 & -- & -- & $\mathrm{Ca}$ & $1 / 1$ & 2,653 & -- \\
\hline $\mathrm{Na}$ & $1 / 1$ & 117 & - & -- & $\mathrm{Na}$ & 114 & -- & -- \\
\hline Mg & $1 / 1$ & 1,206 & -- & - & $\mathrm{Mg}$ & $1 / 1$ & 1,319 & -- \\
\hline $\mathrm{La}$ & $1 / 1$ & 23 & -- & -- & $\mathrm{La}$ & $1 / 1$ & 18 & -- \\
\hline $\mathrm{Sb}$ & $1 / 0$ & $<20$ & -- & -- & $\mathrm{Sb}$ & $1 / 0$ & $<20$ & -- \\
\hline $\mathrm{Pb}$ & $1 / 1$ & 10 & -- & -- & $\mathrm{Pb}$ & $1 / 0$ & $<10$ & - \\
\hline $\mathrm{Tl}$ & $1 / 0$ & $<50$ & -- & - & $\mathrm{Tl}$ & $1 / 0$ & $<50$ & -- \\
\hline As & $1 / 0$ & $<20$ & -- & -- & As & $1 / 0$ & $<20$ & -- \\
\hline $\mathrm{Se}$ & $1 / 0$ & $<30$ & -- & -- & $\mathrm{Se}$ & $1 / 0$ & $<30$ & - \\
\hline $\mathrm{Hg}$ & $1 / 1$ & 0.09 & - & -- & $\mathrm{Hg}$ & $1 / 1$ & 0.05 & -- \\
\hline
\end{tabular}

${ }^{1}$ Detects are the number of samples with concentrations equal to or greater than the laboratory reporting limit.

${ }^{2}$ Only one concentration value for the soils is listed under arithmetic mean. 
Appendix 7.71. Distribution statistics for concentrations (in ppm of dry soil) of metals in soils on geologic unit "Ty"(Mudstone \& siltstone, with interbedded arkosic, glauconitic and basaltic sandstone of the Yamhill Formation \& related rocks; Eocene). For sampling site \#(s) and physiographic province(s) see Appendix 2.

In A Horizon

In B Horizon

\begin{tabular}{|c|c|c|c|c|c|c|c|c|c|}
\hline Metal & $\begin{array}{l}\text { Total } \\
\text { sample } \\
\text { number/ } \\
\text { detects }^{1}\end{array}$ & $\begin{array}{l}\text { Arith- } \\
\text { metic } \\
\text { mean }\end{array}$ & $\begin{array}{l}\text { Mini- } \\
\text { mum }\end{array}$ & $\begin{array}{l}\text { Maxi- } \\
\text { mum }\end{array}$ & Metal & $\begin{array}{l}\text { Total } \\
\text { sample } \\
\text { number/ } \\
\text { detects }\end{array}$ & $\begin{array}{l}\text { Arith- } \\
\text { metic } \\
\text { mean }\end{array}$ & $\begin{array}{l}\text { Mini- } \\
\text { mum }\end{array}$ & $\begin{array}{l}\text { Maxi- } \\
\text { mum }\end{array}$ \\
\hline $\mathrm{Ag}$ & $2 / 0$ & $<1$ & $<1$ & $<1$ & $\mathrm{Ag}$ & $2 / 0$ & $<1$ & $<1$ & $<1$ \\
\hline Mo & $2 / 0$ & $<5$ & $<5$ & $<5$ & Mo & $2 / 0$ & $<5$ & $<5$ & $<5$ \\
\hline $\mathrm{Cd}$ & $2 / 0$ & $<1$ & $<1$ & $<1$ & $\mathrm{Cd}$ & $2 / 0$ & $<1$ & $<1$ & $<1$ \\
\hline $\mathrm{Ba}$ & $2 / 2$ & 225 & 218 & 232 & $\mathrm{Ba}$ & $2 / 2$ & 163 & 163 & 176 \\
\hline $\mathrm{Be}$ & $2 / 1$ & $<1^{*}$ & $<1$ & 1 & $\mathrm{Be}$ & $2 / 1$ & $<1.2^{*}$ & $<1$ & 1.3 \\
\hline $\mathrm{Ni}$ & $2 / 2$ & 23 & 22 & 23 & $\mathrm{Ni}$ & $2 / 2$ & 26 & 25 & 27 \\
\hline Co & $2 / 2$ & 13 & 7 & 19 & Co & $2 / 2$ & 15 & 8 & 22 \\
\hline $\mathrm{Cr}$ & $2 / 2$ & 38 & 30 & 46 & $\mathrm{Cr}$ & $2 / 2$ & 46 & 39 & 54 \\
\hline V & $2 / 2$ & 49 & 34 & 65 & $\mathrm{~V}$ & $2 / 2$ & 61 & 44 & 79 \\
\hline $\mathrm{Cu}$ & $2 / 2$ & 22 & 17 & 27 & $\mathrm{Cu}$ & $2 / 2$ & 27 & 19 & 35 \\
\hline $\mathrm{Zn}$ & $2 / 2$ & 80 & 76 & 85 & $\mathrm{Zn}$ & $2 / 2$ & 86 & 78 & 95 \\
\hline $\mathrm{Fe}$ & $2 / 2$ & 33,172 & 30,787 & 35,558 & $\mathrm{Fe}$ & $2 / 2$ & 39,726 & 38,071 & 41,380 \\
\hline Mn & $2 / 2$ & 765 & 728 & 803 & Mn & $2 / 2$ & 513 & 500 & 525 \\
\hline K & $2 / 2$ & 1,889 & 1,132 & 2,646 & $\mathrm{~K}$ & $2 / 2$ & 1,987 & 1,025 & 2,948 \\
\hline $\mathrm{Al}$ & $2 / 2$ & 41,186 & 26,201 & 56,172 & $\mathrm{Al}$ & $2 / 2$ & 51,576 & 35,519 & 67,634 \\
\hline $\mathrm{Li}$ & $2 / 2$ & 25 & 22 & 28 & $\mathrm{Li}$ & $2 / 2$ & 29 & 25 & 33 \\
\hline $\mathrm{Ca}$ & $2 / 2$ & 2,876 & 1,604 & 4,148 & $\mathrm{Ca}$ & $2 / 2$ & 1,291 & 793 & 1,789 \\
\hline $\mathrm{Na}$ & $2 / 2$ & 87 & 78 & 96 & $\mathrm{Na}$ & $2 / 2$ & 82 & 81 & 84 \\
\hline $\mathrm{Mg}$ & $2 / 2$ & 3,605 & 2,284 & 4,926 & $\mathrm{Mg}$ & $2 / 2$ & 4,045 & 2,457 & 5,632 \\
\hline $\mathrm{La}$ & $2 / 2$ & 21 & 16 & 26 & $\mathrm{La}$ & $2 / 2$ & 23 & 13 & 33 \\
\hline $\mathrm{Sb}$ & $2 / 0$ & $<20$ & $<20$ & $<20$ & $\mathrm{Sb}$ & $2 / 0$ & $<20$ & $<20$ & $<20$ \\
\hline $\mathrm{Pb}$ & $2 / 1$ & $<11^{*}$ & $<10$ & 12 & $\mathrm{~Pb}$ & $2 / 1$ & $<13^{*}$ & $<10$ & 16 \\
\hline $\mathrm{Tl}$ & $2 / 0$ & $<50$ & $<50$ & $<50$ & $\mathrm{Tl}$ & $2 / 0$ & $<50$ & $<50$ & $<50$ \\
\hline As & $2 / 0$ & $<20$ & $<20$ & $<20$ & As & $2 / 0$ & $<20$ & $<20$ & $<20$ \\
\hline $\mathrm{Se}$ & $2 / 0$ & $<30$ & $<30$ & $<30$ & $\mathrm{Se}$ & $2 / 0$ & $<30$ & $<30$ & $<30$ \\
\hline $\mathrm{Hg}$ & $2 / 2$ & 0.08 & 0.06 & 0.09 & $\mathrm{Hg}$ & $2 / 2$ & 0.07 & 0.05 & 0.08 \\
\hline
\end{tabular}

${ }^{1}$ Detects are the number of samples with concentrations equal to or greater than the laboratory reporting limit.

* Where the concentration of a metal in a sample is less than the laboratory minimum reporting level, the minimum reporting level is used for calculating arithmetic mean, and the arithmetic mean is qualified as less than the value given. 


\section{APPENDIX 8. Heavy Metal and Trace Element Contents of Surface Soils of the United States. (Compiled)}

Appendix 8.1 Arsenic, Barium and Beryllium Contents of Surface Soils of the U.S. (in ppm dry) (from Kabata-Pendias and Pendias, 1984)

\begin{tabular}{|l|r|r|r|r|r|r|}
\hline & \multicolumn{2}{|c|}{ Arsenic (As) } & \multicolumn{2}{c|}{ Barium (Ba) } & \multicolumn{2}{c|}{ Beryllium(Be) } \\
\hline Soil & Range & Mean & \multicolumn{1}{|c|}{ Range } & Mean & Range & Mean \\
\hline $\begin{array}{l}\text { Sandy soils and lithosols on } \\
\text { sandstones }\end{array}$ & $<0.1-30.0$ & 5.1 & $20-1,500$ & 400 & $<1-3$ & 1.9 \\
\hline Light loamy soils & $0.4-31.0$ & 7.3 & $70-1,000$ & 555 & $1-3$ & 1.7 \\
\hline Loess and soils on silt deposits & $1.9-16.0$ & 6.6 & $200-1,500$ & 675 & $1-3$ & 1.7 \\
\hline Clay and clay loamy soils & $1.7-27.0$ & 7.7 & $150-1,500$ & 535 & $<1-15$ & 1.9 \\
\hline Alluvial soils & $2.1-22.0$ & 8.2 & $200-1,500$ & 660 & $1-3$ & 1.6 \\
\hline Soils over granites and gneisses & $0.7-15.0$ & 3.6 & $300-1,500$ & 785 & $1-2$ & 1.6 \\
\hline Soils over volcanic rocks & $2.1-11.0$ & 5.9 & $500-1,500$ & 770 & $<1-3$ & 1.7 \\
\hline $\begin{array}{l}\text { Soils over limestones and } \\
\text { calcareous rocks }\end{array}$ & $1.5-21.0$ & 7.8 & $150-1,500$ & 520 & $1-2$ & 1.6 \\
\hline Soils on glacial till and drift & $2.1-12.0$ & 6.7 & $300-1,500$ & 765 & $<1-2$ & 1.6 \\
\hline Light desert soils & $1.2-18.0$ & 6.4 & $300-2,000$ & 835 & $<1-7$ & 2.1 \\
\hline Silty prairie soils & $2.0-12.0$ & 5.6 & $200-1,500$ & 765 & $1-1.5$ & 1.4 \\
\hline Mollisols and dark prairie soils & $1.9-23.0$ & 8.8 & $100-1,000$ & 595 & $<1-3$ & 1.5 \\
\hline Organic light soils & $<0.1-48.0$ & 5.0 & $10-700$ & 265 & $<1-1.5$ & 1.2 \\
\hline Forest soils & $1.5-16.0$ & 6.5 & $150-2,000$ & 505 & $1-3$ & 1.9 \\
\hline Various soils* & $<1.0-93.2$ & 7.0 & $70-3,000$ & 560 & $<1-5$ & 1.6 \\
\hline
\end{tabular}

* All other soils which cannot be encompassed by the groups above.

Appendix 8.2 Chromium, Copper and Lead Contents of Surface Soils of the U.S. (in ppm dry) (from Kabata-Pendias and Pendias, 1984)

\begin{tabular}{|l|r|r|r|r|r|r|}
\hline & \multicolumn{2}{|c|}{ Chromium $(\mathrm{Cr})$} & \multicolumn{2}{c|}{ Copper $(\mathrm{Cu})$} & \multicolumn{2}{c|}{ Lead(Pb) } \\
\hline Soil & Range & Mean & Range & Mean & Range & Mean \\
\hline $\begin{array}{l}\text { Sandy soils and lithosols on } \\
\text { sandstones }\end{array}$ & $3-200$ & 40 & $1-70$ & 14 & $<10-70$ & 17 \\
\hline Light loamy soils & $10-100$ & 55 & $3-70$ & 25 & $<10-50$ & 20 \\
\hline Loess and soils on silt deposits & $10-100$ & 55 & $7-100$ & 25 & $10-30$ & 19 \\
\hline Clay and clay loamy soils & $20-100$ & 55 & $7-70$ & 29 & $10-70$ & 22 \\
\hline Alluvial soils & $15-100$ & 55 & $5-50$ & 27 & $10-30$ & 18 \\
\hline Soils over granites and gneisses & $10-100$ & 45 & $7-70$ & 24 & $10-50$ & 21 \\
\hline Soils over volcanic rocks & $20-700$ & 85 & $10-150$ & 41 & $10-70$ & 20 \\
\hline $\begin{array}{l}\text { Soils over limestones and } \\
\text { calcareous rocks }\end{array}$ & $5-150$ & 50 & $7-70$ & 21 & $10-50$ & 22 \\
\hline Soils on glacial till and drift & $30-150$ & 80 & $15-50$ & 21 & $10-30$ & 17 \\
\hline Light desert soils & $10-200$ & 60 & $5-100$ & 24 & $10-70$ & 23 \\
\hline Silty prairie soils & $20-100$ & 50 & $10-50$ & 20 & $10-30$ & 21 \\
\hline Mollisols and dark prairie soils & $15-150$ & 55 & $10-70$ & 27 & $10-70$ & 19 \\
\hline Organic light soils & $1-100$ & 20 & $1-100$ & 15 & $10-50$ & 24 \\
\hline Forest soils & $15-150$ & 55 & $7-150$ & 17 & $10-50$ & 20 \\
\hline Various soils* & $7-1,500$ & 50 & $3-300$ & 26 & $<10-70$ & 26 \\
\hline
\end{tabular}

* All other soils which cannot be encompassed by the groups above. 
Appendix 8.3 Cobalt, Nickel and Zinc Contents of Surface Soils of the U.S. (in ppm dry) (from Kabata-Pendias and Pendias, 1984)

\begin{tabular}{|c|c|c|c|c|c|c|}
\hline & \multicolumn{2}{|c|}{ Cobalt (Co) } & \multicolumn{2}{|c|}{ Nickel (Ni) } & \multicolumn{2}{|c|}{$\operatorname{Zinc}(\mathrm{Zn})$} \\
\hline Soil & Range & Mean & Range & Mean & Range & Mean \\
\hline Spodosols and Sandy soils & $0.4-20$ & 3.5 & $<5-70$ & 13.0 & $<5-164$ & 40.0 \\
\hline Light loamy soils & $3-30$ & 7.5 & $5-200$ & 22.0 & $20-118$ & 55.0 \\
\hline $\begin{array}{l}\text { Loess and soils on silt } \\
\text { deposits }\end{array}$ & $3-30$ & 11.0 & $5-30$ & 17.0 & $20-109$ & 58.5 \\
\hline Clay and clay loamy soils & $3-30$ & 8.0 & $5-50$ & 20.5 & $20-220$ & 67.0 \\
\hline Alluvial soils & $3-20$ & 9.0 & $7-50$ & 19.0 & $20-108$ & 58.5 \\
\hline $\begin{array}{l}\text { Soils over granites and } \\
\text { gneisses }\end{array}$ & $3-15$ & 6.0 & $<5-50$ & 18.5 & $30-125$ & 73.5 \\
\hline Soils over volcanic rocks & $5-50$ & 17.0 & $7-150$ & 30.0 & $30-116$ & 78.5 \\
\hline $\begin{array}{l}\text { Soils over limestones and } \\
\text { calcareous rocks }\end{array}$ & $3-20$ & 9.5 & $<5-70$ & 18.0 & $10-106$ & 50.0 \\
\hline Soils on glacial till and drift & $5-15$ & 7.5 & $10-30$ & 18.0 & $47-131$ & 64.0 \\
\hline Light desert soils & $3-20$ & 10.0 & $7-150$ & 22.0 & $25-150$ & 52.5 \\
\hline Silty prairie soils & $3-15$ & 7.5 & $<5-50$ & 16.0 & $30-88$ & 54.3 \\
\hline $\begin{array}{l}\text { Mollisols and dark prairie } \\
\text { soils }\end{array}$ & $3-15$ & 7.5 & $7-70$ & 19.5 & $20-246$ & $\overline{83.5}$ \\
\hline Organic light soils & $3-10$ & 6.0 & $5-50$ & 12.0 & $<5-108$ & 34.0 \\
\hline Forest soils & $5-20$ & 10.0 & $7-100$ & 22.0 & $25-155$ & 45.7 \\
\hline Various soils* & $3-50$ & 10.5 & $<5-150$ & 18.5 & $13-300$ & 73.5 \\
\hline
\end{tabular}

* All other soils which cannot be encompassed by the groups above.

Appendix 8.4 Manganese, Selenium and Vanadium Contents of Surface Soils of the U.S. (in ppm dry) (from Kabata-Pendias and Pendias, 1984)

\begin{tabular}{|l|r|r|r|r|r|r|}
\hline & \multicolumn{2}{|c|}{ Manganese (Mn) } & \multicolumn{2}{c|}{ Selenium (Se) } & \multicolumn{2}{c|}{ Vanadium (V) } \\
\hline Soil & Range & Mean & Range & Mean & Range & Mean \\
\hline $\begin{array}{l}\text { Sandy soils and lithosols on } \\
\text { sandstones }\end{array}$ & $7-2,000$ & 345 & $<0.1-3.5$ & 0.50 & $7-150$ & 47 \\
\hline Light loamy soils & $50-1,000$ & 480 & $<0.1-1.2$ & 0.33 & $20-150$ & 77 \\
\hline Loess and soils on silt deposits & $50-1,500$ & 525 & $<0.1-0.7$ & 0.26 & $20-300$ & 102 \\
\hline Clay and clay loamy soils & $50-2,000$ & 580 & $<0.1-1.9$ & 0.50 & $20-150$ & 87 \\
\hline Alluvial soils & $150-1,500$ & 405 & $<0.1-2.0$ & 0.50 & $30-150$ & 79 \\
\hline Soils over granites and gneisses & $150-1,000$ & 540 & $<0.1-1.2$ & 0.40 & $50-200$ & 100 \\
\hline Soils over volcanic rocks & $300-3,000$ & 840 & $0.1-0.5$ & 0.20 & $30-300$ & 136 \\
\hline $\begin{array}{l}\text { Soils over limestones and } \\
\text { calcareous rocks }\end{array}$ & $70-2,000$ & 470 & $0.1-1.4$ & 0.19 & $10-150$ & 72 \\
\hline Soils on glacial till and drift & $200-700$ & 475 & $0.2-0.8$ & 0.40 & $30-200$ & 95 \\
\hline Light desert soils & $150-1,000$ & 360 & $<0.1-1.1$ & 0.50 & $30-150$ & 93 \\
\hline Silty prairie soils & $200-1,000$ & 430 & $<0.1-1.0$ & 0.30 & $50-150$ & 87 \\
\hline Mollisols and dark prairie soils & $100-2,000$ & 600 & $<0.1-1.2$ & 0.40 & $30-150$ & 92 \\
\hline Organic light soils & $7-1,500$ & 260 & $<0.1-1.5$ & 0.30 & $<7-150$ & 38 \\
\hline Forest soils & $150-1,500$ & 645 & $<0.1-1.6$ & 0.40 & $15-200$ & 85 \\
\hline Various soils* & $20-3,000$ & 490 & $<0.1-4.0$ & 0.31 & $0.7-98$ & -- \\
\hline
\end{tabular}

* All other soils which cannot be encompassed by the groups above. 
Appendix 8.5 Mercury and Lithium Contents of Surface Soils of the U.S. (in ppm dry) (from Kabata-Pendias and Pendias, 1984; ${ }^{2}$ from Steinnes, 1993)

\begin{tabular}{|c|c|c|c|c|}
\hline & \multicolumn{2}{|c|}{ Mercury $(\mathrm{Hg})$} & \multicolumn{2}{|c|}{ Lithium (Li) } \\
\hline Soil & Range & Mean & Range & Mean \\
\hline Sandy soils and lithosols on sandstones & $<0.01-0.54$ & 0.08 & $<5-50$ & 16.5 \\
\hline Light loamy soils & $0.01-0.60$ & 0.07 & $9-46$ & 24.5 \\
\hline Loess and soils on silt deposits & $0.01-0.38$ & 0.08 & $9-30$ & 20.5 \\
\hline Clay and clay loamy soils & $0.01-0.90$ & 0.13 & $10-64$ & 23.5 \\
\hline Alluvial soils & $0.02-0.15$ & 0.05 & $10-120$ & $\overline{34.0}$ \\
\hline Soils over granites and gneisses & $0.01-0.14$ & 0.06 & $10-45$ & 23.5 \\
\hline Soils over volcanic rocks & $0.01-0.18$ & 0.05 & $15-41$ & 25.5 \\
\hline Soils over limestones and calcareous rocks & $0.01-0.50$ & 0.08 & $6-88$ & 26.5 \\
\hline Soils on glacial till and drift & $0.02-0.36$ & 0.07 & $10-30$ & 18.0 \\
\hline Light desert soils & $0.02-0.32$ & 0.06 & $9-69$ & 25.0 \\
\hline Silty prairie soils & $0.02-0.06$ & 0.04 & $10-34$ & 20.5 \\
\hline Mollisols and dark prairie soils & $0.02-0.53$ & 0.10 & $8-40$ & 22.5 \\
\hline Organic light soils & $0.01-4.60$ & 0.28 & $<5-71$ & 13.0 \\
\hline Forest soils & $0.02-0.14$ & 0.06 & $10-57$ & $\overline{24.0}$ \\
\hline Various soils* & $0.02-1.50$ & 0.17 & $<5-100$ & 28.0 \\
\hline Surface soils (entire U.S.) ${ }^{\mathrm{a}}$ & $<0.01-4.6$ & 0.11 & - & -- \\
\hline Surface soils (western states) ${ }^{a}$ & $<0.01-4.6$ & 0.08 & -- & -- \\
\hline B horizon (western states) ${ }^{2}$ & $<0.01-4.6$ & 0.06 & -- & -- \\
\hline Surface soils (eastern states) ${ }^{\mathrm{a}}$ & $0.01-3.4$ & 0.15 & -- & - \\
\hline B horizon (eastern states) ${ }^{\mathrm{a}}$ & $0.01-3.4$ & 0.10 & -- & -- \\
\hline
\end{tabular}

* All other soils which cannot be encompassed by the groups above.

\section{Appendix 8.6 Molybdenum (Mo)Content of Surface Soils of the U.S. (in ppm dry) (from Kabata-Pendias and Pendias, 1984)}

\begin{tabular}{|c|c|c|}
\hline Soil & Range & Mean \\
\hline Soils over shales & $0.30-3.30$ & 2.13 \\
\hline Soils over volcanic ash & $0.40-1.80$ & 1.08 \\
\hline Soils over loess & $0.75-6.40$ & 2.53 \\
\hline Soils on lacustrine deposits & $1.20-7.15$ & $\overline{4.14}$ \\
\hline Alluvial deposits & $0.40-2.80$ & 0.88 \\
\hline Alluvial deposits ${ }^{2}$ & $1.50-17.80$ & 5.80 \\
\hline Soils on glacial deposits & $0.08-4.68$ & 1.22 \\
\hline Soils on granitic alluvium & $0.13-0.50$ & 0.35 \\
\hline Soils on calcareous alluvium & $0.30-2.00$ & 1.25 \\
\hline Various soils* & $0.80-3.30$ & 2.00 \\
\hline
\end{tabular}

a Soils from areas of the western states of Mo toxicity to grazing animals.

* All other soils which cannot be encompassed by the groups above. 